Historic, Archive Document

Do not assume content reflects current scientific knowledge, policies, or practices. 



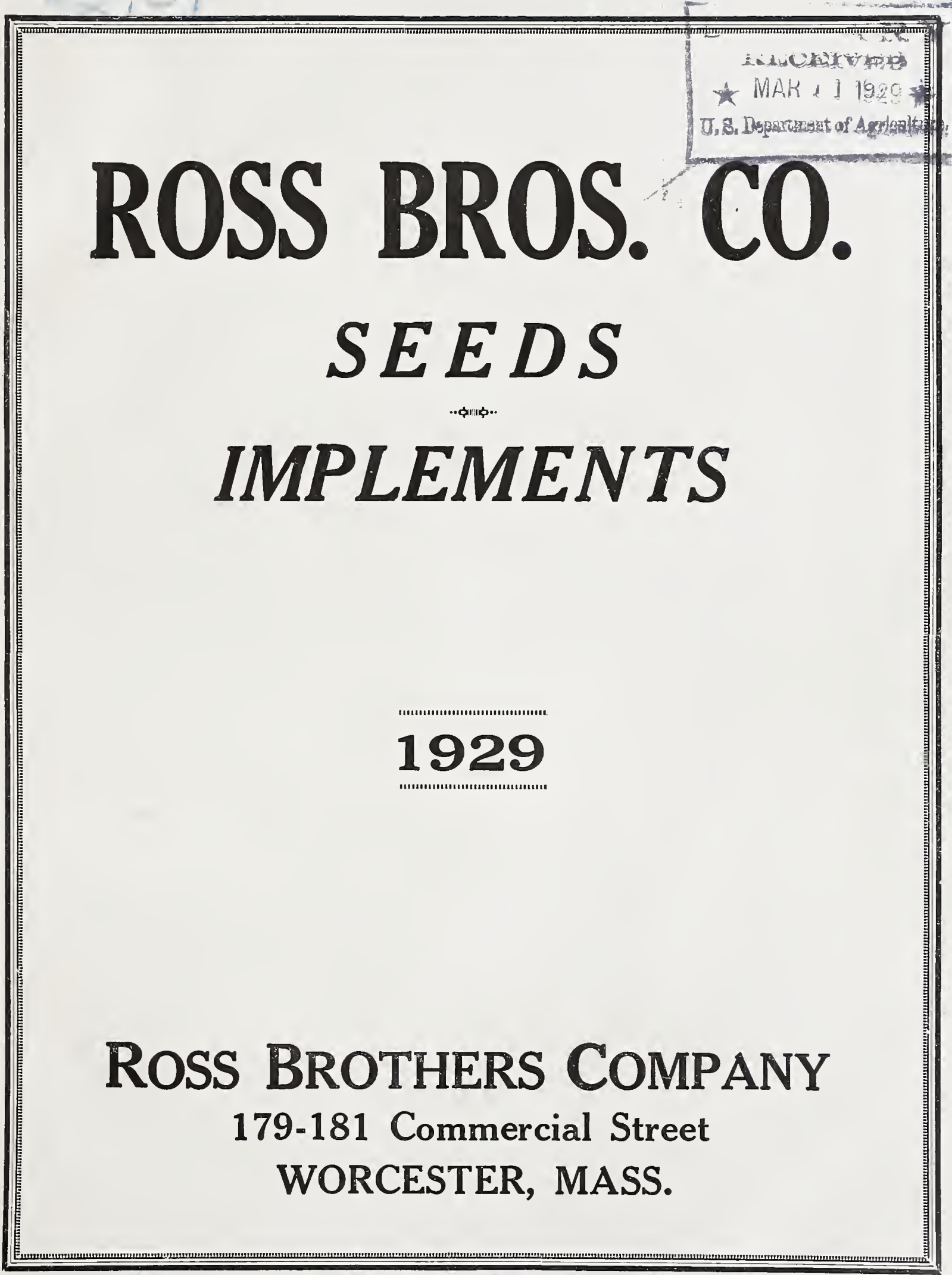


For nearly forty years we have been sending to you our silent salesman in the form of this yearly seed and imple-

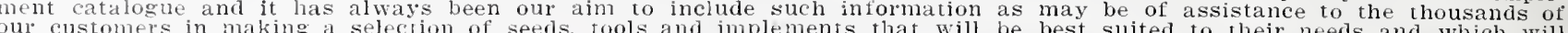
that will be best suited to their needs and which will

The pictures used to illustrate the different varieties and types of vegetables and flowers are reproduced from photographs and show the true tylues as produced with nornal conditions. Cultural directions are given in many instances and trust these will be of henefit to those who are unfamilial with gardening.

The seeds and bulbs listed have been grown especially for us by the best and most experienced growers in the world. each rariety haring been produced in that section which is best suited to grow seed of the highest guality. We do not hesitate to recommend the use of any of the rarieties listed and suggest that customers select such as are best adapted to their particular geographical location.

Te wish to serve again the nany thousands of customers whom we have supplied for years and shall deen it a pleas-
to ard many new ones to our list during the coming season. une to arld many new ones to our list during the coming season.

\section{EVERYBODY KNOWS ROSS' SEED GROWS}

The attention of our customers is respectfully called to the following directions, which if followed will be an aid to purchasers as well as ourselves.

ORDER EARLY - We endeavor to fill all orders as soon as received, but during the rusli season of April and llay, lelays are sometimes un-
avoidable. This, howerer, can be partly overcome if our patrons will send a voidable. This, how
us their orders early.

FREE DELIVERY - We delivel postpaid to any Post Office in the Inited States, legetable and Flower Seeds in packets, ounces, qual'tel pounds and pounds, at prices quoted in this catalogue for such quantities. If larger lost rates.

GRf:S AND FIELD SEEDS-All Grass and Field Seeds, Onion Sets and Potatoes are shipped only at purchasel's expense by express or freight. as ordered. Prices quoted in this catalogue are F. O. B. Worcester. Small at parce

DO NOT ORDER LARGE, HEAVY LOTS OF SEEDS SENT BY EXPRESS unless you are certain that you are willing to pay the express charges, which, even with the reduction now made on such shipments by the express companies, are much more than freight charges.

But do not order a few pounds of seeds sent by freight which could lie sent as cheaply, more safely, and which would reach you much sooner il sent by express.

NOTICE- While it is not our custom to substitute, we fecl that in the event of our being sold out of any variety it would be to the advantage of our patrons to allow us this privilege, for, if on receipt of any substitute will be refunded.

IF GOODS ARE WANTED BY PARCEL POST, POSTAGE MUST BE ADDED AS FER TABIE, EXCEPT FOR THOSE QUANTITIES OF SEEDS WE OFFER TO DELIVER FREE.

FOR IARGE ORDERS, remittances should be made by Express Money Orders, P. 0. IIoney Arder. Bank Draft, or Registered Letter, all of which

Telegraph your order with Western Union Money Transfer and goods will be shipped same clay order is received.

PLEASE do not send stamps unless necessary as they often reach us in

PERSONAI CHECKs. If personal checks are used they should be ertified otherwise shipment of your order may be delayed pending collection.

NAME AND ADDEESS SHOULD ALWAYS BE GIVEN. Frequently We receive unsigned letter's. Sometimes they contain money and orders. Sometimes, too, letters are leceived in which the name of the town is left out
and the postmark is blurred. We cannot fll orders unless we know the name and address of the buyer. The easiest way for you is to use our order sheet filling in the blanks.

ERRORS- We use the utmost care in filling orders. vet in the press of business errors sometimes occur in which event we wish to be promptly notified of the fact and will make sucin corrections as will be satisfactory. Most of the failures with seeds, plants and bulbs are due to causes entirely beyond our control such as unfarolable weather or soil conditions. guarantee success, and although we take all possible care to supply only such goods as will under proper conditions, produce satisfactory results, The fioss Bros. Company gives no warranty, express or implied, as to description, quality, productiveness or any other matter of any seeds (bulbs or plants) it sells and will not be responsible for the crop.

ROSS BROS. CO.

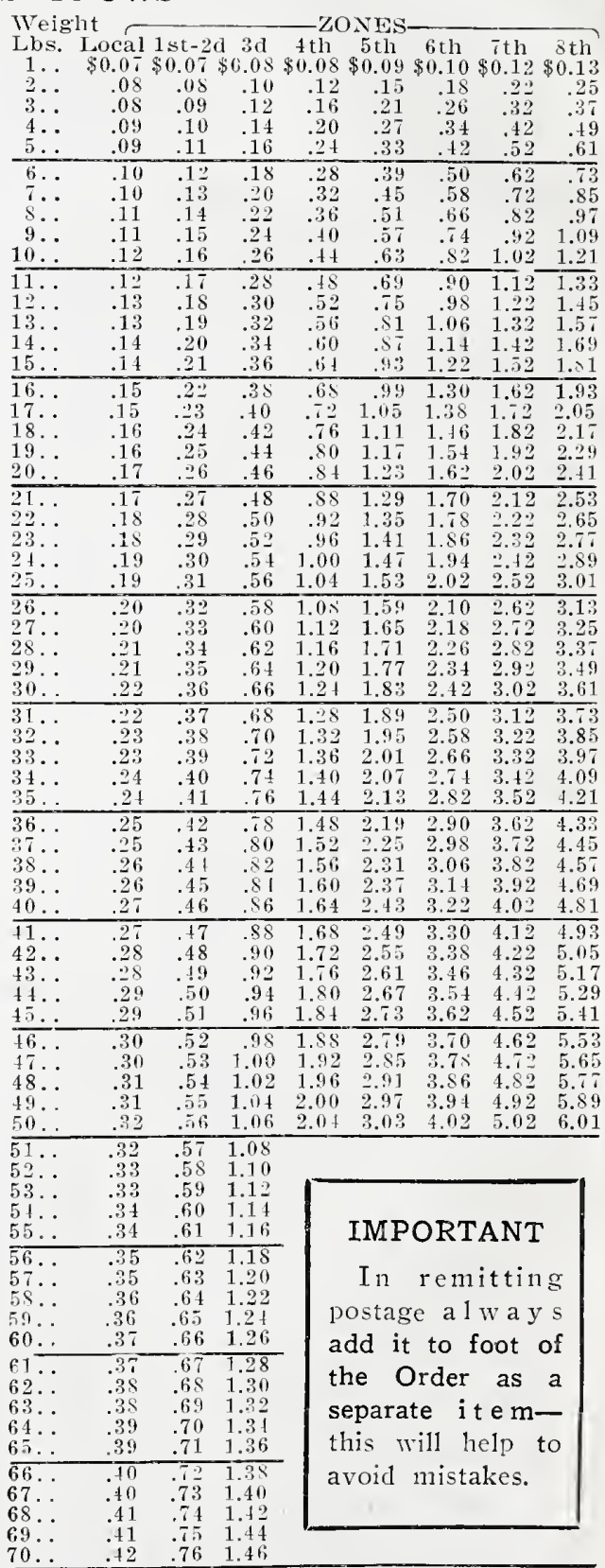


Send to $M$

Street

Post Office

Express or Freight Address

Ship by Freight...... Expres
Date

R.F.D. No.

County

State
AMOUNT SENT

M. 0 .

Check

Cash

Stamps

Total

ROSS BROTHERS COMPANY gives no warranty, expressed or implied, as to description, purity, productiveness or any other matter of any Seeds, Bulbs or Plants it sends out, and it will not be in any way responsible for the erop.

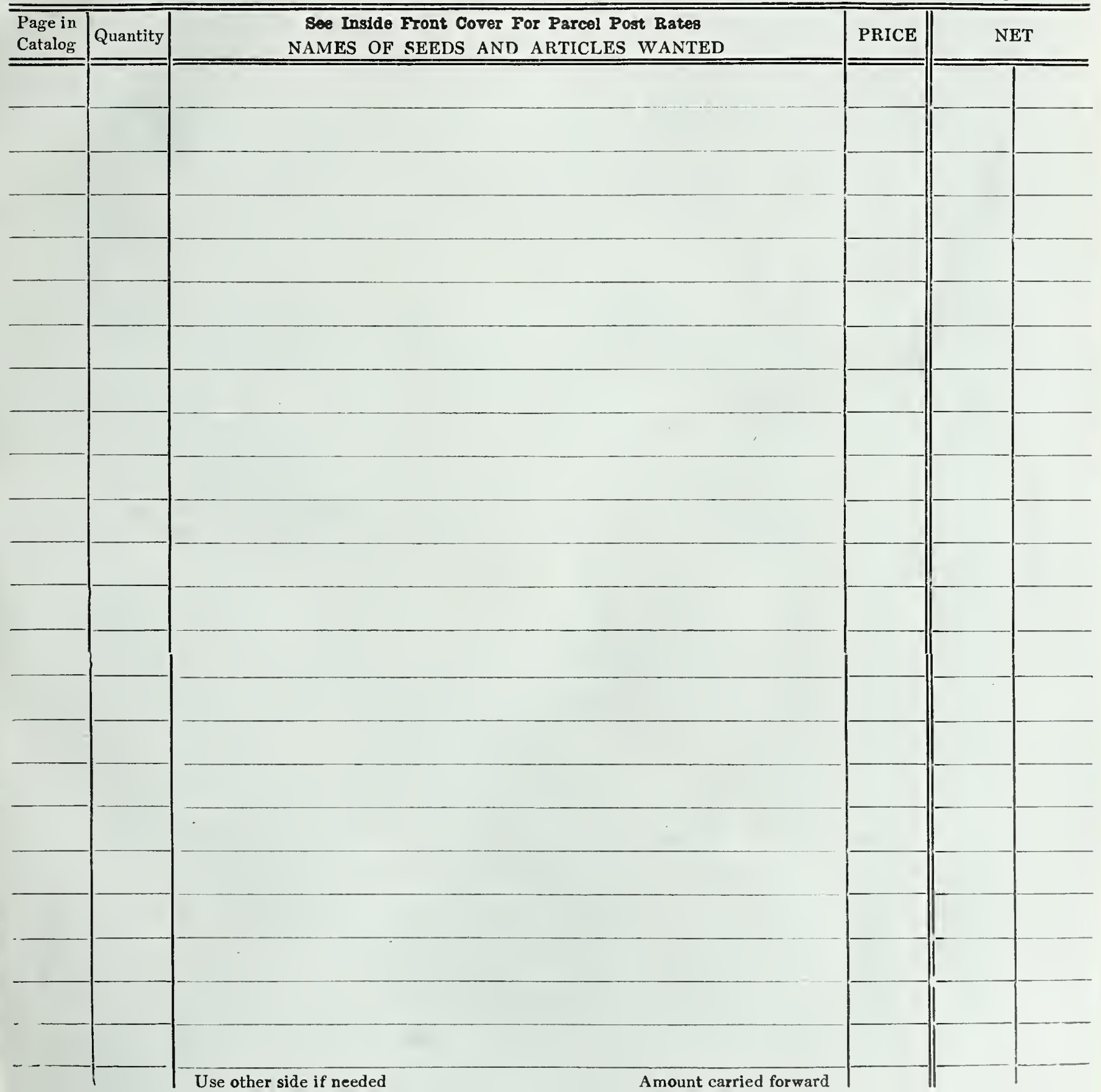




\section{New Forcing Calendula Campfire}

Flower Seed Specialties for 1929

252 A distinct new type originating from a mutation from the florist's strain of Orange King. It is of vigorous growth, the flowers borne on stout stems, needing little disbudding. The blooms are flat and are undoubtedly larger than those of any type previously introduced. The color of the petal is brilliant orange with a searlet sheen with full yellow center. This type has been thoroughly tested under glass, and has been accepted as the best orange foreing Calendula for florist's use. Pkt. $15 \mathrm{cts}$., 1/8 0z. 75 cts., 1/4 0z. \$1.25.

\section{Aster}

CALIFORNIA GIANT DOUBLE. We take pleasure in recommending this type as the best Aster on the market today. Characterized by the well known Crego or Os. trich Feather type of flower, combined with the Beauty Aster's long non-lateral branching stems and sturdy habit of growth, the California Giant Double type of Aster stands at the head of the list, not only for florists' use, but also for private gardens where quality is appreciated.

8 White, new, fine, 9 Peach Blossom. 10 Light Blue. 11 Light Purple. 12 Deep Rose. 13 Dark Purple. Pkt. 10 cts., $1 / 16$ oz. $30 \mathrm{cts}$., $1 / 8$ oz. 50 cts., $1 / 4$ 0z. $90 \mathrm{cts}$.

14 Mixture of above. Pkt. 10 cts., $1 / 8$ oz. 40 cts., $1 / 4$ oz. 75 cts., $1 / 2$ oz. $\$ 1.40$.

\section{Pansy}

780 ROSS' SELECTED GIANT MIXED. This is one of the finest strains known, the flowers being of perfeet form and richest colors. A Giant Pansy, excellent for grow. ing in the frame or out of doors. Pkt. 50 cts., 1/16 oz. $\$ 1.00,1 / 8$ oz. $\$ 1.75,1 / 4$ oz. $\$ 3.25$, oz. $\$ 12.00$.

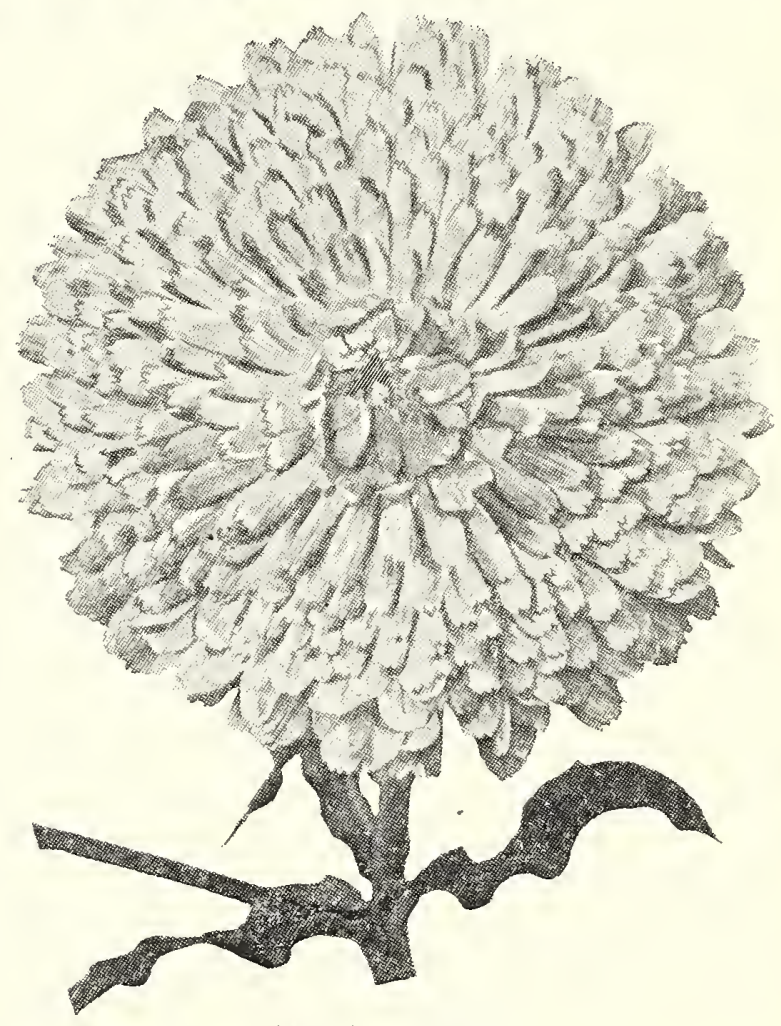

Campfire Calendula

\section{Giant Spencer Varieties of Sweet Peas}

AUSTIN FREDERICK IMPROVED. A very large and long stemmed rosy lavender. This is the most vigorous growing lavender and produces a wealth of fine blossoms. The flowers are nicely waved and borne on long stout stems. Pkt. $10 \mathrm{cts}, 1 / 2$ oz. $20 \mathrm{cts}$., oz. $35 \mathrm{cts}$., $1 / 4$ lb. $\$ 1.00$.

AVALANCHE. The very best white seeded white. This grand white is outstanding beeause of the thick taxture of the petals and the pureness of the color. It is a strong grower and a most satisfactory flower from all angles. Pkt. $10 \mathrm{cts}, 1 / 2 \mathrm{oz} .30 \mathrm{cts}, 0 \mathrm{z} .50 \mathrm{cts}, 1 / 4$ lb. $\$ 1.50$.

MRS. TOM JONES. Deep amethyst blue, very fine forn, the best of the deep blues. Pkt. $10 \mathrm{cts}, 1 / 2 \mathrm{oz} .20 \mathrm{cts}$., oz. 35 cts., $1 / 4$ lb. $\$ 1.00$.
PINKIE. It is by comparison the largest of all we have ever seen in the Deep Pink section of accepted, preferred varieties. A most vigorous grower, producing on long stout stems well waved, nicely placed flowers of a beautiful rose pink shade. Pkt. $15 \mathrm{cts} ., 1 / 2$ oz. 40 cts., oz. 75 cts., $1 / 4$ lb. $\$ 2.50$.

PRINCE OF ORANGE. This, like all orange colored vari eties, requires shading, but this extra labor is amply repaid by the brilliant, rich color. Pkt. 15 cts., $1 / 2$ oz. 40 cts., oz. 75 cts., $1 / 4$ lb. $\$ 2.50$.

SUNKIST. This is a large rose picotee, edged on cream ground, giving a very beautiful effeet, especially when used for table decorations. The large bold flowers are well waved and borne on good, stout stems. Pkt. 15 cts., $1 / 2$ oz. 40 cts., oz. 75 cts., $1 / 4$ lb. $\$ 2.50$.

See Pages 63 and 64 for complete list of Sweet Peas.

\section{Zinnia New Giant Dahlia Flowered The "Gold Medal" Collection}

1366 BUTTERCUP. Creamy yellow.

1368 CRIMSON MONARCH. A good red shade.

1370 DREAM. Deep lavender.

1372 EXQUISITE. Light rose, eenter deep rose.
ORIOLE. Orange and gold bicolor.

1376 OLD ROSE. The real old rose shade.

1378 POLAR BEAR. Pure white.

1380 SPECIAL MIXTURE. Containing all the above nov.

Each of the above $25 \mathrm{cts}$. per pkt. 6 pkts. for $\$ 1.00$.

See page 65 for complete list of Zinnias. 


\section{Specialties in Vegetable Seeds}

\section{Beans}

FENCII POD WAX. This very handsome black wax sort is medium early, fairly hardy and productive. It is one of the very west sorts for home use and for near markets where highest quality is desired. The plants are strong growing with roughened leaves. The pods are long, five and one-half to six inches, straight, round, fleshy and of a bright yellow color. They are tender, absolutely stringless medium sized, solid black. Plt. 20 cts., 1 1b. 45 cts., $\mathbf{2}$ 1bs. 80 cts., 10 lbs. or over 35 cts. per $1 \mathrm{~b}$.

FRIICF'S HORTICUITURAT. This is a bean of the hort1cultural type which has been grown quite extensively in some localities by the Market Gardeners for a number of years. The vines are compact and of upright growth; almost always sending out runners to a height of one and one-half to two feet, but do not climb a pole and are not of sufficient length to affect the bean in any way. The pods when ready to use are a yellowish green splashed with a bright crimson. Very prolific. Pkt. 20 cts., 1 1b. 45 cts., 2 lbs. 80 cts., 10 lbs. or over 35 cts per $1 \mathrm{~b}$.

\section{Beet}

EARIY WONDER. One of the earliest and most perfectly shaped beets. Its beautiful, deep blood-red color, globularshaped roots, make it valuable for the home garden. The attractive appearance, uniform size, shape and color have created a very heavy demand for this variety. It is grown very extensively for late sowing. Pkt. 10 cts., oz. 15 cts., $1 / 4$ lb. 40 cts., $1 \mathrm{~b}$. $\$ 1.40$.

CROSBY'S EARIY FGYPTIAN EXTRA-SILECTPD STRAIN. For several years we have given this especial attention and have largely succeeded in eliminating the light-colored, coarse fleshed specimens peculiar to the Egyptian. Roots are more uniform in shape and tops are more even in growth and a little smaller. We confidently recommend it to market gardeners as an unsurpassed strain. Prt. 10 cts., oz. $15 \mathrm{cts} ., 1 / 4 \mathrm{lb}$. $40 \mathrm{cts}$., $1 \mathrm{~b}$. $\$ 1.40$.

\section{Carrot}

DANVERS HALF IONG. A well known rich orange red variety, very smooth and handsome, producing extra heavy crops. An excellent market variety; crisp, sweet and tender. Although the roots are short, they produce as large a bulk as the longer field sorts and are more easily harvested. This variety has yielded 25 tons per acre. We have given this our special attention and offer at this time as good strain of seed as is possible to obtain. Plt. 10 cts., oz. 20 cts., $1 / 41 \mathrm{~b} .45 \mathrm{cts} ., 1 \mathrm{~b}$. $\$ 1.50$.

PERFrCTrow. This new introduction which is best described as a blunt ended James Intermediate is almost entirely free from core. Flesh is strikingly deep red, tender and very delicate. The roots are rather long and comparatively thick, whereas tops are very small. Grows very uniform. Produces a heavy erop of roots which can be easily kept in prime condition throughout the winter. Pkt. 10 cts., oz. 20 cts., $1 / 4$ 1b. 60 cts., $1 b . \$ 2.00$.

\section{Celery}

GOLDEN SEIF-BIANCHING. The most popular variety for market, easily blanched, very attractive, of good quality, though not equal to some of the green celeries. TRUE PRENCH-GROWN SEED. Pkt. $20 \mathrm{cts.,} 1 / 2$ oz. $65 \mathrm{cts.}$
OZ. $\$ 1.25,1 / 8$ lb. $\$ 4.00$.

Write for our Fall Catalogue of Datch Balbs.

\section{Corn, Sweet}

GOIDIN SUNSHINE. The earliest of the Golden Bantam type, maturing a week to ten days earlier than that variety; more dwarf in habit than Bantam, with ears $6 \frac{1}{2}$ inches long, containing 12 rows of broad, yellow, sweet grains; especially desirable for its extreme earliness. Pkt. 20 cts., 1b. 40 cts., 2 lbs. 70 cts., 10 lbs. or over 28 cts. per lb.

WHIPPIE'S EARLY YELIOW. Twice the size of Golden Bantam and matures about the same time, grows ears 7 to 8 inches long and 12 to 16 rowed, with often two ears to one stalk. Quality is unequaled. Pkt. 20 cts., $1 \mathrm{~b} .40 \mathrm{cts}$., 2 lbs. 70 cts., 10 lbs. or over 28 cts. per lb.

GOLDEN BANTAM SWEFT CORN. See page 15.

\section{Cucumber}

EARIY FORTUNE. The plant is early, very vigorous, with an exceptionally heavy, thick foliage and is almost disease resistant and very productive. Fruits are uniformly nine inches long, slightly tapering toward each end, perfectly round and of a very rich dark green color which does not fade in shipping; flesh very thick, firm and crisp, and with an exceedingly small seed cavity. Pkt. 10 cts., oz. 20 cts., $1 / 4$ 1b. 50 cts., 1b. $\$ 1.50$.

\section{Lettuce}

BLACK-SFEDID TENNISBATI. More extensively grown in New England than any other variety, both for first outdoor crop and for main crop, the medium sized heads being the size most liked by gardeners, while its compact form allows it to be grown more closely together than others. Leaves plain, thick, dark green; blanches to a rich creamy white inside. Plet. $10 \mathrm{cts.,} 1 / 2$ oz. 20 cts., $0 z .30 \mathrm{cts.,} 1 / 4 \mathrm{lb}$. 75 cts.

\section{Peas}

IAXTON'S PROGRESS. This is the earliest of the largepodded dwarf varieties. The pods are as large as Laxtonian, 4 inches long, broad and pointed, deep green in color, containing eight large dark green Peas of very high quality. The vines are 15 to 18 inches in height and are very productive. Laxton's Progress will mature Peas four days earlier than Laxtonian or Blue Bantam. Pkt. 20 cts., 1 lb. 40 cts., 2 lbs. 70 cts., 10 lbs. or over $30 \mathrm{cts}$. per $1 \mathrm{~b}$.

\section{Squash}

BARIY GIANT SUMMrR. Early, mostly straight necked and much larger than the summer Crookneck. A fine quality growing from 14 to 16 inches long. Extensively used by market gardeners and exceptionally good for home
gardeners. Prt. 10 cts., oz. 25 cts.1 $1 / 4$ lb. 70 cts., 1b. \$2.50.

BIUI HUBBARD. The Symmes Blue Hubbard is an entirely distinct variety resembling the Warted Hubbard in shape. It is a pale light blue color, very thick meated, dry and very sweet; its eating qualities cannot be surpassed. The Blue Hubbard is an exceptionally heavy cropper, producing an extraordinary number of squashes, which, though not of the largest, are of even size, thus making it very easy to handle and market. It has excellent qualities, keeping with proper storage much longer than the Delicious. Prt.

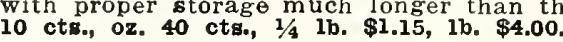



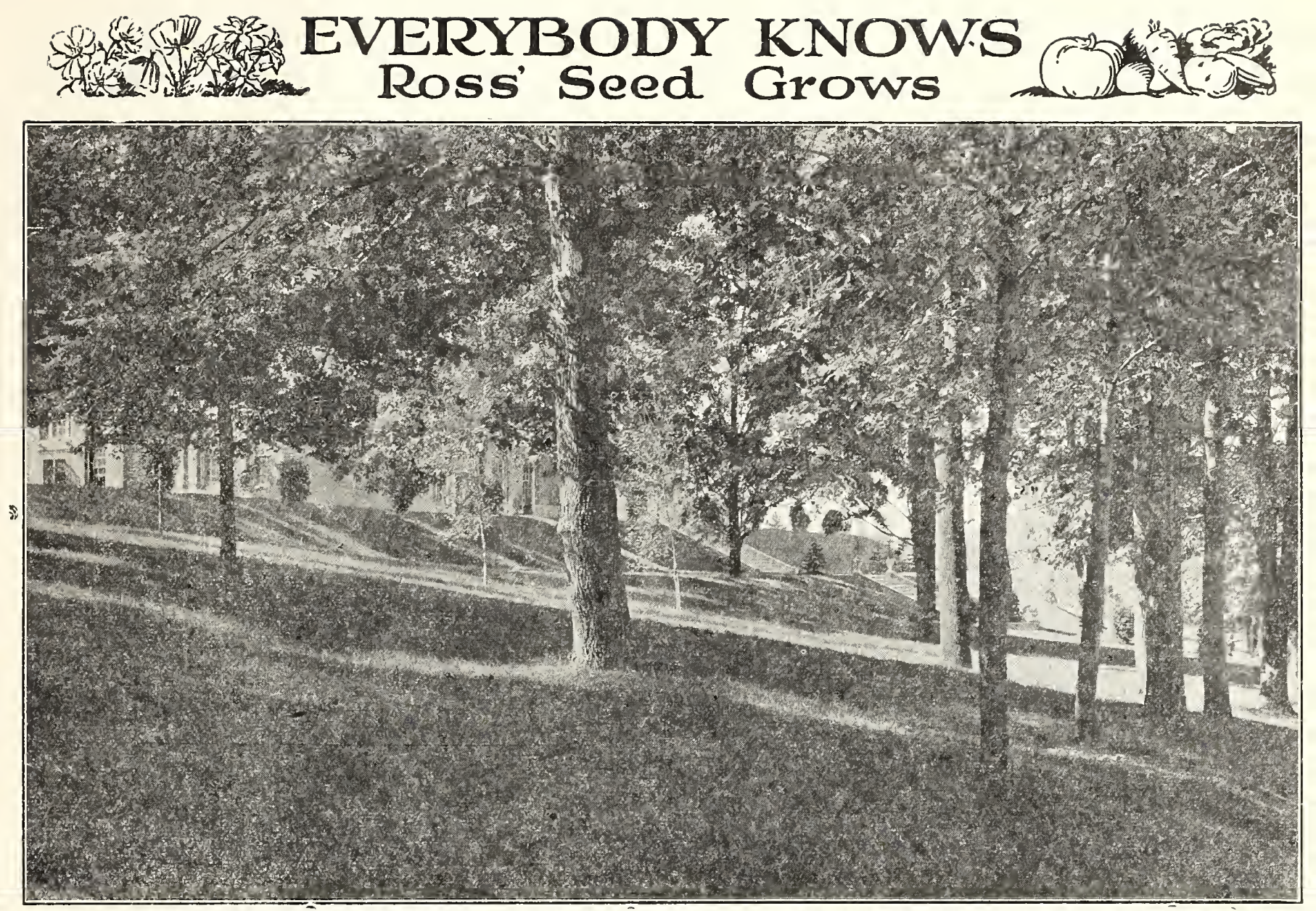

\section{Worcester Lawn Seed}

\section{A Mixture of Unsurpassed Quality}

It is beyond question that a thicker and more prolonged growth is very generally produced by the combination of several grasses than by only one or two.

The Worcester Lawn Grass Seed produces a perfect and enduring iawn of luxuriant richness with closely interwoven, firm and elastic turf, and it is usually ready for cutting in six weeks from time of sowing. This Lawn Grass is composed of a combination of various fine-leaved, deep-rooting grasses of interweaving habit that flourish under our varied conditions, soils and climates, growing during different seasons of the year, so that a deep green, smooth and velvety sward, free from clumps, is maintained without burning brown in Summer. Combined in well-balanced proportions, the result of years of study and observation, the Worcester Lawn Grass Seed will produce in a few weeks a fine, velvety growth, and each succeeding season a continuous thick growth from early in the spring until the ground freezes, forming a close, firm turf which will bear frequent cutting and constant trampling without injury. With reasonable care this desirable condition of the lawn may be maintained permanently.

Worcester Lawn Grass Seed is a mixture of the highest grade seeds of foreign and native grasses. The mixture is heavier than those generally offered, weighing about twenty-five pounds to the bushel, and is as free from weed seeds as it is possible to make it with the most improved machinery.

We advise a minimum sowing of 140 pounds to the acre, but often a larger quantity would probably be preferable; 160 pounds would not be too much when the quickest possible effect is desired. A pound will sow about 300 square feet. Price, lb. 50 cts., 2 lbs. $\$ 1.00,5$ lbs. $\$ 2.10,10$ lbs. $\$ 4.00,100$ lbs. $\$ 38.00$.

\section{Park Lawn Seed}

This mixture is prepared, as far as price will permit, on the same lines as our Worcester mixture. It is designed chiefly to meet a demand for a mixture somewhat lower in price for sowing various large areas and the less important places about the home, but is entirely adequate for all purposes. Prfce lb. 45 cts., 51 bs. $\$ 2.00,10$ lbs. $\$ 3.80,100$ lbs. $\$ 35.00$.

\section{Top Dressing Your Lawn}

The lawn is often neglected by many of us, especially if it seems to be in a thriving condition. We overlook the fact that a continued vigorous growth of any plant life results in reducing in the soil those elements which promote growth The soil must be fed to produce best results and this is easiest accomplished by applying a top dressing. This may be done in many ways-we recommend our Lawn Top Dressing, Pulverized Sheep Manure or Pulverized Poultry Manure; a liberal application of the Ground Limestone is also always recommended.

These items are listed on page 72,73 , giving analysis and prico. 

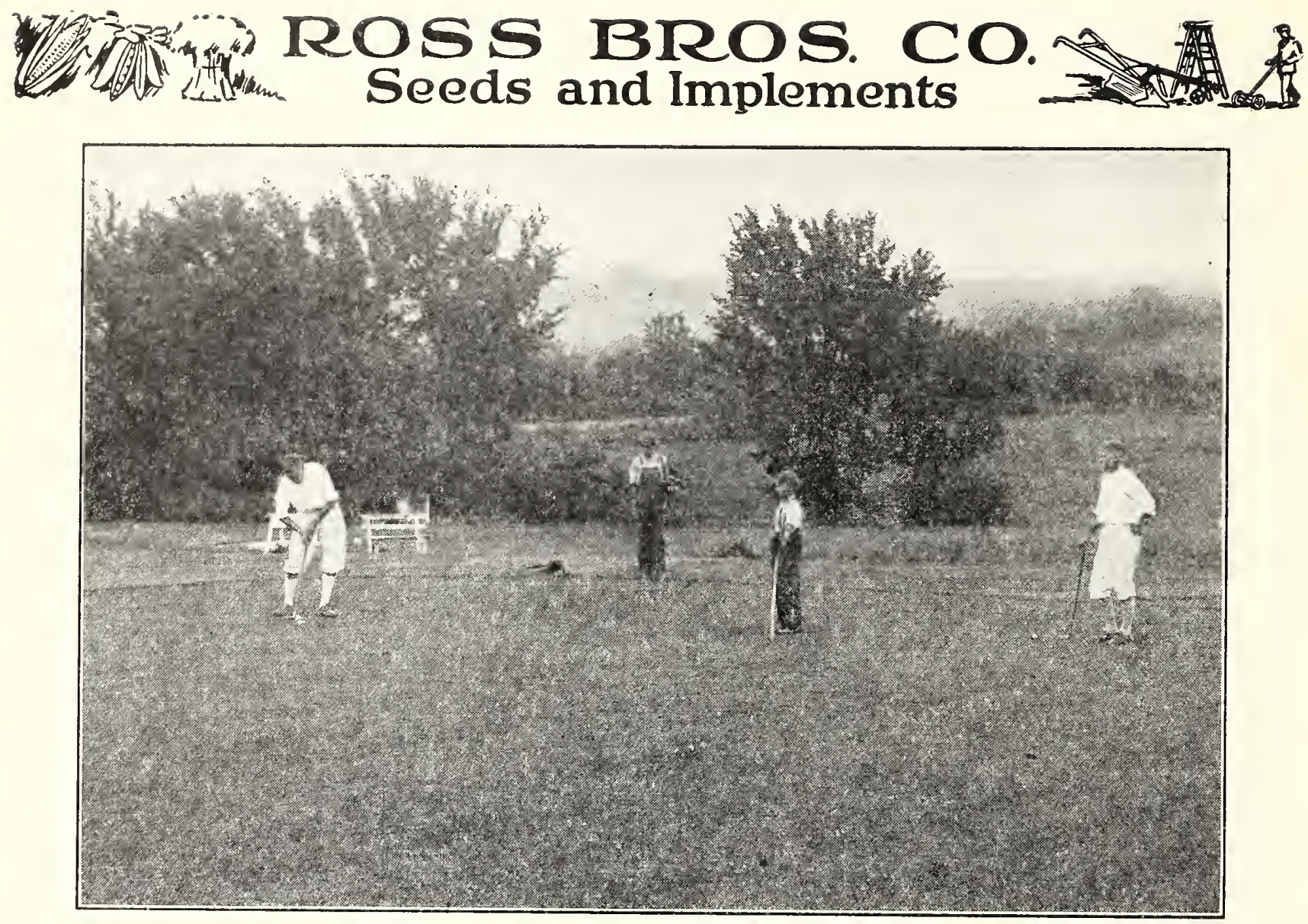

\section{The Shady Spot Lawn Grass Seed}

\section{A Mixture of Our Own Especially Adapted for Use in Shady Places}

Bare spots seriously affect the otherwise attractive appearance of many lawns, and while for renovating or filling such spots our Worcester or Park Mixtures are entirely sufficient, where such spots are caused by the shade of trees, a renovation can be better accomplished by the use of the Shady Spot Mixture. This is composed of varieties which thrive in shade. It includes all known varieties of this class otherwise adapted to the lawn, all of which are of dwarf habit and fine, even growth. To secure a good glowth, however, the soil should be properly prepared before sowing seed. Soil that is naturally moist, which has been densely shaded, often becomes sour, which is indicated by a growth of moss and sometimes by bog grass. In such cases, the moss or grass should be removed, the soil thoroughly worked over, and an application of lime be given at the rate of one bushel to each thousand feet. If the soil is dry, and there has been no growth on it for some time, it is usually very hard and it is useless to sow seed without working it deeply and thoroughly pulverizing it. What would be preferable would be to remove some of the soil and add new soil and rotted turf, and thereby furnish humus, which soils on which nothing has grown for some time usually lack. While, if soil is well prepared, the growth will continue for some time, we do not claim the permanency for this that we do for the Worcester when used in the open exposure to the sun, as there are no grasses which, if cui often, will be as permanent in the shade as others in the open. This is esoecially true if the shade is very dense. We therefore advise yearly attention and applications of a small quantity of seed if growth ls thin. Those who have hitherto been unable to secure a growth under trees because they have not used a special mixture, will find this of great value, and will be well repaid for any slight expense and trouble incurred in following our suggestions by the greatly improved appearance of the lawn. Price, 1b. 60 cts., 5 1bs. $\$ 2.75,10$ lbs. $\$ 5.25,1001 b 8 . \$ 50.00$.

\section{Golf Course Mixtures}

\section{For Putting Greens and Fair Greens}

We have made a close study of the grasses used on Golf Courses and Pleasure Grounds, as there is no purpose for whlch turf is grown that is so exacting. No other grass ls required to stand so much tramping and rough usage and it ls very necessary that the correct proportions of the proper varletles be used to produce a firm, thick and lasting sod. The mlxtures listed below are composed of native and European grasses which have proven of great value for this purpose. They are all of dwarf spreading growth, forming a close smooth surface which lmproves from year to year if given the proper care.

Mixture for Putting Greens, 1b. 75 cts., 24 1bs. (1 bu.) \$15.00.

Mixture for Fair Greens, 1 b. 50 cts., 20 lbs. (1 bu.) \$9.00.

\section{Special Mixtures of Grass Seed}

In addition to the several mixtures of grass seeds whlch we list in this catalogue, we can supply grass seed ln mlxtures suitable for almost any purpose or location. We will also be pleased to name prices on any special formula on request. 


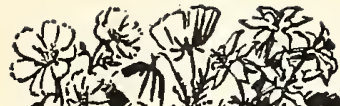 \\ EVERYBODY Ros' Seed.

\section{The Worcester Mixtures of Grass Seed}

\section{For Meadows and Pastures Productive, Permanent, Profitable}

While on heavy natural grass soils there are perhaps no grasses which will produce larger yields for a short period than timothy and red top, it is a fact acknowledged by many of our best farmers that a combination of several varieties is much superior for a continual large production of hay, especially on lighter soils.

\section{Mixture for Permanent Pasture for Medium Soil}

Though many farmers so rotate their crops that the permanency of their mowing fields is not of great consideration, such as regularly pasture their herds, invariably desire that the pasture shall be permanently productive when once seeded. Aside from permanency, an important requisite is that of continual growth from early spring until fall, and as many varieties as possible should be used which bear constant tramping and continued close grazing. This mixture is prepared with these ends in view. 40 to 50 pounds to the acre. Ib. 35 cts., 10 lbs. $\$ 3.00,100$ lbs. $\$ 28.00$.

Permanent Pasture Mixture for Dry, Hilly Lands

In no situation are timothy and red top so unsuitable for seeding as in dry, hilly pasture, for both require strong, rather moist land to thrive for any length of time. This mixture is composed of grasses which thrive on light soil, endure long drought and bear, without injury, constant cropping. Ib. 35 cts., 10 lbs. $\$ 3.00$, 100 lbs. $\$ 28.00$.

\section{Mixture for Permanent Mowing for Dry Soil}

While dry Iand is not the ideal soll for a grass crop, much larger crops can be obtained with this mixture than with tim-

\section{Grass Seeds of the Highest Grade}

\section{For Mowings, Pastures and Lawn}

Prices of all Grass Seeds subject to market changes. Prices include bags or sacks unless otherwise noted, 25 lbs. at 100-lb. price.

BFNT GRASS, SOUTH GERMAN CREFPING. This is particularly valuable for lawns that are to be used for croquet grounds or for tennis courts, because it is benefited more than hurt by tramping and by its bright color adds to the beauty of the lawn. Ib. $\$ 1.00,5$ lbs. $\$ 4.50$.

BENT GRASS CREPPING. (Agrostis stolonifera.) An exceptionally fine strain of high purity and germination. Ib. $\$ 2.00,5$ lics. $\$ 9.00$.

BHWT GRASS RHODE ISIAND. (Agrostis Canina.) Of fine growth, forming a close and permanent sod. One of and polo grounds. I b. $\$ 2.00,5$ lbs. $\$ 9.00$.

ENGIISH or PERENMIAI RYY GRASS (Lolium perenne.) of rapid growth and productive; produces a strong growth in four or five weeks. Made into hay it is rather hard, but is very nutritious and is much relished by cattle and horses. I b. 25 cts., 10 lbs. $\$ 2.00$.

ITAIIAN RYE GRASS (Iolium Italicum.) Thrives on a variety of soils, producing early and large crops. Though a perennial, it shor soiling. Sown in the fall, will produce a large crop of hay the following season. I b. 25 cts., duce a large $\$ 2.00$.

ICENTUCKY BIUE GRASS (Poa pratens18.) One of the most valuable grasses for pasture and lawn, requires some time to become established, but lasts indefinitely on congenial soils. Sown with White Clover it forms a splendid lawn; for this purpose use not less than fifty-four pounds of Blue Grass and six pounds of White Clover per acre. If sown by itself for meadow or pasturage use about twerity-eight pounds per acre. Ib. 50 cts., 10 lbs. \$4.50. MEADOW FESUE (Festuca pratensis.) Largely used for permanent mowing mixtures. Though at once productive, it does not reach its full production for two or three years, when it surpasses most other grasses. Succeeds best on cool, moist soil rich in organic matter. Ib. $30 \mathrm{cts}$, 10 lbs. $\$ 2.50$.

RFD, or CREFPING FRSCUF (Festuca rubra.) Red Fescue is adapted to about the same reneral climatic conditions as Blue Grass and can be grown as far northward as any agriculture is possible. Its leaves are bright green and the plant does not grow in tufts but creeps by underground stems, so that one plant may eventually cover a circle two to four feet in diameter. It is used mainly as a lawn plant. On sandy or gravelly soil it makes exquisite lawns. It will withstand more shade than most grasses and is therefore valuable for shady lawns. Ib. 50 cts., 10 1bs. $\$ 4.50$. CANADIAN BIUE GRASS (Poa compressa.) A hardy perennial with creeping root-stalks which form a strong turf. It withstands drought better than most cultivated grasses and is especially valuable in Lawn Grass mixtures. It succeeds best on clay soils but does well on sandy soils, being better adapted for use on sterile knolls and barren fields than probably any other cultivated grass. For hay or pasturage it is best sown with other grasses. Height 6 to 20 inches. Ib. $40 \mathrm{cts}$., $10 \mathrm{lbs}$. $\$ 3.80$.

CRESTED DOG'S-TAII (Cynosurus Cristatus). A stoloniferous perennial forming a smooth, compact lasting turf. Thrives best on rich moist land but it can adapt itself to almost any soil. Its roots penetrate deeply, thus enabling it to stand severe droughts. The color is the same as that of Kentucky Blue Grass and it is therefore excellent in mixture with that sort for lawns. If sown alone 30 pounds to the acre is none too much but 1 is recommended Grass Seeds Continued on Next Page 


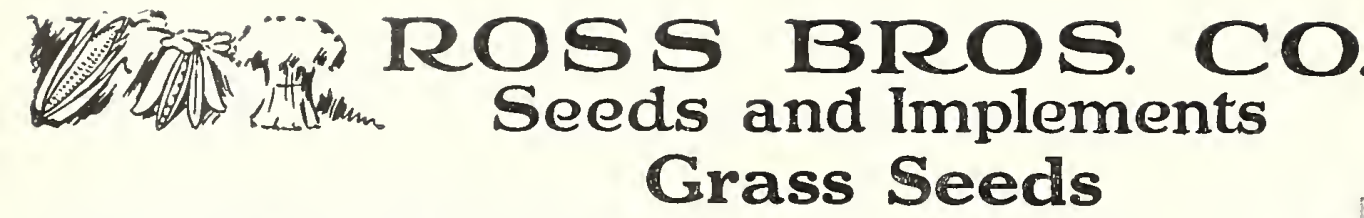

PACEY'S RYE GRASS. Used extensively in lawn mixtures. Valuable because of its quick growth. Ib. 25 cts., 10 lbs. $\$ 2.00$.

FANCY RED TOP, WORCESTER GRADE (Agrostis vulgaris.) Next to Timothy this is the most largely used grass: it is highly recommended both as a permanent pasture and as a meadow grass for hay, throughout New England and the Southern States. It will not do well in sandy or leachy soils, but it is said to be adapted to a wider range of soil and climatic conditions than any cultivated grass grown in America. Used extensively in lawn mixtures. Lb. 35 cts., 10 lbs. $\$ 2.70,100$ lbs. $\$ 25.00$.

ORCFARD GRASS (Dactylis glomerata.). One of the most nutritious and valuable grasses, early, hardy, and permanent, and thrives in all soils and situations. Bears frequent mowing and constant cropping, and is very productive. Should be included in liberal proportions in most mixtures for both mowing and pasture. Ib. 30 cts., 10 1bs. $\$ 2.80$.

TAII MEADOW OAT GRASS (Avena elatior.) A very hardy species, making an early and luxuriant growth and continuing to grow until late in the fall and is, therefore, especially desirable for pastures. It makes good hay and when used for soiling, can be cut several times in the season. Ib. 30 cts., 10 lbs. $\$ 2.80$.

TIMOTHY (Phleum pratense.) Timothy is the standard hay of commerce. The cheapness of the seed, the ease of culture, and excellent quality of the hay makes it a favorite. It is adapted to all soils, but succeeds best on moist loams and clays. The life of a Timothy field varies according to soil and climate. It produces the most profitable yields the first and second years.

WORCESTER GRADE. There are many grades of Timothy in the market and many of these are of a high purity test; but there is a vast difference in the quality of pure seed. Much of this is light seed, cleaned and recleaned until the purity is of a high percentage, almost 100 per cent pure, but still remains light seed which under the best conditions is of only fair germination. Our Worcester Grade is a seed which is of the highest quality at the start. Taken from the best flelds of full ripe seed, we can assure you, that after going through the cleaning process we can guarantee a purity of 99.50 per cent. In the Worcester brand we are offering the best seed it is possible to obtain. Iob. 15 cts., 10 1bs. $\$ 1.20,100$ lbs. $\$ 10.00$.

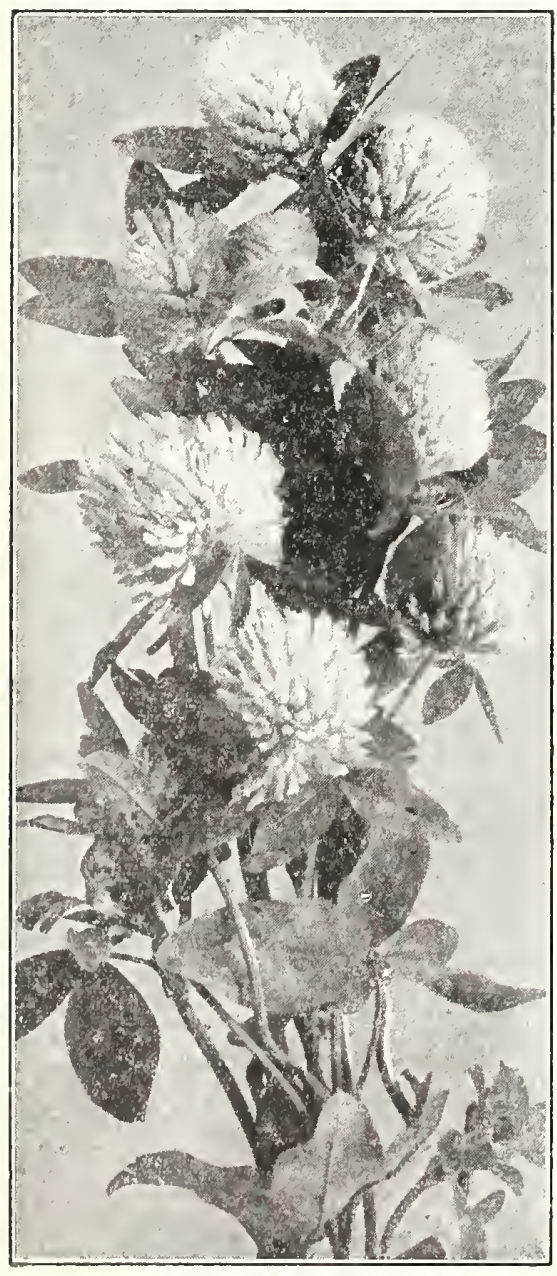

Medium Red Clover
WACHUSETT GRADE. This grade is of fine quality, better than most seed offered as prime. cts., 10 1bs. $\$ 1.10,1001 \mathrm{bs}$. $\$ 9.50$.

\section{CLOVERS}

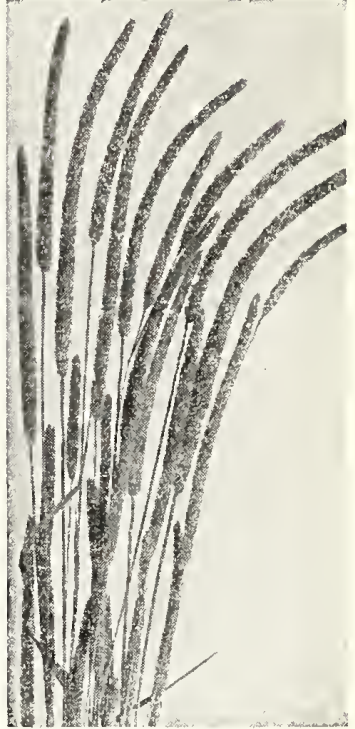

Timothy

\section{BUIID YOUR IAND WITH CIOVERS}

The sowing of clover seed is absolutely essential to proper rotation of crops and to keep up the fertility of the land.

Clovers are the basis of successful farming. Land well set in clover not only makes a good forage or hay crop, but improves the condition and productiveness of the land. In the rotation of crops, clovers are most valuable, and in all sections except possibly the extreme South, are indispensable.

Inoculate your clover with MULFORD CULTURE. SEE PAGE 8.

AISIKE OR SWEDISH CIOVER (Trifolium Hybridum.) One of the best for mixing with timothy; it is perfectly hardy in every climate or soil condition and seldom has to be reseeded. Under ordinary conditions it grows from 1 to 2 feet high; is sown early in the spring or late summer and early autumn. It is as nutritious as red clover and is rapidly coming to the front as a valuable farm crop. Flower resembles white clover except head is larger and has a red tinge on the edge. Sow 10 to $15 \mathrm{lbs}$. per acre alone, or $8 \mathrm{lbs}$. per acre with timothy. Ib. 50 cts., 10 lbs. $\$ 4.50,100$ lbs. $\$ 42.00$.

CRIMSON CIOVER (Trifolium Incarnatum.) This is used principally for soiling or green manuring, for which purposes it is highly valuable. If desired for feed, cut it just before it flowers. When desired for green manure, it should.be allowed to mature; its height is from 1 to 2 feet. Sow any time from April to October, the earlier the better, $20 \mathrm{lbs}$. to the acre. If sown in early spring it can be plowed down the first year. Late summer or fall seeding is usually practiced. It is not hardy and must be sown each year. Ib. 25 cts., 10 lbs. $\$ 2.00$, 100 ibs. $\$ 18.00$.

MAMMOTH RED CIOVER (Trifolium Pratense Perenne.) Sometimes called Sapling or Pea Vine Clover and English Cow Grass. This differs from the "Medium," being of a ranker growth and yielding more fodder per acre. It ripens somewhat later and is more hardy, lasting several seasons longer than the medium red clover. It also does well on poorer soils. The seed cannot be distinguished from the Medium Red. Our supply, however, is strictly reliable. Sow in early spring or in July and August, using $20 \mathrm{lbs}$. per acre alone, or with other crops $10 \mathrm{lbs}$. per acre: flowers pink. It can be cut several times in a season. Ib. 52 cts., 10 lbs. $\$ 4.70,100$ lbs. $\$ 44.00$

MEDIUM RED CLOVER, AMERICAN GROWN (Trifolium Pratense.) More widely known and used than any other; used principally for hay purposes. Height from 18 inches to $2 \frac{1}{2}$ feet. Sow early in the spring or in late summer-July and August: if alone, 20 lbs, per acre: if with other crops, $10 \mathrm{lbs}$, per acre. A red clover fleld can be cut twice a season. It is usually resown every third season: flowers pink. Ib. $50 \mathrm{cts}, 10 \mathrm{lbs}$. \$4.50, $100 \mathrm{lbs.} \$ 42.00$. A,sk for price on imported seed.

WEITE DUTCF OR IAWN CIOVER (Trifolium Repens.) This is valuable for pasturage as well as for lawns: it succeeds where other clovers and grasses fail, and it seldom dies out. It can be sown at all seasons, although early spring is best; flowers greenish white. Sow 10 to $12 \mathrm{lbs}$. per acre if alone, or $5 \mathrm{lbs}$. if sown on old turf or with other crops. $1 / 41$ b. 20 cts., $1 / 2$ Ib, 30 cts., 1b. 50 cts., io libs. or over 45 ctis. per 1b. 


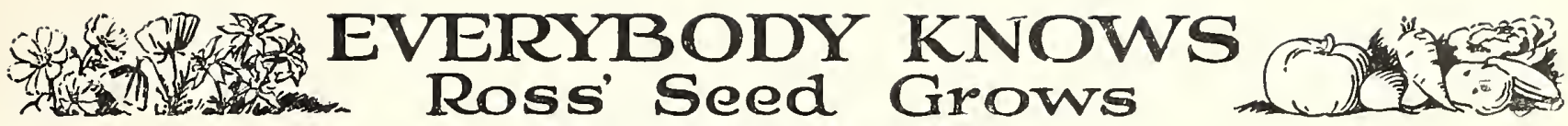 Sweet Clovers}

BOKHARA OR SWEET CIOVER (Melilotus Alba). This is a native of all parts of the United States and Canada and is a valuable addition to farm crops. It is an erect branching biennial plant with woody stems growing the first season two to three feet high and developing a large root. The second year's growth usually reaches a height of four to seven feet. It bears seed the second season and then the plant dies, so it is easily controlled by cutting before the plant goes to seed, which will prevent any seed being self-sown. Sweet Clover grows in a variety of soils, in fact will thrive in any but an acid soil and is a splendia crop for plowing under, as it supplies so much humus and nitrogen to the soil. Sow 15 to 20 pounds per acre. Ib. 20 cts. 10 lbs. or over 16 cts. per $1 \mathrm{~b}$.

HUBAM ANNUAI SWEET CIOVER. This Clover has been grown successfully in every State in the Union, also Canada and Europe. Will yield well on any soil of average fertility that is not sour. Hubam makes as much growth in four months as the biennial does in fifteen months. It grows $4 \frac{1}{2}$ feet high and will produce pasture in a little over 30 days and a hay crop in three months. I.b. 45 cts., 10 1bs. or over 40 cts. per $1 \mathrm{~b}$.

\section{MILLETS}

The varieties of Millet are among the oldest of cultivated grains. A large part of the world's inhabitants subsist upon the different Millets, especially in Africa, Turkey; Persia, India and Japan. However, in our country we are chiefly interested in the use of Millet as a stock food. Millets are especially adapted to regions of light rainfall and hot weather. They are used principally for forage, being very valuable where Timothy is an uncertain crop. The hay is fed most satisfactorily in dairy cows and sheep. In feeding value it ranks well above Timothy.

\section{Hungarian Millet}

An excellent food for horses when cured

This is commonly known as "Hungarian Grass." Each root sends up several slender stems which often branch. The leaves grow upright, rather narrow. Heads are borne erect or nearly so, about four inches long, dark purple in color, bristly and very compact. The seeds are brownish black mixed with yellow. This varlety withstands drought remarkably well. If 1 ts growtl is checked by dry weather the least rain will restore its vigor. It flourishes in light, dry soils, but does best in good soils, well manured. This gives a very fine quality of hay

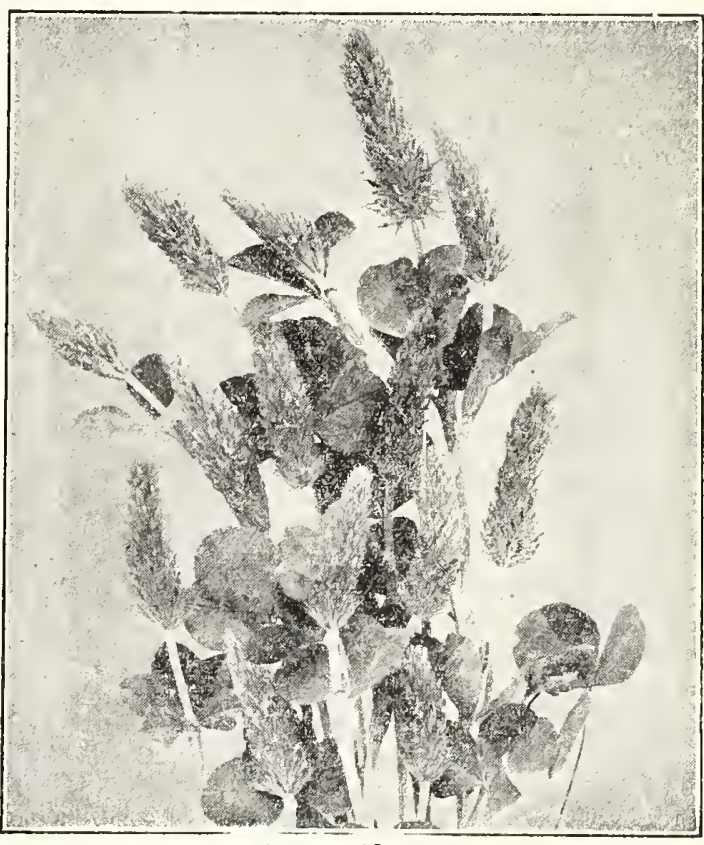
on account of its, slender, leafy growth. Price, lb. 12 cts., 10 1bs. 95 cts., 100 1bs. $\$ 8.50$

\section{Tennessee Golden Millet}

This variety is extensively used throughout the United States, as they find it more nutritious in value for feeding. It is grown' at the same time and at the same rate per acre as the common Millet. Growers once using the Tennessee Cultivated Millet will never plant any other kind. Grows more vigorous, gives a much larger yield of hay. Growing Millet with Whippoorwill or New Era Cow Peas is becoming quite popular, three pecks of Millet being sown with a bushel of Cow Peas.

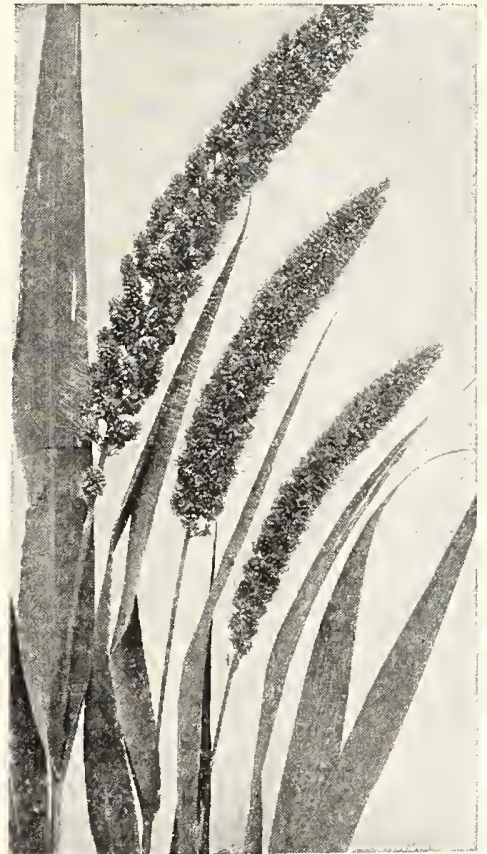

Japanese millet

Price, 1b. 12 cts., 10 1bs. 95 cts., 100 1bs. $\$ 8.50$

Japanese Millet (Panicum frumentacea)

(Villet now cultivated in the United States has descended, was brought to Amherst from Northern Japan by William P. Brooks, Director of the Massachusetts Agicicultural Experiment Station, in 1889. Prof. Brooks, who had become impressed with the great value of the crop for forage, began distributing seed in small quantities to private farmers in various parts of the state. The success of the crop was immediate.

It is entirely distinct from all other millets. It grows from 6 to 9 feet high, stands up well and yields enormous crops. When cured it makes good hay and in quality is superior to corn fodder. It is relished by all kinds of stock and is rich in milk producing qualities.

Japanese Millet stools freely, it is very leafy and the heads are compact. It will thrive best on moist, rich soil as it does not endure drought well. Like all coarse growing plants, it needs abundant plant food and when given this on good soil the yield is immense.

The seed of Japanese Millet never has long awns and is a dark brown color, while the Barnyard Grass is usually long awned and dark gray color, by which it is easily distinguished. Ib. 15 cts., 10 lbs. $\$ 1.25,100$ lbs. $\$ 10.00$.

\section{SUDAN GRASS}

\section{What Sudan Grass Is}

It is the most prolific and dependable hay crop in the area of limited rainfall in the North and West Introduced into the United States by Professor C. V. Piper of the Department of Agriculture, in 1909, it has surpassed the fondest expectations and undoubtedly will replace the millets over a large area where the latter are hay producers at the present time.

If planted in drills, cultivate often and shallow. The roots grow near the surface, and deep cultivation after the plants get well started will cut off a large proportion of the roots and reduce the yield. The cultivation may be done with the ordinary corn cultivator. Keep the soil well worked until the plants cover the ground so that weeds will not grow.

Sudan, growing as it does frequently as high as 9 feet, when planted in rows and cultivated, and 4 to 5 feet when sown broadcast, exceeds any other grass in yield. For a grass it ylelds are nothing short of miraculous, often reaching seven tons per acre, seldom running less than four tons.

The Sudan is a hot weather crop and will produce the largest yields during a season of high temperature.

The quallty of the hay is exceptionally high, chemlcal analysis showing 1 t to be of equal value with Timothy and Johnson Grass. It is equal to Millets in feeding value and gives much heavier yield. The hay is nutritious, palatable and highly relshed by stock. I.b. 15 cts., 10 lbs. $\$ 1.25$, 100 Ibs., $\$ 10.00$, 

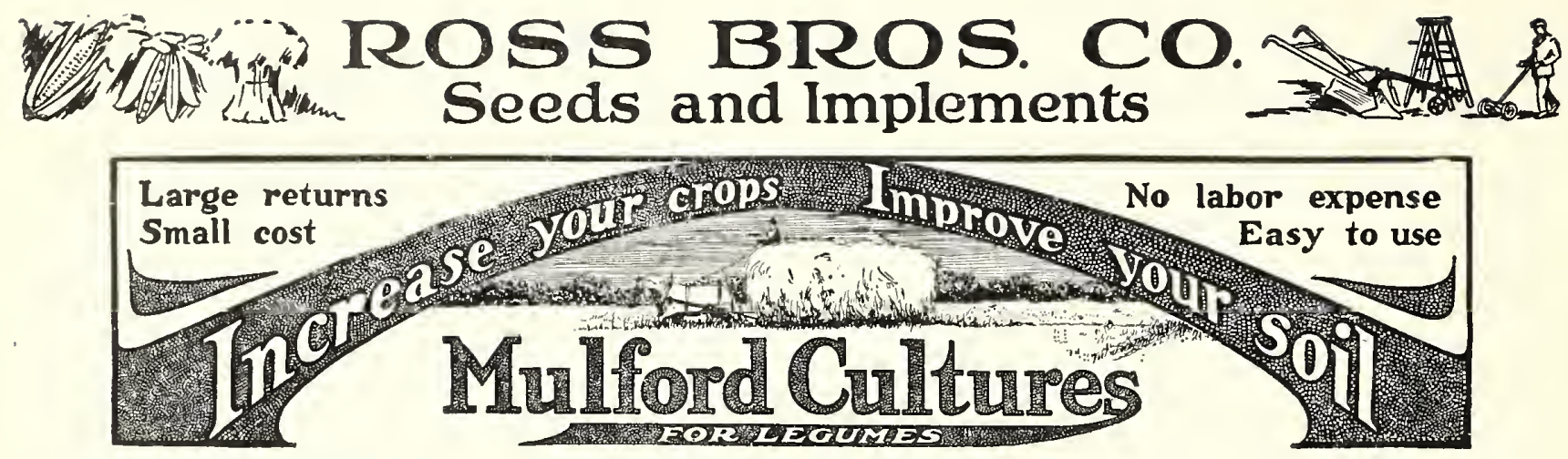

To maintain soil fertility every crop rotation should include legumes. To get the best returns from legumes, inoculate the seed with Mulford cultures. They increase the yield and improve the quality. More nitrogen is draty from the air by inoculated legumes than of the succeeding grain crops. Up-to-date farmers inoculate these crops and insist on the best-Mulford cultures.

Mulford Cultures are scientifically prepared and tested in the world's largest biological laboratories. Sealed containers insure purity, longer life, and a more effective culture.

Easiest cultures to use-simply mix with water and add to seed. Most economical. Insure best results. Cheaper than any nitrogenous fertilizel you can buy Agricultural experiment stations everywhere recommended inoculation.

The date on the package is your protection. FOR SMALI. SEEDS

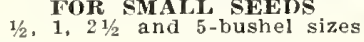

Red Clover

Crimson Clover Mammoth Clover

Alsike Clover

White Clover

Berseem Clover

$1 / 2$ bushel size

bushel size.

$5^{1 / 2}$ bushel size Alfalfa

Sweet Clover Hubam Clover Yellow Clover Burr Clover Salinfoln

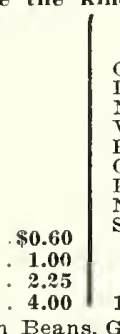

FOR LARGE SEEDS

$1,2,5$ and 10-bushel sizes

$\begin{array}{ll}\text { Cow Pea } & \text { Wax Bean } \\ \text { Lima Bean } & \text { Field Pea } \\ \text { Mung Bean } & \text { Sarden Pea } \\ \text { Velvet Bean } & \text { Hairy Vea } \\ \text { Peanut } & \text { Perennial Vetch } \\ \text { Garden Bean } & \text { Spring Vetch } \\ \text { Kidney Bean } & \text { Soy Bean } \\ \text { Navy Bean } & \end{array}$

Soy Bean 1 bushel size. 2 bushel size. 5 bushel size. 1.00
2.25 4.00 noculate all legume crops with Mulford Cultures to get the best, most natural, economical and lasting form of nitrogen for the soil.

FREF DESCRIPTIVE FOLDER UPON REQUEST

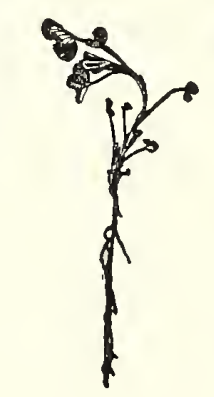

Alfalia plant on lert not inoculated. Plant on ford Culture for All other conditions idenAll other conditions idenfor itself.

\section{A L F A L F A}

Growing Alfalfa is dependent on the grower himself. It's an easy crop to grow if proper precautions are taken, but it's absolutely necessary to buy fresh new crop seed of the very best quality. It is necessary to have a good seed bed. It is necessary to inoculate the seed. It cannot be sown on sour or acid soil without liming. An Alfalfa stand can only be secured by careful attention to above. Any above reasons will keep you from success.

Just bear in mind that the Alfalfa plant produces an enormous root growth, these roots penetrate the subsoil to a great depth, lessening the potash stored below, making it available as plant food in such a manner as is impossible to duplicate with a plow.

NORTHERN GROWN SEED. Very hardy. We guarantee this to be 99 percent pure-and absolutely free from dodder and tree-foil. Price, 1b. 40 cts., 25 1bs. or more 35 cts. per Ib.

GRIMM AIFAIFA. So called from the fact that it was introduced in Minnesota by a Mr. Grimm from Europe, who called it Norwegian Alfalfa. This strain of Alfalfa has proven superior to all others, coming through our most severe winters without being injured, where the ordinary strains sometimes suffer severely. The most important feature connected with the introduction of the Grimm Alfalfa is its spreading root and crown. Its spreading root allows it to be grown on land which has a subsoil that is impossible for roots to penetrate; while lts crown being broad allows closer cropping or cutting without injury. We are able to supply True Grimm Seed. Price, 1b. 65 cts., 10 1bs. or more 56 cts. per 1b. CANADIAN VARIEGATED AIFAIFA. A very hardy strain of Alfalfa, developed in Peel County, Ontario, Canada, a cross between the Grimm and common strains. The root system is between the Grimm and common Alfalfa. It does not spread as much as the Grimm nor does it have the long tap-root of the common. It is adapted to our New England States and as much as the Grimm nor does it have the long tap-root of the common. It is
all sections in the same latitude. Price, 1b. $40 \mathrm{cts}$., 10 1bs. or more 35 cts. per lb.

\section{Barley}

For grain, 2 bushels to the acre; for forage, 3 bushels. 48 lbs. to the bushel.

BEARDIESS. Farlier than any of the bearded varieties and is generally considered more hardy. The straw is heavy and stands up well under a large crop. Very popular for forage and especially valuable for hay as the heads are entirely free from beards which when dry are thought to often be injurious to cattle. Pr. 80 cts., bu. $\$ 2.75$.

CHEVAIIER. A two-rowed variety. Head is a little longer than the six-rowed varieties and the grain is larger, plump. extra-heavy and in favorable seasons nearly white. On account of its attractive appearance and fine quality the grain brings the highest price, while the variety is extensively grown for green forage. Pk. 75 cts., bu. $\$ 2.50$.

MANSURY. In our section this six-rowed variety is largely grown for forage. It yields abundantly. It is early and very vigorous in growth. The straw is strong and stiff and seldom lodges. The heads are long and well filled. Pł. 75 cts., bu. \$2.50.
WIITE HUILESS. About two weeks earlier than the common type. The grain closely resembles wheat, is about as heavy and is said to be nearly equal to it in feeding value. It has neither hulls nor beards. It is very productive, yielding better on poor soils than other varieties, and gives enormous crops on good land, greatly outyielding wheat under equal conditions. The straw is heavy, with good leaves and makes excellent forage. Choice Northern grown seed. Pk. 85 cts., bu. $\$ 3.00$.

\section{Buckwheat}

For grain, 1 bushel to the acre; for solling, $1 \frac{1}{2}$ bushels. 48 lbs. to the bushel.

JAPANESE. This is entirely distinct from all other varleties. It has the advantage of remaining some time in bloom and produces seed earlier. On this account it can be grown farther north. It resists drought and blight better than most varieties. The seed is larger than the
Silver Hull and is a rich brown color. Pk. 70 cts., ba. $\$ 2.35$. 


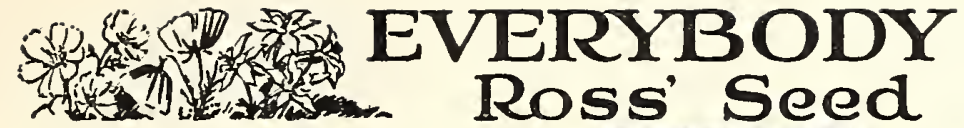

Cow Peas
MULFORD CULTURE
SEED WTH

KNOWS

\section{Grows}

Peas, Canada Field

Mulford Culture for Cow Peas, See Page 6

In arills 1 bu. to acre. Broadcast, $2 \mathrm{bu} .60 \mathrm{lbs}$, to br.

Cow Peas produce enormous bulk and for this reason the plant is a favorite with some as a forage plant and also as a humus maker when plowed into the soil. It is, of course, like all the legumes, a soil enricher as well. The Cow Peas will grow on all kinds of soils from stiff clay to sand, barren uplands, and used either as green fodder, hay or as silage, the product ls of high feeding value. While for plowing under on stiff clay soils the growth should be turned under while green, it is generally considered that on light sandy land the vines should be allowed to partially decay on the surface before they are plowed into the soil. All crops seem to do well after Cow Peas.

NEW ERA. An old stand-by which makes splendid hay. Matures in 60 to 75 days and does splendidly as far north as Minnesota. Vines are smaller than other varieties and are more easily cured. Pk. \$1.40, bu. \$5.00.

WIIP-POOR-WII工. A medium-early variety, vely desirable for a forage crop and for rebuilding worn out land. A very prolific yielder and the most commonly used variety for planting broadcast. (Sold out.)

\section{Selected Seed Oats}

Sow 3 Bushels Per Acre. Price Includes Bags All Prices Subject to Market Changes

Oats and Canada field peas make the best green crop to follow clover. Generally it is advisable to make three sowings; the first as early as possible in the spring, April 20 to 25 , and the second and third fifteen and thirty days later One and one-half bushels each of the oats and peas is the usual quantity to the acre.

The first sowing will be ready about June 25 and cuttlng should begin as soon as the oats show the head. The average yield from the first sowing is 10 tons to the acre. The yield from the second and third sowings is not likely to be as heavy, as the crop matures quickly during the warm weather Oats and peas remain in condition to be cut for 10 or 12 days. CANADA PEAS may also be sown with other grains as well as with oats, and are sometimes sown in August with Barley. They are also sometimes sown alone. Choice stock

for seed. Ib. 12 cts., 10 lbs. or over 9 cts. per lb.

\section{Dwarf Essex Rape}

It is an annual bearing a close resemblance in leaf and stalk to the Rutabaga, but both leaves and stalks are more numerous in the Rape plant which may be eaten off by any klnd of live stock, but it is pre-eminently fitted to furnish pasture for sheep, cattle and swine.

Culture. Rape is best adapted to moist, rich soil in whlch there is plenty of humus. Slough lands are especially good. It grows best in cool, moist weather and the time for sowing depends upon when the crop is to be used. When wanted for pasture, allow $\&$ to 10 weeks for it to attaln maximum growth. Sow 1 to 2 pounds of seed per acle in dills and cultivate, for a weed-cleaning crop. For broad-casting, use 5 pounds per acre on rich, weed-free soil, so that the Rape will not be choked by weeds.

For continued hog pasture, sow Rape early and at successive intervals. It may well follow any grain crop and is always splendid to plow under for green manure. Ib. 15 cts., 10 ine, or over 12 cta. ner ib.

It pays to buy the best, whether you wish to cut for green feed, for fodder, or ripen for grain.

Any one of the varieties we offer will produce enough more feed to many times over pay for the difference in price. This has been proved by actual test and we are confident that in the stover, alone, you will get enough more feed to more than pay the difference in the price of the seed. You also get heavler and plumper heads filled with grain that will produce milk at a lower cost than almost any kind of green feed.

All we ask is a triai, and we are confident that you will be convinced that we are right.

\section{Ross "Swedish Select" Fxtra Re-cleaned Seed}

The same strain we have offered for the past several years.

Introduced a few years ago by U. S Department of Agriculturt and today the most largely planted of all varieties in the Northern Central States. Briefly described the oat is pure white in color: the hull is thin and the kernel large and plump; straw is stiff and strong enough not to lodge. A remarkable root development makes the Swedish Oat a good drought resister-a special feature on light soils. Season nedium early and the earliest of the heavy yielding sorts. Especially suited to high land. Pk. 40 cts., br. (32 lbs.) $\$ 1.35,10$ bu. or inore $\$ 1.30$ per ba.

\section{Long's White Tartar Oats \\ THE IDEAI SIDE OAT FOR AMIERICAN FARMERS}

The earliest, heaviest and most prolific domestic-grown Side Oat in cultivation. It is suitable for all soils; of robust and vigorous constitution, is remarkably early and an immense cropper; the straw is long and stout, stands up well and does not readily lodge or twist. The heads measure from 8 to $101 / 2$ inches, and the kernels are of immense size, thick, plump and heavy; it is undoubtedly the heaviest cropping domestic white Oat ever offered.

Its extreme earliness, great length and strength of straw, thick, plump grains and the heavy yjelds it is capable of producing give Long's White Tartar all the necessary qualifications which go to make an ideal Oat. Sow 3 bushels.

We have only a few hundred bushels of this variey but will fill orders as they are received as long as the supply lasts. Pk. 65 cts., bu. (32 lbs.) \$2.25.

Irrcors OATs. Similar in type to the Swedish Oats. A heavy yielding varlety with straw which stands up well, used for grain or for green feed. Pk. 45 cts, bu. (32 1bs.) $\$ 1.60$.

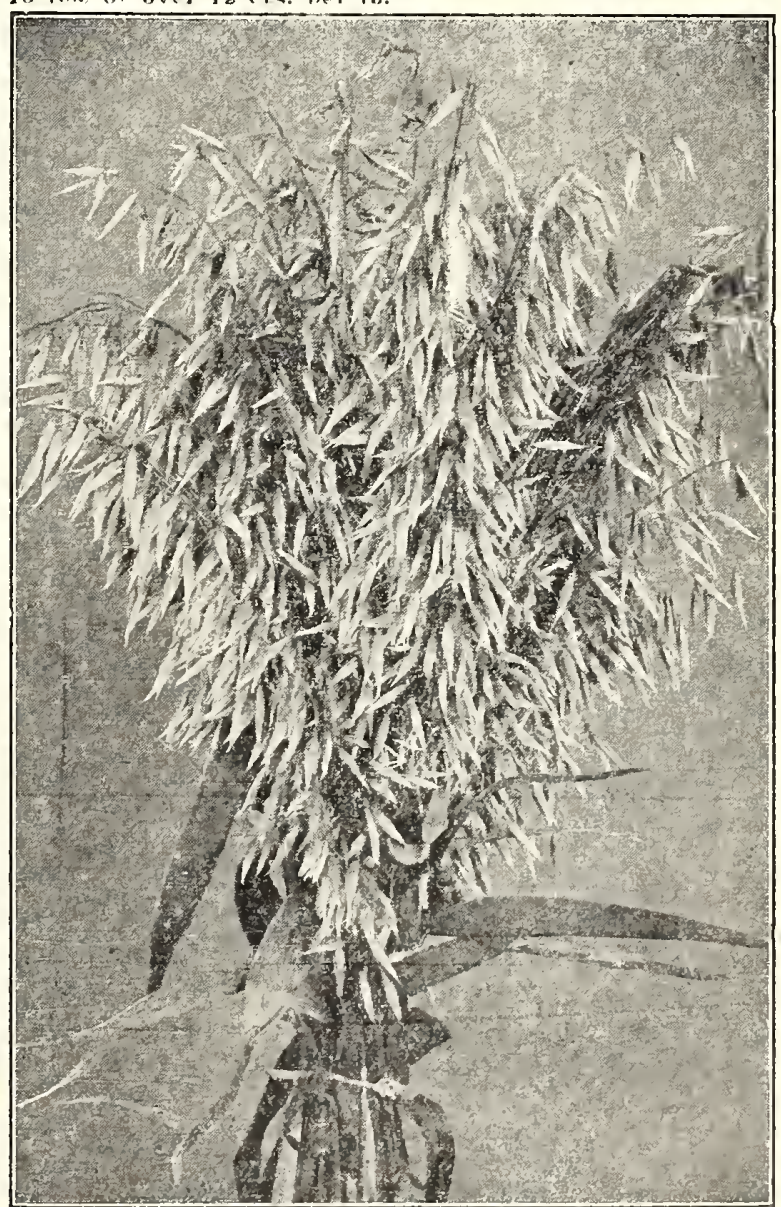

Bwodian select Oars 


\section{Rye}

For grain, $1 \mathrm{bu}$. to the acre, for forage or solling $1 \frac{1}{2} \mathrm{bu}$. 56 1b8. to the bu.

\section{Spring Rye}

True Stock, spring Rye makes an excellent crop where winter grain has been killed out, or for sowing where a fall crop has not been planted. If desired it can be turned under and made to answer a good purpose in adding to the fertility of the soil. Sow seed same time as other spring grain. Does not grow quite so large straw as Winter Rye, but usually yields well and grain is of fine quality.

We wish to emphasize the fact that we sell the genuine Spring Rye, sown in the spring and harvested the same season. $\mathbf{P k} .90 \mathrm{cts.}$ bu. $\$ 3.25$.

\section{Rosen Winter Rye}

To Prof. Spragg, of Michigan Agricultural College, is due The credit for developing this most remarkable grain, which we believe is destined to add many thousands of dollars annually to the value of farm crops in the United States.

A Russian student of the Michigan Agricultural College brought with him from Russia a handful of rye which he gave to Prof. Spragg, who planted it, and from the crop selected a single plant which showed exceptional characteristics. The grain from this plant was saved and planted the istics. the most promising type, repeating this process from year to year until he had sufficient seed to parcel out among a few expert farmers in different sections, at the same time continuing it as a crop at the State Experimental Farm in Michigan, where for three years the average yield has been $\mathbf{4 1 . 3}$ bushels per acre.

The development of Rosen Rye has been of such a character and the present supply has been so carefully handled, that it is safe to say it is the purest pedigree seed in that growers have taken particular pains to prevent cross fertilization and mixing with other grains.

Rosen Rye produces a strong vigorous straw and stools to a remarkablc degree. The grain is large, plump, heavy and of a beautiful color, , smmanding a premium on the market over other grains. O ving to its vigorous stooling property less seed is required, the practice being about one and onehalf bushels per acre. We believe that Rosen Rye is cheaper to sow even at double the price of common rye, for the excess yield will more than pay for the seed, not to mention the better quality and high price to be obtained for the crop. Price, Plr. 70 cts., bu. $\$ 2.45,10$ bu. or over $\$ 2.40$ per bu.

\section{Mammoth Russian Sunflower}

\section{For the Silo}

We believe every farmer, stockman and dairyman who must grow feed crops should plant a small area with sunflower. Start now to become familiar with this crop, which is destined to be a prominent fecd in economical stock feeding. Sunfower experiments have demonstrated it to be peculiarly suited to dry seasons, and producing immense tonnage even under unfavorable conditions. In feeding value, sunflower cut in bloom is fully equal to corn cut green for silace Cattle, sheep, swine and horses find it very palatable. Sunflower silage will keep for several years. Best results are secured by planting in rows 30 to 36 inches apart, drilled four to six inches apart, in the rows. Sunflower can safely be planted at corn planting time, or a trifle earlier, using an ordinary grain drijl. When planted in 36-inch rows, four or flve inches apart in the row, it requires 10 pounds of seed.

Harvest similar to corn. A corn harvester can successfully be used. Best time to cut is when from fifty to eighty per cent in bloom. The great value in sunflower for ensilage lies in its ability to produce big crops in dry hot weather and the small acreage necessary to produce large tonnage any season.

Particularly suited to the high altitudes, as it seems to grow right along during cool weather when corn growth seems to have stopped. Withstands wind better than corn. Lb. 15 ct8., 100 1bB. $\$ 12.00$.

\section{Soy or Sojo Beans}

\section{INOCULATE THIS \\ SEED WITH \\ MuLFORD CuLTUKE}

$1 / 2$ to $3 / 4$ bushel to the acre in arlils $2 \frac{1}{2}$ to 3 feet apart

This is another valuable legume, growing in favor for forage and ensilage, often succeeding well on land too light for clover. While it has not been so generally grown in this country as the Cow Pea, it is considered by some preferable for the North, as it does not require so long a season.

BLACI WIISON. Medium size, black seed. Considered the best all-around variety for the North. Of rather upright growth, with a good amount of foliage and a slight tendency to vine on fertile soil. Matures seeds in 125 days and is ready for cutting in 110 days. A heavy seed producer. Pk. $\$ 2.30$, bu. $\$ 4.75$.

ITO SAN. Ito San Soy should ripen anywhere in the Northit is Northern Grown Seed. Northern Grown Seed sown in the South produces larger yields, stronger vines, higher nutritive value. Matures in 90 days, grows $2 \frac{1}{2}$ to 3 feet high. Immensely productive. (Sold out.)

MIEDIUM EARIY YEIIOW. The largest growing and most Dopular Soja Bean for forage purposes, although a little later in maturing than the other varieties. Pk. \$1.00, bu. $\$ 3.75$.

\section{Vetches}

One bushel to the acrs; with oats or rye, $1 / 2$ bu., 60 lbs. to bushel. Use Mulford Culture for Vetch, See Page 6

SPRING VETCR, or SPRING TARE. This, like Field Peas, is used for both green fodder and for plowing into the soil. In this latitude it can be sown only in the spring and is more largely used in this season than the Hairy Thriving on rather poorer soil than Canada Peas, its use is rapidly increasing as a green fodder. Ib. 15 cts., 10 lbs. or over i2 cts. per $1 \mathrm{~b}$.

WINTER SAND, Or HAIRY VETCE (Vicia villosa.) While this will be of much larger growth on good soil and should be grown on such soil when the crop is designed for green fodder or hay, it thrives remarkably well on light, poor soil. Though it produces on good land an enormous crop and whether used green or as hay is more nutritious than Clover and readily eaten by all kinds of stock and is therefore a profitable crop to grow for feeding, it is perhaps of greater value for other purposes. No other legume surpasses it as a nitrogen gatherer and no other equals it as a cover crop. It is perfectly hardy, remaining green all winter and is therefore much superior to Crimson Clover ibs. $\$ 1.80,100$ 1bs. $\$ 16.00$.

\section{Wheat}

$11 / 2$ bu. to the acre, $601 \mathrm{lbs}$. to the bu.

MARQUIS SPRING WHEAT was originated by Chas. and William Saunders of Ottawa, Canada, by crossing Red Fife and hard Calcutta, a native wheat of India which has become acclimated to northern conditions. The first experiments were conducted in 1886 and it was not until 1903 that it was fully developed. By scientific cross breeding. a variety was produced that inherited the remarkable earliness of the Calcutta, and the frost-resistant and yielding qualities of the Rerl Fife. The original stock of seed was very small, but by careful husbandry the amount was gradually increased so that it might be disseminated throughout America. It has outyielded all other Spring throughout America. It has outylelded all other Spring climate, the increased yield being up to 10 bushels per acre. Marquis Wheat is flinty and dark in color being almost dark red. It is a beardless variety having a smooth yellow chaff. Price, pk. 90 cts., bu. $\$ 3.50$.

WINTER WHEAT. The yield of winter wheat per acre is on the averagc very much larger than any of the spring wheats. It should be sown early in the fall to secure a good firm root to survive our New England winters. Winter Wheat makes an excellent green feed, coming very early in the spring and staying in condition for feed much longer than Spring or Winter Rye.

TONDIKE. A remarkably productive bald white variety large and plump. Excellent for green feed. Price, pk. 95 cts., bu. (60 1b8.) $\$ 3.50$. 


\title{
Dent Corn
}

\author{
$\Delta$ il pricen in this catalogue are vubject to change without notice.
}

\section{Improved Leaming}

The True Improved Leaming which we offer is a pure, flxed, and distinct variety, having been bred for earliness of maturity, size, shape and color, also for the amount of grain that each ear will produce, and in doing this the fact is brought out that the True Leaming is second to none (save our Eureka) in the amount of silage that can be grown per acre.

While Leaming Corn is not grown extensively in our New England States to maturity it is perhaps grown for sllage to a greater extent than any other dent variety except our Eureka. It ranks as one of the early dent corns, has a very heavy stalk growing twelve or thirteen feet high and very leafy. The ears are eight to ten inches long, filled with medium sized but deep kernels which when dry perhaps approach more closely in hardness the flint type than any other dent corn. Price, pk. 80 cts., bu. (56 1b-s.) \$2.75, 10 bu. or over, $\$ 2.65$ per bu.

\section{Worcester County Sweepstakes}

It is a big yellow Dent Corn, stalks very large, $11 / 2$ to 2 inches in díameter, growing 12 to 15 feet high, foliage is long, broad and heavy, starting well down to the ground with an abundance of leaves and produces 15 to 25 tons per acre. It will mature in 120 days and in this latitude when ready for the silo carries an exceptionally heavy crop of ears in the milk stage, making the variety ideal for this purpose. $1 / 2$ pk. 70 cts., pl. $\$ 1.25$, bu. $\$ 4.50,10 \mathrm{bu}$, or over $\$ 4.40$ per ba.

\section{Minnesota No. 13}

This dent corn has been a surprise to its users on account of its extreme earliness. The ears are not as large as some other varieties, but its large production of ears makes it a heavier yielder than most others.

The ears are of handsome appearance, bearing 16 to 20 rows of bright, rich yellow, smooth wedge-shaped kernels packed closely on the cob from butt to tip. The ears average eight inches in length and are borne usually two on a stalk. No corn excels in quality the Minnesota No. 13; the cobs are well fllled and the individual kernels, plump and of good color.

Minnesota No. 13 thoroughly matures in ninety days when planted on favorable soil and in a good location, but ninety-five to one hundred days places it out of danger under average condition. It may be planted as late as the second week in June and yet safely mature a crop. Price, pk. 75 cts., bu. $\$ 2.75,10$ bu. or over $\$ 2.65$ per bu.

\section{White Cap Yellow Dent}

Nearly as early as the Pride of the North with larger ears. The introducer says he will guarantee this corn to mature in ninety to ninety-five days from planting and to produce a larger crop on poor soll than any other variety. Stalks eight to nine feet high, with an abundance of foliage. Ears about eight inches long, sixteen or eighteen rowed, and well filled with deep kernels, the outside ends white, the balance light yellow, which gave it the name

"White Cap." The early and great production of ears and abundant foliage should make this a popular variety with those who desire ears well advanced toward maturity at the season for cutting for the silo. Price, pk. 75 cts., bu. $\$ 2.75$.

\section{King of the Earliest}

This dent variety, a selection from the Pride of the North, made by the originator of that variety, is from ten days to two weeks earlier, which we think makes it safe for planting in this latitude for the purpose of maturing grain. The cob is small and although the ears are not long the kernels are very deep and the yield is large. We may say here that more attention is being given in the East to the dent varieties for growing for grain grow formerly and than formerly and localities $\mathrm{grow}$ almost to the exclusion of the flint type, the growers claiming a much larger yield from the dent. Prics. pk. 75 cts., bu. (56 1bs.) $\$ 2.75$.

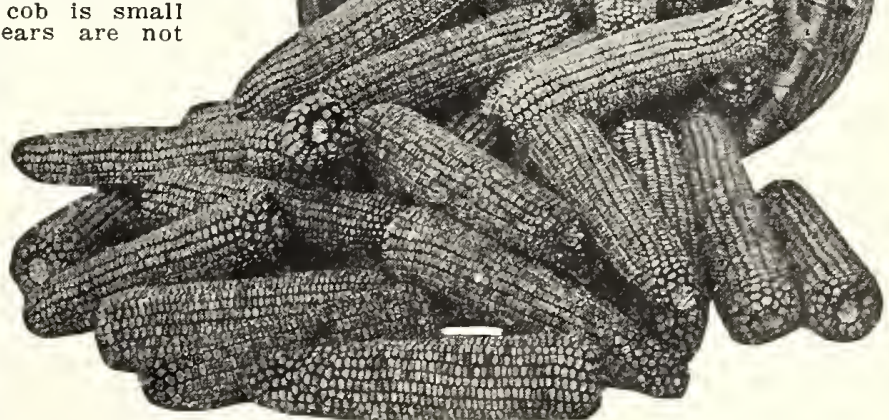
King of the Earliest 


\section{2.}

\section{The Sheffield World Prize Flint Corn}

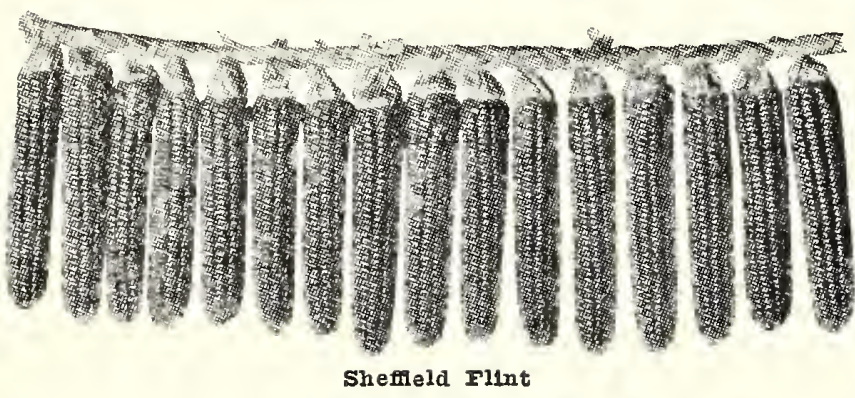

\section{SHEFTEED FORLD'} Prizk ristr cons wher we introduced in 1911, is an eariy elght-row variety which has been grown in Vermon since 1867. The seed was brought to Sheffield, Mass., and has been grown in that town ever since. The ear of this corn has a very compact form, usually well capped at the tip. similar to the improved Canada. The average length of the ear is 8 to $101 / 2$ inches; the kernels are very broad and of dark color. This corn exceeds in proportion of corn to cob any other variety Sheffieid Corn is a safe variety to piant where early frosts are expected or in states where the season is generally short. While it may be possible under favorable conditions and high fertilization to produce more busheis of corn of some of' the lon

Owihg to the fact that Sheffeld Corn will mature in a short season and also give a minimum quantity of forage, it is being used quite generally for silage in the states of New Hampshire and vermont. Price, 1/2 pk. 55 cts., pk. \$1.00, bu. \$3.85.

\section{Early Smoky Dent}

A Dent Corn That Can Be Grown in This Latitude for Grain

It is a very hardy grower and prolific yleider for so early a corn. This corn has nice leafy stalks, averaging 8 feet in height, which very often ylelds two nice ears. measuring 8 to 10 inches in length, well filled with a good sound kernel of a dark red shade, tipped with pure white, making it a very handsome corn in appearance.

It has matured in 75 days from date of planting and yields on an average of 100 bushels good sound corn per acre. This corn can be grown with success anywhere that Early Canada Fint Corn matures, as it is some ten days earlier than Early Canada.

It is the earliest Dent Corn in cultivation, is a good yielder and entirely free from disease. It is the most beautiful colored-up corn in cultivation and has been named Early Smoky Dent because cr its color. It grows strong, quick and has splendid seven to eight foot fodder. It will mature in Corn will.

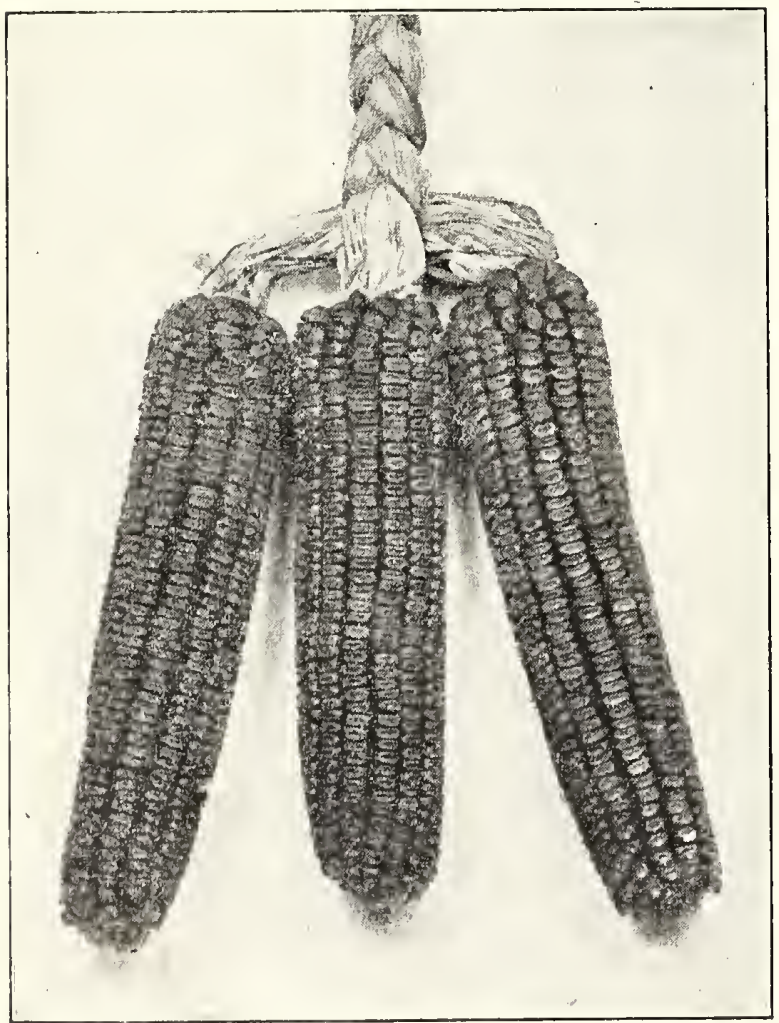

Worcester County Sweepstakes. See Page 11
We are confident that this nev Dent Corn will fill many corn cribs here in New England, where it has been almost impossible to mature a Dent Corn except in an unusual season. Price, 1/2 pk. 50 ets, pk, 90 cts., bu. $\$ 3.25$.

Gentlemen

We planted 3 bushels of your Smoky Dent and it did fine. We husked over 500 bushels and put the rest in the sllo. We were the oniy ones around here to have corn ripen. You can not beat it for eariy corn to flil the corn crib.

Yours truly.

Conety Bros.

\section{Pride of the North}

An early dent variety which has been grown in the East to some extent for grain and to a greater for ensilage. Although not of as rank growth as other varieties of this type, it is on account of its early production of ears popular with some for the latter purpose, especially with those having coid clayey soll. Pk 75 cts., bu. (56 lbs.) \$2.75.

\section{Sweet Fodder}

Unexcelled for cutting green and feeding to stock. It should be inciuded in all solling schedules. 10 lbs. $\$ 1.00,100$ lbs, $\$ 8.50$.
New York.

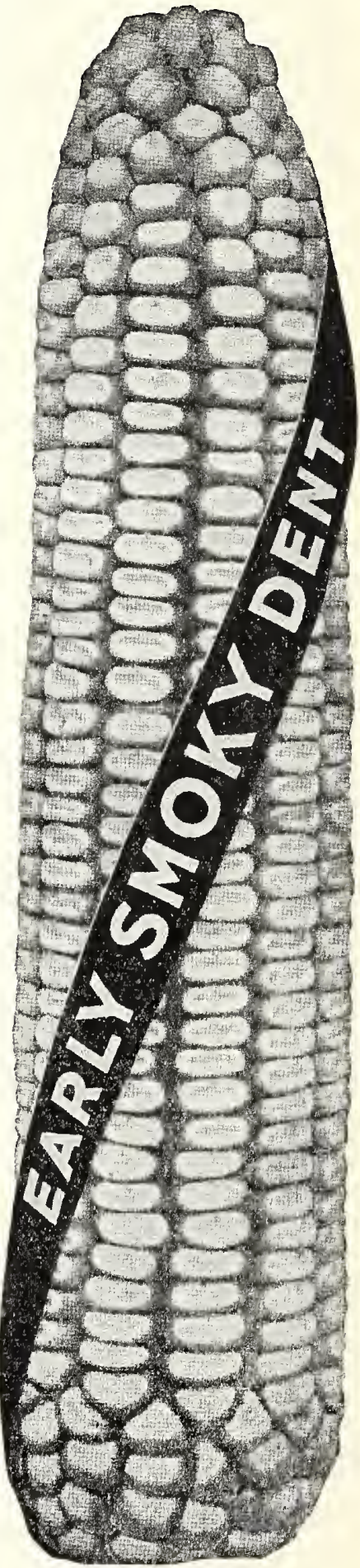




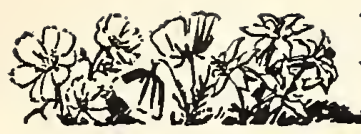 \\ EVERYBODY Ross' Seed KNOW.S Flint and Dent Corn for the Crib and Silo}

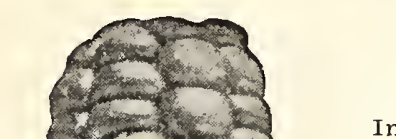

\section{Early Canada Flint}

Improved strain. This strain is in most respects identical with the original, but the ears are longer and stalks are of slightly larger growth. Ears of the original are about six inches in length while of this strain they are about two inches longer, and of similar or nearly identical strains known as Early Greenfield, Deerfield and Connecticut Valley, ears are often nine inches or longer. While in the hands of different growers the type has been largely maintained, the tendency to select larger ears has been followed by an increased growth or size of stalks making such strains later in maturing. We prefer and endeavor to procure a strain of which the ears are about eight inches long with as small stalks as possible because earlier and more distinct from other varieties, and also more desirable for light soils of only average fertility and for late planting. On stronger and richer soils there are other varieties which would probably be preferable, though because of its earliness, the more nearly certain maturity in unfavorable seasons, its great production of ears and more easily handled dry fodder it is preferred by some for planting on their best and richest land. Price, $1 / 2$ pl. 55 cts., pk. 95 cts., bu. ( 56 lbs.) $\$ 3.50$.

\section{Longfellow Flint}

This, for a long time, has been very popular in southern New England. Ears are eight-rowed and of remarkable length-12 to 14 lnches, with occasionally one 15 inches. Stalks are considerably taller than the Improved Canada, but not so large but that they make excellent and easily handled dry stover. When well-grown, owing to the long ear and occasional twin ears, the Longfellow is a very productive variety. Though two ears to the stalk are, of course, desirable, we prefer to give more attention to securing a well-formed and well-ripened ear of typical length rather than to select for breeding stock from stalks bearing two ears if at the sacrifice of any of the above mentioned qualities. The Longfellow is safe for planting in the latitude of Massachusetts and favorable seasons has yielded large crops farther north. Price, 1/2 pk. 55 cts., pk. 95 cts., bu (56 1bs.) $\$ 3.50$.

\section{Sanford White Flint}

We offer this season an exceptionally fine lot of White Flint, well grown and carefully selected for seed.

It is an eight-rowed white flint variety, the popular type in Rhode Island, being cultivated there almost to the exclusion of the yellow fint. The ear of the strain which is more generally grown there and which we offer as the Rhode Island strain, is of about the same size as the Improved Canada, resembles it very closely, except in color, having the same broad kernel and well-flled tip and ripens with or very close to it. The variety is rather more leafy than other fint varieties, which is doubtless the reason for its popularity for ensilage in the northern part of New England. The strain, however, which is more largely grown for ensilage, is seed which is grown in the West and distinctly different. The stalks grow much taller and are more leafy and the ear is much longer and later in maturing. While there are three distinct types of White Flint Corn grown in Rhode Island, we know that the straln which we offer is the most productive, yielding more bushels of corn per acre and also shelling more pounds of corn per bushel. Price, 1/2 pk. $60 \mathrm{ctz.}$., pk. $\$ 1.10$, bu. (56 1bs.) $\$ 4.00$.

\section{Golden Nugget Flint}

This is one of the most prolific varieties of flint corn. The ears will average about 10 inches in length and are well filled wlth $\&$ rows of exceptionally large, broad kernels of a light golden yellow color. These kernels are about twice as large as other flint corns.

The stalks grow from 7 to 8 feet high; are well covered with leaves and of ten produce 2 large ears each It matures in eighty-five to ninety days, making it a safe variety to plant except in the very northern latitude. Golden Nugget produces a large amount of fodder and it is of excellent quality. Price, $1 / 2 \mathrm{pk}$. 60 cts., pk. $\$ 1.10$, bu. $\$ 4.00$.

\section{Luce's Favorite}

This is a large late, semi-dent corn; 8 to 10 rowed ears, 10 to 14 inches long. The fodder is large and abundant and is used for ensilage purposes in large quantities in New York State. This variety is a much heavier yielder and better for ensilage than Longfellow Yellow Flint or any other flint varieties. We can supply true stock of this variety. Price, $1 / 2$ pk. 60 cts., pk. $\$ 1.10$, bu. $\$ 4.00$.

\section{Gentlemen:}

New York.

I have used your seeds for several years and found them good. Your Early Canada Fllnt is the best I ever raised, the only corn that got ripe in town. Sudan Grass was fine.

\section{Respectfully,}

\section{Austin A. Ross.}

Dear Sirs:- The Eureka seed corn makes splendid growth in this district. The earliest corn that I planted averaged about 15 feet high and the late about 12 feet.

I was well pleased with the seed and expect to plant twice as much this year. Most of the stalks were as large as a man's wrist. I have an ensilage cutter and filled silos here for my neighbors and I had the best corn by far that I cut. I am going to plant the corn thicker this year so the stalks won't be so large.

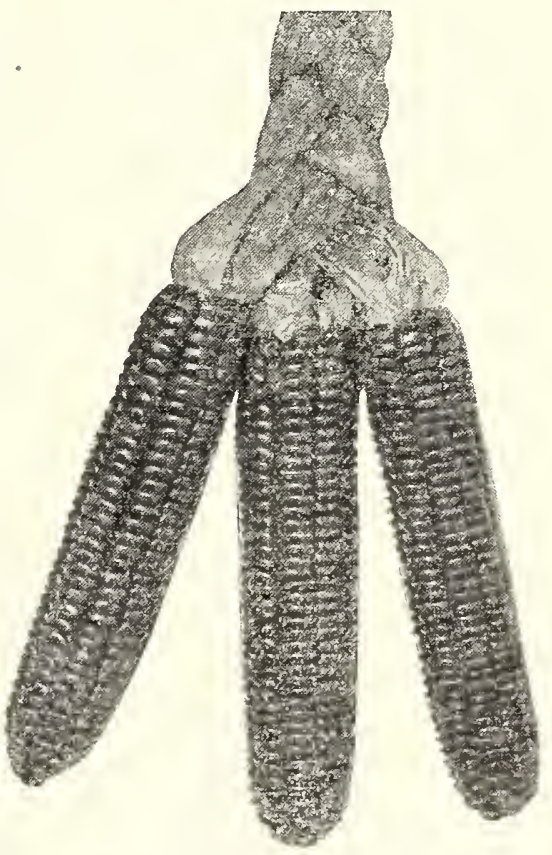

Sanford white Flint 


\section{WOSS BROS. CO}

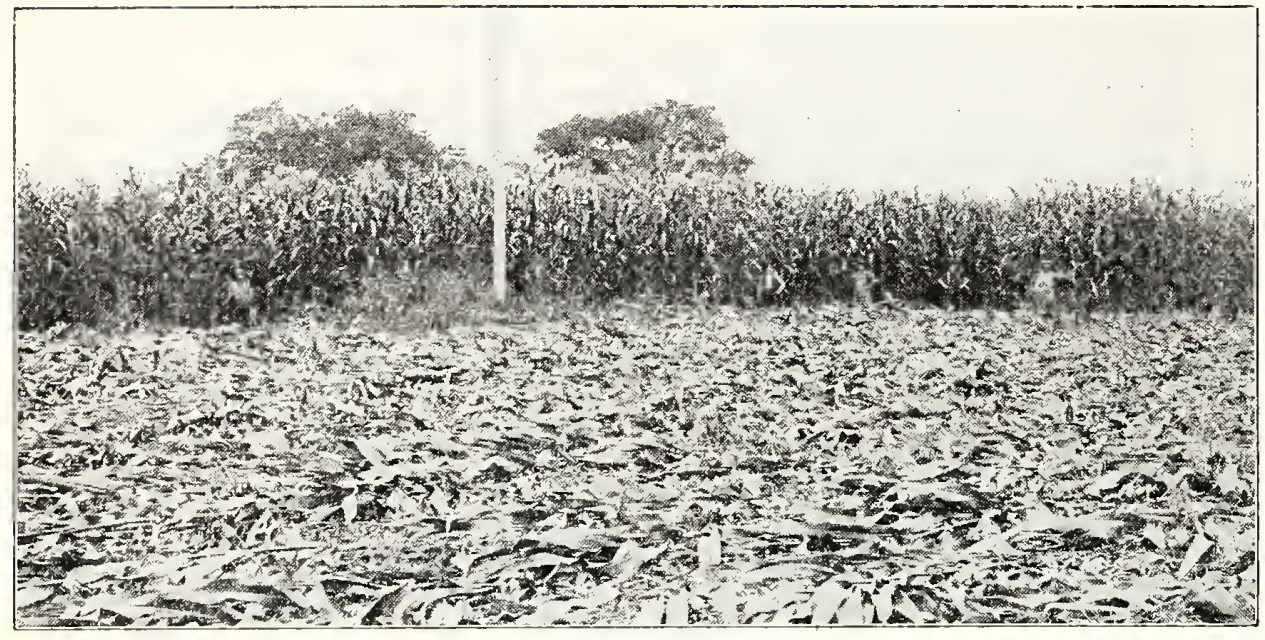

Don't buy a bushel of Eureka Corn unless it has our trade mark printed on the bag.

The season of 1928 has been very disappointing to us in the production of Eureka Seed Corn. A large acreage was planted and a fine crop was in cultivation throughout the valley where this seed is produced for us. During August, however due to excessive rains the entire valley which is the producing section for the Eureka was flooded and hundreds of acres of this land was covered with flood water for days, ruining much of the crop.

We are fortunate in having a few thousand bushels of the Eureka which was harvested from the crop left standing and this is of the usual fine quality. We suggest sending orders for the Eureka early as we do not expect our supply to last throughout the planting season of 1929 .

The genuine Eureka is a very tall growing variety often reaching a height of seventeen feet or more and produces an abundance of heavy leaves the entire length of the stalks. It usually produces two enormous ears to each stalk and while we do not claim the Eureka will mature in our northern states where frosts are expected in September, the ears are generally in the milk stage at harvest time and this greatly increases the quality of the silage. In exceptional seasons we have known it to mature in our own state, in New York and Michigan.

To get the greatest yield, we recommend planting from $1 / 2$ to $3 / 4$ bushels of Eureka Corn per acre in drills 3 feet apart and suggest cultivation as long as it is possible to get through the corn. With the quick start which Eureka Corn will make, it is almost always possible to cultivate entirely with horse or tractor. Price, bags included, $1 / 2$ pk. 75 cts., pk. \$1.35, 1/ bu. \$2.50, bu. (56 1bs.) \$4.75, 10 bu. or over $\$ 4.65$ per bu. in our trade-marled bags.

Gentlemen:

Ohio.

The Eureka Corn I bought from you last year was very good as usual. I flled two big silos from fifteen acres and had enough left to refill.

I have used your Eureka Ensilage corn for about twenty years and will use nothing else if $I$ can get it. You can mark me down for a few bushels again this year. Yours truly,

\section{H. J. Stoneman}

\section{Gentiemen:}

Eureka Ensilage Corn is the best I ever planted. It makes the best ensilage, too. I have planted it for five years now and want some again this year. In 1924 I filled my silo $14 \times 34$ from 4 acres of corn, many staiks measuring 18 feet. Yours truly,

\section{E. I. Holzinger.}

Gentiemen:

New York.

From your Eureka corn I raised a large crop and it gave me From $2 \%$ acres

Yours truly.

Herbert N. Sinsabough.
Gentiemen:

I received your letter today and feel ashamed for not having written you long ago, not because I am afraid to teli you about could find no better than your Eureka. I a the seed houses I silo packed full from 5 acres and a surplus of over 10 tons. Yours truly.

Jacob Sander.

Gentlemen:

Oregon.

I had a fine crop of the Eureka corn this year. The seed I got from you was good. I think nearly every kernel grew. I Yours truly,

James Landreth.

Gentlemen:

Canada.

We have had verv good crops of Eureka corn from seed sup plied by you. In lact, it was so tali and heavy that one of our neighbors suggested that you send up two men with each bushel of seed to heip handie the crop.

Kindly send us prices for this year as soon as possible. Yours truly.

Morris Hali.

Gentlemen:

Michigan.

I have grown Ross' Eureka Ensilage Corn and it has proved to be entirely satisfactory. Have light gravei soli and the corn
grows 12 to 14 feet high. It is the only ensilage corn I would grow.

Yours truly,

\section{J. E. Forster.}

Gentlemen:

Pennsylvania.

The last time we had your Eureka corn some of it measured seventeen feet tall. I sent stalk to bank in Freeport (Armstron Co. Penneel tail. and took prize bile troeport Armstrong some left over. Cut it in shock, using an eleven foot ladder Had to climb to top, throw a rope around it with ring in end, puli it together and tie. I can furnish proof of this by many men.

Yours truly, Hayes Frampton.

Gentiemen

Iowa.

I have used Eureka corn for the last seven years and have always had great success, and from the two bushels ordered of you in 1925 I hed more than I could get into a $16 \times 32$ silo with a 2-foot pit. Wili order again this year. Am looking for your catalogue.

Yours truly.

Wm. Harvey.

Gentlemen:

Michigan.

The Eureka and field corn I purchased from you in 1925 was fine The field corn ripened. The Eureka grew as tall as 15 leet. I am well pleased with it and expect to order for 1926.

Yours truly,

Elton D. Young. 


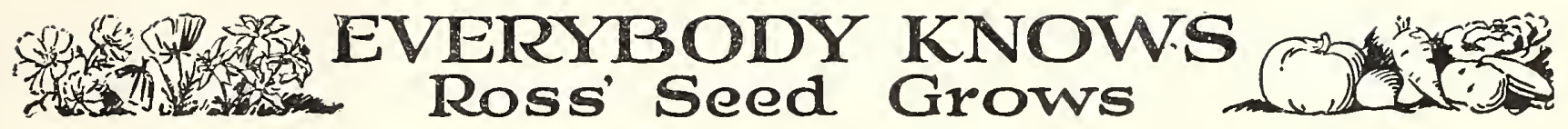 Sweet Corn-Yellow Varieties}

1 1b. will plant about $200 \mathrm{~h} 11 \mathrm{~s}, 10$ to $12 \mathrm{lbs}$. to the acre

We pay postage on one pound or less; for larger quantities by parcel post, remit postage. See inside front cover.

Sweet Corn should not be planted until ground is warm, and can not usually be safely planted in this latitude much before the middle of May. The small, early varieties may be planted in the garden as close as $2 \frac{1 / 2}{b y} 2$ feet, but in the field are generally planted 3 by 3 or $2 \frac{1}{2}$ feet. In the small garden, however, a more economical use of space can be made and the product secured a little earlier by making rows several feet apart, planting in the intervening space any early, lowgrowing crop like radish, spinach, or lettuce, and following this with a second crop of cucumbers for pickles, winter squash,

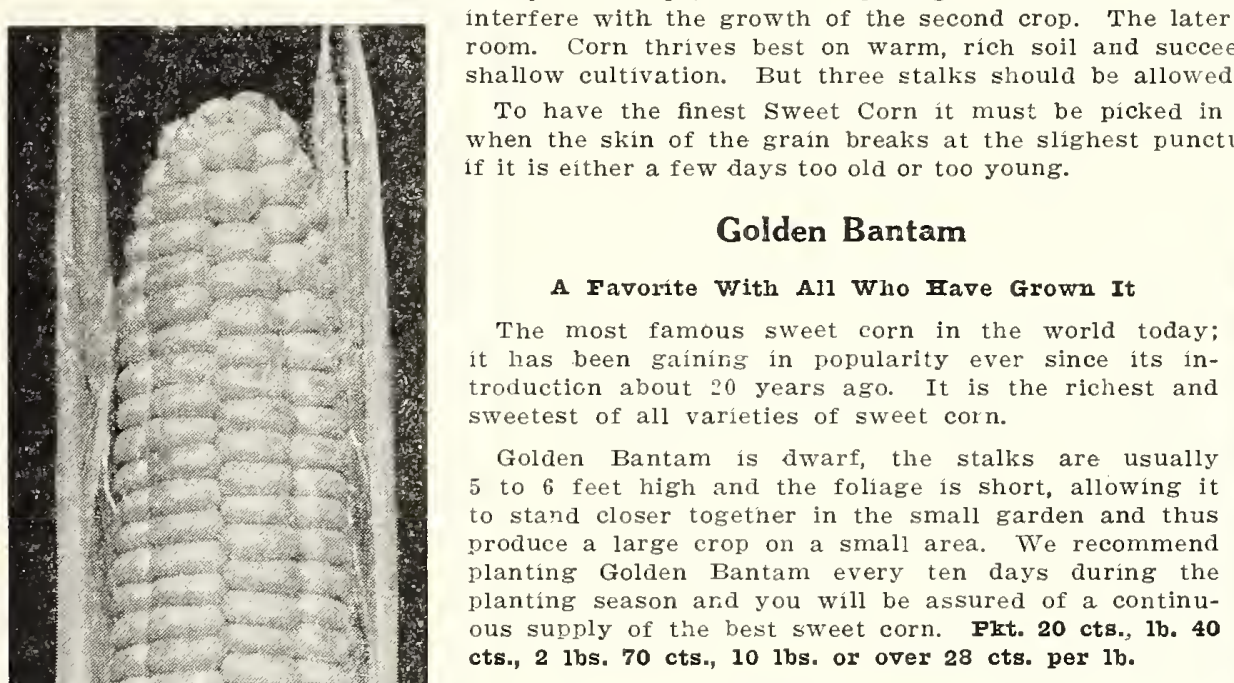

\section{Golden Sunshine}

The earliest of the Golden Bantam type, maturing a week to ten days earlier than that variety; more dwarf in habit than Bantam, with ears $6 \frac{1 / 2}{2}$ inches long, containing 12 rows of broad, yellow, sweet grains; especially desirable for its extreme earliness. Pkt. 20 cts., 1b. 40 cts., 2 lbs. 70 cts., 10 lbs. or over 28 cts. per 1b.

\section{Golden Giant}

Awarded the Silver Medal for novelty and excellence at Massachusetts Horticultural Show. Fars twice the size of Bantam and being from 14 to 16 rowed gives nearly four times tlie yield per acre; richer in color, more delicious, equally early, The husks are striped with red and very heavy. Golden Giant can be higlily recommended to the narket gardener because of the large ears and good shipping qualities of the corn.

Golden Giant is the result of eleven years' selection by Dr. F. S. De Lue of Boston, Mass., from a product of "Howling Mob crossed with Golden Bantam," Pkt. 20 cts., 1b. 40 cts., 2 lbs. 70 cts., 10 lbs. or over 28 cts. per lb.

\section{Whipple's Early Yellow}

Twice the size of Golden Bantam and matures about the same time, grows ears 7 to 8 inches long and 12 to 16 rowed, with often two ears to one stalk. Quality is unequaled. Flt. 20 cts., lb. 40 cts., 2 lbs. 70 cts., 10 lbs. or over 28 cts. per 1b.

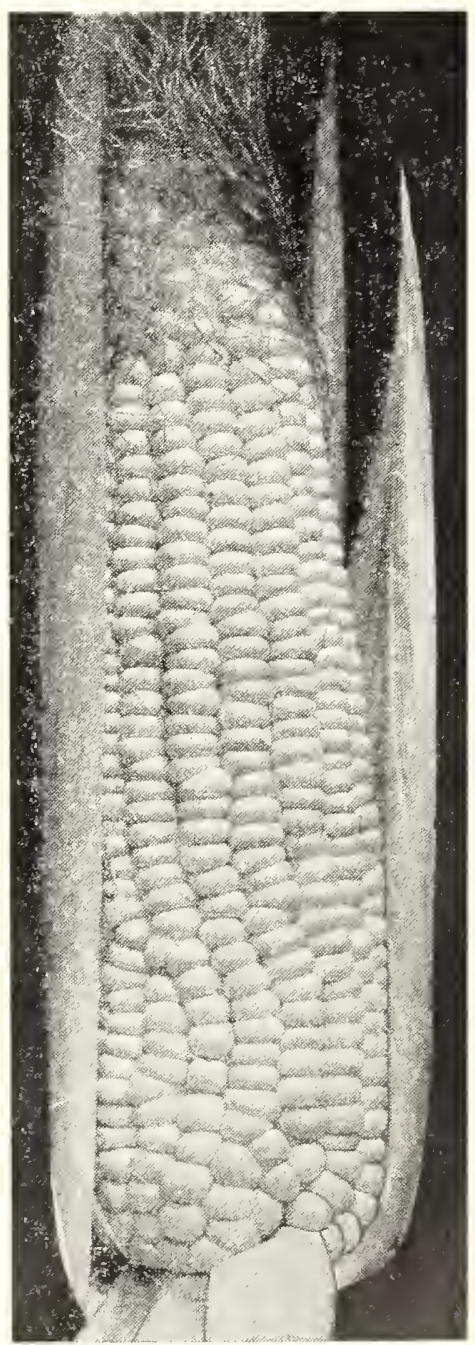

De Lue's Golden Giant 


\section{ROSS BROS. CO.}

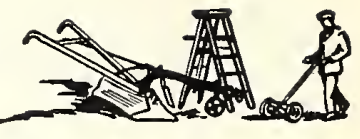

\section{Sweet Corn (Continued)}

Bantam Evergreen (Yellow)

A yellow variety maturing about 10 days after the Golden Bantam and a week earlier than the Stowell's Evergreen white. It has an ear three times the size of Golden Bantam and runs 12,14 and 16 rows to the ear. The stalk is about 6 feet tall and is perhaps 1 foot shorter than Stowell's Evergreen and 2 feet taller than Golden Bantan. The Bantam Evergreen has the tender and sweet qualities of the Golden Bantam and combines the quality of the Golden Bantam with the procts., 1 b. 40 cts., 2 lbs. 70 cts., 10 lbs. or over $28 \mathrm{cts}$. per lb.

\section{Golden Rod}

Golden Rod is the result of a cross between Stowell's Evergreen and Golden Bantam, and proves to be a happy and complete blending of each sort. The ear is none too small nor is it large and bulky, but just large enough for ordinary consumption. The plants are 6 to 7 feet high, strong, profusely leaved, and bear on each stalk at a convenient height, two cars lavishly packed with delicious golden grains of appetizing flavor. Exceptionally fine to follow Golden Bantam on account of its large size, color and sweetness. Plrt. 20 cts., 1b. 40 cts., 2 lbs. 70 cts., 10 lbs. or over 28 cts. per lb.

\section{Black Mexican}

A popular variety; until the introduction of the Golden Bantam, the sweetest of all. Ears of medium size; kernels large, when ripe bluish black, but at proper stage for cooking, the color shows but little if at all. Plit. 20 cts., 1b. 30 cts., 2 1bs. 50 cts., $10 \mathrm{lbs}$. or over $20 \mathrm{cts}$. per $\mathrm{lb}$.

\section{White Varieties-Early Dighton}

An extra early variety growing about four feet high and yielding usually two

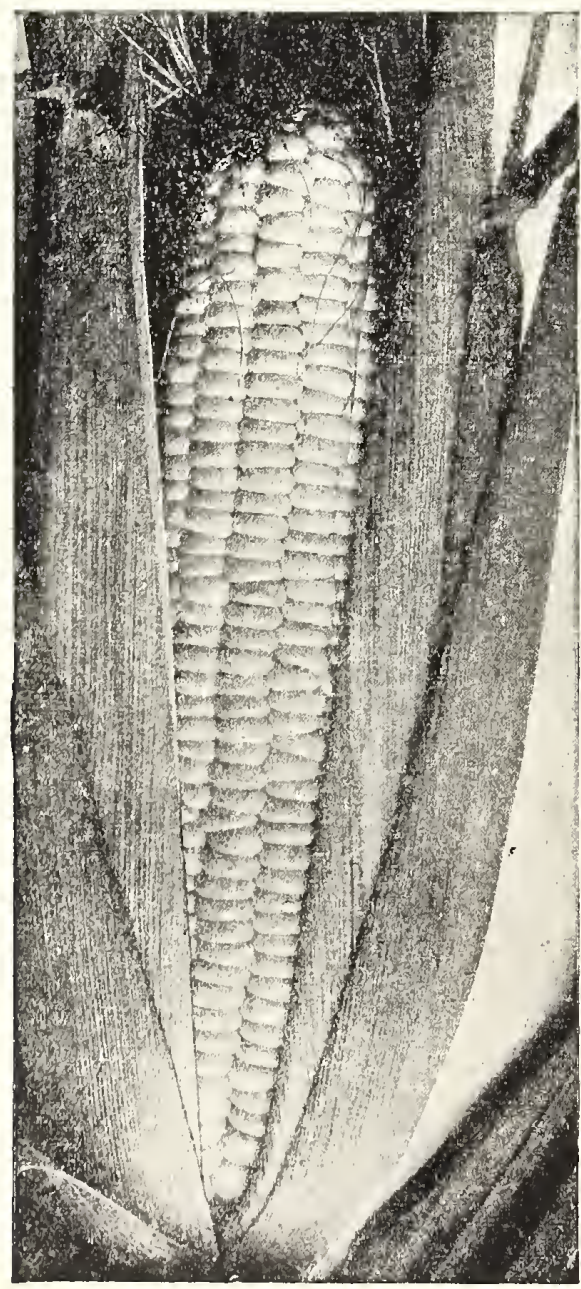
fors to the stalk The ears eight to ten rowed, six to seven inches long. the grain white with pink cob.

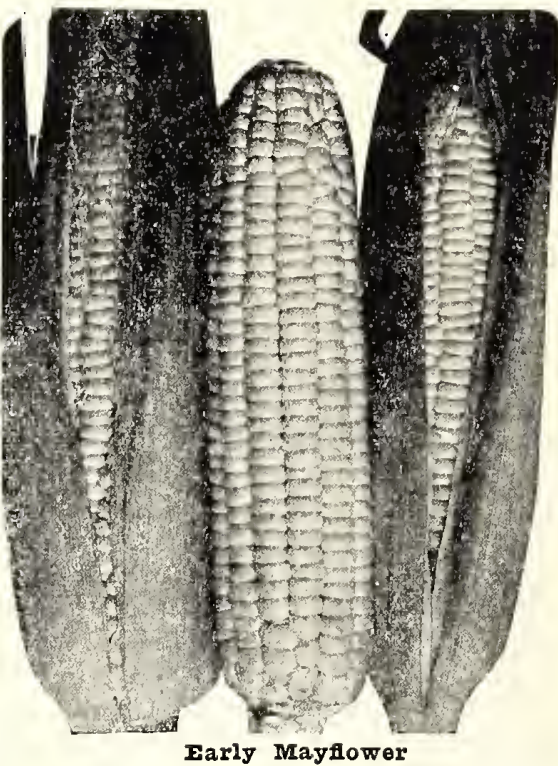

Mayflower and we believe it is a profitable variety for the market gardeners. Pkt. 20 cts., Ib. 40 cts., 2 lbs. $70 \mathrm{cts}$., $10 \mathrm{lbs}$. or over $28 \mathrm{cts}$. per lb.

\section{Alpha Sweet Corn}

The earliest sweet corn. Matures a week or ten days ahead of Mammoth White Cory. The ears average six to seven inches long, are uniformly eight rowed, fully equal in quality to Mammoth White Cory with skin a trifle more tender. The stalks are very uniform in height averaging about four feet. Ears are set low and close to the stalks. For the market grower who reaps an extra profit by getting his produce on the market ahead of his competitors this will be a money-maker; for the home gardener it will produce desirable ears for the table a week ahead of the next earliest variety. Plit. 20 cts., lb. 40 cts., 2 lbs, 70 cts., 10/ lbs, or over 28 cts. per $1 \mathrm{~b}$.

COUNTRY GENTIFMAN. Medium size, with irregular rows of very deep and slender kernels and small cob. Sweet and tender, not surpassed in quality by any other variety with white kernels. Plant very productive, often yieldins three and sometimes four good ears. Plant liberally, as the kernels being much shriveled, seldom germinate so well as those of the regular type. Ready for use a little before the Stowell's Evergreen. Prt. 20 cts., 1b. 40 cts., 2 lbs. 70 cts., $10 \mathrm{lbs}$. or over $28 \mathrm{cts}$. per $1 \mathrm{~b}$.

FARIY CROSBY. New England Strain. This has been for years the most popular second-early strain in New England, and is largely grown elsewhere. Ears are intermediate in size between those of the first-early sorts and the Kendel's Early Giant, especially attractive and distinct, having rather small, almost square kernels packed so closely on the cob that there is no space between the rows, as with other varieties; has always twelve or more rows and tip is completely covered. Not only an unusually attractive ear, but of a size preferred by many, and corn is superior quality. Pkt. 20 cts., 1b. 35 cts., 2 lbs. $60 \mathrm{cts}$., 10 lbs. or over 24 cts. per 1b.

EARIY MAYFIOWER. One of the whitest and sweetest of the early varieties: an exceptionally good yielder and one that deserves to be planted to come in ahead of Golden Bantam; ears average 8 inches with deep kernel. Pkt. 20 cts., lb. 40 cts., 2 lbs. 70 cts., 10 lbs. or over 28 cts. per $1 \mathrm{~b}$.

POTTER'S EXCEISIOR, or SQUANTUM. First named Potter's in Boston market, later named Squantum in Rhode Island. Ears of medium size. Matures soon after the second-early sorts. Prt. 20 cts., Ib. 40 cts., 2 lbs, 70 cts., 10 lbs. or over 28 cts. per $1 \mathrm{~b}$.

STOWrII'S FVERGRIgN. The best known and most largely planted of all the varieties. The Stowell's Evergreen is hald to beat and for a long time to come many will have it in preference to any other sort. This corn is distinguished by the large ear, the long deep kernels, its rich, sugary flavor and its long keeping qualities. It is the standard late sort. Prt. 20 cts., 1b. 35 cts., 2 lbs. 60 cts., $10 \mathrm{lbs}$, or over 24 cts. per lb.

\section{If larger quantities of Seed, other than listed are} desired, write for prices. 

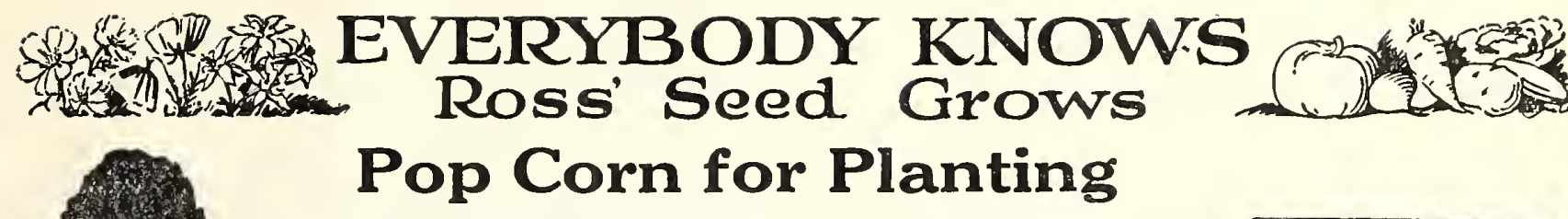

WHITE RICE. This variety of pop corn is an old and tried corn. It is the heaviest yielder of all and of very good quality. The stalks grow from 5 to 6 feet tall and produce two to three ears each. The ears are about 6 inches long and covered from butt to tip with long, hard, flinty kernels. When popped the kernels are very large and tender. We recommend this variety especially for its large yielding ability and its popping qualities. Plt. 15 cts., lb. 25 cts., 10 lbs. or over 20 ct8. per lb.

\section{Dwarf White Hulless}

This is the dwarf variety of pop corn used so extensively by pop corn venders all over the United States. The kernels are similar in color and shape to the older types of white rice, except they are more slender and longer. Is of the dwarf growing habit. Ear about two to three inches long. The kernels on an average cob, however, will produce nearly twice as much popped corn as the average larger sized white rice cob, with practically no wastage. Matures in about 65 days. Pkt. 15 cts., $1 b .30$ cts. $10 \mathrm{lbs}$. or over $25 \mathrm{cts}$, per $1 \mathrm{~b}$.

\section{Corn for Popping}

TANAGER BRAND (shelled) $1 \mathrm{lb}$. pkgs. Price, lb. $13 \mathrm{cts}$.

WHITE RICE (shelled). Price, 1b. 10 cts., 10 lbs. or over 8 cts. per 1b.

WhITE RICE (on the cob). Price, 1b. 10 ots., 12 1be. $\$ 1.00$.

DWART WHITE FUIIESS (shelled). Price, lb. 12 cts., 10 lbs. or over 10 cts. per Ib.

SPECIAI PRICES IN IARGIR QUANTITIES.

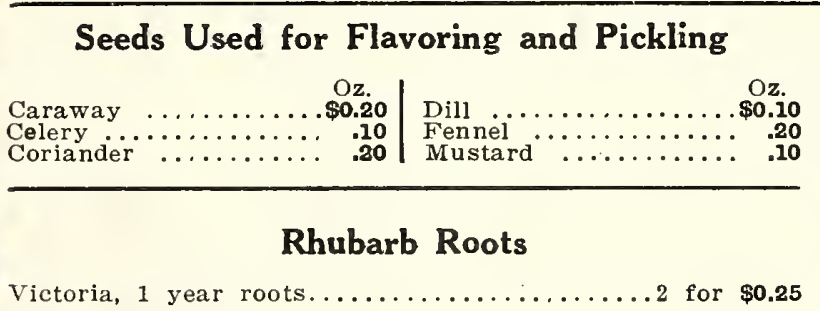

\section{Seed in Packets}

We have for years placed our seed in packets on sale with thousands of stores throughout the New England states. These packets are supplied to the dealers each season filled from the same reliable stocks that are used for sale in our own store at Worcester. Each stock is carefully tested and we guarantee satisfactory germination. We would of course prefer to have you send us your order direct, but if our packet seeds are on sale in your local store do not hesitate to use them as we know they will produce the same satisfactory results as the seed purchased at our own store.

\section{Flower Plants}

ASTER, American Branching.

ANTIREFINUM, Mixed Colors.
CAIENDUIA, Mixed Colors.
Cosmos, Mixed Colors.

PANSY, Mixed Colors.

SAIVIA, Bonfire and Splendens. ZINNIA, Mammoth Mixed Colors.

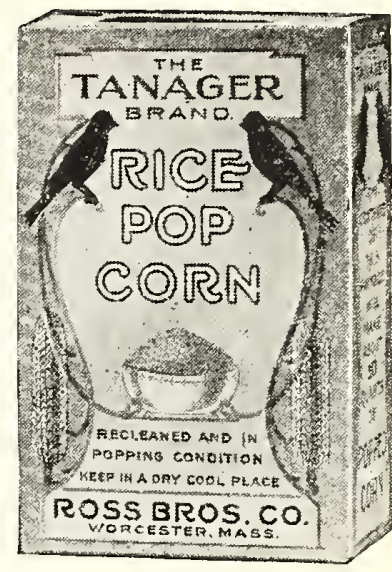

Herbs

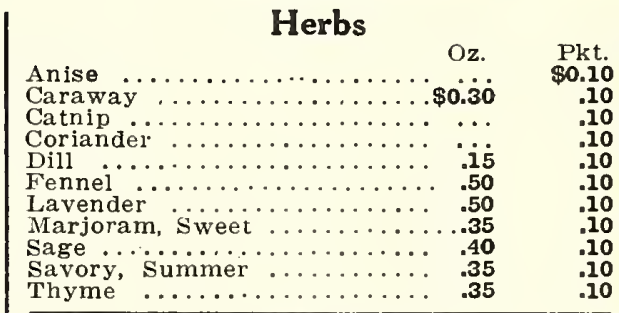

Bird Seeds

Best recleaned; for feeding only

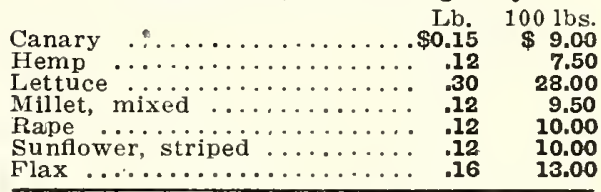

\section{Vegetable Plants}

By express only. Write for prices CABBAG I PIANTS. Best varieties. CEIERY PIANTS. Leading varieties. CAUITFYOWER PUANTS. Snowball. PEPPER PIANTS. TOMATO PIANTS. ties.

\section{Special Vegetable Collection \\ $\$ 1.60$ value for $\$ 1.00$ postpaid}

This is a collection for the small garden prepared for those who do not want to spend lime to make their own selections. All varieties listed are easily grown and include a good list for the home garden, being sufficient for about $20 \times 30$ feet oi space. Mailed anywhere on receipt of price, $\$ 1.00$.

1 Pkt. Beans, sure Crop Black Wax..............\$0.20

1 Pkt. Beet, Crosby's Early Esyptian................ 10

1 Pkt. Carrot, Danvers IIalf Long.

1 Pkt. Cabbage, Copenhagen Market...

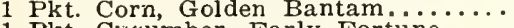

1 Pkt. Cucumber, Early Fortune.

1 Pkt. Endive, Batavian Broad Leaf.

1 Pkt. Lettuce, Black Seeded Tennisbali.

1 Pkt. Parsnip, Hollow Crown..

1 Pkt. Pumpkin. Small Sugar...

1 Pkt. Peas, Sutton's Excelsio

1 Pkt. Squash, Summer Crookneck. .

.10

.10

.20

.10

.10

.10

.10

.10

.20

.10

.10

\section{Raffia for Tying}

Raffia is the straw colored inner skin of a palm found in Madagascar. It is very strong and tough, but soft and flexible, which makes it the very best material for $t$ y ing vegetables, plants, vines, etc. It is better than twine, as it does not cut the plants and is much stronger. It is also used for making baskets. Raffia comes in hanks from 1 to 5 lbs. We offer the best grade.
Price per pound 35 cts.

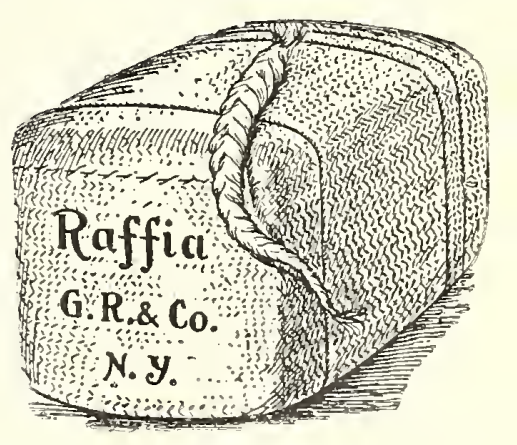

Telegraph your order with westem Union money Trangfer and goods will be shipped same day order is received. 


\section{ROSS BROS. CO. General List of Vegetable Seeds-Asparagus}

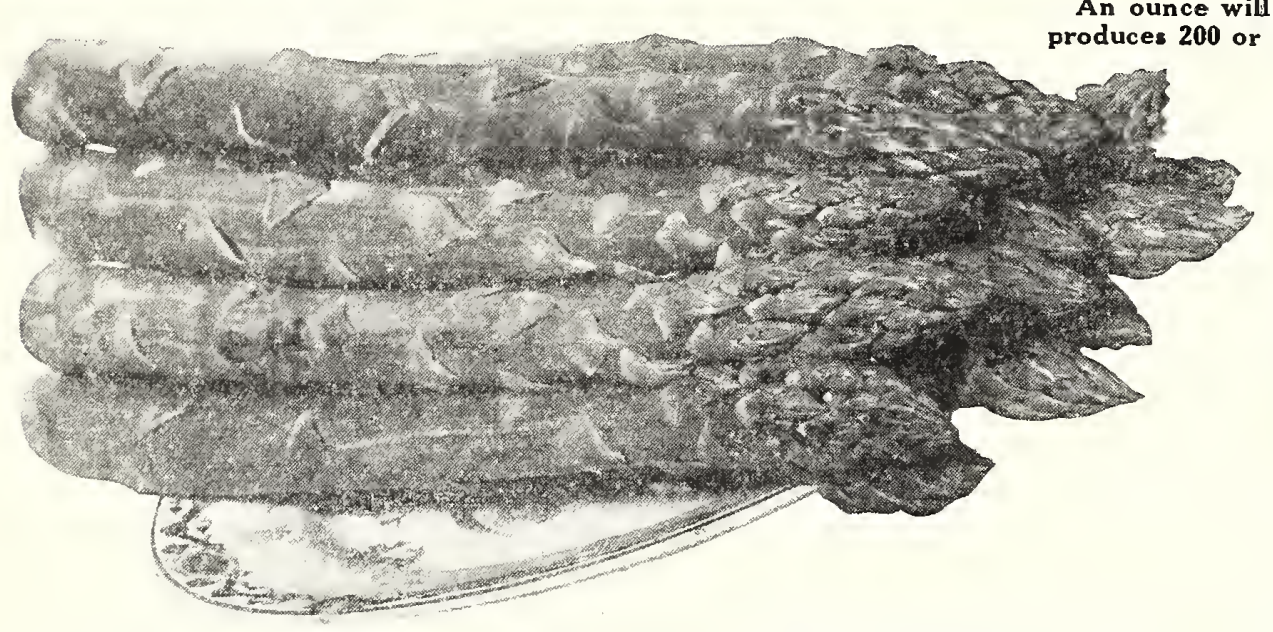

To grow asparagus from seed, sow as early as ground can be worked. Make the soil rich and sow in drills one foot apart and an inch or more deep. If the bed has good care, the roots may as well be transplanted to the permanent bed early the following spring as to wait another year, as is generally done. The soil should be thoroughly and as deeply worked as possible and can hardly be made too rich. In the fleld, the rows should be from four to six feet apart, but in the garden where the cultivation is to be done by hand the rows may be as close as two feet apart. Make broad trenches 8 inches deep, and if the roots are well spread, the crown will be 6 inches below the level. Cover with but an inch of soil at time of setting, filling the treneh gradually as the plants grow. The plants should have frequent cultivation and yearly heavy applications of manure or fertilizer. The third year from setting, two or three cuttings may be made; after that, all that are possible until time for early peas.

MARY WASHINGTON ASPARAGUS. This is a strain which has been under the direction of the Bureau of Plant Industry of the United States Department of Agriculture. The Bureau began this work at Concord, Massachusetts, in 1906, rust-resistance being one of the principal features desired. From a single plant discovered at Concord in 1910, a commercial strain has been developed.

Washington Asparagus is a rust-resistant, vigorous, high yielding strain of giant asparagus. The plants represented in its pedigree of the last three generations are the best found in a ten year's search among millions of plants tested. By test, we mean the ones that have produced offspring, uniform, rust-resistant, high yielding, of large size and rapid growth, all of which qualities indicate tenderness.

Prt. 10 cts., oz. 25 cts., $1 / 4$ lb. 60 cts.

GIANT ARGENTEUII. Popular in France on account of its large, thick, green stalks, being a special favorite in the Paris markets. Pkt. 10 cts., oz. 15 cts., $1 / 4$ 1b. 40 cts.

PAIMETTO. Early and productive. Plst. $10 \mathrm{cts.}$, oz. 15 cts., 1/4 1 b. $40 \mathrm{cts}$.

\section{Asparagus Roots}

The easiest way to obtain an Asparagus bed is to set out the roots. It takes 3 years to establish one from seed, but with our large, two year roots a bearing bed may bo had in 2 years.

We can furnish strong selected roots of the variety listed, 50 in a bunch, at the following prices:

MARY WASHINGTON. Doz. $30 \mathrm{cts}$., $50 \$ 1.00,100 \$ 1.75$, postpaid. By express, $100 \$ 1.50$, $1,000 \$ 12.00$

\section{Artichoke}

GREFN GLOBE. Perennia!, large-flowering heads, cooked like Asparagus. Matures second year; not hardy in the Nortl. Pkt. 20 cts., $1 / 2$ oz. 35 cts., oz. 60 cts.

\section{Brussels Sprouts}

A very hardy plant of the cabbage family, growing from 2 to 3 feet high, producing from the sides of the stalk numerous small heads about 2 inches in diameter. Sow about the middle of May, and treat generally as directed for cabbage.

IMPROVED HAIF-DWARE. Plst. 10 cts., Oz. 25 cts.

\section{Broccoli}

ST. VAIENTINE BROCCOLI has a clear white head like a cauliflower, surrounded by heavy leaves which may be tied to further blanch the heads. It stands cold and wet well, and heat better than any cauliflower. Be sure that the plants have plenty of water. Seed started in June will make heads which will be in good condition all winter. Seed started earlier will bring heads in for summer. Remember that Broccoli takes longer to mature than Cauliflower and so allow two or three weeks more. Pit. 15 cts., $1 / 2$ oz. $\$ 1.00$, 02. $\$ 1.75$.

All prices in this catalogue are based on the lowest market price at time catalogue goes to press, but they are subject to market changes. This applies to both advance and decline. 


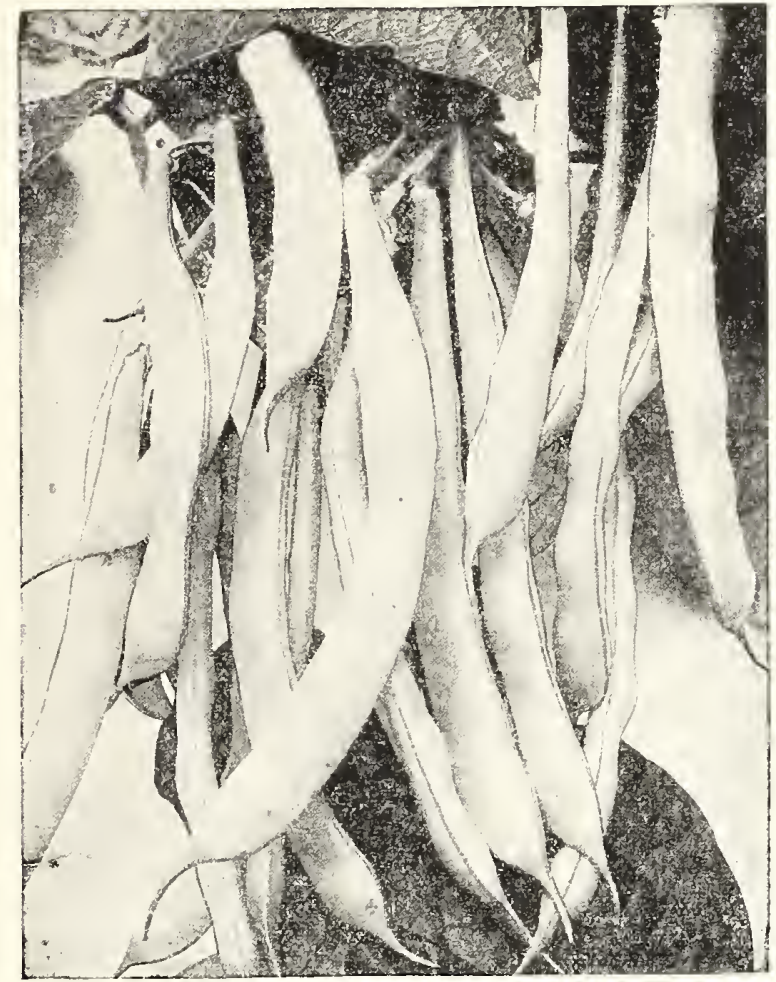

Improved Golden Wax Beans
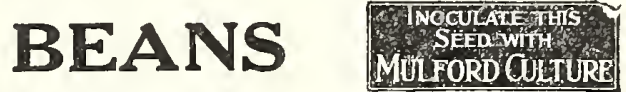

$1 \mathrm{lb}$. will plant 100 feet of drill. 60 to 90 lbs. will plant an acre.

Beans succeed best in warm, light soil of at least average fertility. In this latitude it is not usually safe to plant much earlier than the middle of May. If planting is made earlier and not blame the seedsman if beans fail to re minate plant the dwarf varieties in drills 2 to 3 feet apart about 2 inches deep. and thin plants 4 to 6 inches apart. Give frequent, shallow cultivation until time of blossoming.

\section{Dwarf Wax or Butter Beans}

BIACK WAX, PROIIFIC. One of the best for a home garóc.. perfectly stringless and of excellent flavor Pods are medium size, round and of a clear waxy white color. Pkt. 20 cts., 1 lb. 40 cts., 2 1bs. 70 cts., 1010 s. or over 32 cts. per $1 \mathrm{~b}$. BRITTIE WAX. One of the best early varieties. The pods are round and long, often six inches in length, and a rich golden yellow: stringless and tender. When ripe, makes good shell beans. Pkt. 20 cts., 1 lb. 45 cts., 2 lbs. 80 cts., 10 lbs. or over 35 cts. per $1 \mathrm{~b}$

CURRIE'S RUST-PROOF WAX. It has been claimed that this medium early bean is absolutely rust-proof and we have found it as nearly rust-proof as any wax-podded bean. The plants are very vigorous, hardy and productive. The pods are five to six inches long, nearly straight, broad and fiat; color, golden yellow. Plrt. 20 cts., 1 ib. 40 cts., 2 lbs. 70 cts., 10 lbs. or over 32 cts. per 10 .

We send one pound or less postpaid; for larger quantities by parcel post, postage must be sent. See inside front cover.

We suggest Prolific B la c k Wa $x, B$ rittle Wax, Pencil Pod B lack Wax or Sure Crop Stringless Wax for the home garden.

GOIDEN-EYED WAX. Next to Horticultural Wax in its freedom from rust, and superior to that in quality though not equal to most others in the list. Pods of good length, flat, straight, waxy yellow and attractive. Popular with market gardeners. Prt. 20 cts., 1 1b. 40 cts., 2 1bs. 70 cts., 10 lbs. or over 32 cts. per 10 .

IMPROVED GOIDEN WAX. An old, well-known and popular variety of excellent quality. Pods flat, long, golden yellow. One of the earliest and best dwarf wax varieties for the private garden. Prt. 20 cts., 1 1b. 45 cts., 2 1bs. 80 cts., 10 ibs. or over 35 cts. per $1 \mathrm{~b}$.

PFNCII POD WAX. This very handsome black wax sort is medium early, fairly hardy and productive. It is one of the very best sorts for home use and for near markets where highest quality is desired. The plants are strong growing with roughened leaves. The pods are long, five and one-half to six inches, straight, round, fleshy and of a bright yellow color. They are tender, absolutely stringless and are produced through a long season. Seed long, round, medium sized, solid black. Pkt. 20 cts., 1 1b. 45 cts., 2 lbs. 80 cts., 10 lbs, or over 35 cts. per $1 \mathrm{~b}$.

EOUND-POD KIDNEY WAX. Of unsurpassed quality. One of the best for the home garden and very desirable for market, where round-podded varieties are popular. Pods are long, very white and wax-like; uniformly perfect in shape and vine is very productive. Plst. 20 cts., 1 lb. 45 cts., 2 1bs. 80 cts., 10 10s. or over $35 \mathrm{cts}$. per $1 \mathrm{~b}$.

SURE-CROP STRINGLFSS WAX. An absolutely stringless, rust-proof waxpod, bush bean. Pods seven to seven and one-half inches long, about half an Inch in diameter, and a beautiful rich yellow color. Plant hardy, extremely prolific, in fact, bears more freely than any other variety of recent introduction. Just the bean for the family garden. On account of its size it fs always a ready seller on the market. Plt. 20 cts., 1 lb. 50 cts., 2 lbs. 90 cts., 10 lbs. or over 40 cts. per $1 \mathrm{~b}$.

WARDWEII'S KIDNET WAX. A very popular variety, especially in some localities bece size, handsome appearance and excellent quality of the pods. The pods are flat, broad, and usually five to six inches long, or delicate, waxy yellow color, stringless and brittle. Very widely used by market gardeners. Prt. 20 cts., 1 1b. 45 cts., 2 lbs. 80 cts., 10 lbs. or over $35 \mathrm{cts}$. per $1 \mathrm{~b}$.

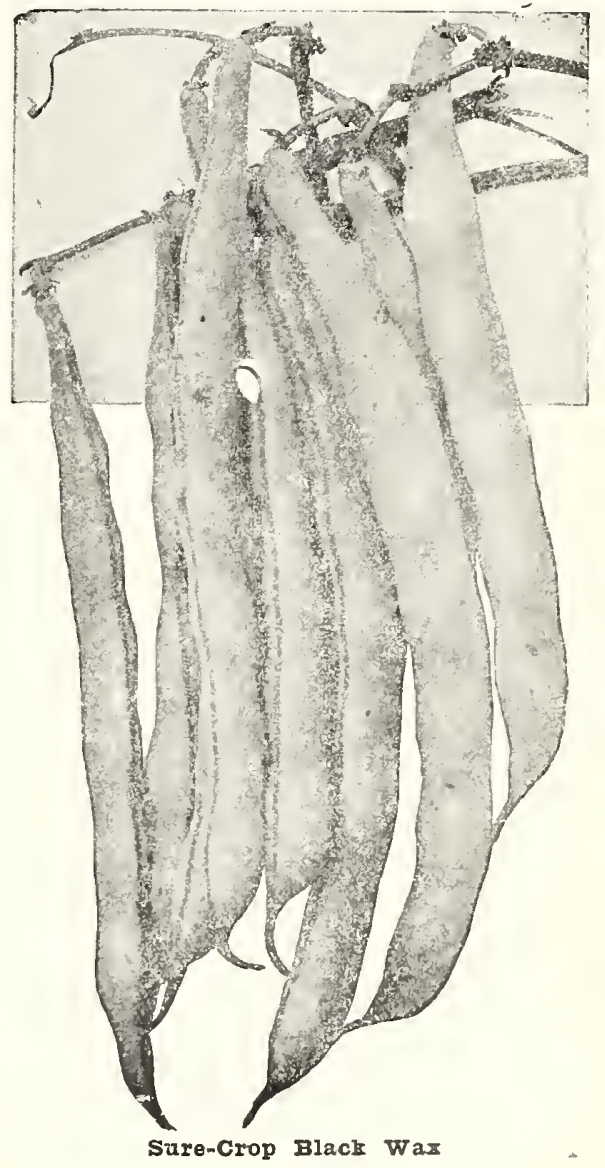




\title{
S Ross' Seed Grows

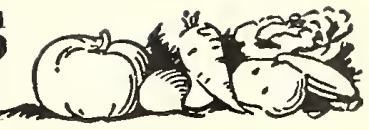 Drawf Lima Beans
}

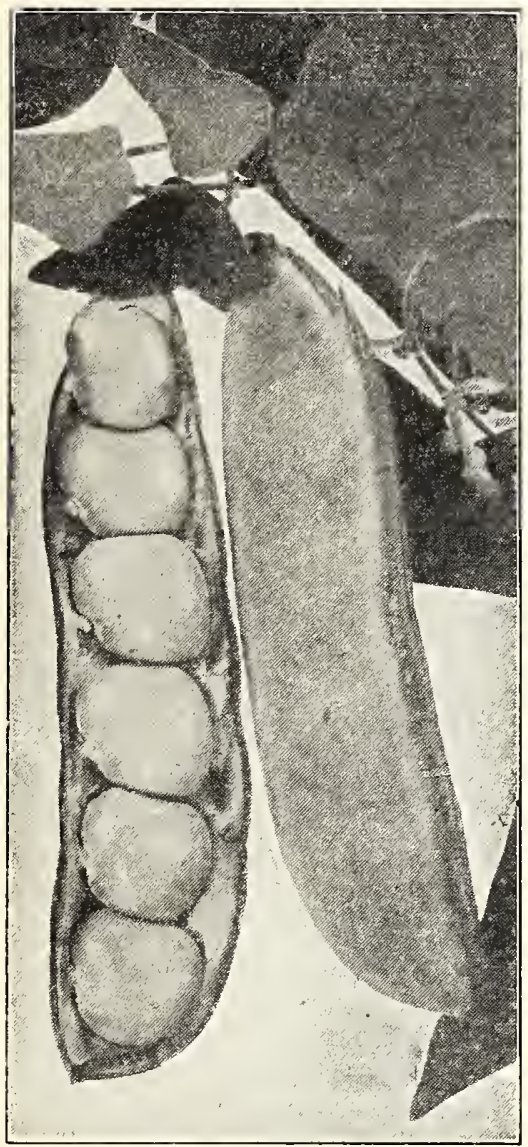

Fordhook Bush Iima Beans

\section{1b. Wlll plant about 50 hills}

The dwarf lima class cannot be recommended too highly. The beans can be grown and gathered much more easily than the pole limas, as the vines require no support. They can also be grown closer together than those, are equal in quality to pole limas and as a rule are earlier maturing.

Limas require a longer season for maturing than other garden beans. Do not plant till the ground is dry, weather warm and danger of frost is over. If possible, select rich, light soil. Plant in drills two or three feet apart, dropping the beans three to four inches apart and covering one and one-half to two inches deep. If planted in hills, make the hills two or three feet apart one way and two to two and one-half the other and plant four to six beans in a hill. Hoe often, but only when the leaves are dry.

HENDIRSON'S BUSH IIMA. A bush of the Sieva lima; beans small but vine is productive and bears early. Prt. 20 cts., 1 1b. 35 cts., 2 1bs. 60 cts., 10 1bs. or over 27 cts. per $1 \mathrm{~b}$.

BURPFr's BUSE ITMA. A bush form of the Large Lima which it closely resembles and approaches in size. Very popular. Plt. 20 cts., 1 1b. 45 cts., 2 ibs. 80 cts., 10 1bs. or over $37 \mathrm{cts}$. per $1 \mathrm{~b}$.

BURPEE'S IMPROVED BUSH IIMA. A distinct strain. The earliest, largest and the best of all large limas. This new strain differs from the popular Burpee's Bush Lima in bearing uniformly much larger pods, producing more beans, while both pods and beans are much larger and thicker. While the beans are as large as those of the Large Lima, the crop of the Improved is ready for gathering from eight to ten days earlier. In quality the beans are equal to any, being thinskinned, juicy and of fine flavor. Pkt. 20 cts., $11 \mathrm{~b}, 45 \mathrm{cts.}, 2$ 1bs. $80^{\circ}$ cts., $101 \mathrm{bs}$. or over 37 cts. per 1 .

FORDFOOF BUSH IIMA. The Fordhook Bush Lima Bean is not a selection made by man from the Dreer's Bush Lima, but created by nature, a single sport found in the fleld of Dreer's or Challenge Pole Lima, and has now become one of the leading varieties of Bush Lima Beans. The plant is of stiffy erect habit, the beans are much larger and of superior quality and even when full size are juicy and of fine flavor. Sold out.

\section{Pole or Running Lima Beans}

\author{
1 1b. will plant about 100 hills
}

These, like the Dwarf Lima, are tender and should not be planted in this latitude much before the first of June, and even then a liberal quantity of seed should be used to be more nearly certain of a uniform stand. Three plants, however, are all that should be allowed to grow in a hill.

CARPENTERIA. This is just the lima for the market gardener to grow for main crop. It is early and large, and enormously prolifle, without much vine. Pkt. 15 cts., 1 1b. 35 cts., $21 \mathrm{bs}, 60$ cts., 10 1bs. or over $27 \mathrm{cts}$. per $1 \mathrm{~b}$.

GING OF THE GARDEN IIMA. Earlier than the Large lima, and pods are longer and often contain five beans of the largest size. 'The vine is large and of remarkably vigorous growth and will produce larger pods and bear earlier if only two are allowed to grow to the pole. Pkt. 15 cts., 1 1b. 35 cts., 2 1bs., 60 cts., 10 1bs. or over 27 cts. per $1 \mathrm{~b}$.

IARGE IIMA. The old standard variety. Pods are broad, thin and borne in clusters. The vine grows tall, is vigorous but slender. Later in bearing than the preceding varieties. The beans are large and of a greenish tinge, which is considered an indication of superior quality. Pkt. 15 cts., 1 1b. 35 cts., 2 1bs. 60 cts., $101 \mathrm{bs}$. Or over 27 cts. per $1 \mathrm{~b}$. SEIBIRT'S FARIY IIMA. The earliest variety; vine vigorous and very productive and continues so from the first to the last of the season. While the pods are short and rarely contain more than four beans, the total yield com pares very favorably with other varieties. A desirable feature of this variety is the ease with which the pods are opened, owing to the fact that they are very thin Plst. 15 cts., 1 1b. 35 cts., 2 1bs. 60 cts., 10 1bs. or over 27 cts. per $1 \mathrm{~b}$.

\section{Beans-Pole or Running-Wax Podded Sorts}

\author{
1 1b. will plant about 100 hills
}

Although pole beans require considerable care and labor they are when properly grown, usually of longer bearing period. Pole beans are more sensitive to wet and extremes of temperature than the dwarf varieties and should not be planted as early. Poles should be set in rows about 4 feet apart, preferably running north and south, allowing about 3 feet between the poles in the row. The safer way is to plant six to eight beans around each pole and thin to three or four plants. Beans should be about two inches below the surface and are more generally pressed into the soil, eye down, instead of dropped and covered, as they come up a little sooner planted in this way. Like the dwarf beans, they require frequent shallow cultivation.

GOIDEN CIUSTER WAX. Pods long, broad, thick and fleshy borne in clusters, creamy white in golden yellow; of best quality. Pkt. 20 cts., 1 lb. 40 ots., 2 lbs. 70 cts., 10 lbs. or over 32 cts. per $1 \mathrm{~b}$.

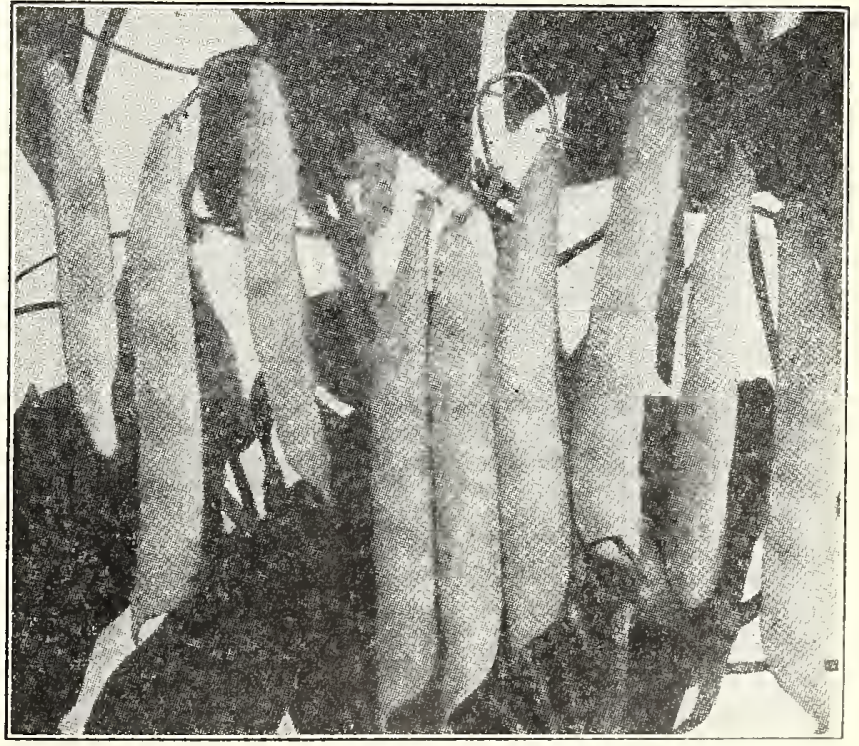

Wardwell's Ildneg Wax 


\section{W}

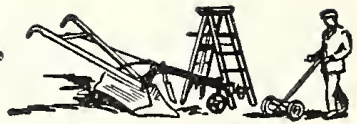

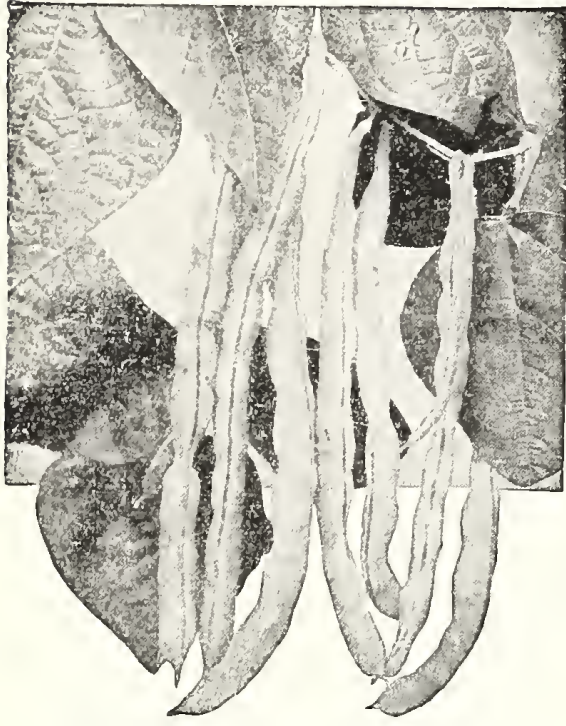

Fole Beans-Kentucky Wonder

\section{Beans-Pole or Running- Green Podded}

\section{Don't Forget Mulford Culture for Beans}

\begin{abstract}
"KENTUCKY WONDER WAZ." This pole bean is quite similar to the very popular green podded Kentucky Wonder, except that the very long pods are a little broader, and of a waxy golden yellow. These are very attractive, fleshy, stringless and not surpassed in quality. The vine is remarkably vigorous and its earliness and hardiness commend the variety as one well adapted for even northern latitudes. The seed even from the most matured crop is usually somewhat shriveled. Like the green podded Kentucky Wonder, this is very productive, and we believe it to be generally superior to any other wax podded pole hean. Pkt. 20 cts., 1 lb. 45 cts., 2 lbs. 80 cts., 10 lbs. or over $37 \mathrm{cts}$. per $1 \mathrm{~b}$.

KENTUCKY WONDER, or OID HOMESTEAD. Pods are borne in large clusters, are of unusual length, nearly round, silvery green; when young, crisp, entirely stringless, of fine texture and flavor. Vine bears early and is very productive. Used only as a string bean. Pkt. 20 cts., 1 lb. 40 cts., 2 lbs. 70 cts., 10 lbs. or oper $32 \mathrm{cts}$. per $1 \mathrm{~b}$.

IONDON HORTICUITURAI, OF SPECKIED CRANBERRY. Pods short, broad, yellowish, streaked with bright red. Beans in general appearance identica with Dwarf Horticultural, of about the same size, more nearly round; of the best quality. Pkt. 20 cts., 1 lb. 40 cts., 2 lbs. 70 cts., 10 lbs. or over 32 cts. per lb.
\end{abstract}

SCARIET RUNNER. Largely grown as an ornamental climber; its rapid growth and early production of dazzling flowers make it a favorite for covering screens, walls, etc. It is also of excellent edible qualities, but rarely grown for that purpose. Pkt. 20 cts., 1 lb. 40 cts., 2 lbs. 70 cts., 10 lbs. or over 32 cts. per $1 \mathrm{~b}$.

WORCISTER MAMMOTH HORTICUITURAI. This variety, while similar in general character to the Horticultural Pole, is much superior in several ways. The beans, though closely resembling those of the common strain, are much larger. Its strikingly handsome pod combined with its great size are both features of excellence which recommend it. Added to these excellent qualities are those of thrifty, vigorous growth of vine and great productiveness, all making it a variety especially desirable to the market gardener. It easily brings a higher price in the market than any other, and is not excelled by any other sort for the home garden. Pkt. 20 cts., 1b. 45 cts., 2 lbs. 80 cts., 10 lbs. or over 35 cts. per 1b.

BDFT An ounce will sow about 100 feet of drill.

5 or 6 pounds required for an acre.

The beet thrives best in deep, rich, but rather light soll. Sow in drills about 15 inches apart and one inch deep. Make the soil frm over the seed. For early use, sow as soon as the ground can be worked; for fall use, in May; for winter, from the 20 th of Junc to the middle of July, according to the variety. Thin plants to 4 or 5 inches apart. Give frequent shallow cultivation.

EARIY WONDER. One of the earliest and most perfectly shaped beets. Its beautiful, deep blood-red color, globular-shaped roots, make it valuable for the home garden. The attractive appearance, uniform size, shape and color have created a very heavy demand for this variety. It is grown very extensively for late sowing. Fist. 10 cts., oz. 15 cts., $1 / 4$ 1b. 40 cts., $1 \mathrm{~b}, \$ 1.40$.

CROSBY'S EARIY EGYPTIAN. An improved form of the Early Egyptian, roots much thicker and more regular. Nearly as early and of better quality. The most popular early valiety for market throughout New England, if not elsewhere, and is now beins considerably used for last sowing. Pkt. $10 \mathrm{cts.}$. 0z. $15 \mathrm{cts.}, 1 / 4$ 1b. 35 cts., 1b. \$1.25.

CROSBY'S EARLY EGYPTIAN EXTRA-SIIECTED STRAIN. For several years we have given this especial attention and have largely succeeded in eliminating the light-colored. coarse fleshed specimens peculiar to the Egyptian, Roots are more uniform in shape and tops are more even in growth and a little smaller. We confidently recommend it to market gardeners as an unsurpassed strain. Pkt. 10 ctв., oz. 15 cts., $1 / 4$ lb. 40 cts., $1 b . \$ 1.40$.

ROSS PERFECTION. A strain selected by us as the best early beet for the market gardener. Nearly as early as the Early Egyptian, but the roots are much thicker and more regular in shape. By careful selection the coarsefleshed and light-colored specimens have been practically eliminated. The tops are even in growth and a little smaller than the Egyptian, making it an ideal beet for all uses. Pkt. 10 cts., oz. 15 cts., 1/4 1b. 40 cts., 1 . $\$ 1.40$.

Germination on All Seeds Sent on Request Also Purity on

Grass Seeds, Clovers and All Field Seeds

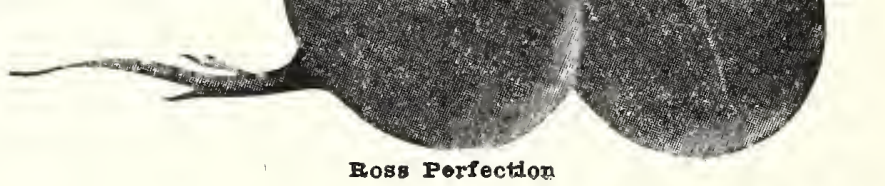

Ross Porfection 


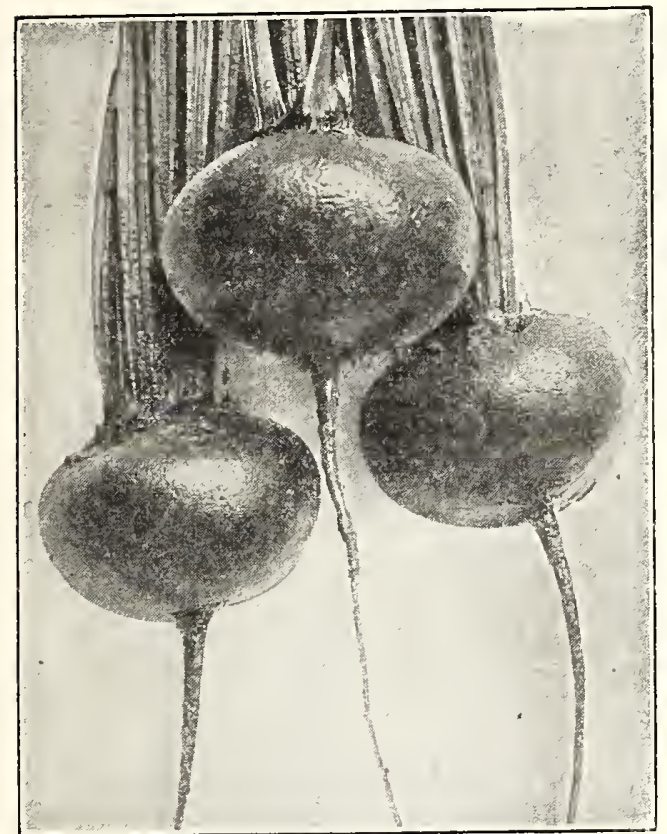

Selected Crosby's Egyptian

\section{BEET}

\section{Continued}

EARIY EGYPTIAN. The earliest variety; roots flat; deep crimson; top small. Pkt. 10 cts., oz. 15 cts., $1 / 4$ lb. 35 cts., $1 \mathrm{~b}$. $\$ 1.25$.

EARIY ECIIPSE. An early globe-shaped variety of good quality and deep color. Plt. 10 cts., oz. 15 cts., $1 / 4$ lb. 35 cts., 1b. $\$ 1.25$.

EDMAND'S BLOOD TURMIP. A standard variety used for both secondearly and main crop. Of good quality and keeps well. Pkt. 10 cts., oz. 15 cts., $1 / 4$ lb. 35 cts., 1b. $\$ 1.25$.

DEWING'S BIOOD TURNIP. One of the leading main-crop varieties. Pkt. 10 cts., oz. 15 cts., $1 / 4$ lb. 35 cts., lb. $\$ 1.25$.

DETROIT DARK RED. A superior second-early and main-crop variety rapidly growing in favor for late planting. Tops uniformly small and grow upright so that the rows may be close together. Plkt. 10 cts., oz. 15 cts., $1 / 41 b .40$ cts., 1 b. $\$ 1.40$.

SWISS CFARD, or SIIVER SEA KAIE BEET. Used for greens only. Until recently but little used in this country, but for the last few years has rapidly increased in favor. Much superior to other beets for greens. Of very rank growth, plants should be thinned to about one foot apart. When the plants have attained full size, the stems and mid-ribs are sometimes cooked and served like asparagus. Pkt. 10 cts., oz. 15 cts., 1/4 1b. 35 cts., 1b. $\$ 1.25$.

SWISS CHARD, GIANT IUCUIIUS. The Swiss Chard, or Spinach Beet, is prepared for the table in the same manner as Spinach; sometimes, however, the mid-rib is prepared like asparagus. Seed planted early in the spring will quickly produce plants from which cuttings may be made all summer, as you can cut right down to the ground and new shoots will soon spring up and make a fast growth, while those plants which are allowed to grow on without any cutting will make large curly leaves, with thick, light-colored mid-ribs which are delicious when cooked and served like asparagus. You should not fail to plant at least one long row in your garden. Pkt. 10 cts., oz. 15 cts., $1 / 41$. 35 cts., 1b. \$1.25.

\section{Sugar Beets and Mangel-Wurzels for Stock Feeding \\ 1 oz. to 100 feet of arill; 5 lbs. per acre}

Roots of all kinds are highly valuable for stock feeding and are worth more general cultivation than they have had in the past. A liberal feeding of Mangels insures a large flow of milk and healthy condition of the animals. Fifteen or twenty tons per acre is not an unusual yield for any of the large growing varieties. They are easy to cultivate and can be raised almost wholly with horse culture and will respond readily to any kind of fertilizer. A yield of 20 tons per acre is equal to 2 tons of the best Timothy Hay or 65 bushels of corn, but they will produce more milk, and, in addition to the feeding value found in protein and fat, you also get a large amount of water, which, to our mind, has a feeding value in any of our field crops.

GOIDEN TANKARD. It is one of the best stock beets grown. It has yellow flesh, a very distinct variety, being short with very little tap root and very easy to harvest. Top and neck very small; root ovoid, flesh yellow, zoned with white; an excellent sort. Price, oz. pkt. 10 cts., 1/4 Ib. 25 cts., lb. 75 cts.

MAMMOTH LONG RED. This is truly a mammoth, a single root often weighing twenty to thirty pounds. The extra large, long roots are blood-red in color and very nutritious. Enormously productive, vielding, under favorable conditions, thirty to forty tons of roots per acre. Price, oz. pkt. 10 cts., $1 / 4$ lb. 25 cts., 1b. 75 cts.

NORBITON GIANT IONG RED. Similar to the Mammoth Long Red; has smaller top and neck; flesh scarlet. Price, oz. pkt. 10 cts., 1/2 1b. 25 cts., 1b. 75 cts.

EIVErraLI GIANT. This is one of the finest types of the yellow globe mangel in cultivation. The roots are immense size and exceptionally even in shape. The skin is an orange-yellow with a reddish-yellow base. The flesh is white, being firm and flne grain which renders it an excellent keeping variety. It grows fully threefourths above ground with a very small tap root which makes it well adapted to light soil. Price, oz. pkt. $10 \mathrm{cts.,} \mathrm{1/4} \mathrm{1b.} 25$ cts., 1b. 75 cts.

\section{SUGAR BEETS}

KIEIR WANZIEBEN. This variety is cultivated on a larger scale than any other Sugar Beet. Root is conical, straight and even, large at top and rapidly tapering. Not as large as some of the other sorts, but contains the largest percentage of saccharine matter. Price, pkt. 10 cts., oz. 15 cts., 1/4 1b. 30 cts., 1 b. $\$ 1.00$.

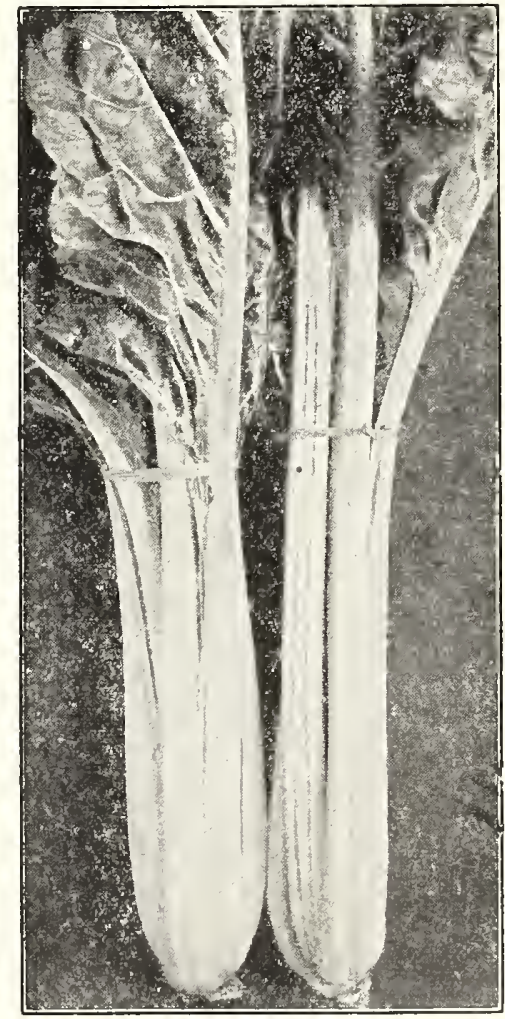

Swiss Chard

The ground for root crops, such as beets, carrots, parsnips, salsify, etc., should be dug deeply and well pulverized to insure straight and well-formed roots. 


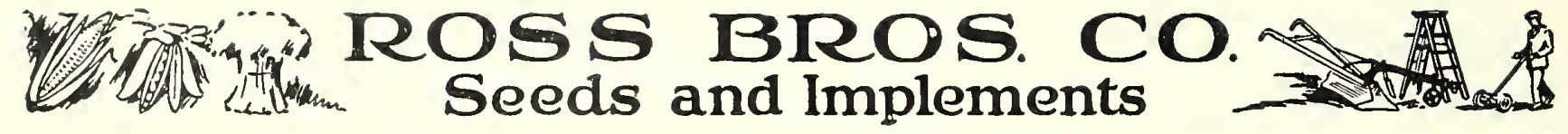

\section{CABBAGE}

An ounce will produce about 3,000 plants

Cabbage will thrive on any good garden soil but is more successfully grown on deep, strong loam, and new soil is much preferable, as on old land the roots are more liable to be affected by the disease called club-root. Especially should land be avoided upon which, within two years, cabbage, cauliflower, turnips or radishes have been grown.

For the earliest crop seed is usually sown in Februaly or March in hotbeds with only moderate bottom heat, and the plants hardened by gradually exposing them to the night air and transplanted as early as the ground is in suitable condition. Seed of the second-early, autumn and winter varieties, may be sown in the open ground. If a second crop is desired to follow closely the early crop, seed of some second-early sort should be sown as soon as ground can be worked. For later crops, successive sowings may be made, in this latitude, until about the middle of June, possibly some later, the time depending somewhat on the nature and condition of the soil the season, and more on the variety.

\section{Yellows Resistant Cabbage}

The term, "Yellows-Resistant" cabbage seed, does not necessarily imply that this seed is to be planted only in soil infested with the Yellows or Wilt. Our Resistant seed has a very high germination test, and produces a hardier plant, surer producer and yields greater tonnage than ordinary commercial strains.

The production of Resistant stock seed requires many years of reselection and cross-breeding. more than is necessary with the ordinary commercial strains, resulting in uniformly better seed.

In some sections, this disease is called the "Yellows"; in others, the "Wilt." It is present and spreading fast in many sections where they are not aware of it and do not recognize it as such. A poor crop of cabbage or some dried up plants, is often times ascribed to weather conditions or other causes, when in fact the field is infested with the Yellows.

At the present time we are in a position to offer only one variety of this seed which is rapidy coming into favor by all growers of cabbage.

DANISH BAIIFEAD "YEILOWS-RESISTANT." Pkt. 10 cts., $1 / 2$ oz. 25 cts., 0z. 40 cts., $1 / 4$ 1b. $\$ 1.25$.

\section{Copenhagen Market}

\section{The Best Early Cabbage}

As early as the Charleston Wakefield it fully meets the requirements of earliness expected of an Extra Early variety, while the heads are as large or larger than the Danish Ballhead, averaging in weight about ten pounds. This type is remarkably wellfixed, the heads perfectly ball-shaped, all maturing at the same time. The plant is short-stemmed, the heads being produced only a little above the ground. The light green, rather small leaves are saucer-shaped and always tíghtly folded, permittins of closer planting than usual with other varieties, having a head of equal size. No other early variety will produce so great a weight per acre and we doubt if any of the later varleties will much surpass it in this respect. The Copenhagen Market has proven itself a valuable addition to the market garden varieties. Pkt. 10 cts., $1 / 2 \mathbf{~ o z}$ 20 cts., oz. 35 cts., $1 / 4$ 1b. $\$ 1.00$.

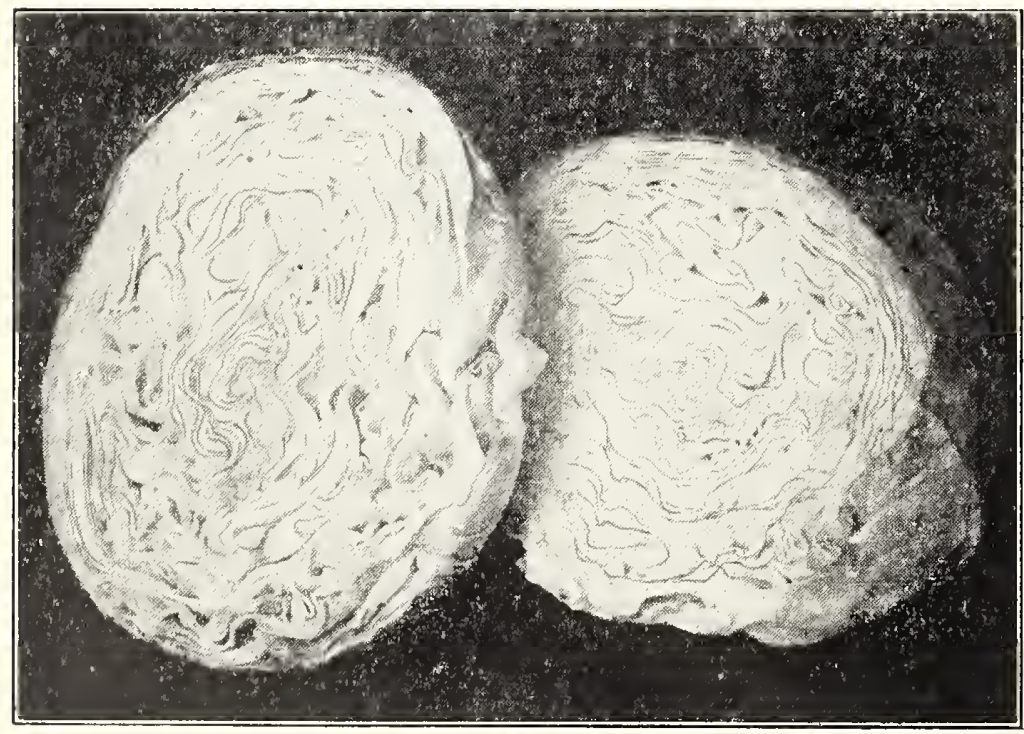

AIL SEASONS. For reliability in heading, not surpassed by any other variety, and few equal it in ability to stand the hot sun and dry weather and when mature to remain in the field so long without bursting. Heads as large as most of the later sorts, nearly round or somewhat flattened, solid and of finest or somewhatity. Extensively used for both second early and main crop. Pkt. 10 cts., 1/2 oz. 15 cts., 0z. 25 cts., $1 / 4$ lb. 75 cts.

AMERICAN IMPrOVED SAVOY. The best of the Savoy type, which should be more largely grown. Plt. $10 \mathrm{cts.}, 1 / 2$ oz. 15 cts., oz. 25 cts., $1 / 4$ lb. 75 cts.

CHARTESTON EARIY WAKEFIEID. A favorite with the market gardeners. Resembles the Early Jersey Wakefield in form but is much larger. Matures equally as early. Very uniform in shape and very desirable for the market gardener. Pkt. 10 cts., $1 / 2$ oz. 15 cts. 1 oz. 25 cts., $1 / 4$ lb. 75 cts.

Do you receive our fall catalogue for Dutch bulbs? We list a full line of Tulips, Hyacinths and miscellaneous bulbs, also American grown Narcissus. If you do not receive this book send us your name and address and we will gladly put you on our mailing list for our next fall catalogue. 


\section{华 \\ EVERYBODY Ros' Seed

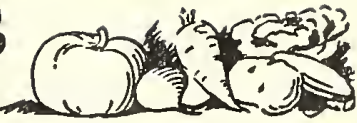

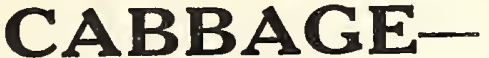

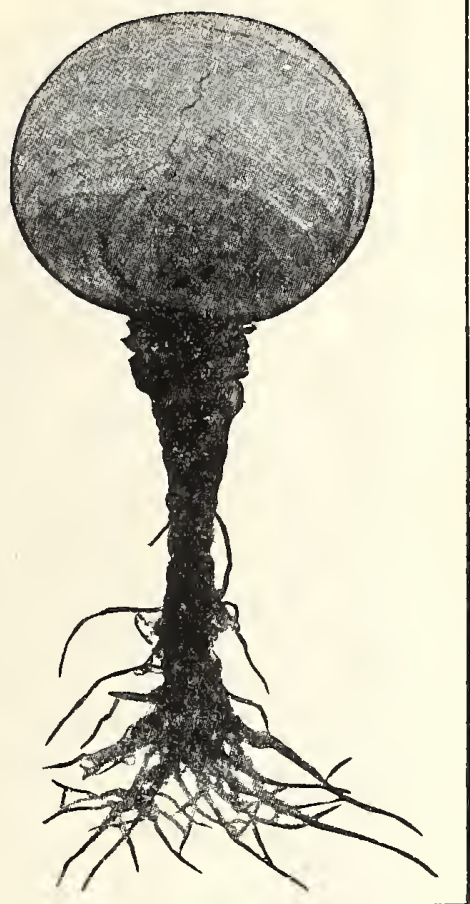

Danish Ballhead
EARIY JERSEY WAKEPIEID. Although $t h$ is variety is not as early as the preceding one, it will be found the very best conical heading sort to come in immediately after. It is very compact, medium size, conical and a sure header. Plrt. 10 cts., 1/2 0z. 15 cts., 1 oz. $25 \mathrm{cts}$. $1 / 2$ lb. $75 \mathrm{cts}$ DANISF BAIIFEAD. This is now the most popular main erop variety for market, due to its remarkable solidity, weight, uniformity in size, fine keeping qualities and attractive round head. It is especially valuable for shipping to distant markets and for late spring use. Though the heads are but of medium size, owing to their great weight the product of an acre exceeds in weight that of any other variety. We offer a strain of seed which has been proved by repeated trials to be unsurpassed. Pkt. 10 cts., $1 / 2$ oz. 20 cts., 1 oz. 35 cts., $1 / 4$ lb. $\$ 1.00$.

DANISH ROUNDFEAD. Matures a little earlier than the Danish Ballhead.

The heads are nearly round and have a short stalk and ale very hard. The inside leaves are white and sweet. It is a healthy variety and able to stand heat and resist disease. The heads, although making quicker growth, are fully as large as Ballhead and equally as good in every way; keeping well during the winter and of excellent quality. Prt. 10 cts., $1 / 2$ oz. 20 cts., 1 oz. 35 cts., $1 / 4$ 1b. $\$ 1.00$.

ENKFUIZIN GIORY. This comparatively new cabbage has proved to be the best second-early variety yet introduced. Earlier than All Seasons, it is more solid than either that or Henderson's Early Summer, and is of better shape than either, being nearly round, approaching closely in this respect the Copenhagen Market. Pkt. $10 \mathrm{cts.,} \mathrm{1/2} \mathrm{02.} 20$ cts., 02. $35 \mathrm{cts.,1/4}$ 1b. $\$ 1.00$.

EARIY WINNIGSTADT. Head large, conical, hard, and keeps well. Plant very hardy and sure to head. Pkt. 10 cts., 1/a oz. 15 cts., oz. 25 cts., $1 / 4$ lb. 75 cts.

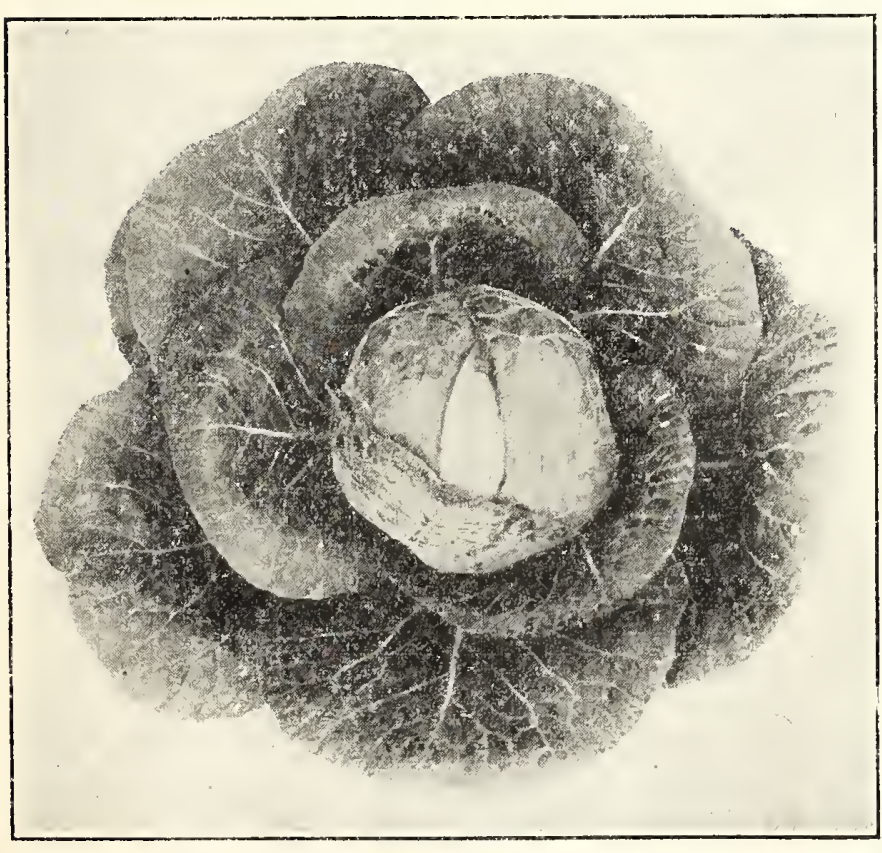

The Golden Acre
THE GOLDEN ACRE matures 10 days earlier than the earliest strain of Copenhagen Market. The Golden Acre begins to form heads as soon as the leaves have reached only the size of a as soon as the leaves have reached served from day to day. It matures in only eighty (80) days from date of sowing, and no other cabbage of which we know-including the earliest strain of Jersey Wakefleld-has proven quite as early. We believe it to be the earliest cabbage in existence. Plt. 15 ots., 1/2 oz. 45 cts. 02.75 cts. $1 / 41 \mathrm{~b} . \$ 2.50$.

PREMIUM FIAT DUTCH. An old standard late variety Head large, flat and solid. Pkt. $10 \mathrm{cts}$., 1/2 0z. $15 \mathrm{cts}$., oz. 25 cts., $1 / 4$ 1b. 75 cts.

MAMMOTH ROCK RED. Head larger and more solid than Red Drumhead; reliable in heading. Pkt. $10 \mathrm{cts.}, 1 / 2$ oz. 15 cts. oz. 25 cts. $1 / 1$ lb. 75 cts.

SUREHFAD. The heads are uniform in size and very hard and firm. They weigh from ten to fifteen pounds each. Is of the flat Duteh type. Plst. 10 cts., $1 / 2$ oz. 15 cts., oz. 25 cts., $1 / 4$ 1b. 75 cts.

WARRFN STONE MASON. An improved strain of the old Stone Mason Previous to the introduction of the Danish Ballhead, the most popular variety in New England for main crop. Earlier and more nearly round than the old strain, of medium size, hard, solid and of excellent quality. Reliable and keeps well. Pkt. 10 cts., 1/2 oz. 15 cts., 0z. 25 cts., $1 / 4$ 1b. 75 cts.

CHINGS CABBAGE, PR-TSAT Distinct from the Cabbage of Commerce. Somewhat resembling Cos Lettuce, in fact sometimes called Celery Lettuce. It can be eaten either as a salad or cooked like ordinary Cabbage. Culture same as late Cabbage. Sow early in July. Plt. 10 cts., $1 / 2$ oz. 15 cts., oz. 25 cts., 1/4 1b. 75 cts.

\section{Have you tried our}

EUREKA ENSILAGE CORN

Sold only in our trade marked bags. 


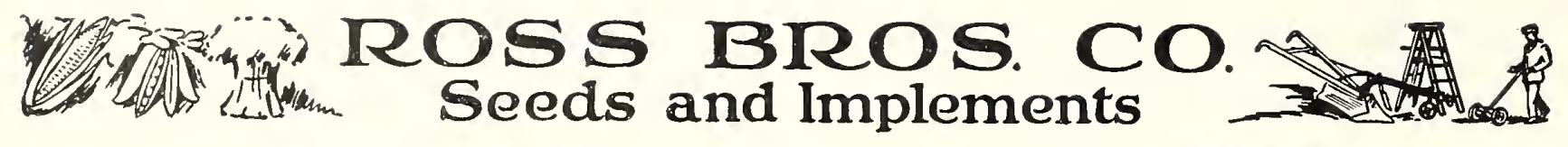

\section{CARROT}

An ornce wlll sow about 150 feet of drill; 3 pounda to the acre

Modern cooking methods furnish numerous recipes in which Carrots are a most delicious dish. Creamed alone, or in combination with Peas or other vegetables, they meet the approval of the most epicurean taste. They are used extensively in the best restaurants. For home use they are deservedly increasing in popular favor, not only a table delicacy, but because of their high food value. For stock feeding the nutritive value of Carrots surpasses most other vegetables. Every stock owner should plant at least a small acreage of Carrots to supplement his fodder ration next winter to take the place of grain. In proportion to other costs they furnish very cheap food.

The Carrot thrives best in a light, sandy soll, free from stones, well enriched, and deeply and thoroughly worked. Make the top surface fine and smooth by raking. Sow in drills 14 inches apart and half an inch deep and thin plants to 3 or 4 inches apart. Sow from the middle of April to the middle of June.

CHAXTEMAY. A most excellent medium early, half long variety. It is one of the best in quality for the market and home garden, while its great productiveness and the ease with which it can be harvested make it desirable as a field sort. The tops are medium sized with small neck The mature roots are thick, five and one-half to slx inches in length, uniformly half long or stump rooted but tapering slightly, smooth, deep orange-red in color. The flesh is very crisp and tender. Although a medium early sort the roots are suitable for use nearly as early as any. The variety is extensively used for bunching. Plet. 10 cts., oz. 20 cts., 1/4 1b. 45 cts., 1b. $\$ 1.50$.

DANVERS HALF IONG. A well known rich orange red variety, very smooth and handsome, producing extra heavy crops. An excellent market variety; crisp, sweet and tender. Although the roots are short, they produce as large a bulk as the longer field sorts and are more easily harvested. This variety has yielded 25 tons per acre. We have given this our special attention and offer at this time as good strain of seed as is possible to obtair. Pl. 10 cts., oz. 20 cts., 1/4 1b. 45 cts., 1b. $\$ 1,50$.

HUTCEINSON. Unquestionably the finest strain of Carrot yet introduced. This is a selection from the well-known Danvers, made by the late Mr. Amos Hutchinson, of Peabody, Mass. This Carrot always commanded the highest price in the market. In color it is a little darker than the Danvers, grows from one to two

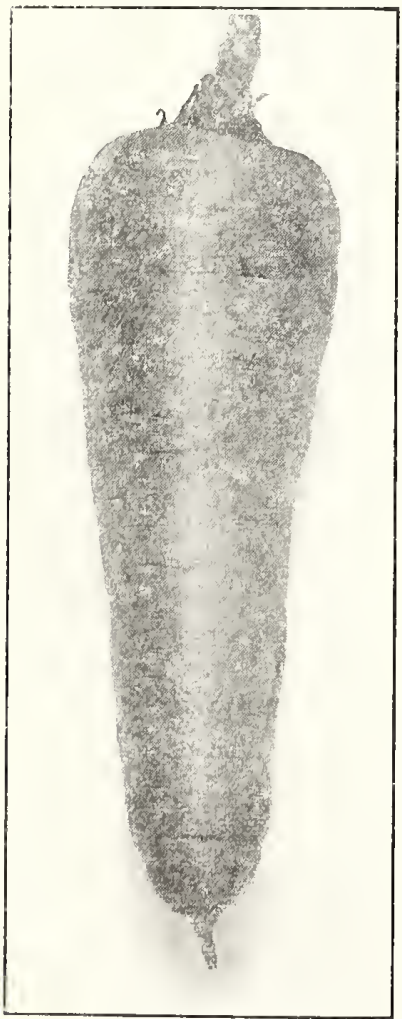

Danvers Half Iong inches longer, and holds its fullness well down, and is a much heavier cropper. Two Carrots go across the box. You will actually secure 20 per cent more Carrots per acre from this variety than from the Danvers, and the flavor is superior to all other Carrots. Pkt. 10 cts., oz. 20 cts., $1 / 41 \mathrm{~b} .60$ cts., $1 \mathrm{~b} . \$ 2.00$.

IONG ORANGE IMPROVED. The roots of the improved strain of this variety we offer are very deep orange, long and comparatively thick, often twelve inches in length and three inches in diameter at the crown, tapering regularly to a point. The tops are rather large. This intermediate to late maturing sort is suitable for table use as well as stock feeding, combining great productiveness with uniform shape

where grown in light, deep rich soil. When of size suitable for the table, the roots are tencier and of good quality. Pkt. 10 cts., oz. 15 cts., $1 / 41$ 1b. 35 cts., 1b. \$1.25.

IARGE WFITE BELGIAN. Grows one-third out of ground. The portion above ground is green, that below white, large and rather coarse. Used only for stock. Pkt. 10 cts., oz. 15 cts., 1/4 1b. 35 cts., 1b. $\$ 1.00$.

INANTES. (Scarlet Stump Rooted.) This early variety has small tops and is excellent for the market or home garden. The roots are smooth and of a bright orange color. It is of fine quality and is one of the most symmetrical of the medium size sorts. Pkt. 10 cts., oz. 15 cts., $1 / 4$ 1b. 35 cts., 1b. $\$ 1.00$.

\section{Perfection}

This new introduction which is best described as a blunt-ended James Intermediate is almost entirely free from core. Flesh is strikingly deep red, tender and very delicate. The roots are rather long and comparatively thick, whereas tops are very small. Grows very uniform. Produces a heavy crop of roots which can be easily kept in prime condition throughout the winter. Pht, 10 cts., oz. 20 cts., $1 / 4$ lb. 60 cts., 1b. $\$ \mathbf{2} .00$.

\section{Pride of Denmark}

A carrot of great promise. It is a cross between the Nantes and Chantenay and resembles the Hutchinson in shape and is of equal good quality. Its bright orange-scarlet color, its size and productiveness are in favor of its becoming one of the leading market varieties. Our trials during the past season would indicate that this variety will be in great demand as soon as Its qualitles are known. Flct. 10 cts., oz, 20 cts., 1/4 1b. 60 cts., 1b. \$2.00. 


\section{\&u Ross' Seed Grows}

\section{Cauliflower}

An ounce will produce 3,000 plants

In general, the Cauliflower requires about the same treatment as the cabbage; moist land is, however, more essential and heavier manuring and more frequent cultivation aids to a greater extent the full development of the plant. In this climate the plant heads well only in the cool fall months. Seed should therefore be sown as for late cabbage, from the middle of May to middle of June, the late varieties, however, requiring a little more time than most late cabbage.

EARIY SNOWBAII. The earliest and surest to head. Probably more largely used than all others combined. We offer an unsurpassed strain from one of the leading growers in Denmark. Pkt. 20 cts., $1 / 4$ oz. 90 cts., $1 / 2$ oz. $\$ 1.65$, oz. $\$ 3.00$.

EARIIEST DWART ERTURT. One of the earliest varieties; very dwarf, with large, white, compact heads of finest quality. Excellent for forcing. Pkt. 20 cts., $1 / 4$ oz. $\$ 1.00$, $1 / 2$ oz, $\$ 1.85$, oz. $\$ 3.50$.

EARIY IONDON. A well-known variety, maturing its head soon after the extra-early sorts. Plt. 10 cts., $1 / 2$ oz. 45 cts., oz. 75 cts., $1 / 4$ 1b. $\$ 2.50$.

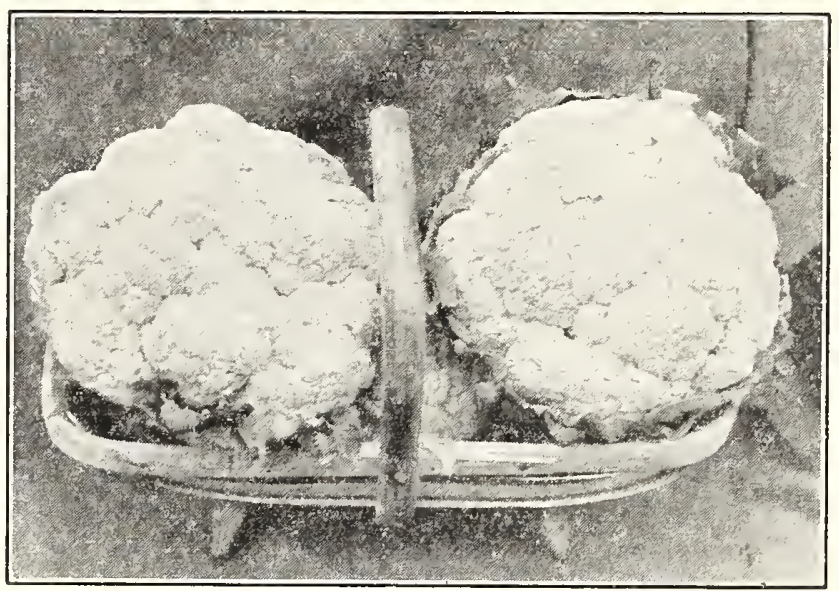

Snowball Camliflower (Selected \$tock)

\section{Celery}

An ounce will produce about 10,000 plants

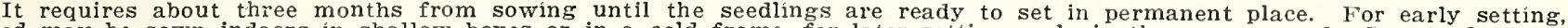

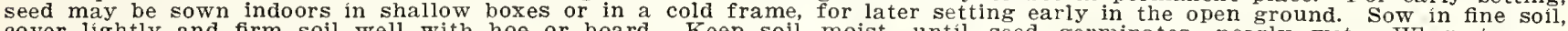

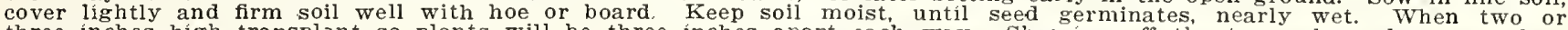

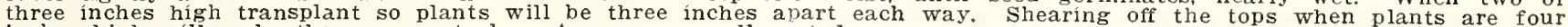
inches high will make them more stocky. As soon as well rooted transplant to permanent location. In the field, plants are set in rows four to six feet apart with plant eight to twelve inches apart in the row. In the garden they are often set much closer. To blanch, draw earth about the plant from time to time, taking care that the tops of the center shoots are not covered.

EASY BIANCHING. A distinct sort. Very quick and easy to blanch, has exceptional keeping quality. The plant is of medium height, of great vigor, having thick rather than broad stalks, with shallow ribs. The stalls are very brittle and the flavor extremely spicy. Pkt. 10 cts., $1 / 2$ 0z. 20 cts., 1 oz. 30 cts., $1 / 4$ ib. 85 cts.

GIATT PASCAI. A green leaved variety which developed from the Golden Self-Blanching. Very solid and crisp, of the finest quality, stringless, tender and of a peculiarly sweet, nutty flavor. Pkt. 10 cts.r $1 / 2$ oz. 20 cts.. oz. 35 cts., 1/4 1b. $\$ 1.00$.

GOLDEN SIIF-BIANCHING. The most popular variety for market, easily blanched, very attractive, of good quality, though not equal to some of the green celeries.

TEUE FRENCE-GROWN SEED. Pkt. 20 cts., $1 / 2$ oz, 65 cts., oz. $\$ 1.25,1 / 4$ 1b. $\$ 4.00$.

AIMRICAN-GROWN SHED. Seed plants grown direct from French seed. Pkt, 10 cts., $1 / 2$ oz. 20 cts., 0z. 35 cts., $1 / 4$ 1b. $\$ 1.00$.

WHITE PIUME. The earliest and most easily blanched of all varieties, very showy, of good quality. Pkt. 10 cts., 1/2 oz, 20 cts., oz. 30 cts., $1 / 4$ 1b. 85 cts.

WINTrR oUrFis. of medium height, but stout, thick, and heavy, with a larger amount of heart than most other sorts of fine quality, more easily handled than the Giant Pascal, and an excellent leeper. One of the bes for late winter use. Pkt. 10 cts., $1 / 2$ oz. 20 cts., oz. 30 cts., $1 / 4$ 1b. 85 cts.

\section{Celeriac-Turnip Rooted Celery}

Sow seed and treat in first stage of growth as directed for cel-

ery. Set in rows 2 feet apart and 6 inches apart in the row. As the roots only are used, no banking is necessary. When roots have reached a size of 2 inches in diameter they are ready for use. These are boiled, sliced and eaten with vinegar. To keep through winter, roots should be packed in moist sand or earth.

IARGE SMOOTH PRAGUE. An improved sort with nearly round roots which have but few side roots. Pkt. 10 cts., oz. 25 cts., 2 ozs. 45 cts., $1 / 4$ lb. 80 cts.

\section{Chervil Curled}

A hardy annual, used for flavoring and garnishing. It is thought by some to exceed even parsley in beauty. Seed should be sown early in the spring and when plants are well-rooted, transplant to one foot apart. The leaves will be ready for use in seven to ten weeks from planting. Pkt. 10 cts., oz. 25 cts., $1 / 41$ b. 80 cts.

\section{Germination on All Seeds Sent on Request, \\ Also Purity on \\ Grass Seeds, Clovers and all Field Seeds}

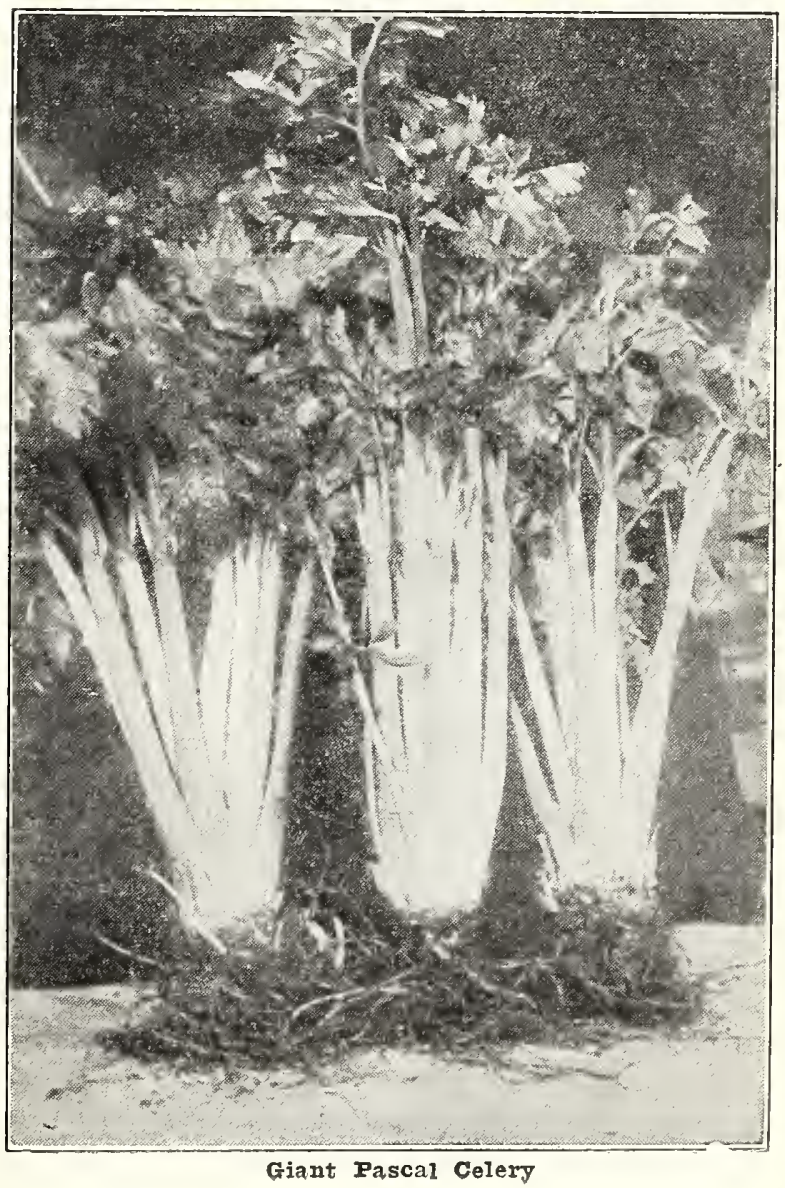




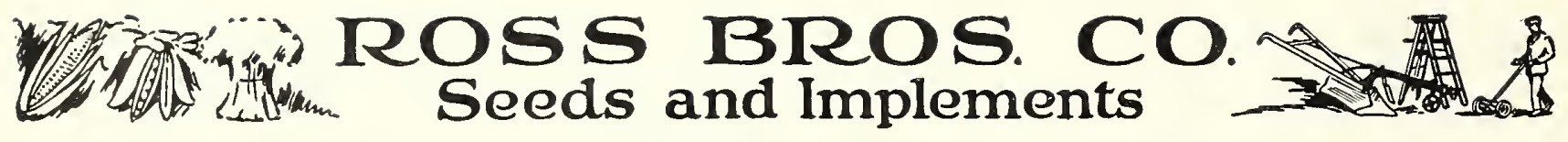

\section{Cucumber}

An ounce will plant about $50 \mathrm{hills}$. $1 \frac{1}{2}$ to 2 pounds to the acre

The Cucumber requires well-enriched soil, and should not be planted until settled warm weather, in this latitude, seldom before the middle of May. Plant the early, small kinds in hills $31 / 2$ to 4 feet apart. the larger varieties 5 to 6 feet. Make the hllls broad, use 15 to 20 seeds to the hill, dropping them well apart. Cover with not over an inch of earth and firm this well with the hoe. If the young plants are attacked by the striped bugs or other insects. dust frequently with air-slacked lime, soot or ashes mixed with road dust, taking care that too much is not used at one time. When all danger from bugs is past, thin to three plants to the hill. Give frequent shallow cultivation as long as vines will permit.

\section{Davis Perfect}

Flne length, slimness, beautiful dark green color, transparent-like flesh wlth deliciously cool refreshing flavor, and enjoyable crispness, are distingulshing features and qualities of this, the most popular of the extra long white spine cucumbers. For indoor, and outdoor planting it is most popular. Its extremely vigorous growth makes it the best olight resister of the longer sorts, Plrt. 10 cts., 0z. 20 cts. $1 / 4$ lb. 50 cts., 1b. $\$ 1.50$.

BOSTON PICKIING. For pickling this variety ls superior to all others. Its fruit is short, polnted at each end, bright green, uniform in size, very productive and of superior quality. Pkt. 10 cts., oz. 20 cts., $1 / 4$ lb. 45 cts., 1b. $\$ 1.35$.

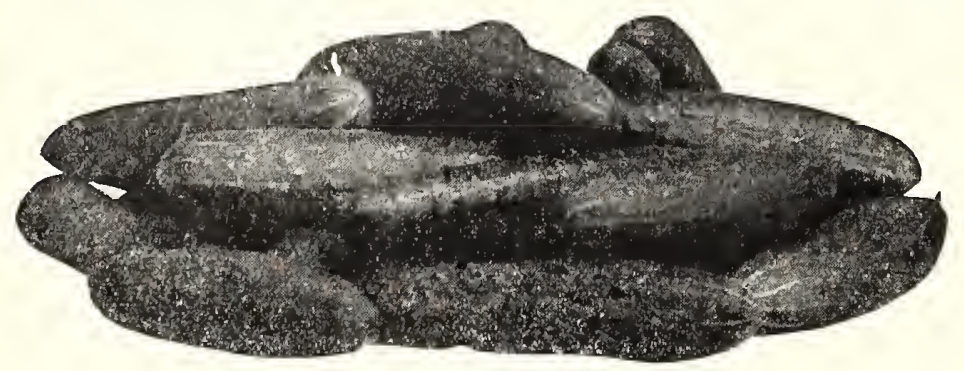

Improved White Spine

JAPANESE CIIMBING. Vlne very vigorous with especially strong grasping tendril. Fruit of good size and quality. Plt. 10 cts., oz. 20 cts., $1 / 41 \mathrm{~b} .45$ cts., $1 \mathrm{~b}$. $\$ 1.35$.

IONG GREEN. An old standard variety, very popular for home gardens but little used for market. Fruit very long, slender, very firm and crlsp, uniformly dark green; makes fine pickles and ls the best of all when ripe for making sweet pickles. Pkt. 10 cts., 0z. 20 cts., $1 / 4$ 1b. 50 cts., $1 \mathrm{~b}$. $\$ 1.50$.

\section{Corn Salad, Fetticus, or Lamb's Lettuce}

A hardy, rapid-growing plant, often used in winter as a substitute for lettuce and is sometimes cooked and used like spinach. It does not thrive in hot weather and if sown in the spring it should be very early and on extremely rich soll. It will then be ready for use in four to six weeks. It, however, succeeds best when sown in August or September. If sown in the former, it will be ready for use in the late fall. If left in the ground during winter, lt should, on the approach of cold weather, be protected with straw or litter. Plt. 10 cts., 0z. 30 cts., 2 ozs. 55 cts., $1 / 41 \mathrm{~b}$ $\$ 1,00$.

We send one pound or less postpaid; for larger quantities by parcel post, postage must be sent. See inside front cover.

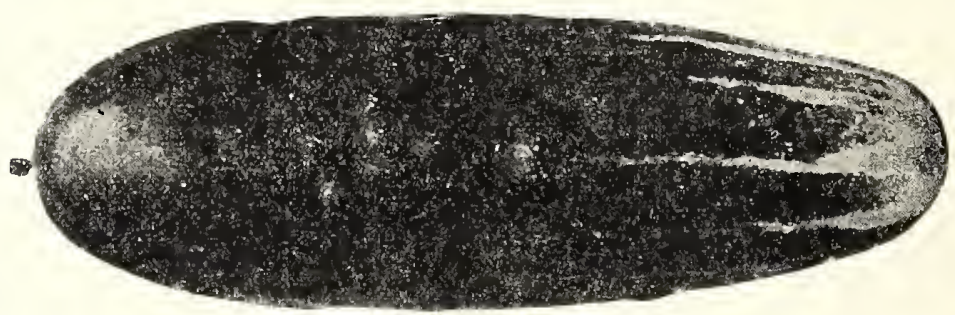

Eariy Fortune

The most uniform and best colored Cucumber of recent introduction.

EARIY FORTUNE. The plant is early, very vigorous, with an exeptionally heavy, thick foliage and is almost disease resistant and very productive. Fruits are uniformly nine inches long, slightly apering toward each end, perfectly round and of a very rich dark 0z. $20 \mathrm{cts}$., $1 / 4 \mathrm{lb}$. $50 \mathrm{cts}$., $1 \mathrm{~b}$. $\$ 1.50$.

ARIY CIUSTER. Early and productive. Fruit small, dark green, cts., 1/4 1b. 45 cts., 1b. $\$ 1.35$

EARIY RUSSIAN. The earliest and hardiest variety. Fruit 3 to 4 inches long. Vlne vigorous and productive. Plt. 10 cts., 02.20 cts. $\$ 1.35$

EXTRA IONG, OT EVERGREEN WHITE SPINE. A distinct and superior strain of this popular type. Fruit long, cylindrical, dark green, crisp and tender. Vine productive and comes lnto bearlng soon after the Early White Spine. Popular with market gardeners. Pkt. $10 \mathrm{cts.}$, 0z. 20 cts., $1 / 4 \mathrm{lb}$. 50 cts., 1b. $\$ 1.50$.

IMPROVED WHTTE SPINE. Perfection has been attained in this grand improvement in the White Spine family. It is early, proliflc and produces a continuous crop of uniformly large and symmetrical fruits of an intensely rich deep green color, faintly marked with light yellowish shading toward the tip. It runs very close to type, bearing practically no mis-shapen frult or culls. It is the ideal for sllcing; the flesh ls compact, fine-grained, sparkling white and of most refreshing and delightful flavor. The vines are vigorous, quite healthy, and mildew-proof, maintainlng their luxuriance and bearing abundantly from the earliest to the latest season. Flrt. 10 cts., oz. 20 cts. $1 / 4$ 1b. 50 cts., 1b. $\$ 1.50$. 


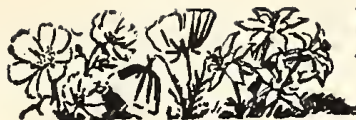 \\ EVERYBODY
Ros' Seed. KNOWS}

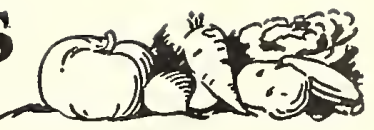

Chicory

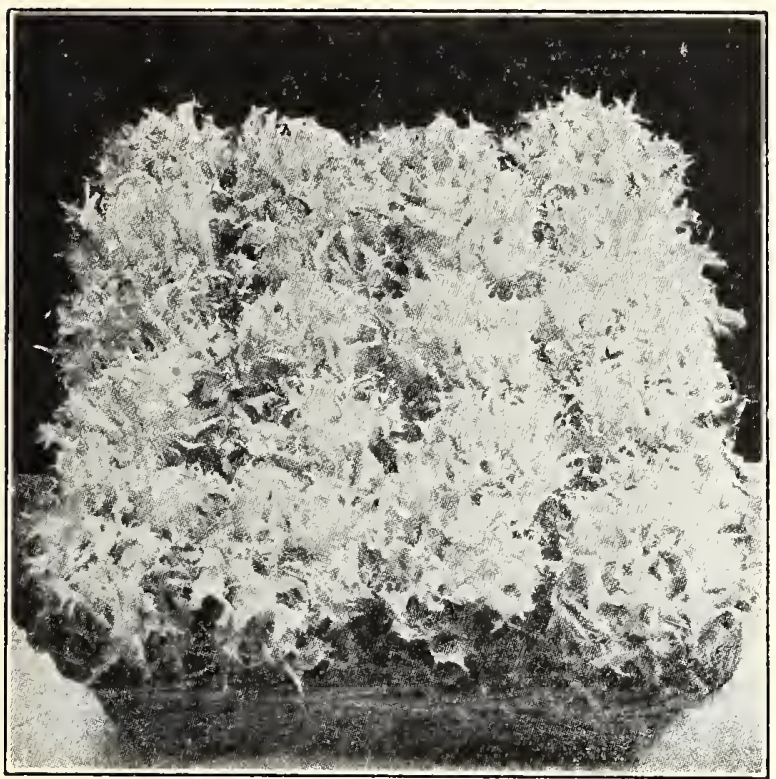

Enaive Batavian Broad Ieaf
WAITLOOF, or FRENCF ENDIVI. Esteemed as a salad plant. Spring-sown seeds produce parsnip-like roots by November. Cut the leaves off $1 \frac{1}{2}$ inches from the neck, trench $1 \frac{1}{2}$ inches apart, cover with soil 8 inches over crown; then place a 2 or 3 foot layer of fresh manure which induces new growth of blanched leaves folded like Cos Lettuce, which are eaten raw as salad. Plat. $10 \mathrm{cts}$., 0z. $30 \mathrm{cts.,} 1 / 4 \mathrm{lb}$. $85 \mathrm{cts}$.

\section{Chives}

CHIVES. A re a small hardy perennial plant resembling onion in appearance and grow in clusters. They are grown for the leaves, which are produced freely from early spring and give a mild onion flavor to sausages, salads and soups. They can be easily

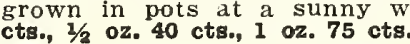

\section{Collards}

(One oz. for about 5,000 plants)

Collards are very largely used as "greens" in some parts of the country, especially in the South. They are a form of loose-headed cabbage

GEORGIA. The most satisfactory variety for general use. Pkt. 10 cts., 1 oz. 25 cts.

\section{Dandelion}

An ounce will sow 200 feet of drill. Two pounds to the acre. Sow early in the spring in rich soil in drills 15 to 18 inches apart, cover lightly but make the earth firm. Thin to 5 inches apart in row. Cultivate frequently through the summer. Plants ready for cutting the following spring.

IMPROVED TEICK- IEAVFD, Or CABBAGING. A distinct variety unsurpassed in thickness of leaf and deep green color. It grows compactly, forming a regular upright tuft. Plt. 10 cts., $1 / 2$ oz. 35 cts., 1 oz. 55 cts., $1 / 4$ 1b. $\$ 1.75$.

CUITIVATED, or FRENCH COMDION. A greatly improved strain of the common Dandelion. Pirt. $10 \mathrm{cts.}$, 1/2 $02.20 \mathrm{cts}$., 0z. $30 \mathrm{cts}$. $1 / 4$ lb. 85 cts.

\section{Dill}

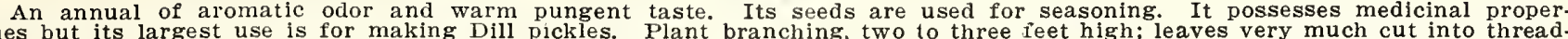
like segments. Plst. 10 cts., oz. 20 cts., $1 / 4$ 1b. 50 cto.

\section{Endive}

An ounce will sow 300 feet of drill, producing from 2,000 to 2,500 plants

Endive, like lettuce, may be grown at any season, but is more generally used in the fall. For early use, sow in April, for later, until July, in drills 18 inches apart, or in beds for transplanting, plants should stand 10 to 12 inches apart in the row. When nearly full grown tie outer leaves over center to blanch the heart, or blanch with boards as with celery. MOSS CURIFD. Of dense growth and finely curled. Plrt. 10 cts.s $0 z_{.} 20$ cts. $1 / 4$ 1b. 50 cts., 1b. $\$ 1.50$.

LARGE GREEN CURLED. Of larger growth, not so much curled as preceding. Pkt. 10 cts., $0 z .20$ cts., $1 / 4$ 1b. 50 cts., lb. $\$ 1.50$.

BATAVIAN BROAD IFAVED (Escarole). A variety having broad, more or less twisted and waved bright green leaves with thick, nearly white midribs. The inner leaves form a fairly solid, clustering head which blanches a beautiful deep creamy white and is crisp, tender, and of fine flavor.

Unsurpassed for salads. Plt. 10 cts., oz. 20 cts., $1 / 41 \mathrm{~b}$. $50 \mathrm{cts}$., 1b. $\$ 1.50$.

\section{Fennel (Finocchio)}

(FIORENCE, or NAFIES.) Resembles Celery in flavor, but has a sweet taste and delicate odor. Should be sown in Spring in drills 18 inches apart and the plants thinned to 5 or 6 inches apart. Pkt. 10 cts., oz. 50 cts., $1 / 4$ 1b. $\$ 1.50$.

\section{Cress, Curled or Pepper Grass}

A small pungent salad plant, much liked by some with lettuce. Like al salad plants, it should be grown on rich ground. Seed may be sown early in the spring, but if desired through the summer, repeated sowing will be necessary. Plit. 10 cts., oz. 20 cts., 2 oz, 35 cts., 1/4 1b. $60 \mathrm{cts}$.

\section{Water Cress}

WATER CRESS. Hardy plant which can be grown in a pond or along the banks of a running stream. Largely used as a garnish during the winter and early spring months. Plt. $10 \mathrm{cts.,} 1 / 2$ 0z. 35 cts., 0z. $60 \mathrm{cts.,} 1 / 4 \mathrm{lb}$. $\$ 2.00$.

\section{Egg Plant}

An ounce will produce about 2,000 plants

The Egg Plant, like all sub-tropical plants, requires, for both germination of seed and vigorous growth of plant, a high temperature. The seed is slow in germinating, and should be sown about the first of April. When the young plants show two rough leaves, transplant 3 to 4 inches apart, and when settled warm weather comes, set in rich, warm soil, $2 \frac{1 / 2}{2}$ to 3 feet apart each way.

BIACK PEKIN. An early variety, nearly round, large, smooth, black and glossy. Plants prolific, leaves purplish black. Plit. 10 cts., $1 / 2$ oz, 30 cts., 02. 55 cts.

NEW YORZ IMIPROVED (Spineless). The favorite variety. Fruit of largest size, rich purple and finest quality. Plant large, spreading and very productive; foliage light green. Prt. $10 \mathrm{cts} ., 1 / 2$ oz. $30 \mathrm{cts}$., oz. $50 \mathrm{cts}$.

BLACK BEAUTY. A valuable variety, ready for use two weeks earlier than any other sort. The fruit is thick and of a rich purplish-black color. Plt. 10 cts., $1 / 2$ oz. 30 cts., oz. 50 cts.

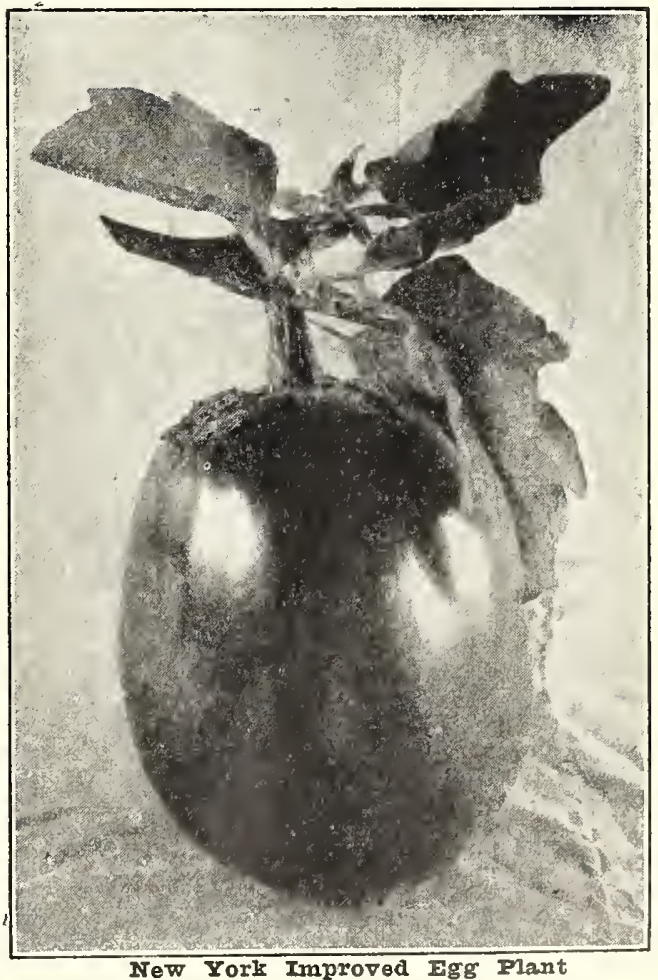




\section{ROSS BROS. CO.}

\section{Kohl Rabi}

An ounce will sow about 200 feet of arill The edible part is the turnip-shaped bulb formed above ground. It is tender and excellent when used before fully grown, combining somewhat the flavors of cabbage and turnip. Seed should be sown in light rich soil as early in spring as possible, in rows one and one-half feet apart and when well established thin to six inches apart in the row. Plantings at intervals of ten days will give a succession until hot weather; when they fail to grow well. Planting may be made the latter part of July for fall use.

EARLY WHITE VIENNA (Eutra for forcing). This variety is extremely early with distinctly small tops. The bulbs are of medium size, very light green or nearly white, and are of best quality for the table if used when about two inches in diameter. Pyt. 10 cts., $1 / 2$ oz. $20 \mathrm{cts}$., oz. $30 \mathrm{cts}$., $1 / 4$ 1b. $35 \mathrm{cts}$.

EARIY PURPIE VIENAA. Very early, with small top, the leaf stems being tinged with purple. Bulbs of medium size, purple, flesh white. Desirable for forcing and early outdoor planting. Pixt. 10 cts., 1/2 oz. $20 \mathrm{cts}$., oz. $30 \mathrm{cts}$., $1 / 4 \mathrm{lb}$. $85 \mathrm{cts}$.

\section{Leek}

Leeks require rich soil. Sow early in spring in deep drills, eighteen inches apart, but cover with but one-half inch of soil, thin plants to about eight inches apart and as they grow gradually fill the drill and draw the earth around them as with celery. Or if very tender and white leeks are desired, sow in bed and transplant when plants are six inches high into trenches six or eight inches deep and as they grow gradually fill the trench and later draw the earth around them so that it will be two or three inches above the level.

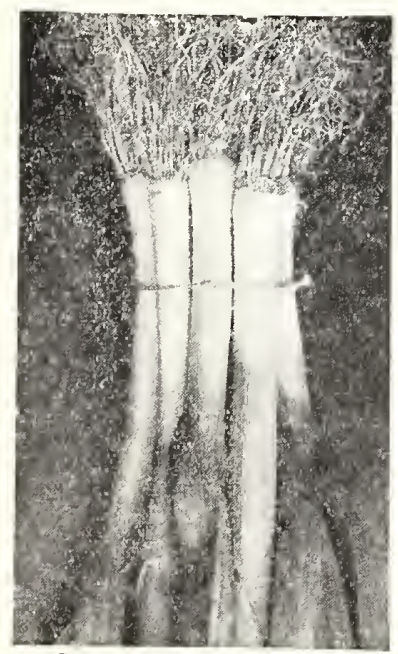

Ieek

AMIERICAN BROAD FIAG. A desirable strong growing, broad leaved leek, hardy and productive. It is a favorite with many markec gardener's and is also extensively used for the home garden. Pkt. 10 cts., $1 / 2$ oz. 20 cts., oz. 30 cts., 1/4 1b. 85 cts.

GIANT MUSSEIBURGI. A very hardy variety of extra-large size; the leaves are fan-shaped of a dark green color, the edible stem is 6 to 8 inches long and 3 inches in diameter. Pkt $10 \mathrm{cts} ., 1 / 2$ oz. $20 \mathrm{cts}$., oz. $30 \mathrm{cts} ., 1 / 41 \mathrm{~b} .85 \mathrm{cts}$

\section{KALE or BORECOLE}

An ounce will produce 2,000 plants

DWARE CURIED SCOTCF. For early use, sow in May and transplant in June, and treat generally as for cabbage. One of the best plants grown for greens. This is a finely curled, low growing variety, the leaves of which when properly cooked make very palatable greens. The plant is very hardy, the leaves are long, and of an attractive bright green color. This sort ls also very often used for garnishing. Pkt. 10 cts., oz. 15 cts., 1/4 1b. 40 cts.

\section{LETTUCE}

An ounce will produce from 3,000 to 4,000 plants

Lettuce thrives on nearly all soils, but because the rrowth should at all times be rapid to insure crispness and best favor the soil should be heavily enriched and well worked before planting. Lettuce being quite hardy, seed may generally be sown as soon as ground can be fitted, as while prolonged or continued freezing will kill the plants, they are but little injured by an ordinary frost. Seed may also be sown in the hotbed in gentle heat, and the plants, if well hardened by having been often exposed to the air, may usually be set in the open ground very soon after the time suggested for sowing seed outdoors.

\section{General Crop, Heading and Loose Leaved Varieties}

BrIMONT FORCING. This is a plain-leaved variety. It forms a compact head and is, like the Tennisball, almost certain to head, making it a desirable and profitable variety for forcing. Plt. 10 cts., $1 / 2$ oz. 40 cts., oz. 75 cts., $1 / 4$ 1b. $\$ 2.50$.

BIG BOSTON WHTE SEEDED. Probably the most generally used in cultivation It ls a cabbage head, butter type, medium larse, finely shaped, globular, medium light green with slight tinge of brown on margins of outer leaves. It is early and hardy and stands shipping well. The leaf is smooth and practically not blistered or savoyed, with a tendency to a bright sheen. The head itselt is brittle, buttery and the interior quite a golden yellow. Pkt. 10 cts., 1/2 oz. 20 cts., oz. 30 cts., $1 / 4$ 1b. 75 cts.

GREEN-IEAVED BIG BOSTON. A cabbage butter head; medium size; medium green. Is practically the same as Big Boston with no tint of brown and the head is of a whitish green. Pkt. 10 cts., $1 / 20 z .20 \mathrm{cts}$., oz. $30 \mathrm{cts}, 1 / 41 \mathrm{~b} .75 \mathrm{cts}$

BIACK-SEEDED TENNISBAI工. More extensively grown in New England than any other variety, both for first outdoor crop and for main crop, the medium sized heads being the size most liked by gardeners, whlle its compact form allows it to be grown more closely together than others. Leaves plain, thick, dark green; blanches to a rich creamy white inside. Prt. 10 cts., 1/2 0z. 20 cts. oz. $30 \mathrm{cts.}, 1 / 4 \mathrm{lb} .75 \mathrm{cts}$.

BIACE-SEEDED SIMPSON. Much larger than the preceding, but not so much curled. Forms a large, loose cluster of leaves rather than a head; leaves light

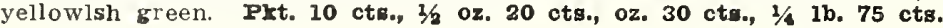

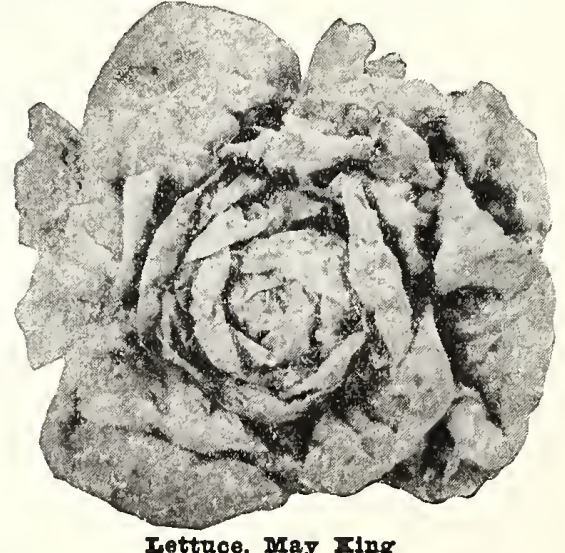




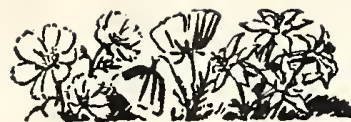 \\ EVERYBODY
Ross' Seed

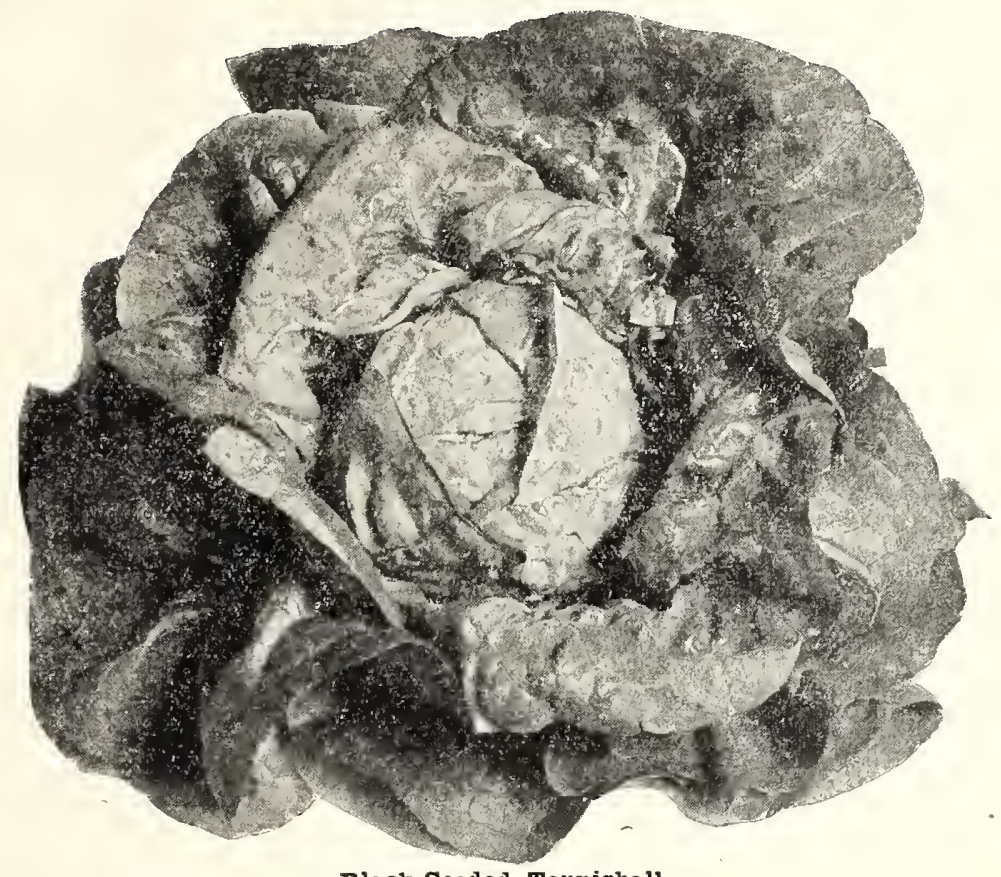

Lettuce

BOSTON FINE CURIED. Beautifully curled, excellent for garnishing. Pkt. 10 cts., 1/2 oz. 20 cts., oz. $30 \mathrm{cts}$., $1 / 41 \mathrm{~b} .75 \mathrm{cts}$.

CRISP AS ICr. A midsummer variety, surpassing all of this class in crispness, tenderness and fine flavor. Forms large solid heads, with leaves crimped and curled, those outside being variegated dark green and bronze, the inner portion blanching to a rich creamy yellow. Pkt. 10 cts., $1 / 2$ oz. 20 cts., oz. 30 cts. $1 / 41 \mathrm{~b} .75 \mathrm{cts}$.

EARIY CURIED SIMPSON. (White-seeded.) An old variety, with broad, often frilled very curly light green lcaves; sweet, tender of fine flavor. $\begin{array}{llllll}\text { Pkt. } 10 & \mathrm{cts}_{\text {. }} 1 / 2 & \text { 0z. } 20 & \text { cts., oz. } 30 & \text { cts., } 1 / 4 & 1 \mathrm{~b} .\end{array}$ 75 cts.

GRAND RAPIDS. Without doubt this is one of the easiest varieties of lettuce to grow. It forms no head but produces an abundant crop of pale green leaves, slightly but closely crumpled which have an excellent flavor. Pkt. 10 cts., $1 / 2$ oz. 20 cts., oz. 30 cts., 1/4 1b. 75 cts.

HANSON. An old variety of great merit. Forms a large flat, cabbage-like head, very slow to run to seed. The outer leaves are bright green, with veins of lighter shade, inner leaves white, usually curved and twisted at the base. A very attractive variety of excellent quality and extensively grown for home use. Pkt. 10 cts.

Black-Seeded Tennisball $1 / 2$ oz, 20 cts., oz. $30 \mathrm{cts}, 1 / \mathrm{s}$ 1). $75 \mathrm{cts}$.

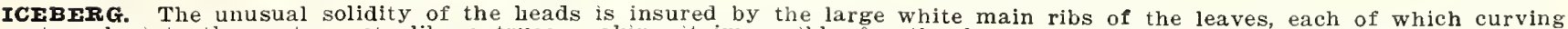

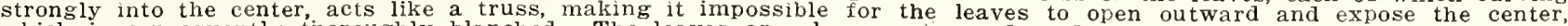

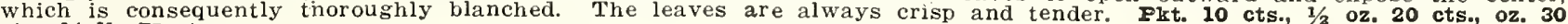
cts., $1 / 4$ 1b. 75 cts.

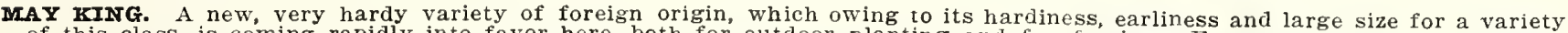

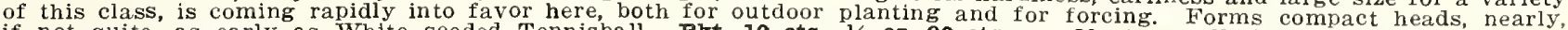
if not quite, as early as White seeded Tennisball. Pkt. 10 cts., 1/2 0z. 20 cts., $0 z$. 30 cts., 1/4 1b. 75 cts.

NEW YORK MARKrT. One of the largest varieties in cultivation. The heads are very solid with but little tendency to run to seed. It blanches itself naturally, is crisp, tender, and of excellent flavor, and always free from bitterness. Pkt. 10 cts., $1 / 2$ oz. 20 cts., oz. 30 cts., $1 / 41 b_{0} 75$ cts.

PRIZE IIAD. A large, loose-leaved variety, which has been very popular for home use. Leaves very thin, crimped, bright green tinged with brownish red; sweet, tender and of good flavor, but not equal to Crisp as Ice. Pkt. $10 \mathrm{cts.} 1 / 2$ oz. $20 \mathrm{cts.}$ oz. $30 \mathrm{cts.,} \mathrm{1/4} \mathrm{1b.} 75 \mathrm{cts.}$

SAIAMANDER. A large, compact head of good quality. Leaves light green, broad, thick, somewhat crumpled, closely overlapping so that inside they blanch to a creamy white. Withstands heat remarkably. One of the best varieties for midsummer. Fkt. $10 \mathrm{cts.,} \mathrm{1/2} \mathrm{0z.} 20$ cts., oz. $30 \mathrm{cts.,} \mathrm{1/4} 1 \mathrm{~b} .75 \mathrm{cts}$.

WIITE-SREDED TENNISBATI, or BOSTON MARTET. An old and popular variety for forcing; heads small and compact. Not suitable for outdoor planting. Plet. 10 cts., 1/2 oz. 20 cts., $02.30 \mathrm{cts.}, 1 / 41 \mathrm{~b} .75 \mathrm{cts}$.

\section{Romaine or Cos Varieties}

These are distinct from the ordinary lettuce, and much liked on account of their tender, crisp leaves and delicious flavor. The leaves are long and narrow and need to be tied up when they soon form solid heads and bleach snow white. EXPEESS COS. A fine dwarf early sort requiring no tying up. Pkt. 10 cts., 1/2 oz. 15 cts., oz. 30 cts., $1 / 4$ 1b. 65 cts.

PARIS WHITE COS. One of the finest varieties for summer use. Pkt. 10 cts., $1 / 2$ oz. 15 cts., oz. 30 cts., $1 / 4$ 1b. 65 cts.

TRIANON Cos. Similar to above but grows whiter and matures earlier. Pkt. $10 \mathrm{cts.}, 1 / 2$ oz. $15 \mathrm{cts}$., $0 \mathrm{z}$. $30 \mathrm{cts}$., $1 / \mathrm{s} \mathrm{lb} .65 \mathrm{cts}$.

\section{Mustard}

Used mainly for salads but is sometimes boiled for greens. Sow as early as ground can be worked in drills eighteen inches apart and one-half inch deep. If desired throughout the season, successive sowings should be made about every three weeks.

WIITE, or YEIIow. The common variet.y. The seeds are often used to flavor pickles. Pkt. 10 cts., oz. 20 cts., $1 / 4$ lb. 50 cts.

SOUTHRRN GIANT CURIED. Large, light green leaves, much crumpled at the edge. The best for salads. Pkt. 10 cts., $02.20 \mathrm{cts}, 1 / 4 \mathrm{lb} .50 \mathrm{cts}$.

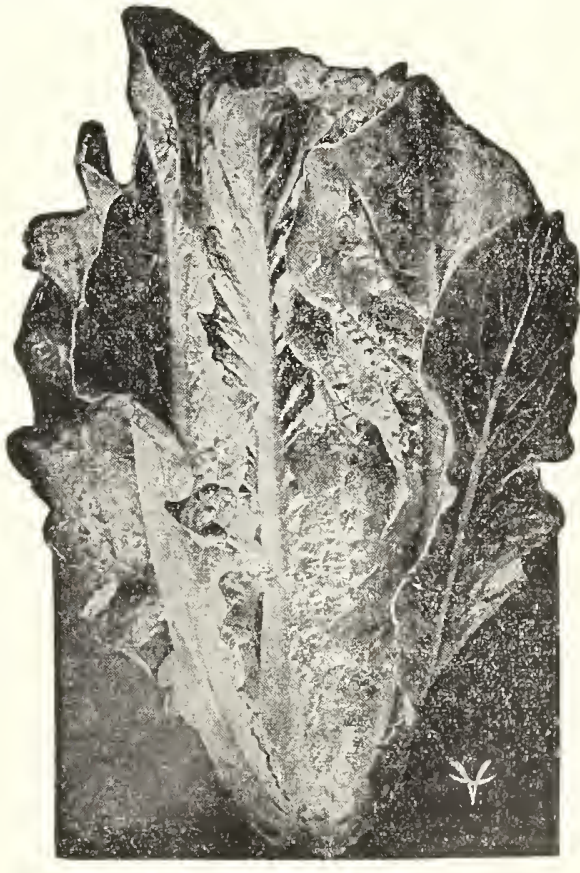

Parto white Cos Iettuce 


\section{ROSS BROS. CO.}

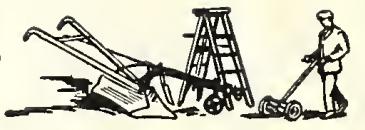

\section{Muskmelon}

An ounce will plant about 50 hills. $1 \frac{1}{2}$ to 2 pounds are required for an acre.

The Muskmelon succeeds best in warm, rich soil. Plant when all danger of frost is past, in broad hills 4 to 5 feet apart, 10 or more seeds to each hill. Cover with one inch of soil and firm well with the hoe. If young plants are attacked by insects, dust them with air-slack lime or ashes mixed with twice as much road dust. Use this frequently but sparingly, as a large quantity at one time is liable to injure the plants. When all danger from insects is past, thin to three plants to the hill.

BENDER's SURPRISE. (The Bender Melon)-A very popular variety in the east, particularly around Albany, N. Y. A selection from Surprise and a close kin to Irondequoit differing from that variety in being more oblong, more full and rounded at the ends, not quite as well netted or as early; skin light greenish-yellow when ripe. A very delicious, large salmonfleshed melon with superior shipping and keeping qualities. Pkt. 10 cts., oz, 20 cts., $1 / 41 \mathrm{~b}$. 60 cts.

BURRELL'S GRIM. The melons are six to seven inches long by four and a half to five inches in diameter, rather sharply sloping at the ends. They are quite well ribbed and covered with

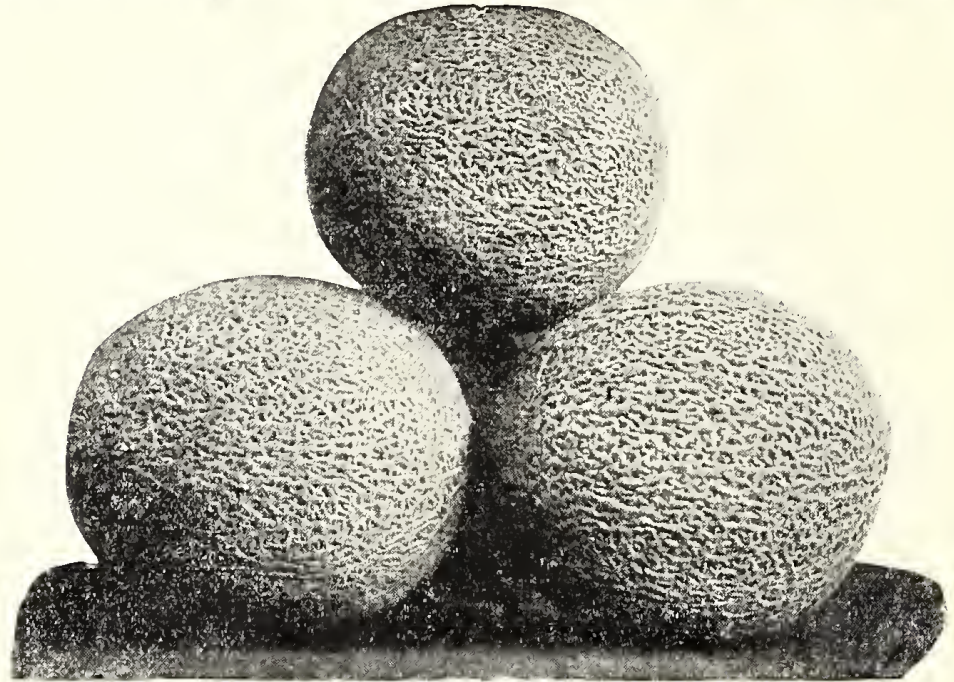

Rocky Ford

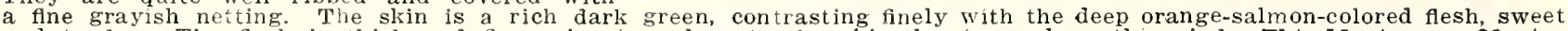

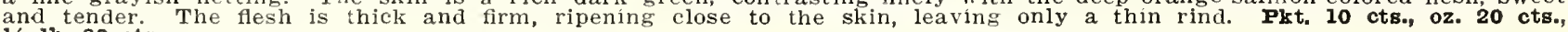
$1 / 4$ 1b. $60 \mathrm{cts}$.

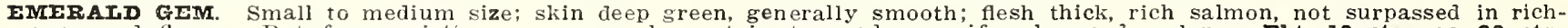

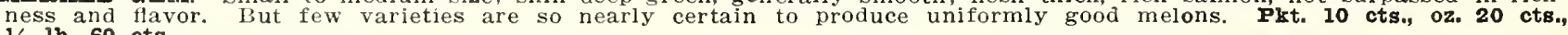
$1 / 4$ 1b. $60 \mathrm{cts}$.

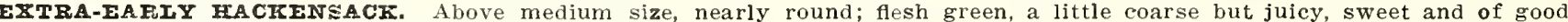
flavor. Fkt. $10 \mathrm{cts}$, oz, $20 \mathrm{cts} ., 1 / 41 \mathrm{~b}, 60 \mathrm{cts}$.

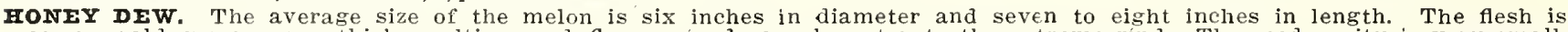

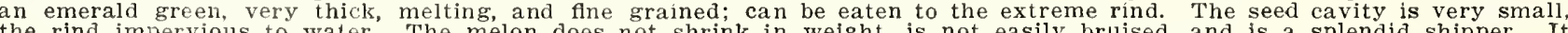

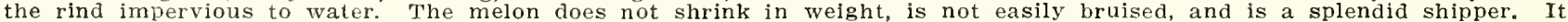
is later than Rocky Ford strains and is very prolific. Plt. 10 cts., oz. 20 cts., 1/4 $\mathbf{l b}$. 60 cts.

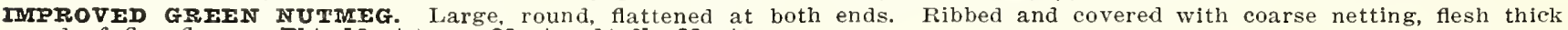
and of fine flavor. Plst. 10 cts:, oz. 20 cts., $1 / 4$ 1b. 60 cts.

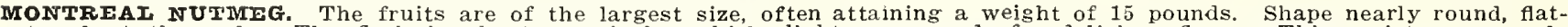

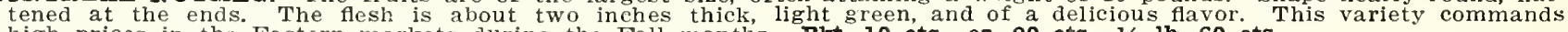
high prices in the Eastern markets during the Fall months. Pkt. 10 cts., oz. 20 cts., 1/4 1b. 60 cts.

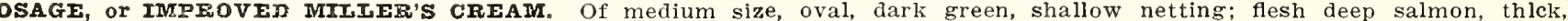
very firm, sweet and of rich flavor. Plt. 10 cts., oz. 20 cts., 1/4 1b. 60 cts.

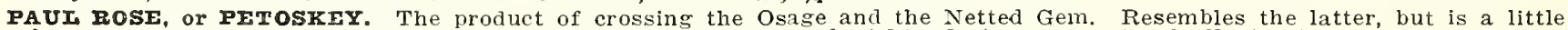
larger, and flesh is rich orange. Very sweet and high flavoled. Pkt. 10 cts., 0z. 20 cts., 1/4 1b. 60 cts.

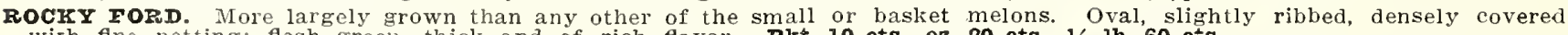
with fine netting; flesh greell, thick and of rich flavor. Plrt. 10 cts., $02.20 \mathrm{cts.}, 1 / 41 b .60 \mathrm{cts}$.

\section{Watermelon}

An ounce will plant about 25 hills-

4 pounds to the acre

The culture of the Watermelon is mainly the same as recommended for the Muskmelon, hills should, however, be about 10 feet apart.

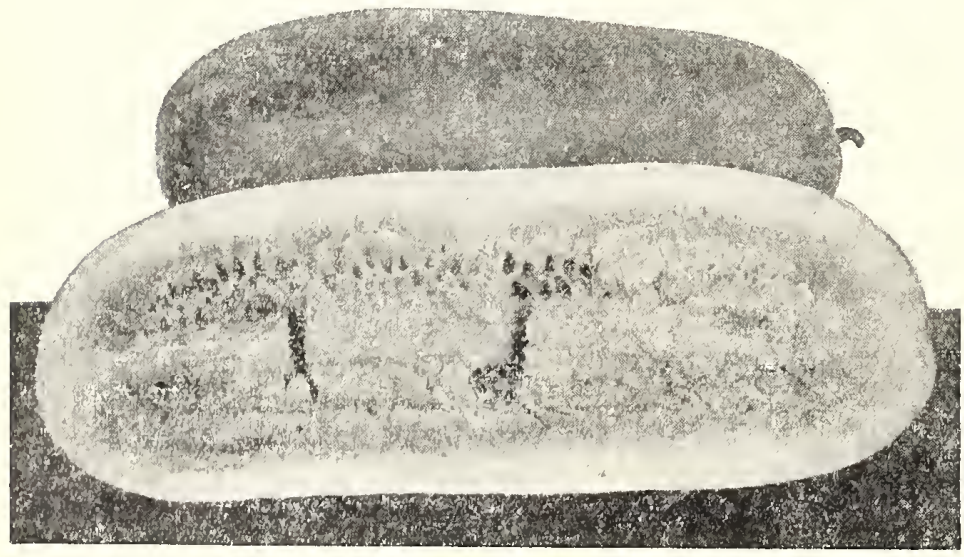

Kleckley'B Swoet
COLE'S SARIY. Small but very early; of fine quallity and sure to mature in any latitude where melons can be grown. Pkt. 10 cts., 0z. 20 cts.,

HAIBERT HONEY. A variety which rivals the Kleckley's Sweet in quality, while the vine is more productive. Fruit of medium size, blunt at both ends, deep glossy green; rind very thin; flesh crimson, entirely free from flbre, rich, sweet and melting. Unsurpassed for home use. Pkt. 10 cts.,

HARRIS' EARIIES'. A new extra-early variety, large, and of exceptionally fine quality. Slightly: oval, mottled in stripes of light and dark green. Flesh bright red. One of the most desirable for planting in the North. Plst. 10 cts., oz. 20 cts., 1/4 1b. 50 cts.

IRISH GREY. A long melon, rather large in size and is becoming more popular as a shipping kind. The rind is light green in colors; the seeds are white and its eating qualities very flne. Average weight is 25 pounds. Prst. 10 cts., oz. 20 cts., 1/4 1b. 50 cts.

KLECKLEY'S SWEET, or MONTE CRISTO. One of the sweetest, above medium size; dark green; rind thin; flesh bright red. Pkt. 10 cts., oz. 20 cts., $1 / 4$ Ib. 50 cts. 


\section{Fing Watermelon}

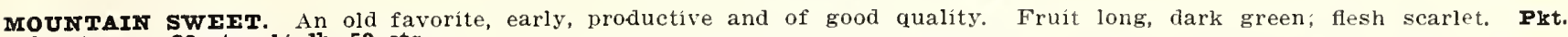
10 cts., oz. $20 \mathrm{cts} ., 1 / 4$ lb. $50 \mathrm{cts}$.

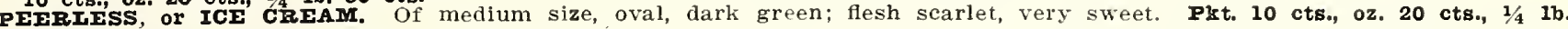
$50 \mathrm{cts}$.

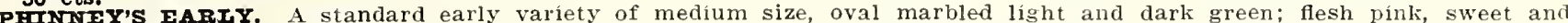
crisp. Pkt. 10 cts., oz. 20 cts., $1 / 4$ lb. 50 cts.

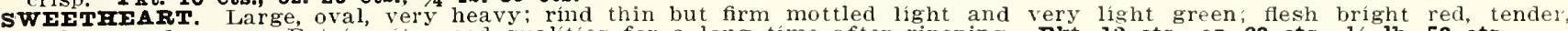

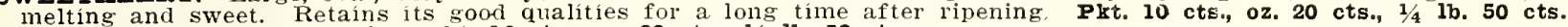
CITRON. For preselving only. Pkt. $10 \mathrm{cts.,} 0 z .20 \mathrm{cts.}, 1 / 41 \mathrm{~b} .50 \mathrm{cts}$.

\section{Mushrooms}

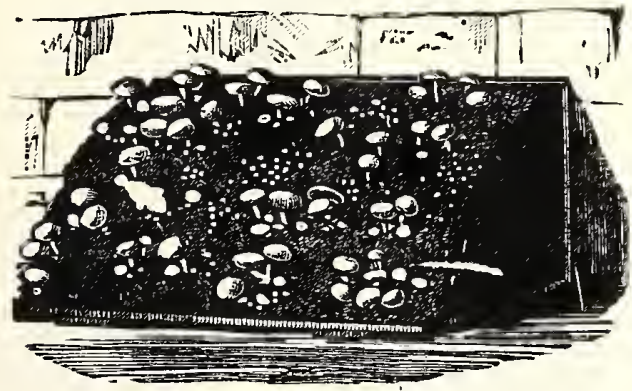

Mushrooms

Cultural directions, to be of any value, would be too lengthy to rive here but we will forward full directions for the planting and culture of spawn with each order.

IAMBERT'S PURE CULTURE SPAWN. This will

produce Mushrooms of a specific variety, selected with reference to size, color and yield, and eliminates absolutely any danger of poisonous specimens. Standard bricks weighing from 1 to $1 \frac{1 / 4}{4}$ pounds, of the variety most largely cultivated. 40 cts. each. Postpaid, 50 cts each; 4 bricks, by express, $\$ 1.45$

\section{Okra or Gumbo}

The young seed pods are used in soups or stewed and served like asparagus. Much esteemed in the South. In the North requires an especially warm location and probably best results would be obtained by sowing seed in the hotbed. Set plants in rows two feet or more apart and about a foot apart in the row. The seeds are a long time in germinating. DWART GREER. Early and productive; best for Northern cultivation. Prt. 10 cts., oz. 20 cts., $1 / 4$ 1b. $50 \mathrm{cts}$.

PFRKIN'S MANOMOTH IONG POD. A dwarf but enormously productive variety. Pods long, slender, deep green and remain tender much longer than most sorts. Plit. 10 cts., oz. 20 cts., $1 / 4$ 1b. 50 cts.

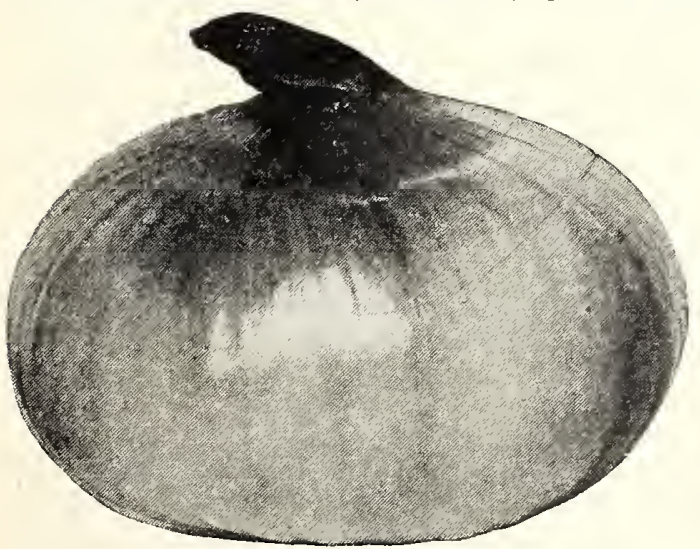

Red Wethersfield

\section{Onion Sets}

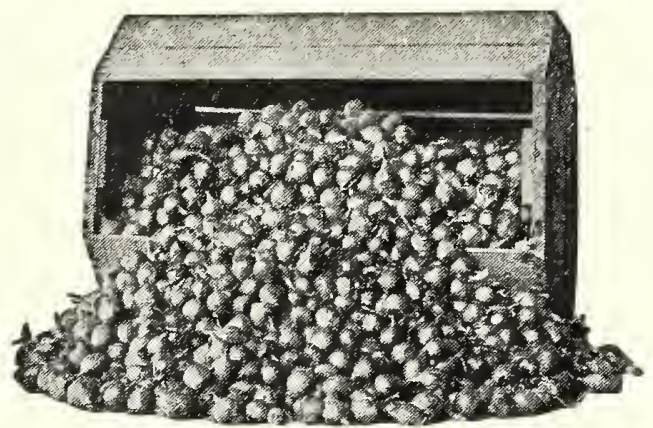

Yellow Onion Sets we do not deliver onion Sets free; pur chaser pays transportation. Onion Sets weigh 1 lb. per quart. For Parcel Post zone rates see inside front cover.

Onion Sets requíre rich soil and with the exception of the Egyptian, early planting. Rows should be the same distance apart as suggested for onions $\mathrm{g}$ row from seed and sets should be planted from 2 to 4 inches apart, and only lightly covered with earth, the top of set just below the surface, with any growth it may have made above Culture same as of onions from seed.

WFITE GIOBE. Ib. 30 cts., 4 1bs. $\$ 1.00,8$ 1bs. $\$ 1.75$.

Y EIIOW GIOBE. Ib. 30 cts., 4 1bs. \$1.00, 8 1bs. \$1.75.

EGTPTION, or PEREINIAI. (Fo1 Delivery in September.) Ib. 30 cts., 4 1bs. $\$ 1.00,8$ lbs. $\$ 1.75$.

Special prices on bushel lots.

\section{Onion}

An ounce will sow about 200 feet of drill. 4 to 5 pounds to the acre. The Onion usually thrives best on old, rich land, but can be profitably grown only on such as has been kept free from weeds. If stable manure is used it should be either well rotted or plowed into the soil the prevíous fall. As manure always contains mole or less weeds, many large growers use nothíng but commercial fertilizer. The soíl should be worked untíl manure or fertilizer is thoroughly mixed with it and the surface made fine and even by raking. Sow as early as ground can be prepared, in rows 12 to 14 inches apart, one-half inch deep, and make soil firm. Keep free from weeds, especially at first, for if the weeds once get ahead of the young plants it is almost useless to continue cultivation-the land would better be plowed and replanted with some other crop.

AIISA CRAIG. Of mammoth size, largel than the Prizetaker ovalshaped, pale straw-colored skin; of very mild flavor. one of the best for exhibition on account of its enormous size. In England the most popular large onion. Bulbs have been grown that weighed $2 \frac{1}{2}$ pounds. Extra large onions can, however, be obtained only by sowing seed early in the spring in the hotbed and transplanting to the open ground when plants are of sufficient size. Seed from English Prize-winning stock. Pkt. $10 \mathrm{cts.g} 1 / 2$ oz. $20 \mathrm{cts}$., oz. 35 cts., $1 / 4$ 1b. $90 \mathrm{cts}$.

SOUTFPOR YFIIOW GrOBE. Bulbs nearly spherical, slightly elongated: does not mature quite so early as our selected strain of Yellow Globe Danvers; a little more inclíned to grow stiff-necked on some soils or in unfavorable seasons, but when well-grown brings the highest price, especially in New York markets. Pkt. 10 cts., $1 / 2$ oz. 15 cts., oz. 25 cts., $1 / 4$ 1b. 60 cts.

SOUTFPORT RED GIOBE. Identical in form with the preceding: rích, deep red, above medium size; an excellent keeper and one of the most attractive of all. Prt. jo cts., $1 / 2$ oz. 20 cts., oz. 30 cts., $1 / 41 \mathrm{~b} .80 \mathrm{cts}$.

SOUTHPOT WHIT GIOBE. Of true globe shape. Later than White Portugal; keeps better and, like all globular varieties, a greater weight can be obtained on the same area. Pkt. 10 cts., 1/2 oz. 20 cts., oz. 35 cts., 1/4 1b. 90 cts. 


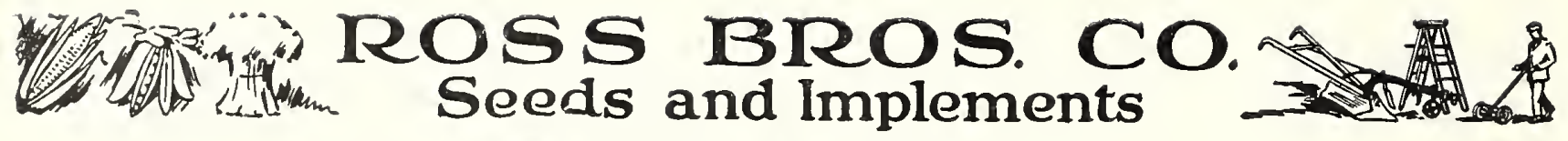 Onion-(Continued)}

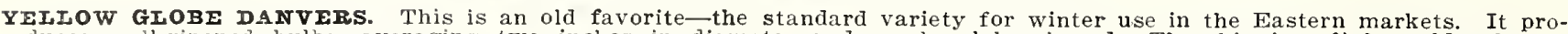

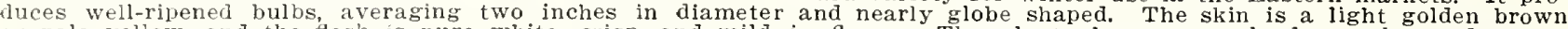

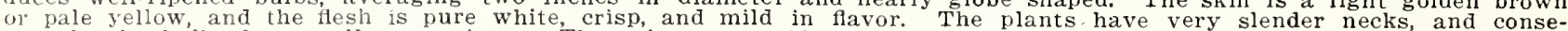

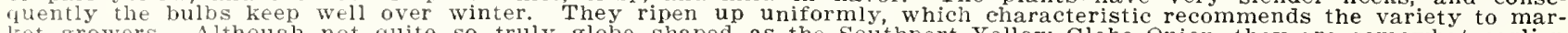

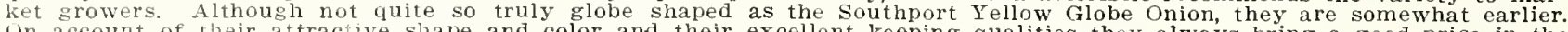

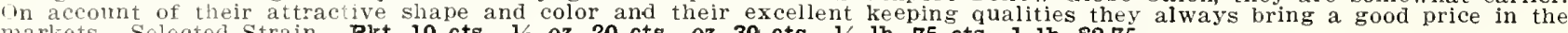
markets. Selected Strain. Pkt. 10 cts., $1 / 2$ oz. 20 cts., oz. 30 cts., 1/4 1b. 75 cts., 1 1b. $\$ 2.75$.

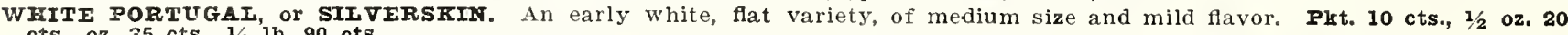
cts. oz. $35 \mathrm{cts.}, 1 / 4$ lb. $90 \mathrm{cts}$.

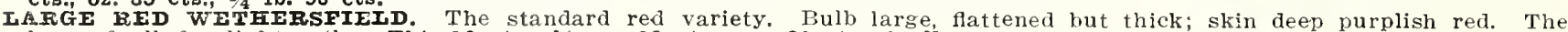
best of all for light soils. Pkt. 10 cts., $1 / 2$ oz. 20 cts., oz. 30 cts., 1/4 1b. 75 cts.

PRIZETAKER. Of the largest size, form nearly globular; skin thin, light straw-color. Quite certain to bottom, but is later in maturing than any of the preceding, and though fine bulbs are often obtained from seed sown in the open ground in favorable locations, the largest and finest bulbs are grown from seeds sown in a hotbed and the plants set in the open ground when about six inches high. Plt. 10 cts., $1 / 2$ oz. 20 cts., oz. 30 cts., 1/4 1b. 75 cts.

\section{Parsley}

One ounce will sow 200 feet of arill

CULTURE-Parsiey thrives in rich, mellow soil and, owing to the very slow germination of seed, succeeds best when seed is sown as early in the spring as ground can be worked. Sow in drills, one-half inch deep, 14 to 16 inches apart, and when well up thin plants to required richness will afford several cuttings during the season. The Moss Curled is perhaps slightly more curled, while the Double Curled is claimed by some to be the more productive of leaves and to better withstand dry weather.

CHAMPION MOSS CUREED. This is a prize winning English variety, very distinct. It makes remarkably handsome, compact plants and its leaves have the appearance of nnely curled moss. The plant is quite hardy and very slow to run to seed. Fit. 10 cts., oz. 20 cts., $1 / 4$ lio. $50 \mathrm{cts}$.

DOUBLE CURLED. Plants compact, very curly and finely cut; bright green color. Pkt. $10 \mathrm{cts}$., oz. $20 \mathrm{cts.}, 1 / 1 \mathrm{l}$. $50 \mathrm{cts}$.

PLAIN IEAF. The leaves of this variety are flat, deeply cut but not curled. Very desirable for flavoring soups and stews and for drying. It is a favorite on account of its very dark green leaves as well as its hardiness of plant. The curled sorts are more extensively used for garnishing. Pkt. $10 \mathrm{cts.,}$ oz. $20 \mathrm{cts.,} 1 / 4 \mathrm{lb} .50 \mathrm{cts}$.

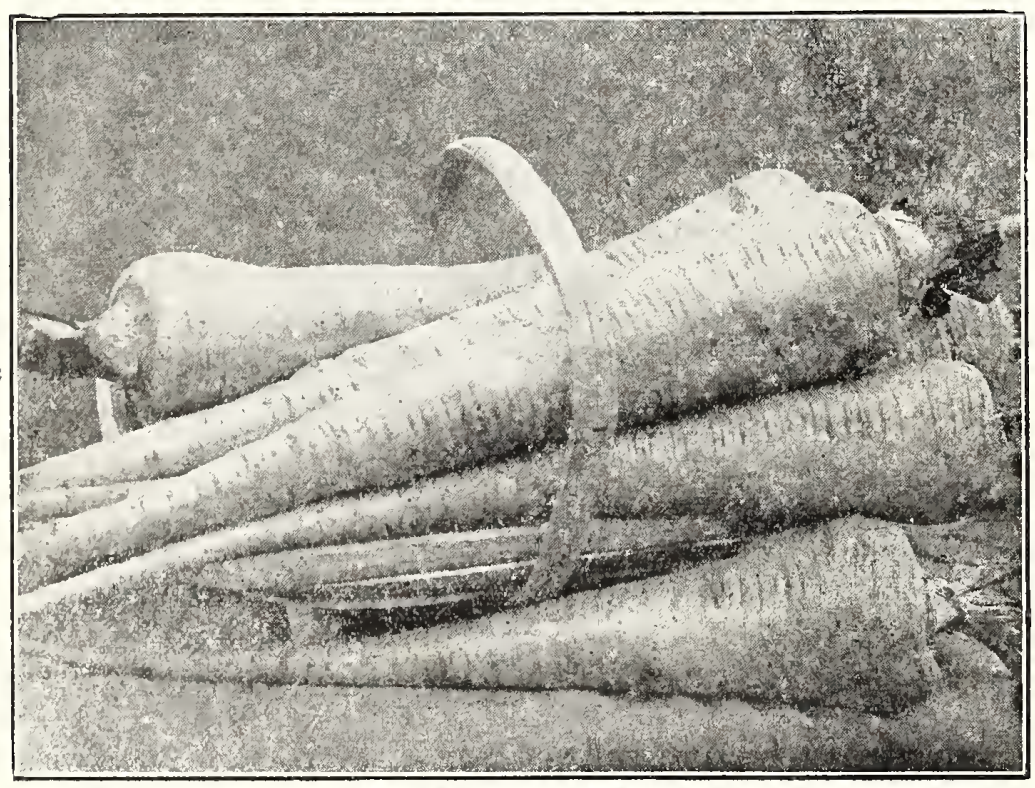

Eollow Crown Parmin

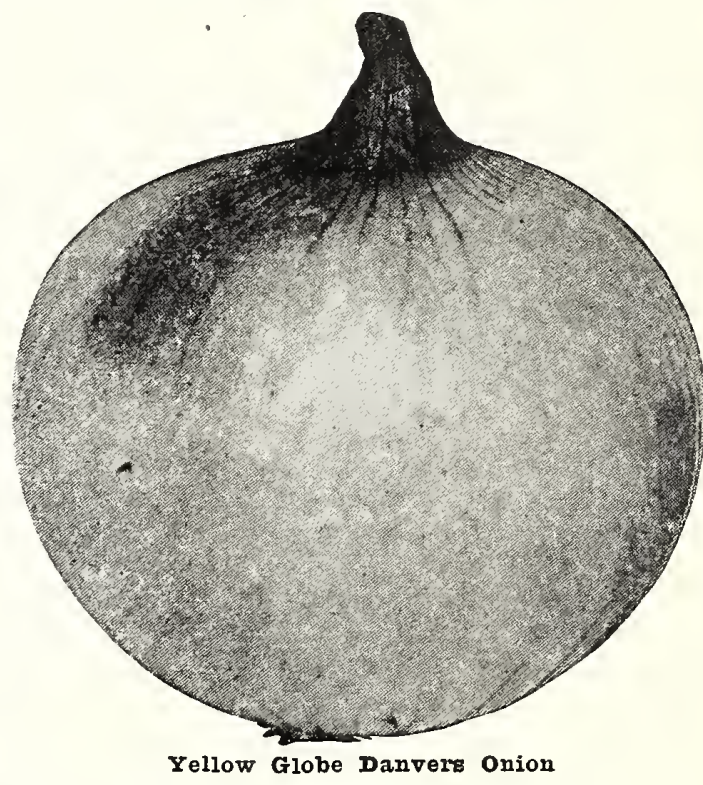

\section{Parsnip}

One ounce will sow 200 feet of drill, 6 pounds are required for an acre

CULTURE-The Parsnip thrives on any soil which is deep, mellow and moderately rich, but best on that which is rather light or sandy. Avoid the use of fresh manure, as, when used roots are nore inclined to be coarse, spongy and ill-shaped. Seed gerininates slowly, should be sown fairly eal'ly and immediately after ground is preparedthat is, before the soil has become dry. Sow in rows 18 inches apart, cover with one-half inch of soil and make latter firm by rolling or with back of hoe. Thin plants to three inches apart.

of each variety we offer a choice selected strain. Each pkt. 10 cts., oz. 20 cts., 1/4 1b. 50 cts.

ARIINGTON IONG SMOOTH. Roots very long and smooth, with full crown, desirable for deep soil and, owing to the full crown, is less liable to rot if left in the ground through the winter than the Hollow Crown.

HOLIOW CROWN. Roots of medium length, thicker at the top or shoulder than the preceding; succeeds better on shallow or stiff soil crown slightly depressed; does not, on this account, keep so well in the ground through the winter as the Arlington Long Smooth, but is more easily harvested and more extensively grown.

\section{Peanuts}

SPANISH. For a long time this has been the best variety. An early, heavy bearer; bushes growing close, so very easily cultivated. Grains or nuts are smaller, but more sweeter and finer flavored than the larger sorts. Best recleaned seed stock. Pkt. 10 cts., Ib. 40 cts., postpaid. By express, 10 Ibs. or more 35 cts. per $1 \mathrm{~b}$. 

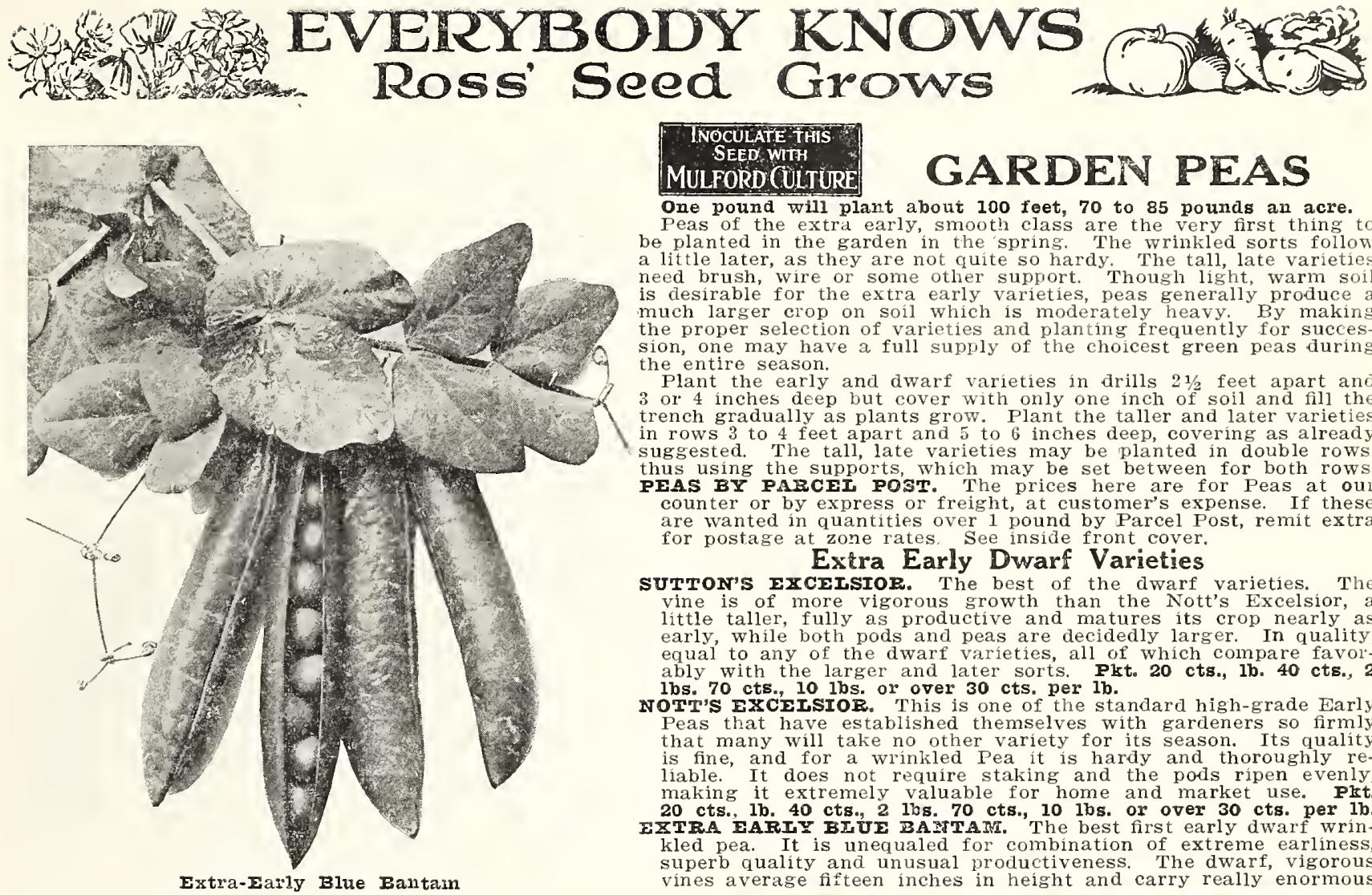

One pound will plant about 100 feet, 70 to 85 pounds an acre. Peas of the extri early, smooth class are the very first thing to be planted in the garden in the spring. The wrinkled sorts follow a little later, as they are not quite so hardy. The tall, late varieties need brush, wire or some other support. Though light, warm soil is desirable for the extra early varieties, peas generally produce a much larger crop on soil which is moderately heavy. By making the proper selection of varieties and planting frequently for succession, one may have a full supply of the choicest green peas during the entire season.

Plant the early and $d$ warf varieties in drills $2 \frac{1}{2}$ feet apart and 3 or 4 inches deep but cover with only one inch of soil and fill the trench gradually as plants grow. Plant the taller and later varieties in rows 3 to 4 feet apart and 5 to 6 inches deep, covering as already suggested. The tall, late varieties may be planted in double rows, thus using the supports, which may be set between for both rows. PEAS BY PARCEL POST. The prices here are for Peas at our counter or by express or freight, at customer's expense. If these are wanted in quantities over 1 pound by Parcel Post, remít extra for postage at zone rates. See inside front cover.

\section{Extra Early Dwar Varieties}

SUTmoN's ExCEISTOe. The best of the dwarf varieties The vine is of more vigorous growth than the Nott's Excelsior, a little taller, fully as productive and matures its crop nearly as early, while both pods and peas are decidedly larger. In quality, equal to any of the dwarf varieties, all of which compare favolably with the larger and later sorts. Pkt. 20 cts., 1b. 40 cts., 2 1bs. 70 cts. 10 lbs. or over $30 \mathrm{cts}$. per $1 \mathrm{~b}$

NOTT'S EXCEISIOR. This is one of the standard high-grade Early Peas that have established themselves with gardeners so firmly that many will take no other variety for its season. Its quality is fine, and for a winkled Pea it is hardy and thoroughly reliable. It does not require staking and the pods ripen evenly, making it extremely valuable for home and market use. Prt 20 cts. 1b. 40 cts., 2 lbs. 70 cts., 10 lbs. or over 30 cts. per lb. EXTRA EARIY BIUE BAYTAM. The best first early dwarf wrinkled pea. It is unequaled for combination of extreme earlíness, superb quality and unusual productiveness. The dwarf, vigorous vines average fifteen inches in height and carry really enormous

crops of large, deep bluish-green pods. The pods measure four to four and one-half inches long and are tightly packed with eight to ten large, deep bluish-green peas. These peas are not only large ín síze, but of most luscious flavor. Pkt. 20 cts., 1 lb. $45 \mathrm{cts.}, 2$ lbs. $30 \mathrm{cts}$., $10 \mathrm{lbs}$. or over $35 \mathrm{cts}$. per $1 \mathrm{~b}$.

IARTOF'S PROGRZSS. This is the earliest of the large-podded dwarf varíeties. The pods are as large as Laxtonian, 4 inches long, broad and pointed, deep green in color, containing eight large dark green Peas of very high quality. The vines are 15 to 18 inches in height and are very productive Laxton's Progress will mature Peas four days earlier than Laxtonian or Plue Bantam. Pkt. 20 cts., 1 lb. 40 cts., 2 lbs. 70 cts., 10 lbs. or over $30 \mathrm{cts}$, per $1 \mathrm{~b}$.

IAXTONIAN. A grand early dwarf Pea. The pods of Laxtonian are very large and are produced on a low-growing sturdy vine, without support of any kind. Unlike many of its class, Laxtonian fills to the full its ample pods with large, luscious peas. The flavor is just as rich and good as any of the later varieties, which entitles it to a permanent place in every garden. It is ready for use just about a week later than the very early sorts and is incomparably good in quality. It is admirable for private gardens, where its abundant crop, produced so early in the season, is extremely welcome. The plant is only $1 \frac{1}{2}$ feet high, branching in habit. Pods and plant are rich, dark green in color, revealing a constitutional strength which enables it to resist the extreme conditions to which Peas are subjected in many sections of the United States. Pkt. 20 cts., I lb. 45 cts., 2 lbs. $80 \mathrm{cts}$., $10 \mathrm{lbs}$. or over $35 \mathrm{cts}$. per $1 \mathrm{~b}$.

IITTIE MARVEx. The Little Narvel Pea in size and shape all podded is very similar to the Nott's Excelsior but far more prolific. It is of exceptionally fine quality and enormously productive. The pods of this pea are about 3 to 4 inches long It should be planted in every garden. Pkt. 20 cts., 1 lb. 45 cts., 2 lbs. 80 cts., 10 lbs. or over 35 cts. per $1 \mathrm{~b}$.

\section{Extra Early Varieties of Taller Growth}

ALAskA. Very early, smooth, blue pea. Popular with canners and market gardeners for a first early sort. Height $21 / 2$ feet. Foliage and pods light green; pods 21/2 inches long, round, straight and square ended, containing 6 light green peas. Very uniform in maturity. Plt. 20 cts.. 1 lb. 30 cts., 2 lbs. 55 cts., 10 lbe. or orer 25 ote. por $1 \mathrm{~b}$.

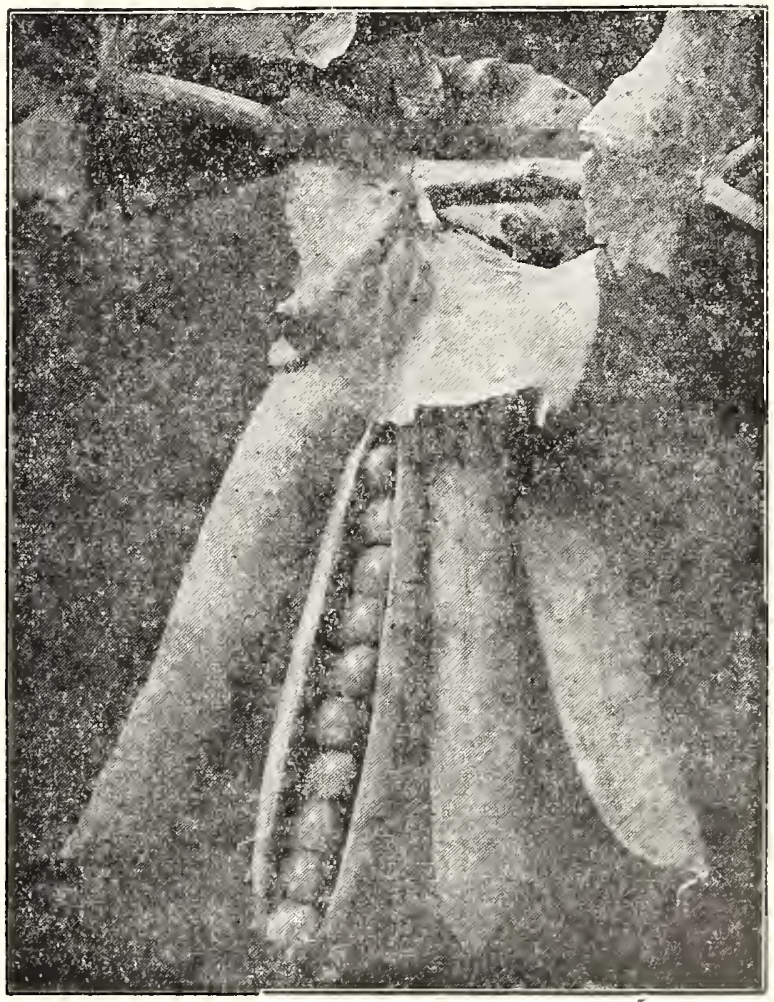

Thomas Iaxton 


\section{ROSS BROS. CO}

\section{PEAS-Continued}

GRADUS. A emarkabe variety, combining earliness with peas of largest size and best quality. Mature soon after Nott's Excelsior. Vine resembles the Telephone but is only 3 to $3^{1 / 2}$ feet high on rich land; productive. Pods 4

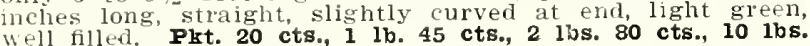
or over 35 cts. per $1 \mathrm{~b}$.

MARKET SURPRISE. This is a smooth seeded sort and, like all of this class, may be planted very early. It is the ear.iest maturing variety to date, vines growing to a licight of about 30 inches, bearing abundantly pods 3 to $3 \frac{1 / 4}{4}$ inches long, well filled with peas of the finest quality. Ever.y garden, large ol small, should give this new sort a trial.
Prt. 20 cts. 1 lb. $\mathbf{3 5}$ cts., 2 lbs. 60 cts., 10 lbs. or over 25 cts. per 10.

PREMIUM GEM. One of the most popular peas of this class in America Hardy, prolitic, and uniform in habit of glowtl and productiveness, bearing pods single on both sides of the stalk, beginning ncal the ground. Peas of fine $21 / 2$ inches long, nearly straight, round, well filted to the end. Seed green, wrinkled Height of the vine 1.8 inches. Pkt. 20 cts., 1 lb. 40 cts., 2 lbs. 70 cts.. 10 lbs. or over 30 cts. per lb.

THOMAS IAXTON. Vine of about the same height as the Gradus, of similar habits but much dartier, hardier and inore ploductive. More attractive and better filled with peas as large and equal in quality. Pkt. 20 cts., 1 lb. 40 cts., 2 lbs. 70 cts., $101 \mathrm{bs}$. Or over $30 \mathrm{cts}$. per $1 \mathrm{~b}$.

ROSS' WORID'S RECORD. A large, early wrinliled pea with pods $31 \%$ to 4 inches long. The pods are well filled with peas of excellent quality. The vines ale vigorous, growing about 36 to 40 inches high. Peas are leady to pick $4 \mathrm{or}^{5}$ days before Gradus. A variety which should be in los. or over 35 cts. per lo.

SECOND-EARIY MEDIUM AND IATE VARIETIES

AIDERMAN, This mid-season pea is tall growing, of English origin and a few days later than the "Improved Telephone." The pods are very large, straight and darli green colol. The vines are exceedingly vigorous and immensely prolific; of the best quality. Pkt. 20 cts., 1 lo. 40 cts., 2 1bs. 70 cts., 10 lbs. or over 30 cts. per $1 \mathrm{~b}$.

CHAMPION OF ENGIAND. Vine $4 \frac{1}{2}$ to 5 feet high, pio ductive. Pods $2 \% / 4$ to 3 inches long, broad, well filled. Peas of medium size, much siriveled, of unsurpassed quality. 25 cts. per $1 \mathrm{~b}$.

DWARF CFAMPION. A variety claimed to be equal in quality to Champion of England. Botl peas and pods are Pkt. 20 cts., 1 lb. 35 cts., 2 1bs. 60 cts., 10 lbs. or over 25 cts. per $1 b$.

\section{PEPPERS}

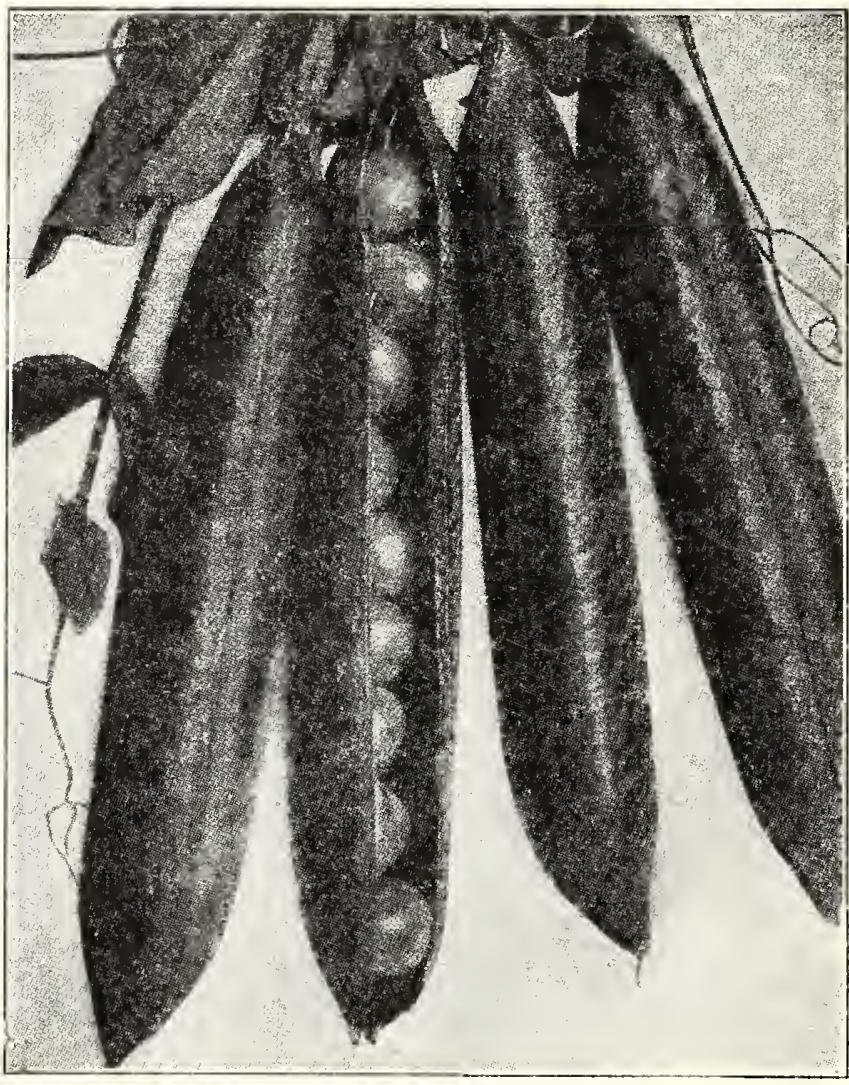

Improved Telephone

EVERBEARING. An excellent variety of branching habit. Pods about 3 inches long and well filled. Sweet and of fine flavor. Height 3 feet. Plst. 20 cts., 1 lb. 35 cts., 2 1bs. 60 cts., 10 lbs. or over 25 cts. per $1 \mathrm{l}$.

TRLEPHONE. Extensively grown. Vine $31 / 2$ to 4 feet. On good soil productive. Pods large. Peas above medium cts., 10 1bs. or over 30 cts. per $1 \mathrm{~b}$.

An ounce will produce from 1,500 to 2,000 plant:

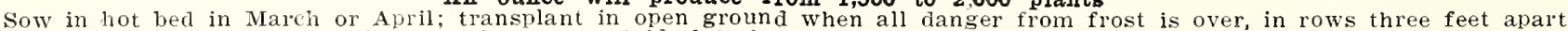

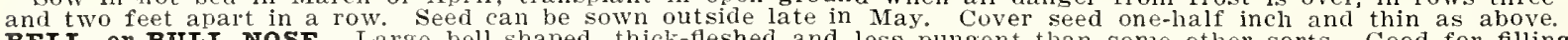

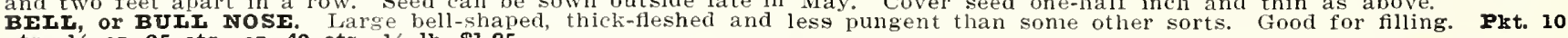
cts., $1 / 2$ 0z. 25 cts., oz. 40 cts., $1 / 4$ lb. $\$ 1.25$.

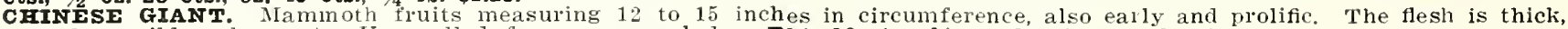
tender, mild and sweet. Unexcelled for use as salads. P rt. 10 cts., 1/2 oz. 35 cts., oz. 60 cts.

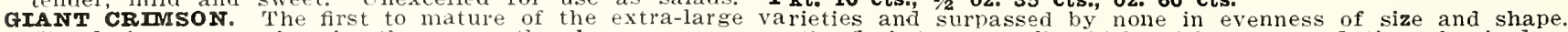

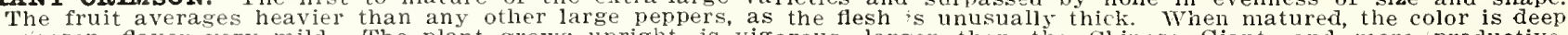

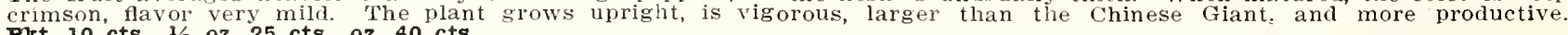
Pkt. 10 cts., 1/2 oz. 25 cts., oz. $40 \mathrm{cts}$.

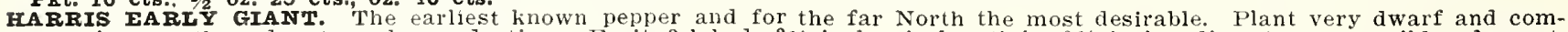

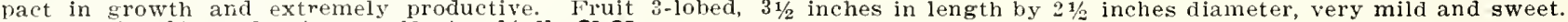
Pkt. 10 cts., 1/2 oz, 25 cts., oz. 40 cts., 1/4 lb. \$1.25.

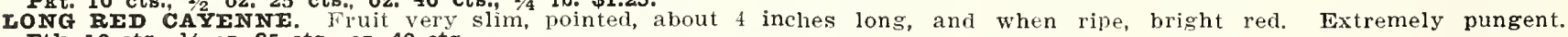
Ptr. 10 cts., $1 / 2$ oz. 25 cts., oz. $40 \mathrm{cts}$.

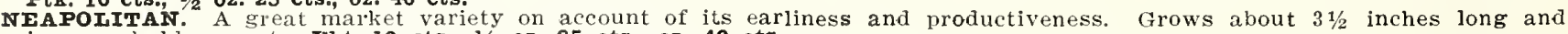
is lemarkably sweet. IJit. 10 cts., 1/2 oz. 25 cts., oz. 40 cts.

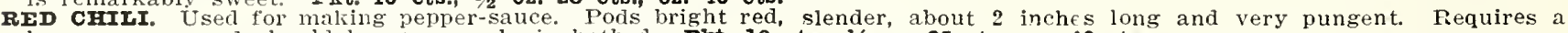
long season; seed should be sowll early in hotbed. Plst. 10 cts., 1/2 0z. 25 cts., 0z. 40 cts.

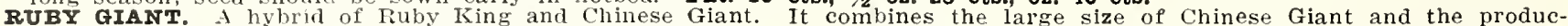

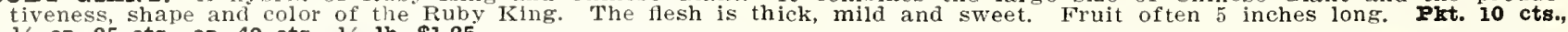
$1 / 2$ oz. 25 cts., oz. 40 cts., 1/4 1b. $\$ 1.25$.

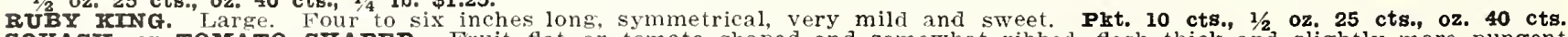

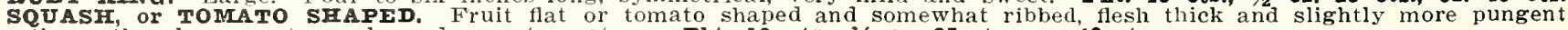
than other large sorts, early and sure to mature. Pkt. 10 cts., 1/2 0z. 25 cts., oz. 40 cts.

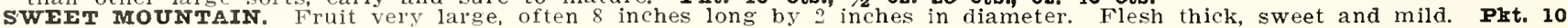
cts., $1 / 2$ oz. 25 cts., 02.40 cts. 


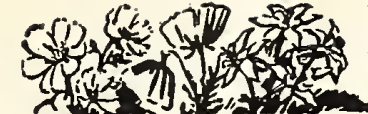 EVERYBODY Ross' Seed}

\section{SELECTED} SEED POTATOES

Fight to ten bushels will plant one acre. One peck will plant 75 hills. by the most reliable growers in Aroostook County, Maine.

The stock is a!l carefully selected, free from rot 100 Ibs., and the price we quote includes sacks.

Potatoes will be sinipped as soon in the Spring as the weather will permit of their being sent in ordinary cars without danger of freezing. Full carloads can be shipped at any time in heater cars.

There is no one thing that we will sell in the line of seeds that is more important to change each season than seed potatoes. As it is, impossible to grow just the right quantity of each variety to supply the demand, we urgently request our customers to give us a first and possibly a second choice in case we should be out of varieties ordered, for after the season is well advanced it often happens we are sold out of a great many varieties.

\section{Irish Cobbler}

An early, white-skinned variety, very short, thick, inclining to round. This is yearly increasing in popularity for the early market. But few varieties, if any, combine earliness, size and production in as great a degree. This crop is ready for market about ten days earlier than the Early Rose; tubers are uniformly larger and in average production of large crops it is not equaled by any of the extra early varieties nor greatly surpassed in yield by any of the main crop varieties. The vine is very stocky and vigorous, not as liable to be affected with blight or to suffer by drought as most others. No other of the early varieties is as dependable as this and is so certain to produce a crop.

\section{Early Fairmount}

\section{An Improved Irish Cobbler}

The seed stock which we offer is grown for us and scab, and carefully packed in burlap bags holding

\section{KNOWS Grows}

\section{Culture}

good, sandy loam produces the best potatoes, but they can be grown on all kinds of scil. New or pasture land, with the turf freshly turned, produces the finest crop. Make furrows of good depth, 3 feet apart. Scatter a liberal dressing of phosphate or decayed stable manure along the drill, and set the seed about 10 inches apart in the rows. Cover with about 2 inches of soil, and begin to cultivate when the plants are well up. At each successive hoeing, bring additional soil about the plants. A change of seed is the best antidote for disease.

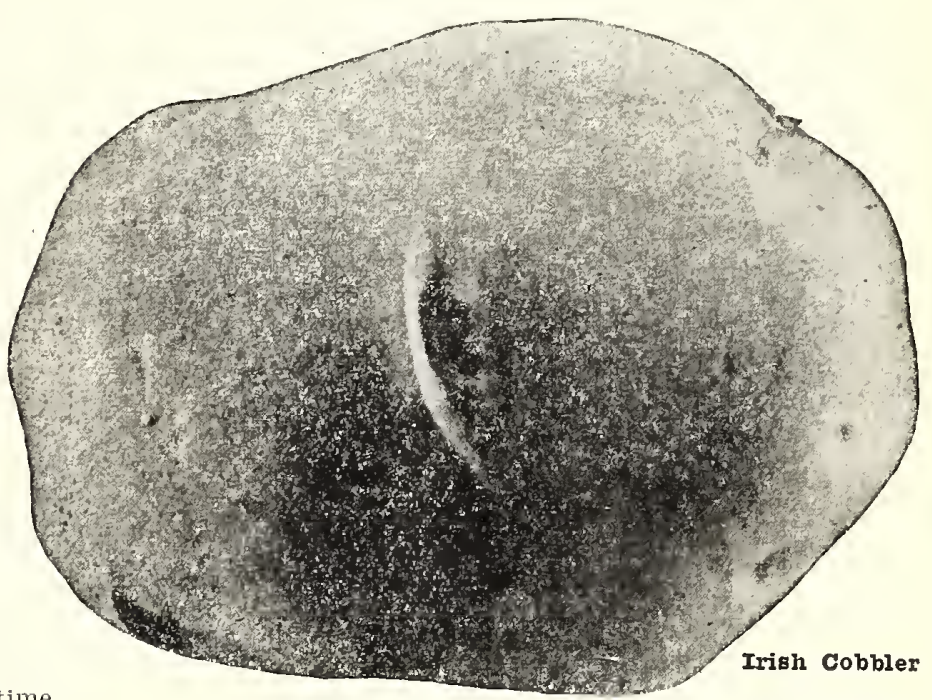

It is an early variety which in shape, color, size and time of ripening is very much like the Irish Cobbler; but the Early Fairmount has outyielded the Cobbler in every case where we have made an inquiry. One market gardener has said of the Early Fairmount: "The extra yield of potatoes would pay for my seed and fertilizer." This is certainly in favor of the new potato.

It is generally known that many of the large Cobbler potatoes have a cavity in the center, but in the Fairmount we have failed to find one with this defect; also the eyes are more shallow, which means less waste in cooking.

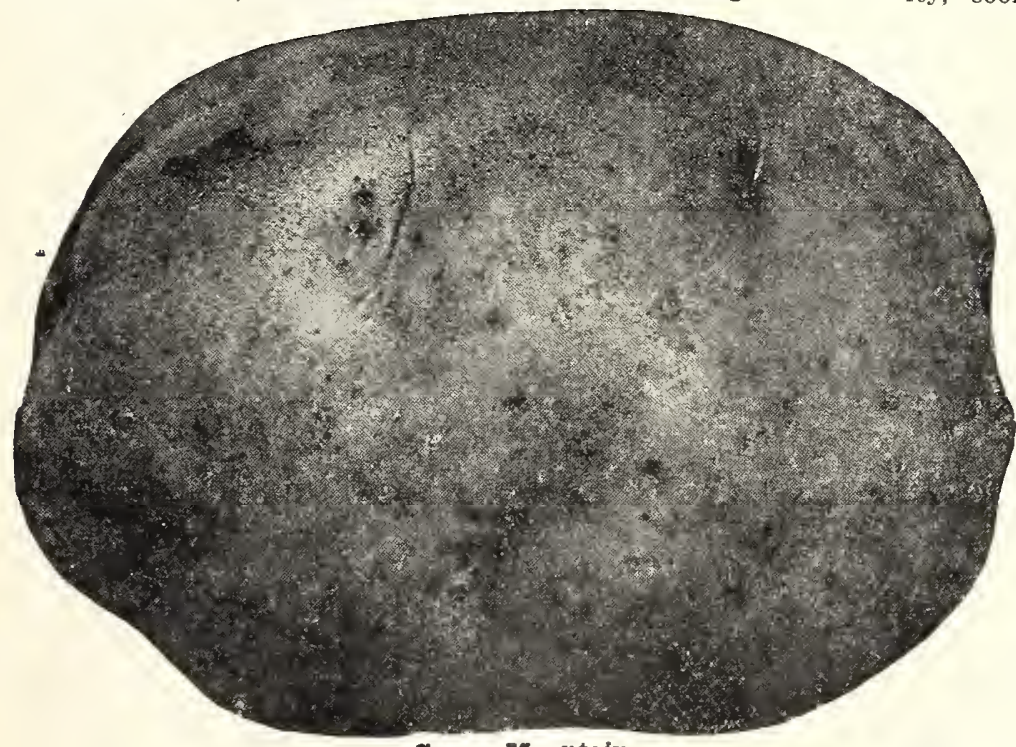

Price of potatoes listed on this pa

Price of all Potatoes Subject to Change Without Notice.

EARIY SIX WEERS. An extra early variety, of good quality, cooking well as soon as it attains marketable size. In size, medium to large; color, light red or rose; form, round oblong, resembling the Ohio and having the speck peculiar to the ohio type. Keeps well. A good yielder.

EARIY ROSE. (Early.) Its tubers are roundish, oblong and somewhat flat, while the skin some of the later sorts, but is extremely early.

GRESN MOUNTAIN. A white skinned variety of fiat, oval form, smooth and attractive. Ripens slowly and is a good keeper. Quality excellent when well grown. This variety has been growing in popularity and is now the leader of all varieties for general crop.

GOLD Cors. Productive and of unsurpassed quality. Very uniform in size never overlarge, but few small tubers. Form oblong, rather broad and thick. Skin almost white, with just enough of a light golden tinge to make it distinct from the white-skinned varieties, and having that rich russet appearance generally considered an indication of good quality. Vine of strong, vigorous growth, not easily affected with blight.

CARMES No. 3. A handsome, round, white variety of the best quality: large, almost no small tubers. Claimed by the introducer to outyield any potato of its class. Vines large and vigorous, not troubled by bugs or blight as much as those of other sorts.

Seed Potatoes Continued on Next Page 

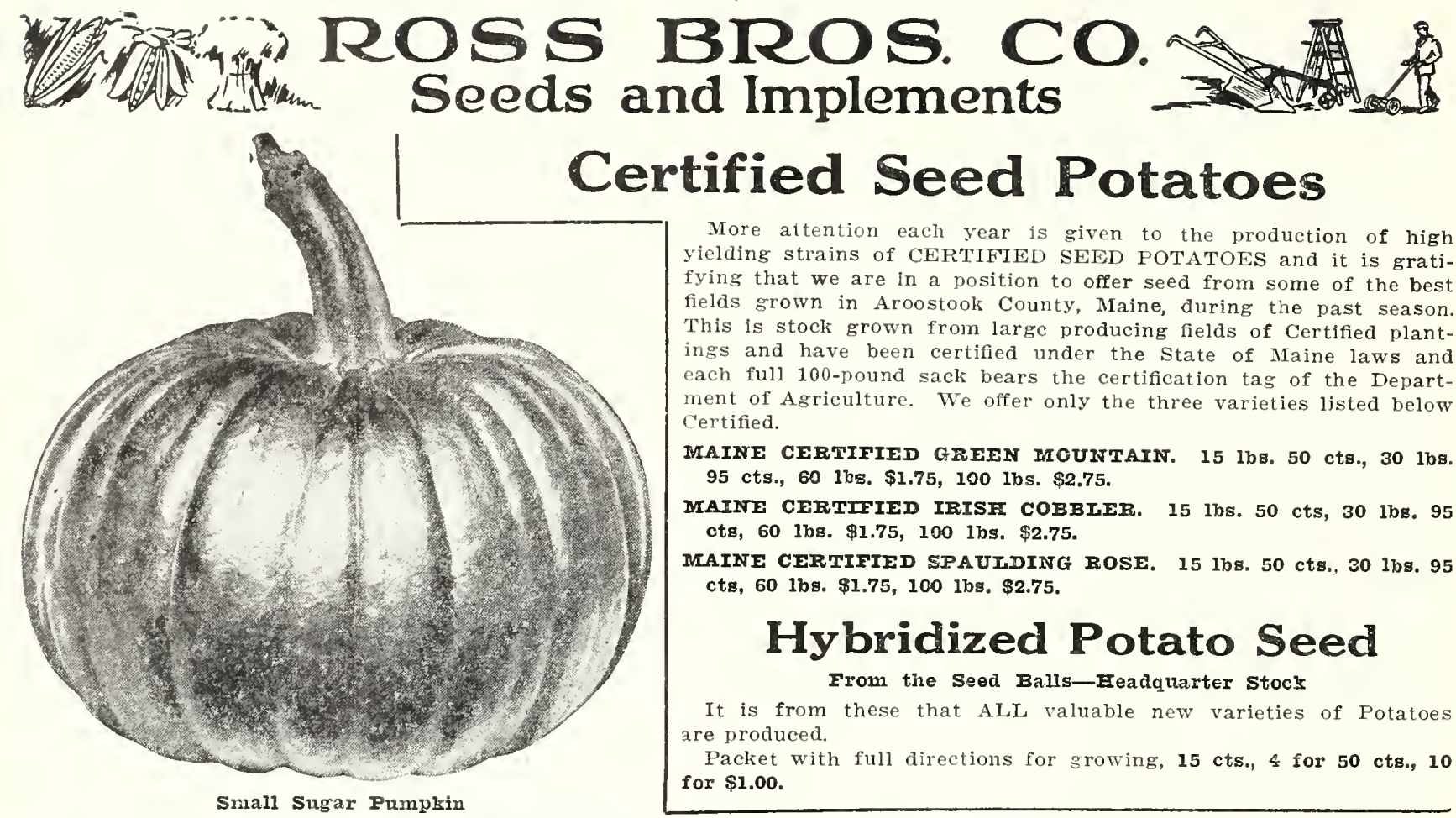

More altention each year is given to the production of high yielding strains of CERTIFIED SEED POTATOES and it is gratifying that we are in a position to offer seed from some of the best fields grown in Aroostook County, Maine, during the past season. This is stock grown from large producing fields of Certified plantings and have been certified under the State of Maine laws and each full 100-pound sack bears the certification tag of the Department of Agriculture. We offer only the three varieties listed below Certified.

MAINE CERTIFIED GRESN MOUNTAIN. 15 lbs. 50 cts., $301 \mathrm{bs}$. 95 cts., $601 \mathrm{bs} . \$ 1.75$, 100 lbs. $\$ 2.75$.

MATNE CERTIFIED IRISF COBBIER. 15 lbs. $50 \mathrm{cts}, 30$ 1bs. 95 cts, $601 \mathrm{bs}$. \$1.75, 100 1bs. \$2.75.

MAINE CERTIFIED SPAUIDING ROSE. 15 lbs. 50 cts., 30 1bs. 95 ctg, 60 lbs. $\$ 1.75,100$ 1bs. $\$ 2.75$.

\section{Hybridized Potato Seed}

\section{From the Seed Balls-Eeadquarter Stock}

It is from these that ALL valuable new varieties of Potatoes are produced.

Packet with full directions for growing, 15 cts., 4 for 50 cts., 10 for $\$ 1.00$.

\section{PUMPKIN An ounce will plant $50 \mathrm{hills}$}

SMALI SUGAR. The popular variety in New England for pies; fine-grained and sweet. Plkt. 10 cts., oz. 15 cts., 1/4 1b. 35 ct8., 1b. $\$ 1.00$.

IARGE CHEESE, or KENTUCKY FIELD. Shape flat, skin of rich cream color when ripe, flesh tender and of fine quality. Plst. 10 cts., oz. $15 \mathrm{ctg}$, $1 / 4$ lb. $40 \mathrm{cts.}$. 1b. \$1.25.

MAMMOTH TOURS. One of the largest in cultivation, good for feeding stock. Pkt. 10 cts., oz. 15 cts., 1/4 1 b. 40 cts., 1 b. $\$ 1.25$. CONNECTICUT FIETD. The standard variety for feeding stock. Pkt. $10 \mathrm{cts} .9$ oz. $15 \mathrm{cts} ., 1 / 41 \mathrm{~b}$. $35 \mathrm{cts}$., $1 \mathrm{~b}$. $\$ 1.00$.

JUMBO, or KING OF THE MAMTMOTHS. The largest of all Pumphins. Skin, orange-salmon; flesh, bright yellow, very thick, fine grained and of excellent quality for pies. Prt. 10 cts., oz. 15 cts., 1/4 1b. 40 cts., $1 \mathrm{~b} . \$ 1.25$.

QUAKER PIE. Fruits broad, pear-shaped to slightly oval; skin rich cream-buff; flesh fine grained and of rich flavor. Pkt. 10 cts., oz. 15 cts., $1 / 4$ lb. 35 cts., 1b. $\$ 1.00$.

\section{RADISH}

An ounce will sow 150 feet of drill

Radishes are now orown the entire year, and may be sown when desired in hotbeds with moderate heat, either in rows 6 inches apart or sired in hotbeds with moderate heat, either in rows 6 inches apart or
broadcast. Soil should be light and rich, preferably new soil and fine rotted turf and commercial fertilizer. Seed may be sown outside very early, as soon as ground can be worked, in rows, 6 to 12 inches apart, as desired, and one-half inch deep. For our own use, we prefer that plants shall be thick, commencing to use roots when twice the size of a large nea and only thinning when plants are so crowded as to prevent the formation of roots of a size suitable for use. Grown in this way and used from the size noted to that of a small marble, roots are tender and crisp and never have the thick skin so generally a feature of those found in our markets.

EARIY SCARIET GIOEE. A very early globe-shaped radish suitable for forcing or open ground. The radishes are of handsome shape, attractive bright red, and are crisp, solid and of the finest quality. They grow so rapidly that under favorable circumstances they may be pulled 20 days from sowing the seed. This is the most popular variety for forcing. Our seed is of the very finest strain grown from transplanted roots and will be found unsurpassed. Plrt. 10 cts., oz. 15 cts., 1/4 1b. 35 cts., 1b. $\$ 1.00$.

CRIMSON GIANT. An early but large, round or slightly globular radish adapted for either forcing or outdoor cultivation. While it grows much larger than other forcing varieties, it does not become pithy under glass, nor outdoors, even when it is twice as large and older. Beautiful crimson-carmine, attractive and of fine quality. Pkt. 10 cts., oz. 15 cts., $1 / 41 \mathrm{~b} .40 \mathrm{cts}_{\mathrm{c}}, 1 \mathrm{~b}$. $\$ 1.25$.

EARIY SCARIET TUENIP. A small round variety, with small tops; quick grower. Popular for forcing and outdoors. Deep scarlet. Pkt. 10 ctg., 0z. 15 cts., $1 / 41 \mathrm{~b}$. 35 cts. $1 \mathrm{~b}$. $\$ 1.00$.

EARIY SCARIET TURMIP, WUITE-TIPPED. Root nearly round, slightly fattened at bottom, bright scarlet with tip of clear white, early and attractive: suitable for forcing and outside planting. Pkt. 10 cts., 0z. 15 cts., 1/4 1b. 35 cts., 1b. $\$ 1.00$.

EARIY IONG SCARIFT, SHORT-TOP. Once the most popular radish, but has been largely displaced by the round varieties; 6 to 8 inches long, ready to pull in twenty-five to thirty days from sowing. Pkt. 10 cts.s, oz. 15 ots., $1 / 216.40$ ctw., 1h, 81.25,

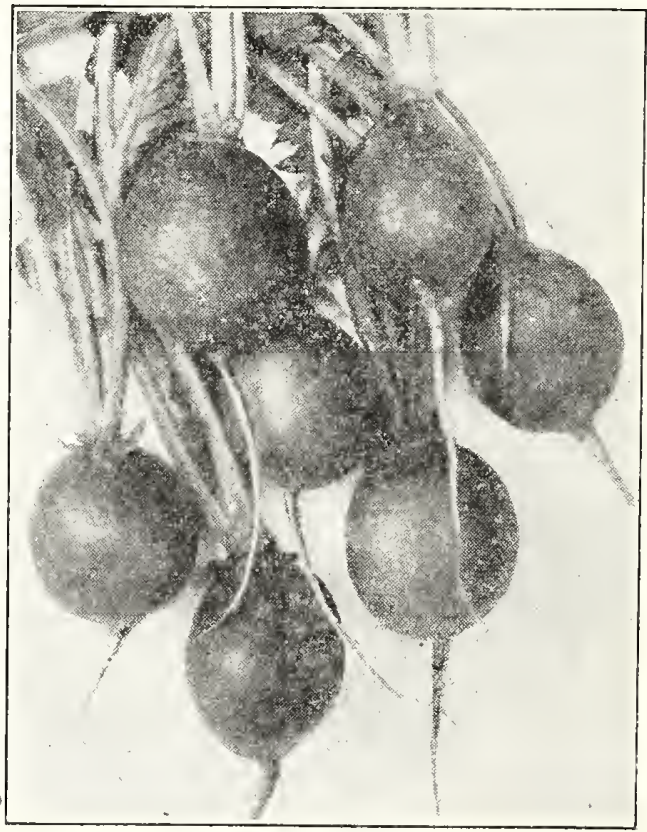

Badish, Scarlet Globe 


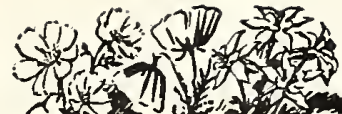 \\ EVERYBODY Ros' Seed}

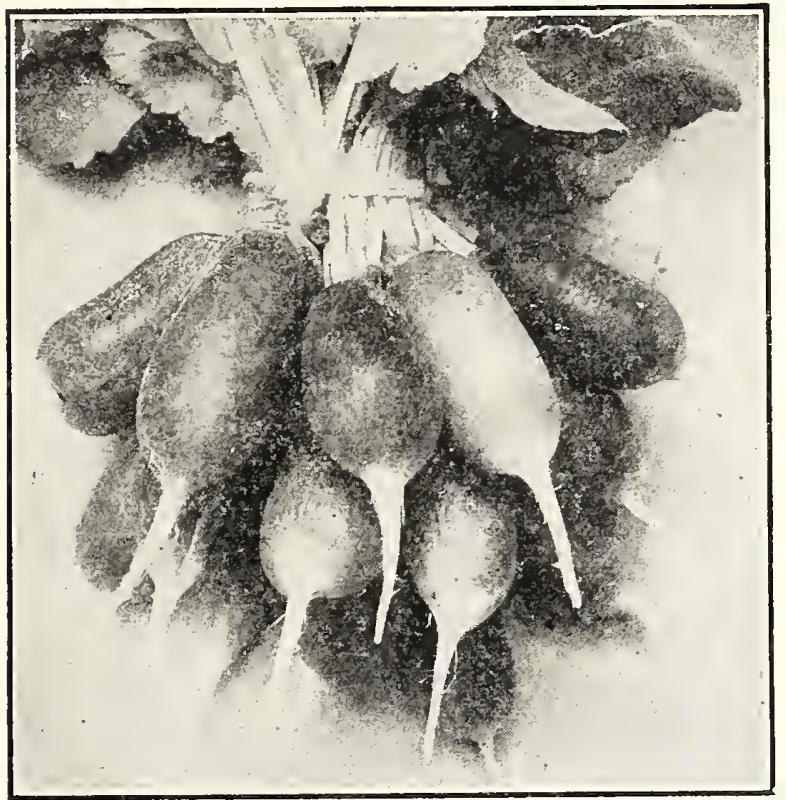

French Brealfast Radish
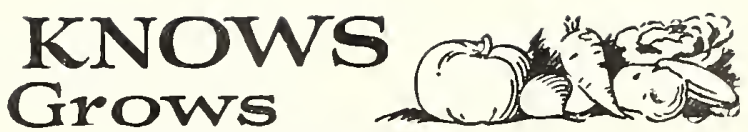

RADISH

EARIY WHITE GIANT STUTTGART. Root large, clear white, often 4 inches in diameter, does not become pithy until very late. Those not used for summer radish can be stored for winter use. Pkt. 10 cts., oz. 20 cts., $1 / 4$ 1b. 40 cts., 1b. \$1.40. FIFNCF BREAKFAST. A stump-rooted radish about 3 inches long. Bright scarlet, tipped white. An old favorite for home garden. Pkt. 10 cts., oz. 15 cts., 1/4 1b. 35 cts., 1b. $\$ 1.00$.

IONG BIACK SPANISH WINTER. One of the hardiest and best for winter use. Pkt. 10 cts., oz. 15 cts., $1 / 4$ lb. 40 cts., 1b. \$1.25. ROUND BIACK SPANISF. White flesh with black skin. Pkt. $10 \mathrm{cts} ., 0 z$. $15 \mathrm{cts.,} \mathrm{1/4} \mathrm{1b.} 40 \mathrm{ctg}, 1 \mathrm{~b} . \$ 1.25$.

WHIPE ICICIE. The earliest pure white, long, summer radish of most excellent quality. Roots when matured are 5 to 6 inches long by about $1 / 2$ inch in diameter. One of the best cts., 1b. $\$ 1.00$.

WFITE STRASSBURG, A fine summer variety, growing about 4 inches long and 2 inches thick. Pure white. Plet. 10 cts., oz. 15 cts., $1 / 4$ 1b. 40 cts., 1b. \$1.25.

\section{Rhubarb or Pie Plant}

An ounce should produce 100 plants

The roots can be raised from seed sown in spring, and are ready to tlansplant to the permanent bed the next spring. The seed must be sown in fine, rich soil, and the seedlings must have good care.

TICTORIA. The most popular variety, fine for family use and market. Comes quite true from seed. Pkt. Io cts., oz. 25 cts., $1 / 4$ 1b. $90 \mathrm{cts}$.

RHUBARB ROOTs. Sent by express at buyer's expense. 2 for 25 cts.

\section{Salsify or Vegetable Oyster an onnce will sow 50 feet of arill}

Sow early and deeper than parsnip, otherwise culture is the same and, like that, roots, if desired, may be left in the sround through the winter, but should be dug very eariy in the spring, as they deteriorate after growth commences.

MAMMOTH SANDWICH ISIAND. Larger, of stronger growth, and less liable to grow spongy than the old Long White. Pkt. 10 cts., 0z. 25 cts., $1 / 4$ 1b. 90 cts.

\section{SPINA CH An ounce will sow 100 feet of drill, 14 to 16 pounds to the acre}

CULTURE-For spring and summer use sow in drills 1 foot apart and 1 inch deep, as early as the ground can be worked, and every two weeks for a succession. For winter and early spring use, sow in September in well-manured ground; cover with straw on the approach of severe cold weather. The ground cannot be too rich.

With StraW GITT TEMCK-IEAVED. Leaves very large and thick, deep green, attaining a size suitable for use early and plant

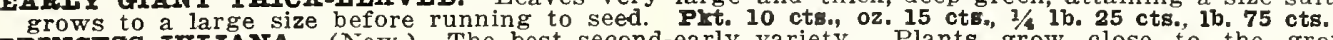

PRINCESS JUIIANA. (New.) The best second-early variety. Plants grow close to the ground and have dark green, crumpled leaves which retain their crispness for a long time after being cut. Pkt. 10 cts., oz. 15 cts., 1/4 1b. 25 cts., 1b. $75 \mathrm{ctg}$.

Fic or DEMMAR. Also known as "Antvorskov." This new varlety is undoubtedly the most valuable introduction of spinach in recent years. Although the plants are ready for use almost as soon as the medium early. sorts, they remain in good condition for a wcek to two weeks after other varieties have gone to seed. The plants are of rapid growth, resemble the Long Season in type, but leaves are more crumpled or blistered and are of darker green color. The leaves are thick, stand well after cutting and are of good quality. Pkt. 10 cts., 02.15 cts., 1/4 1b. 25 cts., 1b. 75 cts.

LONG SEASON. A new variety claimed to surpass all other in its ability to withstand hot weather without running to seed, I eaves very dark green, much crumpled, thick, tender and succulent. Pkt. 10 cts., 0 z. 15 cts., 1/4 1b. 25 cts., 1b. 75 cts. IONG STANDING. A variety which matures early and remains in condition for use longer than most others. Leaves smot. 10 cts., oz. 15 cts.. 1/4 1b. 25 cts., 1 b. 75 cts.

SAVOY-IEAVED, or BIOOMSDAIE. The earliest variety and used almost entirely for fall sowing, as it runs quickly to seed in warm weather. Leaves of medium size, dark green, pointed and crimped. Pkt. 10 cts., oz. 15 cts., 1/4 1b. 25 cts., 1b. $75 \mathrm{cts}$.

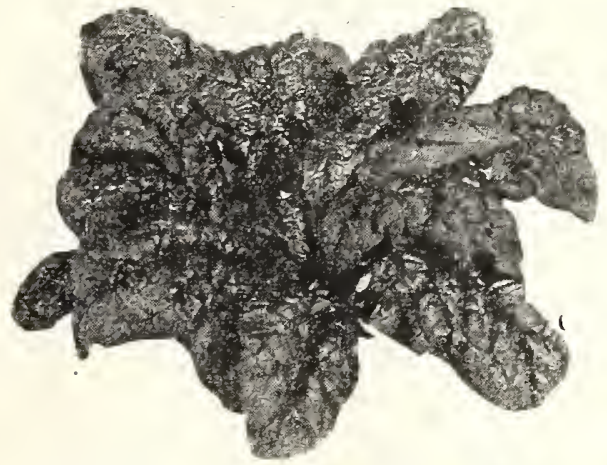

Iarly Giant Thick-Ieaved Spinach
NEW ZEALAND. Thrives during the hottest summer weather in any soil, rich or poor, a single plant covering The tender tips may be cut every few days; after cutting, the plant puts out new growth and continues till frost. Soak for 24 hours and plant 4 seeds in hills 2 feet apart each way. Pkt. 10 cts. oz. 15 cts., $1 / 4$ ib. 35 cts., $1 \mathrm{~b}$. $\$ 1.25$.

If larger quantities, other than ifsted, are wanted, write for prices.

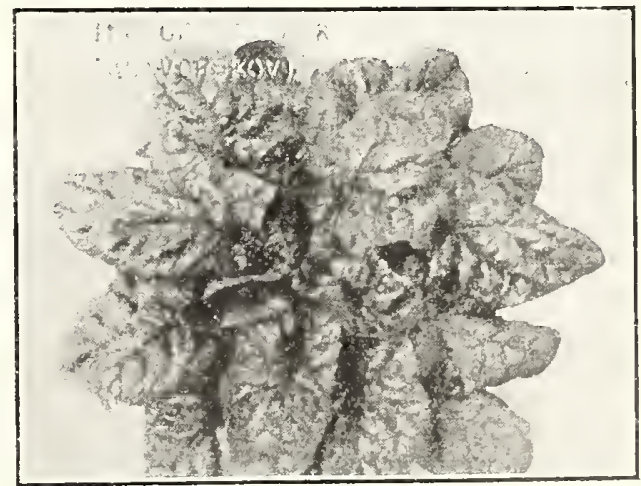

King of Denmark Splnach 


\section{ROSS BROS. CO.}

\section{Squash}

An ounce will plant from 10 to 25 hills Squash seed should be planted at about the same time and in the same manner as cucumbers and melons. The hills should be 9 feet apart each way, slightly elevated and highly manured. Bush varieties may be planted closer together. Use plenty of seed, as the bugs will destroy sone plants

\section{Blue Hubbard}

The Symmes Blue Hubbard is an entirely distinct variety resembling the Warted Hubbard in shape. It is a pale light blue color, very thick meated, dry and very sweet: its eating qualities cannot be sur-

passed. The Blue Hubbard is an exception-

ally heavy cropper, producing an extraordinary number of squashes, which, though not of the largest, are of even size, thus making it very easy to handle and market. It has excellent quadities, keeping, with proper storage, much 1onger $\$ 4.00$

\section{Chicago or Warted Hubbard}

A selection of the Hubbard, with thickly warted sleml Equal in quality to that and generally considered to be of more attractive appearance. Of this also we offer a carefully selected strain unsurpassed by any we have ever seen. Pkt. $10 \mathrm{cts} .$, oz. 20 cts., $1 / 4$ lb. 50 cts., lib. $\$ 1.75$.

\section{Green Hubbard}

A welk-known and favorite winter variety more largely grown than any other. We offer a choice strain, considered by some of our customers to be superior to the popular Chieago Hubbard. Pkt. $10 \mathrm{cts}$., oz. $20 \mathrm{cts}$., $1 / 4 \mathrm{lb} .50 \mathrm{cts}$., 1b. $\$ 1.75$.

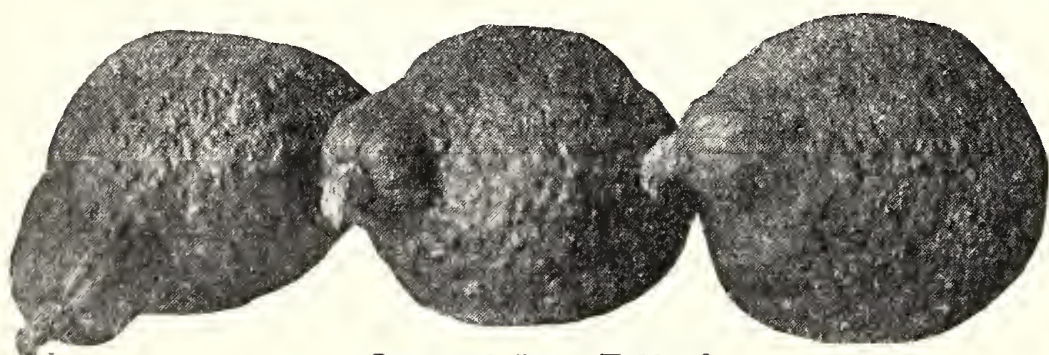

Improved Green Fubbara
BOSTON MARROW This rrotw larcer than either the Prolific or Orange Malrow, but is not of so deep color. Skin thin, yellow, with pinkish tint. Desirable for pies; not so dry as the Hubbard. Pkt. 10 cts., 02.15 cts., $1 / 4$ 1b. 40 cts., 1b. $\$ 1.40$.

DEIICIOUs. A fall and winter variety Color, usually dark rreen but sometimes lighter in color and mottled: shell, moderately hard but very thin; flesh, thick, vely fine grained, sweet and of finest flavor. Even when not quite mature is in condition for use and of good flavor. Pkt. 10 cts., oz. 20 cts., $1 / 4$ lb. 50 cts., $1 b . \$ 1.75$.

FARIY SUMMER CROOINECK. For early planting the Crookneck type is used in New England to almost the exclusion of any other. This, while much smaller than the Mammoth Crookneck, is yet largely grown, many considering it of better flavor. Pxt. 10 cts., oz. 20 cts., $1 / 4$ 1b. 50 cts., 1b. $\$ 1.75$.

ESSEX FYBRID. A cross of the Hubbard and old Turban, partaking somewhat of the features of both. Like the Hubbard, it is hard-shelled. In color it is like the Turban, but greatly improved in form. Flesh thick, solid and of good quality. Pkt. 10 cts., oz. 15 cts., $1 / 4$ 1b. 40 cts., 1b. $\$ 1.40$.

GOIDEN FUBBARD. A distinct solt of the shape and general character of the Hubbard, but a little smaller, earlier to mature, and a rich orange-red instead of the dark olive-green of the old Hubbard, while the flesh, which is thick, is a little deeper colored, of fully as good quality, fine grained and dry. Plet. 10 cts., oz. 20 cts., 1/4 1b. 50 cts., 1b. $\$ 1.75$.

MAMMOTH SUMMPR CROOKNECK. Vinc larger and of more vigorous growth than the Summer Crookneck and fruit is twice as large and deeper colored. Its large size and attractive appearance have made it popular with market gardeners. Plt. 10 cts., oz. 20 cts., $1 / 4$ 1b. 50 cts., 1b. $\$ 1.75$.

ITAIIAN VEGETABIE MARRO W Vines of bush habit, producing large. much elongated fruits. Dark green at flrst, but becoming marbled with yellow as they mature. The young fruits, when fricd in oil, constitute a vegetable dellcacy very popular. Pkt. 10 cts., oz. 20 cts., $1 / 4$ lb. 50 cts., 1 b. $\$ 1.75$.

ORANGE MARROW. An early variety, much like the Prolifle Marrow in color and pitting, but is more nearly round, later much thicker meated and of better quality. Pkt. 10 cts., oz. 15 cts., $1 / 4$ 1b. 40 cts., 1b. $\$ 1.40$.

THE WARREN. Has a sliell generally harder and thicker tlian the Essex Hybrid and the color is a deeper and richer orange, while the quality is decidedly better. The Warren is now grown very extensively by marketgardeners. Pkt. 10 cts., oz. 20 cts., $1 / 4$ 1b. 50 cts., ib. $\$ 1.75$.
EARIX GIANT SUMMER. Eally, mostly straight necked and much larger than the Summer Crookneck. A flne quality growing from 14 to 16 inches long. Extensively used by marliet gardeners and exceptionally good for home gardeners. Plst. 10 cts., oz. 25 cts., 1/4 lb. 70 cts., 1b. $\$ 2.50$.

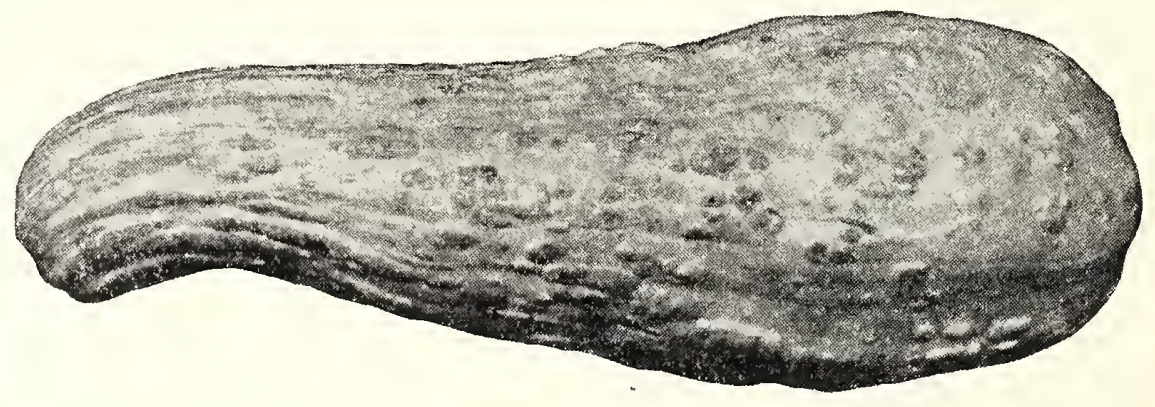

Early Giant Summer 


\title{
EVERYBODY KNOWS Ross' Seed Grows
}

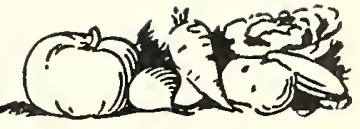

\section{TOMATO}

\author{
An ounce will produce about 2,000 plants
}

Tomatoes do best on light, warm, not over-rich soil. Sow in hotbed or windowbox (where 60 degrees Fahr. is the ninimum night temperature) in March, in rows 3 inches apart and $1 / 2$ inch deep. Cover firmly. Later sowings may be made to the end of April. When seedlings are 3 inches high, transplant 4 inches apart each way in hotbeds, coldframes, or singly in 3-inch pots. Harden plants by exposing to the air occasionally. After warm weather is settled, set out by exposing to the air occasionally. After warm weather is settled, set out
plants 3 to 4 feet apart each why in hills, into each of which fertilizer has been previously mixed. Water freely at time of transplanting and shelter from sun until plants are well established.

AcMrs. Vine hardy and productive. Fruit in clusters of four or five round, smooth and of good size; flesh solid and of excellent flavor. Pkt. 10 cts., 1/2 0z. 25 cts., oz. 40 cts., $1 / 41$ b. $\$ 1.25$.

AVOr EARIY. This new extra early scarlet fruited variety is the result of several years of caretul selection. 'The fruits are large for so early a variety, round or slightly flattened, deep scarlet red color, smooth, free from cracks and of fine quality. It produces ripe fruit as early as Earliana and continues to yield marketable fruit for a longer period than the other first early varieties. The vines are vigorous and very productive. We consider this a valuable addition to the list of early tomatoes for the market or home garden. Plt. 10 cts., $1 / 2$ oz. 35 cts., oz. 60 cts., $1 / 41 \mathrm{~b}$. $\$ 2.00$.

BEAUTY. Vines large, vigorous and heavy bearers; fruit large, uniform in size, very smooth, and excellent flavor; color, purplish pink. The best purple sort. Plst. 10 cts., $1 / 2$ oz. 25 cts., oz. 40 cts., $1 / 4$ lb. $\$ 1.25$.

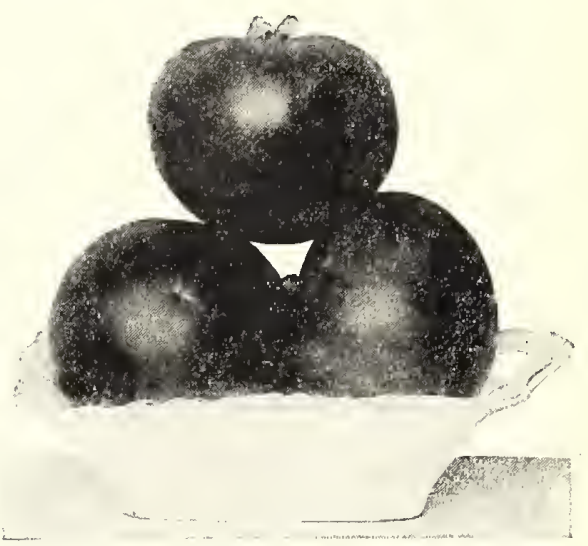

John Baer

BONNY BEST. This tomato has been tested and found eight to ten days earlier than the Chalk's Early Jewel and ripens about with the Earliana. Very strong grower and the fruit is uniform and smooth; ripens evenly all over, excellent shipper. Pkt. 10 cts., $1 / 2$ oz. 25 cts., oz. 40 cts., $1 / 4$ 1b. $\$ 1.25$.

Comrr. Fruit medium size, scarlet. The heaviest yielder of the grcen-house sorts. Plst. 10 cts., 1/2 oz. 35 cts., oz. 60 cts., $1 / 4$ 1b. $\$ 2.00$.

DWARF Champiov. Sometimes sold as the "Tree Tomato." A second early, purplish pink variety, especially desirable where garden space is limited. Vine about two feet high, vigorous, upright and compact. Fruits, medium sized, exceptionally smooth and of very good quality. Our stock is a very superior strain with more even, smoother fruit than the original. Pkt. 10 cts., $1 / 2$ oz. 25 cts., oz. 40 cts., $1 / 4$ lb. $\$ 1.25$.

DWARF STONE. Vine dwarf but vigorous and productive. While maturing with the later sorts, the bright red fruits are of good color, exceedingly smooth and very solid. We consider this the best of the large fruited, dwarf tomatoes. Pkt. 10 cts., $1 / 2$ 0z. 25 cts., oz. 40 cts., $1 / 4$ 1b. $\$ 1.25$.

JUNE PINK. An extra early, purplish pink tomato similar to the popular scarlet fruited Earliana in growth of vine, shape and size of fruits and time of maturing. 'This is a variety of exceptional value to market gardeners who want an early purplish pink tomato, either for home market or to ship; also desirable for planting under glass. Pkt. 10 cts., 1/2 oz. 25 cts., oz. 40 cts., $1 / 4$ lb. $\$ 1.25$.

JOHN BAER. An extra early scarlet fruited variety of superior merit. The vines are very hardy and exceptionally productive. The fruits are the largest of the extra early and are most attractive in color. They are nearly round, smooth, firm and of excellent quality. It is one of the earliest to ripen and it continues to furnish marketable fruits much longer than the other very early varieties. It is a very valuable sort for markel gardeners' use. Plrt. 10 cts., 1/2 oz. 25 cts., oz. 40 cts., $1 / 4$ lb. $\$ 1.25$.

PONDEROSA. This is one of the largest smooth tomatoes. Color, deep purple. The fruit is exceptionally solid, having but few seeds and is quite free from acid. It is also an ideal variety for shipping. Pkt. 10 cts., $1 / 2$ oz. 30 cts., oz. 50 cts., $1 / 4$ 1b. $\$ 1.50$.

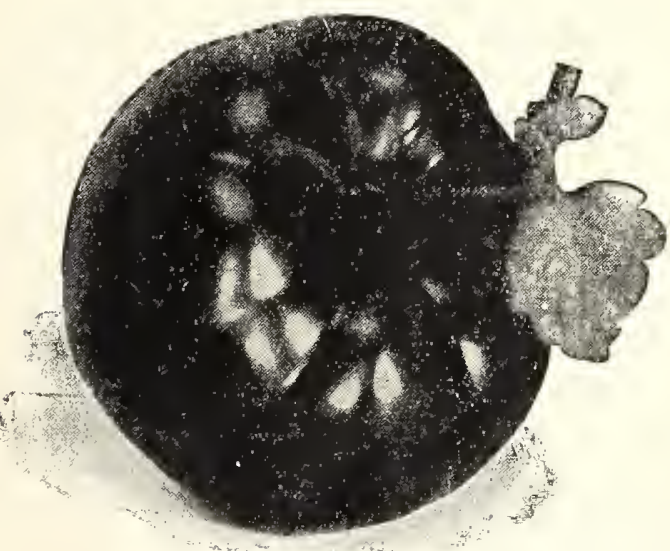

Dwarf Stone
SPARE'S IARITANA. A deep red tomato The vines are compact in growth, with short, close-jointed branches, This is an extra early tomato and the best so far produced. Very productive. Fruit fair size and firm. In test it ripened fruit in 108 days from date of sowing seed. Pkt. 10 cts., $1 / 2$ oz. 25 ctE., oz. 40 cts., $1 / 4$ lb. $\$ 1.25$.

RED HEAD. An excellent red variety: medium size, very prolific heavy fruit, ripens with John Baer. Pkt. 10 cts., 1/2 oz. 25 cts., oz. 40 cts., $1,41 b . \$ 1.25$.

STOFE. Vines vigorous and productive; fruit, large, smooth, deep red in color, and heavy. The best all around variety, where earliness is not important. Plit. 10 cts., $1 / 2$ Oz. 25 cts., 0z. 40 cts., 1/4 1b. $\$ 1.25$.

YEILOW PIUM. Small, plum-shaped fruit of rich flavor. Desirable for preserving and pickling. Plst. 10 cts.

YELLOW HUSK, or STRAWBgRRY. Fruit about the size of a small cherry, borne in husks; of very rich flavor; used only for preserves. plant also distinct. Pkt. 10 cts.

Have you tried our EUREKA ENSILAGE CORN? Sold only in our trade marked bags. 


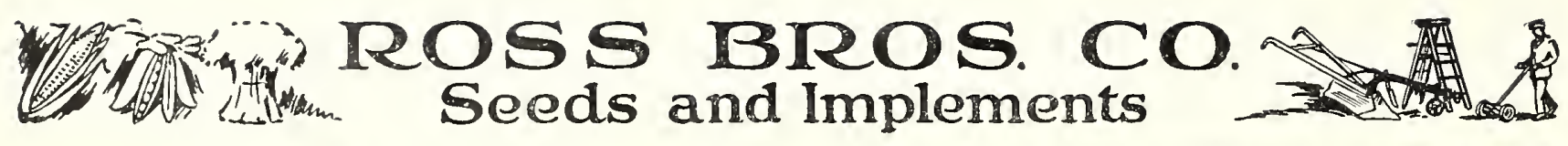

\section{Turnip}

An ounce will sow 200 feet of drill. If gown in drills, one pound is required for an acre; if sown broadcast, less seed is sufficient if sown evenly.

CULTURE-For early, sow seed of fat varieties in open ground in spring in drills one foot or more apart, using seed sparingly. Thin to 3 or 4 inches apart. For succession, sow every two weeks until June. For fall and winter, sow in July and August. A good crop may often be grown by scattering seed thinly in the cornfield at last cultivation. For Rutabagas, sow seed in seed-bed in spring and transplant to good warm soil, in rows at least 2 feet apart and 8 or 10 inches apart in the rows, or sow in open ground during June and early July. Take up the roots just before winter, top and store in cool cellar, or pit outdoors.

EARIY WHITE MIIAN. Roots flat, smooth and symmetrical, pure white. Top very small, upright, and compact, permitting close planting. The earliest and much the best of any extra early white variety. Flt. 10 cts., oz. 20 cts., 1/4 1b. 50 cts.

EARIY PURPIE MIIAN. Differs from the preceding in that the roots are not quite so thick and are purple on top. Pkt. 10 cts., oz. 20 cts., $1 / 4$ lb. $50 \mathrm{cts}$.

EARIY FURPLE-TOP FIAT. A well-known variety and very extensively grown. Foots smooth, white, with the upper portion purplish red. Pit. $10 \mathrm{ctss.,} \mathrm{oz.} 1.5 \mathrm{cts}, 1 / 4 \mathrm{lb} .25 \mathrm{cts} ., 1 \mathrm{~b} .75 \mathrm{cts}$.

FARIY PURPIE-TOP WHITI GIOBE. One of the handsomest varieties, the upper portions of the root being a purplish red, the lower pure white. A rapid grower, attaining a marketable size sooner than other large globular varieties. Of the best quality and an excellent keeper. Pkt. 10 cts., oz. 15 cts., 1/4 1b. 25 cts., $1 \mathrm{~b} .75$ cts.

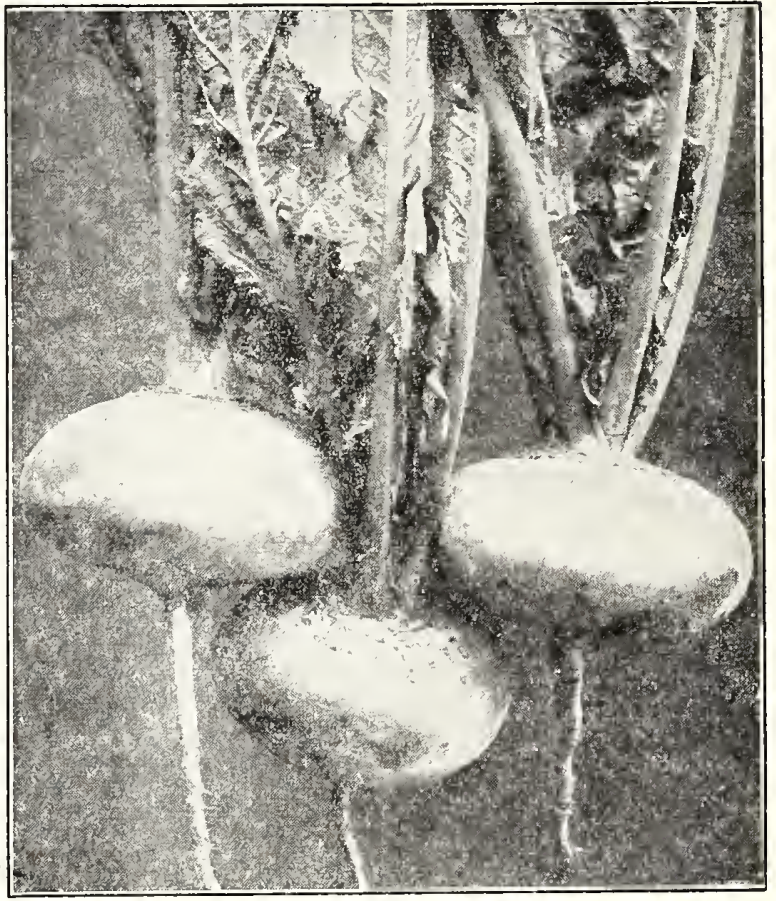

Early Purple Top Flat

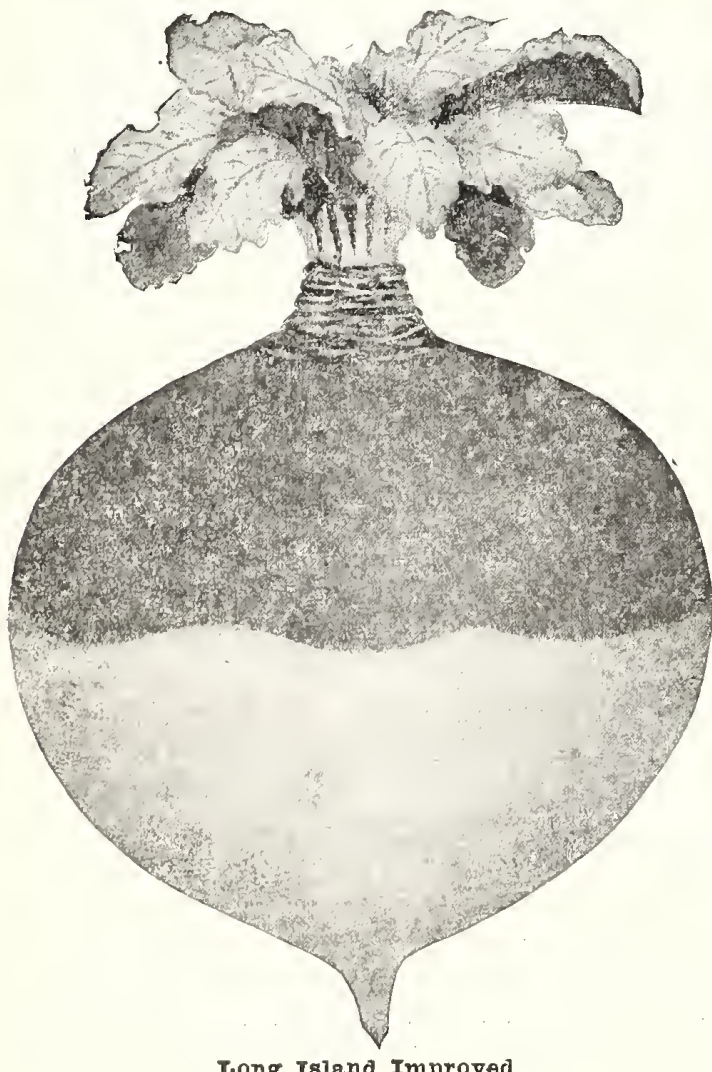

Iong Island Improved
WHITE EGG. More extensively grown than any other variety. White, egg-shaped, smooth and symmetrical, of medium size; flesh firm, sweet and mild. Plit. 10 cts., oz. 15 cts., $1 / 4$ lb. 25 cts., lb.

GOIDEN BAII, or OFANGE JEIIY. Of globular form, medium size skin rich orange; flesh, pale amber, very fine-grained, mild and sweet. One of the most attractive, of the best quality and keeps Well. Pkt. 10 cts., oz. 15 cts., $1 / 4$ lb. 25 cts., 1b. 75 cts.

YrIIOW GIOBE. The standard yellow variety. The form is round, slightly flattened. Largely grown for stock, and to some extent for market. An excellent keeper, Plrt. 10 cts., oz. 15 cts., 1/4 1b. 25 cts., 1b. 75 cts.

COW HORN, or IONG WHITE, Root long, slightly crooked and grows nearly half above ground. Clear white, except a little green at top. Though more largely used for feeding stock, it is a fine table variety, being tender and of mild flavor. Of very rapid growth. Plt. 10 cts., oz. 15 cts., $1 / 4$ 1b. 25 cts., 1b. 75 cts.

\section{Swedish, Russian or Rutabaga}

SWEET IUUSSIAN, An old variety yet largely grown, mainly for table use. Sweet and mild. Plkt. 10 cts., 0z. 15 cts., 1/4 lb. 35 cts., $1 \mathrm{~b}, 90 \mathrm{cts}$

WHITE FRENCH, or ROCK. Also an oid and popular sort. Roots a little longer than Sweet Russian, but does not otherwise differ. Valuable for table or feeding. Plit. 10 cts., oz. 15 cts., 1/4 1b. 35 cts., 1b. 90 cts.

BREADSTONE. An early variety, white, faintly colored at top: medium size, tender, mild and sweet. Fkt. 10 cts., oz. 15 cts., 1/4 1b. 35 cts., 1b. 90 cts.

SHAMROCR. A popular English Yellow Swede. A decided favorite with our local trade. Has short neck, shape oblong. Pkt. 10 cts., oz. 15 cts., $1 / 4$ lb. 35 cts., 1b. 90 cts.

IONG ISLAND IMPFOVED. This is undoubtedly the finest variety of Purple-Top Rutabaga. It grows much larger than other American varieties, is, therefore, desirable for stock, but equally desirable for the table and market, as it is tender and sweet and of very attractive appearance. Pkt. 10 cts., oz. 15 cts., 1/4 1b. 35 cts., 1h. $90 \mathrm{cts}$

\section{Tobacco}

CONMECTICUT SEED IEAF. A hardy cigar variety, well adapted to growing in the Middle and Northern States. Fkt. 10 cts., oz. 40 cts.

HAVArA. Leaf very thin, fine texture. Much used for clgar wrappers. Pkt. 10 cts.; oz. 40 cts. 


\section{Reference Table for Sowing, Etc.}

\begin{tabular}{|c|c|c|c|c|c|c|c|c|}
\hline \multirow[b]{2}{*}{ Name } & \multicolumn{2}{|c|}{ Date of Sowing } & \multirow{2}{*}{$\begin{array}{l}\text { Days to } \\
\text { Come Up }\end{array}$} & \multirow{2}{*}{$\begin{array}{l}\text { Ready to use } \\
\text { from Seed Sown }\end{array}$} & \multicolumn{2}{|c|}{ Distance } & \multirow{2}{*}{$\begin{array}{l}\text { Depth to } \\
\text { Cover }\end{array}$} & \multirow{2}{*}{$\begin{array}{l}\text { Quantity of } \\
\text { Seed }\end{array}$} \\
\hline & $\begin{array}{l}\text { Tnder } \\
\text { Glass }\end{array}$ & $\begin{array}{c}\text { Open } \\
\text { Ground }\end{array}$ & & & $\begin{array}{l}\text { Apart in } \\
\text { Rows }\end{array}$ & $\begin{array}{l}\text { Rows } \\
\text { Apart }\end{array}$ & & \\
\hline Asparagus Roots & & April & & $2-3$ years & 1 foot & 4 feet & 4 inches & 100 for 100 feet of row \\
\hline Beans, Dwarf & & May-Aug. & $6-10$ & $45-80$ days & 2 inclies & 3 feet & 2 inches & $1 \mathrm{lb}$. for 100 fect of row \\
\hline Beans, Pole & & May-June & $6-10$ & $60-100$ days & 3 feet & 4 feet & 2 inches & $1 \mathrm{lb}$. for 100 hills \\
\hline Beets & March & April-Aug. & $7-10$ & $60-80$ days & 4 inches & 1 foot & $1 \mathrm{inch}$ & $1 \mathrm{oz}$. for 100 feet of row \\
\hline Cabbage, Early & Feb. & & $6-10$ & $80-125$ days & 18 inches & 2 feet & $1 / 4$ inch & $1 / 2 \mathrm{oz}$. for 200 fect of row \\
\hline Cabbage, Late & & May-June & $6-10$ & $110-180$ days & 2 feet & 3 feet & $14 \mathrm{inch}$ & $1 / 2$ oz. for 200 feet of row \\
\hline Carrots, Early & Mareh & April & $10-15$ & to- 85 days & 4 inches & 14 inches & $1 / 4$ inch & $1 \mathrm{oz}$. for 150 feet of row \\
\hline Carrots, Late & & May-June & $10-15$ & 100-120 day"s & 4 inches & 14 inches & $1 / 4 \mathrm{inch}$ & $1 \mathrm{oz}$. for 150 feet of row \\
\hline Cauliflower, Early & Feb. & April & $6-10$ & $100-115$ days & $11 / 2$ feet & 3 feet & $1 / 4$ inch & $1 / 1 \mathrm{oz}$. for 100 feet of row \\
\hline Cauliflower, Late & & May-June & $6-10$ & 100-125 days & $11 / 2$ feet & 3 feet & 14 inch & $1 / 4$ oz for 100 feet of row \\
\hline Celery Seed & March & April & $12-20$ & $125-150$ days & $1 \mathrm{inch}$ & 3 inches & $1 / 4 \mathrm{inch}$ & Pkt. for 100 feet of row \\
\hline Celery Plants & & May-June & $\cdot$ & & 6 inches & 6 inches & & \\
\hline Corn, Sweet & & May-July & $8-10$ & $55-100$ days & 8 inches & 3 feet & $1 \mathrm{inch}$ & 1 pkt. for 100 hills \\
\hline Cucumber & & May-July & $6-8$ & $60-85$ days & 4 fcet & 4 feet & $1 / 2 \mathrm{inch}$ & $1 \mathrm{oz}$. for 50 hills \\
\hline Eg\& Plants & March & & $10-14$ & $125-160$ days & 2 inches & 3 inches & $1 / 4$ inch & 1 pkt. for 100 feet of row \\
\hline Endive & Feb. & April-Aug. & $6-10$ & 75-100 days & 1 foot & 1 foot & $1 / 1$ inch & $1 \mathrm{oz}$. for 300 feet of row \\
\hline Kohl Rabl & & April-Aug. & $6-8$ & $65-85$ days & 8 inches & 1 foot & $1 / 4$ inch & 1 pkt. for 100 feet of row \\
\hline Let tuce & Feb. & April-Aug. & $6-10$ & $6 \overline{2}-100$ days & 8 inches & 1 foot & 1's inch & 1 pkt. for 100 feet of row \\
\hline Melon, Musk & & May-June & $6-10$ & $90-120$ days & 5 feet & 5 feet & $1 \mathrm{inch}$ & $1 \mathrm{oz}$. for 50 hills \\
\hline Melon, Water & & May-June & $8-12$ & 100-125 days & 6 feet & 6 feet & 2 inches & $1 \mathrm{oz}$. for 25 hills \\
\hline Okra & & May & $6-10$ & $120-150$ days & 2 feet & 3 feet & 1 inch & $1 \mathrm{oz}$. for 50 feet of row \\
\hline Onion Seed & Feb. & April-May & $6-14$ & s0-100 days & 3 inches & 14 inches & $1 / 2$ inch & $1 \mathrm{oz}$. for 200 feet of row \\
\hline Onlon Sets & & April-May & & & 2 inches & 14 inches & $1 \mathrm{inch}$ & $4 \mathrm{lbs}$. for 100 feet of row \\
\hline Parsnips & & April & $12-18$ & $120-150$ days & 4 inches & 18 inches & $1 / 2$ inch & $1 \mathrm{oz}$. for 200 feet of row \\
\hline Parsley & . & April-May & $18-24$ & $90-100$ days & 4 inches & 1 foot & $1 / 2$ inch & $1 \mathrm{oz}$. for 200 feet of row \\
\hline Peas, Wrinkled & & April-July & $5-10$ & $50-75$ days & 2 inches & 3 feet & 2 inches & $1 \mathrm{lb}$. for 100 feet of row \\
\hline Peppers & March & & $10-14$ & $135-150$ days & 2 feet & 2 feet & $1 / 2 \mathrm{inch}$ & $1 / 2 \mathrm{oz}$. for 100 feet of row \\
\hline Potatoes & March & April-Junc & $10-25$ & $75-100$ days & 1 foot & 3 feet & 4 inches & 15 lbs. for 100 feet of row \\
\hline Pumpkins & & May-Junc & $6-10$ & 100-125 days & 8 feet & 8 feet & 2 inches & $1 \mathrm{oz}$. for 50 hills \\
\hline Radish & March & April-Sept. & $4-6$ & $25-50$ days & 1 inch & 1 foot & $1 / 2$ inch & $1 \mathrm{oz}$. for 150 feet of row \\
\hline Salsify & & April-May & $8-12$ & $125-160$ days & 3 inches & 1 foot & 1 inch & $1 \mathrm{oz}$. for 60 feet of row \\
\hline Splnach & & April-Sept. & $6-12$ & $60-75$ days & 3 inches & 1 foot & $1 \mathrm{inch}$ & $1 \mathrm{oz}$. for 100 feet of row \\
\hline Squash, Summer & & May-June & $6-10$ & $60-120$ days & 8 feet & 8 feet & 2 inches & $1 \mathrm{oz}$. for 25 hills \\
\hline Squash, Winter & & May-June & $6-10$ & $60-120$ days & 8 feet & 8 feet & 2 inches & $1 \mathrm{oz}$. for 10 hills \\
\hline Tomato Seeds & Fcb. & & $6-12$ & $12 \tilde{-150}$ days & 2 inches & 2 inches & $1 / 2$ inch & 1 pkt. for 100 plants \\
\hline Tomato Plants & & May-June & & & 4 fect & 4 feet & & \\
\hline Turnip & & April-Sept. & $4-8$ & $50-75$ days & $3-6$ inches & $1-11 / 2$ feet & $1 / 2$ inch & $1 \mathrm{oz}$. for 200 feet of row \\
\hline
\end{tabular}

The following vegetables can be produced on a space of $20 \times 45$ feet.

25 dozen green onions, 1 bushel of dry onions, 1 bushel of green peas, 12 dozen of beets, 25 dozen of radishes, 150 heads of celery, 2 bushels of string beans, 20 heads of cauliflower, 20 heads of cabbage, 2 bushels of spinach, 2 bushels of carrots, 2 bushels of parenips, 20 egg plants, 50 heads of lettuce, 10 head 5 of endive, $10 \mathrm{kohl} \mathrm{rabi,} 8$ dozen sweet corn, 50 musk melons, 200 pickling cucumbers, 10 large cucumbers, 4 bushels of tomatoes, 2 bushels of potatoes, 3 bushel 8 of turnips.

After the early sorts are taken off you can follow with varieties that can be planted late and produce two crops on the same grounds. 


\section{ROSS BROS. CO. Selected List of Flower Seeds}

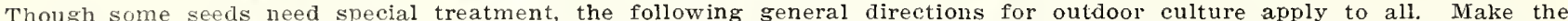

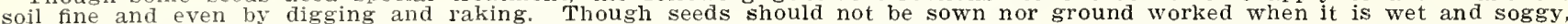

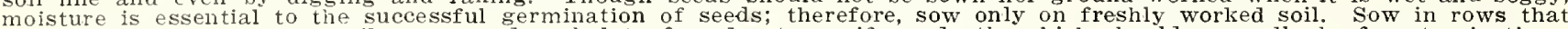

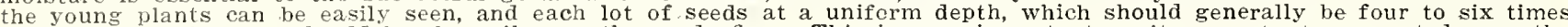

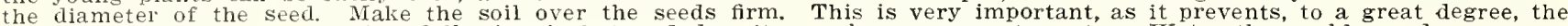

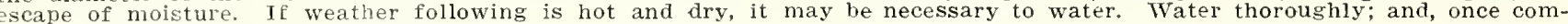
menced, regularly or not at all.

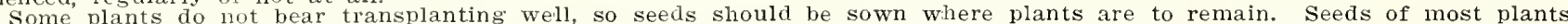

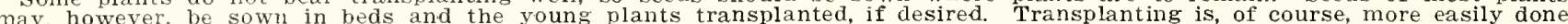

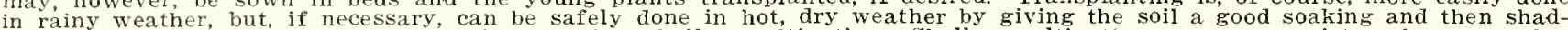

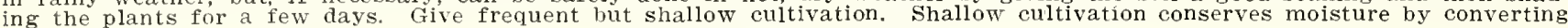
the top soil into a fine mulch.

\section{HOW TO ORDER}

When ordering, always give catalogue variety number; and, while it is not necessary to give name, it often serves to indicate more fully what the customer desires, as in the event of the number and name differing, we always send the variety indicated by the name as probably the one desired. All flower seeds mailed free on receipt of price quoted

Plants are usually divided into three classes-Annuals, Biennials and Perennials. Annuals are plants which normally live but a single season. Biennials are plants living two years, particularly those which do not bear flowers and fruit until the second season. Perennials tend to live from year to year. Half-hardy Biennials and Perennials require winter protection of plants. Sow part of your seed early and make frequent sowings, so that when the soll becomes warm and mellow you will be ready to set out strong, well-developed plants, neither too young nor too old.

ASTERS One of the very best

The Aster is of easy culture and very popular. Plants from seed sown in open ground in May bloom freely in September and october For July and Aurust flowers, sow in March or April in cold-frame, spent hotbed, or in pots or boxes in the house. Cover the seeds about half an inch deep with rich. light soil, and when the plants have three or four leaves transplant about 18 inches apart each way into well prepared beds. Manure too fresh or used in too large quantities sometimes induces disease in Asters. When used, they should be thoroughly well decayed and mixed with the soil.

\section{NEW AND IMPROVED STRAINS}

\section{California Giant Double}

We take pleasure in recommending this type as the best Aster on the market today. Characterized by the well known Crego or Ostrich Feather type of flower, combined with the Beauty Aster's long, non-lateral branching stems and sturdy habit of growth. the California Giant Double type of Aster stands at the head of the list, not only for florists' use, but also for private gardens where quality is appreciated.

8 White, new, fine. 9 Peach Blossom. 10 Tight Blue. 11 Light Purple. 12 Deep Rose, 13 Dark Purple. Pst. Light Purple. 12 Deep Rose. 13 Dark Purple. 14 Misture of ahove. Pkt. $10 \mathrm{cts}$., $1 / 8$ oz. $40 \mathrm{cts} ., 1 / 4$ oz. 75 cts., $1 / 2$ oz. $\$ 1.40$.

\section{California Giant Single}

We are offering this wonderful Aster for the first time this year. It was developed out of the California Giant Double type. The flowers are large, measuring three to four inches across, with stems 18 to 24 inches in length. The petal has a slight twist, which adds a piquant touch to its beauty. The white blossoins resemble Shasta Daisies in appearance but their greater length of stem makes them more graceful and better adapted to florists' use. In the garden Aster, California Giant Single adds a charming note of simplicity among the fuller types of Asters. We believe this new, single type of Aster is destined to become very popular.

15 Finest Mixed. Pht. 10 cts., $1 / 8$ oz. 40 cts., $1 / 4$ oz. $75 \mathrm{cts}$. $1 / 2$ oz, $\$ 1.40$.

\section{Late Beauty Type}

Plants about 2 to 3 feet high, of branching habit, commencing to bloom in early september and lasting until destroyed by frost. Flowers large, borne on long and stout stems, from 18 to 24 inches. This applies to all of the Beauty Class, making them most desirable for cut flowers.

16 Azure Blue. 17 Crinson. 18 Lavender. 19 Purple. 20 Rose. 21 Flesh Pink. 22 White. 23 Finest Mixed. Pltt. 10 cts., $1 / 8$ oz. $40 \mathrm{cts}$., $1 / 4$ oz. 75 cts.

\section{Early Beauty Type}

This type has all of the characteristics of the Late Beauty Type, and is valuable for locations where the season is too late to flower the late type before frost, and for early forcing. We wish to emphasize. however, that this is not an Early Aster as compared with Queen of the Market, but earlier than the late Beauty Type. Planted at the same time this type flowers with the Crego and American Branching.

24 Azure Blue. 25 Crimson. 26 Iavender. 27 Purple. 28 Rose. 29 Flesh Pink. 30 White. 31 Finest Mixed. Plit. $10 \mathrm{cts}$., $1 / 8$ oz. $40 \mathrm{cts}$., $1 / 4$ oz. $75 \mathrm{cts}$., $1 / 2$ oz. $\$ 1.40$.

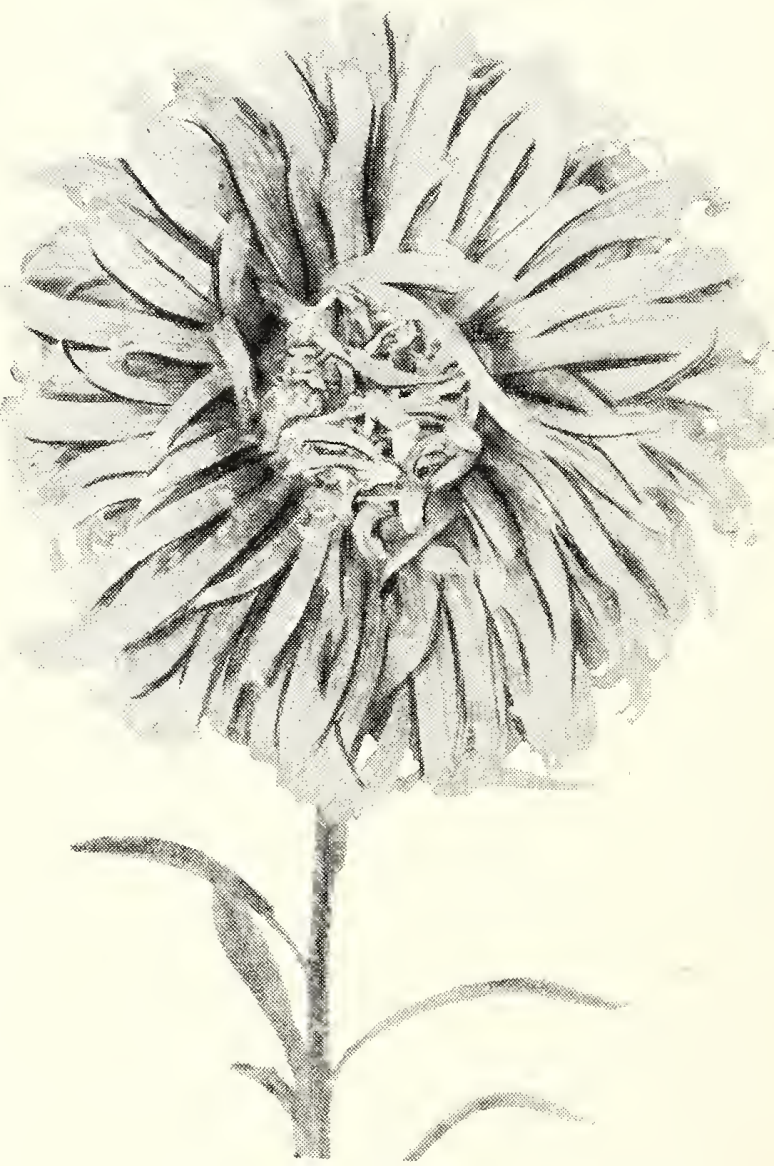

California Giant Double

Do you receive our fall catalogue for Dutch bulbs? We list a full line of Tulips, Hyacinths and miscellaneous bulbs, also American grown Narcissus. If you do not receive this book send us your name and address and we will gladly put you on our mailing list for our next fall catalogue. 


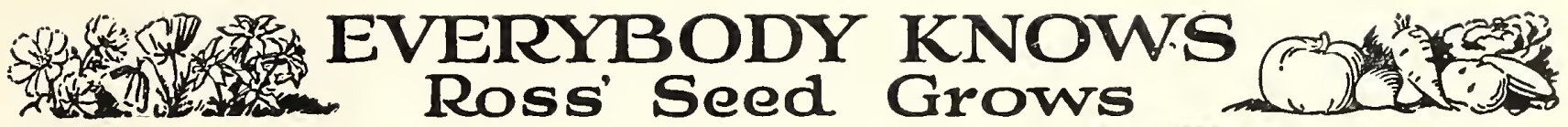

\section{ASTERS}

\section{Heart of France}

32 The best pure-red Aster ever introduced, All others have sombre shades of blue or too much yellow in the color pigments. Heart of France opens red as the purest ruby, deepens with ase and retains its remarkable beauty to the very end. The petals appear strikingly changeable, showing now a glow and sheen quite unique, now a soft, warm, velvety texture. In any light, natural or artificial, Heart of France is startlingly beautiful and will command instant admiration. Pkt. 15 cts., 1/16 oz. $50 \mathrm{cts} ., 1 / 8$ oz. $90 \mathrm{cts}$.

\section{The Rochester}

The plants of Rochester Asters, like those of the Late Branching variety, are large and strong, with many long branches. Their flowers have, in common with others of the Comet type, petals that are very long and narrow and gracefully recurved, giving them a lightness and grace that make them the most artistic of all Asters. The immense size of these flowers - they are the largest Asters now in cultivationtheir artistic beauty, delicacy of coloring and freedom of bloom, make the Rochester, in our estimation, the superior of any Aster of its class heretofore offered to the public. 33 sheil Pink. 34 Lavender. 35 white. Plt. 15 cts., $1 / 16$ oz. 50 cts., $1 / 8$ oz. $90 \mathrm{cts}$.

\section{Pink Enchantress}

36 This splendid Aster, introduced recently, is highly commended, and large quantities are grown annually by commercial florists. The immense flowers of a soft, delicate pink, are borne on strong upright plants. The color is that of the popular "Pink Enchantress" Carnation. In Asters, the color is between that of Daybreak

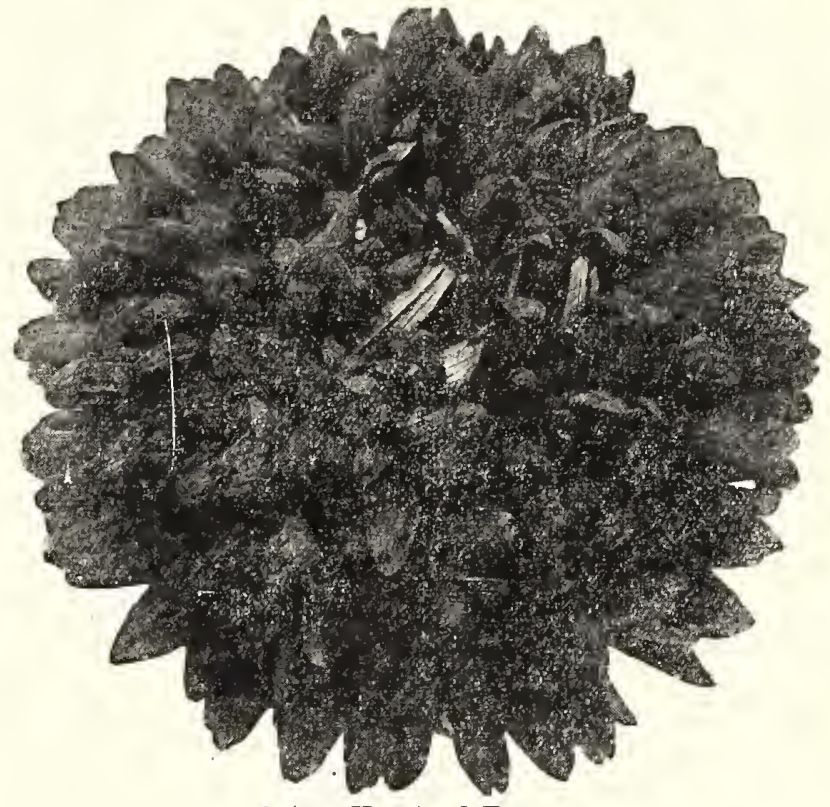
and the Semple's Pink Branching and although very delicate does not facte. the largest Branching Asters. Plit. 10 cts., 1/8 oz. 60 cts., $1 / 4$ oz. $\$ 1.10$. QUEEN OF THE MARKET. A very eally blooming strain, which, though plant is only $11 / 4$ feet high, bears from ten to fifteen well-formed, medium-sized flowers on long stems. Much used by florists. 37 white. 38 Rose. 39 Iight Blue. 40 Pink. 41 Crinuson. 42 IMíxed Colors. Each, pkt. $10 \mathrm{cts}, 1 / 8$ oz. $40 \mathrm{cts}$.

43 DAYBREaK. Flowers very large and full, and borne on long stems, color a beautiful shell-pink. The plant blooms early and profusely, and is of a strong and compact habit, Very popular; 2 feet. Pkt. 10 cts., 1/8 oz. 50 cts.

44 PURITY. Pure white. A desirable companion to Daybreak. Identical in form of flower and general habit. Blooms at the same time. Plit. 10 cts., $1 / 8$ oz. $50 \mathrm{cts}$.

45 IAVENDER DAYBREAK. Soft, clear, lavender, Of same type as Purity and Daybreak. Pht. 10 cts., 1/8 oz. 50 cts.

ROYAI. This is considered by many to be the very best general purpose Aster ever introduced. It is very much like our American Branching variety, having all its good qualities, but coming into bloom in July or early August and lasting in perfect condition for a long time. The habit of the plants and their free fowering make them very desirable for beds or borders/ and the long stemmed flowers are ideal for cutting. 46 Shell Fink. 47 White. 43 Iavender. 49 Mixed Colors. Pkt. $10 \mathrm{cts}$, $1 / 8$ oz. $60 \mathrm{cts}$.

VICTORIA. Considered for a long time one of the finest types and improved in recent years. The flowers are large, double, imbricated, having petals which curve outward like those of the show dahlias. Bears freely, beautiful longstemmed flowers. 62 Mixed Colors. A superb mixture. Pkt. 10 cts., 1/6 oz. 40 cts.

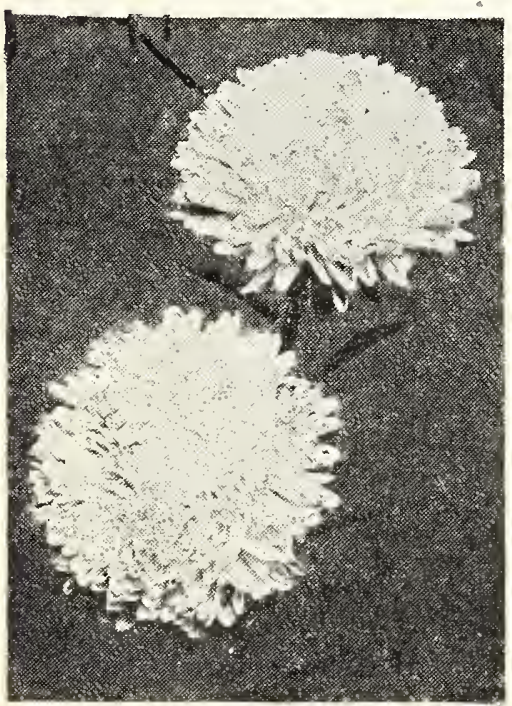

American Branching
GIANT BRANCHING COInET. Distinct and valuable; flowers resemble the Japanese chrysanthemum. Not only larger, but petals are longer and somewhat broader than the old Comet section. The plant is of vigorous, luxuriant growth and produces freely its long-stemmed, graceful flowers; $11 / 2$ to 2 feet.

70 white, 71 Light Yellow. 73 Rose. 74 Lavender. 75 Crimson. 76 Shell Pink. Each, plit. $10 \mathrm{cts} ., 1 / 8 \mathrm{oz} .40 \mathrm{cts}$.

80 Mixed Colors. Many color's and shades. Pkt. 10 cts., 1/8 oz. 40 cts.

AMERICAN BRANCHING. A superior late-blooming strain of American origin. The flower's are of the largest size, borne on long, graceful stems of ten 15 or more inches in length, are exceedingly beautiful and unsurpassed for cutting. The plants are of extra large and strong growth, and bloom profusely; $2 \frac{1 / 2}{2}$ feet.
108

116

118

124

125
White. 109 Pink. 110 Lavender. 111 Crimson. 112 Purple. Each, plrt. 10 cts., $1 / 8$ oz. 40 cts., $1 / 4$ oz. 75 cts.

Mixed Colors. Plt. $10 \mathrm{cts}$., $1 / 8$ oz. $30 \mathrm{cts}, 1 / 4$ oz. $50 \mathrm{cts.,}$ oz. $\$ 1.50$.

SEMPIE'S BRANCHING. The plants of this Early Branching Aster attain the size and vigor of the famous American Branching, but bloom from 10 days to 2 weeks earlier. Extra large, perfectly formed flowers on long, stiff stems make them especially desirable for cutting, for exhibitions or for sale.

Iavender. I19 White. 120 Shell Pink. 121 Crimson, 122 rixed. Each, Pkt. 10 cts., 1/8 oz. 40 cts., $1 / 4$ oz. 75 cts.

WORCESTER MIXTURE. Our own mixture of the leading choice varieties includes every color and shade known among Asters, and will afford, especially if purchased in bulk, the greatest discovery of both colors and types. Purchaser of a single packet may be certain of securing a choice collection of desirable varieties. Fkt. $10 \mathrm{cts}$., 1/8 oz. $40 \mathrm{cts}$, 1/4 oz. $75 \mathrm{cts}$., oz. $\$ 2.75$.

GOOD MXED. Our own mixture of many varieties; a wide range of colors. Pkt. $10 \mathrm{cts.}, 1 / 8$ oz. $30 \mathrm{cts.,} 1 / 4$ oz. 50 cts., oz. $\$ 1.75$.

ASTERMUM. A strain of Giant Comet Asters which, on account of their immense size and Chrysanthemum-like appearance, have appropriately been named Astermums, The plants grow about 2 feet high with long, strong stems and should come into bloom about the middle of August.

White. 127 Pink. 128 Iavender. Pkt. 15 cts. 


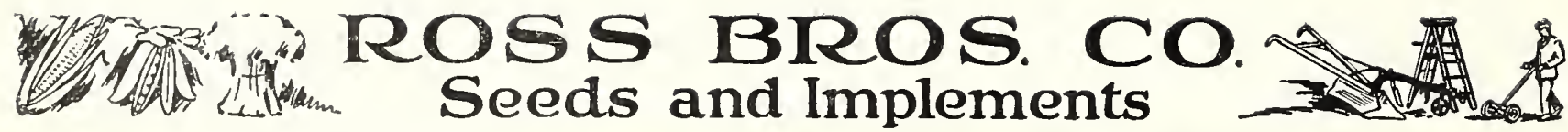

Achillea

135 PtARIIICA, The Pearl. One of the best white, hardy perennials, bearing profusely and continuously from June untíl frost, beautiful small, white, double flowers; useful for cutting. Wasily grown from seed, cemeteríes. 2 feet. Prt. 15 cts.

\section{Acroclinium}

Everlasting Flower

A half-hardy annual, bearing attractive white and rose-colored single and double flowers chiefly used when dried for winter bouquets and wreaths; for this purpose flowers should be cut before fully expanded, $1 \frac{1 / 4}{4}$ feet.

139 Light Fose and Pure White, Mixed. Plst. 10 cts.

\section{Adlumia}

140 CIRREOSA. (Mountain Fringe; Allegheny Vine.) A beautiful hardy, climbing biennial, which usually self-sows. The feathery foliage resembles that of the maiden-hair fern. of rapid growth and produces, in great profusion, small, tubeshaped pink blossoms. Of the easiest culture. Defeet pkt. 10 cts.

\section{Adonis}

Hardy, free-flowering plants, bearing showy, attractive flowers, and requíring líttle care. Seed should be sown in the open ground in the Autumn, or started early in March. 145 VRRALIS. (Ox-Eye.) Hardy perennial, blooming early in spring; when once established, may be easily increased by division. Flowers large, yellow. 18 inches. May and June. Pkt. 10 cts.

\section{Ageratum}

One of the best hardy annuals for summer bedding fiowers. Easily grown from seed, which should be sown in the house, as it lensthens the time of blooming which continues untíl frost. Its season, however, compares favorably in length with other annuals when seed is sown in the open ground. Set the dwarf kind 10 inches apart, and they soon make a mass of color

148 MrXICANUM. Blue, $1 \frac{1 / 2}{2}$ feet. Pkt. 10 cts., 1/4 oz. 30 cts., oz. $80 \mathrm{cts}$.

149 MEXICANUM ALBUM. White, $1 \frac{1}{2}$ feet. Pkt. 10 cts., $1 / 4$ oz. 30 cts., oz. $80 \mathrm{cts}$.

150 TMPERIAL DWARE WHIRE. \& inches. Pkt. $10 \mathrm{cts} ., 1 / 4$ oz. 30 cts., oz. 20 cts.

151 IITIE DORRIT. Azure-blue. 8 inches. Plt. 10 cts.,

$1 / 4$ oz. 30 cts. $02.80 \mathrm{cts}$.

152 IMPERIAI DWARE BIUE. $\&$ inches. Pkt. $10 \mathrm{cts.}$ 1/4 oz. 30 cts., oz. 80 cts.

153 IITTLE BLUE STAR. A miniature variety with beautiful mave flowers. 5 inches Pkt. $10 \mathrm{cts} ., 1 / 8$ oz. 60 cts.

154 BLUE PERTCTION. Large heads of Amethyst-blue flowers; plant of very even growth, about 8 inches high. Pkt. 10 cts., 1/8 oz. 25 cts.

158 MXED COLOR. All valietles mixed. Pkt. 10 cts., 1/2 oz. 30 cts., oz. 55 cts.

\section{Agrostemma}

Pretty, flee-blooming plants of easy culture, especially desirable for dry situations. Excellent for cutting.

160 COFIr-rosa. (Rose of Heaven.) Rose, white center. Hardy annual. $11 \%$ feet. Pkt. 10 cts.

161 COROFARIA. (Rose Champion,) One of the earliest hardy perennials. $1 \frac{1}{2}$ feet. Mixed colors. Pkt. 10 cts.

\section{Alyssum}

A well-known favorite, hardy annual, blooming profusely the entíre season. Excellent for edging. No other white flower is so well adapted for a dênse, low carpet, or as borders and ribbons in garden work. Extremely fragrant and frequently used for bouquets. Of easy culture. Sure to make a good display. Sow seed early in April.

166 SwEZT AIYSSUM. Fragrant, white, 1 foot. Prt. 10 cts., 1/4 0z. 25 cts., 0z. 75 cts.

167 IITTIE GEM. Of spreading habit, forming compact masses of bloom often a foot or more in diameter. White, fragrant, 6 inches. Pkt. $10 \mathrm{cts} ., 1 / 40 z .25$ cts., ox. $75^{\prime} \mathrm{cts}$.

\section{Sweet Alyssum, Fine for Edging}

168 CARPET OF SNOW. Of very dwarf habit; white, fragrant, 4 inches. Plst. $10 \mathrm{cts}$., $1 / 4$ oz. $30 \mathrm{cts}$., $1 / 2$ oz. $50 \mathrm{cts}$. 170 SAXATIIE COMPACTUM. Hardy perennial, bearing in grcat profusion in early spring golden yellow flowers. Desirable for rock work or for massing. 1 foot. Prt. $10 \mathrm{cts} ., 1 / 8$ oz. 25 cts.

171 IITTIE DORRIT. Little bushes fairly smothered with miniature white flowers. A gem for edging and beds 4 inches high. Pkt. 10 cts., $1 / 4$ oz. 35 cts., oz. \$1.25.

\section{Amaranthus}

Brilliantly colored foliage, and bearing peculiarly formed fowers. While in rich soil the plants and leaves are much larger, the colors are seldom as brilliant as when grown on rather poor soil. Of easiest culture. Give plenty of room to develop.

175 CAUDATUS. (Love-Lies-Bleeding.) Long, frooping flower, blood red. Half-hardy annual. 2 feet. Pikt.

178 TRICOIOR SPLENDENS. (Joseph's Coat.) Red, yellow and green foliage. One of the most beautiful of ornamental-leaved plants. Hardy annual. 2 feet. Pkt. $10 \mathrm{cts}$.

\section{Anchusa}

H. P. Flowers borne on spikes of a variety of blue shades. Useful in shrubbery and perennial gardens.

185 CAPENSIS. (Cape Forget-me-not.) Attractive annual with azure blue flowers. 11/2 feet. Pkt. 10 cts.

186 DROPMORE VARIETY. The bright blue Forget-MeNot-like flowers are borne on graceful stems during. the entire season and way late into the Fall. It is a great improvement over the existing varieties. 50 cts.

\section{Anemone}

A very popular, hardy garden perennial.

188 CORONARIA. Single, mixcd colors. The well-known 189 Poppy flowered Anemone. 1 foot. Pkt. 10 cts.

CORONARIA, ST. BRIGID. An improved strain, bearing large and more brilliant flowers, and remaining in bloom longer. 1 foot. Pkt. 10 cts.

\section{Anthemis}

\section{(Hardy Golden Marguerite)}

A beautiful, hardy perennial of easy culture, bearing all summer, golden yellow daisy-like flowers, excellent for cutting. Plants bushy and snouid stand at least 2 feet apart.

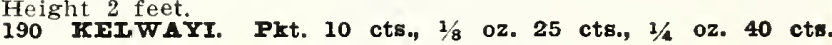

\section{Antirrhinum (Snapdragon)}

One of the most beautiful and useful bedding plants, blooming profusely throughout the summer. Fine for cutting.

191 SIIVER PINR. A splendid commercial variety, longstemmed, large flowered, delicate rosy pink, seemingly
covered with a silver sheen. Pkt. 25 cts., $1 / 16 \mathbf{o z}$. $30 \mathrm{ctw}$. 


\section{EVI ERTBODY KNOWS Ross' Seed Grows}

\section{Antirrhinum (Continued)}

192 VENUs. A bright pink on white ground, sel off by pure white throat Plt. 10 cts., $1 / 8$ oz. 35 cts.

Tall Varieties. 193 Rose. 194 Crimson. 195 White. 196 Yellow, 197 Mixed. Plst. $10 \mathrm{cts.}, 1 / 8$ oz. $20 \mathrm{cts}$., oz. $\$ 1.00$.

198 Grandiflora. Giant varieties. Mixed, pkt. 10 cts., 1/4 0z, 35 cts.

199 Dwarf Varieties. Mixed colors. Skt. $10 \mathrm{cts.}, 1 / 4$ oz. $35 \mathrm{cts}$.

\section{Aquilegia (Columbine)}

Beautiful free flowering hardy perennials, blooming throughout the spring and early summer. Of easy cultivation and will thrive in partial shade 1 to 3 feet.

200 Single Inixed. Plkt. $10 \mathrm{cts} ., 1 / 8$ oz. 25 cts., $1 / 4$ oz. 40 cts.

202 Double Mixed. Fkt. $10 \mathrm{cts.}, 1 / 8 \mathrm{oz} .30 \mathrm{cts} ., 1 / 402.50 \mathrm{cts}$.

204 COERUIEA HYBRIDA pl. 11. Long spurred, flowering hybrids in fine colors. Pkt. 25 cts. Arabis

209 AIPIVA. (Rock Cress, A pretty little hardy perewnial thriving in dry soil, and one of the earliest to bloom. Flowers white and deliciously fragrant; resembles Sweet Alyssum. The plant is covered with bloom and is excellent for rockwork and edgings; 6 inches. Fkt. 10 cts.

Aristolochia

215 SIPEO. (Dutchman's Pipe.) A hardy perennial vine of rapid growth with large, glossy heart-shaped leaves, bearing curious yellowishbrown blossoms, somewhat resembling a pipe; 15 to 20 feet. Fkt. 15 cts.

\section{Asparagus}

216 PLUmous NaNUS. Beautiful house plants; the ferthery foliage is un216 rivaled for cutting. Prt. 25 cts., 100 seeds $\$ 1.00$

217-SPRENGERI. Excelient plants for table decorations. Pkt. 15 cts.

\section{Asperula}

220 ODORATA. (Sweet Woodruff.) A hardy perennial, blooming freely and continuously in rather moist soil and a partially shaded location. The flowers are white, but the plant is largely grown for its fragrant leaves and stems, which are used when dried for the same purpose as those of lavender; 1 foot. Pkt. 10 cts.

\section{Balsam}

This old favorite annual, sometimes known as Lady's Slipper has been continually improved for several years, the flowers of some strains now closely rivaling in size and beauty those of the Camellia. Requires rich, soil, full exposure to the sun and plenty of water to be grown to perfection, but is otherwise of easy culture. We offer seed of the most improved types which will, with favorable conditions, produce a large proportion of double towers: 2 feet.

225 IMPROVED CAMERLIA-FLOWERED, MIXED COLORS. Double flowers of the finest type and a wide range of beautiful colors. Plst. 10 cts., $1 / 4$ oz. 40 cts.

227 DOUBLE DARK RED. Beautiful rich color.

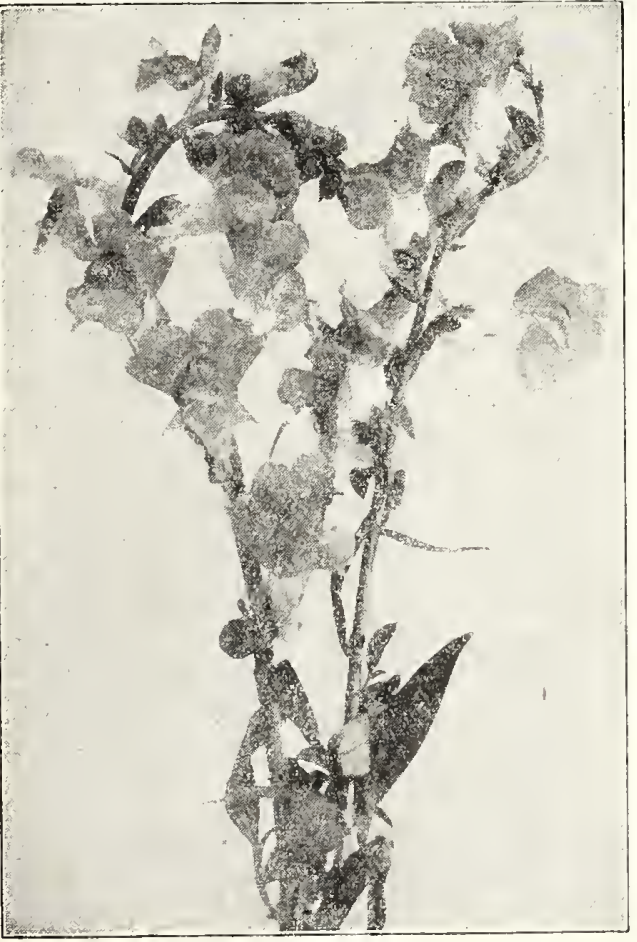

Antirrhinum

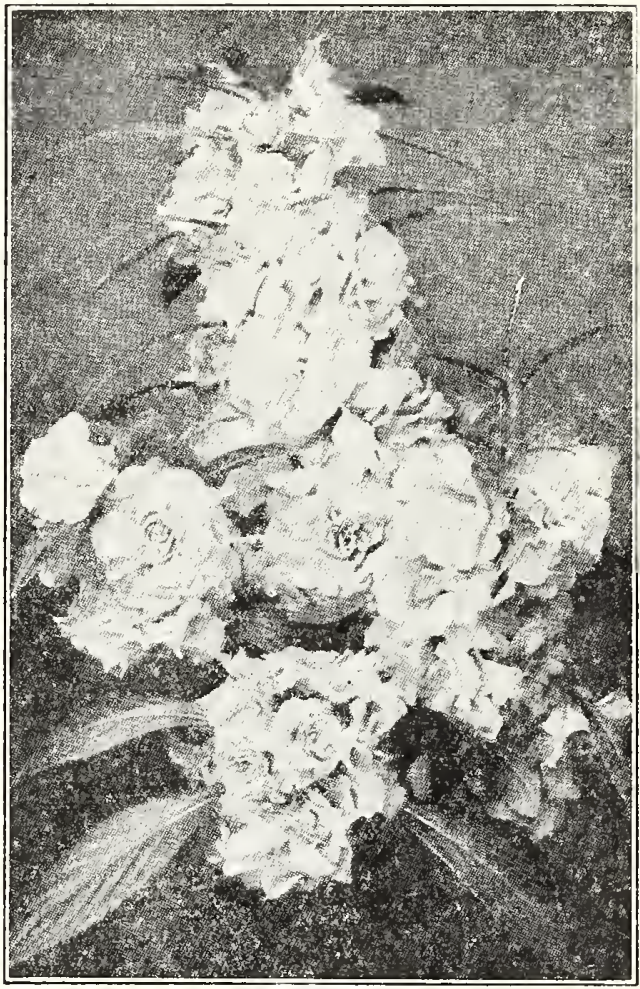

Balsam
228 DOUBIE PINK (PRINCE BISMARCK). Plt. $10 \mathrm{cts.,} \mathrm{1/4} \mathrm{0z.} 40 \mathrm{cts}$ 280 CHOICE MIXED. Double tlowers of many colors. Pkt. 10 cts., 1/4 oz. 20 cts., 0z. 75 cts.

235 A tender annual climber of rapid orowth bearing small white flowers, followed by curious inflated seed-vessels, somewhat resembling a balloon. 10 to 15 feet. Plet. 10 cts.

\section{Bartonia Aurea}

236 Showy, hardy annual of distinct character, its golden yellow flowers being freely produced; it grows well in partial shade, but sloould not be crowded. Pkt. 10 cts.

\section{Beans, Ornamental Varieties}

The Scarlet and White Runner Beans are deservedly popular as ornamental climbers, as but few plants grow so rapidly, and none is more easily srown. The former is largely grown alone for ornament, but all are very attractive. The beans of the White Runner are used in some localities as green shell beans. Scarlet are also edible, but seldom used. All should be treated as directed for Pole Beans.

240 SCARIET RUNNEIR. Plit. $10 \mathrm{cts.,} 241$ WHITE RUNNFR, Pkt. $10 \mathrm{cts}$

\section{Bellis Perennis-(Double Daisy)}

A perennial plant bearing in early spring small double white or rosecolored flowers. It succeeds best here in a rich loamy-soil, partially shaded. It is generally classed as hardy, but really needs a slight protection througl the winter; 4 inches. 245 Mixed Colors. Pkt. $10 \mathrm{cts.}, 1 / 8$ oz. 50 cts., 1/2 oz. $\$ 1.75$. 246 IONGFILLOW. Dark Rose Pkt. $10 \mathrm{cts.,} 1 / 8$ oz. $50 \mathrm{cts}$.

247 SNOWBALI. Pure white. Pkt. $10 \mathrm{cts.}, 1 / 8$ oz, 50 cts.

248 MONSTROSA DOUBIE MIXID. These new "Double" Daisies surpas all strains of this popular plant in strong, robust growth and abundance of large bloom. Each plant produces 12 to 15 flowers that measure 2 to 3 inches across, carried on long, strong stems. Pkt. 10 cts., $1 / 16$ oz. $50 \mathrm{cts}$.

\section{BLUE IACE FIOWER. See Didiscus.}

\section{Brachycome-(Swan River Daisy)}

A free-flowering plant of dwarf, compact growth, bearing in great profusion beautiful single blue or white flowers. Effective as edgings or in beds, and suitable for rustic baskets or pot culture. Half-hardy annual; 1 foot. 250 Mired Colors. Plrt. 10 cts.

\section{Browallia}

A beautiful, free-blooming half-hardy annual. Seed may be sown in the open ground when warm, but preferably should be sown in the house or hotbed and, if possible, repotted once or twice. For beds, borders or pots, few equal it; 11/2 feet. 251 Blue and white Mixed. Pkt. 10 cts. 


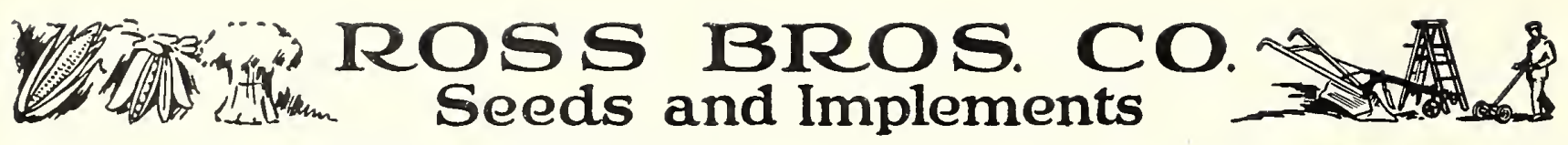

\section{Calendula-(Pot Marigold)}

A very free-blooming hardy annual of easy culture. Grows well in nearly all soils. Flowers double, borne on stiff siems, and are cut to some extent, but the plant is more desirable for bedding. 1 to $11 / 2$ feet.

952 CAMPFIRE (NEW). The blooms ale flat and very large. The color of the petal 252 CAMPFIRE (NEW). The blooms are flat and very large. The color of the petal is brilliant orange with a scarlet sheen with ful

255 THE 1b.ALL. A large ball-shaped double flowcr. Color bright orange, much used by liorists. Plit. 10 ets., $1 / 8$ oz. 60 ets., $1 / 4$ oz. $\$ 1.00$, oz. $\$ 2.50$.

256 ORANGE GIANT. Extra large, orange. Plit. 10 cts., $1 / 2$ oz. 30 ets., oz. 50 cts.

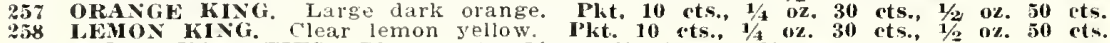

259 MIXED VMRIETIES. Plit. 10 ets., $1 / 2$ oz. 15 cts., o\%. 25 ets.

\section{Calliopsis}

Well-known, profuse-flowering hardy annuals of the easiest culture. Number 260 and 263 reliresent the tyre more commonly known. Numbers 261 and 262 resemble in habit, foliage and flower the perennial type, generally known as Coreopsis.

260 MIXED COLORS. 13 so to 2 feet. Pht, 10 ets., 1/2 oz. 30 ets., oz. 50 ets.

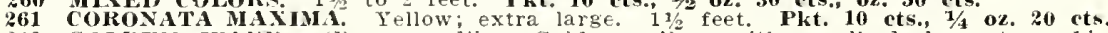

262 GOLDEN WAVk. (1)rummondii.) Golden yellow with small dark center. 1 \%

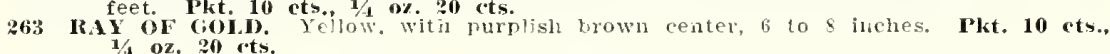

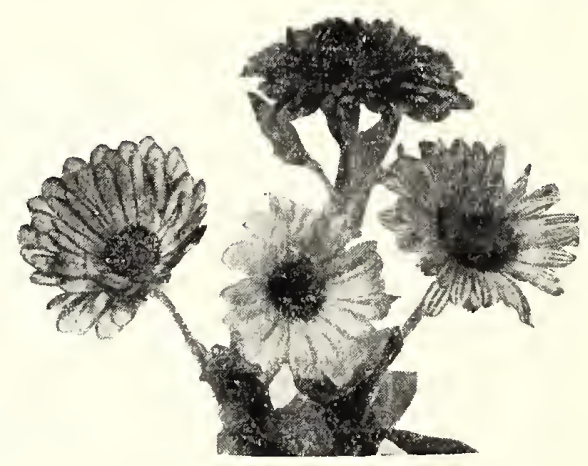

\section{Canterbury Bells (Campanula Medium)}

Well-known, beautiful, hardy biennials. Like all of this class, may be sown where they are to remain any tine after miasummer, or in beds in the spring for transplanting. The Calycanthema (Cup-and-Saucer) class is so named because of the broadening of the calyx into a saucr-shaped secondary tiower. In permanent situations, plal:ts should stand 18 to 20 inches apart. All varieties succeed best in a rich, rather sandy well-drained soil.

267 PRIZE MINTL1RE. A superb mixture of all classes, single, 27? C.IYCANTHEMA. (Cup-and-saucer.) Mixerl Colors. Pki 28 couts.

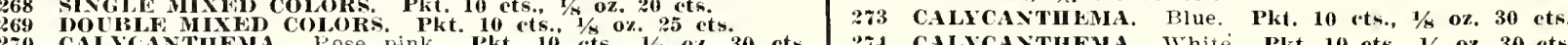

\section{Canary Creeper (Tropaeolum Canariensis)}

375 A rapld-growing, halt hardy annual climber, hearinğ currouslyormed yellow flowers. Blnoms until frost. Fine for sharly plares. 10 to 15 feet. P'kt. 10 c.ts., 1/4 0\%. 20 c.ts.

\section{Candytuft}

Popular hardy annual, growing in any soil, requiring but little care, and by repeated sowings may be had in bloom all summer to inches to 1 foot.

276 CARMINE. Pkt. 10 cts., 1/2, oz, 20 cts., oz. 35 ets.

27f DARK Crimson. (Dunnett's.) Pkt. 10 ets., $1 / 2$ oz. 20 ets., oz. 35 ets.

278 CMPRESS. Large trusses; pure white. likt. 10 cts., $1 / \%$ oz. 20 cts. $1 / 10 z, 35$ cts.

2z9 GIANT IIYACINTH-FLOWERED. Heaos of immense size, resemhling the Hyacinth. White. Generally considered superior to Empress. Pkt. 10 ets., 1/8 0z. 20 cts., 1/4 oz. 35 cts., oz. $\$ 1.00$.

280 MIXED COLORS. IPkt. 10 ets., 1/2 ox., 20 ets., oz. 60 cts.

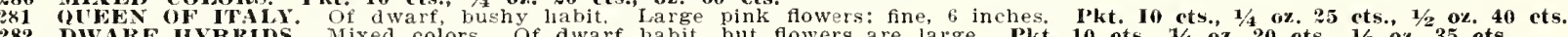

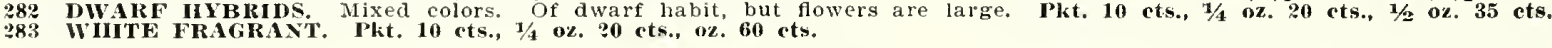

\section{Canna}

The Crozy Cannas are wcll known for their dwarf growth and luxuriant foliage. The flowers are large and of most brilliant colors. Soak the seeds in warm water until they show signs of swelling. then sow in sandy loam and place in hotbed.

284 CRozY's DWARF. Large flowering varieties. Mixed. 3 to 4 feet. Pkt. 10 cts., 1/1 0z. 20 cts.

285 TALL, DARK-LEAVED VARIETIES. Mixed. Pkt. 10 ets., 1/1 oz. 20 ets.

CARIINAL CIIMBER. Sce Ipomoea, number 549.

CARDINAL FLOWLR. See Lobelia, number 588 .

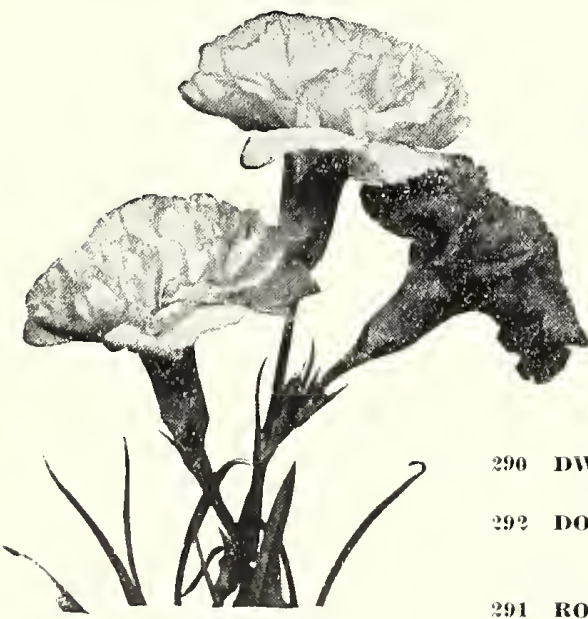

Carnation

Well-known and very popular half-hardy perennial, which until the introduction of the Marguerite class was mainly grown by the florist in the greenhouses and occasionally by the amateur in pots in the house. The Marguerite class, including the original and later introductions of similar type, are treated as annuals, blooming in about four months from seed, which may be sown in the open ground early in the spring, usually by May 1, but preferably earlier in the house, and plants set in the open about the middle of May, as thls greatly lengthens the period of blooming. By cutting off the flower-stems early in the fall and potting the plants, they will bloon freely through the winter if kept in a cool room. The Carnation requires a rich soll, and in such, the plants should stand about 12 inches apart.

286 MARGULRITE MIPROVED SEMI-DWARF. An improved strain, blooming four months after sowing. Flowers are,larger, a greater proportion double and the iarirty of colors much gleater than those of the original. Pkt. 10 ets., 1/s oz. 30 ets.

98 MARGUERITE GIANTS. Flower approaches in form, size, fragrance and beauty those grown by the florist. Great varlety of color. Blooms four months after sowing. Pkt. 10 cts., $1 / 1 / 0.40$ cts.

288 CHAUBAUD'S GIANT PERPETUAL. A new strain, remarkable for its combination of earliness with the continuity of bloom and perfection of flowers large, a high percentage double. Deliciously fragrant and greatly varied in coloring. Pkt. 15 cts.

WWAF VIENNA. Blooms early the second summer from seed. The hardiest sort, sai: to stand the winter with slight protection. Flowers large, double, fragrant and of varied colors. Plk. 10 cts. $1 / \%$ oz. 25 cts. from sowing. Most desirable for house culture. Pkt, io ets.

\section{Cineraria-(Hybrida Grandiflora)}

391 ROSS' PRIZE MIXTCRE. The plants are of compact growth, carrying extra large flower heads with flowerets of unusual size and substance. This strain includes the brightest and richest self colors as well as a good mixture of all colors. Pkt. 25 cts. 


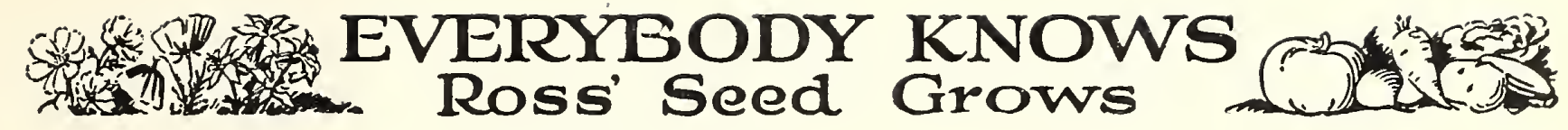

\section{Castor Bean (Ricinus)}

Well-known tender annual; tall, stately, majestic plants ef very rapid growth, with palmlike leaves of glossy green, brown or bronze hue; very effective for lawns, planted singly or in groups,

62 to 15 feet. 295 Bormonsis. Large, showy foliage of purplish hue. 15 feet. Pkt. 10 cts., 1/2 oz. 20 296 CAMBOD. 35 cts., $1 / 4$ lb. $\$ 1.00$.

296 CAMBODGENSIS. Staks and stems nearly black; leaves large, of a deep bronze maroon. 297 SANGUINEUS. (Tricolor.) Stalks blood-red, foliage, reddish bronze, with scarlet seedpods. 6 feet. Pkt. 10 cts., $1 / 2$ oz. 20 cts., 0z. 35 cts.

298 zanzIBAREzisis. A comparatively new class, with gigantic leaves, ranging in color from light green to deep bronze. 10 to 15 feet. Ilixed varieties. Pkt. 10 cts., 1/2 oz. 20 cts., oz. 35 cts.

299 GIBSONI. Large dark-red leaves. 5 feet. Pkt. 10 cts., 1/2 0z. 20 cts., 0z. 35 cts.

300 All Varieties Mixeâ. Frt. $10 \mathrm{cts}$., $1 / 2$ oz. $15 \mathrm{cts.,} 02.25 \mathrm{cts}$.

Cockscomb (Celosia cristata)

Popular free-blooming, half-hardy annual bearing flowers of comb-like form, the recently improved sirains producing under best cultivation heads of enormous size. Grown either by itself or combined with other plants, the Cockscomb makes a striking and effective display. While seeds may be, and more generally are, sown in the open ground, for best results it should be sown early in the house, and the young plants transplanted into small pots, in which they should remain until they show signs of blooming, when they should be shifted to a permanent location. The Cockscomb requires good, rich soil, ample room and plenty of moisture to fully develop its flowers.

305 GIASGOW PRIZs. Crimson; dark foliage. 9 inches. Pkt. 10 cts., 1/8 306 Oz. 30 cts.

310 DWARF, EXTRA-CHoICE MIXrD. Ineludes all the latest introductions and colors of the Cockscomb. Pkt. 10 cts., 1/8 oz. 50 cts.

Feathered Celosia (Celosia plumosa)

Often used for winter bouquets, and for this purpose should be cut before fully ripe and dried in the house. This class requires the same treatment as the preceding half-hardy annual. 1 to $1 \frac{1}{2}$ feet.

311 THOMPSON SUPERB Graceful, feathery plumes of rich crimson, which contrast beautifully with the purplish bronze foliage. Prt. 10 cts., 1/8 oz. 20 cts., $1 / 4$ oz. 35 cts.

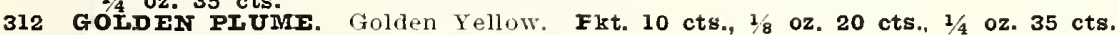

313 THONPSONIA MAGNIrICA. A splendid strain, large plumes, ranging from 313 THOMPSONIA MAGNIFICA. A splendid strain, large

316 CHOICE MIXED. Plt. $10 \mathrm{cts} ., 1 / 4 \mathrm{oz} .20 \mathrm{cts.}$. oz. $50 \mathrm{cts}$.

\section{Centaurea}

To this family belongs the well-known annuals, Bachelor's Button and sweet Sultan, and also the plants known as Dusty Millers.

CYANUS. (Bachelor's Button, or Cornflower.) Popular hardy annual of the easiest culture, blooming quickly after seed is sown and for a considerable time if flowers are kept well cut. 2 feet.

317 DOUBIE BIUE. A selection of the old-fashioned Bachelor Button, producing a large percentage of beautiful double blue flowers. Fkt. $10 \mathrm{cts} .1 / 8$ oz. 35 cts.

318 SINGIE and DOUBIE MIXED. Pkt. $10 \mathrm{cts}, 1 / 4 \mathrm{Oz} .20 \mathrm{cts}$., $02.60 \mathrm{cts}$.

'319 SINGIE WHITE. 320 SINGIE IIIAC. Each, pkt. 19 cts., $1 / 8$ oz. 20 cts.

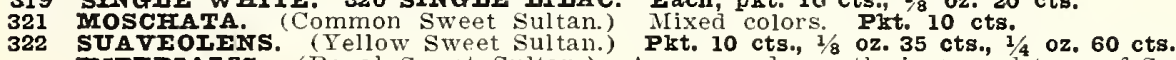

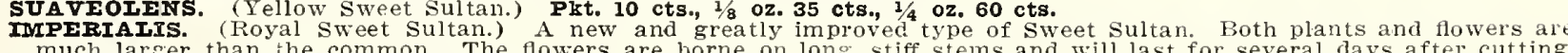
much larger than the common. The flowers are borne on long, stiff stems and will last for several days after cutting. They are very fragrant and colors delicate and bea utiful.

323 BIUT. 324 WHITE. Each, pkt. 10 cts., 1/8 oz. 30 cts.

325 MXED COLORS. Pkt. 10 cts., $1 / 8$ oz. 25 cts.

WHITE-ITAVED CENTAUREAS. (Dusty Miller.) Half-hardy perennials which ale grown annually from their seed for their follage only. Used with other foliage and flowering bedding plants.

326 CANDIDISSIMA. Deeply cut, silvery white foliage, densely covered with white hairs. 1 foot. Pkt. 10 cts.

327 GYMNOCARPA. Silvery-white foliage; of graceful drooping habit. $11 / 2$ feet. Pkt. 10 cts.

328 MONTANA BIUz. (Perennial Corn Flower.) Large violet-blue flowers. 2 feet. Pkt. 10 cts., 1; oz. 30 cts.

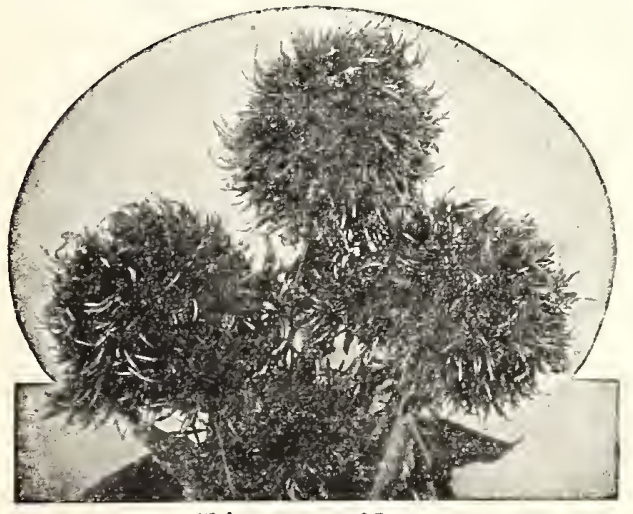

Chinese woolflower

\section{Chinese Woolflower}

CEIOSIA CHILDSI. Its ease of culture and long continued blooming season (July until frost) together with its massive bunches of wool-like flowers and glowing colors combine to make it the most odd as well as the showiest novelty for the general flower garden. Plants grow about three feet high. Seed may be sown in open, after danger from frost, or sown in pots; may be transplanted when ground is ready.

329 Crimson, 329A Dark Pink, 329B Yellow, 329C IIixed Colors. Each, pkt. 20 cts., 3 pists. 50 cts.

\section{Chrysanthemum-(Annual Varieties)}

Free-flowering plants of branching habit, with rich, finely cut and very ornamental dark green foliage, bearing on long stems daisy-like flowers of bright and varied colorings. These colorings on the single varieties are usually in distinct rings and look, on the flat petals, as though they were painted on. Both grow freely from seed, are of easy culture, very desirable for cutting and are effective bedding plants. They should be given plenty of room-from 2 to $2 \frac{1 / 2}{2}$ feet, and will bloom more freely on soil of medium fertility. Hardy annual. 1 to $1 \frac{1 / 2}{\text { feet. }}$

330-SINGIE. (Painted Daisies.) Mixed colors. Pkt. $10 \mathrm{cts.,} \mathrm{1/4} \mathrm{oz.} 20$ cts. 331-EVINING STAR. Covered with bright golden yellow single flowers. 333 Pkt. $10 \mathrm{cts}, 1 / 8$ oz. $20 \mathrm{cts}$.

333 Dousis. (Marguerites.) Pkt. $10 \mathrm{cts.,} \mathrm{1/8} \mathrm{0z.} 20 \mathrm{cts.}$ 


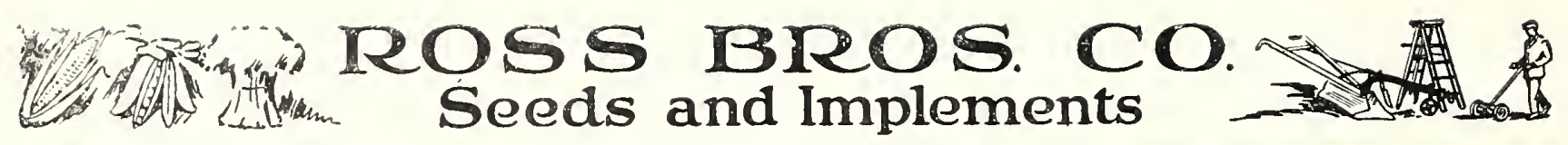

\section{Clarkia}

A pretty, hardy annual from California, much improved in recent years. Blooms profusely in either sun $0^{\circ}$ partial shade. Colors: Rose, salmon-pink, purple and white, in mixture. 1 foot.

338 Single and Double Mixed. Plt. $10 \mathrm{cts.}, 1 / 4 \mathrm{oz}, 30 \mathrm{cts}$.

\section{Clematis}

340 PANICULATA. One of the finest hardy perennial climbers. Of robust habit, and covered from the ground to the summit with pure white fragrant flowers. The flowers are followed by pretty seed pods of

341 Large-Flowering, Mixed. (Jackman's.) Flowers 3 to 4 inches across, of charming shad
feet. Firt. 10 cts.

\section{Cleome "Giant Spider Plant"}

343 GIGANTEA ROSEA. A showy garden annual producing curious heads of flowers of bright rose color with long antennae-like stamens; of easy cultivation, blooming early until late. 4 to 5 feet. Pkt. 10 cts.

\section{Cobaea} 345 SCANDENS. (Climbing Cobaea.) (Cathedral Bells.) A beautiful, from seed bearing large bell-shaped flowers; at tirst green, but changing to a beautiful deep violet-blue. A clean porch climber, free from insects. Sow early in the house and pot the plants, as this greatly lengthens the period of bloom, and the plants will make a much greater growth. Seed germinates more readily if pushed into the ground edgewise and barely covered. 20 to 30 feet. Prt 10 cts. $1 / 4$ oz. $30 \mathrm{cts}$.

\section{Coix Lachryma-(Job's Tears)}

347 An ornamental grass g."owing from 7 to 9 feet high. Large broad leaves bearing large shiny seed. Prt. 10 cts., $1 / 2$ 0z. 25 cts., oz. 35 cts.

\section{Coleus}

Popular ornamental foliage plants, usually propagated by cuttings, but easily grown from seed, from which many new varieties may be expected, affording an interesting experiment to the amateur. Sow in heat in March or April and transplant to open ground about the first of June. For borders of geranium or canna beds and in carpet-bedding very useful. Grows rapidly. 350 Choice Hybrids, Mixed. From a large collection; of greatly diverse shades and markings. Pkt. 10 cts.

351 New Large-Leaved Varieties, Mixed. Saved from new varieties with very large and richly variegated foliage. Plt 25 cts.

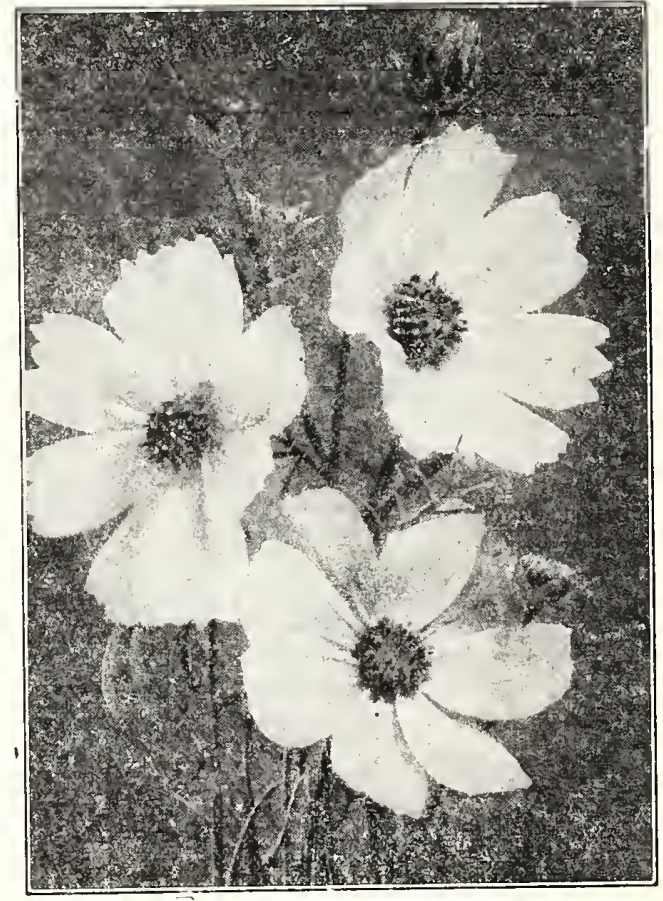

Early Flowering Cosmos

\section{Collinsia}

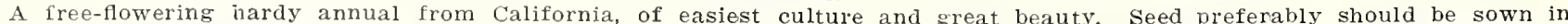

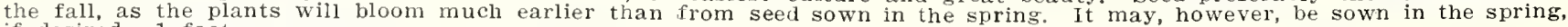

if desired. 1 foot. Pixed Colors. Pkt. 10 cts.

COJUMBINE. See Aquilegia.

\section{Convulvus Minor-(Dwarf Morning-Glory)}

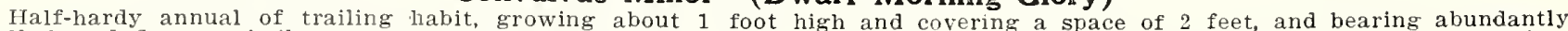

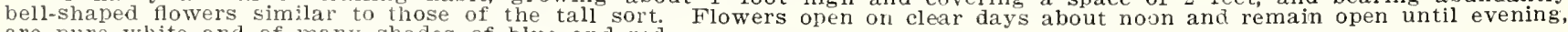
are pure white and of many shades of blue and red.

356 Mixed Colors. Pkt. 10 cts., $1 / 2$ oz. 20 cts., oz. 35 cts.

\section{Burbank's Rainbow Corn}

357 The stalks, including tassel grow five and a half feet tall and are clothed with many various variegated leaves three inches wide and two feet long. The leaves (both on main stalks and suckers) are all superbly striped with broad bands of crimson, yellow, rose, white and bronze. The small hardy seed can be planted early, and as it does not ripen until very late the plants present their rich tropical beauty for a long season. Plrt. 10 cts., 1/4 oz. 30 cts.

\section{Coreopsis}

For Anrual Varieties, seo Calliopsis.

358 IANCEOLATA GRANDIrLORA. A beautiful, hardy perennial, blooming profusely the first season until frost from

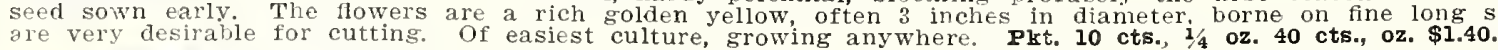

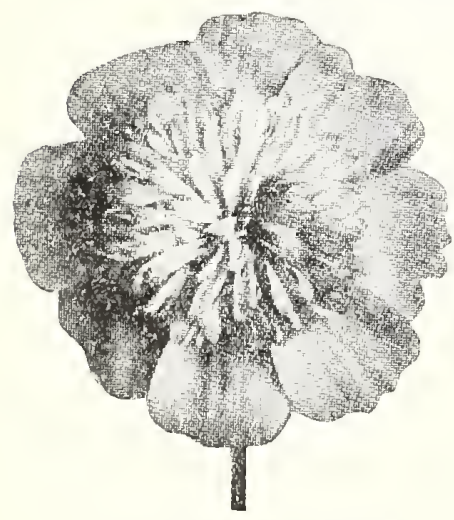

Double Crested Cosmos

\section{Cosmos}

Beautiful autumn-blooming plants. They produce thousands of artistic flowers in pure white, pink and crimson shades, furnishing an abundance of cut blooms for autumn decorations when other flowers are scarce. Should be sown in spring in the open ground, when danger of frost is past, or the seed may be started under cover and afterwards transplanted. Plant not less than 18 inches apart in rows or in masses in beds. When the plants are about a foot high the tops should be pinched out to induce a bushy growth. They prefer a rather light not too rich soil, but do well almost anywhere.

359 KLONDIKE. Large orange colored flowers. Pkt. $10 \mathrm{cts}, 1 / 8$ oz. 20 cts.

360 MCAMMOTH PERTECTION. Mixed colors. Flowers of mammoth size, rather late in flowering; seed should therefore be sown as early as possible in the house in spot in

362 IARGE FARIX FIOWFING. In the New Large Early Flowering we have a strain which combines the desired features of good size and early production. The flowers are fully twice as large as the Early-Flowering, while the plant blooms as early. Crimson, Rose and White Mixed. Pkt. 10 cts., 1/4 oz. 30 cts., $1 / 2$ oz. 55 cts., oz. $\$ 1.00$.

362A Crimson, 362B Plnk. 362C White. Each, pkt. 10 cts.

IADY IFNOX. Long stemmed flowers, often measuring 5 inches across. Unsurpassed for garden decoration and cut flowers. 6 to 7 feet.

364 Pink. 364A White. Fach, pkt. 15 cts., $1 / 8$ oz. 30 cts., $1 / 4$ oz. 50 cts., 1/2 0z. 75 cts., oz. $\$ 1.25$. 


\section{EVERYBODY KNOWS Ross' Seed Grows}

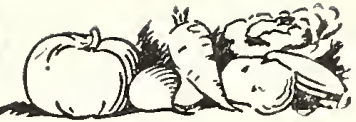

\section{Double Crested Cosmos}

These hybrids form bushy plants 5 to 6 feet high and flower profusely during the autumn months. Only 40 to 50 per cent of the plants will bear double flowers, the balance producing large single blossoms, the reason being that the double flowers and pistillate-having no stamina and consequently bear no pollen-so to produce seed must depend on staminate singles of pollination. The progeny thereof comes about half doubles and half singles. Double cosmos flowers aside from their novelty. and beauty are of lasting substance, both on the plants and as cut flovers. and CRIMSON KiNG. Dark crimson.

365 CRIMSON KING. Dark crim
365A PINK BEAUTY. Soft pink.

365A PINK BEAUTY, Soft pink.

365C WIITE QUEEN. Pure white. 1/8 oz. 35 ets., $1 / 4$ oz. 60 ets., $1 / 2$ oz. $\$ 1.00,0 z . \$ 1.75$.

\section{Ross' Giant Cyclamen}

Charming house plants, with beautiful foliage and rich colored, fragrant flowers. Universal favorites for winter and sping blooming. May be successfully raised from seed with a little care and patience. 369 Giant Mixed. Pkt. 50 ets.

\section{Cypress Vine}

A popular climbing vine, with delicate fern-like foliage, bearing in abundance small, star-shaped. rose, scarlet, or white flowers. of easy culture. Half-hardy annual. 10 to 12 feet 370 Mixed Colors. Pkt. 10 ets., $1 / 4$ oz, 20 ets., oz. 60 ets.

\section{Dahlia}

The growing of the double varieties from seed is always more or less of an experiment, but fine flowers of the single type can, be easily secured from seed the first season. If seed of the double sorts is sown in March and the young plants set in the open ground as soon. as danger of frost is past, some of the plants, perhaps half, will bloom the first season. The past, some of the plants, perhaps half, will bloom the first season. The single varleties, however, wil all bloom the frst season from the seed sown in the open ground. as late as the first week in the An tubers formed planting is, however, preferable. Tender perennial.

each season should be stored in a frost-proof cellar. 35 cts., oz. 75 cts.

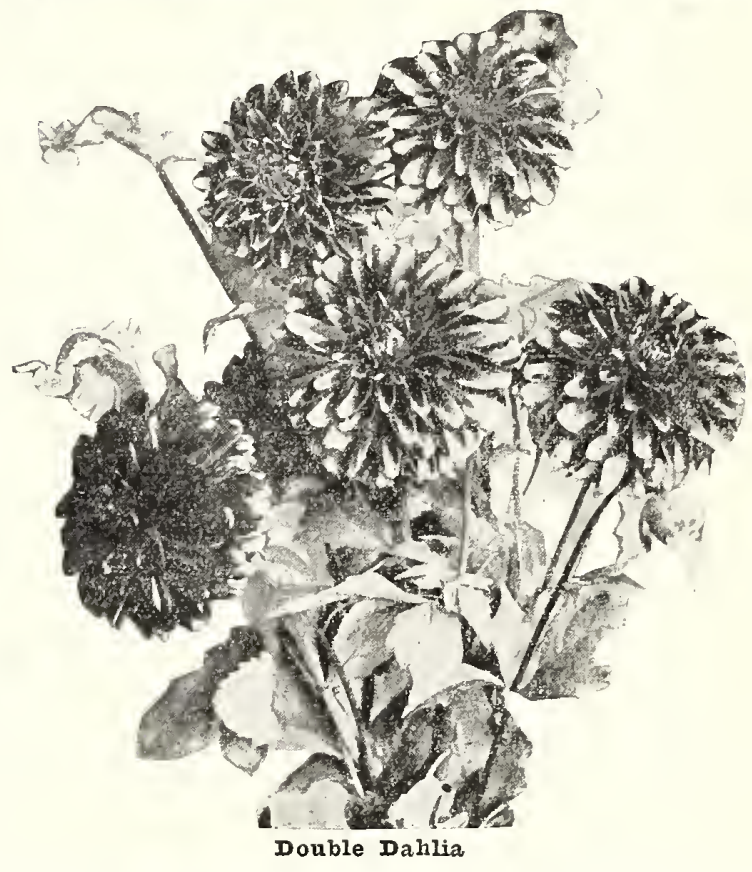

from noted English and Holland grower's, and includes diversity of color. Pkt. 15 ets., $1 / 402.30$ ets., $1 / 402.50$ ets.

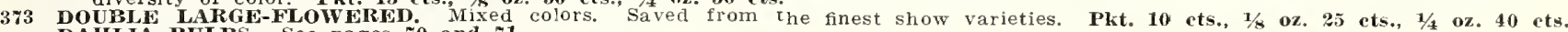

DAILIA BULBS. See pages 70 and 71 .

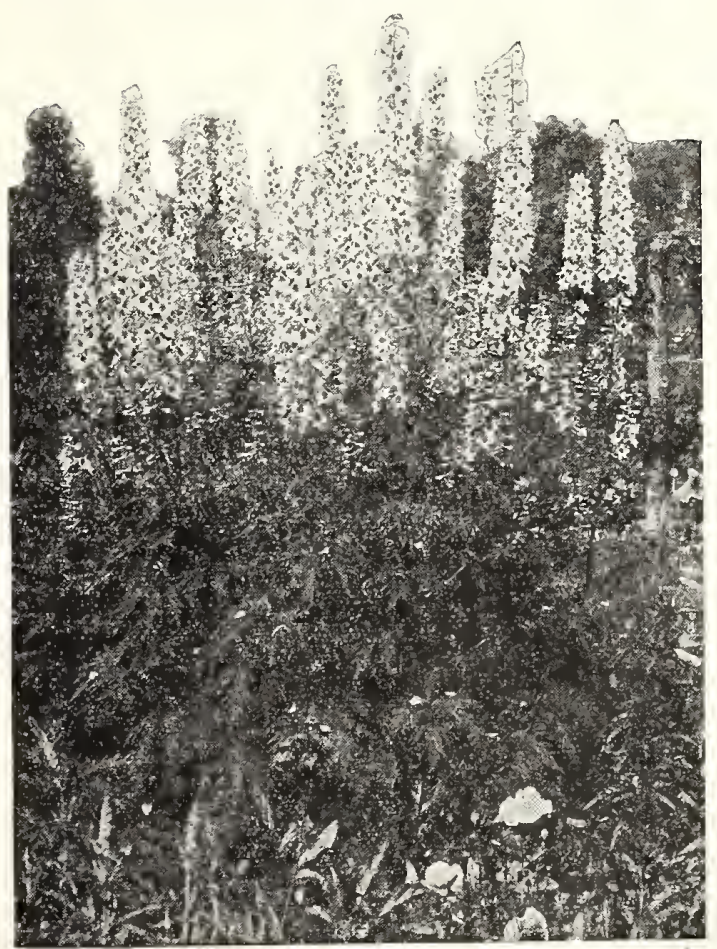

Delphinium
Daisy

It has always seemed to us unfortunate that the English Daisy (Bellis perennis) should have been given its common name as we are quite sure that nearly every one instinctively associates with the term "daisy" or daisy. We therefore, list under this head the famous shasta Daisy and Michaelmas Daisies and call attention to other flowers often known a Dut listed elsewhere

376 AFRICAN GOLDEN. (Dimorphotheca An annual plant is a valuable addition to the list of hardy annuals. When annual plant is a valuable addition to the list of hardy annuals. When Iondon, has heen tural papers of this tural papers of this country and Europe, and all who have seen the plant in bloom praise it. A bed of these plants is remarkably effective, and the fowers are excellent for cutting, while the plant is of beauty of flower, profusion and length of bloom and ease of cul ture should commend this plant to all who cultivatellowers and will. we are sure, make it a general favorite when once its merit is known. Pkt. 10 ets., $1 / 16$ oz. 25 ets.

SIASTA DAISY. An extremely hardy perennial, thriving in all soils, blooming more freely each. season and when once established, fo several months. Easily grown from seed and can be also increased by division of the root. The flowers are from 3 to 4 inches across. borne on very long, stiff, wiry stems, and remain in good condition fo many days after being cut.

3 is ALASKA. Pure glistening white. Plit. 15 cts., $1 / 16$ oz. 40 cts., $1 / 8$ oz.

379 SELEC'TED HYBRIDS. A mixture of seeds saved from the best seedlings, including some with double rows of petals. Pkt. 15 ets.

MICHAEIMAS DAISUES. (Perennial Single Asters.) Beautiful an showy, hardy perennials easily grown from seed, blooming profusely showy, hardy perennials easily grown from seed, blooming profu

381 IIXED CoIORS. Ple io ets.

For other flowers known as Daisies, see Anthemis, Brachycome and Chrysanthomums.

\section{Datura}

DATURA. (Trumpet Flower.) Strong growing ornamental annual shrubs. Flowers trumpet shape, large and fragrant.

\section{Delphinium-(Larkspur)}

Showy, hardy annuals and perennials, thriving in nearly all soils if well enriched and open to the sun. Seed of the annual sorts, though more gen erally sown in the spring, should preferably be sown in autumn, as plants commence blooming much earlier. Seed of the perennial kinds may be sow in the open ground from April to October, or inside in March, and if plant are kept growing well until June, and then set in the open border some will bloom well in the autumn months. (See next page.) 


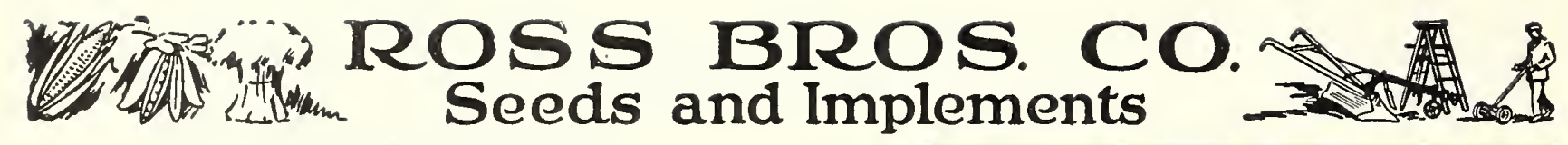

\section{Annual Delphiniums}

385 DOUBIE DWARF ROCKET. 1 foct. Mixed colols. Pkt. 10 cts.

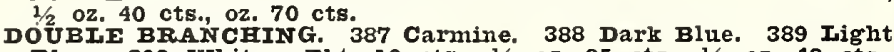
Blue. 390 white. Plrt. 10 cts., $1 / 8$ oz. 25 cts., $1 / 4$ oz. 40 cts., $1 / 2$ oz. $70 \mathrm{cts}$.

391 DOUUBE IMPERTAI BRANCRING. Mixed colors. A superior strain. 2 feet. Plit. 10 cts., $1 / 8$ oz. 25 cts., $1 / 4$ oz. 40 cts.

\section{Perennial Delphiniums}

393 ELATUM. (Bee Larkspur.) Flowers have curiously folded, hairy petals in the center, which give them a fancied resemblance to a bee. Rich shades
$10 \mathrm{cts} .1 / 8$ oz. $30 \mathrm{cts}$.

394 Formosum. The la:ge flowers are deep, rich blue, with white

394 FoRmosum. The the pkt. 10 cts., 1/8 oz. 30 cts.

395 STBIRICUM HYBRIDUM. Shades of blue. If sown early, will bloom in August. 2 feet. Pkt. 10 cts., $1 / 8$ oz. 25 cts.

\section{Dianthus, Pinks}

Hardy biennials, blooming the first year from seed. So easily grown rrom seed as to be rarely treated as biennials. Seed may be sown in the open ground any time in May. Plants 6 inches apart. Height 1 foot.

398 Double CHINA. (D. Chinesia fl. pl.) small, double flowers, borne in large clusters of many colors, mostly with white edge. Pkt. 10 cts., $1 / 4$ oz. 20 cts.

399 HFD DEWIG'S DouBIE. (D Hedidewigi fl pl) Japan Pinks. Very large, double flower's of a wide range of color, running from white and light pink through shades of red to rich, velvety crimson and deep maroon almost black. Pist. 10 cts., $1 / 4$ oz. 25 cts.

400 SINGLE MIXED. Large single flowers, of rich and varied colorings. Pkt. $10 \mathrm{cts.}, 1 / 4$ oz. $20 \mathrm{cts}$.

406 DOUBIE PRINGED JAPAN. (D. laciniatus fl. pl.) Large, double fringed flowers of rich and varied colorings. Pkt. 10 cts., $1 / 4$ oz. 25 cts.

407 FIREBAII. Of dwarf habit. Flowers globular, double, dark, blood red. Pkt. 10 cts., $1 / 8$ oz. 25 cts.

408 sNowbasi. Very double, pure white. Excellent. Pkt. 10 cts. 415 WORCESTER MIXED. All the above and other choice strains. Unsurpassed, Pkt. 10 cts., $1 / 4$ oz. 30 cts., oz. $\$ 1.00$.

Hardy Perennial Varieties Clove or Grass Pinks;

Improved forms of the old well-known Clove Pink. They grow anywhere and bloom very profusely. Flowers of many pleasing colors and deliciously fragrant. Very useful for the hardy border.

416 SINGLE. (Pheasant's Eye, Pink.) Mixed colors. Pkt. $10 \mathrm{cts.}, 1 / 8$ oz. 20 cts.

417 DOUBIE AND SEMI-DOUBIE. Mixed colors. Prt. 10 cts. $1 / 8$ oz. 25 cts.

418 FIORIST'S PERPE'TUAI PINK. (D. semper-florens.) Double and semi-double; large flowers; very fragrant and of a great diversity of colors.
Pkt. 15 cts., $1 / 8$ oz. 35 cts.

\section{Didicus}

420 Cokeureus. (Blue Lace Flower.) An attractive annual, blooming from July until frost. The flowers are pale to lavender and are valuable for cutting. Pkt. 10 cts., $1 / 8$ cz. 25 cts.

\section{Digitalis-(Foxglove)}

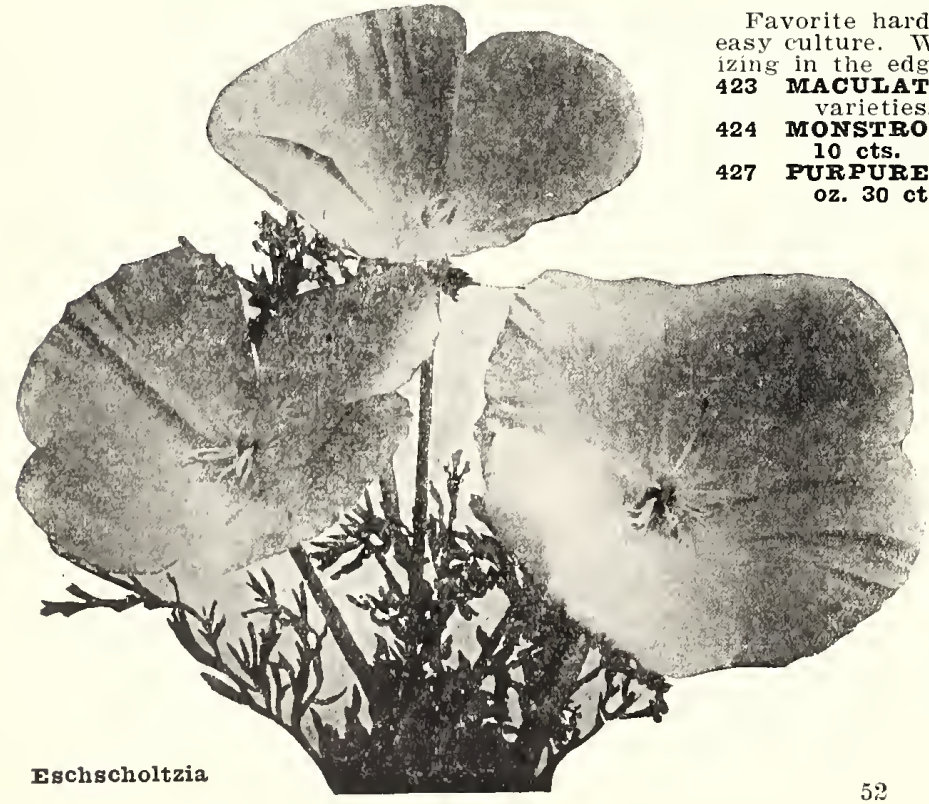
$10 \mathrm{cts}$. oz. 30 cts.

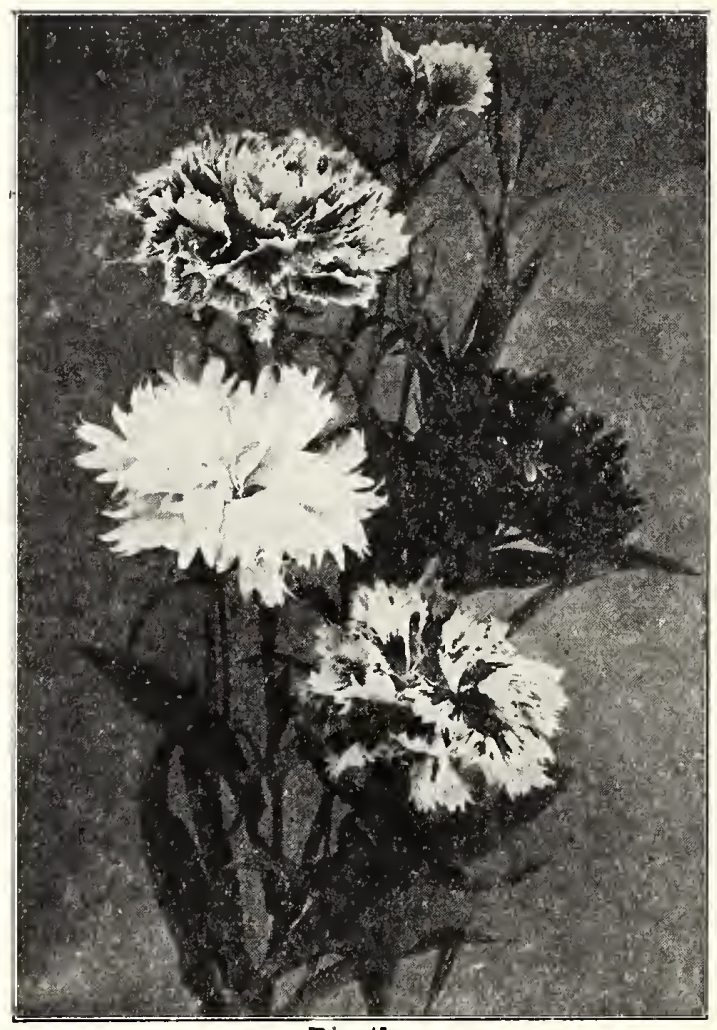

Dianthus

plant bearing in June and July tall flower spikes. Of Well suited for background to other plants, and for naturalizing in the edges of woods. Hardy biennial or perennial. $21 / 2$ to 3 feet.

ONSTROSA. Mixed colors. Monstrous flowers. Attractive. Pkt.

428 PURPUREa. Rose. Plt. 10 cts. Dolichos-(Hyacinth Bean) summer clusters of white or purplish blue flowers, followed by ornamental seed-pods. Sow in May where plants are to remain. 10 feet.

433 Mixed Colors. White and purple. Fkt. 10 cts. $1 / 4$ oz. 20 cts.

\section{Dracaena-(Dragon Plant)}

434 INDIVISA Beautiful ornamental-leaved plants long narrow, green foliage; indispensable for vases and house decoration. Plt. 10 cts., 1/8 oz. 40 cts.

Eschscholtzia-(California Poppy)

A very showy hardy annual, with beautiful, finely cut, glaucous foliage, bearing poppy-like flowers of bright colors. Of easy culture. Sow as early as soil can be worked, where plants are to remain, as they do not bear transplanting well. 1 foot.

439 CAIIFORNIA. Yellow. Pkt. $10 \mathrm{cts}$.

442 MIXed COIORS. Pkt. 10 cts., $1 / 2$ oz. 20 cts.,

443 ERECTA COMPACTA. ROSE QUEEN. Rose carmine. Pist. 10 cts. 


\section{EVERYBODY Ros' Seed \\ Euphorbia}

Ornamental foliage plant; easily grown from seed. Striking and effective appearance Hardy annual.

452 VARIDGATA. (Snow-on-the-Mountain.) Foliage-veined and margined with white. 2 feet. Prt. 10 cts., $1 / 8$ oz. 25 cts.

\section{Forget-Me-Not-(Myosotis)}

Farorite hardy perennials, mostly treated as annuals, nearly all blooming the first season from seed sown early in the open ground. They succeed to a degree that warrants their cultivation in average soil and open situation, but thrive better in cool, moist soil, considerably shaded. 6 inches.

454 AIPESTRIS. (Blue Alpine Forget-Me-Not.) Pkt. 10 cts., 1/8 457 PAIUSTRIS.

AIUSTRIS. (True Forget-Me-Not.) Dark blue; blooms the first season. Pkt. $10 \mathrm{cts.,} 1 / 8 \mathrm{oz}, 40 \mathrm{cts}$.

459 DISTINCTION. (Ever-flowering.) New; blooms in eight to ten weeks from sowing. Pkt. 10 cts., $1 / 8$ oz. 30 cts.

461 VICTORIA. The flowers are large bright azure blue, with yellow centers. The plants form neat bushes completely covered with blooms. Best for edging. Pkt. $10 \mathrm{cts.}$ 1/8 oz. $35 \mathrm{cts}$

Four O'Clock-(Marvel of Peru)

A well-known favorite plant, bearing freely funnel-shaped, white, led and striped flowers, which open about four o'clock in the afternoon. Will grow anywhere. Plants should be given plenty of room, about 2 feet apart. Hardy annual. 2 feet.

465 Mixed Colors. Pkt. 10 cts., $1 / 2$ oz. 20 cts., oz. 35 cts.

\section{FOXGIOVE. See Digitalis. Page 52}

\section{Gaillardia}

\section{ANNUAI VAKIFTIES (Blanket Flower)}

Very showy free-blooming, hardy plants of easy culture seed rerminates very slowly and should be sown in the house in March. The fiowers are very brilliant, borne on long stems. Fine for cutting. 2 feet.

470 PICTA. Single; mixed colors. Pkt. 10 cts., $1 / 4$ oz. 20 cts. 471 PICTA. Double; mixed colors. Pkt. 10 cts., 1/4 oz. 20 cts.

\section{Perennial Gaillardia}

Hardy perennial Gaillardias thrive in nearly all soils and situations, requiring no protection and GNOWS

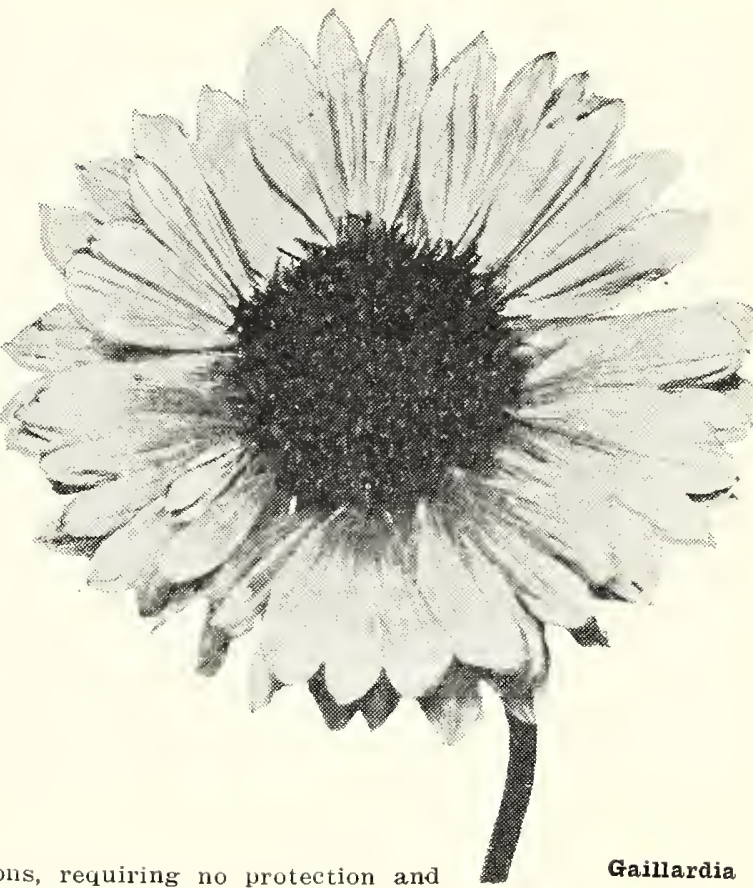
almost no care. Flowers large; with rich shades of scarlet, orange and crimson the three often combined in one flower. Desirable, for the perennial border. season. $11 \%$ to 2 feet.

478 Newest varieties. Mixed. A splendid mixture; com. prises all the colorings known. Pkt. 15 ctso, 1/8 oz. $50 \mathrm{cts}$

\section{Geranium}

Well-known, half-hardy, greenhouse perennials, easily raised from seeds. Seeds sown in the fall or early winter will produce flowers in June, while from that sown in March, plants will not bloom until September, and from seed sown in the open ground in May or June plants will bloom in midwinter.

485 ZONAIE. (Fish or Horseshoe Geranium.) Saved from the largest and finest varieties. Pkt. $10 \mathrm{cts}$.

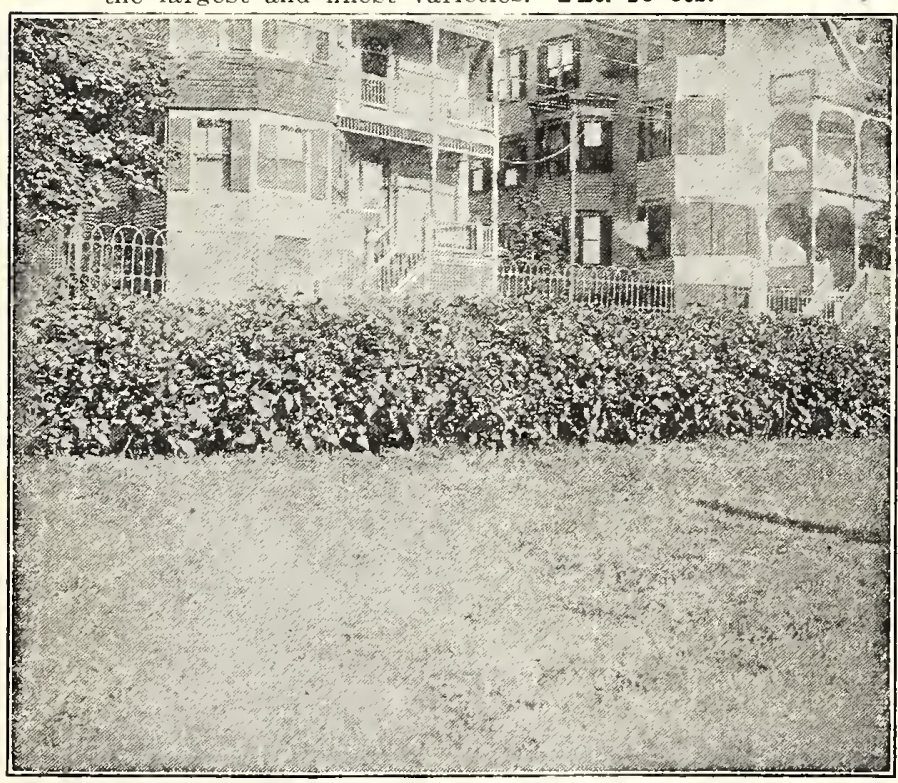

A Fedge of Four O'Clociss
If sown early will bloom in the first

\section{Globe Amaranth-(Gomphrena)}

488 MXED COLORS. A tender annual plant, bearing globeshaped ever-lasting flowers, often used, when dried, in winter bouquets. Blooms freely and is an excellent bedding plant. $11 / 2$ feet. Prt. 10 cts.

\section{Gloxinia}

One of the most beautiful greenhouse pereunials. May be successfully grown by the amateur. Give them a porous and well-enriched soil; a warm, moist atmosphere, and as soon. as they begin to fower remove them to a cooler house, and afterwards dry them off gradually and keep them free from moisture till they again begin to grow. The seeds are small and should be sown on an even surface and slightly covered.

489 SPIENDID MTXTURE. A mixture of ali classes unrivaled in richness of colors. Pkt. 25 cts.

\section{Godetia}

A showy and beautiful hardy annual, bearing fairly large delicately shaded, satiny flowers; of easy culture blooms best in rather poor soll. Seed may be sown in the open ground, or sown in the house in March and transplanted to the open ground as soon as danger from frost is past. The plants require plenty of room. Close planting weakens them.

490 MIXED COLORS. Tall. Includes all varieties and the latest introductions. Plst. $10 \mathrm{cts} ., 1 / 402.20 \mathrm{cts}$.

\section{Gourds}

Ornamental tender annual climbers, with curiously formed and colored fruit: of very rapid growth; useful fol covering unsightly objects. 10 to 20 feet.

491 Apple-shaped. Small, striped. Plrt. io cts.

492 Dipper. The fruit is of slender, neck-like form for two-thirds its length, widening at the apex in the form of a bowl. Sometimes used as a dipper. Pkt. $10 \mathrm{cts}$.

493 DISH-CIOTH. Fruit large and elongated, with a spongy net-work of tough fibre inside, which when dried is used by the Japanese to form the soles of sandals. It is also used like a sponge for bathing. Pkt. 10 cts.

494 Proshaped. Pl. $10 \mathrm{cts}$

496 Miniature Bottle shaped. Pkt, $10 \mathrm{cts}$.

497 Orange-shaped. Pkt. $10 \mathrm{cts}$.

498 Pear-shaped. Green, white-striped. Pkt. 10 cts.

500 Mixed Varieties. Small sorts. Plt. $10 \mathrm{cts}, 1 / 20 \%$ 20 cts. 


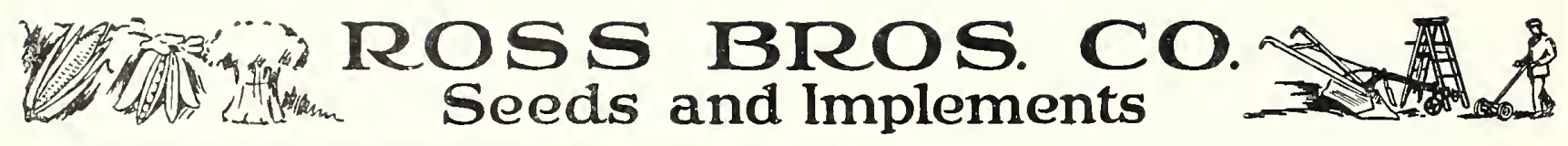

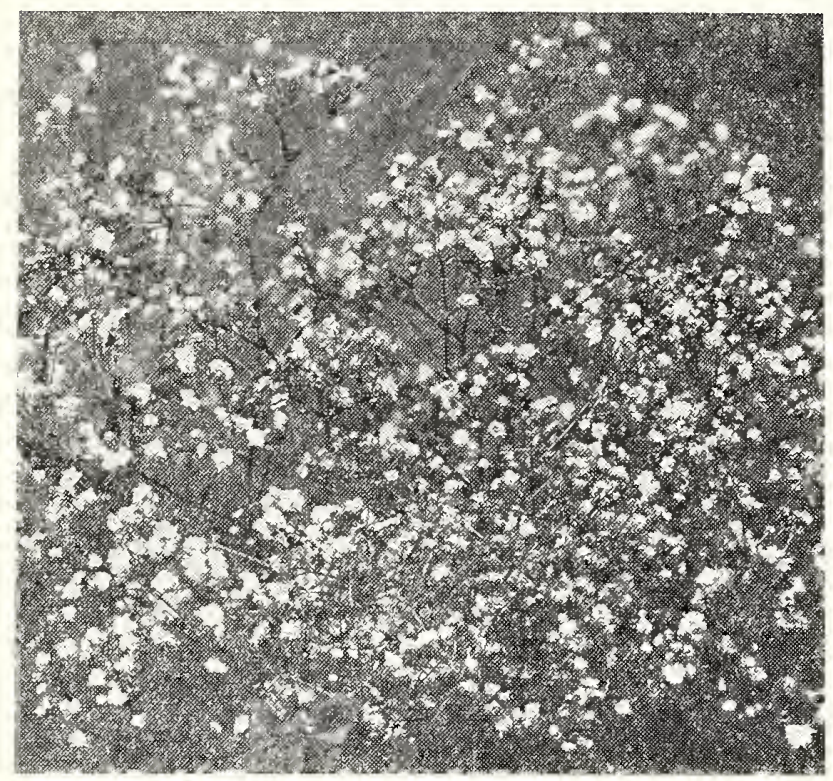

Gypsophila

\section{Gypsophila}

\section{(Baby's Breath)}

Very useful, free-blooming plants of easiest culture. Flowers very small, borne in loose, graceful panicles. Very largely used in bouquets with other cut-flowers, such as Sweet Peas, Roses, Carnations, etc. 2 feet.

504 PANICUIATA FLORE PLENO. A great improvement on the single-flowered type and more lasting, the flowers forming miniature balls of white petals. Not quite fixed, but about 25 per cent come true. The plant is difficult to propagate by division, and seedlings prove much more vigorous. Pkt. 25 cts.

505 ELEGANS GRANDIFIORA AIBA. White. An improved form of the annual Gypsophila. Grown by the acre for the London and Paris flower markets. Blooms quickly after sowing: several sowings should be made Pkt. 10 cts., $1 / 4$ oz. 20 cts., oz. 60 cts., $1 / 4$ lb. $\$ 1.50,1 / 21$ b. $\$ 2.50$.

506 PANICULATA. White. The variety more generally known as Baby's Breath. Hardy perennial. Pkt. 10 cts., 1/8 oz, $20 \mathrm{cts}$.

\section{Grevillea}

507 ROBUSTA. (Silk Oak.) The graceful evergreen fernlike foliage combines admirably with palms and other massive-leaved plants. Excellent for table decorations. Płt. $10 \mathrm{cts} ., 1 / 8$ oz. $40 \mathrm{cts}$.

\section{Helenium}

A very valuable hardy perennial, bearing in profusion August and September, long stemmed single flowers; flne for cutting. Effective as a background.

510 AUTUMNAIE SUPEFBUM. Deep golden yellow. 5 to feet. Plt. 10 cts.

\section{Helichrysum}

(Straw Flower; Everlasting)

One of the best everlasting flowers and an effective bedding plant, succeeding in any well enriched soil. If flowers are desired for winter use, they should be cut just as the buds are opening. Hardy annual. 2 feet.

515 DOUBIE MIXED CoIoRs. (H. monstrosum fl. pl.) Largest double flowers. Pkt. 10 cts., 1/4 oz. 25 cts., 1/2 oz. 40 cts.

\section{Heliopsis}

516 PITCherina. One of the best hardy perennials for dry soils and its graceful flowers among the best for cutting. The plant commences to bloom early in season. The flowers are of a beautiful deep yellow, of great substance, and about 2 inches diameter. 3 feet. Pkt. 10 cts.

\section{Heliotrope}

A well-known and favorite plant, largely grown in pots, but thriving in the open border; usually grown from cuttings, but grows readily from seed, blooming the flrst season if sown early. Half-hardy perennial.

518 Mired Colors. All shades. Plt. 10 cts.

519 Large-flowering. Mixed colors. Heads of flowers nearly double the size of the old sorts. Prt. 10 cts.

\section{Heuchera}

525 SANGUINEA. A fine, hardy perennial, bearing in graceful spikes rich crimson flowers. Useful for cutting, and the plant is useful in the mixed border. 1 foot. Pkt. $10 \mathrm{cts}$.

\section{Hibiscus}

Vigorous-growing plants, producing large, handsome flowers, often six inches across, Very desirable for mixed beds or borders.

526 AFRICANUS. Hardy annual, yellow, 2 feet. Prt. 10 cts., 1/8 oz. 20 cts.

\section{Hollyhock}

One of the oldest hardy favorites, greatly improved in recent years, flowers bein. large and of better form and plant of more sturdy growth While the Hollyhock delights in deep, rich soil, it must be dry and well drained, or plants will not live through the winter. 'Though often sown latel', seeds should be sown not later than June. As young plants bloom better and are hardier, seed should be sown every year. Hollyhocks are most effective planted in long rows. Hardy perennial. 5 to 7 feet.

530 CHATER'S FINEST MIXED. Choicest double varieties, a large percentage of the flowers coming double. Pkt. $10 \mathrm{cts.} 1 / \mathrm{g}$ oz. $35 \mathrm{cts}, 1 / 4 \mathrm{oz} .60 \mathrm{cts}$.

531 Double. Mrixed Colors. Pkt. $10 \mathrm{cts}$., $1 / 8$ oz. $25 \mathrm{cts}$

532 AIIGHExт. Large, semi-double flowers, beautifully fringed, of silky texture and richly colored. Plet. 10 cts., $1 / 8$ oz. 25 cts.

Evere Souble Semi-Double and Single. Mixed. A new strain, blooming the first season from seed. Plants from seed sown inside in March or April will bloom in July and those from seed sown in the open ground in August, and, both cases. continuously until frost if main stem is pinched off when $3^{3}$ or 4 feet high. Pkt. 10 cts.

CFATER'S DOUBLE. 535 Maroon. 535A Pink. 536 snow White. 536A Yellow, Plt, 10 cts., $1 / 8$ oz. 35 ctg.

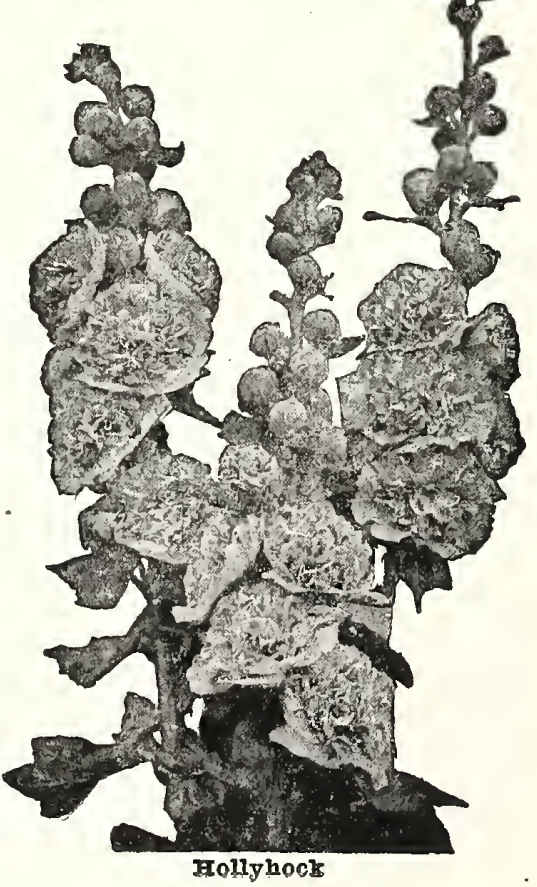




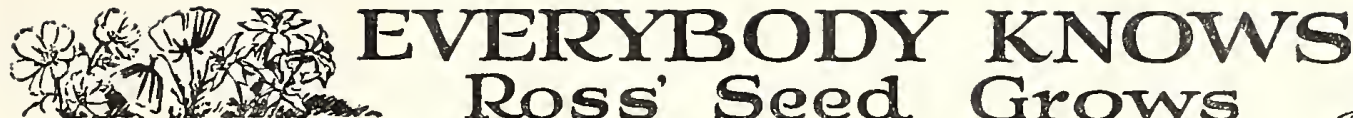

Humulus-(Hop)

Rapid-growing climbers with attractive foliage, especially valuable because seldom injured by insects or drought. The Japanese variety is a hardy annual and among the best for quickly covering unsightly objects. The Lupulus, or Common Hop, is a hardy perennial, easily grown from seed and, when established, of very rapid growth. 10 to 20 feet.

537 TARIFGATA Variegated foliage, green and white. Pkt. 10 cts.

538 IUPUTUS. The Common Hop. Pist. 10 cts.

\section{Hunnemannia}

540 FUMARIAForia. (Giant Tall Poppy, or Bush Eschscholtzia.) A valuable plant of the Poppy family, closely allied to the Eschscholt zia. A perennial, always treated as an annual, blooming by middle of July and from seed sown early in May, and continually until frost. The large flowers are of a deep, rich yellow, borne on very long stems and last a remarkably long time after cutting. 2 feet. Pkt. $10 \mathrm{cts}$., $1 / 8$ oz. 25 cts.

HYACINTH BEAN. See Dolichos.

\section{Iberis}

543 SFMPERVIRFNS, (Perennial Candytuft.) A desirable hardy perennial of easiest culture. Dwarf spreading habit; suitable for rockeries. Flowers pure white. Pist. $10 \mathrm{cts}$., 1/8 oz. 30 cts.

\section{Ice Plant-(Mesembryanthemum)}

546 CRYSTrIITMUM. A trailing plant, with succulent stems and leaves. Excellent for hanging baskets and rockwork. Tender annual. 9 inches Prt. 10 cts.

\section{Ipomoea}

The Ipomoea family includes the well-known Morning Glory the Moonflower and the Cypress Vine. Rapid-growing climbers of easiest culture bloom earlier and more profusely on rather poor soil, but of higher growth and more attractive foliage when grown on rich soil. Tender annuals. 15 to 30 feet.

549 CARDINAI CIIMBER. (Ipomoea Quamoclit Hybrida, Treaves are dark green, fern-like and deeply laciniated; bears a oreat profusion of fiery, cardinal red flowers which are about $11 / 2$ inches in diameter. It delights in a warm, sunny situation and good soil. In order to have good germination of the seed a small notch should be flled or cut in each seed. Pkt. 15 cts., 2 pkts. 25 cts.

550 BONA NOX. (Evening Glory.) Beautiful, large, violetblue flowers which open at night. of extremely rapid growth. Pkt. 10 cts.

552 SETOSA. (Brazilian Morning Glory.) A handsome variety of luxuriant growth, having very large threelobed leaves, the under side of stem being thickly set with small reddish hairs. Flowers are a pleasing rose, about $21 / 8$ inches across, of delicate satiny texture and borne in clusters, hut one or two in each cluster opening at nnce. Pkt. 10 cts.

553 RUBRA COFRUIFA. (Heavenly Blue.) Large, heartshaped leaves: flowers 4 to 5 inches across, borne in clusters and in such profusion as to nearly cover the foliage; bright sky-blue. Pkt. 10 cts.

\section{Jerusalem Cherry-(Solanum)}

An ornamental and interesting genus of fruit-bearing plants; singularly bright in fruit and foliage. Popular for greenhouse or house decoration.

555 SOIANUM CAPSICASTRUM. Covered with scarlet fruit during the winter. One and one-half feet. Pst. $10 \mathrm{cts}$.

\section{Kochia}

556 TRICOPHYTIA. (Sumner Cypress.) A ver'y auickgrowing annual; cultivated for its beautiful foliace, Which is feathery and fine as moss. Through the summer this is bright green, but commences in early fall to gradually take on a red tinge, becoming entirely red before its dies. The brilliant coloring has given it its other two common names of Mexican Fire Plant and Burning Bush. It is often grown in rows as low hedges. Seeds may be sown in the noen ground about May 1. Hardy annual, $2 \frac{1}{2}$ feet. Fkt. 10 cts., $1 / \mathrm{az}$. $20 \mathrm{cts}$.

JoB's TriRs. See Colx Lachryma.

\section{Kudzu Vine-(Peuraria)}

560 THUNBgRGIANA. (Jack-and-the-Beanstalk Vine.) A vine of wonderful rapid zrowth, when well established growing to the great height of 40 to 50 feet. Leaves are of enormous size. One of the best for forming a screen for any purpose. In the North the plant dies to the ground in the winter. but in the South becomes woody. Hardy perennial. Prt. $10 \mathrm{cts} ., 1 / 4$ oz. $25 \mathrm{cts.}$ $1 / 6$ oz. $40 \mathrm{cts}$.

\section{Lantana}

A favorite plant of rapid growth, blnoming continually through the summer; desirable for the garden or house. Tender perennial. 2 feet.

562 nired Colore. Pist. $10 \mathrm{ctat}$.

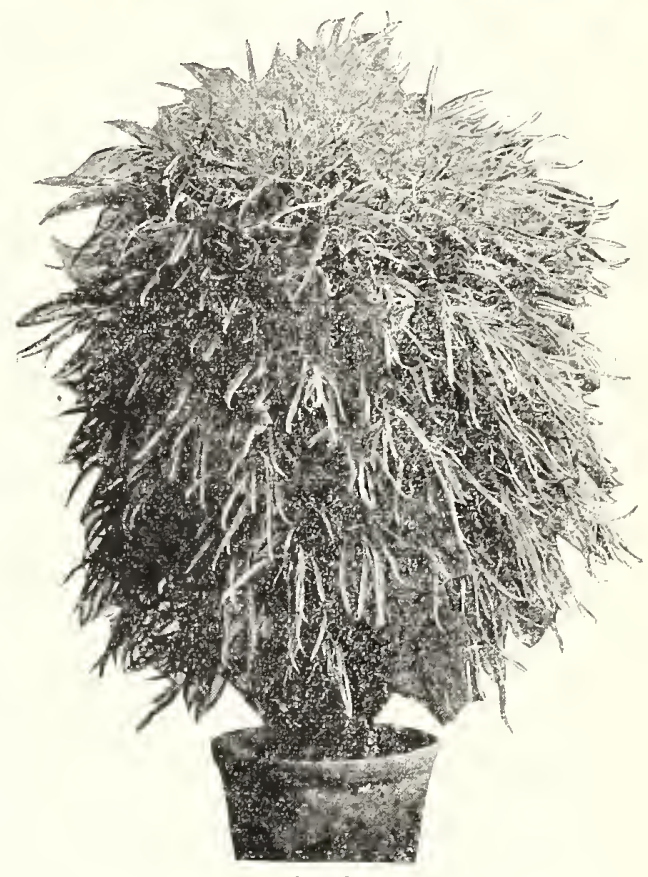

Kochia
Lathyrus Latifolius-(Everlasting Sweet Pea)

An easily grown hardy perennial climber, bearing freely flowers somewhat similar in form to the sweet Pea. If grown on moist soil, will bloom nearly all summer. Colors: Reddish purple. rose and white. 6 to 8 feet.

570 Mixed Colors. Pltt. 10 cts., $1 / 4$ oz. 20 cts., $1 / 2$ oz. $35 \mathrm{cts}$. IARKSPUR. See Delphinium.

\section{Lavender-(Lavendula Vera)}

575

VFRA. A well-known hardy perennial grown chiefly for its lasting fragrance. Pkt. $10 \mathrm{cts.,} 1 / 8$ oz. $20 \mathrm{cts}$.

\section{Lavatera Tremestris}

Beautiful and effective hardy annual, covered during the entire summer with pretty and showy blossoms.

576 Rose Pink. 577 White. Plt. 10 cts., $1 / 4$ oz. 20 cts.

\section{Linum-(Scarlet Flax)}

580 GRANDIFIORUM. (Scarlet Flax.) Hardy annual of slender habit, bearing in profusion brilliant scarletcrimson flowers. An effective bedding plant. 1 foot. Pkt. $10 \mathrm{cts}$.

\section{Lobelia}

Pretty little plants of easy culture, blooming profusely from June until frost. The dwarf varieties are useful for bedding and edging, the trailing variety is excellent for hanging-baskets, vases and rock-work. Half-hardy annuals.

585 CRYSTAI PAIACE COMPACTA. Rich blue flowers, dark foliage. Plit. $10 \mathrm{cts.}, 1 / 4 \mathrm{oz} . \$ 1.00$.

586 WHITE GgM. White Dwarf; very profuse. Pkt. 10 cts. 587 GRACIIIS. Light blue, trailing. Pkt. $10 \mathrm{cts.}$

588 CARDIRAI FIOWRR. (Cardinalis.) Intense scarlet. 3 feet. Pkt. 10 cts.

LOVI-IN-A-NIST. See Nigella. Pags 58

\section{Lupin}

590 Annual Varieties, Mixed. Easily grown plants, with Iong, graceful spikes of pea-shaped flowers of various colors. 2 feet. Pkt. $10 \mathrm{cts}$., $0 \mathrm{z}, 35 \mathrm{cts}$

591 Perennial Varietiss, Mixed. Hardy, plants of easy culture, useful as a background in the perennial border. Mixed blue and white. 2 to 4 feet, Plst. 10 cte., 1/2 02. 30 cts., 0 . 50 cts. 


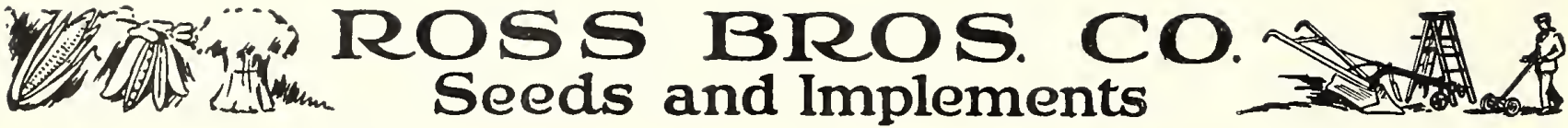

Lychnis

Perennial plants of easy culture, blooming the first season

if sown early.

shaped like Maltese cross. of fine color and thrifty

growth: very effective in the
Pkt. 10 cts. Marigold Favorite annual plant, blooming the entire summer; easily
cultivated. The African varieties bear large yellow or orang
flowers and the plants are usually tall. The French type is
of dwarf habit and flowers are striped. Hardy annual. 1 to

6imo AfricAN ELDORADo. Flowers very large, extremely dou-

600 AFRICAN ELDOR.ADO. Flowers very large, extremely dou-

601 LEMON B.IIL. The largest of all Marigolds, nearly ball-

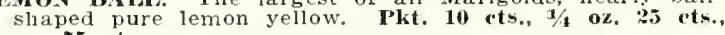

60: orivge 15ixce. Large, rich orange. Pkt. 10 ets.

603 AFRICAN DoUBLE MLED. All shades of the African

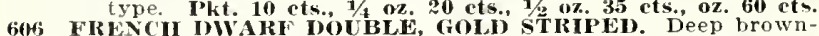

ing red, striped yellow. I'lit. 10 cts., 1/s oz. 20 cets.

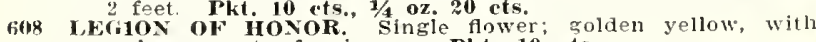

Mathiola Bicornis-(Night Scented Stock)

610 A hardy annual with purplish red flowers, giving forth

delightful fragrance-especla
l'kt. 10 i.ts., 1/4 oz. 20 cts.

\section{Matricaria}

Free-flowering annuals useful for groups, borders or pot

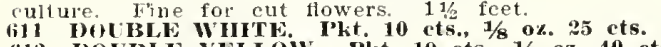

\section{Mignonette (Reseda Odorata)}

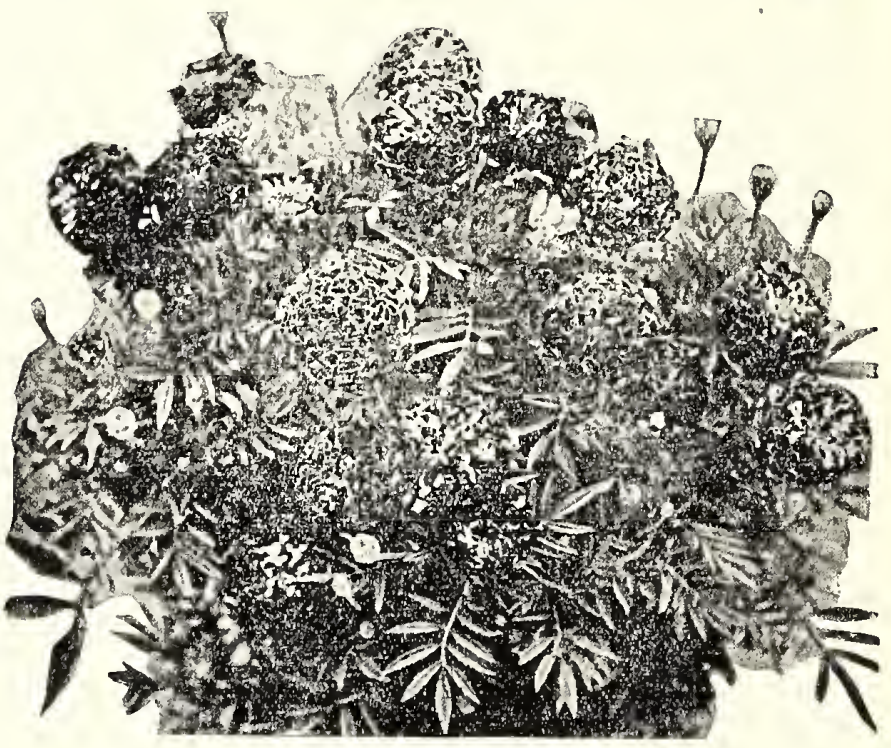

Marigold, Gold Striped

A wllknown and popular hardy anrual prized for its delight ful fragrance and when sown the last of July will come into flower in a few weeks and continue until cut down by frost.

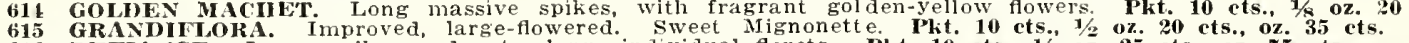

616 DEFIANCE. Large spikes and extra-large individual florets. Pkt. 10 cts., 1/8 oz. 25 cts., oz. 75 cts.

617 GIANT PYRAMIDAL. (Crimson Giant.) of branching growt h: iarge, of reddish cast." Pkt. 10 ets., 1/4 ar. 20 ets., 0\%. 60 ets.

618 GOLDEN QUEEN. Golfen yellow. Pkt. 10 cts., 1/4 oz. 20 ets., oz. 60 cts.

619 MACHET. Large thick spikes of reddish cast, of dwarf habit, dark foliage. One of the best for pots. 1Pkt. 10 (ts., 1/8 oz. 20

690 PARSöN's Winte. Nearly white. Pkt. 10 cts., 1/4 oz. 20 ets., oz. 60 ets

621 VICTORIA. Of deep reddish cast. Pkt. 10 ets., $1 / 4$ oz. 20 ets., oz. 60 ets.

6\%2 GOLATII. Of strong yet compact habit, with rich green foliage, the giant trusses of flowers being borne on erect, strong. stiff stalks and surpassing all others in brilliancy of color; especially suited for house culture. Pkt. 10 cts., 1/8 o\%. 25 cts.

\section{Mimulus}

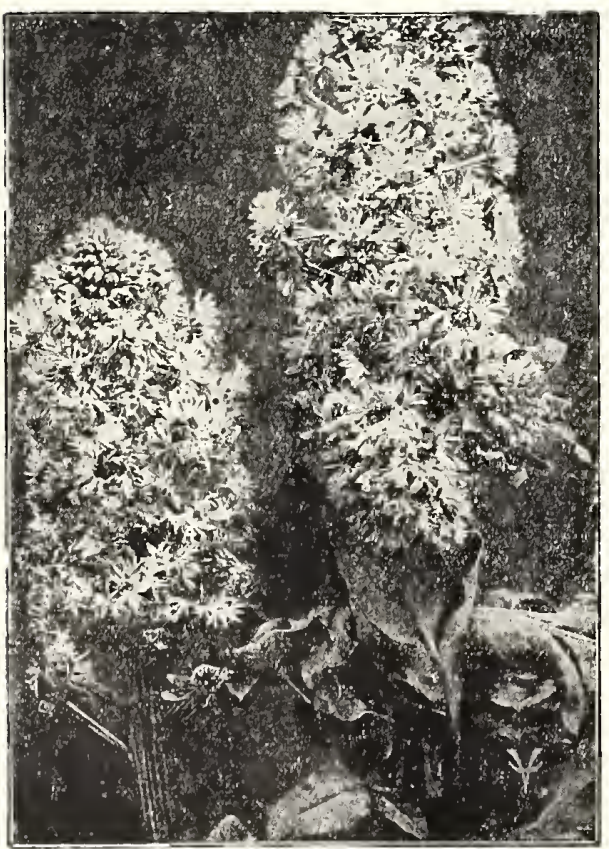

Mignonette Showy, free-flowering plants of easy culture. Half-hardy perennials, blooming the
filst season by July, if started early in the house, and continually until october. Thrives best in moist soil and somewhat shaded location. 1 foot.

631 Moschatus. (Musk Plant.) Small yellow flowers, musk-scented foliage, of Moonflower-(Ipomoea)

635 G HA N D I F L O R A ALB.I.

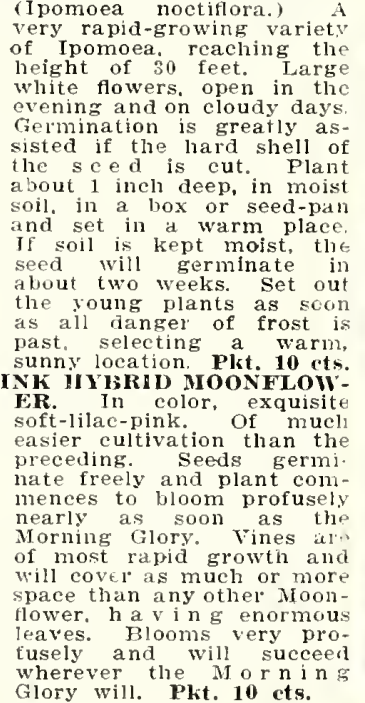

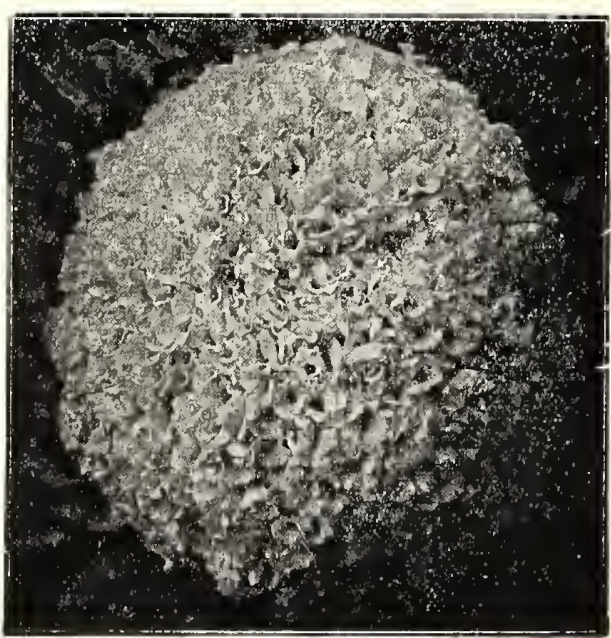

Marigold, Eldorado 


\section{EVERYBODY KNOWS Ross' Seed Grows}

\section{Morning Glory}

(Convolvulus Major)

A well-known vine of easiest culture. Hardy annual. 10 feet.

636 MIXED COLORS. Pkt. $10 \mathrm{cts.,} 1 / 2$ oz. $20 \mathrm{cts.}$ oz. $35 \mathrm{cts}$.

637 JAPANESE GIANT MORNING GIORY. The flowers of this strain are much larger than those of the cominon type, the range of colorings much greater, while the foliage is greatly varied and very attractive. The colors range from deepest purple through all shades of blue and red to pure white, in a great variety of beautiful blendings and markings. The vine is not so hardy nor so vigorous in its growth as the common type. Germination is assisted by soaking the seed in water for twenty-four hours before sowing. Tender annual. \& feet. Pkt. 10 cts., $1 / 2$ 0z. 20 cts., oz. 35 cts.

MOURNING BRIDE. See Scakiosa.

MUSK PIANT. See Mimulus.

MORNING GIORY, DWAIF. See Convolvulus minor.

\section{Nasturtium}

No other annual plant combines in so great a degree ease of culture, profusion of bloom and grace and beauty of flowers as the Nasturtium. Also, it thrives on all soils except that which is very wet and succeeds on soil so poor that many other plants would fail to grow at all.

\section{Tall Nasturtium}

(Tropaeolum majus)

644 SCARIET. Rosy scarlet.

646 DUNNETT'S ORANGE. Bright orange, blotched red.

648 EDWARD OTTO. Brownish lilac.

654 HEMISPARRICUM. Straw-colored blotched rose.

656 KING T표 ODORE. Deep crimson-maroon; dark foliage.

658 IUTEUM. Clear light yellow.

662 PEARI. Very pale yellow, nearest approach to white.

671 VESUviUs. Salmon rose, dark leaved.

Fach of the preceding varieties, pkt. $10 \mathrm{cts.}$ oz. $20 \mathrm{cts}$. 2 ozs. 35 cts., $1 / 4$ lb. $60 \mathrm{cts}$.

672 CHOTCE MIXED. Many varieties: a wide range of colors. Pkt. 10 cts., oz. 15 cts., 2 ozs. 25 cts., $1 / 41 \mathrm{~b} .40$ cts., $1 \mathrm{~b}$.

\$1.40. See also, Worcester Mixed Tall Nasturtiums.

GIANT-FIOWERED, TAII NASTURTIUMS MIXED

673 A choice selcction of the largest flowered varieties and seedlings. Especially desirable for exhibition. Pkt. I0

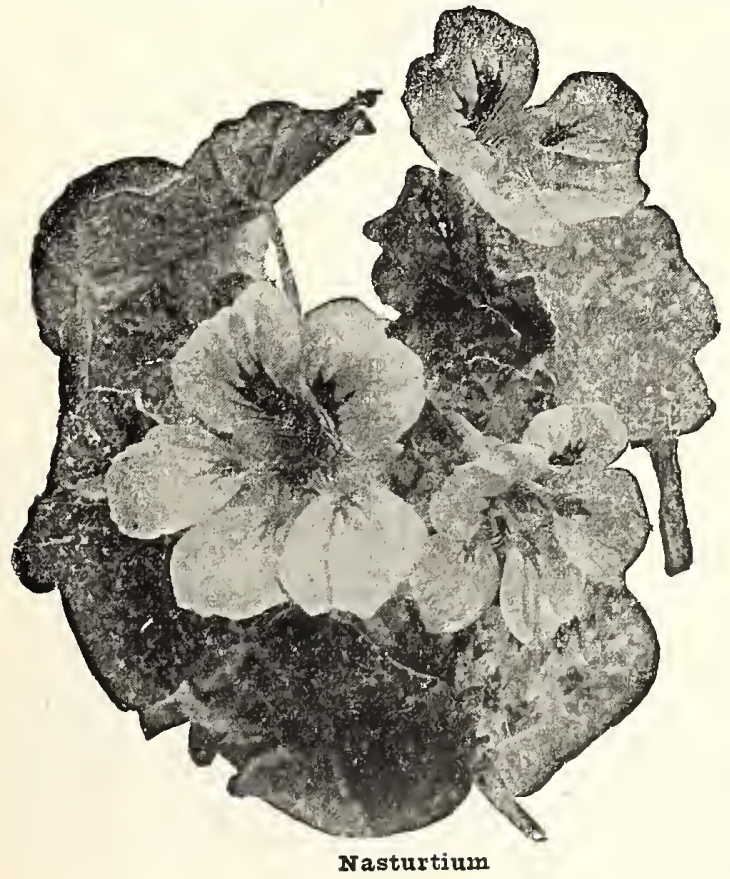

Nasturtiums prefer dry, rather rocky soil, such as we usually call "poor" soil, and bear their flowers in such locations in greater profusion than in a rich garden, where they run too $\mathrm{much}$ to leaves. This adds to their value for plant ing over many unsightly places.
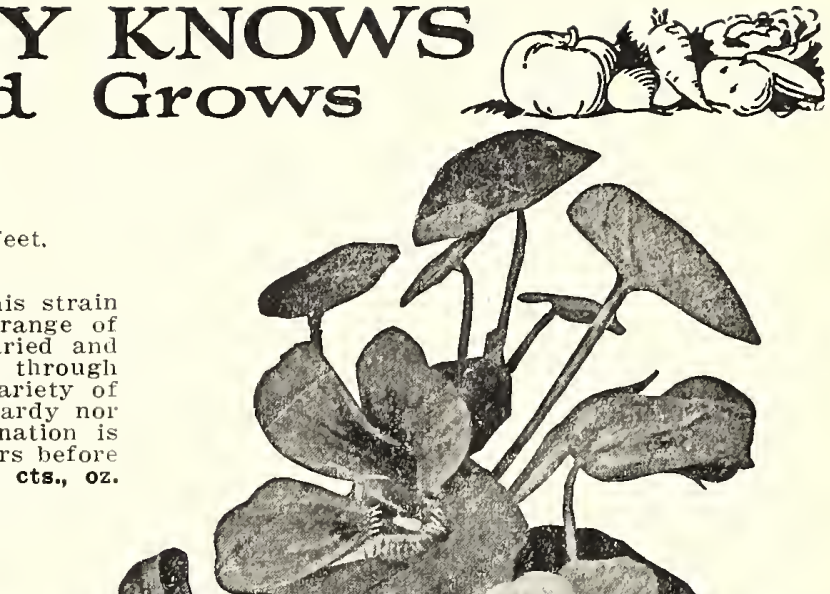


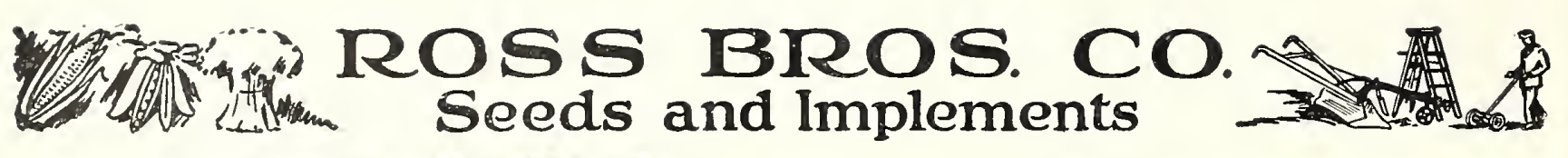

\section{NASTURTIUM}

(Continued)

\section{Dwarf, or Tom Thumb Nasturtiums}

While the flowers, not having as long stems, are perhaps not quite as desirable for cutting as those of the Tall Nasturtium, the Dwarf Nasturtium is not surpassed by any other annual plant for bedding, being of the easiest culture, thriving in nearly all soils and blooming profusely the entire season.

Except where otherwise noted, all of the following varieties at uniform prices. Plt. $10 \mathrm{cts} ., 0 z .20 \mathrm{cts.}, 2$ ozs. $35 \mathrm{cts.}, 1 / 41 \mathrm{~b} .60 \mathrm{cts}$. 712 BEAUTY. Orange with scarlet markings.

714 BRONZE-COIORED. A very distinct and peculiar shade.

718 CIOTH OF GOID. Brilliant scarlet, foliage golden yellow.

722 CRYSTAI PAIACE GEM. Rich, sulphur-yellow, spotted carmine.

724 EMPRES OF INDIA. Dark scarlet, foliage distinct dark purplish green.

726 GOIDEN KING. Rich golden yellow.

730 KING THEODORE. Dark maroon; dark foliage.

732 KING OF TOM THUMBS. Rich scarlet, dark foliage.

736 PEARI. Light cream, nearly white.

742 RUBY KING. Ruby-red, dark leaved.

744 VESUVIUS. Rich salmon-pink.

$7 \$ 6$ CEOIC. IIIXED. While not equal to the Worcester Mixed. of wide range of colors and will give pleasing results. Pkt. 10 cts., oz. 15 cts.s 2 ozs. 25 cts., 1/4 lb. 40 cts., 1b. $\$ 1.40$.

\section{Worcester Mixed Dwarf Nasturtium}

$\mathbf{7 4 7}$ Like the Worcester Tall Mixed, this is of our own preparation and cannot be surpassed in diversity of colors and types includes all the named varieties and classes here described and other choice mixtures of noted growers. Pkt. 10 cts.,

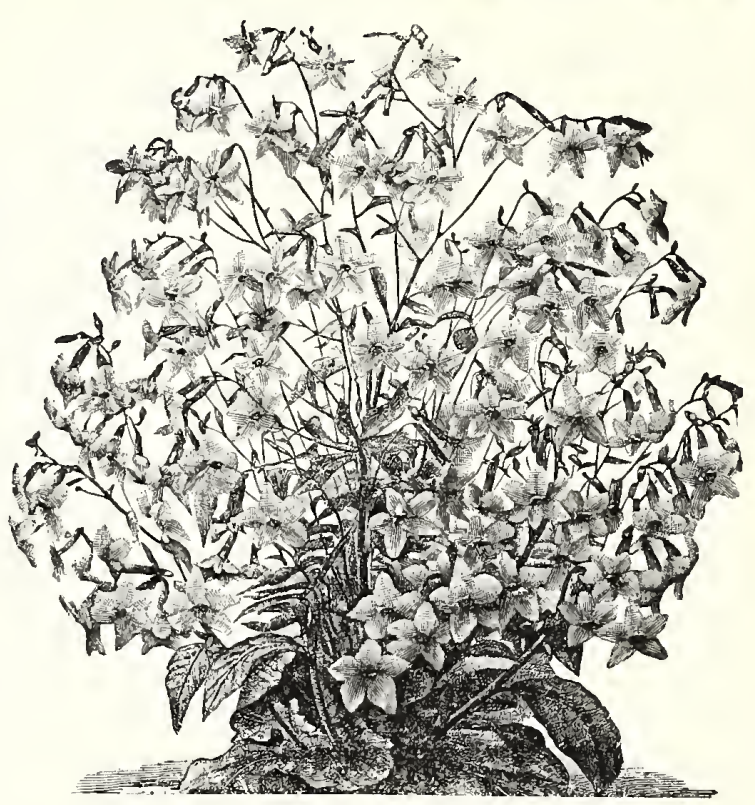

Nicotiana Sanderae

Photo reproduced of plant, showing its bushy habit and great production of flowers. VARIEGATED IEAVED, ON QUEEN OF TOM THUMBS, IIIXED. 作 oz. 25 cts.

\section{Nemesia}

A very valuable introduction-long blooming annual with large flowers, varying from creamy white to deep orange and

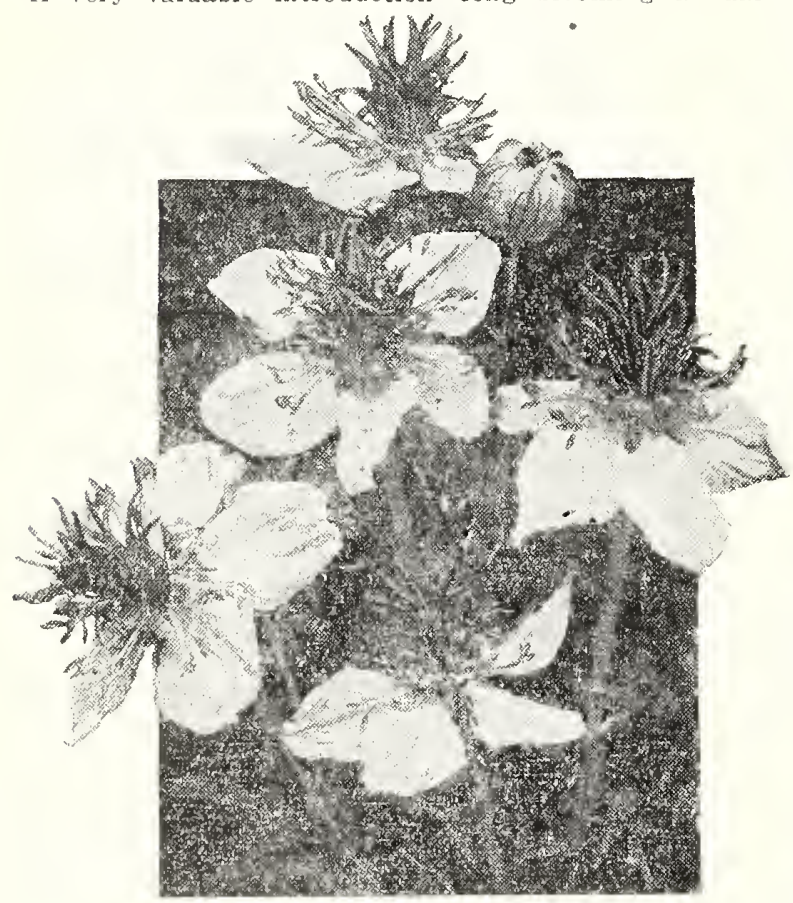

rigella carmine. Most useful for bedding. $11 / 2$ feet.
756 STrumosa SUTtoNI. Plt. $15 \mathrm{cts}$.

\section{Nemophila}

(Love Grove)

An attractive hardy annual, bearing cup-shaped flowers about an inch in diameter, usually in shades of blue and white, often spotted with brown. Succeeds in cool, shaded places, in light but rather moist loam. 6 inches.

757 MIXED. Pkt. 10 cts., $1 / 4$ oz. 20 cts.

\section{Nicotiana}

(Flowering Tobacco)

Handsome, effective, half-hardy annuals, blooming profusely the entire season and thriving in all soils. Seed may be sown early in the house or in the open ground as soon as the soil is warm.

758 ArFINIS. White, star-like flowers, deliciously fragrant, expands fully in the evening. 2 to 3 feet. Pkt. 10 cts.

759 SAMDERAE. Rose-carmine: remarkably profuse in bloom Unlike the Affinis, is in full bloom during the day. 3 to $3 \frac{1}{2}$ feet. Prt. $10 \mathrm{cts}$.

760 SANDERAI HYBRIDS. New Hybrids, comprising several distinct colors or shades. Pkt. 10 cts.

\section{Nigella}

(Iove-in-a-Mist; Iady-In-Green; Devil-in-a-Bush)

A favorite hardy annual of the easiest culture The blue or white flowers are half hidden in the abundant finely cut foliage hence its common names. 1 to $11 / 2$ feet.

761 Blue and White. Mired. Pkt. 10 cts., $1 / 4$ oz. 20 cts.

\section{Ornamental Grasses}

764 AGROSTIS NEBUIOSA. An airy and graceful annual grass, grows 18 inches high and looks like a line of mist when in bloom. Beautiful to mix with cut flowers. Pkt. 10 cts.

765 COIX IACFR YMA. (Job's Tears.) 9 feet. Large, broad leaves, large shiny seed. Hardy annual. Prt. 10 cts.

767 PTNNISETU: IONGISTYITM Graceful drooping heads. Fxcellent for bouquets 2 feet. Hardy annual. pkt. 10 cts. 768 PENMTSETUM RUPEIIANUM. Foliage long and slender, the silvery plumes tinged with violet. 3 feet. Hardy annual. Pkt. 10 ots. 

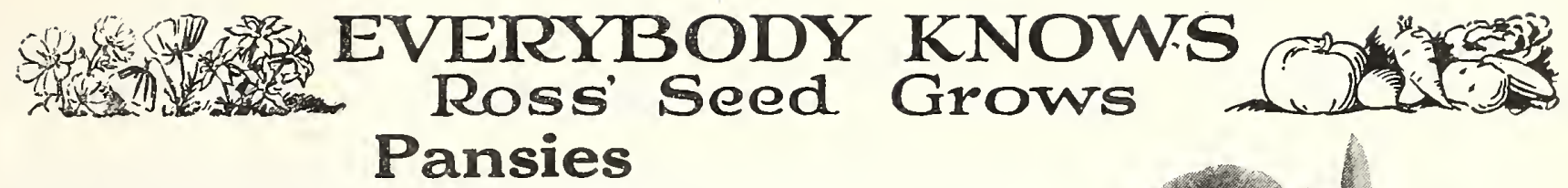

Pansies are too well known to require any description, as they are favorites with all. For best results you must start with a good strain. The finest Pansies are, as a rule, shy seeders, which accounts for the difference in the price of the various mixtures offered.

Sow Pansy seed in August or September, in fresh, moist soil, cover lightly and press seeds in with a board. Keep the bed moist by watering, and if the weather is hot and dry by mulching with straw or by shading with cloth. The seeds will germinate in about two weeks, when the straw or cloth should be removed In from four to six weeks, transplant to a slightly raised bed, setting the plants about 3 inches apart each way. Protect during winter with straw or leaves, and transplant to desired location early in the spring. Seed may be sown in the open ground in the spring as soon as soil can be fitted.

Gentlemen:

We have been using your Ross' Selected Giant Pansy seed exclusively for the past twelve years and they have produced the finest pansies both in color freedom of bloom, and strength of growth in this section

Onr pansy beds are noted all over the eastern part of Massachusetts and people come from miles around to see them in April and May.

We can cheerfully recommend them to any who desire the best. They are well named "Ross' Selected Giants." Very truly yours,

Newton Cemetery Corp., H. Willson Ross, Supt, and Treas.

770 BUGNOT'S SUPERB BIOTCFED. Rare shades of red, bronze or brown Pkt. 25 cts., $1 / 8$ oz. 80 cts., $1 / 4$ oz, $\$ 1.40$, oz. $\$ 5$.

771 CASSIER'S GIANT BIOTCHED. A very carefully selected strain of five blotched varieties remarkable for the enormous size of the flowers and the many rare combinations of shades and colors. Pkt. 25 cts., 1/8 oz. 80 cts., $1 / 4$ oz. $\$ 1.40$, oz. $\$ 5$.

774 TRIMARDEAU PARISIAN, IARGE-STRAINED. A beautiful improved strain mostly white ground and five blotched varieties. Pkt. 15 cts., 1/8

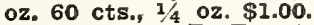

776 MADAMR PERRTT. (Fhenomena.) A strain, distinctly beautiful pink, blotched or veined with rose, crimson, or purple, the upper petals either self-colored with rich wine-red or deep purple, or with a margin of white. Pkt. 15 cts., $1 / 8$ oz. 60 cts., $1 / 4$ oz. $\$ 1.00$.

778 MASTERPIECE. Euffed Pansies. A strain having ruffled and curled petals, giving the flowers the appearance of being double. Colors rich and striking. Pkt. ance of being double. 1 color $\$ 1.25$.

779 WORCESTER GIANT MIIXED. OUr own selections of choice large-flowered strains and varieties, including a proportion of all the preceding strains, the named separate sorts, and several choice strains from different growers. Wonderful colors, shades and markings representing nearly every type of Pansy. Plat

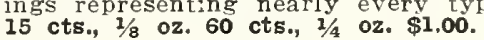

780 ROSS' SEIFCTED GIANT MIXED. This is one of the finest strains known, the flowers being of perfect form and richest colors. A Giant Pansy, excellent for srowing in the frame or out of doors. See testímunial above. Pkt. 50 cts., $1 / 16$ oz. $\$ 1.00$, $1 / 8$ oz. $\$ 1.75,1 / 4$ oz. $\$ 3.25$, oz. $\$ 12.00$.

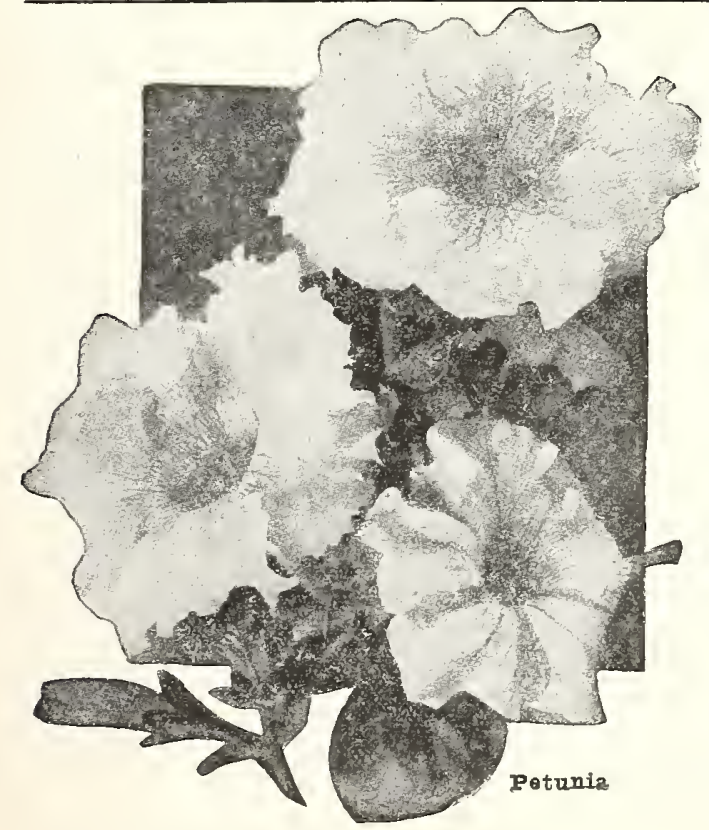

804 PEACOCK. top. Plit. $10 \mathrm{cts} ., 1 / 8$ oz. $60 \mathrm{cts}$.

Pkt. 10 cts 1 blue and purple, edged with white; very striking 806 RUBY FING. Superb reddish shades, Pkt. $10 \mathrm{cts.}$ 1/8 oz. $60 \mathrm{cts}$.

808 STOWFIARE. Pure white Plst. $10 \mathrm{cts.1} 1 / 8 \mathrm{oz} .60 \mathrm{cts}$.

811 YELIOW. With large, black eye. Pkt. 10 cts., $1 / 8$ oz. 60 cts.

\section{Petunia}

The Petunia is easily grown, and, blooming profusely all summer, is very popular for bedding. It thrives best in a warm sunny location. Sow seed thinly where plants are to remain, in beds for transplanting, or, for early blooming, in the house in boxes. Almost invariably the weaker plants produce the finer flowers, especially of the choice strains. 814 IINEST MIXED. A superior mixture. Pl. $10 \mathrm{cts}, 1 / 8$ 02. $20 \mathrm{cts}$. $1 / 4$ oz, 40 cts., oz. $\$ 1.50$.

815 STRIPED AND BIOTCHED MXID. A choice strain. Pkt. 10 ctr., $1 / 8$ oz. 25 cts., 1/4 oz. $40 \mathrm{cts}$

816 HOWARD'S STAR. Rich shade of maroon, with five-pointed star of white. Very pretty. Pkt. $10 \mathrm{cts} .1 / 8$ oz. $40 \mathrm{cts}$.

817 DWARF INMITABIE MIXED COIORS. Dwarf, bushy plants, flowers mostly beautiful striped and blotched. Pkt. $10 \mathrm{cts.}, 1 / 8 \mathrm{oz}$. 40 cts.

818 IOSY MORN. A single flower, color soft carmine pink. A profuse bloomer Pkt. $10 \mathrm{cts} ., 1 / 80250 \mathrm{cts}$

824 GIANTS OF CAITPORITA. markable substance, enormous size and many are beautifully fringed. Of almost every conceivable shade; veined, striped or blotched with some contrasting shade. Plant of vigorous growth and blooms profusely. Pkt. $25 \mathrm{cts}$

825 DOUBIE, IARGE-FIOW ERED, CHOICE MIXED. An excellent mixture comprising a large varlety of colors, with a good percentage of double flowers. Plt. 50 cte.

826 BAICONY BIUE. Dwarf type for porch or window boxes. Plt. 20 cts. $1 / 16$ oz. 50 ot.

827 BALCONY ROSE. Pit. 20 cts., I/16 oz. 50 ct. 


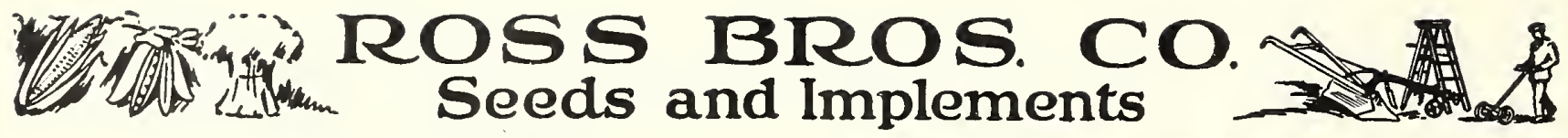

\section{Phlox Drummondii}

Seed may be sown in the open ground early in the spring either where the plants are desired to bloom, or in beds and the young plants iset in the desired location when 2 or 3 inches high. The tall sorts should stand about 12 inches apart, the dwarf about 6 inches. The plants will be more bushy and cover the ground better if pinched off while small.

830 Mixed Colors. Plt. 10 cts., 1/4 oz. 15 cts., oz. 50 cts.

IARGE-FLOWERING. (Phlox Drummondii giandifiora.) A great improvement on the common type, both heads and florets being nearly twice as large.

831 Extra-Choice, Mixed Colors. Our own mixture of the choicest and best strains from different growers Pkt. 10 cts., $1 / 4$ oz 30 cts., oz. $\$ 1.00$

833 ISABELIINA. Pure yellow. Pkt. $10 \mathrm{cts.}$ 1/8 oz. 30 cts.

DWARF. (P. Drummondii nana compacta.) The plants of this class, growing only 6 to 8 inches high, are considered by many, very desirable for bedding.

841 Mixed Colors. Pkt. 10 cts., 1/8 oz. 30 cts.

STAR, or FRINGED. (P. Drummondii Cuspidata) A distinct class with petals partly fringed, partly toothed, and some longer than others and regularly placed, give the flowers a star-like shape.

843 Mixed Colors. Pkt. 10 cts., 1/8 oz. 25 cts.

DоUвдE. Double and semi-double flowers. A very desirable class for cutting.

845 Mixed Colors. Pkt. 10 cts.

\section{Hardy Perennial Phlox}

Ifardy herbaceous perennial and quite distinct from the varieties of Phlox Drummondii offered above, which are annuals, The seed we offer has been saved from the best varieties and is supplied in mixture only.

847 Choicest mixed. Pkt. $10 \mathrm{cts}$., 1/8 oz. 75 cts.

\section{Platycodon}

(Chinese Bellflower)

855 GRANDIFIORUM. One of the best hardy perennials, and one of the easiest grown, its propagation being more easily accomplished by seed than by division of the root. It forms clumps and is well adapted to the hardy border. Blooms from .July to Septcmbor. The flowers are large steel-blue, rather more open than bell-shaped, 2 to $2 \frac{1}{2}$ feet. Plkt. 10 cts.

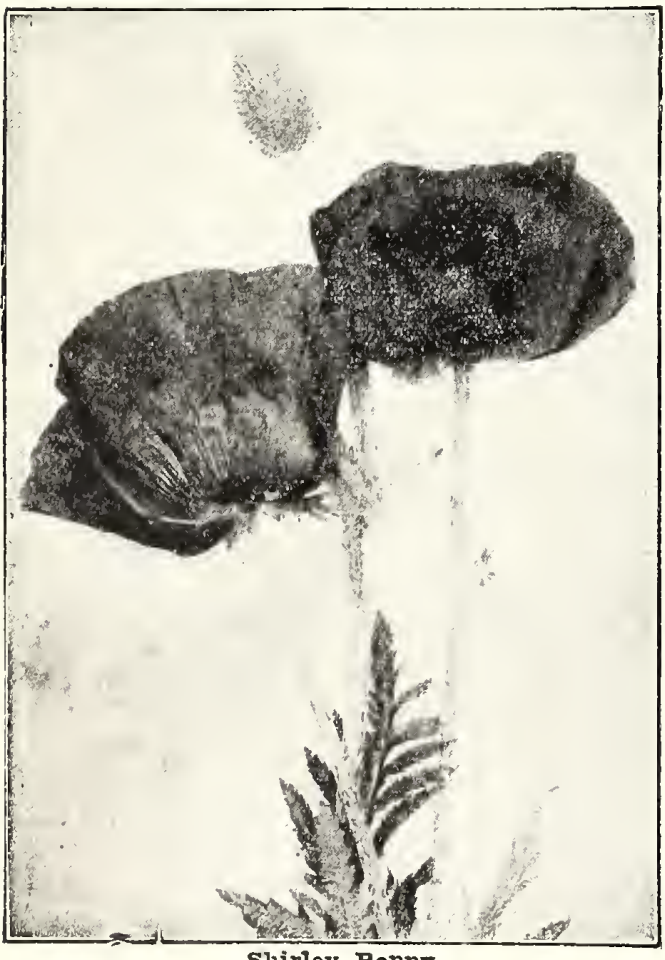

Sliviey Poppy

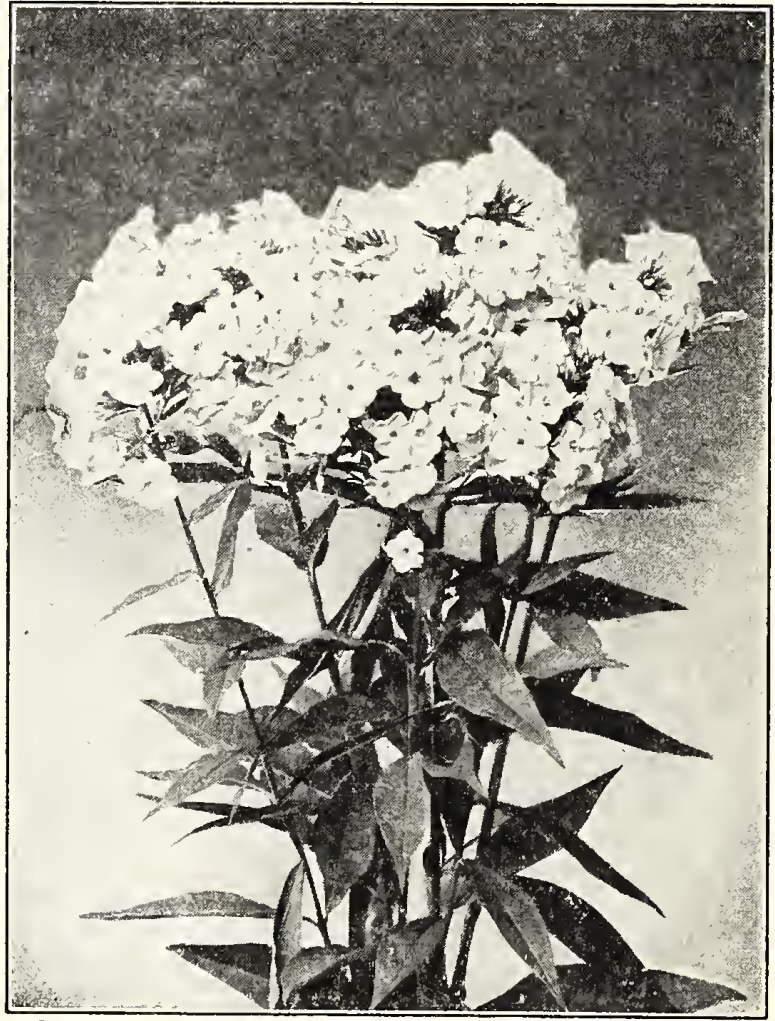

Polemonium

857 Cofruteum. A hardy perennial, very popular in olden times. Easily grown from seed, preferably sown in the fall. Large heads of showy blue flowers from May to August. 2 feet. Pkt. 10 cts.

\section{Poppy}

Well-known hardy plants of quick growth, blooming profusely for a considerable time, thriving best on light, sandy loam. Seed of the annual varieties should be sown as early in the spring as possible and where desired to bloom as they do much better when they start to grow in cool weather and are very difficult to transplant. The seed is fine and should be only slightly covered.

SINGIE ANNUAI POPPIJS

860 ADMIRAI. Large, single, peony-flowered variety, glistening white With broad band of brilliant scarlet at the top. Pkt. 10 cts.

FIRLEY. A lovely strain, comprising many delicate and rich shades, ranging from pure white through pink, rose, scarlet and red to the deepest crimson, the darker shades often having a margin of white. Many of the flowers have crimped or wavy petals, all are of fine silky texture, but of good substance, and not surpassed by any for cutting. Plit. 10 cts., 1/4 oz, 20 cts.

871 TRUE FIATDERS. The scarlet Poppy of the fields of Flanders made famous in the great war, and familiar to all the members of the A. E. F. who served in Belgium and France. Adopted by the American Legion for their emblem. They do not attain as large a size as a well grown Shirley Poppy, but apart from the sentiment now attached to them, they are a decided acquisition. They flower the first season from spring-grown seed. Pzt. 10 cts., 1/4 0z. 25 cts. DOUBLE ANNUAI POPPIES

878 CARNATION-FTOWRRED ANinged flowers of many colors, a popular class. Plrt. 10 cts., oz. 30 cts.

880

884

886

888
CARDINAL. Very large, pure cardinal-red; deeply cut, dark green foliage; very attractive. Pkt. 10 cts.

PONY-FIOWERED. Mixed. Large, globular flowers, resembling a peony. Prt. 10 cts. oz. 30 cts.

SNOWDRITT, or DOUBIE WHITE FRINGFD. Flowers from 3 to 4 inches across: very double and finely fringed. Pure white. Plst. 10 cts.

WORCESTER MIXED. Our own mixture of single and double annual varieties. All types and colors. Pkt. 10 cts., 1/4 oz. 20 cts., oz. 60 cts. 


\section{Gis}

\section{Hardy Perennial Poppies}

ICELAND POPPIES. Though hardy perennials, generally treated as annuals, blooming the first year, if seed is sown early. of graceful habit, with fern-like foliage. They bloom profusely and, if no seed-pods are allowed to form, until October. Pkt. 10 cts., $1 / 8$ oz. 25 cts.

ORIENTAL POPPIEs. Extremely desirable for hardy perennial border; gorgeous blooms. Easily grown from seed sown either in late fall or early spring. They bloom the second spring from sowing, and though their season is short-about three weeks in June-they make a very effective display. June-they make a very effective display. with bloteh of black
on each petal. Plit. 10 cts. 1/8 oz. 25 cts. W

893 NEW ORIENTAL HYBRIDS. Flowers of enormous size, sometimes 6 inches

colors. Plit. 10 ets: See Eschscholtzia.

\section{Portulaca}

Well known tender annuals, blooming profusely all summer. Thrive in most soils and locations but succed best in a light, sandy soil and sunny spot, enduring any amount of dry weather. Form a dazzling display when sown in masses.

894 DOUBLE CHOICE MIXED. Usually from fifty to sixty per cent of the flowers will come double.

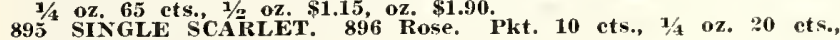
${ }_{899^{1 / 2} \text { Oz. } 35 \text { ets. }}$ SINGE JIINO. Pkt. 10 ets., $1 / 1$ oz. 25 cts., $1 / 2$ oz. 40 ets.

\section{Primula}

\section{(Primrose)}

PRIMCLA SINENSIS (Chinese Primrose). A beautiful winterblossom greenhouse perennial and one of the most pleasing for the home, blooming froml December to spring. While its culture is not easy, it is by no means impossible for the amateur to raise fine thrifty plants from seed. For early winter bloom ing seed should be sown the first week in April. Two sowings are advisable, but the second should not be later than the middle of May. Sow in well-drained shallow pans or boxes, using finely sifted loam, leaf mold and sand in equal parts. Cover lightly and water carefully, but well. Keep moist and in shade, and in a temperature of about 60 degrees. In summer keep in a cool, shady location, in winter in a north window in a temperature of 45 degrees.

900 CHOICEST MINED. Comprises the finest fringed varieties. Pkt. 35 cts.

PRMIULA stellata, or Star Primrose. This valuable and very distinct variety should be extensively grown for greenhouse and effective contrast to the attractive dark foliage.

902 MIXED CoLoRs. Pkt. 35 cts.

\section{Hardy Primroses}

Although known as a hardy perennial, these require in this climate some protection. They may be placed in a cold frame, or if protected with leaves covered by a box, they will live through blooming plants.

ELATIOR (Polyanthus). Excellent for either pot or outdoor. Colors mostly shades of yellow, and red and yellow.

903 CHOICEST MIXED. Pkt. $10 \mathrm{cts..1} 1 / 4 \mathrm{oz} .85 \mathrm{cts}$.

904 VULGARIS. True, yellow English Primrose: canary yellow fragrant Plit. 10 cts.

\section{Pyrethrum}

Well known hardy herbaceous perennials of easy culture. 910 AUREUM (Golden Feather). Golden foliage; small, white flowers. Cultivated for its foliage alone and usually treated as an annual. 1 foot. Pkt. 10 cts.

913 ROSEUM IYYDIDUM. Blooms freely from June to september, bearing large-flowering, daisy-like flowers ranging from light pink to deep red, with bright yellow center; excellent for cutting. Pkt, 10 ets.

ROSE CHAM PION. See Agrostemma Coronaria.

ROSE OF HEAYEN. See Agrostemma coeli.

RICINUS. See Castor Bean.

RESEDA. See Mignonette.

\section{Rodanthe}

One of the finest everlasting flowers and an excellent plant for garden decoration. If flowers are gathered before they are fully expanded and dried in the shade, they will retain: their color for years. Tender annual. 1 foot.

920 MXED COLORs. All shades of pink, rose, crimson and white. Pkt. 10 cts.

\section{Rocket-(Sweet)}

(Hesperis Matronalis)

Hardy perennial plant of easy culture, bearing clusters of pur921 MIXED. Pkt. 10 cts.

\section{Rudbeckia \\ (Cone Flower)}

To this family belong the favorite plant, Golden Glow, and the wellknown wild flowers, Blackeyed Susan, or Yellow Ox-eye Daisy. Both the annual and the perennials are of the easiest culture and grow in nearly all soils and situations, thriving alike in partial shade or fully exposed to the sun.

923 BICOLOR SUPERBA. Free-blooming annual of dense, bushy growth bearing on long stems, large, bright yellow fiowers with velvety brown spots at base of petals, and disc or cone of brown. Excellent for cutting.

925 feet. Plit. 10 cts. showy; blooms for a long time. One of the best hardy perennials. feet. Pkt. $1 \overline{5}$ cts.

926 PURPUREA (Echinacea; Giant Purple Cone-Flower). Large flowers, about 4 inches in diameter; reddish purple, with large cone of brown. Hardy perennial. 3 feet. Pkt. 15 cts.

\section{Salpiglosis}

(Velvet Flower; Painted Tongue)

Graceful, half-hardy annual, bearing from August to October, richiy colored funnel-shaped fiowers, ranging from deepest purple to almost black and blue through various shades of red, brown and yellow to creamy white, usually marbled or veined with several contrasting colors. These are born on long, slender stems, and are excellent cutting, keeping well in water. See may be sown in the house the last of March or in the open ground in May. The plant succeeds best in deep, rich, rather light loam of medium mixture.

2 feet. cts., 1/8 oz. 25 cts.

29 EMPERor. Mixed colors. New type with one thick leading stem, flowers oz. 30 cts.

\section{Salvia-(Scarlet Sage)}

A mass of bloom from late summer until killed by frost; tender parennial, treated as an annual. Seed should be sown early indoors, or in hot bed and the plants set out when the weather has become warm.

933 SPLENDENS GRANDIFLORA. The well-known Scarlet Sage. 3 feet. Pkt. 10 ets., 1/8 oz. 40 cts.

936 BoNFIRE (Clara Bedman). Compact bushy growth, blooms earlier and more profusely. Intense scarlet. 2 feet. Pkt, 10 cts., $1 / 80 z .40$ ets.

937 FARINACEA. A perennial variety, but best grown as an annual. Seed sown in the open ground in May, blooming from July to frost. The fine light blue fowers are borne on long spikes held above the foliage. Pkt. 10 cts., $1 / 8$ oz. 40 cts.

938 ZURICH. One of the best of recent introductions: dwarf compact habit. producing long, thick spikes of brilliant scarlet flowers blooming in July.

Salvia 


\section{Scabiosa-(Mourning Bride)}

The flowers are large and double with a great variety of colors of easy culture and biooms freely from July until hard frost. Hardy annual, $21 / 2$ feet. 945 IARGE-FLOWERED. Mixed Colors. Fine, large, double flowers in a 947 Wide range of colors. Plrt. 10 cts., 1/4 0z. 20 cts.

bloom all summer. Pkt. 10 cts., $1 / 8$ oz. 40 cts.

SCARLET RUNIER. See Beans-ornamental varieties.

\section{Schizanthus-(Butterfly, or Fringe Flower)}

Beautiful dainty, half-hardy annual. Seed may be sown in the open ground or in the house, and the plants set in the garden in May. Should be planted in a sheltered place or the plants tied to stakes, as the stems are very brittle and easily broken by strong winds. An excellent house-plant. 1 to $11 \%$ feet.

948 GRANDIFLORUS HYBRIDUS. Very fine varieties. Pht. 10 cts.

949 WISETONENSIS. Containing the most beautiful shades of white, pink, rose and crimson. Excellent for pot culture. Plt. 25 cts.

Sensitive Plant-(Mimosa Pudica)

950 PUDICA. Globular heads of small pink flowers. Grown chiefly for the peculiar habit of the plant, the leaves closing and drooping at the slightest touch. Tender annual. $1 \frac{1 / 2}{2}$ feet. Pkt. 10 cts.

\section{Silene-(Catchfly)}

Profuse flowering plants of easy culture. Seed of the annual sorts may be sown in the open ground early in spring or in the fall if early bloom is desired.

951 ArmeriA. Mixed (Common Catchfly.) Annual; blooms from July to 953 September. White, pink and red. $11 / 2$ feet. Pkt. 10 cts. rose and red. Annual. Largely used for edgings. May to August. 6 inches. Firt. $10 \mathrm{cts}$. Smilax

955 smruax. A climbing plant, unsurpassed for its graceful foliage and orange-blossom fragrance of its flowers. Makes a fine pot
plant. Elegant for table decoration when cut. Pkt. 10 cts.

SNAPDRAGON. See Antirrhinum.

SoIANUM CAPSICASTRUD. See Jerusalem Cherry.

\section{Statice}

Beautiful everlasting with spreading panicles of tubelike flowers that are decorative either in the garden or when cut. Their most effective use, however, is in bouquets for Winter, either alone or with other dried flowers. It is surprising how well these novel flowers retain their splendid colors. Sow outside in May after danger from frost. Hardy annual.

956 Suworowi PInk. Pkt. $10 \mathrm{cts.}, 1 / 4$ oz. $35 \mathrm{cts}$.

956A Sinuata Blue. Pkt. $10 \mathrm{cts.} 1 / 4 \mathrm{oz} .25 \mathrm{cts}$.

956B BONUEILI YEILOW. PEt. $10 \mathrm{cts}$., 1/4 oz. $25 \mathrm{cts}$.

\section{Stock-(Gilliflower)}

One of the most popular annuals, remarkable for its profusion of bloom, brilliancy and diversity of colors and lasting quality of its flowers. Plants from seed sown inside in March or April commence to bloom in July and those from seed sown in the open ground in about ten weeks and continue until frost. Plants grown in rich soil and well cared for, produce 80 to 90 per cent of double flowers.

957 BEAUTY OF NICE. Mammoth flowering. Delicate flesh pink extra large spike. Fkt. 10 cts., 1/8 oz. 50 cts.

MONTE BLANC. Purest white. Pkt. 10 cts.

959 MONTE CARLo. Canary yellow. Pkt. 10 cts. DRESDEN PERPETUAL, or BRANCEING. (Cut-andCome-Again.) A perpetual blooming class of branching habit; double, fragrant flowers. 2 feet.

967 CHOICEST MIXED. Pkt. $10 \mathrm{cts.,} 1 / 16$ oz. 25 cts., 1/8 oz.

$40 \mathrm{cts}$.
LARGE-FLORED DOUBLE TEN WEERS.

RD DOUBLE TEN WEEKS. A very choice strain, producing a very large per cent of
double flowers. Fine for bedding. $11 / 2$ to 2 feet.

970 CHOICEST MIXED. Pkt. $10 \mathrm{cts}, 1 / 16$ o2. $25 \mathrm{cts} ., 1 / 8 \mathrm{oz}$. $40 \mathrm{cts}$.

971 DOUBLE TEN WEEKS. Mired Colors. Seeds grown in the open glound instead of in pots, therefore cheaper A good range of colors. $1 \frac{11 / 2}{2}$ feet. Pkt. 10 cts., 1/8 oz. 25 cts., $1 / 4$ oz. $40 \mathrm{cts}$.

Stockesia Cyanea-(Cornflower Aster)

973 BIUz. A beautiful, hardy perennial, growing about 2 feet high and bearing from August to hard frost, beautiful centaurea-like lavender-bly

974 MIXED. Containing many new colors. Prt. 10 cts.

\section{Sunflower Hellianthus}

The Sunflower grows well in all soils if fully exposed to the sun. The taller varieties make excellent background to other plants.

975 CUCUMERIFoIrUs. (Miniature Sunflower.) Small single flower, rich yellow. $4 \mathrm{ft}$. Pkt. $10 \mathrm{cts.}, 1 / 2$ oz. 20 cts.

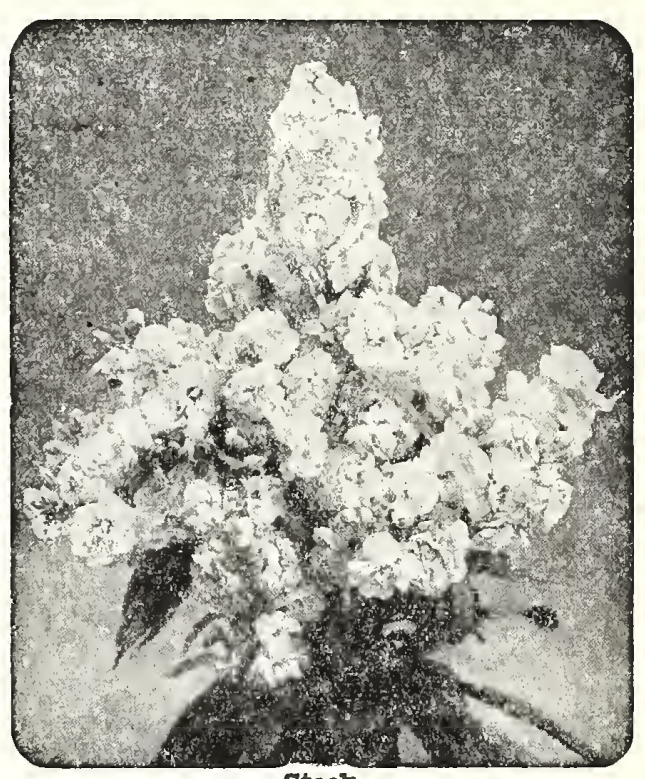

stock

976 GLoBosus EISTUIosus (Globe or Dahlia Sunflower). Flowers large, double, of a rich saffron color. 6 feet. Plst. 10 cts., $1 / 8$ oz. $25 \mathrm{cts}$.

977 RED SUNPTowrer. The new red Sunflower is easily grown from seed the same as all of the Helianthus family, and usually thive in any sunny location with ordinary garden soil. Colors are not truly fixed and may produce some yellow blooms, but the larger proportion are of a fine red, tipped yellow. Plst. 15 cts., $1 / 4$ oz. $30 \mathrm{cts}$.

980 NEW MINIATURE VARIETIES. Many new varieties of the miniature type of various shades of yellow and creamy white. Some are large, some have twisted petals and some blach centers. Flrt. 10 cts., 1/4 oz. 25 cts.

981 PERKEO. A distinct dwarf variety of the Miniature and growing only a foot high and blooming from the last of June until hard frost; is especially valuable

984 DOUBIE CERYSANTFEMUM - FIOWERED. Flowers larger than the preceding; full and double. Orangeyellow. 5 feet. Pkt. 10 cts., 1/2 oz. 35 cts.

986 RUSSIAN MAMMOTH. Very large. 7 to 9 feet. Oz. pkt. 10 cts.

SWEET SUITAN. See Centaurea. Rage 49. SWEET PRAS

\section{Grandiflora or Standard Varieties}

Sweet Peas succeed best when planted very early in the spring The soil should be at least of medium fertility and well prepared. Sow thickly in drills about 5 inches deep, but cover" with but 2 inches of soil, filling the drill when plants are a few inches high. Seed may be sown in either single or double rows, the latter being preferable because more economical of space, and requiring only half as much material for support of the vines, For this purpose poultry netting is often used, but brush is better. The season of blooming will be prolonged if all flowers are cut and seed-pods not allowed to form.

All of the following varieties at uniform pice. Plrt. $10 \mathrm{cts.}$ oz. 20 cts., 2 ozs. 35 cts., $1 / 416.65$ cts.

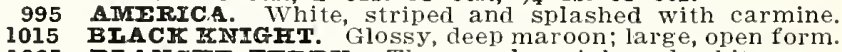
1025 BLANCEE FERiYY. The popular pink and white.

1045 DOROTHY ECKFo:D. The largest pure white of this 1080 FIORA NORTON. Almost true sky-blue.

1100 JANET SCOTT. Clear deep but bright pink. Large size, hooded form. The wings stand upright and are curled, giving the flower an unusual but rather at-

1125 IrING EDWARD VII. Crimson-scarlet, large; the best

1135 IADY GRISEL FAMIITON. Soft lavender, tinted with 1150 IORD NEISON. The best dark blue. Distinct and a 


\section{EVERYBODY}

The Spencer-Waved or Giant OrchidFlowered SWEET PEAS

Spencer Sweet Peas grown under the ríght condítion should produce robust plants attaining a heíght of from 5 to 8 feet and for full development should not be less than six inches apart.

There are hundreds of the orchid-flowered varietíes of Sweet Peas; many of which are almost identical in color or some characteristic which all first class sorts should have. Our list contains only those varieties which we have found to be worthy of the growers' best attention and are selected because of some special merit.

All at uniform príce except where noted, Pkt. 10 cts., 1/2 oz. 20 cts., 02. 35 cts., $1 / 4$ lb. $\$ 1.00$, postpaid.

APPIE BLOSSOM SPENCER. Bright rose standard with wings of very light primrose llushed or tínted rose-carmíne. Very large Spencer form.

ASTA OHN. Large flowers, waved and fluted in the standard with very large wavy wings, lavender, suffused or tinted with mauve superior to any other lavender.

AUSTIN FREDERICK IMPROVED. A very large and longstemmed rosy lavender. A vigorous grower and producer. A wealth of fine blossoms.

AVALANCHE. A white seeded white. Thís grand white is out standing because of the thick texture of the petals and the pureness of the color.

BARBaza. An excellent sort for exhíbítion or table decoration large salmon-orange and much superior to Earl spencer, as it retaíns its oríginal color.

BIANCHE FERRY SPENCER. Closely resembles the variety of the older type, Large, well waved and crinkled.

BuUE PICOTrE. Almost pure white except for a narrow edging of violet blue on the standard and wings. Flowers large and of fine form.

CONSTANCE HINTON. A beautiful white Spencer of enormous size. Young flowers usually tinted a trifle pink, but they soon turn pure white.

CRIMSON TING. The color is a solid rich, deep, clear crimson throughout becomíng rícher in the throat, Absolutely no dis tinguishing difference between the color of standard and wings. The flowers are of precisely the same distinct color from bud to "passing oft" stage Entirely free from sunburn and wind scald at all times. The strong, straight stems, sixteen to eighteen inches long, stand out well from the foliage and invaríably carry more four fine blooms than three. The flowers or blooms are perfectly placed on strong, stiff stems and are seemingly always properly spaced.

COUNTESS SPENCER. The original of this type. Soft rosepink, deepening somewhat at the edges.

DAINTY SPENCER. White ground with beautiful picotee edge of rose pink.

DOBBID'S CREAM. Rích primrose, perfect form, waved edge, usually four flowers on a stem.

DOBBIE'S SUNPROOF CRIMSON. Flowers are large and of fine Spencer form. A vigorous grower and a good variety for exhibition

DORA. A beautiful large waved flower of great substance. The color is soft pink with white wings.

EIFRIDA PEARSON. The flowers are of extra large size, great substance and lasting quality when eut. They are nicely disposed on extremely long, stiff stems, invariably borne in fours. The vines bloom in wonderful profusion and are of such vígorous growth that the flowers frequently come with double standards. The color is lovely pink throughout, the buds and flowers being tinted with salmon pink.

ETTA DYKE. A superior strain of "White Spencer," larger, whiter, and better frilled.

FIERY CROSS. This sensational novelty was exhíbited in 1916 and was received with great favor by the experts, and is now offered to the public as one of the leaders, The flowers are of good size and beautífully waved, but its greatest merít is íts color, a brilliant fiery-scarlet, and its well-deserved name ís truly descriptive.

FIORA NORTON SPENCER. Bright blue, with a little deeper tint of purple than the oríginal Flora Norton, Large, both standard and wings are wavy.

FIORENCE NIGHTINGRLE. Best soft lavender,

EAWIMARK FINR. Quite dístinct from any other pink variety, the general effect being rose-pink suffused with salmon, undoubtedly the mast beautiful pink Sweet Pea

HERCUIES. A magnificent soft rose-pink. The standard frequently measures two and one-half inches in díameter.

KING EDWARD SPENCER. Rich crímson-scarlet, large and of fine form; the best of this color.

FITG WHTIE. The grandest of all white Sweet Peas, and of the most up-to-date Spencer form. It is much the largest white Spencer-the buds are of exceptional size before opening, even the seed pods are unusually large. The stems are long and stout, and bear practically always four blossoms, King White created a sensation wherever shown

MARGARET ATLEE. The largest and finest Sweet Peas yet introduced. It is a rosy salmon-pink on a creamy buff oround, a rích soft color, and extremely attractive, both as individual flowers and in the bunch. The standard is large, wavy and frequently double, The wings are also large, wavy, well set. There are usually four blossoms to a stem; well poísed and graceful.

MISS CAIIFORNIA. Salmon pink.

Mris. TOM JONEs. Deep amethyst blue, very fine form, the best of the deep blues.

OTHELIO SFENCER. Of immense size with large drooping wings and large wavy standard; rich maroon, very dark.

PRINCE OF ORANGE. Líke all orange colored varieties, requíres shading, but this extra labor is amply repaíd by the brilliant, rich color. Prince of Orange is the deepest and richest orange colored Sweet Pea we have ever seen Pkt. 15 cts., $1 / 2$ oz. 40 cts., oz. 75 cts., $1 / 4$ 1b. $\$ 2.50$.

Do you receive our fall catalogue for Dutch bulbs? TVe list a full line of Tulíps, Hyacinths and míscellaneous bulbs. also American grown Narcissus. If you do not receive this book send us your name and address and we will gladly put you on our maílíng líst for our next fall catalogue. 


\section{2. \\ Spencer Sweet Peas \\ CONTINUED}

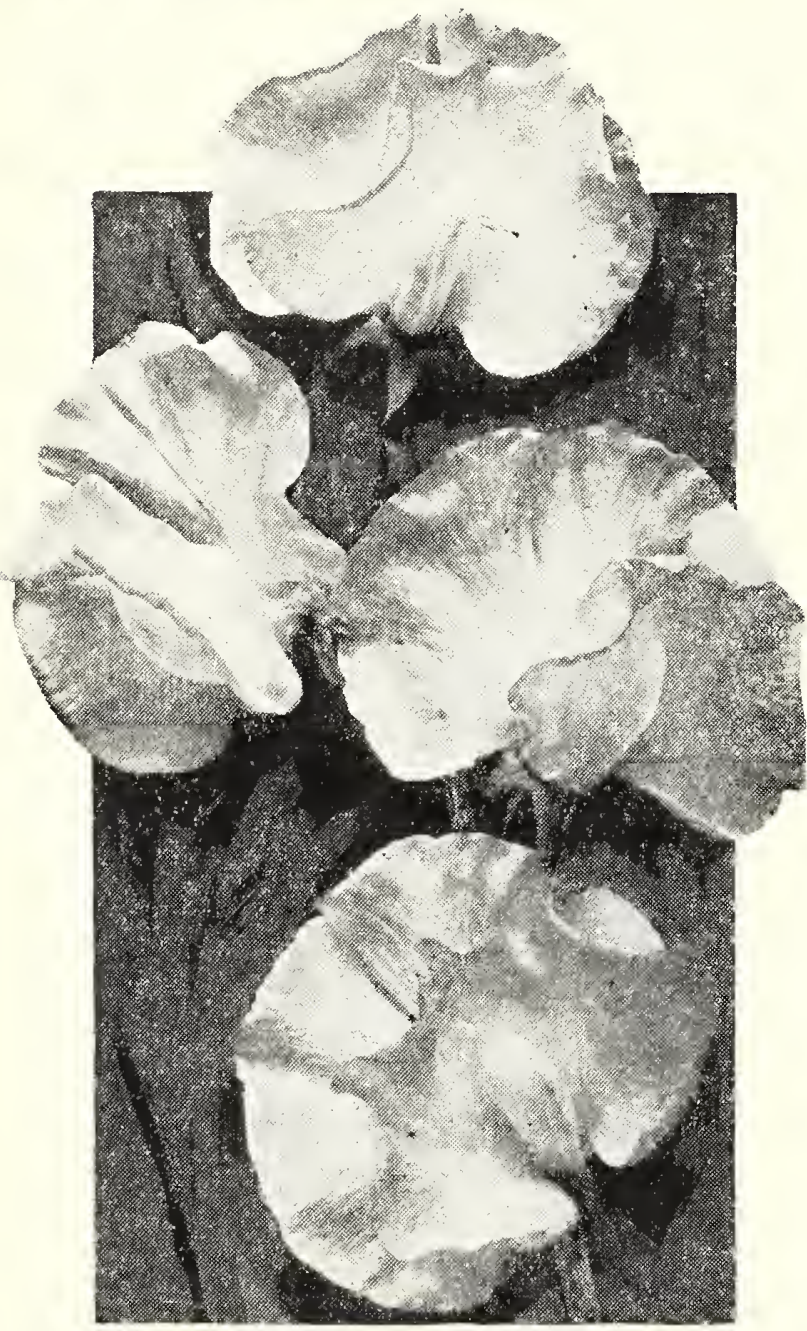

Pinkie

\section{Sweet Pea Mixtures}

\section{Spencer Varieties and Seedlings Mixture}

This is a superb mixture of Spencel or Giant Waved Flowered varieties. It contains not only the named kinds, but many of the unnamed seedlings. It must be remembered that the Spencer sorts do not come as true as the old standard kinds, but a very large percentage will be of the spencer type with a waved flower. This is the very best mixture that you can buy and it is well worth the difference in price. Ptt. 10 cts., 02. 25 cts., 1/4 1b. 75 cts. 1 1b. $\$ 2.50$.

\section{Our Best Mixed}

1295 This mixture we make up ourselves of the choicest large flowered varieties, including the best of the standard varieties, all of the varieties of the New Giant and Orchid-Flowered, both of the Spencer and Unwin types and many of the unnamed Spencers. 'This mixture comprises all shades, but is blended in carefully studied proportions and is the most desirable and popular mixture which can be prolucerl. Plst. 10 cts., oz. 15 cts., $1 / 4$ lb. 50 cts., lb.
PINKIE is by comparison the largest of all we liave ever seen in tile Deep Pink section of accepted, preferred varieties. A most vigorous grower, producing on long stout stems well waved, nicely placed flower's of a beautiful rose pink shade. Pkt. 15 cts., 1/2 oz. 40 cts., oz. 75 cts., $1 / 4$ lb. $\$ 2.50$.

SUNKIST is a large rose picotee, edged on cream ground, giving a very beautiful cffect, especially when used for table decorations. The large, bold flowers are well waved and borne on good, stout stems. Prt. 15 cts., 1/2 oz. 40 cts., oz. 75 cts., $1 / 4$ 1b. $\$ 2.50$.

ROYAI PURPLE. A new shade in sweet Peas, a rich purple and almost a true royal purple. The same shadc effect does not exist in the grandiflora type.

WARRIOR. Deep cliocolate, almost black, uneyualled for mixing with other shades for bouquets and table decorations. The darkest Sweet Pea introduced.

WEDGEWOOD. This is a unique shade of lovely light blue and completely eclipses the Flora Norton Spencer The flowers are well waved in both standard and wings and are borne almost uniformly in sprays of four upon long, stout, stems. Wedgewood is a color long sought for in Sweet Peas and has been eagerly welcomed by lovers of this beautiful annual.

WHITE SFENCER. Pure white. Of the largest size, has beautifully poised wings and the standard is erect and wavy. Stems often 12 inches long.

YOUTR. The color is an exquisite pink picotee edge on a oure white ground and a combination that cannot fail to excite enthusiasm on the part of all growers.

Price of the above except where noted: Prt. 10 cts., 1/2 oz. 20 cts., oz. 35 cts., $1 / 4$ lb. $\$ 1.00$.

\section{Early Flowering Spencers}

EARIY GIANT ROSE. Largest of all rose-pink. Pkt. 20 cts., $1 / 2$ 0z. 60 cts., 0z. $\$ 1.00$.

EARIY HARMONY. 'This is the outstanding lavender in early flowering sweet peas because of the vigor of growth and the wealth of blossoms produced. Plst. 15 cts., $1 / 2$ oz. 40 cts., 02. 75 cts.

FARIY SUPERIOR PINK. It is a beautiful shade of rosepink slightly shaded with salmon of perfect form and beautifully waved. Plrt. 20 cts., $1 / 2$ oz, 60 cts., oz. $\$ 1.00$.

EARIY SIIVER BIUE. This is a light blue lavender and is very popular because the light blue lavender shade harmon. izes with all pink shades. Pkt. 15 cts., 1/2 0z. 40 cts., $0 z$. 75 cts.

EARIY SNOW WHITE. It is popular on account of the purity of the whiteness of the petals and the length of the stems. Pirt. 20 cts., $1 / 2$ oz. 60 cts., 0z. $\$ 1.00$.

EARIY VUICAN. It is a very vivid scarlet. The flower is not affected by the bright sunshine, in fact the brighter the sun, the more intense the color. Plrt. 15 cts., $1 / 2$ oz. 40 cts., oz. 75 cts.

YARRAWA. A Sweet Pea novelty of sterling merit, coming from Australia. The flowers are waved, of large size, many of them being double. Color, a soft, bright rose pink with a creamy base. One of the best for forcing under glass, and when grown out of doors blooms two weeks earlier than the Summer Spencers. Plrt. $15 \mathrm{cts.}, 1 / 2 \mathrm{oz} .40 \mathrm{cts.,} 02.75 \mathrm{cts}$.

\section{Choice Mixed}

1296 Also prepared by us; a well-blended mixture comprising many of the large-flowering varieties of the older type, and Eckford's Large-Flowering Hybrids in great variety. The mixture will compare favorably with those generally offered at a higher price, and is surpassed only by mixtures which, like our Best Mixed, contain the new orchid-flowering varieties. Oz. $10 \mathrm{cts} ., 1 / 41 \mathrm{~b}$. 35 cts., lb. $\$ 2.15$. 


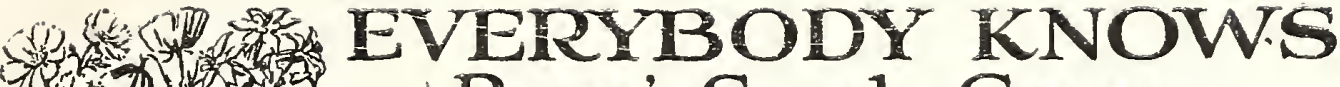 Ross' Seed Grows}

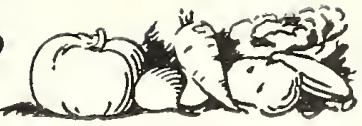

\section{Sweet William}

\section{(Dianthus Marbatus)}

A splendid hardy biennial with large trusses of sweel and scented flowers produced in abundance. Seed should be sown at any time from early spring to the last of August, the late sown generally making as good plants as the early, and blooming to the full extellt the following summer. $11 / 2$ feet.

1300 SINGLE MUXID COLORS. I'lit. 10 ets., 1/4 $0 \% 15$ ets. 1302 HOLBORN GLORY. A new strain of the auricularyed section; both the head and individual flowers are of the largest size and each of the latter shows a clear white eye; of an exce

1308 DÖUBL LARGEST-FOWERED. Choicest mixed. A greatly improved strain. Plit. 10 rts. $1 / 4$ oz oz ts. 1309 SCARLET BEAUTY. A very effective rich, deep, scar-

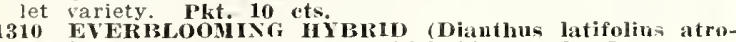
coceineus fl. pl.) A variety which blooms the first season coecineus fl. plol A variety which blooms the first season hardy plant of very easy culture. Plit. 10 ets.

\section{Thunbergia}

1315 MIXED. An annual vine, growing about if leet high, bearing medium-sized flowers, white, buff or orange, with dark eye. Largely used in hanging baskets or window hoxes. Pkt. 10 ets.

\section{Tritoma}

1317 TRITOMA (Red-flot Poker Plant, or Flame Flower), H. P. Magnificent, large spikes of orange-red flowers,
attaining a height of 4 feet; effective in single clumps or a mong shrubbery. Pkt. 10 ets.

\section{Verbena}

Favorite annuals, thriving in nearly all soils. Useful for beds, borders, carpeting ground and vases. Plants from seed sown in open ground in May will begin to bloom in August. and those sown jnside in March will bloom from June until frost.

1320 MIXED CoLORs. A good strain, all colorg of old type Pkt. 10 ets. $1 / 4$ ox, 25 cts.

CoLoRs. Comprises the best large flowering sorts of many colors. l'kt. 10 ets., $1 / 8$ oz.

1322 SCARLET DEFIANCE. Large trusses of deep, rich scarlet.

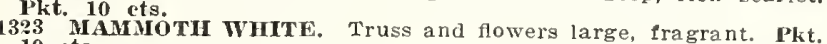
10 ets. 1324 ITALIAN STRIPED. Large trusses of medium-sized flowers, each distinctly striped. Plit. 10 ets.

325 "BURBANK'S GIANT MAYFLOWER." A selected strain from Luther Burbank, having a powerful fragrance like that of the Trailing Arbutus. The flowers are of the largest size and most beautiful colors. pht. 15 ets., 2 pkts. 25 ets.

1326 I.EMON. An old favolite with delightfully scented foliage. It is a low-growing tender plant and may be grown in the garden in summer and in pots in winter. Pkt, 10 cts.

\section{Veronica}

1330 One of the prettiest of the spring flowering herbaceous plants. bearing pretty blue flowers on long spikes. Valuable both for
the garden and for cut flowers. They should be in every garden. Hardy perennial. Pkt. 10 ets.

\section{Viola Cornuta}

\section{(Tufted Pansies)}

Flowers are not so large as the Pansy proper, but is very desirable, as it blooms profusely and is more quickly and easily grown. Seed sown in April will produce blooming plants in June that will be covered with flowers for a long time, and, if planted in cool, moist soil, party shaded, nearly all summer. Hardy perennial

35 MXED TUFTED PAXSIES. Finest mixture of all colors. Pkt. $10 \mathrm{ets.,}, 1 / 8$ oz. $35 \mathrm{ets}^{1 / 4}$ oz; $60 \mathrm{ets}$.

Half-hardy perennial. A universal favorite in England. Though a fine bedding plant, is not well known in America. It is more often grown as a pot plant and for this purpose is well adapted. The flowers are very often fragrant and usually of various shades of yellow, brown and reddish brown. Seed may be
sown in the open ground in the spring when warm and, If given about 12 inclies of room will make strong, stocky plants for winter bloom

1340 SINGLE. Mixed colors. Pkt, $10 \mathrm{cts}$.

1341 DOLBLE BRANCHING. Mixed colors. Pkt. 10 ets.

34 PARIS EXTRA-EIRLY, A new single-flowered strain, light brown, brownish red, yellow and creamy-white. Mixed, Pkt. 10 ets., $1 / 4$ oz. 20 ets.

1346 WILD (Echinoestis Lobata). One of the most rapid-growing of all annual climbers and blooms early in the season and continuously until fall. Of the easiest culture, growlng wild in the West from self-sown seed. One of the most desirable annual the West from self-sown seed. One of the most desirable annual climbers for quick coveling any unsightly object, growing 30 feet, covered with small white, iragrant flowers, followed by times presents a striking and effective appearance. Seed may be sown either in the fall or spring. Plit. 10 cts., 1/g oz. 20 ets., or. 35 ets.

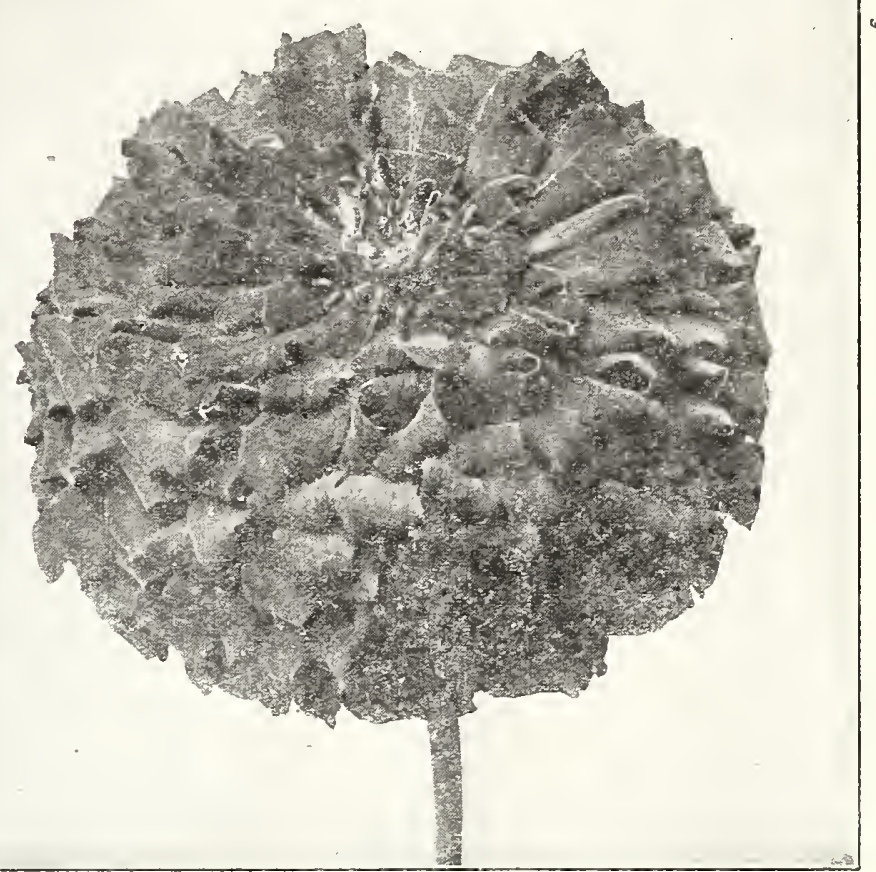

Mammoth Zinnia

\section{Zinnia}

(Youth and Old Age)

The most gorgeous annuals with a wonderful range of color Beautiful old rose, dainty cream, striking red and brilliant yellow flowers of velvety texture, extremely double with long stems and good keeping qualities, make this old-fashioned flower a joy in the garden. The Mammoth varieties produce such enormous blooms they appear as greenhouse Chrysanthemums that have mistaken their time. and place of fiowering. If you want but one annual. plant this. The plants may be taken up when in full bloom and transplanted without any visible effect.

1350 MIXED COLORS. An improved strain, comprising all colors and many large flowers. 2 feet. Pkt. 10 ets., 1/4 oz. 20 ets., 07.60 cts.

\section{Mammoth Flowered Zinnia}

These grand annuals are of the Giant or Mammoth flowering type and are in every way superior to the old-fashlioned "Youth and Old Age."

The plants grow from $2 \%$ to 3 feet high and are covered with myriads of densely double flowers, measuring from 4 to 6 inches in diameter. Giant Zinnias are one of the best plants for beds borders and cutting.

1351 MANDOTH CRNSON. 1352 Mammoth White. 1353 Manmoth Searlet. 1354 Mammoth Yellow. 1355 Burnt orange. 1354 Deep Salmon Rose. Each, plit. $10 \mathrm{cts.,} 1 / 4$ oz, 25 ets.

1358 MAMIOTH. Mixed colors. pkt. 10 ets., $1 / \frac{1}{4}$ oz. 25 ets., $0 \%$ 5 ets.

1360 CURLED AND CRESTED. A pleasing variation from the regular type, the petals being twisted, curled and crested. All colors. $2 \frac{1}{2}$ feet. Pkt. 10 ets., 1/4 oz, 25 ets.

1362 z.EBRA. Striped flowers, the colors varying on each plant. Pkt. 10 ets., $1 / 4$ oz. 25 ets.

1363 LILLIPUT (P'ompon). Small, double flowers of many colors. Very profuse. 11/2 feet. Plit. $10 \mathrm{cts} ., 1 / 40 \mathrm{z} .25 \mathrm{cts}$.

13Gt ILAAGEANNA fi. pl. (Mexican Zimmia). A distinct type with small, pretty double and semt-double flowers which would hardly be recognized as Zinnias by those unfamiliar with the type. $O$ dwarf and slender growth, the plant is excellent for bedding. while the deep orange flowers are good for cutting. Pkt. 10 ets.

Gentlemen:-My shipment of seeds arrived in flrst class condlion and are fine specimens of their respective kinds.

I wish to thank you for the prompt attention and careful packing you gave my order and will say that I know where to go for first-class goods and attentlon. Youls truly, T, FORD 


\section{Zinnia New Giant Dahlia Flowered}

This splendid new and distinct race is without a doubt the greatest improvement in Zinnias yet developed and will greatly increase the popularity of this flower. The plants are of strong viorous habit from $2 \frac{1}{2}$ to 3 feet high, and produce mammoth flowers 4 to 6 inches across and $2 \frac{1}{2}$ to 3 inches deep. The broad petals are closely imbricated, sometimes seeming almost to be piled one upon the other, the flowers so closely resembling decorative Dahlias, that when placed by their side, it is difficult to distinguish one from the other. This new variety is also valuable for growing under glass for cutting.

1366 BUTTERCUP. An immense deep creamy yellow. A very desirable flower, which should be included in every collection.

1368 CFIMSON MONARCA. By far the largest and best of the red shades. Flowers often eioht inches in diameter. Plants very vigorous. A marvelous production of extraordinary merit.

1370 DREAM. A fine, deep lavender, turning to purple (Mallow Purple), a new, desirable shade in Zinnias.

1372 EXQUISITE. By far the most pleasing of our collection. Truly DAHLIA flowered as regards form and size. Color light rose with center a deep rose. (Tyrlan Rose.)

1374 ORIOLE. We consider this the most beautiful of its class. It is an immense orange and, gold bicolor, changlng slight$1 \mathrm{y}$ as it ages, but al all times worthy of the beautiful bird for which it is named.

1376 I DOSE. This is adequately described by its name, as it is of the real old Rose Shade; it is large, and for charm and beauty we consider it ranks next to Exquisite.

1378 POLAR BEAR. A very large pure white, the best white yet seen in Zinnias. True Dahlia form. Each of the above, prt. 25 cts., 6 pkts. $\$ 1.00$.

1380 SPECTAT MIXTURE. A well blended mlxture containing all the above novelties. Plt. 25 cts., 1/8 oz. 40 cts., 1/4 oz. $70 \mathrm{cts}$. 1386 WIID FLOWER GARDEN MIXTURE

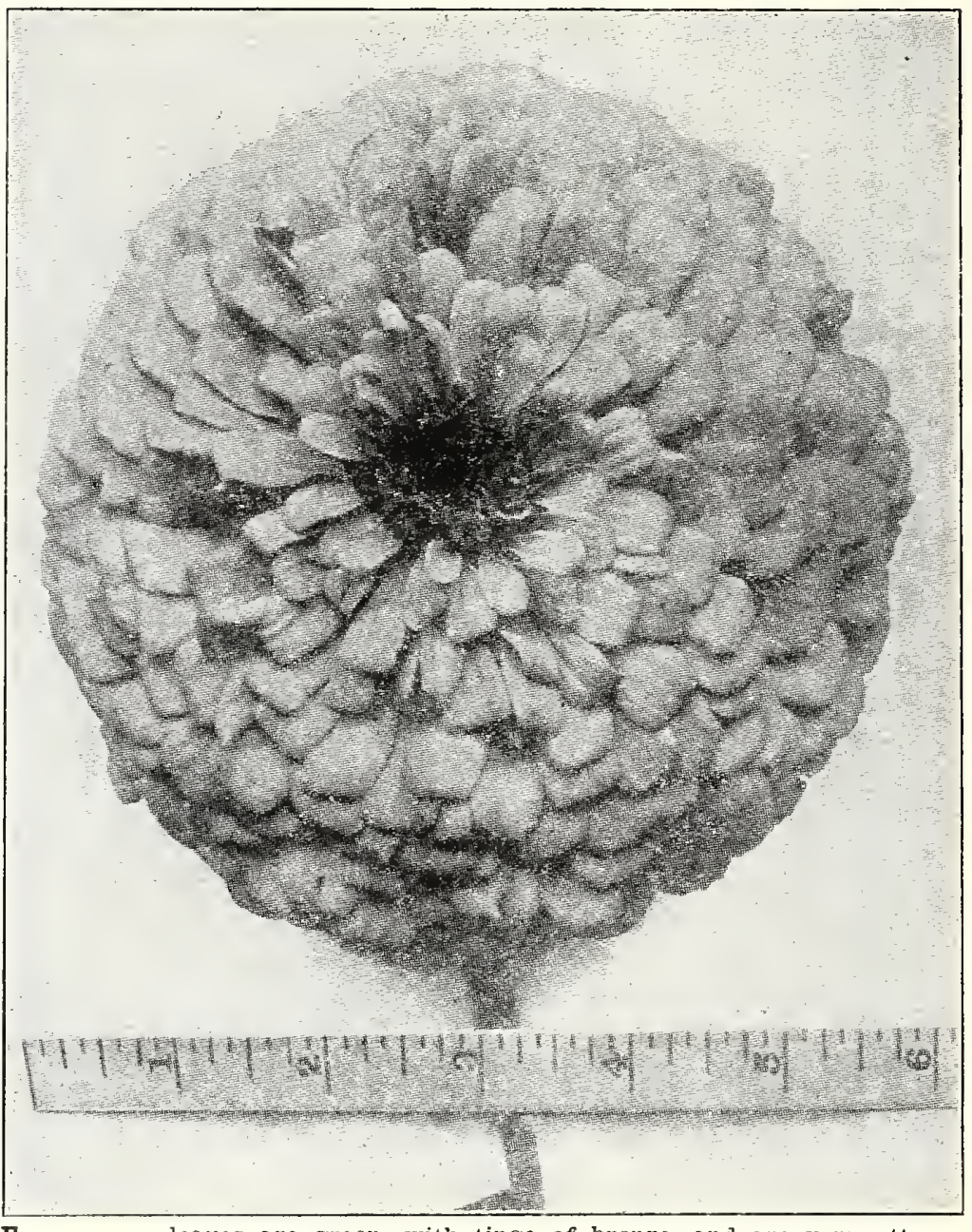

mixture of many free-blooming annuals which, once sown, require little care, and, sown in this way, almost none. In fact, with the exceptions of thinning out some plants where they grow too thickly and removing an occasional weed the bed often looks better let alone, is more in keeping with its name, and more like some lovely spots where wild plants grow. The possibilities of this mixture are great, the different seasons of blooming insuring constant succession of flowers from early in the season until hard frost, and in the helght of bloom, some new flower nearly every day. It affords a very easy and cheap way to quickly fll large areas of any unsightly place, and the results will surprise those who never saw a wild-flower garden; not only will the bed be attractive, but also will furnish many good flowers for cutting. To insure the greatest possible variety, the bed should be quite large. Pkt. 10 cts., 1/2 07.20 cts., 0z. 35 cts., 1/4 lb. 80 cts.

\section{Cinnamon Vine}

A beautiful hardy climbel of extremely rapid growth, growing the first season from 15 to 30 feet and, when the root becomes fully established, to a much greater length. The

\section{THE WORCESTER "DOLLAR" COLLECTION OF ANNUAL FLOWERS}

Owing to the popularity of this collection during 1928, we are again offering this collection of 15 pkts. postpaid for $\$ 1.00$.

Each the best in its class. With one of these collections you can have flowers all Summer.

Alyssum-Llttle Dorrlt

Aster-Worcester Mlxed

Balsam-Choice Mlxed

Calendula-Choice Mixed

Candytuft-Mixed Colors
Four O'clock-Mlxed Colors

Marigold-Double Mlxed

Mignonette-Grandlflora Mlxed

Nasturtium-Dwarf Mlxed

Petunla-Finest Mixed
Phlox-Finest Mlxed

Pansy--Worcester Mixed

Sweet Peas-Spencer Mixed

Sceolosa-Mixed

Zinnla-Mammoth Mixed Colors

The above collection will be sent postpaid to any address for $\$ 1.00$. 


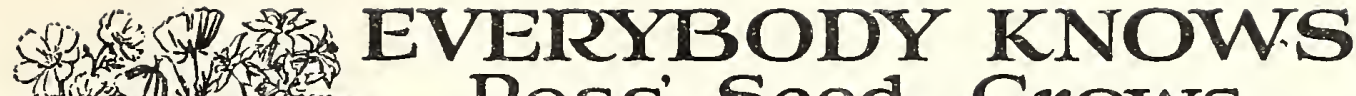 Ross' Seed Grows}

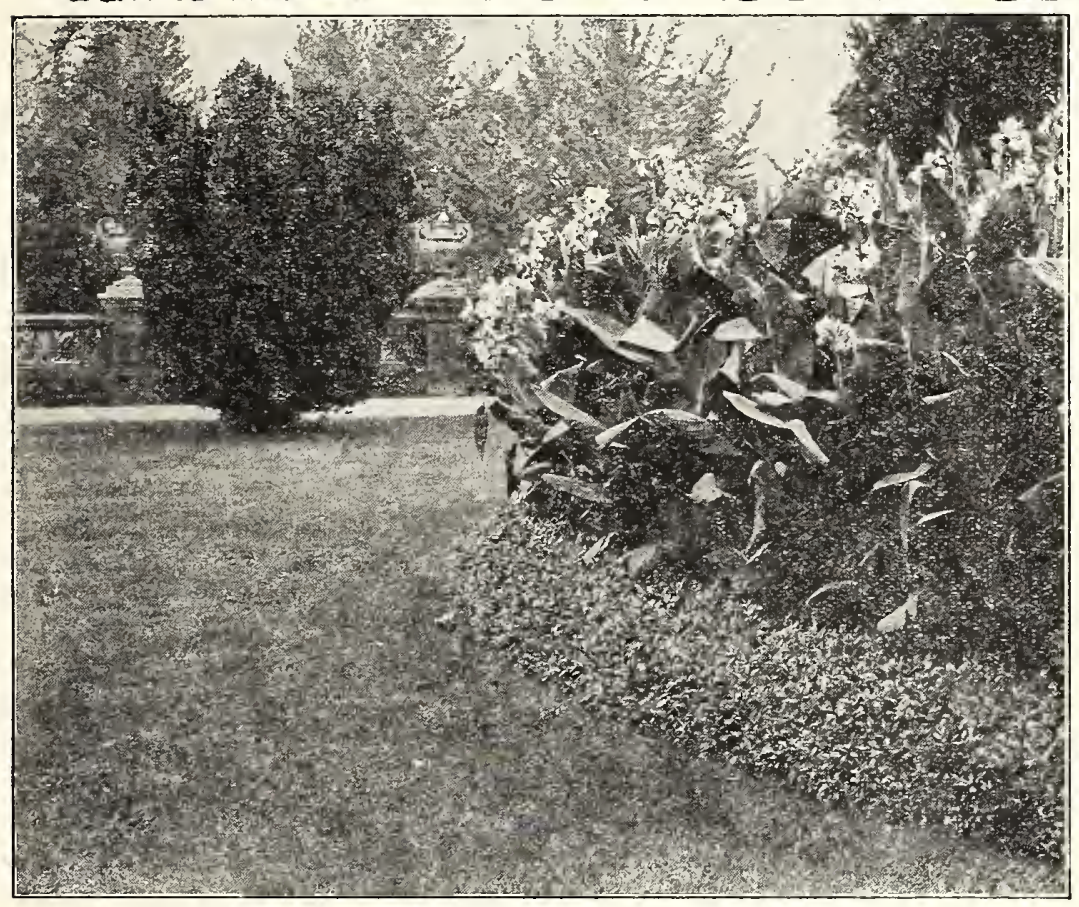

\section{Best Quality Cannas}

Dormant roots of the varieties listed below until May ist only. For a brilliant show all summer there is no plant excelling the Canna; it even surpasses the Geranium in its gorgeous display or brillant colors, bloom18 inches apart each way.

APRICOT. This recent introduction brings us a new shade of red and a most gorgeous flower. The blossoms are very large and of a clear, velvety shade of deep cerise. The foliage is a pure deep green of pleasing appearance and the flowers come in succession on good stems from four to five feet tall. One must see this magnificent canna to appreciate it. Each 20 cts., 3 for 50 cts., doz. \$1.75.

KIMG EUMBERT. Truly a king among the cannas, its majestic growth is doubly enhanced by a massive coppery scarlet flower and the broad, deep bronze foliage. It grows 4 feet high and is splendid as a center, edge with a dwarf yellow canna. Each 20 cts., 3 for 50 cts., doz., $\$ 1.75$.

IOUISIANA. Strong, vigorous grower; attains a height of 7 feet; producing a dense mass of glossy green foliage and large, vivid scarlet flowers. Each 15 cts., 3 for 40 cts., doz. $\$ 1.50$.

SHENANDOAF. This is a dwarf bronze foliage, pink of merit. The blossoms open a light carmine pink and later develop a light salmon tint which is
spread evenly over the whole flower. It grows from three to four feet. Each 15 cts., 3 for 40 cts., doz. $\$ 1.50$.

THE PRISIDENT. Height 4 feet. In color, a rich, glowing scarlet and the immense, firm rounded flowers, 7 inches across when open, are produced on strong, erect stalks well above the large, rich green foliage. Each 20 cts., 3 for 50 cts., doz. $\$ 1.75$.

WYOMrNG. Might be called King of the Giants, for it is one of the most majestic, with the double attraction of having a luxuriant growth of rich purple foliage. Above this are borne great plumes of massive orangecolored blossoms, true orchid-shaped with large rounded petals, Each 15 cts., 3 for 40 cts., doz. $\$ 1.50$.

WINTZERS CoIOSSAI. 5 feet. Green foliage. A striking, vivid scarlet that retains its brilliancy. One of the largest flowering of all, producing immense trusses. Each $15 \mathrm{cts} ., 3$ for 40 cts., doz. $\$ 1.50$.

YFIIOW EING HUMBERT. A sport of that most popular of all Cannas, King Humbert, producing larger flowers of a beautiful shade of yellow lightly spotted red, with green foliage, five and six clusters of flowers at a time. Each 20 cts., 3 for 50 cts., doz. $\$ 1.75$.

\section{JAPANESE LILIES'}

AURATUM (Golden Banded Iily.) Enormous, measuring frequently 8 to 12 inches across; pure white, spotted crimson, each petal marked in the center with a band of yellow. Flowers in August; delightfully fragrant. Each 35 cts., doz. $\$ 3.50$

SPECIOSUM AIBUM. The best late flowering, pure white, hardy garden lily; of easy culture. The graceful stems and foliage are set off to wonderful advantage by the pure white blooms. Each $35 \mathrm{cts}$., doz. $\$ 3.50$.

SPECIOSUM RUBRUM OR ROSEUM. Delicate pink, almost white, spotted red; one of the old garden favorites; height, 3 leet; flowers in August and September. Each 50 ots., doz. $\$ 5.00$.

\section{REGALE LILY}

(Lilium Myriophyllum)

It is pure, waxy white, with a lemon yellow throat and a trumpet about 6 inches long, and when the flower is fully developed it is about 7 inches across. It has a wonderfully delightful perfume, somewhat resembling the variety Lilium Auratum. If you want the best of the hardy family, plant some of this variety. $2-21 / 2$ in. diameter. Each 45 cts., doz, \$4.50. Smaller

\section{STRAWBERRY PLANTS}

All Strawberry plants are growing when your order is received. We do not handle cold storage plants. All orders will be sent direct from the nurseries in Massachusetts whenever possible and the plants should reach our customers in fresh condition.

Because of excessive wet weather the past season not as many plants were produced but these are exceptionally good plants and should come through the winter in fine condition.

While it is not our custom to substitute we feel that in the event of our being sold out of any variety it would be to the advantage of our patrons to allow us this privilege. We cannot supply potted plants. Varieties marked Imp. are imperfect and must be planted with some perfect variety marked Per.

BUBACH (IMP.) A large but very uniform berry of good color, one of the best.

SAMIPIE (IMP.) One of the best market berries in cultivation. Fruit of fine color and flavor.

SEFATOE DUNIAP (PER.) A dark red berry, good size, excellent flavor.
HowAR 17 (PER.) One of the best early berries, bright red color, large size, very

FIRST QUAIITY (PER.) Fine quality,

dark green foliage, yields well, very uni-

form in shape and color.

(Postpaid, $100 \$ 2.00,500 \$ 8.00$. 1,000 by express not prepaid $\$ 13.50$.)

\section{Everbearing Varieties}

PEERIESS. An excellent berry for home use, of large size and beautiful, glossy in spring and fall.

SUPERB. Fruit is large and firm, good shape and color. A fine home variety. Postpaid, $100 \$ 2.50,500 \$ 10.00$.

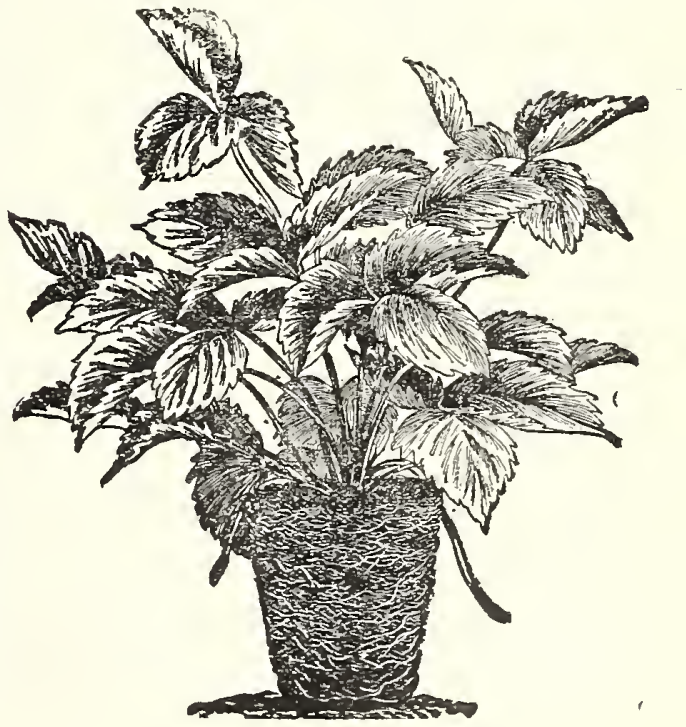



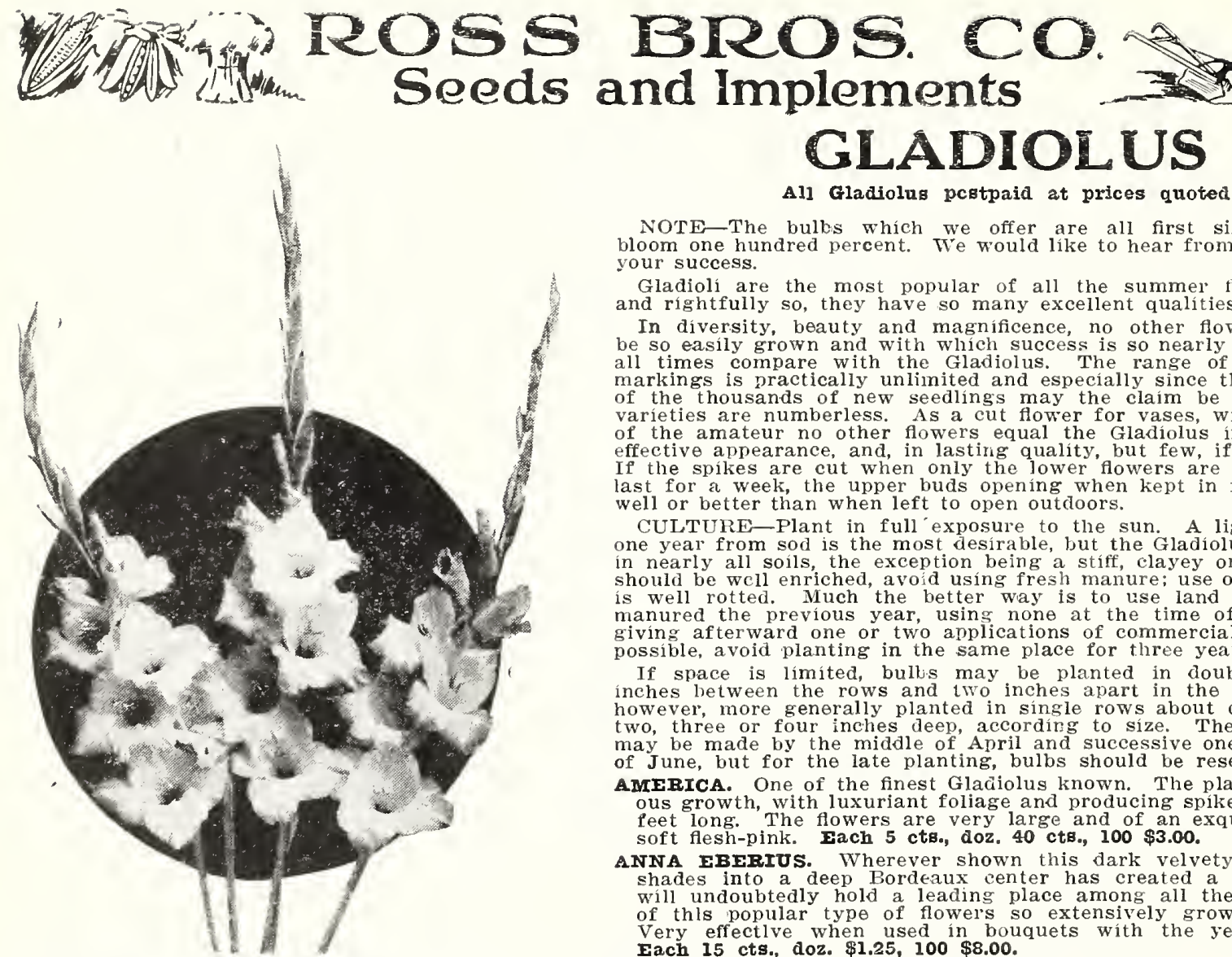

All Gladiolus pcatpaid at prices quoted

NOTE-The bulbs which we offer are all first size and should bloom one hundred percent. We would like to hear from you regarding your success.

Gladioli are the most popular of all the summer flowering bulbs and rightfully so, they have so many excellent qualíties and uses.

In diversity, beauty and magnificence, no other flower which can be so easily grown and with which success is so nearly certain, can at all times compare with the Gladiolus. The range of colorings and markings is practically unlimited and especially since the introduction of the thousands of new seedlings may the claim be made that the varieties are numberless. As a cut flower for vases, within the scope of the amateur no other flowers equal the Gladiolus in striking and effective appearance, and, in lastirig quality, but few, if any, compare. If the spikes are cut when only the lower flowers are open they will last for a week, the upper buds opening when kept in fresh water as well or better than when left to open outdoors.

CULTURE-Plant in full exposure to the sun. A light, moist soil one year from sod is the most desirable, but the Gladiolus thrives well in nearly all soils, the exception being a stiff, clayey one. While soil should be wcll enriched, avoid using fresh manure; use only that which is well rotted. Much the better way is to use land that was well manured the previous year, using none at the time of planting, but giving afterward one or two applications of commercial fertilizer. If giving afterward one or two applications of commercial f
possible, avoid planting in the same place for three years.

If space is limited, bulls may be planted in double rows, four inches between the rows and 1 wo inches apart in the row they are, however, more generally planted in single rows about one foot apart, two, three or four inches deep, according to size. The first planting may be made by the middle of April and successive ones till the first of June, but for the late planting, bulbs should be reserved.

AMERICA. One of the finest Gladiolus known. The plant is of vigor-

ous growth, with luxuriant foliage and producing spikes two to three reet long. The flowers are very large and of an exquisite shade of soft flesh-pink. Each 5 cts., doz, 40 cts., $100 \$ 3.00$.

ANNA EBERIUS. Wherever shown this dark velvety purple which shades into a deep Bordeaux center has created a sensation, and will undoubtedly hold a leading place among all the darker colors of thls popular type of flowers so extensively grown for cutting. Very effectlve when used in bouquets with the yellow varieties. Each 15 cts., doz. $\$ 1.25,100 \$ 8.00$.

BARON HULOT, or BLUE KING. A really fine blue Gladiolus, in color a rich royal violet blue; very effective when cut and used in conjunction With Sulphur King or other yellow variety. Each I5 cts., doz. $\$ 1.50,100 \$ 10.00$.

CRIMSON GIOW. A striking shade of a brlliant crlmson, one of the most effective. Each 15 cts., doz. \$1.35, 100 \$9.00. EVELYN KIRTLAND. A splendid varlety with large flowersof wonderful substance. Rosy pink at the edges passlng to shell pink in the throat, with flery scarlet blotches on lower petals. Each I5 cta., doz. \$1.25, $100 \$ 7.50$.

EMPRESS OF INDIA. Rich, velvety maroon with white blotch in the throat; the darkest Gladiolus A very handsome flower. Each 10 cts., doz. $\$ 1.00,100 \$ 7.50$.

FLoRA. Beautiful golden yellow, large pure flowers. Each 10 cts., doz. \$1.35, $100 \$ 9.00$.

GLORY OF HOILAND. Very fine white, tinted rose. Each 10 cts., doz. 80 cts., $100 \$ 5.00$.

GOIDEN MEASURE. Very large, dark golden yellow; the best in the yellows. Each 20 cts., doz. $\$ 2.25,100 \$ 15.00$.

GRETCHEN ZANG. Large, heavy blooms; a beautiful, soft shade of pink, blending into searlet on lower petals. Each 10 ctü., doz. 80 cts., $100 \$ 5.00$.

HERADA. Blooms of lmmense size on tall straight spikes; the color is pure mauve, gllstening and clear whth deeper markings in throat. Each 10 cts., doz. 80 cts., $100 \$ 5.00$.

HAIIEX. Delicate salmon-pink predominates, with a slight rosy tinge, lower petals have a creamy blotch with a bright red stripe in center. Each 10 cts., doz. 80 cts., $100 \$ 5.00$.

IDA VAN. A beautiful deep salmon red, or flaming orange pink. Each 10 cts., doz. $80 \mathrm{cts.,} 100 \$ 5.00$.

IE MARSHAL FOCH. Flower is of immense size, well opened and beautifully ruffled. The color is a warm salmon pink, flaked and striped deeper salmon towards the edges of petals. It is a most unusual and striling flower, and is universally admiled. Fach 10 cts., doz. 80 cts., $100 \$ 5.00$.

LOUISE. The showiest of all Gladioll; wherever shown, meets with favor; dis: tinct in form; clear, pure lavender; a blotch of velvet red towards center; resembles the orchid color; the flowers have been used as a substitute for orchlds by leading florists; this is one variety that differs from all others: big flowers: free grower; this varlety is in a class by itsclf. Each 15 cta., doz. $\$ 1.50,100 \$ 10.00$.

MARY PICKFOR.D. Dellcate creamy white. Each 15 cts., doz. \$1.25, $100 \$ 8.00$.

MARY FENNEL. Beautiful deep lavender flowers on tall slender splkes; lower petals penciled with primrose-yellow. Each 15 cts., doz. \$1.25, $100 \$ 88.00$.

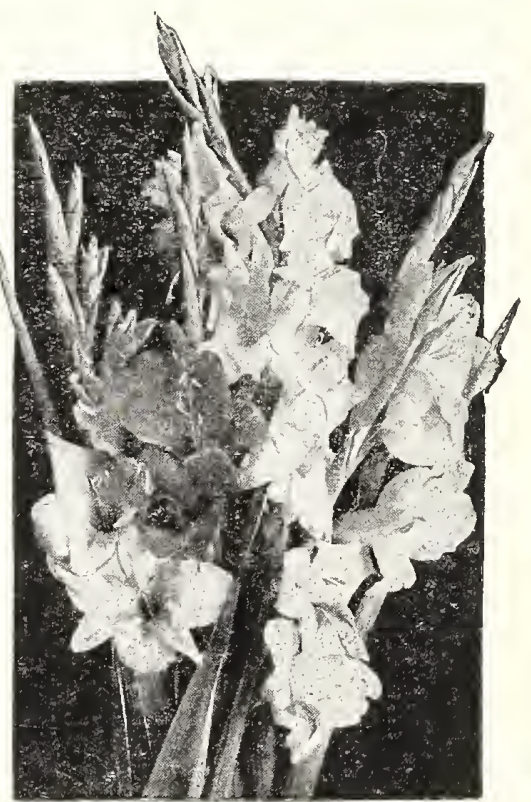




\section{GVRYBODY KNOWS}

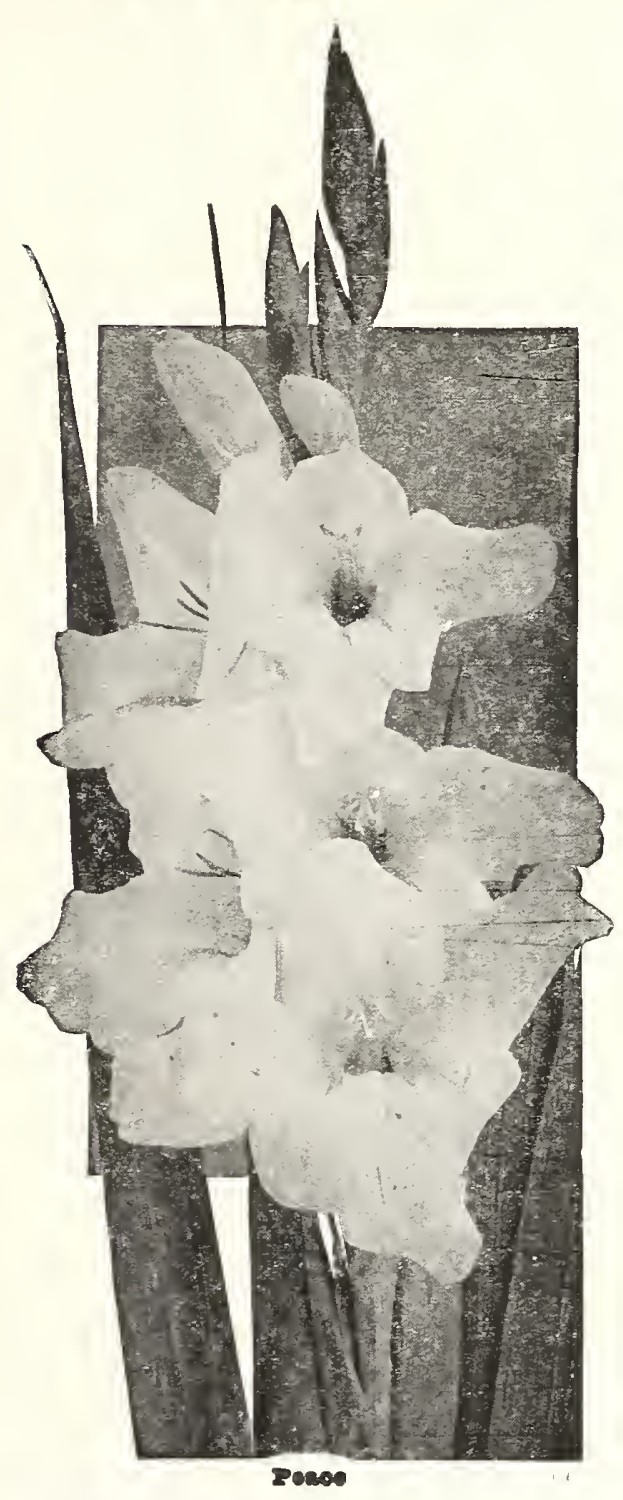

GLADIOLUS-Continued

All Gladiolus sent postpaid at prices quoted

MaS. MaRk: Light blue with darker spot. Each 15 cts., doz. \$1.50, $100 \$ 10.00$.

MES. PRANCIS KING. A new variety which excited great comment and admiration, both for size of flower and beauty; the color of the flower is light scarlet; the flowers are very large, usually measuring from $31 / 2$ to 4 inches in diameter. Fach 10 cts., doz. 80 cts., $100 \$ 5.00$.

MIRS. FRANK PENDIETON. Large open flowers of light pink with dark red blotch at throat. Flowers well set on exceedingly tall spike. A very attractive and strong growing kind. Each 10 cts., doz. 80 cts., $100 \$ 5.00$.

IIRS. WATT. Brilliant wine, having no markings of other shades, closely resembling a Hadley Rose. Flowers are well placed on a very stout stalk with many open at one time. Midseason to late. Fach 10 cts., doz. \$1.00, $100 \$ 7.50$.

MYRTIE. Tender and delicate rose pink. One of the most beautiful pink varieties yet introduced. Each $15 \mathrm{cts}$. doz. \$1.50, $100 \$ 10.00$.

NIAGARA. A shade of rich cream combined with canary yellow; the individual flowers are very large and are borne in pairs, one opposite the other. Each 10 cts., doz. \$1.00, $100 \$ 7.50$.

1910 EOSE. Pure rose pink of extra fine shade. Narrow white central line on lower petals. Each 10 cts., doz. $\$ 1.00,100 \$ 7.50$.

ORANGE GIORY (Kunderdi Glory type.) Grand orange colored with beautiful lighter throat. Very rich and striking color. Beautiful and distinct. Each 15 cts., doz. $\$ 1.35,100 \$ 9.00$.

PANAMA (Seedling of America.) Long spike, color deeper pink than America, admired by all who have seen it in flower. Each 10 cts., doz. 80 cts., 100 $\$ 5.00$.

PEACE. Fine large white with wine pencilings on lower petals. Very good, strong and healthy. Each 10 cts., doz. 80 cts., $100 \$ 5.00$.

PRIDE CT GOSERE (K.) One of Kundred's giant ruffled Gladiolus; color salmon or flesh pink; petals elegantly waved. Each 10 cts., doz. \$1.35, $100 \$ 9.00$.

PRINCE OF WAIES. Beautifully shaded apricot, with brush-marks of orange on a yellow-tinted throat. Perfect in form, large in size, with a good stem, and one of the first to bloom. Each 10 cts., doz. 80 cts., $100 \$ 5.00$.

RED EMPEROR. Very large flower of bright scarlet color. A choice red. Fach 20 cts., doz. $\$ 2.25,100 \$ 15.00$.

ROSE ASH. A grand novelty named Rose Ash by reason of its distinctive combination of old rose tones and ashes of roses. Each $15 \mathrm{cts}$. doz. $\$ 1.50$, $100 \$ 10.00$.

SCAEIANO. Light, bright orange-red. Fine spike and flower, finely ruffled. Each 10 cts., doz. \$1.00, $100 \$ 7.50$.

SCARIFT PRINCEPS. Large spike of massive crimson-scarlet flowers, 5 to 6 open at one time. Each 10 cts., doz. $\$ 1.35,100 \$ 9.00$.

SCHWABEN. Canary yellow shading to sulphur; stripes of carmine on lower petals. Blossoms large. Stalks tall and straight. Each 10 cts., doz. 80 cts.,
$100 \$ 5.00$.

SUIPHUR KING. A long spike of clear sulphur yellow flowers. The best yellow in Gladiolus. Each 15 cts., doz. $\$ 1.50,100 \$ 10.00$.

WAR. Deep blood red, shaded crimson. One of the largest and finest of the red Gladioli. Each 10 cts., doz. \$1.35, $100 \$ 9.00$.

WILBRINK. Sport of Halley. It retains the earliness of that variety, but has a delicate pale pink color, somewhat similar to "America." Each $10 \mathrm{cts}$., doz. 80 cts., $100 \$ 5.00$.

YEILOW HAMIMER. Pure yellow with a little red mark in the throat. Each 10 cts., doz. \$1.00, $100 \$ 7.50$.

Our worcester Mistare-From Named varleties

A mixture of our own preparation comprising many named varieties, selections from all classes, unsurpassed in diversity of both colors and types and in quality of flowers. Includes a good proportion of white and light shades and well balanced generally in proportion of colors. We consider this mixture the best value we offer. Doz. $65 \mathrm{cts} .100 \$ 4.50$

OUR CHOICE MIXTURE. We are making this just as good as we can for the price. It does not contain all the varieties it has been our purpose to make this better each year, and we know that this season it will be the best mixture that can be purchased for the prire. Doz. $10 \mathrm{cts}, 10083.00$

\section{Primulinus Hybrids}

The original of this type introduced in South Africa has been very much improved by crossing with choice garden varieties and the mixed hybrids which we offer are sure to produce some beautiful flowers. The colors are bright and varied with an undertone of yellow; from pure yellow to the deepest orange and from soft salmon pink to rich crimson. AIICE TIPIADY (Prim.) A grand, large vigorous saffroncolored Primulinus, extra fine. Strong grower. Excep. tional cut flower. Each 10 cts., doz. 80 cts.

DOROTFY WHEEIER. Richest rose pink with lighter throat. Each 10 cts., doz. 80 cts.

MAIDEN'S BIUSH. Enchantress pink. Well shaped flowers on slim strong stem, the earliest of all forcing varieties.

Each 10 cts., doz. 80 cts,
soUvirim. Beautiful, rich canary-yellow; tall, graceful spike. Each 10 cts., doz, $\$ 1.00$.

STAIDDARD MOXTURE. This mixture is made up of good standard sorts in a big variety and should not be compared with the bargain mixtures of culls and discarded kinds often offered. We recommend this mixture to those who desire a quantity of good tlowers without speclal who desire a quantity of good flowers Without special
reference to color effect. \$ach 5 ets., doz. 50 cts., 10083,50 . 


\section{New and Rare Dahlias}

EAGLE ROCK BEAUTY. A most beautiful combination of pink and cream and is greatly admired by all who have seen it. It has strong stems holding perfectly erect the inmense blooms. Each \$5.00.

EIIINOR VANDERVEFR. One of the most admired Dahlias in our garden. Color lavender pink; flowers large size, on long stiff stems; good bloomer and keeps well when cut. Each \$2.00.

EI DORADO. Vivid gold coloring, which is emphasized by tlie deeper tones at the base of the petals. Extra fine flower and a good stem. Each $\$ 2.00$.

FAITH GARIBAIDI (Dec.) Deep lavender rose, very large, stem extra strong, growth of plant good. Each \$2.00.

JGRSIY'S BEAUTY. A very fine true pink, flowers of perfect shape produced on long, straight, stiff stems. Very flee bloomer, and a splendid keeper. Each $\$ 1.00$, doz. $\$ 10.00$

JERSEY'S KING. The color is carmine, the flowers are
large and exceptionally fine. Each $\$ \mathbf{I . 0 0}$, doz. $\mathbf{\$ 1 0 . 0 0}$.

MRS. JOFN I. EMTERSON. One of the largest and most attractive Decorative Dahlias grown. In color, a beautiful light golden yellow, overlaid carmine red. A favorite garden and exhibition Dahlia that will produce six to eight inch flowers. Each \$1.C0, doz. \$10.00.

PRIDE OF WAYME. Produces flowers of enormous size on stiff stems. Color a beautiful rich plum. Fine for exlibition, and should be in every garden. Each \$1.00, doz. $\$ 10.00$.

MRS. C. R. BENEDICT. A clear light yellow, one of the largest grown, a wonderful flower. $\mathbf{E a c h} \mathbf{\$ 2 . 0 0}$.

\section{Peony-Flowered Dahlias}

BESSIE SEABURY. White, very dainty, overlaid a delicate mallow-pink. Each 25 cts., doz. \$2.50.

ELIEN KEIIEY. A long stemmed, free-flowering, golden yellow. Each 25 cts., doz. $\$ 2.50$.

HEIFI KETIER. Almost identical with the well known pink dallia, Rosemawr, Each 50 cts., doz. \$5.00.

MME. VAN BYSTEIT. A very distinct and new shade, lilacblue throughout, holding blooms well above the foliage. An early and abundant bloomer. Each 25 cts., doz. \$2.50.

MLR. BOWEN TUFTS. Deep rosy-purple blossoms, which are produced well above the foliage upon long, graceful stems. Each 25 cts., doz, \$2.50.

MRS. JACQUES FUTREIIE. Flowers of medium size, but very attractive. An exquisite lemon-yellow, heavily splashed scarlet. Very freeflowering. Each 25 cts., doz. $\$ 2.50$.

MRS. M. W. CROWEII. Color, a beautiful orange-yellow. Very free-flowering. Each 25 cts., doz. \$2.50.

NEWPORT DANDY. A lilac-pink of the most delicate shade The yellow center is open with the inner petals curling and twisting over it. Each 25 cts., doz. \$2.50.

QUEEN MARGUERITE. Salmon pink. A wonderful large flower. Each \$1.00, doz. \$10.00.

UNCIE SAM. Orange buff, blending into pink at edge; reverse spinal red. Very large on long stems. Each $\mathbf{\$ 1 . 0 0}$, doz. $\$ 10.00$.

\section{Pompon Dahlias}

AMBER QUEEN. Rich, clear amber, shaded apricot. Each 50 cts., doz. $\$ 5.00$.

GANYMEDE. Anber, tinted lilac, a novel and distinct variety. Each 50 cts., doz. \$5.00.

JESSICA. Yellow, edged red-a very effective combination. Each 50 cts., doz. \$5.00.

IITTL BEAUTY. (Pom.) Soft pink. Each 50 cts., doz. $\$ 5.00$.

IITTIE MARION (Alexander.) Salmon-pink with a veining of crimson through each petal, tipped amber. Each $\mathbf{5 0}$ cts., doz. $\$ 5.00$.

PRINCE CFARIING. Cream, tipped purple. One of the best. Each $50 \mathrm{cts.,} \mathrm{doz.} \$ 5.00$.

\section{Up-to-Date Decorative Dahlias}

BONNIE BRAF. Cream shaded to blush-pink. The flowers are of a true decorative form of immense size. Each $\$ 1.00$, doz. $\$ 10.00$.

CrAmpaGNE. An immense flower. The color is a delightful warm autumn shade. Very free bloomer, and has long rigid stems. Each $\$ 1.00$, doz. \$10.00.

EIIZABETE SIOCOMEE. Color rich purplish-garnet. The large flowers are carried on long stiff stems. Each 50 cts., doz. $\$ 5.00$.

EARI WIIIIAMS. The brilliant crimson and white of this flower are well cistributed. It has both blooming quality and size. Fach \$1.00, doz. \$10.00.

GIORIASA. Immense flowers of pure gold color, slightly reddish towards cellter. Long leafless stems. None better for exhibition or cutting. Fach 50 cts., doz. \$5.00.

JUNIOR. An enormous flower, one of the largest Dahllas grown. A pure lavender. Fine for exhibition purposes. sach \$1.00, doz. $\$ 10.00$.

IARI ERIE. One of the deepest lavender Dahlias grown. Fine exhibition flower. Each \$1.00, doz. \$10.00.

MAS. EDITE HAXWARD. The color is a clear lemon yellow, it will produce flowers from 6 to 8 inches in diameter and has a wonderful stem and will keep longer after being cut than any other Dahlia. Each \$2.00.

MRS. I. DE VER WARNER. Deep mauve-pink. One of the very best Dahlias grown. Long stiff stems and excellent for cut-flowels. Each \$1.00, doz. \$10.00.

SNOWDRIFT. A giant, clear white. The flower has good depth with broad waxy petals of the true Decorative type. Each \$1.00, doz. \$10.00.

THE BASHFUI GIANT. One of the largest dahlias grown, its beautiful color being an apricot with golden shadings. Each $\$ 1.00$, doz. \$10.00.

WM. H. STocomBr. The largest and best pale yellow Decorative to my knowledge. A clear sulphur yellow passing to martinus vellow at tips. Each \$1.00, doz. \$10.00.

\section{Decorative Dahlias}

AZAIIA. Very large, soft creamy yellow, with outer petals suffused pink. Each 50 cts., doz. \$5.00.

CAIIBIA. A beautiful soft rose pink passing to a lighter pink towards the center. Extra good stem. Fach 50 cts., doz. $\$ 5.00$.

CIIFORD W. BRUTON. A large canary-yellow. Each 25 cts., doz. \$2.50.

FIANK A. WAITER. A charming shade of deep lavenderpink. For garden decoration or for cut flowers this variety is exceptionally good, having long stems and producing flowers in great abundance. Each 25 cts., doz. \$2.50.

JACK ROSE. The identical shade of the rose with the same name. Free-flowering. Each 25 cts., doz. \$2.50.

IE GRAND MANTTOU. The color of this superb variety is pure white artistically striped, splashed and blotched deep violet-purple. The nlants occasionally bear a solid purplecolored flower. Each 50 cts., doz. \$5.00.

MIIIIONAIRE. Most delicate lavender, with faint pink cast overshading it, the whole having a blending of white Each 50 cts., doz. \$5.00.

PRIDE OF CAIIFOris. Called the "American Beauty" Dahlla. Huge crimson red flowers, produced on long straight stems. Each $\mathbf{5 0}$ cts., doz. \$5.00.

ROSA NEII. The color is a clear bright rose, and the flowers are very large. Good stems and habits. Each 50 cts., doz. $\$ 5.00$.

OrA DOW. A beautiful velvety maroon, effectively tipped white. Each 25 cts., doz. \$2.50.

SYIVI. White, heavily edged pin. Each 25 cts., doz. \$2.50. SOUVENIR DE GUSTAVE DOAZON. The color is a pleasing shade of orange-red. The plant is a very tall, vigorous grower, glossy green foliage. Very long stems. Fach 25 cts., doz. \$2.50.

WIIEEIM MIIIER. Very brilliant purple, This is a fine variety. Each 25 cts., doz. \$2.50. 


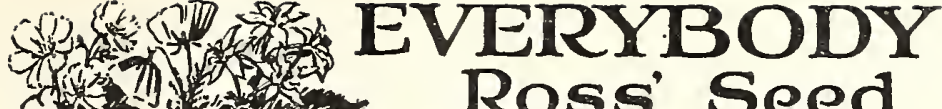 Ross' Seed}

\section{Cactus Dahlias}

BERTRAM S. VARIAN. (Incurved Cactus.) A very brillant, deep scarlet of the moderately incurved form, of good size on long stems. This is one of the freest flowering Dahlias in our !ist. $75 \mathrm{cts}$, each, doz. $\$ 8.00$.

BRIDE'S BOUQUET. (Hybrid.) An ideal white cactus and profuse bloomer, extra long stem, and a Dahlia that stands. up well when cut. 50 cts. each, doz. $\$ 5.00$.

COUNTESS OF IONSDAIE. (Hybrid.) Deep salmon-red. One of the best. Very free. $50 \mathrm{cts}$. each, doz. $\$ 5.00$.

EARI OF PEMREOKE. (Hybrid.) Bright plum color; large bold flower. $25 \mathrm{cts}$. each, doz. $\$ 2.50$.

EUREKA. (Straight.) Color very deep purple. Petals are long, straight and tightly quilled. $25 \mathrm{cts}$. each, doz. $\$ 2.50$.

J. H. JACKSON. The finest black Cactus Dahlia in existence, Color, a perfectly gorgeous, deep velvety, blackish-maroon. 25 cts. each, doz. $\$ 2.50$.

IIB EIIE. (Straight.) Clear, deep rose-purple. 25 cts. each, d02. $\$ 2.50$.

PERIE DE IYON. (Hybrid.) A pure white exhibition yariety of great value. Petals fringed or nicked, giving unique appearance. 35 ct\$, each, doz. $\$ 3.50$.

TUSTU. (Straight.) The color is perfectly gorgeous-a beautiful velvety maroon. The petals are very long, tightly quilled. $50 \mathrm{cts}$. each, doz. $\$ 5.00$.

W. B. CHIIDs. (Hybrid Cactus.) A very reliable varlety. Color a beautiful dark purple-maroon. 35 cts. each, doz. $\$ 3.50$.

\section{Single Dahlias}

AUBRIGHT BEAUTY. A pure, waxy white variety. $25 \mathrm{cts}$. each, doz. $\$ 2.50$.

ECFFORD CENTURY. One of the largest of the single varieties. Pure white, streaked and dotted purple-crimson. 25 cts. each, doz. $\$ 2.50$.

CARDINAI CENTURY. Rich cardinal. One of the best in form and coler. $25 \mathrm{cts}$. each, doz. $\$ 2.50$.

ROSE PINK CENTURY. A rose pink shade. A very large variety and without doubt the best of its color. $25 \mathrm{cts}$. each, doz. \$2.50.

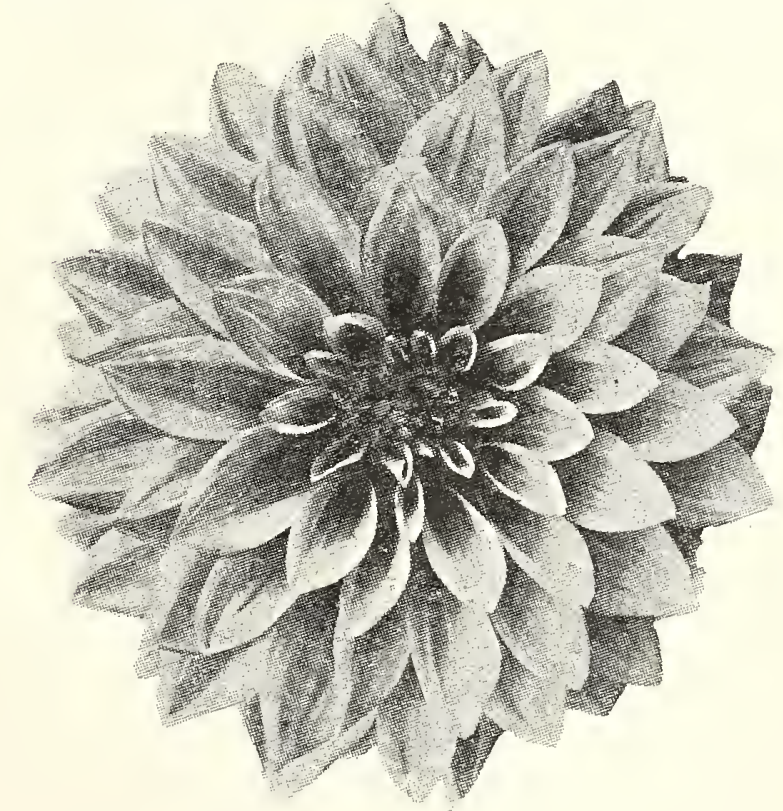

Mrs. I. De Ver Warner

Do you receive our fall catalogue for Dutch bulbs? We llst a full llne of Tulips, Hyacinths and miscellaneous bulbs, also American grown Narcissus. If you do not receive this book send us your name and address and we will gladly put you on our malling list for our next fall catalogue.

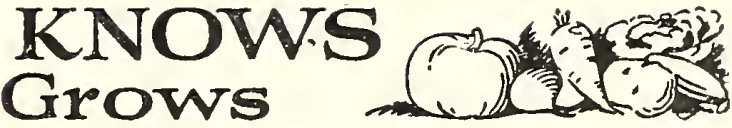

Mixed Dahlias

Postpaid, \$1.00 per doz.; bj expless, 90 cts. per doz.; $\$ 6.00$ per 100 .

These include some of our best varieties, those of which labels have been lost, and at times varietles of which we have a surplus. While all classes are usually included, we give no guarantee that any lot sent out will include all, nor should it be understood that thc customer is privileged to order those of any one class. We shall, however, send a good assortment of colors, and are sure the mixture will be found very satisfactory.

\section{Choice Collection of Mixed Dahlias}

We are offering for this season a wonderful opportunity to secure a collection of our named varieties at a very low price.

There are twelve good strong roots in this assortment whlch at catalogue price would sell at $\$ 3.50$. Our price cash with order, $\$ 2.00$, postpaid.

\section{Show Dahlias}

A. D. IIVonI. Beautiful soft pink. Well formed flowers with long stems. Free-flowering. $25 \mathrm{cts}$, each. doz, \$2.50.

AMIERICAN BEAUTY. The flowers are of gigantic size and are produced on long, heavy stems, well above the foliage. The color of this acquisition is a gorgeous wine-crimson. $35 \mathrm{cts}$. each, doz. $\$ 3.50$.

ARABEIrA. Pale lemon, shading to primiose at the tips, the whole being daintily overlaid with pink. 25 cts. each, doz. $\$ 2.50$.

DOROTFIY PEACOCK. The color is that beautiful, clear, live pink that appeals to everyone. $35 \mathrm{cts}$. each, doz. \$3.50.

D. M. MrOORE. Deep velvety maroon, almost black; extra fine. $50 \mathrm{cts}$. each, doz. $\$ 5.00$.

GLORIE de GUISCARD. An almost indescribable combination orange, red, yellow, pink and white. 25 cts. each, doz. $\$ 2.50$.

IMPERIAI. Deep purplish maroon. $25 \mathrm{cts}$. each, doz. \$2.50.

IES AMOURS DE MADAMI. Delicate pale rose, striped scarlet. 35 cts. each, doz. $\$ 3.50$.

IUCY rAUCET. Pale yellow, striped deep pink or light magenta. Very large and free-flowering. $25 \mathrm{cts}$. each, aoz. $\$ 2.50$.

MAUDE ADAMS. The color is a pure snowy white, very effectively overlaid clear delicate pink. 50 cts. each, doz. $\$ 5.00$.

MISS HEIFN HOIIIS. Deep scarlet. Blossoms are on long, stiff stems, well above the foliage. $50 \mathrm{cts}$. each, doz. $\$ 5.00$.

STORM KITG. Color, a pure white. Flowers produced on good stems, well above the foliage. Free-flowering. 25 cts. each, doz. $\$ 2.50$.

STRADIIIA. Beautiful deep purple-crimson. Exceptionally free-flowering. Stems long and wiry. $25 \mathrm{cts}$. each, doz. $\$ 2.50$.

VIVIAN. A wonderful flower, the color being white, effectively edged, rose-violet. One of our champions and a variety worthy of the highest words of praise. 25 cts. each, doz. $\$ 2.50$.

\section{Collarette Dahlias}

ACHISVEMTNT. The flower is a clear, rich velvety maroon collarette a beautiful snowy white, very daintlly overlaid with a delicate shade of pinkish-crimson. 25 cts. each, doz. $\$ 2.50$.

AMI CACHAT. Orange-red, yellow collarette. 25 cts. each, d02. $\$ 2.50$.

EXPOSIIION do IYON. Bright garnet tipped yellow. Collar white, lavender and crimson. $25 \mathrm{cts}$. each, doz. $\$ 2.50$.

VIEGINIA IEI. In color a deep velvety carmine, edged sulphur-yellow; collarette, pale sulphur-yellow. $25 \mathrm{cts}$. each, doz. $\$ 2.50$. 


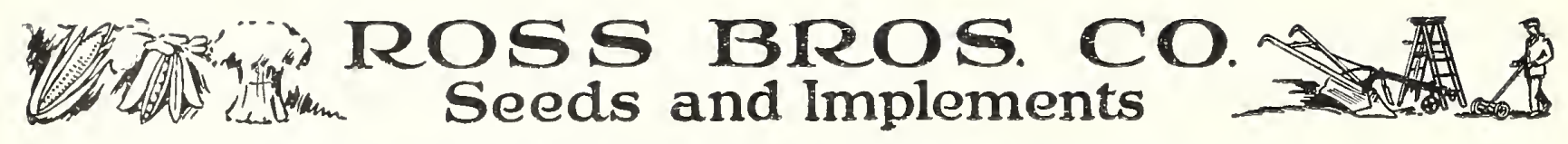

\section{Fertilizer and Fertilizing Materials}

This is one of our specialties and we can furnish either ready mixed or unmixed goods for all purposes. Parties wishing for lalger quantities than are quoted are requested to write for special price. We can make you very low price on carload of mixed goods, also on Canada Hardwood Ashes, Bone, Lime, Nitrate of Soda and Sulpiate of Aminonia, Where we can save the expense of handling and storing this material and can sell on a cash all carry basis, we can compete with anyone selling similar goods.

ROSS BROS. CO.'S MARIET GARDEN FERTILIZER An ideal fertilizer for Market Gardeners and potato glowers.

Ammonia Guaranteed Analysis:

Availab

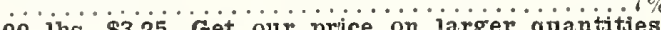

\section{ROSS BROS. CO.'S POTATO AND ONION FERTIIIZER}

This is a strictly high grade fertilizer designed for potatoes, vegetables, onions, etc.

\section{Guaranteed Analysis:}

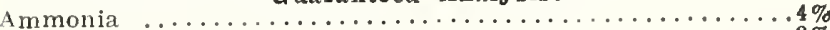

Total Phos. Acid .....................

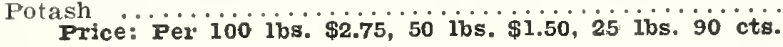

ROSS BROS. CO'S IAWN GRASS TOP DRESSIITG

Especially adapted for top dressing to grass and can bo used to seed grain where more Potash is handled. We also recommend it as being by far the best lawn fertilizer on the market.

\section{Guaranteed Analysis:}

Ammonia

Total Phos. Acid.

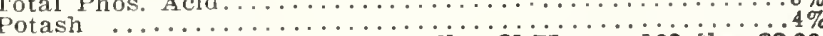
Price: Per 25 ibs. $\$ 1.00$, per 50 los. $\$ 1.75$, per 100 ibs. $\$ 3.00$.

\section{CANADA HARDWOOD ASHFS}

Unleached Haldwood Ashes, spread on the earth thickly and spaded into the earth well before planting, will clean the soil of maggot, worms, and all kinds of insects injurious to plant growth, and at the same time proride plant food. The result is better growth.

CANADA HARDWOOD ASHES. Analysis: Potash, 3 to 5 per cent: Phos. Acid, 1 to 3 per cent: Lime, 30 to 40 per per cent; Phos. Acid, 1 to pert. We handle these in large quantities and can quote carload price delivered at any freight station in New England. F. o. b. Worcester. Price: Fer $50 \mathrm{lbs}$. $\$ 1.00$, per $100 \mathrm{lbs}$. $\$ 1.85$, per ton $\$ 32.50$. Car lots in bulk delivered at all throush points, $\$ 23.00$ ton.

AGRICUITURAI IIME. Should be applied at the rate of one ton per acre. Prices: Per bag, $100 \mathrm{lbs}$., \$1.25, 500 1bs. $\$ 1.00$ per 100.

Lime is an essential element of the soil and is necessary to plant life and if it is lacking in the proper proportion the crop can not develop normally even if all other essential elements are present in abundance.

\section{SOIITEZ}

A test for Acid Soils. A money-saver and money-maker for farmers. Tells how much lime your soil requires. Full directions with each package. Price, postpaid, \$1.00.

PLATN SUPERPEOSPIATE. 16 per cent soluble and available phosphoric acid. Prices: Fer ton \$27.00, $100 \mathrm{lb}$. bag $\$ 1.50$.

PLASTrR. Gypsum (Land Plaster). Plaster plays a very important part in the proper fertilization of the land. The ideal way to use Agricultural Gypsum is with manure, for in this way the Agricultural Gypsum serves the double purpose of preserving the nitrogen in the manure and directly supplying sulphate sulphur to the land. Price: Per bag, 100 ibs., $\$ 1.50$; per ton $\$ 25.00$.

CHAMPION BRAND CHILEAN NITRATE OF SODA. The new nitrate of soda. No beating or regrinding. It is snow white and is in the form of small round pellets wlich cannot stick together. It can be distributed by side dressing machines because it will not solidify into lumps that require beating and regrinding. Purity 97 per cent. New moisture proof 100-1b bags. Price: 5 lbs. 50 cts, 25 lbs. $\$ 1.50,50$ 1bs. $\$ 2.50$, 100 1bs. $\$ 4.00$.

MURIATE OF POTAST 48\% A highly concentrated form of potash. Used in forcing vegetables and with a filler as a general fertilizer. Price: $100 \mathrm{lbs}$. $\$ 4.00$.

SUIPHATE OF AMNONIA 25\%. The most concentrated nitrogencus top dressing on the market. Price: 5 lbs. 50 cts., 25 lbs. $\$ 1.75,50$ los. $\$ 2.75,100$ lbs. $\$ 4.50$.

SUIPFATE OY POTASF $48 \%$. It is the most highly concentrated form in which this very important plant food element is obtainable. Price: 100 lbs. $\$ 4.50$.

FINE GROUND BONE. 3 to 4 per cent ammonia, 22.80 to 25.33 per cent phosphoric acid. Price: Per 25 lbs. \$1.00, per 50 lbs. $\$ 1.85$, per 100 lbs. $\$ 3.50$.

TOBACCo DUST. Fine, ground; for greenhouse use this is one of the best articles for dusting all kinds of plants that are affected with insects of any kind. Per bag 100 1bs. $\$ 4.00$, 50-1b. bag $\$ 2.25,5$ lbs 40 cts.

FUMIGA TING TOBACCO. Price: $100 \mathrm{lbs}$. \$4.50.

TOBacco strins. Used for fumigating, also used by some as a top dressing for fertilizer. We can furnish these in any quantity, even to carload lots. Prices: 5 lbs. 50 cts., 100 1bs. $\$ 3.00$.

Buyers of ton lots or over ask for prices.

\section{Groz-It Brand Pulverized Sheep Manure}

\section{For Market Gardeners and Ipecially Recommended for Lawns}

Is excellent for Golf Greens, for flower beds and especlally for fertilizing trees of all kinds, for composting for window hoxes and also good for the home garden.

Will not burn your plants, no matter in what quantities you use it, but is highly concentrated and safe for anyone to use. Can be used safely at the rate of $501 \mathrm{bs}$. per $1,000 \mathrm{sq}$. $\mathrm{ft}$., or as a general fertilizer for all crops from 1,000 to $2,0001 \mathrm{bs}$. per acre. It makes the richest and safest liquid manure, using 1 lb. to 5 gallons of water.

\section{ANAIYSIS}

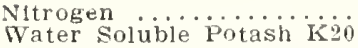

1.25 Available Phosphoric Acid.

Prices: 5 lbs., 30c; 10 lbs., 50c; 25-lb. bag, $\$ 1.00$; 50-lb. bag, $\$ 1.75 ; 100-\mathrm{lb}$. bag, $\$ 3.00$; ton $(2,000 \mathrm{lbs}),. \$ 50.00$.

Ail prices in this catalngue are based on the supposition that we get cash with the order. Parties wishing to buy goods on credit, but have never had an open account with us, will avofa delay if they furnish with the ordar bank references. 


\section{EVERYBODY Ross' Seed}

\section{Premier Poultry Manure}

\section{Pulverized Poultry Manure-Nature's Best Plant Food}

Poultry Manure in concentrated form can be used profitably on a greater range and variety of vegetation than any other fertilizing material whether of an organic or a chemical origin.

Processed Poultry Manure is one of the safest and most reliable forms of plant food that can be applied to soil and will not burn or injure the most delicate and tender vegetation if used in reasonable amounts. Last, but not least, it possesses a bulk that adds available humus forming material to the soil, and the plant food is not readily lost by leaching.

\section{Analysis}

Nitrogen ............... 4.93\%

Equivalent to ammonia.........6.00\%

Total phosphoric acid.......... $2.75 \%$

Available phosphoric acid.......2.50\%

Potash as $\mathrm{K}_{2} \mathrm{O} \ldots \ldots \ldots \ldots \ldots \ldots \ldots$

From the foregoing you will readily see how rich in plant food Premier Brand Poultry Manure really is.

Prices: 5-lb. bag 40 cts., 10-lb. bag 75 cts., 25-lb. bag $\$ 1.00,50-\mathrm{lb}$. bag $\$ 1.75,100-\mathrm{lb}$. bag $\$ 3.25$, ton (2,000 lbs.) $\$ 50.00$.

\section{Lōma}

\section{beautifies lawns and gardens}

To build up a lawn you can be proud of, use Loma - the scientific plant food. Lōma is rich in potash, phosphate and nitrates - just the food elements your lawn or garden needs Löma promotes deep rootgrowth-makes the grass so sturdy it

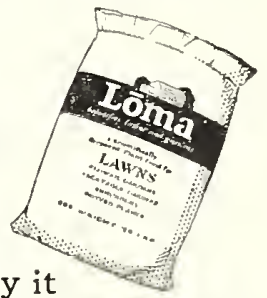
won't burn out quickly in the summer sun, so thick that it actually crowds out the weeds. Loma is odorless, clean-many times more powerful than barnyard manures. Just sow it over the lawn like grass seed. Then wet it down. A 5-pound package fertilizes a $10 \mathrm{ft}$. x $10 \mathrm{ft}$. plot.

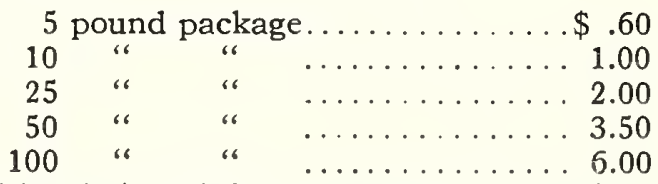

(Sold only in original packages-never in bulk)

\section{APPLICATION}

5 pounds for. . . . $10 \mathrm{ft}$. $10 \mathrm{ft}$. or $100 \mathrm{sq}$. ft. 10 pounds for. . . . $10 \mathrm{ft} . \times 20 \mathrm{ft}$. or $200 \mathrm{sq}$. $\mathrm{ft}$. 25 pounds for. . . $20 \mathrm{ft}$. $\times 25 \mathrm{ft}$. or $500 \mathrm{sq}$. $\mathrm{ft}$.

50 pounds for. . . $25 \mathrm{ft} . \times 40 \mathrm{ft}$. or $1000 \mathrm{sq}$. ft. 100 pounds for . . . . $40 \mathrm{ft}$. x $50 \mathrm{ft}$. or $2000 \mathrm{sq}$. ft.

\section{Niagara Dusting Machines and Equipment}

Dusting saves time, labor and money, and, because of the ease and rapidity in making applications of insecticides and fungicides, very often produces the difference between failure and success.

NIAGARA QUALITY PRODUCTS are known wherever fruit and truck crops are grown.

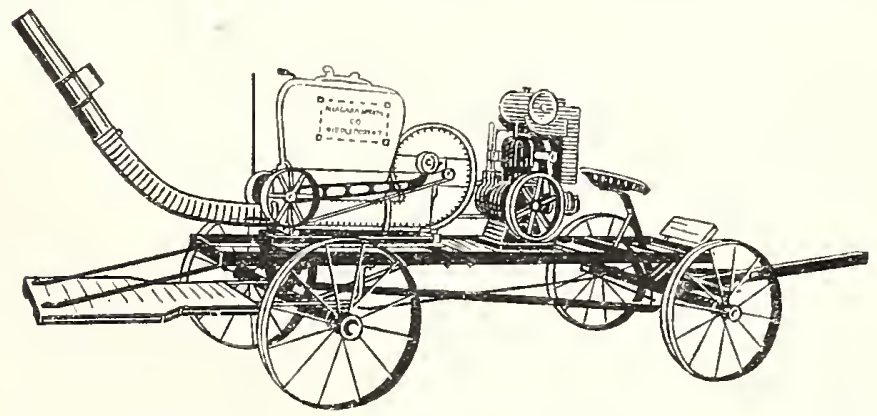

\section{NIAGARA Model F Fruit Duster}

This is the duster that has perfected and substantiated the Dusting Method wherever fruit is grown.

With this duster, a man and boy can dust 50 acres of mature apple trees planted 35 feet each way, from both sides, in ten hours.

The NIAGARA Model F Orchard Duster, equipped with 5 H. P. New-Way air-cooled Engine, mounted on a special all-steel Cross Reach Orchard Truck.

Price f. o. b. factory. $\$ 480.00$

All prices in this satalogue are subjent to change whthont notice. 


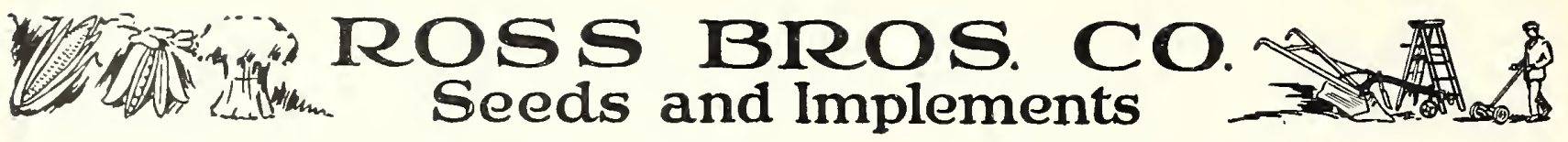

The NIAGARA Crop Dusters have "put the Dusting Method over' in every section where insecticides and dis. eases must be controlled if clean crops are grown.

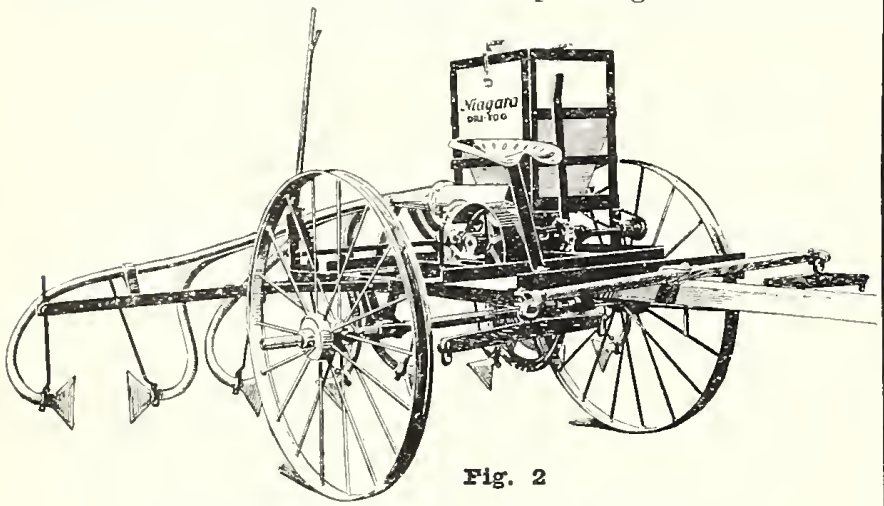

NIAGARA "Dri-Fog" Crop Duster

This is the latest NIAGARA achievement.

This 4-row potato and truck crop duster will completely cover the under and upper surfaces of the foliage with a film of dust and do it at the rate of 30 to 35 acres per 10-hour day. It will deliver from $3 \mathrm{lbs}$. to $100 \mathrm{lbs}$. of dust per acre and distribute it absolutely accurately on each of the four rows.

The NIAGARA Dri-Fog Crop Duster, 4-row, 8-nozzle. Price f. 0. b. factory...................\$200.00

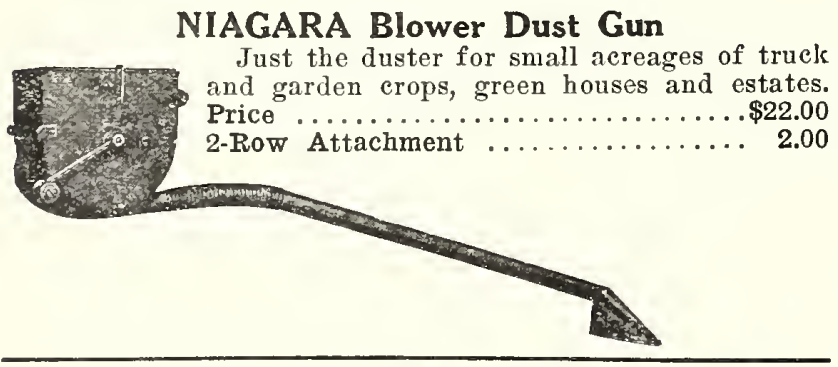

Niagara Spraying Materials

These materials manufactured and distributcd exclusively by the Niagara Sprayer and Chemical Co., Ine., Middleport, New York, represent the greatest spray material service in the trade. Each material represents a distinet specialized package service and contains just exactly the correct ingredients in the right proportions to control.

NIAGARA Soluble Sulphur Compound

The Complete Dormant Spray used to control scale, aphis, and diseases in the dormant and delayed dormant, on apples, pears, quinces, etc., and wherever a dormant Sulphur spray is needed.

Per 100 lbs.......................... \$9.50

\section{NIAGARA Koloform}

The New Exclusive NIAGARA Suminer Sulphur Spray Material that has the greatest toxicity to disease of any Sulphur Spray Compound, used for the control of diseases only in summer spraying. Carton contains $871 / 2-\mathrm{lb}$. bags.

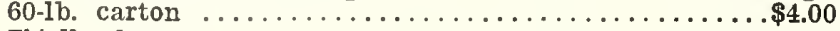

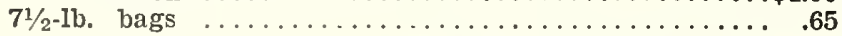

\section{EMULSO (A NIAGARA Product)}

Emulso is a typical LARGE DROP, MECHANICAL TYPE OIL EMULSION made from especially selected oils, using an exclusive Emulsifying Agent and stabilized to insure its not breaking down in shipping and storage.

$\begin{array}{cc}\text { Price } & \text { Price } \\ \text { Packed in } & \text { pergal. }\end{array}$ 50-gal. bbls. .......\$0.60 5-gal. cans $\ldots \ldots \ldots . \$ 1.10$ 25-gal. bbls. ........ .65 1-gal. cans $\ldots \ldots \ldots \ldots 1.35$

10-gal. cans $\ldots \ldots \ldots . .90$

\section{NIAGARA Copospray}

The New Bordeaux Service Spray made from dehydrated Copper Sulphate and packed in a service package containing $10 \mathrm{lbs}$. of material. These are packed in a metal airtight, 100-1b. container.

Per 100 lbs........\$11.50 Per 10-1b. bags......\$1.75

\section{NIAGARA Copokil}

The New Bordeaux Service Spray containing poison also, to control chewing insects as well as diseases on potatoes and truck crops. This is packed in 10-1b. bags, 10 bags in a metal air-tight $100-1 \mathrm{~b}$. container.

Per 100 lbs.......\$13.50 Per $10 \mathrm{lbs} \ldots \ldots \ldots \ldots . \$ 2.00$

\section{Niagara Dusting Materials}

NIAGARA Dusts are the standard by which all dusts are judged. The years of knowing how and actually processing dusts by the Niagara Sprayer and Chemical Co., Inc., is your assurance that the dusts offered below are MECHANICALLY CORRECT and SCIENTIFICALLY ACCURATE.

\section{NIAGARA Vitidust}

The Standard Copper Lime and Poison Dust for apples and grapes used to control disease and chewing insects.

Per 100 lbs . . . . . . . . . . . . . . . . . . . \$9.65

NIAGARA D-18

The Standard Copper Lime and Poison Dust used to control potato bugs and diseases on all truck crops.

Per 100 lbs.......................... \$10.35

NIAGARA D-25

The Standard Copper Lime Dust used for the control of diseases only, on potato and truck crops.

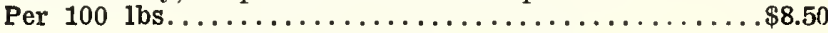

NIAGARA A-1 Nicotine Dust

The Standard Contact Dust used to control sucking insects, aphis, red bugs, pear psylla, etc.

Per 100 lbs............................. \$15.60

NIAGARA Kolodust

The New Exclusive NIAGARA Dust that "sticks through rain and wind.' This is a fungicide only, used in the control of diseases on fruit and flowering plants.

Per 100 lbs...........................\$5.20

\section{NIAGARA Kolotex}

The New Exclusive NIAGARA Sulphur and Poison Dust that "sticks through rain and wind." 'This is a fungicide and stomach poison combined used for the control of codling moth, strawberry weevil and diseases on apples, pcars, etc. Per $100 \mathrm{lbs} \ldots \ldots \ldots \ldots \ldots \ldots \ldots \ldots \ldots \ldots \ldots \ldots \ldots . \ldots \ldots$ NIAGARA Kolokil

The New Exclusive NIAGARA Sulphur and Poisou Dust containing extra large percentage of Arsenate of Lead. This material is used wherever extra heavy ravages of chewing insects prevail; also in controlling such diseases as may be present.

Per 100 lbs. 


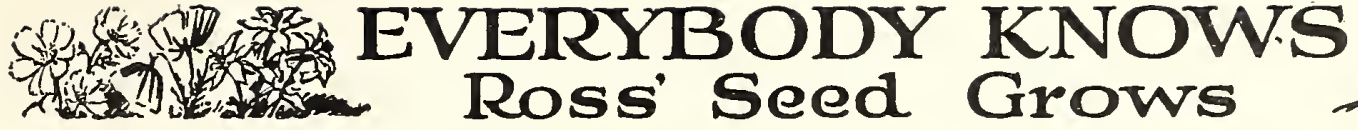

\section{The McCormick-Deering 10-20 Tractor}

Read over the following important features, then come in and ask us all the questions you can think of. Don't miss the opportunity to get acquainted with the McCormick-Deering 10-20 and also 15-30, which, owing to the great belt power, is especially adapted to saw mill work.

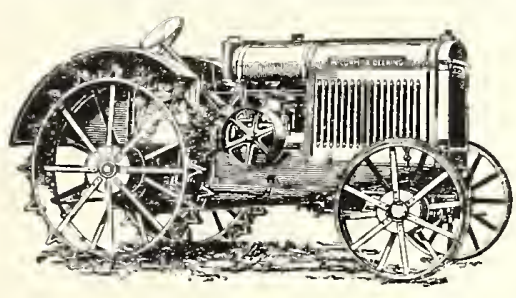

Fig. 4
Ball and Roller Bearing at 28 points.

Ball Bearing Crankshaft.

All wearing parts, including cylinders, replaceable.

Entire main frame in one sturdy unit.

All parts easily accessible, easily removed.

Alemite lubricating system. Send for inlustrated circular.

\section{WARBANTY}

The crankshaft and crankshaft ball bearings of every McCormick-Deering Tractor are now guaranteed against breakage for the life of the tractor. Ask for details regarding this remarkable warranty - a feature offered with no other Tractor.

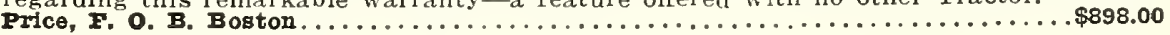

\section{McCormick-Deering P \& O Little Genius Tractor Plow-Two-Furrow}

The power for raising and lowering the bottoms is supplied by the land wheel. Only one short jerk of the rope is necessary to engage this lever and lift the plows. When the plows are in the ground the levers set ahead within easy reach of the operator and when the plows are raised the levers swing back and do not interfere with the tractor when a turn is being made. When necessary the bottoms can be easily raised by hand regardless of the depth at which the plow is working. The hitch is adjustable by a pin and can be adjusted to suit any make of tractor-is very rigid and the locking device controls the action of the rear wheel permitting the plow to be backed. There is a good clearance between the bottoms, which enables the plow to work in the trashiest ground and to cover well in deep plowing. The rolling coulters are made of the finest grade of coulter steel, carefully ground and polished and set in cone bearings, and can be taken out for adjustment. The beams are of heavy highcarbon I-beam steel, securely braced, with a hard steel moldboard and solid steel quick detachable share.

Two-Furrow, 14-inch. Weight 841 lbs. tittle wonder, Two-Furrow, 14-inch. Weight 615 ibs.

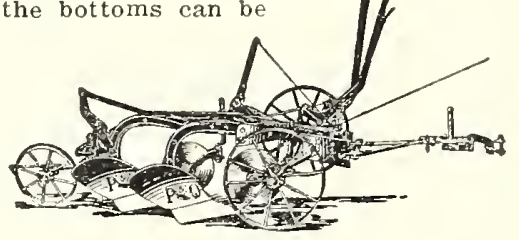

Fig. 5

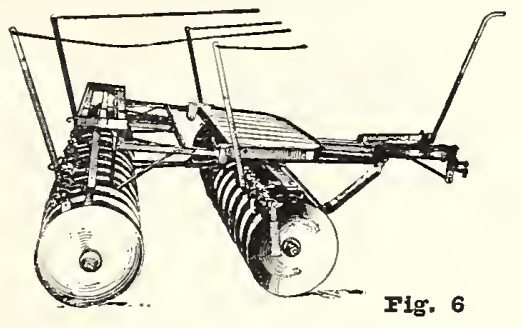

\section{McCormick-Deering Tractor Disk Harrow}

This disk harrow is a genuine tractor tool. It is not intended to be used with horses but is built for tractor use only. The gangs are controlled entirely by the action of the tractor. To secure his angle the driver puts the draft lock in the notch glving the desired pitch, then when he moves forward the gangs assume the angle without further attention. To straighten the gangs the tractor is backed and the draft lock returned to its original position. Then as the tractor again moves ahead the gangs straighten themselves. It is built in $5,6,7,8$ and $10 \mathrm{ft}$. sizes to fit any tractor. Prices on application. Weight 931 lbs.

\section{Clark "Cutaway" Double Action Tractor Harrows}

The Clark "Cutaway" line of Double Action Tractor Disc Harrows is the most complete on the market. There are rigid frame and flexible frame types of harrows, made in many sizes, with 16-inch or 18-inch discs. The harrow illustrated here is the late model Flexible Tractor Harrow. Prices and descriptive folders of other sizes on request. Cutout or solid discs same price.

A-6 $2416-$ Inch Discs, $61 / 2$ ft. cut, $7651 b s \ldots \ldots \ldots \ldots \ldots \ldots \ldots \ldots \ldots \ldots \ldots$

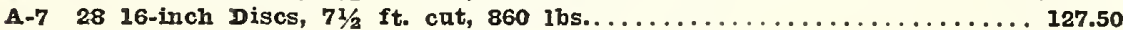
$5 \%$ Discount for Cash.

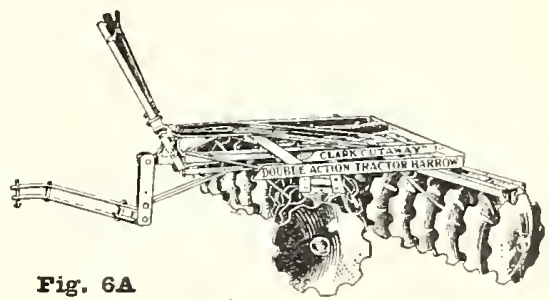

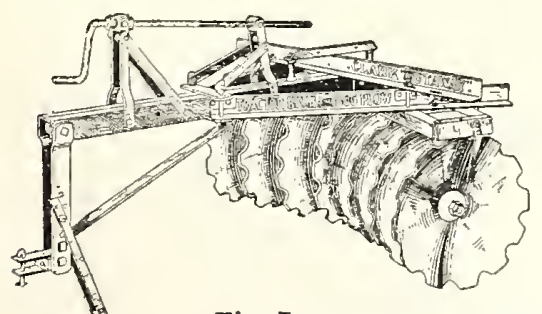

Fig. 7

\section{Clark "Cutaway" Bush and Bog Plow}

This Bush and Bog Plow and Harrow is the original "new land" plow and has been used successfully by farmers for more than thirty years. For cutting brush land and cut-over timber, land, for plowing of bogs, or for doing any extraordinary hard plowing and discing it soon pays for itseif. It is made in three sizes for tractor and two sizes for horses.

Price, 8-24 in. discs, $5 \frac{1}{2}$ ft. cut, tractor or 4 -horse hitch . . . . . . . . $\$ 110.70$

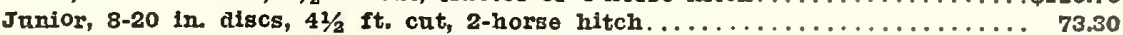
$5 \%$ Discount for Cash. 


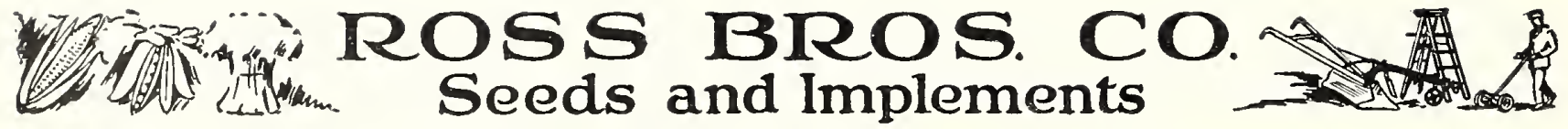

\section{McCormick-Deering Two-Way Success Sulky Plow}

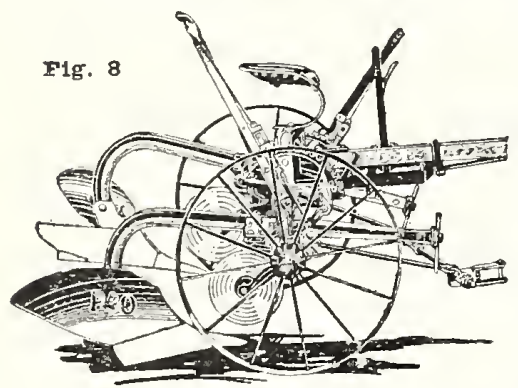

The Two-Way McCormick-Deering Sulky has all the conveniences for an ideal New England Plow. It is built to work on hillside or irregular shaped fields, in fact, any place that a plow is to be used.

TURNS AII FURROWS THE SAMIE WAY-IEAVES NO DEAD FURROWS

The Two-Way success has a right and left hand bottom. Instead of plowing around a land, it plows on the same side all the time, using the right hand bottom one way and left hand bottom returning. This method leaves the land in a "solid body," eliminating dead and back-furrows. It is therefore the proper plow for hillsides, irrigated fields, and irregular fields, though it is equally efficient as a general purpose sulky. Another advantage is that the two outside horses. when using three, "take turns" walking in the furrow and on the land, which rests them.

\section{EASY TO OPERATE}

The two main levers regulate the dop right angie hand grips, which are more convenient than the ordinary grips. The bottoms are raised by ratchets on the wheels, the only effort required by the operator being a slight pressure on the foot-trips, which causes a "dog" to engage the ratchet when the horses raise the bottom. A bottom is lowered by throwing its lever backward until the desired depth is reached.

\section{IITCB}

The plow is regularly set for two horses, but can be quickly set for using three or four horses, either abreast or tandem As a bottom is lowered, the hitch allomatically shifts. The dial feature gives ample lateral and vertical adjustment.

A draft link from the hitch to the beam places the draft directly on tho beam, so none of the plowing strain is thrown on the plow frame.

\section{BOTTOM EOUTPMPT}

12, 14, or 16-inch bottoms, either all steel, all chilled or any combination as ordered. Shares are the McCormick-Deering quick-detachable. The rolling coulters are 13-inch and have "take-up" cone bearings. Jointers or Knife Cutters can be furnished instead of coulters, or purchaser may have combined coulters and jointers at a slight additional cost.

Price with 2-two 12-inch bottom and two horse hitch, $\$ 111.50$. $5 \%$ Discount for Cash.

The Wiard Reversible or Two-Way, Power Lift Sulky Plow (Lift and Trip Operated by Hand or Foot), with Shifting Pole, Automatic Shifting Clevis and Adjustable Tilting Seat and Steel

Wheels.

No. 400-Two- or Three-Horse-Weight 550 lbs.

Cut 5 to 8 in. decp, 11 to $15 \mathrm{in}$. wide with chilled or steei moldboards.

As shown in the fllustration, there are two plows, one right and one left hand, each operated by separate levers and having an AUTOMATIC POWER IIFT which can be operated by the driver from the seat either by the ase of a trip-lever operated by the foot, or by a hand lever which can be operated by the driver either when riding or walking. The plows have the highest grade chilled iron or soft-center steel moldboards, and either forged steel or cast iron points as ordered, and can be fitted with jointer, plain coulter or rolling coulter, as desired.

This Sulky is adapted to all soils, leaving no ridges or dead furrows and does perfect work on elther level land or side hill.

It is very simple, easy to handle, and is lightly constructed, the material used being mostly steel and malleable iron, making it very strong and durable.

Price, with chilled moldboards and point..........\$100.00 Add for steel moldhoards................... $\mathbf{4 . 0 0}$ 5\% Discount for Cash
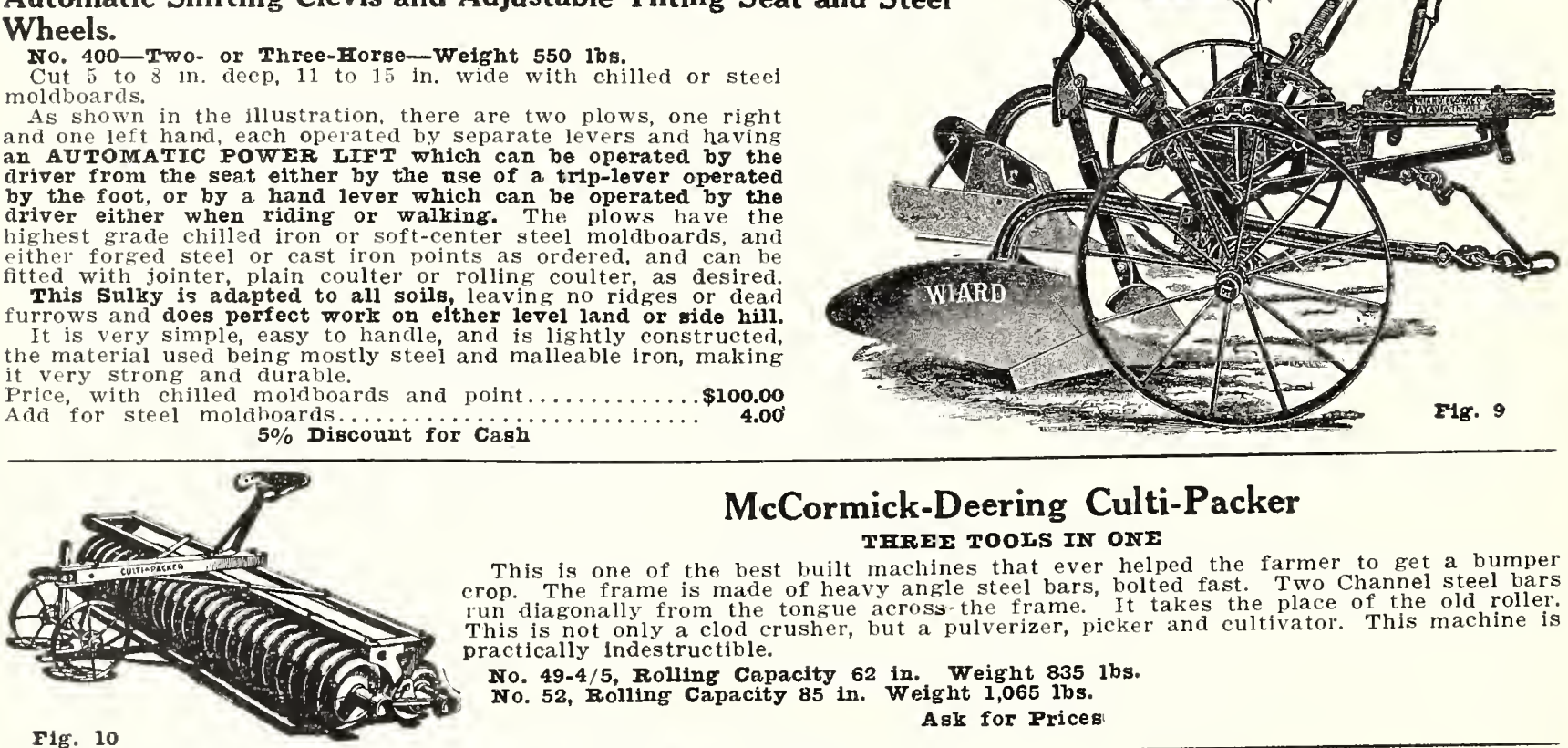

\section{McCormick-Deering Culti-Packer THREE TOOLS IN ONE}

This is one of the best built machines that ever helped the farmer to get a bumper The frame is made of heavy angle steel bars, bolted fast. Two Channel steel bars un diagonally from the tongue across the frame. It takes the place of the old roller. This is not only a clod crusher, but a pulverizer, picker and cultivator. This machine is practically indestructible.

No. 49-4/5, Rolling Capacity 62 in. Weight 835 lbs.

No. 52, Rolling Capacity $85 \mathrm{in}$. Weight $1,065 \mathrm{lbs}$.

\section{Ask for Prices}

\section{McCormick-Deering Chattanooga Hillside Plows}

All sizes are made on trussed beam chilled shares, one extra share shipped with each plow. Furnished in four sizes as follows: share shipped with each plow. Width No. Description Depth "Width 4 " Weight Price

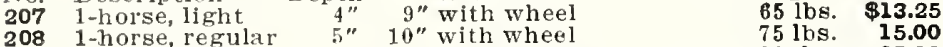
208 1-horse, regular 6 " $10^{\prime \prime}$ with wheel 12 with wheel and jointer $130 \mathrm{lbs}$. 25.00 210 2-horse, heavy 7" 14 " with wheel and jointer $157 \mathrm{lbs} . \quad \mathbf{3 1 . 0 0}$ $5 \%$ Discount for Cash

Nos 207,208 and 209 come regularly equipiped with solld steel moldboards. A hard steel board can be furnished on special orders. The beam is made of two flat steel bars, trussed together in such a way as to form a beam that is both light and strong. The beam and handles are long, giving good leverage, both while plowing and when reversing the bottom.

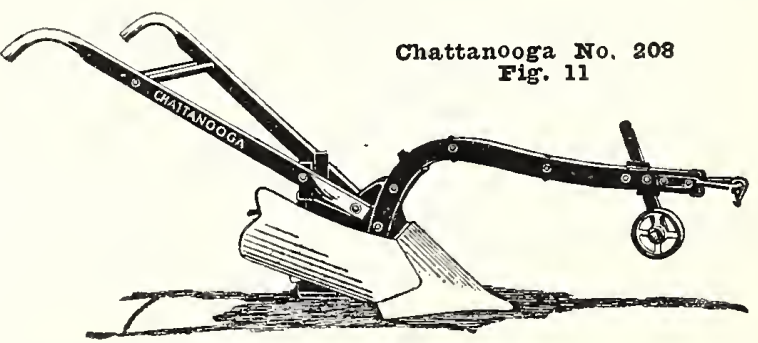

Au prices in this catalogne anbject to change withont notice 


\title{
EVERYBODY KNOWS Ross' Seed Grows
}

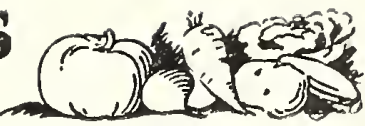

\section{No. 130X with New Automatic Adjustable Colter and Adjustable Clevis}

No.

Light two-horse 5 to 8 in. deep, 10 to $13 \mathrm{in.} \mathrm{wide}$

5 Light two-horse 8 in. deep, 10 to $13 \mathrm{in.} \mathrm{wide}$
Specifications and pescription

Capacity

Beam-White oak, selected stock

Moldboard-Cast iron; add for steel moldboard $\$ 2.00$.

Shoo-Cast iron, a good length, chilled on bottom.

Coulter-Adjustable steel blade, automatically shifted when moldboard is reversed.

Wheel and Standard-Rigid, with malleable standard, wheel runs under beam.

Clevis-Plain or adjustable, operated by lever between handles.

Points-Plain or stony, cast iron steel-edged marsh or forged steel.

Finish-Iron work, except polished surfaces, painted green, striped and varnished. Woodwork natural finish, two coats oil and varnish.

No. 140 Medium Two-Florse Plow

Weight, $135 \mathrm{lbs} . \ldots \ldots \ldots \ldots$ Fo. $\ldots \ldots \ldots \ldots \ldots \ldots$ steei board add $\$ 2.00$

88.50

$5 \%$ Discount for Cash

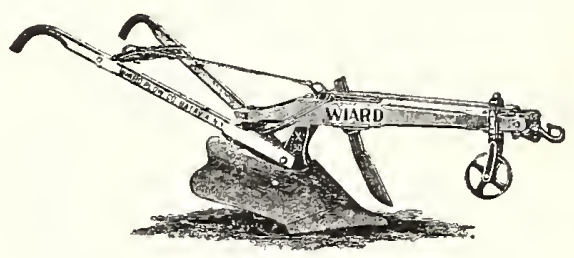

Ftg. 12

\section{Two-Horse, Steel Beam Wiard}

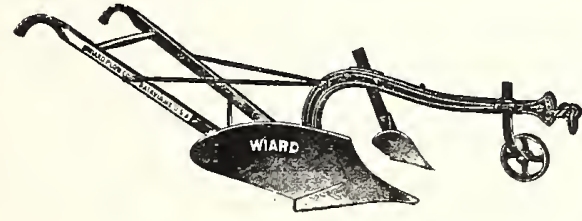

Flg. 13
Right Hand. Fitted with Jointer or Steel Knife Coulter as ordered. Size

Two-horse

Two-three-horse

Capacity

4 to $7 \mathrm{in}$. deep, 9 to $13 \mathrm{in}$. wide

5 to 8 in. deep, 11 to 15 in. wide

Wt

120 lbs.

130 lbs.

Cast iron points for this series of Plows are made in the following styles: Plain, pitch, stony, slip nose and cutter. Also for the Nos. 43 and 44 an extra wide (13-inch) plain cast point is made. Forged steel points are furnished for all sizes and a Special Alfalfa Point.

20. 43. With chilled moldboard Jointer and Coulter and Wheel.........\$26.50

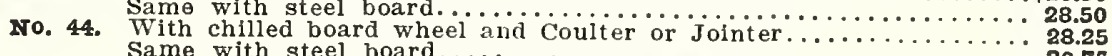

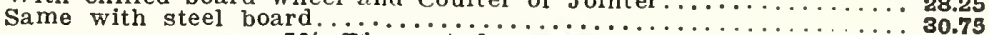
$5 \%$ Discount for Cash

\section{No. 67 Wiard Pavement or Rooter Plow}

No. $\quad$ Four- or six-horse Wt. with Clevis

67 This Plow has great Ftrength and is adapted to contractors' work and for

tearing up cobblestones or macadam pavements.

The Beam is made of cast Crucible steel. The tendency to wear off the lower front end of the Beam in this class of Plows is entirely overcome by a separate ohoe casting attached to the beam at this point, which can be replaced at slight expense when worn; this of ten saves the cost of the beam. In ordering always specify kind of Beam wanted.

The point is 32 inches in length and one inch thick, and is made from the best quality of forged steel. It is wedge shaped and pointed at both onds. The Point can be ertended when it becomes worn by removing the bolts and adjusting towards the front. It can also bo reversed end for end, making a point that has strength, durability and great wearing qualities. It can be forged or drawn by any blacksmith.

The Handles are made of steel, strongly braced, being a new departure, as heretofore the handles for this style of Plow nave been made of wood and were easily broken.

The Construction of this Plow throughout is iron and steel, and it is made to stand the wear and tear to which this style of Plow is subjected. 'This Plow, together with either of our Contractors' or Road Plows, makes a pair that is unsurpassed for this class of work. Price, $\$ 60.50$. Discount for cash, $5 \%$.

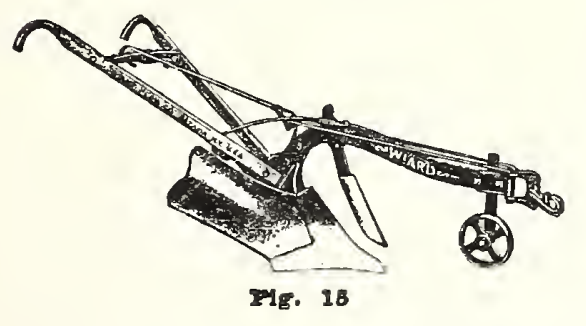

\section{No. \\ 120 \\ 127 Size \\ Light two-horse \\ Heavy two-horse \\ One-horse}

\section{No. 120 Me}

Beam-Forged steel, two pieces.

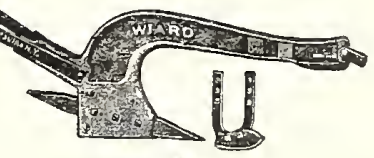

Iig. 14 moldboard, \$2.00.

shoe-Cast iron, chilled on bottom.

Jointer-Adjustable, automatically shifted when moldboard is reversed.

Coniter-Adjustable, automatically shifted when moldboard is reversed.

Wheel and standard-Wheel can be run under beam or at side.

Clevis-Plain or adjustable, operated by lever between handles.

Points-Plain and stony, cast iron.

Finish-Ironwork painted green, striped and varnished.

\begin{abstract}
No. 21 Wiard Plow

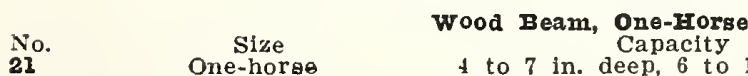

Wt. with Clevis

77 lbs. By an ingenious but simple olevis attached to these Plows they can be used
horse walking in the furrow, a great convenience for garden and vineyard work. The No. 21 is made with cast-iron moldboard......................\$16.75

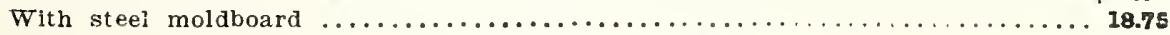
$5 \%$ Discount for Cash
\end{abstract}

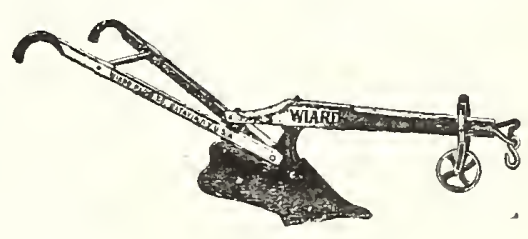

F15. 19 


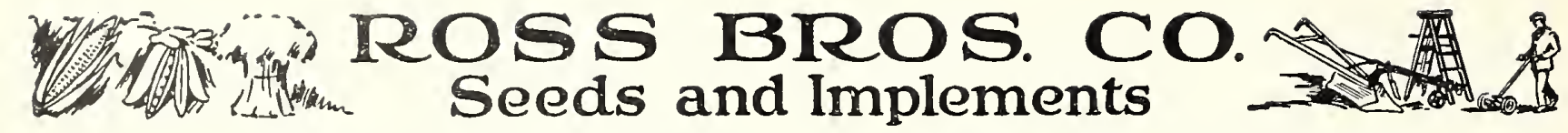

McCormick-Deering No. 3 Potato Digger

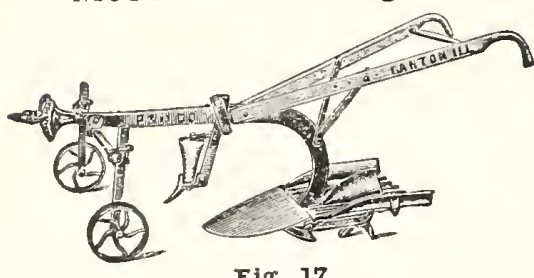

A o o d practical potato digger at a the use of two front wheels, the crushing and mutilating of pot a t o e s is avoided. The vines will not clog as they frequently do with a digger with only one whcel as the wheels run on solid ground between the row s keeping the digger on an even course and working at a uniform depth. The wheels are adjustable. The grate at the rear is hinged at the front and is given an up and down motion by a 5-tooth wheel at the rear. This sifts out the dirt as the potatoes pass over the rod. Weight, 155 lbs.

Price, \$27.00. 5\% discount for cash.

\section{Two-Horse Steel Land Roller}

\begin{abstract}
Made very strong and durable. $8 \mathrm{ft}$. wide, 3 sections 24 in. in diameter. Has patented closed end which excludes all which excludes all Runs on hardwood oiled bearings, which can be easily renewed in case of wear. An up - to-date roller in every respect.

Price, $\$ 47.00$. Less
\end{abstract} $5 \%$ for cash.

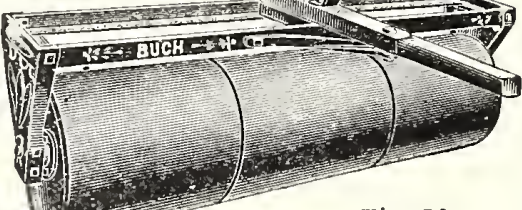

Fig. 19
One-horse roller, two-section. Price, $\$ 47.00$.

The Hitchcock Potato Digger and Shovel Plow Combined

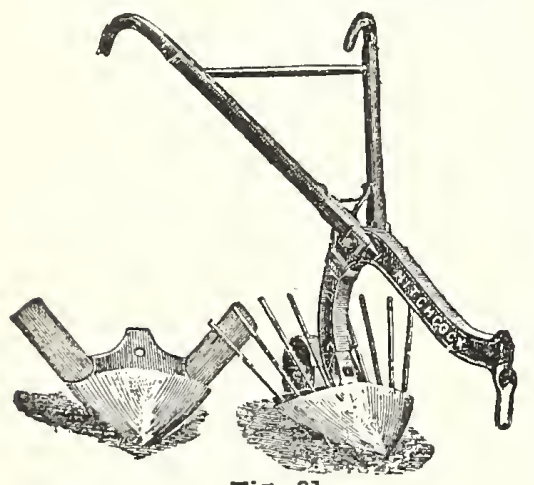

Fig. 21
This Potato Digger will not only dig potatoes, but can also be used as a hiller by attaching the special hiller wings. Also can be used for furrowing out. You get best results by using two horses, allowing one to walk on each side of the row.

Price, as Digger, $\$ 12.50$.

Price, complete with wings, \$16.50.

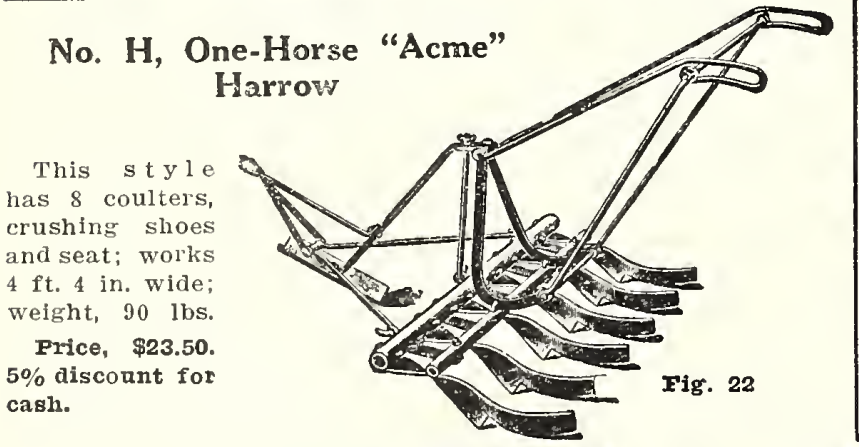

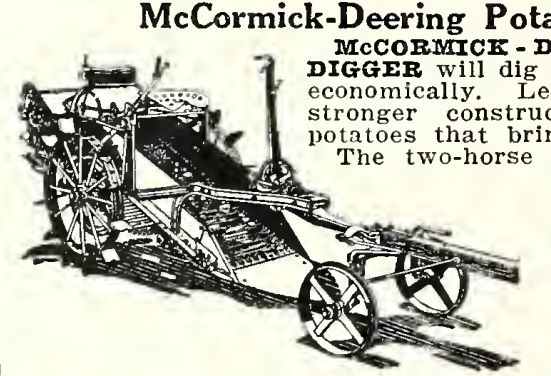

Fig. 18 TAK - DFFTYG P TATO DIGGR will dig your crop quickly and economically. Less power, less labor, stronger construction, digging better otatoes that bring better prices. 6 -ft. size has a 5 -ft. elevator 22 in. wide. This machine can be furnished with rodlink made of highcarbon spring steel or with the riddle or grade bar elevator.

We also have this in a 7-foot digger for foul horses, elevator being $6 \mathrm{ft}$. $x 22$ in. wide.

These diggers get all the potatoes, whole and unbruised. The weight of the front end of the digger is carried on truck, relieving horses of all neck weight. The construction is strong throughout. The main wheels are $30-\mathrm{in}$. on the $6-\mathrm{ft}$ digger and 36 in. on the $7-\mathrm{ft}$. without the lugs.

Light draft is made possible by a close-up hitch. Dust caps keep the dust away from the working parts. Drive wheels are high and the shovel is correctly designed.

Regular equipment consists of vine turners, including kickers, shaker, two extra rollers, sprockets, wheel type truck, main wheel lugs, pole, ncckvoke and hitch.

Price, No. 5, with rod link elevator, 6 ft., $\$ 140.00$. 5\% discount for cash.

Send for special circular.

\section{Dunham Water Weight Lawn Roller}

The Dun ham Water Weight Lawn Roller is electric welded, making the water section one solid drum; no rivets are used. It cannot leak. The roller surface is perfectly smooth and cannot injure the lawn.

A good lawn cannot be obtained unless a roller is used. Continued freezing and thawing separates the turf from subsoil, which leaves an air space for grass roots to dry out. A good rolling is absolutely necessary to put the lawn in condition again.
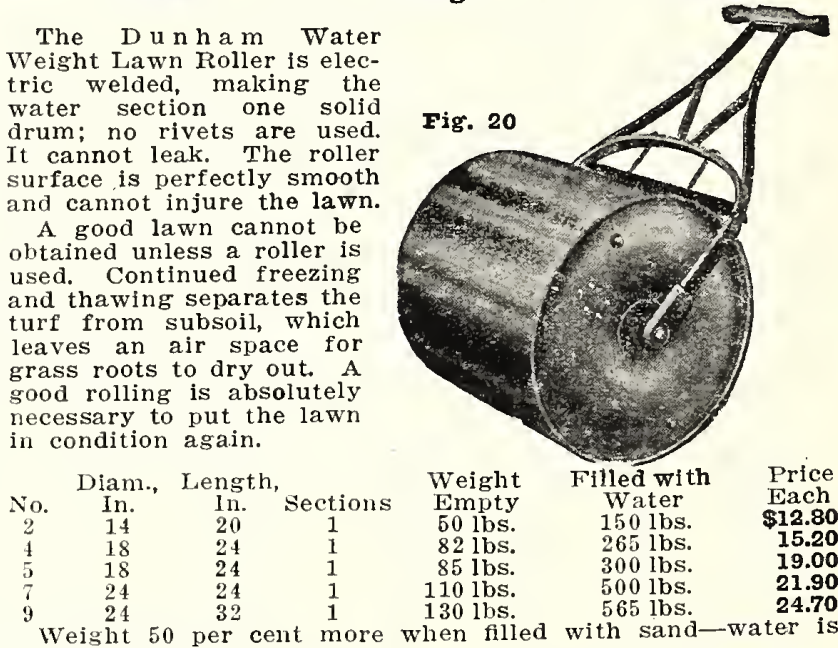
most convenient

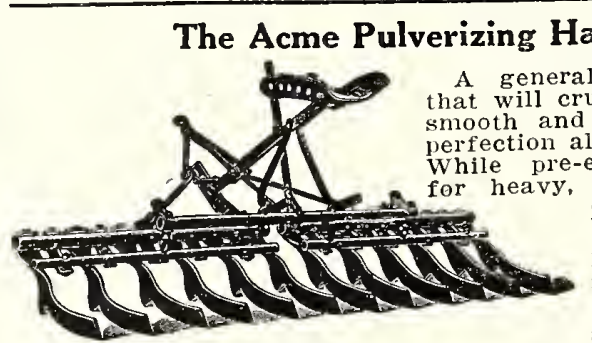

P1g. 23 trash that has been turned under by the plow. It prepares a perfect seed bed, and also covers seed in the best manner. The draft is reduced to a minimum. Being made entirely of cast steel and wrought iron, it is practically indestructible.

Price, \$30.00. $5 \%$ discount for cash.

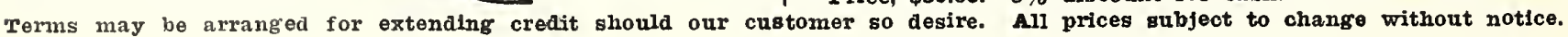




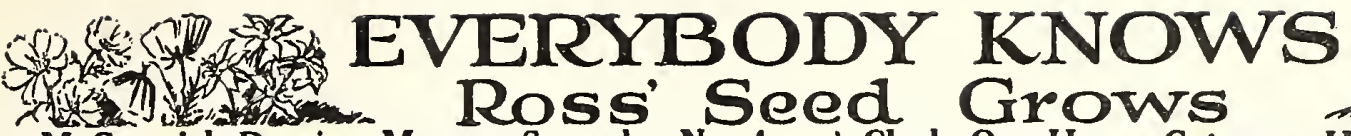

McCormick-Deering Manure Spreader No. 4 Improved Design-Now Features

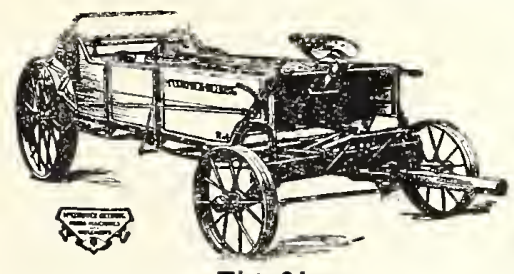

kivery convenience that could possibly be built into a mechanical spreading unit has been embodied in the construction of the new McCormickDeering. With a carrying capacity of from $571 / 2$ to built low which pormits easy loading.

The levers on both sides of the spreader are within convenient reach of the lever controls the spreading mechanism and the right hand lever controls the operation of the conveyor at six different speeds. The seat swings back while loading and the narrow width of the spreader allow

There are eight roller bearings, two on the axle, two on each of the upper and lower beaters, and two on the widespread shaft. This feature provides light-running and reduces wear to a minimum. The box is wider at the rear than at the front thus preventing the load from wedging against the sides. The upper beater is set forward of the lower one so they don't dig into the load at once when starting. Two steel beaters and a widespread spiral insure perfect pulverization and uniform spreading beyond the rear wheels.

Six conveyor speeds permit placing more or less manure on certain spots as desired. The driver can instantly regulate the quantity of fiow while the spreader is in operation. The short wheelbase, tracking of the front and rear wheels, and the auto-steer front truck makes the McCormick-Deering a strong, durable, light-draft spreader. Weight. 1,435 lbs.

Get our prices before purchasing.

\section{Wood Wheel Farm Truck}

A handy farm truck with low wood wheels. Can be used for logging or any other farm work. This truck has extra long, well braced rear hounds and wood f r o n t hounds, fitted with a heavy cast reach plate. The axles and bolsters are made of hardwood, either oak, hard maple or rock elm. The bolster stakes are mortised into the bolster, are ringed for tying, or binding and all are well ironed. The wheels are of the best French and Hecht with grooved tires. I\%-inch spokes. Price, Monarch Truck with 36 and 40-inch wood wheels, $\$ 73.00$ - Less 5\% cash.

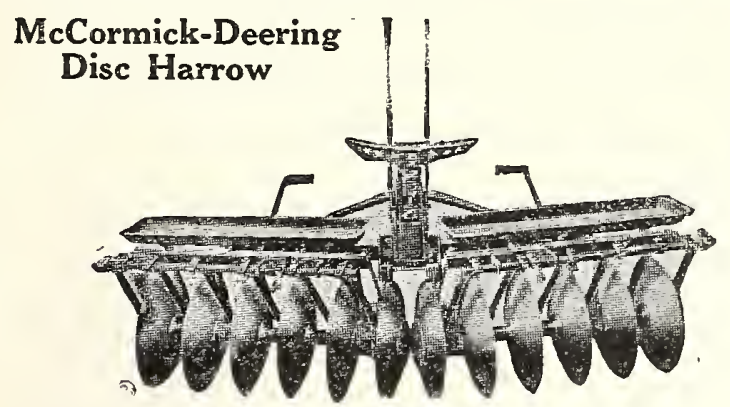

Fig. 26

Has 12 16-inch dises and weight boxes. The main frame of this harrow is constructed in such a manner that the heavy bent iron bars which fasten the main frame to the bearings are hinged both to the main frame and in the bearings. This allows the rigid frame to be used and gives an opportunity for the disc gangs to work close together. The cross beam of the frame is made of angle steel and the bars running from the ends of the cross beam to the tongue are heavy steel. The bearings are arranged so they can be easily oiled and are fitted with metal bushings which can be replaced when they become worn. This makes the harrow very strong and durable. Weight, 423 lbs. Price includes weight boxes, scrapers and two-horse hitch. Ask for price.

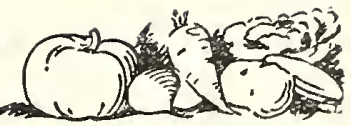

Clark One-Horse Cutaway Harrow with Shifting

A-4 Single Acting Harrow, 8 16-in. discs, $4 \mathrm{ft}$. c $u t$, fitted with shafts a n d $t$ wo shifting leve r s. Th is harrow is an i $\mathrm{m}$ p rove$m$ e $n t$ over $\mathrm{t} h \mathrm{~h} \quad \mathrm{O}-5$, not have the levers and also has 16 inch instead of $14-\mathrm{inch}$ discs. We think it is we 11 worth the differ e $n$ c e e i n price.

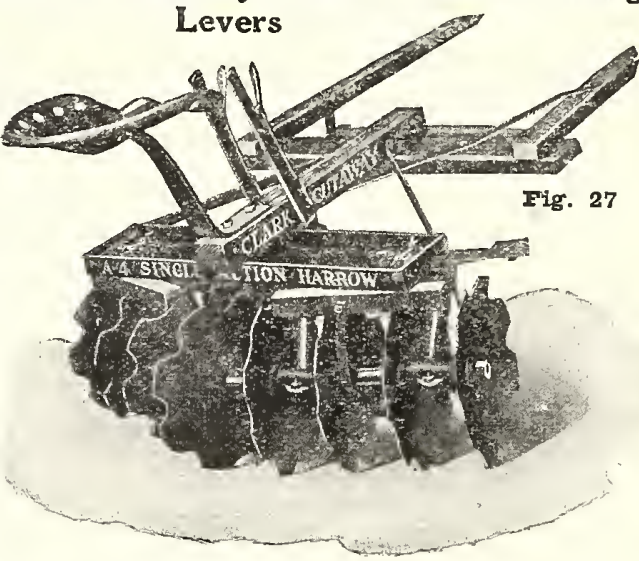

$5 \%$ Discount for Cash. for one horse

Price, $\$ 42.00$

\section{Clark's One-Horse Cutaway Harrow}

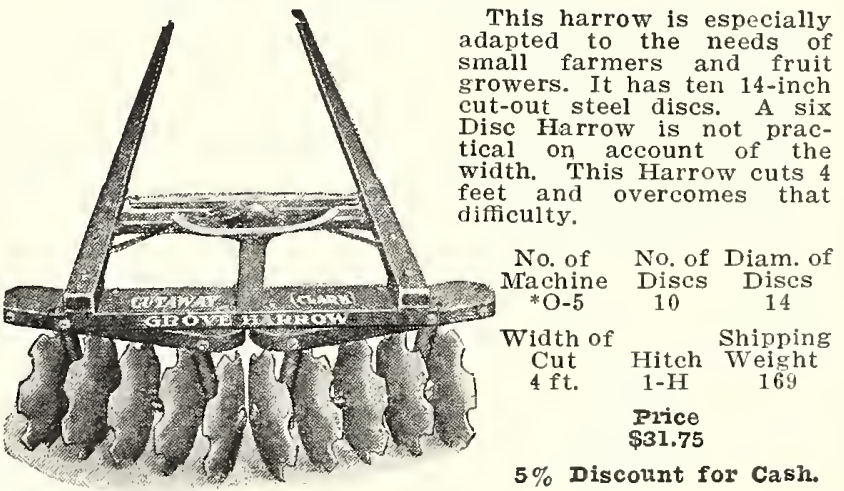

Fig. 28

$\mathbf{5 \%}$ Discount for Cash.

\section{$-$}

\section{Clark Reversible Single Action Cutaway Harrow \\ All Cutaway Single Action Har-}

rows are revergible If you will

observe the illustration you will

see that the "dish" of the discs

is out, and consequently the soil

is moved outwardly. To reverse

this harrow, you simply discon-

nect the lever links

from the gang frames

and swing the gangs

around on the king

bolts until what were

formerly the out e r

dises become the

connect the links. In

this latter position

the discs will throw

the soil inwardly.

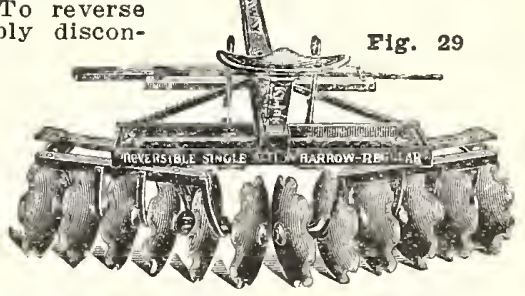

Like those on all other Cutaway implements, the discs on this harrow are the famous Clark cutlery steel discs forged sharp. This feature partly accounts for the remarkably long service always given by cutaway disc implements.

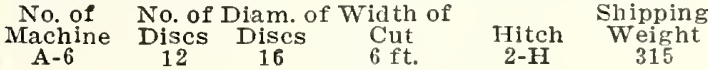

$5 \%$ Discount for Cash

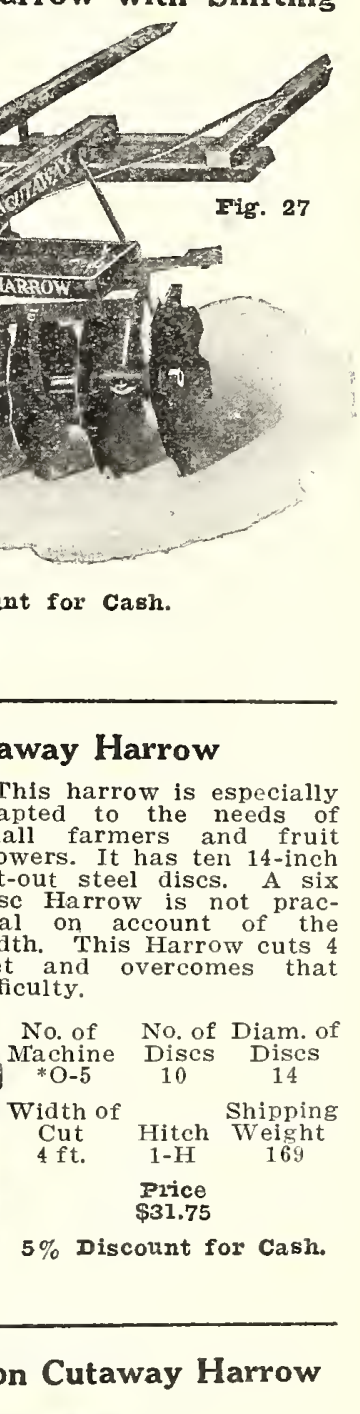




\section{4}

McCormick-Deering One-Horse Vineyard Harrow This harrow is particularly adapted for small fields, orchards and nurseries where a large two-horse harrow cannot be used. The main frame is of angle steel bent up at the front so that it passes over obstructions easily. The tooth beams are placed high and made of pipe of sufficient dimensions to make them both light and strong. The teeth are placed on the tooth bars so that trailing is impossible. Each tooth does its full share of the work. Weight, 126 lbs. Price $\$ 17.00 .5 \%$ cash.

\section{Prout's Two-Horse Hoe}

Each standard, as shown in the cut, has two hoes attached, and, in working, one set of hoes work on
one side of the hill and the other on the opposite side, hoeing a row at a time. The hoe operates the same as a hand hoe, moving fresh earth to the plant a $\mathrm{nd}$ crowding the old dry earth away from the plant. The hoes, being made $\begin{gathered}\text { Fig. } 31 \\ \text { tapering, permit of cutting close up to the plant without }\end{gathered}$ injury to corn roots which run close to the surface. Price, with wheels, weight 120 lbs., $\$ 35.00$; price, no wheels, weight 110 lbs., $\$ 30.25$. $5 \%$ discount for cash.

\section{Dixie Wonder Cultivator}

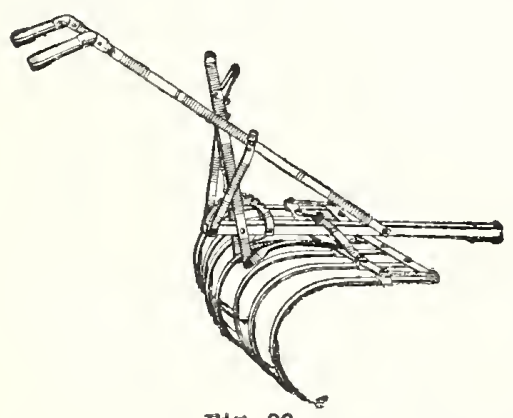

F'19. 32
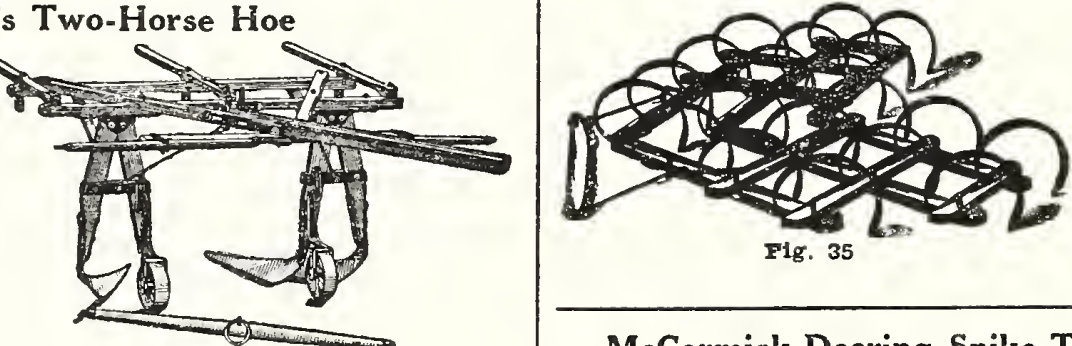

There is a harrow made for every bind of work, and the spring tooth has its place and should be will take hold and pulverize where other makes have failed. The action of the and leaves bed.

15 -tooth $\ldots \ldots 825.00$

17 -tooth $\ldots \ldots 26.75$

5\% Discount for Cash.

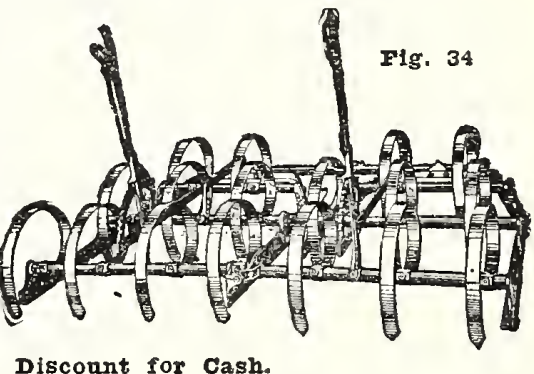

\section{The Original Perry Spring Harrow}

For durability it is equal to any harrow made. The wood frame is lined with c a r b on steel. Bolt heads are protected. The teeth cannot get loose. Us ed among rocks and stum $\mathrm{ps}$ which would soon break any other harrow to pieces. Price, 16 tecth, $\$ 19.50$

5\% Discount for Cash.

\section{McCormick-Deering Spike-Tooth Smoothing Harrow}

Designed as a lev eling harrow and for covering ali kinds of grain and grass seed; a lso largely used for cultivating corn and potatoes just af ter they come up. The teeth are adjusted by means of a lever and can also be thrown

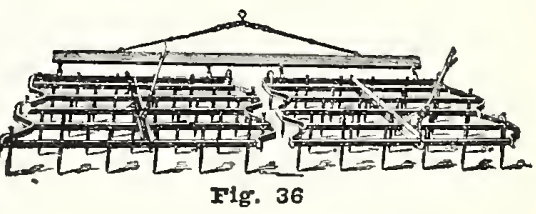
be adjusted to throw the soil to the rows or away from them. This is done by pulling the outside teeth forward or backward as desired. Dixie Wonder is an excellent soil mulcher and weed $\mathrm{kille} r$ The teeth are mounted on flat steel bars, pivoted at the beam. Teeth are adjusted by means of levers or by a movable hook, according to the style ordered. With wheel, $5 \%$ Discount for Cash. $\$ 10.25$

up from the ground

and harrom the field on the shoes at the end. Each tooth is held in place by two bolts, while nearly all other harrows usc but one. Teeth can be moved down as they wear. The entire harrow is made of steel. Price, 60 teeth, \$23.50. Weight, 231 lbs. 5\% discount for cash.

\section{The Bolens Power Hoe}

BOLENS Power Hoe is different from any other garden tractor that you have seen or heard about.

It has a patented arched axle to straddle the row and pass over plants 14 to 20 inches high without damage.

It has a simple and wonderful tool control to cultivate closely in straight or crooked rows. You simply guide the tractor and the tools follow the row.

It has a differential drive to make turning easy and is equally at home in small or large gardens. You can start or stop instantly without stopping the motor.

It has gauge wheels to regulate the depth of cultivation. All you do is guide the tractor and regulate the speed.

It has offset handles so you walk between the rows in a natural position.

The wheels have deep traction lugs to give plenty of pull from the $11 / 2$ horse power motor although the tractor weighs but 200 pounds Ask for price.

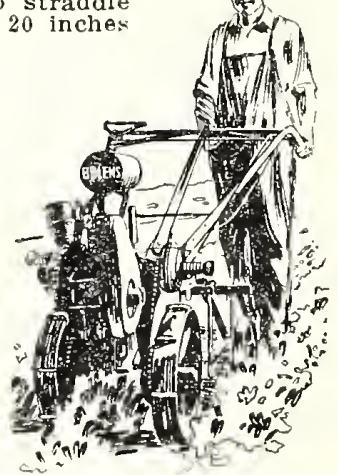

Fig: 37 


\section{rus

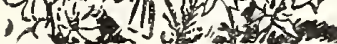 \\ Ross' Seed Grows}

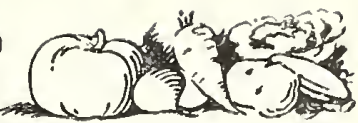

McCormick-Deering 4-Pivot Axle Riding Cultivator No. 251

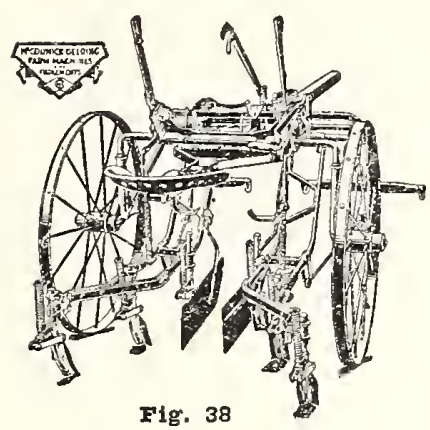

This cultivator runs on ball bearings, gangs are always parallel; cultivating depth is controlled by levers, draft direct to the gangs. it is equipped with 8 double pointed shovels and trip slotted shanks. This style is especially adapted for the Fastern States, Can be adjusted from deep to shallow work, wide and narrow cultivation, without leaving the seat. Equally good on corn, Potatoes, Peas, Beans. etc. A boy who can handle a team can do clean cultivating with this implement. Weight, $50 \mathrm{~s}$ ibs. Ask for price.

\section{McCormick-Deering 5-Tooth One-Horse Cultivator}

This cultivator has 5 steel teeth, expanding width from 12 to 25 inches. Frame is high to clear trash and is good length, which enables it to run steady. Each standard has 3 holes for adjusting. Equipped with adjustable whe els and expanding lever. Weight, 79 lbs, Frice, $\$ 10.50$.

$5 \%$ Discount for Cash
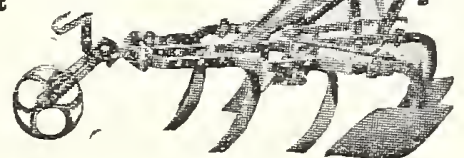

Fig. 39

\section{Centennial Crown Cultivator}

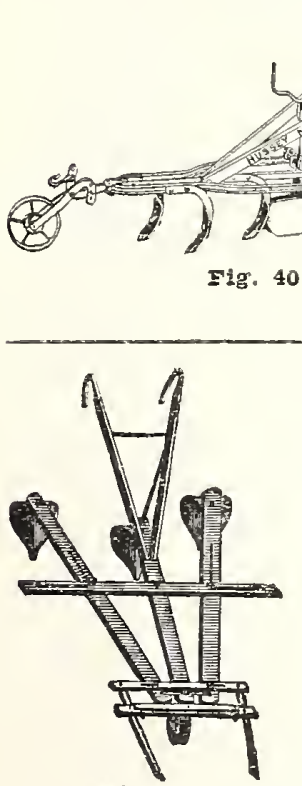

The Goslee Improved Marker

Adjustable Tooth, Spreads 2 to $4 \mathrm{ft}$.

This machine is designed to mark out rows of any width, and in doing so it makes a furrow suitable for planting. Price, $\$ 19.75$.

$5 \%$ Discount for Casu

\section{Spring Tooth Cultivator}

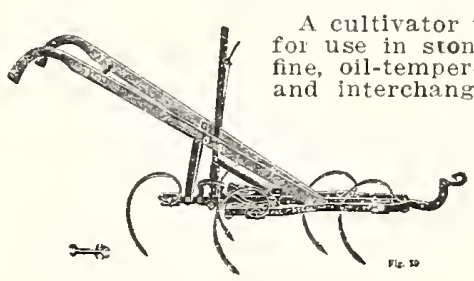

Fig. 42 hat is especially adapted for use in stony ground. The teeth are fine, oil-tempered springs, and are alike justable for angle and depth. Has expanding lever, five spring teeth and wheel. Price, $\$ 10.00$.

7 Tooth Spring Cultivator, \$11.25.

5\% Discount for Cash

\section{Spike Tooth Cultivator}

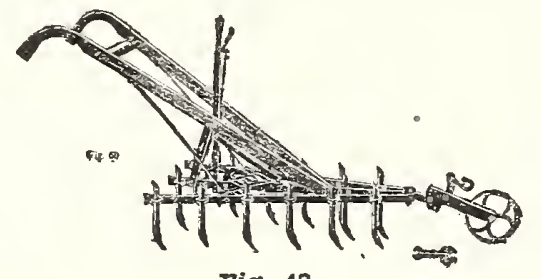

Fig. 43
This cultivator and harrow is particularly designed for cultivating between verize the soil and leave it smooth and level, thus conserv. ing molsture.

Price, $\$ 9.75$

5\% Discount for Cash small fruits. Especially adapted to puI

\section{McCormick-Deering Hoosier Fertilizer Drill}

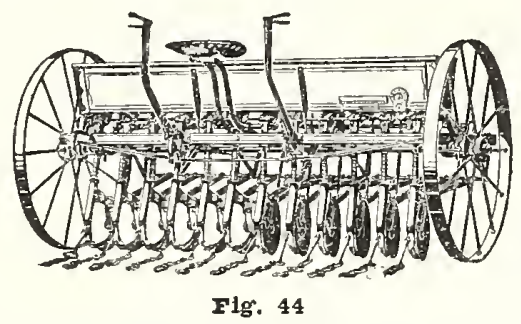

By the use of a Grain Drill you decrease the quantity of seeds used and increase the yield. Every seed is properly planted, which is just as necessary as with any hoed crop. The increased yield, even if it is only a few bushels per acre, will well pay for the interest on the drill. Ask for showing the Hoosier. complete catalogue ing it in detail.

No. 11-7-Single Disc Fertilizer Drill with pole, 1,078

Ask for Price.

\section{MicCormick-Deering Hoosier No. 3 Lime Sower}

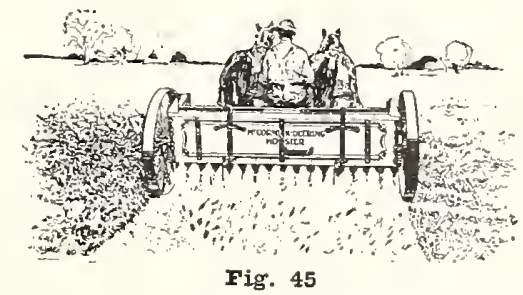

A big strong and -eliable implement for spreading lime on sour soils. It is the most practical machine of its kind because it broadcasts the lime where the wind has no chance to blow it away. A wire screen is part of the regular equiplumps to keep large the feed openings. 'The strongly bolted hopper has a capacity of 8 bushels and two additional bushels in the screen. By reason of the various adjustments it is possible to spread from 42 to 3,435 quarts of ground lime rock per acre. It is 8 feet wide. Neight 735 lbs.

\section{Ask for Price.}




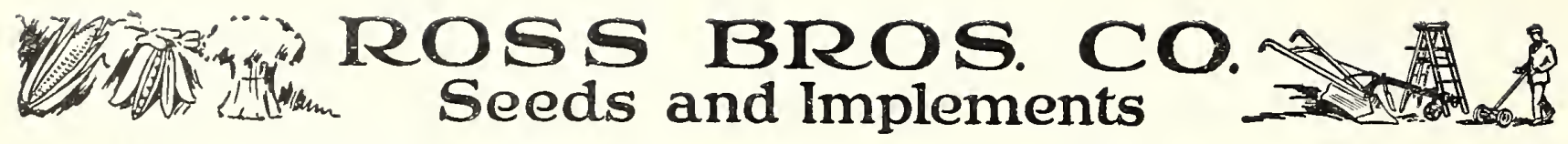

\section{McCormick-Deering Potato Planter}

This Machine plants a greater range of seed, both as to size and shape, than ever before and handles it with the least possible friction or wear. In lieu of the cumber. some wooden struct u re, a galvanized hopper has been substituted, which overcomes all tendency to clog or bridge with either the whole or
cut seed. Both the feed and covered ten.

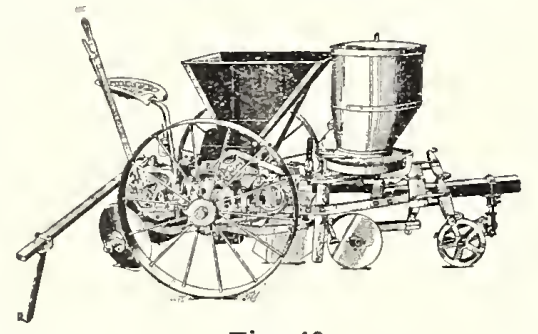

Fig. 46 sion are regulated from the seat. Iist price, with fertilizer and attachments and disc covers, $\$ 149.00$. 5\% cash. Weight $915 \mathrm{lbs}$.

\section{Eclipse Corn Planter and Fertilizer Distributor}

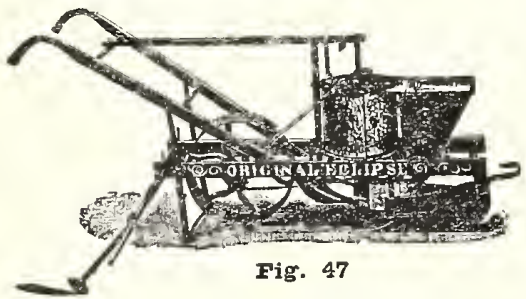

Plants field or ensilage corn, be a n s, peas or beet seeds in it will drop $6,12,24$ or 36 inches apart. By scattering pumptin seeds in with the fertilizer in filling the hopper will place seeds in hills when planting corn. It accurately distributes from 50 to 450 lbs, as desired, of commercial fertilizer, wet or dry, in the rows of hills, first drawing moist earth in the seed before the fertilizer is dropped each side of the seed, and hill is covered to a uniform depth. Price, complete, $\$ 45.00$. $5 \%$ Iiscount for Cash

\section{Nonpareil Fertilizer and Lime Sower}

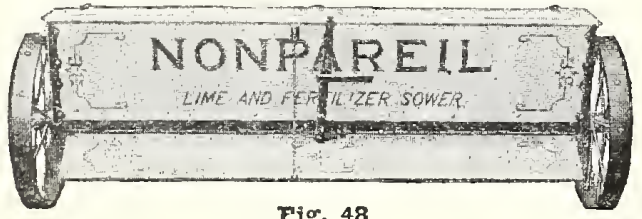

Fig. 48

Nonpareil Sowers will distribute successfully every known kind of Agricultural Lime and Commercial Fertilizer used on the farm, providing it will pass through the scrcen into the hopper of the sower.

The sowers are equipped with an agitator which revolves in the bottom of the hopper making all sowers positively force feed. 'This agitator is divided in the middle, it having a very strong and substantial bearing in the middle of the hopper and at both ends. This feature eliminates the use of the ratchet wheel and at the same time insures a very even distribution when turning corners.

A strong feed lever operates the feed plate. This lever passes through a quantity gaugc on which there are 20 notches, each notch representing 250 pounds to the acre, so that different quantities from 100 to 5,000 pounds can be distributed to the acre by opening and closing the feed plate.

Each half of the agitator is driven direct from each wheel, so that there are no gears or sprockets to get rusty and break, thereby causing a continual annoyance to the user.

The Nonpareil Sowers are equipped with an all steel wheel with cast iron hub boxings. They are 32 inches in diameter, with $121 / 2$-inch steel staggered spokes. The tire is $1 / 4$-inch in thickness and $31 / 2$ inches wide.

Capacity, 15 bushels. Sowing swath, 8 feet. Weight, 435 pounds. Price, $\$ 60.00$.

5-foot Orchard, 1-Horse, $\$ 60.00$.

$5 \%$ Discount for Cash
"King of Cornfield"

Corn, Bean and Pea Planter and Fertilizer Distributor Does perfect work, not only in planting corn in hills or drills, but does equally as good work planting peas, beans and all similar seeds, putting in the fertilizer as well, in any desired quantity, or the fertilizer may be stopped off altogether, if desired. Another great feature in this machine, corn and beans may be planted at the same time in the same row, the beans half way between the corn, or $4 \frac{1 / 2}{2}$ or 9 inches from the corn, as desired. The fertilizer may be put with the

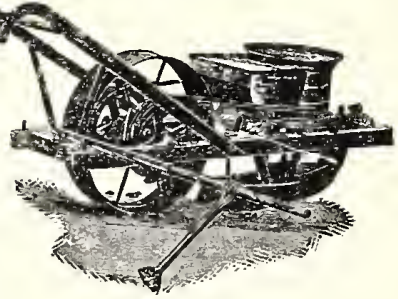

Fig. 49 Price, \$45,00,5\% Discount for

\section{McCormick-Deering Two-Row Corn Planter}

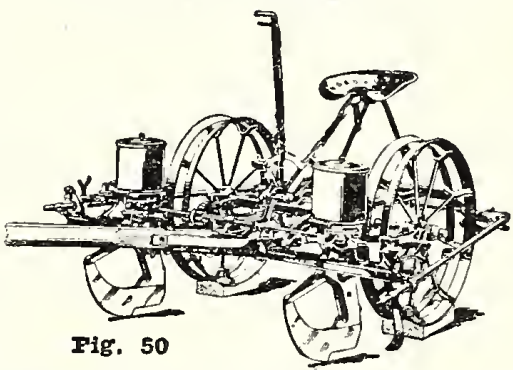

Is especially adapted to our New Tn a l a d condition. Will plant in drills or hills and is adjustable for rows from 28 to 44 inches apart every 2 inches. The fertilizer cans are placed up out of the way of the driver and do not interfere with the working of the machine. Feed tubes lead from the fertilizer cans to the rear of the regular runners and deposit the fertilizer about 3 inches back of the corn hill. When the runners are raised the entire machine is thrown out of gear and marker raised. Price quoted upon application.

Farmer's Friend Fertilizer Sower

Attaches to any ordinary farm wagon and sows to perfection grass and grain seeds of all kinds and in any desired quantity per acre 50 to 100 acres a day. It also distributes al dry commercial fertilizers; also ashes, land plaster, lime, etc. It has positive feed and an adjustment opening the holes from $1 / 4$ to $1 \frac{1 / 2}{2}$ inches, which allows the sowing of seeds of any size; the flow can be shut off anywhere, either on one side or the other. or altogether, as required; it is instantly thrown in or out of gear. Price, complete to attac

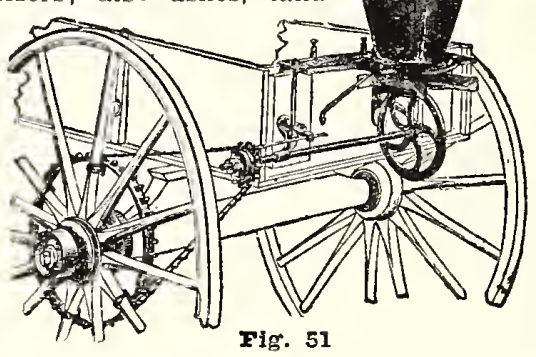

\section{McWhorter Hand Fertilizer Sower}

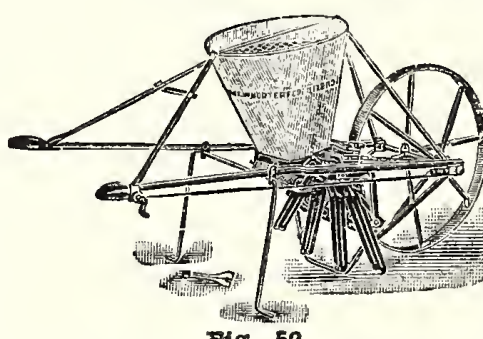

This fertilizer sower can be instantly changed so that the stream is divided from one into two or more streams, and thus be applied beside one, two or more rows of plants at the same time. The spouts or channels through which it passes to the ground open and close, so that starting with a width of about 4 inches, the spread can be gradually increased to 30 Fig. 52

cially adapted for top dressing strawberry beds and lawns. Price, \$21.00. 


\section{Sa on Ross' Seed Grows}

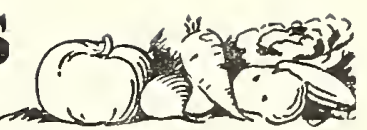

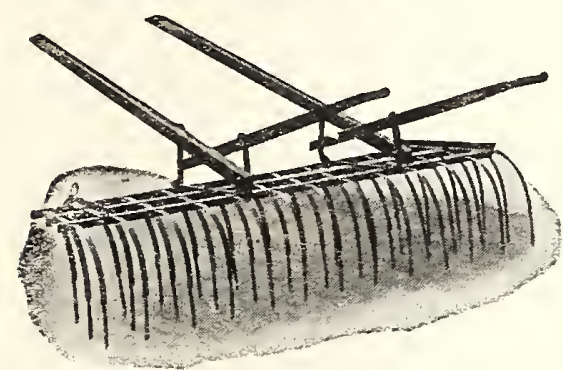

-io. 53

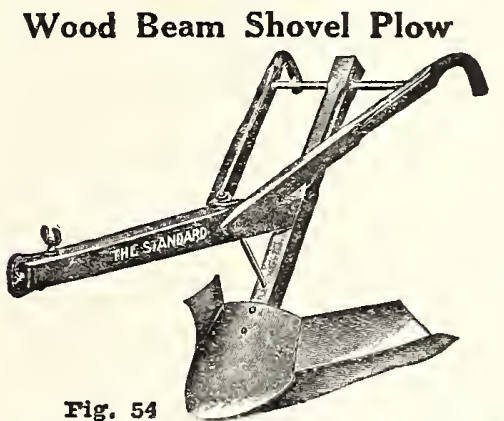

Very handy for furrowing out rows and for hilling up. All parts strong and well braced and very durable

Price, $\$ 5.50$

Steel Beam, \$5.75

$5 \%$ Discount for Cash

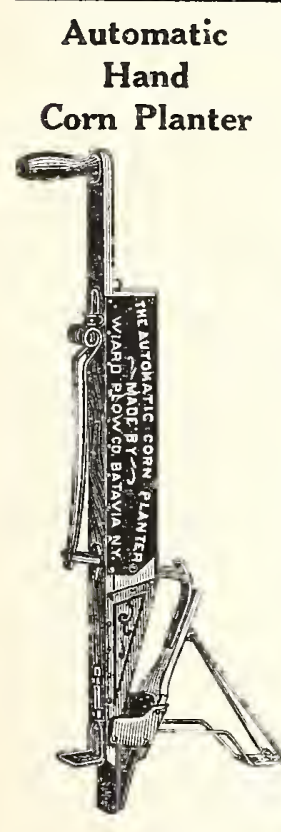

Fig. 55

Very handy for replanting and for small gardens.

Price, \$2.75 Malling wt., 5 lbs.
The Worcester Weeder-The Farmer's Best Friend

One of the indispensable articles on any farm where horse cultivated crops are grown, or where corn or grass seed are sown. This weeder is made of high carbon angle iron steel, teeth attached to frame with bolts are held tight by a spring steel lock washer. This is the best implement made for preparing a seed bed and will pay for itself in one season. In cultivating corn it should be used just before the crop is up and immediately after Destroys the weeds, but does not injure the crop. Price, $\$ \mathbf{1 6 . 0 0}$. 5\% Discount for Cash

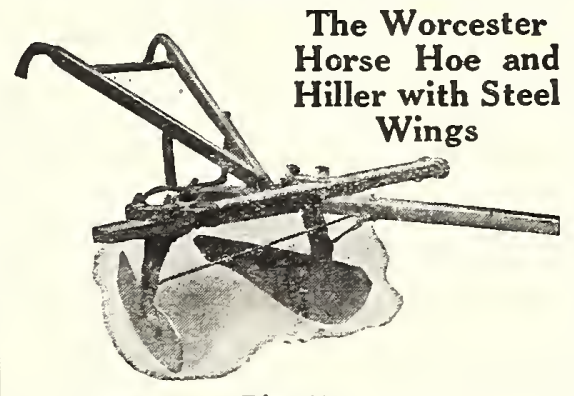

Fig. 57

The best implement made for furrowing, covering and hilling potatoes and similar crops. The steel covers or wings can be adjusted for making any style of hill desired in furrows of uniform width All potato growers know the value of this tool and none of them attempt to get along without it. It is necessary to cover young plants completely when just out of the ground. The steel wings are made of best crucible spring steel. Price, $\$ 13.00$.

The Worcester Horse Hoe and Furrower with Disc Wings

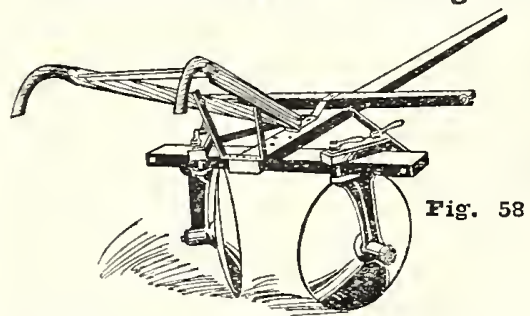

This implement is the same as the Worcester Horse Hoe and Hiller, with exception of discs, which are used in place of steel hillers or covered wings. They are adjustable and by many are preferred to the steel hillers. All potato growers should have one of these two implements. These discs are made of best crucible steel and will last for a long time. Price, $\$ 15.00$

Cahoon's Improved Broadcast Seed

Will sow all kinds of grass and grain seeds from 4 to 8 acres per hour at a common walking gait. Heavy seeds, such as wheat, it will throw 40 feet ( 20 feet from each side of the operator); lighter seeds, of course, will not be thrown so far. Price, $\$ 4.25$. 8 lbs.

See Inside Fiont Cover of Catalogue for Parcel Post Rates. Sower

Fastest of All Grass Seeders

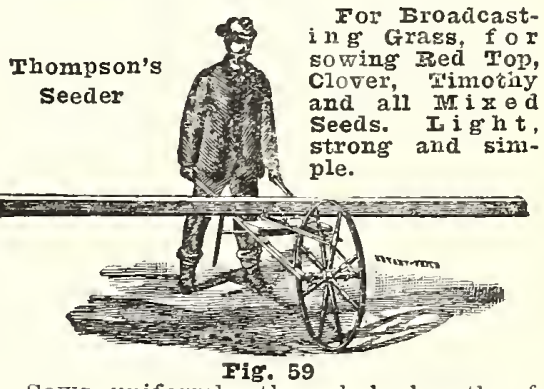

Sows uniformly the whole length of the hopper. Weight, 45 los.

This is really the Greatest Grass Seeder made today. Not a toy, but a strong and durable implement specially designed and adapted to its use, 14 feet long. Over two hundred thousand are now in use on the farms of this country. It will sow easily 40 acres per day. So close to the ground that the wind can never blow the seed away.

Seeder No. 5. Sows Clover, Timothy, Hungarian Millet, Alfalfa, Chaffy Seeds, like Red Top, Orchard Grass and Kentucky Blue Grass. Price, \$15.00

No. 4. Grain Seeder Box, 10 feet, for sowing all kinds of orain. Fits No. 5 Seeder, and witl both boxes all kinds of grain and grass seeds can be sown. Price, $\$ 10.00$.

Price, \$25.00.

The Cyclone Broadcast Seeder

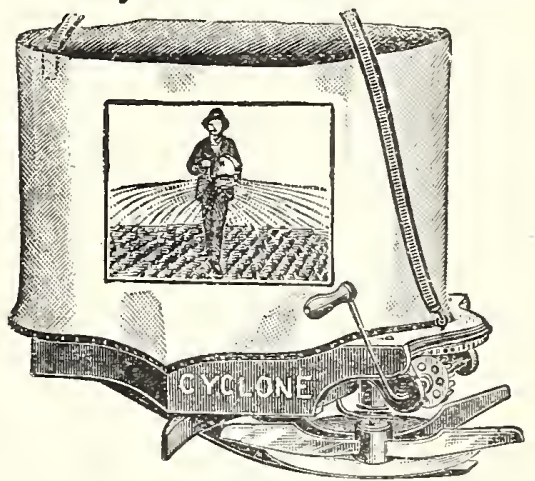

ritg. 60

Will sow Timothy Clover Wheat, Oats, Rye, Buckwheat, Hurgarian, Red Top, Millet and all other grains and seeds perfectly even, and any desirea amount to the acre, and from 40 to 60 acres a day. Net price, \$2.25. Mailing

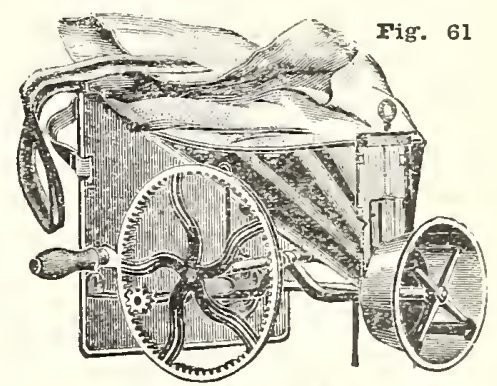
weight, 2 los. 


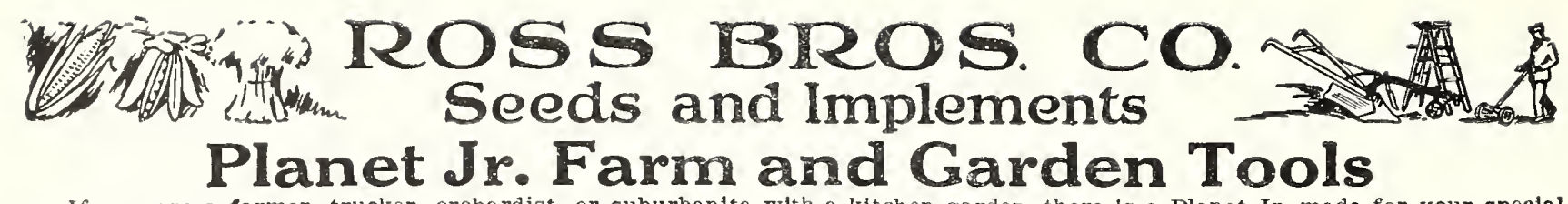

If you are a farmer, trucker, orchardist, or suburbanlte with a kitchen garden, there is a Planet Jr. made for your speclal leed You can't afford to work without a Planet Jr. 72-page Planet Jr. catalog free. Describes 70 tools, including Seeders, Wheel Hoes, Horse Hoes, Harrows, Orchard and Beet Cultivators. Writs postal for it.

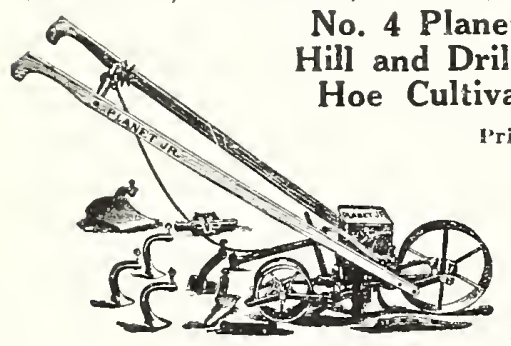

Fig. 62 of a garden a pleasure as well as very profitable. Can be used suc. cessfully by men, women or growing boys. Pays for itself in a season and will last for years.
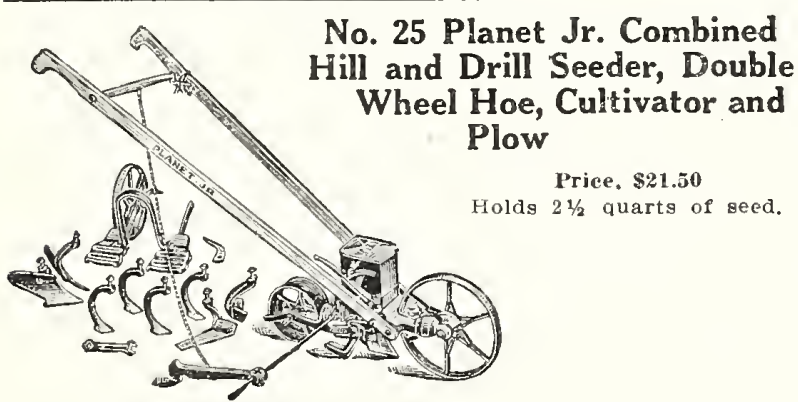

Fig. 63

A splendid combination for the family garden, onlon grower, or larger gardener. It is a perfect seeder, and combined double and ingle wheel hoe.

No. 11 Planet Jr. Combined Double and Single Wheel Hoe, Cultivator, Plow and Rake

Price, with Attachment as in 14-inch Steel Wheels cut, $\$ 13.75$

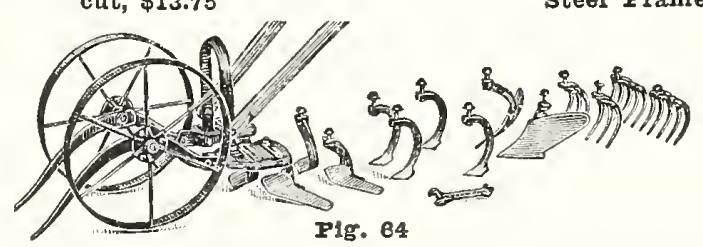

A single and double wheel hoe in one. Straddles orop till 20 inches high, then works between. Has steel frames and 14 -inch steel wheels. The greatest hand-cultivating tool in the world.

No. 12 Planet Jr. Double Wheel Hoe, Cultivator and Plow

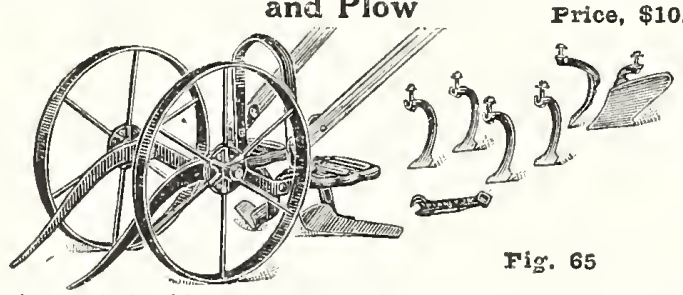

This tool is identical with No. 11 Double Wheel Hoe, except that it has one pair plows, one pair hoes, four cultivator teeth and a pair of leaf lifters only. They are what gardeners use most, and the others can be added as wanted. All prioes in this catalogue are
No. 3 Hill and Drill Seeder

Price, $\$ 17.50$

Iade for the market gardener or tarmer who has a good size garden. Hopper holds

three quarts-enough to plant about onequarter acre in seed. Plants practically all vegetable seeds in straight. hills $4,6,8$. 12 or 24 Inches apart. Marks the next row at the same time. Seed control and shut-off located at top of handle. making easier operation.

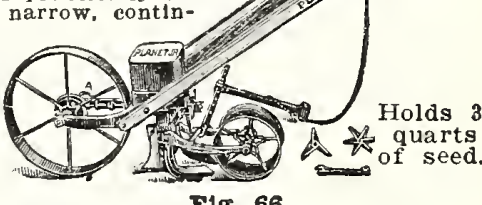

IIg. 66

\section{No. 5 Planet Jr. Hill and Drill Seeder}

price, \$20.00, $16 \frac{1}{2}$-inch steel driving wheel. Holds 5 quarts. No, $\overline{5}$ is undoubtedly the best seeder we make for market gardeners, onion set growers and other large planters. The style of construction is the same as in No. 3 , the valuable mechantcal features being common to both.

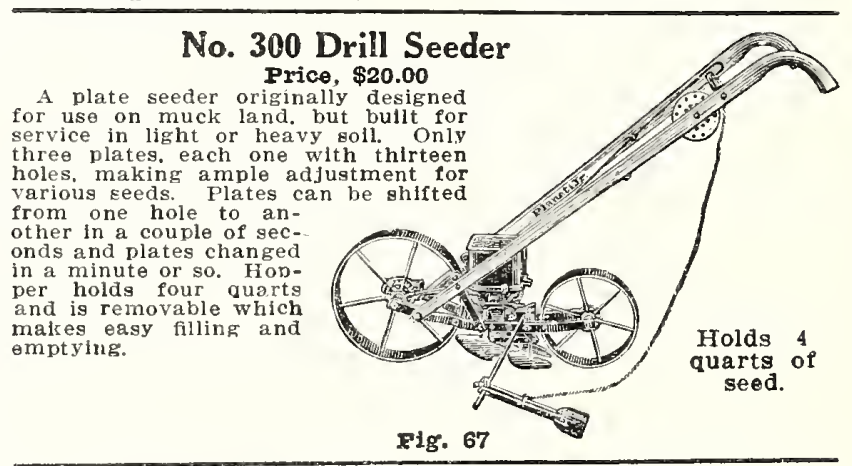

No. 16 Planet Jr. Single Wheel Hoe Price, $\$ 9.00$

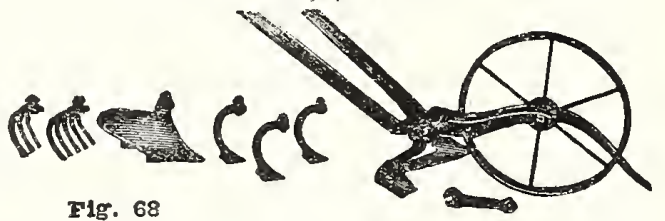

The highest type of Single wheel Hoe made. Light, but strong. and can be used by man worn in your garden in the easiest, quickest and best way.

No. 17 Planet Jr. Single Wheel Hoe Price, \$7,75

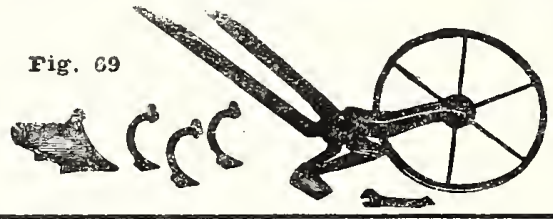

No. 19 Planet Jr. Single Wheel Hoe Price, $\$ 6.00$

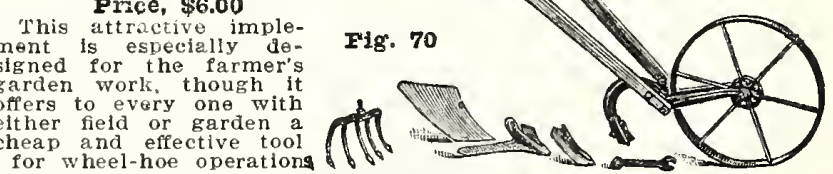

for wheel-hoe operations abject to change without notice. 


\section{EVERYBODY KNOWS Toss Seed Grows}

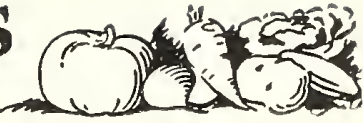

\section{PLANET JR. FARM AND GARDEN TOOLS}

No. 119 Planet Jr. Garden Plow and Cultivator

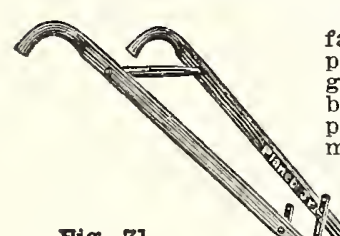

Fig. 71

This member of the "Planet Jr." family will appeal to all those who prefer a high wheel tool for their garden work. Where the soll has not been so thoroughly and carefully prepared, the high wheel undoubtedly makes an easy running tool.

The wheel is 24 in in diameter with

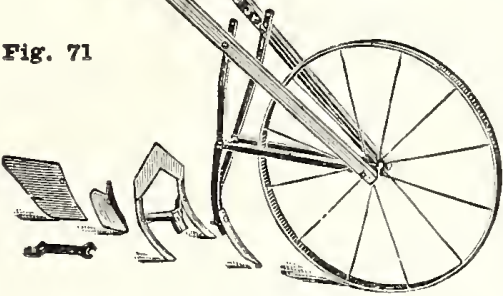
rim $1 \frac{1 / 2}{\text { in. wide, }}$ insuring easy run ning in the lightest soil

The equipment is so complete that it will meet all the needs of the ordinary garden, where the adjustments and refinements of the igher priced Hoes are not re-
Fire-Fly Garden Plow

Price, \$4.25

This tool will enable a busy man to do in his spare minutes nearly all the work of a family garden. Chicken ralsers find it of great advantage in plowing up their scratching yards. It will throw a furrow four to six inches wide and one to three inches deep.

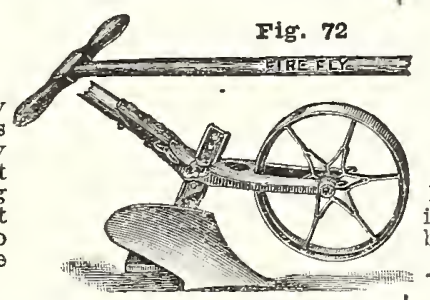

rig. 72

Fig. 76

\section{Planet Jr. No. 2 Grass Edger}

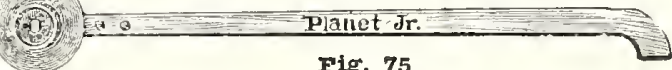

Every one who uses a lawn mower should have a Planet Jr. No. 2 Grass Edger. The cutting blade is made of the best quality steel and well sharpened. The handle is strong, being made of good quality wood. In order to have attractive lawns, keep the edges well trimmed. There is no better tool for this purpose than the Planet Jr. No. 2 Edger. Price, $\$ 1.60$.

\section{No. 8 Planet Jr. Horse Hoe}

Price with cast wheel, $\$ 16.00$

Stronger, better made and capable of a creater variety of work than any other cultivator $m$ a de. Non-clogring s te e wheel. Dept $\mathrm{h}$ regulator and extra long frame make it run steady.

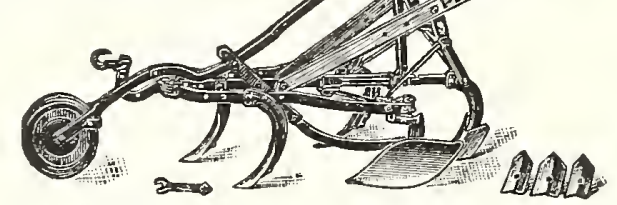

The No. 7 Forse Foe is the No. 8 without the depth regulator. It works the same as No. 8 in every way except that t lacks the steadiness and easy control of depth made possible by the depth regulator. Frice with cast wheels, $\$ 15.50$.

\section{No. 9 Planet Jr. Horse Hoe}

Price, with Cast Wheels, $\$ 14.00$

Star Cultivator, Weeder and Pulverizer

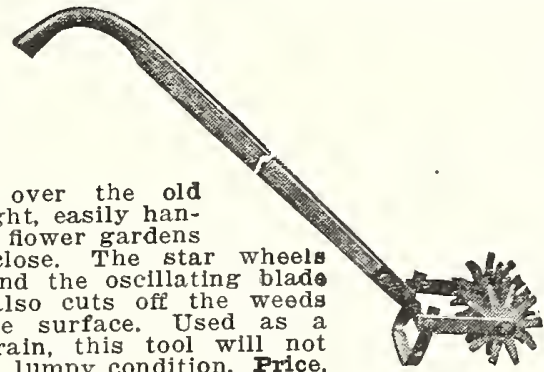

Fig. 73

An improvement over the old style pulverizer. Light, easily handled. Very useful in flower gardens where plants are close. The star wheels break up the soil and the oscillating blad pulverizes it, and also cuts off the weeds directly beneath the surface. Used as a leave the ground in a lumpy condition. Price, $\$ 3.00$.

\section{Planet Jr. Double Celery Hiller}

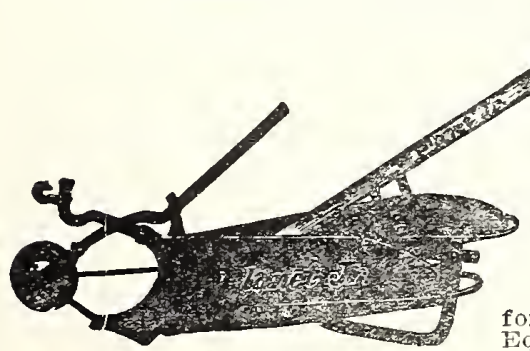

Pig. 74

Produces a great s a ving in growing celery and is almost ex clusively used where known. Leaf lifters are adjustable in height to suit crops by bending slightly; especially valuable for early working. Equipped with lever standards, leaf lifters Hilling blade is 43 inches long, adjustable in width or height works all rows up to four feet apart. Before billing, the soil should be thorovghly loosened with a horse hoe. Price, \$27,50.
Is identical with No. 8 except that it has no depth regulator, and has a plain wheel instead of lever wheel.

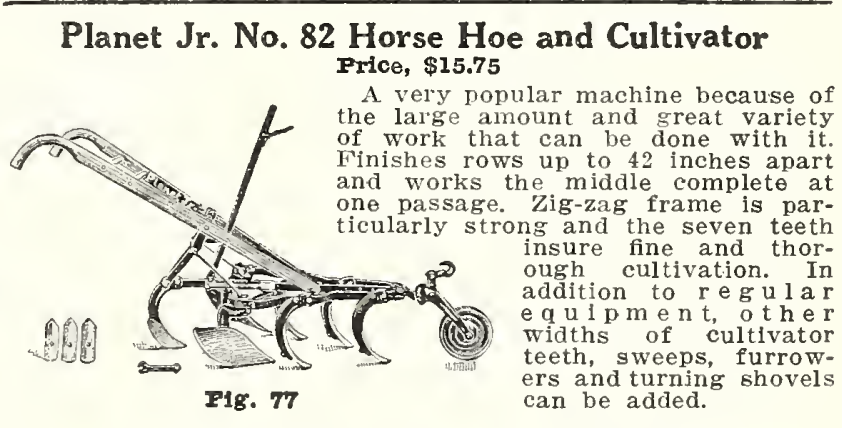

No. 90 Complete, with Cast Wheel

$\$ 16.75$

Weight, packed, 74 lbs.

No. 90B (without Pulver-

izer), $\$ 13.50$.

No. 91 (with wheel), $\$ 12.50$

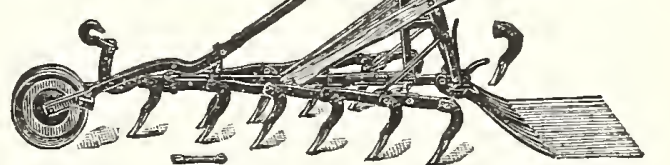

A valuable tool in the market garden, truck and strawberry patches. Has new steel wheel which prevents clogging. Its 12 chisel-shaped teeth cut out all weeds, stir and mellow the soil and leave the ground in the finest condition without throwing dirt on plants. 


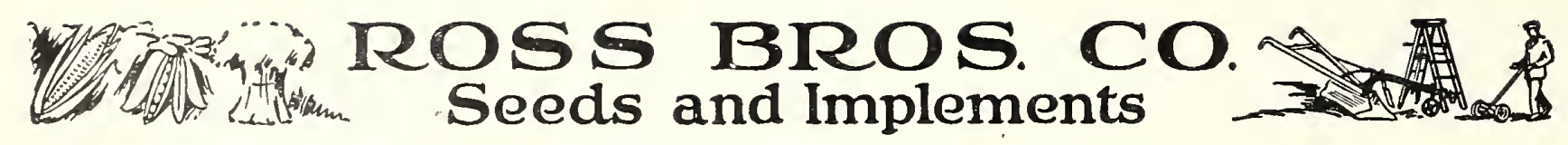

McCormick-Deering Vertical Lift Mowers

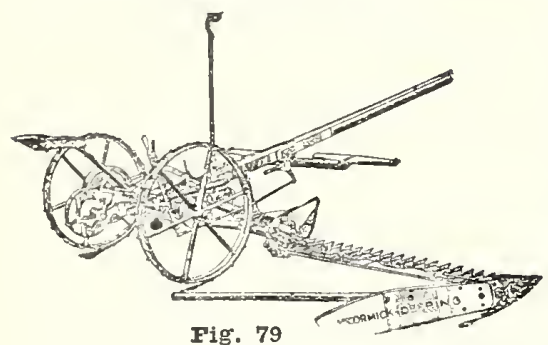

This mower, so well known by the farmer in general, is $\mathrm{particularly}$ adapted for $\mathrm{New}$ England use. It is made in $r u g g e d$ shape to stand the local conditions and the vertical lift which we sell especially in McCormick mower is recognized as a great addition to the hay tool line in general.

The main lifting lever is equipped with automatic locking Equipped with tongue, neckyolie, whiffletrees, and two knives.
$5-\mathrm{ft}$.
$6-\mathrm{ft}$.
745 lbs.
Ask for Price

\section{McCormick-Deering Vertical Lift} One-Horse Mower

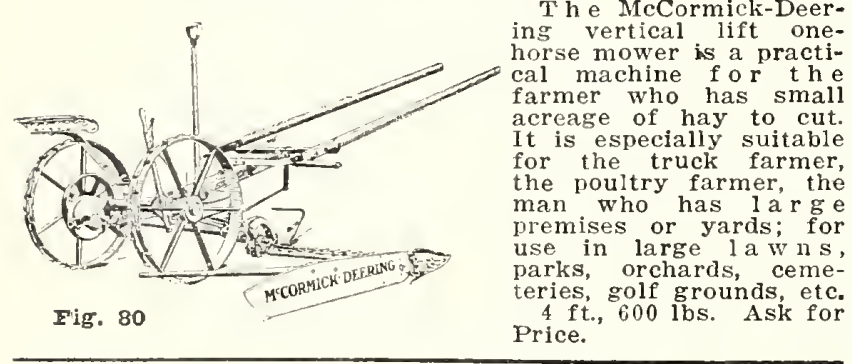

\section{Mowing Machine Sections}

We have these sections or linives for every machine, including the Deering, McCormick, Worcester, Buckeye, Adriance Buckeye.

Per box of 25 sections $\$ 1.65$.

Sections livets, 25c per $1 \mathbf{b}$.

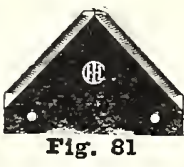

\section{McCormick-Deering Steel Frame Rake}

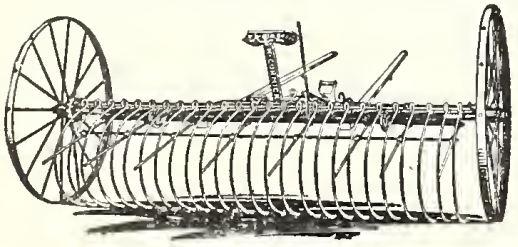

This rake is made to supply the demand for an all-steel rake. We believe that it is the best of the entire lot. It is a horse dump-rake. Strength a nd simplicity are two features of its construction. 8 FT. 25 TEETH. Price, $\$ 45.00$.

Fig. 82

5 per cent Cash

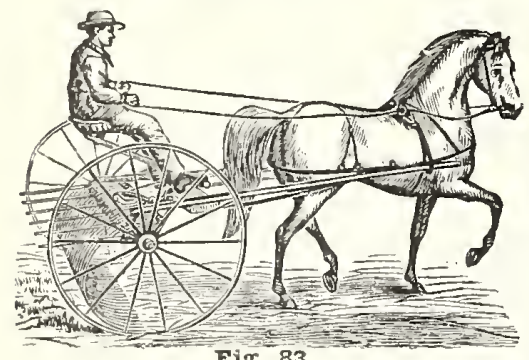

Yankee Hay Rake

\section{TEFTH}

This is the old reliable Yankee, wh i ch needs no introduction. It is a very easy rake to operate, each tooth being independent; it will pass over large stones without breaking the teeth. It is so easy to operate that a child can handle it.
Ask for Price.

\section{McCormick-Deering Windrow Hay Loader}

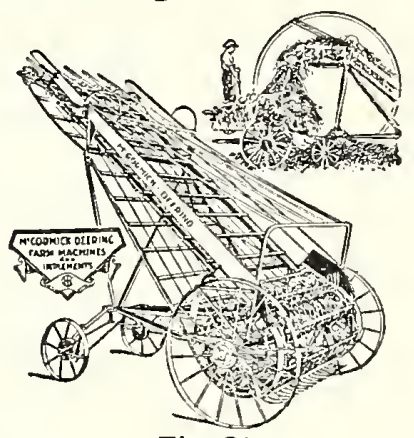

Fig. 84

This Loader is built principally of steel and is made to last. A Hay Loader is just as essential as a side delivery rake for the economical handling of hay. It does quicker and better work and at the same time saves labor. The McCormick-Deering Loader enables you to keep ahead of the weather. Tlie loader can be detached from the wagon by the driver simply pulling a rope extending to the top of the load which enables him to drive to the barn, while the next team picks up the loader. Weight, $910 \mathrm{lbs}$.

\section{Ask for Price}

\section{McCormick-Deering Combined Side-Delivery Hay} Rake and Tedder

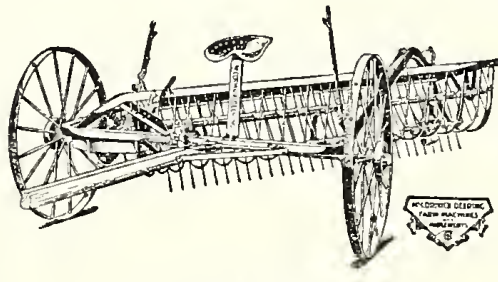

Fig. 85
The left hand delivery of the Keystone combined side delivery rake and tedder allows you to follow the mower closely and rake the hay before the leaves begin to wilt This is practically the same construction as the regular Keystone $S$ id e Delivery Rake, which does not have the reversing mechanthis machine has. The teeth strike the head of the hay first and rake much cleaner and turning the hay into a neat, airy windrow, where the air gets an equal chance at stems and leaves. Air cured hay is better than sun-dried hay.

The left-hand delivery deposits the windrow on the clean stubble and not on the unturned swath, as in the case of the right-handed rake. Weight, 991 lbs. Ask for Price.

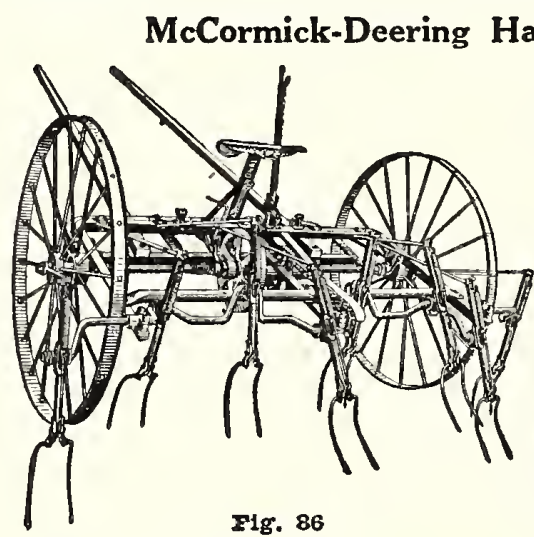
This is the neatest and most substanframe hay tedder on the market. It has solid steel axle and on stony ground we recommend $\mathrm{th}$ is to any other tedder. We believe an entire stee tedder made like this one will outlast any other tedder on the market today. It has two levers, one throwing in and out of gear and one for raising and $10 \mathrm{wer}$ ing the forks for uneven bined pole and shafts so it can be used for either one or t wo horses. It is the best steel-frame hay tedder on the marketsix forks. Ask for Price. Weight, $578 \mathrm{lbs}$.

All prices in this catalogue are subject to change without notice. 

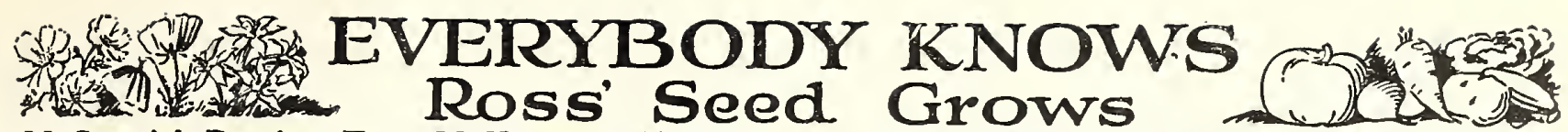

McCormick-Deering Type M Kerosene Engine $11 / 2,3$ and 6 HORSE POWER

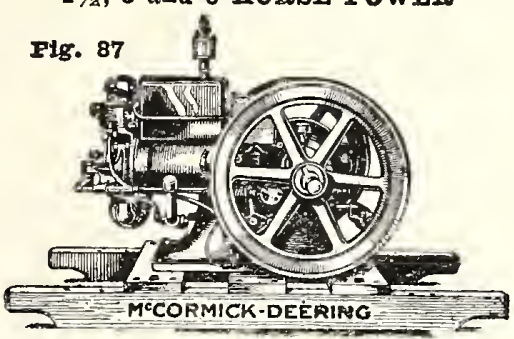

Ross Tilting Table Wood and Pole Saw

The a b o ve will give you an excellent idea of the high type of these saws. They are made of good material throughout and are built in a thoroughly workmanlike manner in every respect. The arbors are of steel, the bearings long and well babbitted. The balance wheels are heavy and well balanced. This machine is finished in an attractive manner. It has a tilting table pivoted so that it balances perfectly, and is therefore a great favorite with

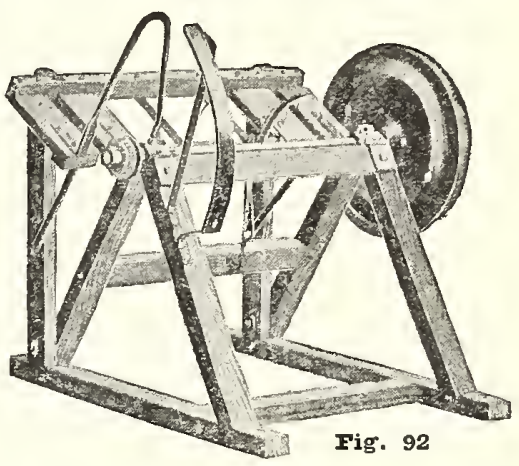

Here are some of the good points. When taken apart the engine is in ten units or groups of parts, so that any trouble can be easily detected and remedied. The base crank case perfect alignment of parts. There are three openings into the crank case that give access to every part. The crank case can be drained of oil. This means a clean engine. The piston has four rings that hold compression perfectly. The connecting rod has wide, thick bearings. The mixer adjustments are so simple

il/2 Horse Power, Weight 350 lbs............\$ 68.75

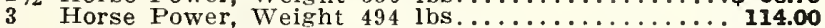

6 Horse Power, Weight $890 \mathrm{lbs} . \ldots \ldots \ldots \ldots \ldots \ldots . \mathbf{1 7 7 . 5 0}$ the sawyer. Weight, 275 lbs.

TIITING TABIE WOOD SAW FRAME with $95 \mathrm{lb}$. bal-

ance wheel less saw TIITING TABIE POLE SAW FBime with $95 \mathrm{ib}$ bal-

ance wheel, less saw............................... 32.00

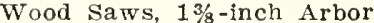

20 inch $\ldots \ldots \ldots \ldots \ldots \ldots \$ 4.10 \quad 26$ inch $\ldots \ldots \ldots \ldots \ldots . \$ 65$

22 inch $\ldots \ldots \ldots \ldots \ldots \ldots \ldots \ldots \ldots \ldots .8 .85$

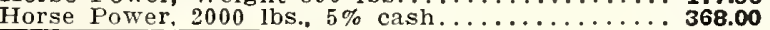

24 inch $\ldots \ldots \ldots \ldots \ldots \ldots \ldots \ldots \ldots+5.75 \quad 30$ inch

8.90

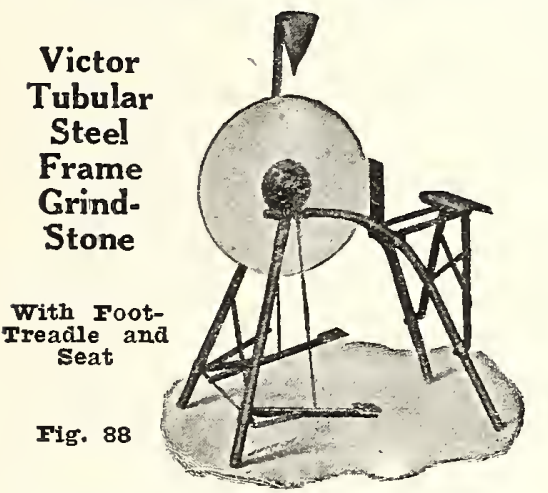

Adjustable seat, 4 to 5 inches, vertically. Stone movable for w a $\mathrm{rd}$ and back on frame. Frame being slightly flexible, it adjusts itself to uneven floors or surfaces. Rigid and easily set up. Bi-treadle with power properly applied. Hinged connection with ball-bearings on crank. Ball-bearings in journals. Frame is narrow at top, making it convenient to apply power, and spread at base, giving greater rigidity. Crated complete, stone protected. Made in one size about stone protected. Made in o.
$100 \mathrm{lb}$. Stone. Price $\$ 9.50$.

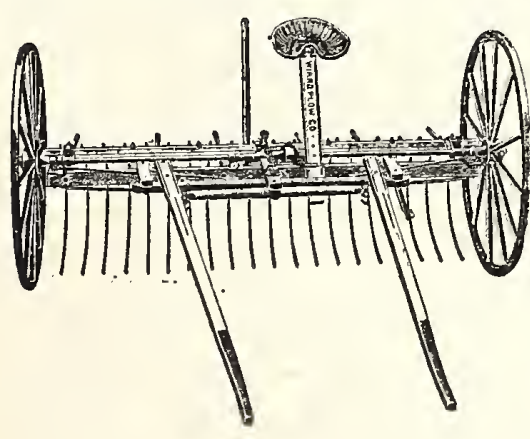

Fig. 91

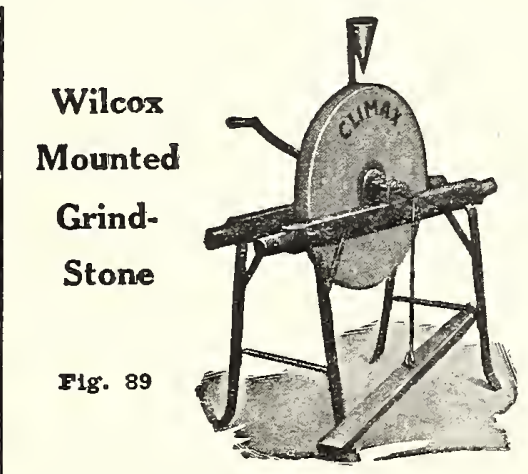

This is the best low-priced grindstone on the market. The stone is best Berea Grit (Ohio), the legs are iron which will not rot if left out during haying; the wood sidepieces are painted bright vermilion. Runs on ball-bearings, and every stone warranted to run true.

No. 1 , about 100 lbs............\$9.00

No. 2 , about 120 lbs............. 9,25

No. 3 , about $135 \mathrm{lbs} \ldots \ldots \ldots \ldots . .9 .75$
Hecla Wood Frame Mounted

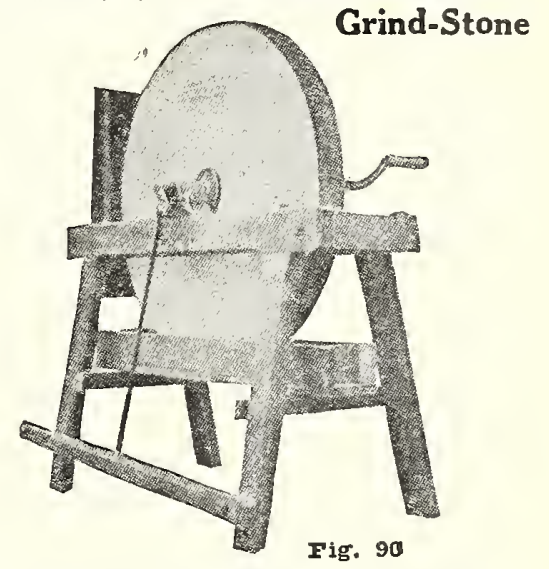

The stones in these are best Nova Scotia Grit mounted on heavy hardwood frame. It pays to buy a good article.

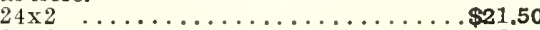

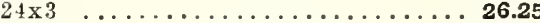

$26 \times 21 / 2 \quad \ldots \ldots \ldots \ldots \ldots \ldots \ldots \ldots \ldots \ldots \ldots \ldots+26.50$ $26 \times 3$

All Emperor Rakes Have Combination Thills for One or Two Horses Among the many valuable features of the Emperor are:

A double-trussed frame that prevents all sagging of frame or axle.

A hand lever that cannot change position when the foot dump is used.

A revolving steel axle and positive dump that cannot get out of order.

A dumping ratchet provided with flanges that strengthen the axle.

A reversible dump dog of hardened steel than can be changed to four different positions should any wear occur.

A cam action for releasing the dog, which drops the teeth without shock or noise A flexible joint by which the teeth may be held down to their work or carried high for any distance with the same foot

The tooth head is so attached to the axle that the teeth keep their places and rake clean, going up or down hill, no matter how steep.

The teeth are so hung in the head that they can be taken out and put in with the least trouble: are flattened and have chisel points that will not dig, take up least dust, offer least resistance, and reduce the draft.

We furnish short teeth at end to keep hay out of wheels and hooks to keep hay from rolling, when so ordered.

Adjustable seat, secure foot rest, best selected material, steel axles and truss rods, hickory cleaners, and wheels of our own make, with round felloes and clipped joints.

Price, $\$ 45.00$.

All prices in this catalogue are subject to change without notice. 


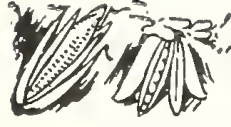 RO Seeds and Implements \\ BROS. CO.}

McCormick-Deering Ensilage Cutter

"A Safety First" ensilage eutter with a boller plate fly wheel. This type of boiler plate, wheel is especially strong, insurIng safety at all speeds. The feed throats on this machine are high as well as wide, giving the machlne a very great capacity, so arranged that the fans blow straight up the pipe.

Extra set of knives packed with each machlne. Come regularly equipped, with straight knives, but curved knives can be furnished on special order. Knives and cutter bar instantly removable.

on skids, G, $\$ 257.00 ; E, \$ 205.00$. 5\% discount for cash. MLounted, G, $\$ 284.00 ; E, \$ 230.75$. $5 \%$ discount for cash.

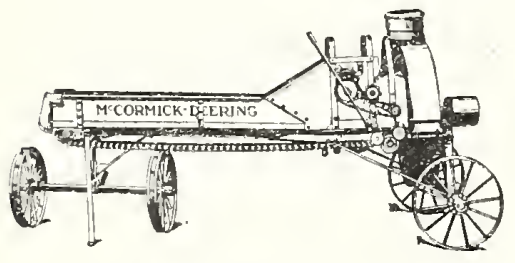

F'ig. 93

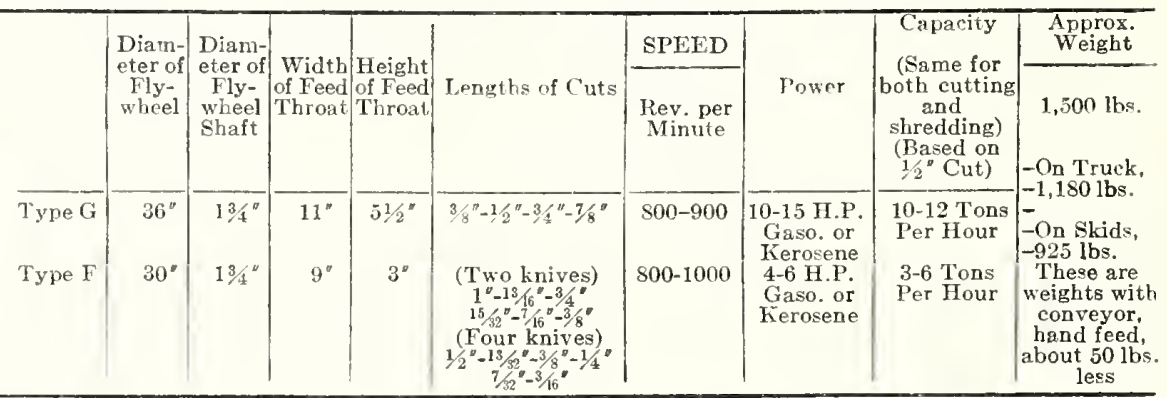

\section{The MicCormick Corn Binder}

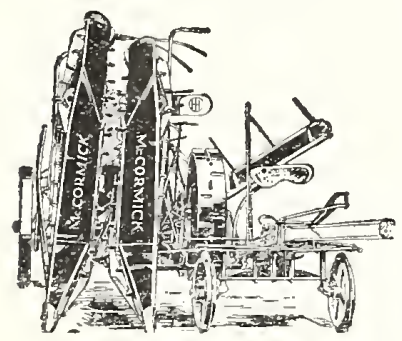

Fig. 94
The McCormick Corn Binder picks up down and tangled coln. There is bound to be some down corn in practically every corn field. The storms and wind will blow it down and it is sometimes badly twisted and tangled. Coln in this condition is difficult to handle either by hand or by machine. The McCormick is especially adapted for that particular class of work. It cuts and binds into even sized bundles. It is equipped with elevator chains which help especially to pick up down corn. There s no waste and you always get a neat job when you use the Mccormick. The binder can be set up any desired height. The distance hetween the gathering points on the corn binder is 22 inches. This will enable anvone to follow the row without missingt a single hlll.

Complete catalogue showing the McCormick line in detail will be mailed on request. Weight, $1,610 \mathrm{lbs}$. Ask for price.

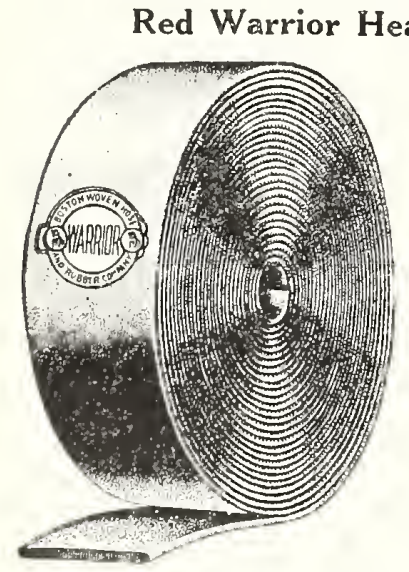
been developed from longcontinued tests and experiments under severest conditions of a e tu al use, to anticipate the rapidly growing demand for a high quality red rubber belt.

The body is of 32-oz. closely woven duck with a 22-1b. friction binder. Red Warrior conquers the foes of efficient power transmission. It is made for the hardest $k$ ind of service.

Fig. 96

PEICE

$\begin{array}{ll}4 \text { in. } & 4 \text { ply } \\ 5 \text { in. } & 4 \text { ply }\end{array}$

6 in

1 ply

$70 \mathrm{c}$ per $\mathrm{ft}$

All prices in this catalogue axe
The Harder Silo

Every man who keeps and milks a cow desires to do so with the greatest measure of ease and profit. Authorities advise that every third cow in the country is an unprofitable boarder. Flease consider this statement. but do not blame the cow too much. Many of the unprofitable third would remove themselves from this class if they were given a chance.

To make cows pay we must feed both liberally and economically. The two principle elements of the dairy ration are carbohydrates and protein. The best and cheavest source of carbohydrates is good silage. Alfalfa and clover are the best sources of protein. In these two feeds we have a dairy ration in a balanced and succulent form.

Thirty years ago liarder develoned the original and continuous opening front round original and continuous opening front round
stave Silo. From that time to now Harder sllos have been known by farmers everywhere as "The Bulwark of the Paying Dairy." In order to merit this confidence of the dalrying public certain qualities have been maintained throughout the years. A Harder silo sweet, succulent ensilage from every pound of lodder placed in th A Harder Silo must be so sturdy that will withstand wind and weather for a long perod of years wilhout work or worry on th part of the user. A Harder Silo must be so easy and simple of operation that it will lighten the lab
helpers. Send for complete catalogue.

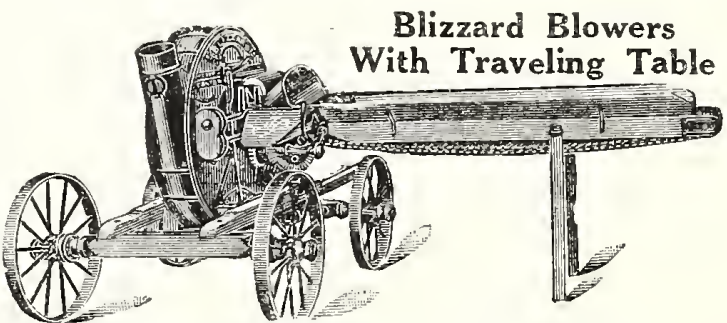

Fig. 97-Wheel Ifounted Truck, $\$ 40.00$

This illustration shows Blizzard Cutter and Blower with self-feed table. The endless apron is composed of two steel chains on which are riveted hardwood slates. These chains are propelled and travel over sprocket wheels secured to a separate shaft directly in the rear of the lower feed roll. The bearings on this shaft are made adjustable, to take up the wear on the drive. The lower feed roll and the traveling table are driven from the same shaft, each by its own sprocket wheel and chain. This device reduces the strain on the drive chain to a large extent. This machine can be operated successfully with a smaller amount of power than any similar cutter of the market. Price with
Length

ot' Knives

No. $400-131 / 2$ in.

-6 tons
L18-11 in rapacity
Power
H.P.
$31 / 2-5$ 800 $5 \%$ Discount for Gash $30 \mathrm{ft}$. Pipe and Angle Defectors 235.00 


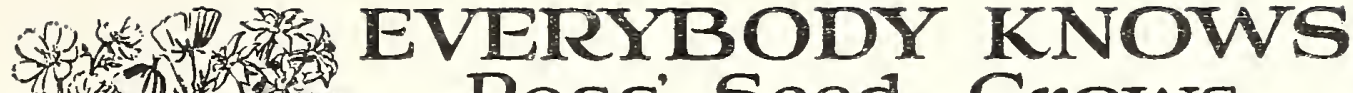 等}

\section{No Barn Is Complete Without One of These Horse Hay Fork Fixtures}
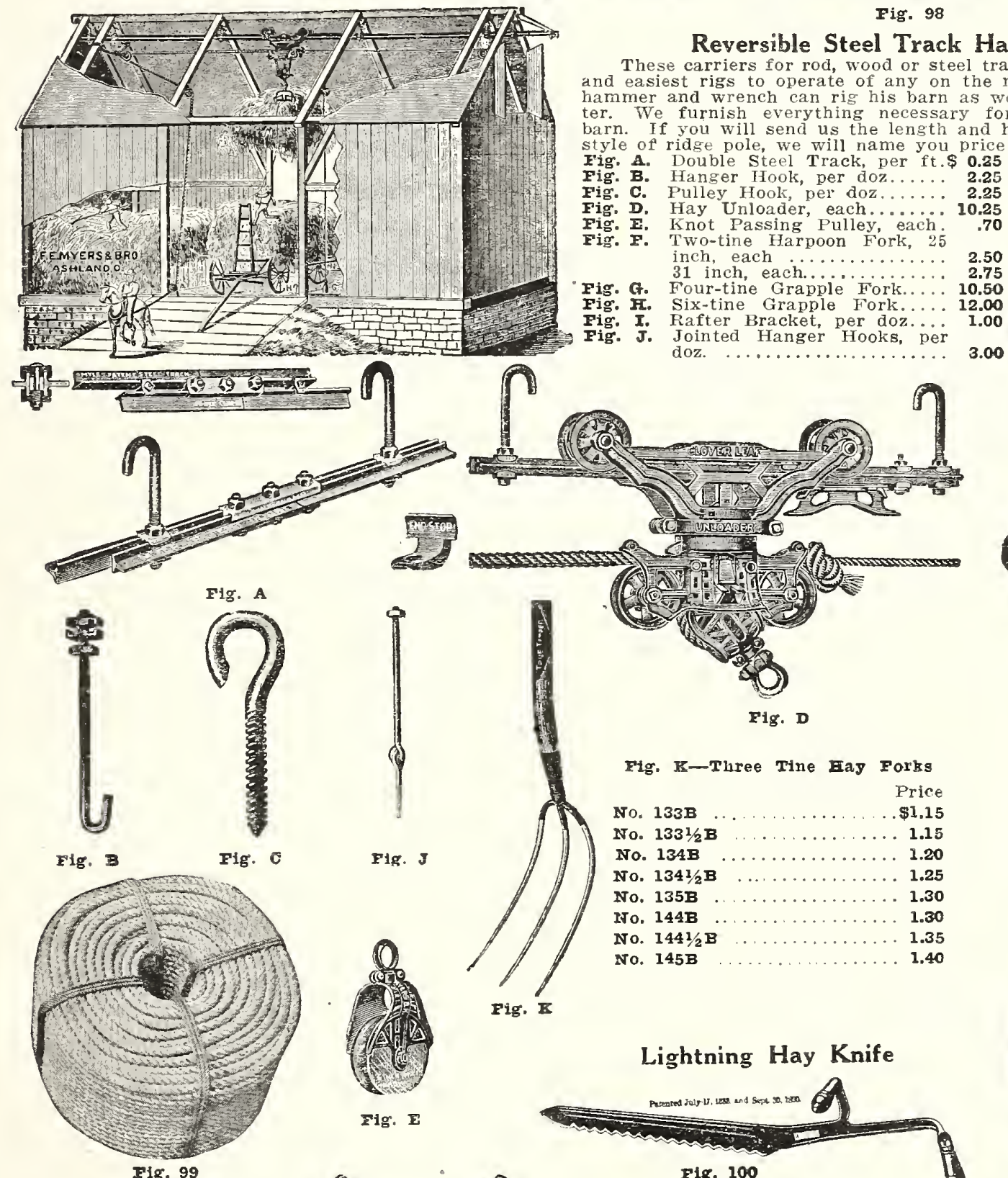

Pure Manila Rope

Coils about 50 lbs. each.

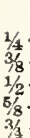
Price

-inch 55 feet Per L

27 feet $32 \mathrm{c}$

$\quad 7$ feet 6 in. 300

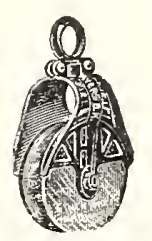

Eig. E

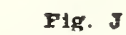

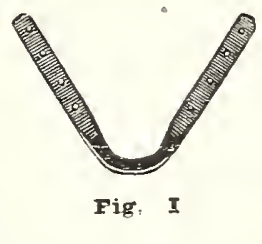

Fig: I
Fig. K-Three Tine Eay Forks

Price

No. $1331 / 28 \ldots \ldots \ldots \ldots \ldots . . \ldots \ldots$

No. $134 \mathrm{~B}$

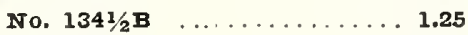

No, $1358 \ldots \ldots \ldots \ldots \ldots$

No, $1448 \ldots \ldots \ldots \ldots$

No. $144 \frac{1}{2}$ B $\ldots \ldots \ldots \ldots \ldots \ldots . . \ldots 1.35$

No. $145 B$. . . . . . . . . 1.40

Fig. I
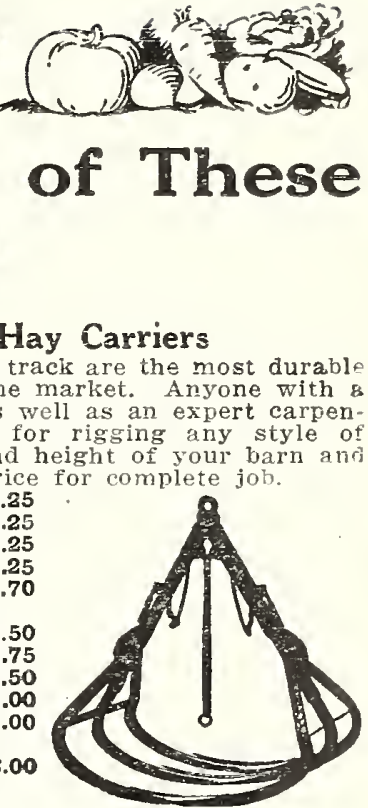

Fig. H

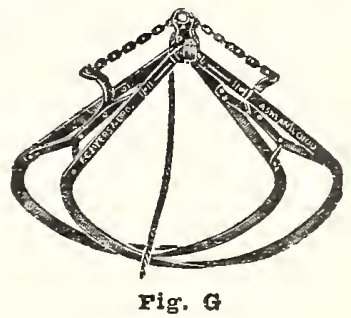

Fig. G

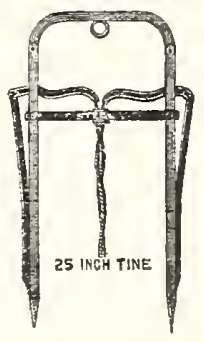

Fig, $\mathbf{P}$

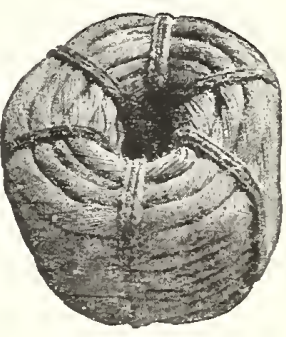

Fig. 101

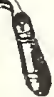

gacin $\$ 2.00$

Binder Twine

Put up six balls to bale. raxket Price.
Tarred Lath Yarn

in coils of about $50 \mathrm{lbs}$, wound in rope form. Each rope contains 130 ends. Used in tying corn and for various other uses.

Per 1b.
$22 \mathrm{c}$

Terme may be arranged for extended credit Bbouid our customerg go degirs 

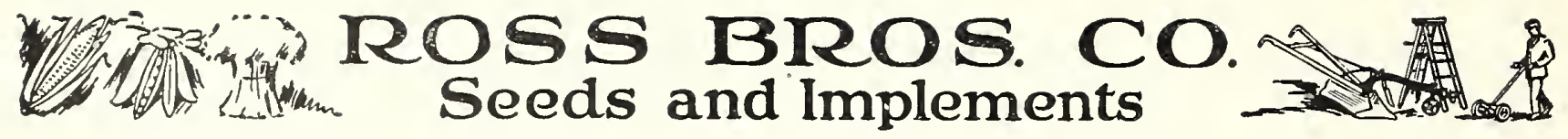

\section{McCormick-Deering Knife Grinder}

It is poor economy to operate a mower it racks the machine and worries the horses. The Deering grinder is so arranged that the emery wheel sharpens two mower sections at once and preserves the correct bevel. For grinding out nicks the the operator to control the action of the wheel and the pressure. The knife is firmly held in place by clamps and may be easily removed from section to section of the wh e e 1; grinds any make of knife. Price, $\$ 5.75$.

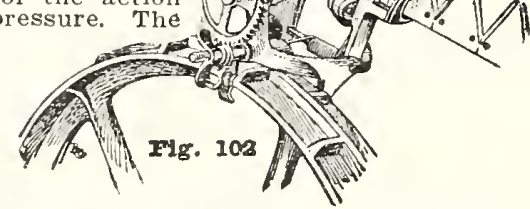

McCormick-Deering Mounted Portable Saw Rig This outfit makes a i d e a l equipment to $u s e$ for home work or for going out sawing wood. The engine is mounted on Worcester Farm Truck with stee l

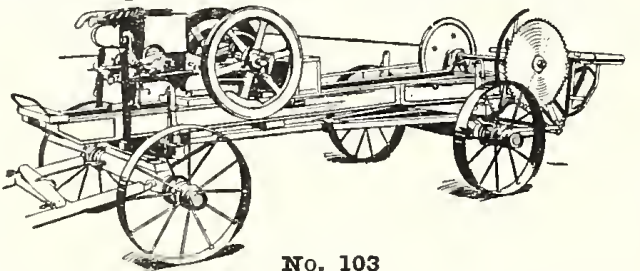
wheels, fitted with tiltirg table saw mounted on the rear. The balance wheel on the saw may be taken off for sawing long wood. Each equipment is fitted with 5-in. 4-ply rubber belt and belt tightener and is operated by handle with latch. This prevents belt from slipping. A convenient seat directly in front of the encine with foot rest. Easy to travel on the road. A first-class engine. Can be furnished with any size engine, but $6 \mathrm{H}$. $P$. is the usual size for sawing wood and general farm work.

All complete with 6 Horse Power engine, belt, etc., ready to use, $\$ 335.00$. $5 \%$ discount for cash.

\section{Chip Egg Boxes}

(3x4)

Handy for Retail Trado

Wt. Price

Dozen ......2 lbs.\$0.15

Bundle of 125.12 lbs. 1.00

Per $1,000 \ldots \ldots \ldots 7.7 .50$
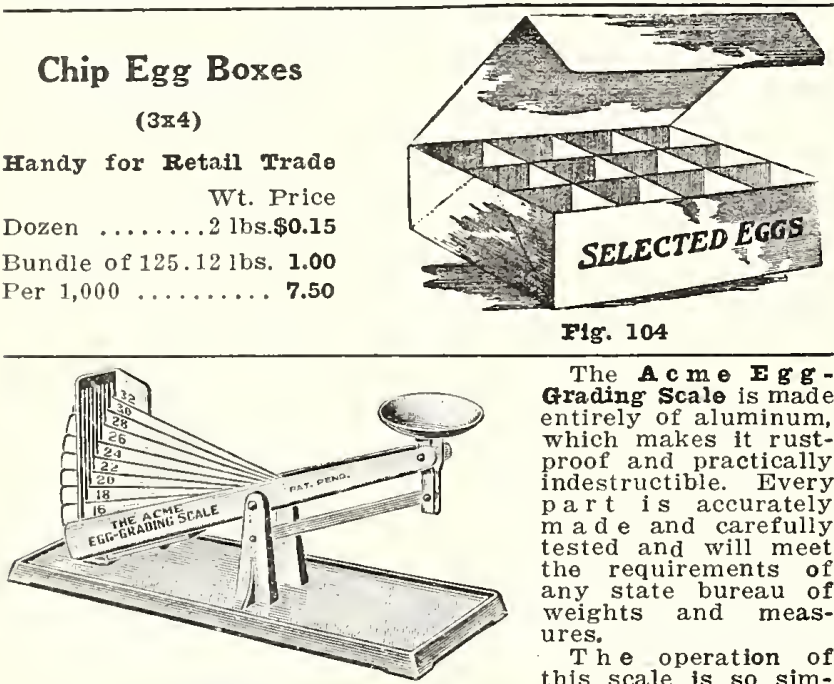

The Acme $\mathbf{E g}$. Grading Scalo is made entirely of aluminum. which makes it rustproof and practically indestructible. Every part is accurately $\mathrm{m}$ a d e and carefully tested and will meet the requirements of any state bureau of weights and measures.

The operation of Fig. 105 this scale is so simple that a child can operate it. By placing an egg in the cup the beam will automatically adjust itself. The lowest visible number on the blades will indicate the weight in ounces of one dozen like eggs. Hence this egg should be placed in a carton, or case, which is properly marked for that particular grade of eggs.

Price—\$3.00, Weight, 2 lbs.

Barnes' Worm Emulsion builds the general health and vitality of the birds at the same time it is destroying the worms and worm eggs, and because the worms and worm eggs are absorbed and assimilated by the digestive juices of the bird, there is no contamination of other birds as is possible by the expelling method. Worms are often present in flocks that are apparently in a normal state of health and giving a fairly good egg yield, but when the worms have multiplied and filled the intestinal tract so that there are digestive disorders and an irritated condition of the In-

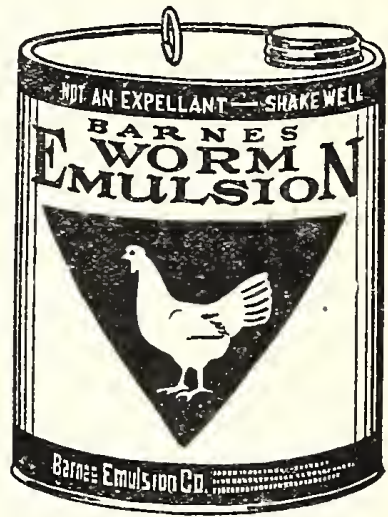

Fig. 106 testinal iining, mal-nutrition and low vitality will be noted by a paleness of the head and legs, loss of flesh (even though the birds are eating heartily) and a general unthrifty condition. The droppings may contain numbers of worms.

Prices-1 qt., weight 4 lbs., \$1.co; 1 gal., weight 12 lbs., $\$ 3.00$; 5 gal. keg, \$12.50.

Send for circular on Common Sense vs. Worms.

\section{The Putnam Brooder}

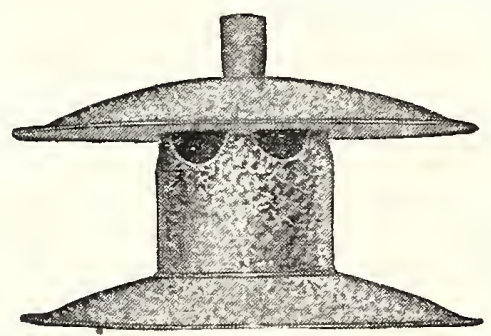

Fig. 107
This little article makes the best little mooder in the world. Stove costs $\$ 4.75$. With the stove we will furnish directions for building. Anyone can make this brooder out of a shoe box in a little while.

A shoe box, a few nails, this stove and an hour's time gives you a brooder which will serve you as well as any other on the market. Weight, 6 lbs. Aluminized Metal Egg Crate

\section{FOR PARCEI POST}

have proven itself by constant use to be the most practical. Ideal for shipping eggs, butter and other farm products by parcel post.

It is practically egg-breakprooî.

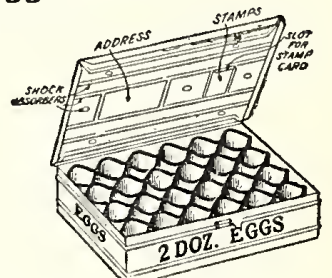

Fig. 108

\section{Reversible Address Card}

placed under the lid provides for going and returning addrsses, making the Crate intermailable between two parties. This eliminates readdressing for each shipment. Stamp slips aré also provided, so that shipper may pay and place postage for the return mailing.

Postage is no more than for other Egg Carriers. Price 1 dozen size-all eggs, $13 / 4$ pounds............\$1.00 $11 / 2$ dozen size-all eggs, 3 pounds.............. 1.25 2 dozen size-all ergs, 3 pounds . . . . . .

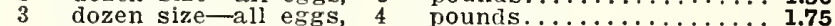

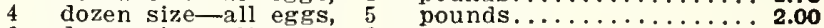

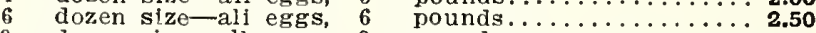
9 dozen size-all eggs, 8 pounds...............25 Price on combination buter pounds................... 4.00 application.

All prices in this catalogue are subject to change without notice. 


\section{EVERYBODY KNOWS Ross' Seed Grows}

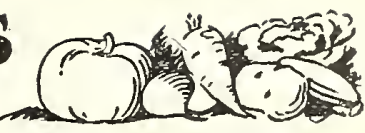

\section{The Newtown Coal Burning Colony Brooder}

The Newtown Coal Burning Brooder is constructed on scientiflc principles. Has a heavy metal facing around the flre bowl which prevents Chicks from getting burned. Has a double bottom, all parts securely bolted and cemented together. Built to last a lifetime. It has a large heating surface and a large fuel capacity, and a self-feeding coal magazine. The magazine holds sufficient coal to last from twenty-four to thirtysix hours. Has a special revolving draw center grate which cannot become clinker-clogged. Has both direct and check draft, controlled by an automatic regulator, which makes an absolutely even fire. The automatic regulator is so arranged that it cannot come in contact with the Chicks or be molested in any way. Special arrangement of the draught openings insures a constant change of air beneath the deflector.

We have three sizes: No. 7 , suitable for a house $6 \times 8$ to $10 \times 12$, which can accommodate two or three hundred Chícks. No. 11, designed more especially for two-room colony houses, but can be used in any single room, would take care of five hundred Chicks.

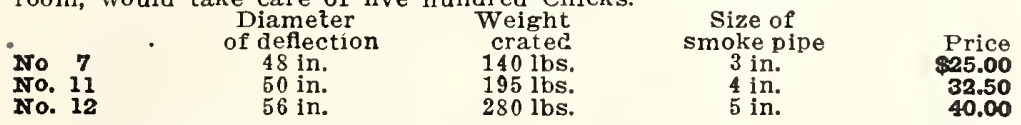

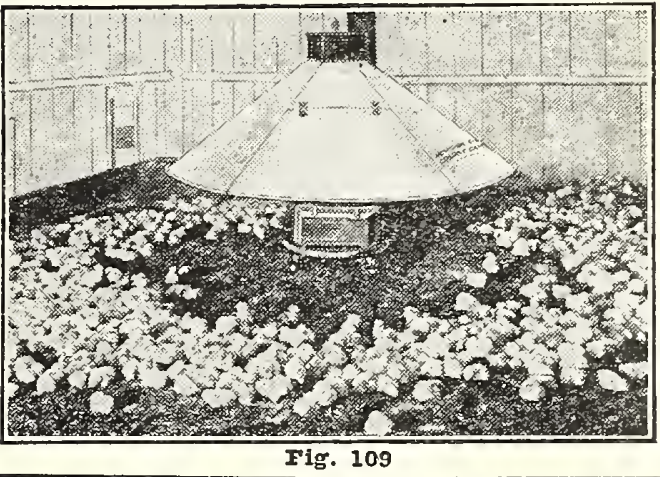

\section{The "Master Breeders" Chick Box}

The box is well ventilated-built to offset acute weather changes. Partition boards on both 50 and 100 chick sizes are made full height to add rreater strength to the box and to prevent chicks from crowding over the top, becoming squeezed and injured

No. S25. 25 chick size, $9 \times 11 \times 5$ t/ $/$ deep. one compartment. welght $12 \mathrm{lbs}$. per doz. bundle. Per doz, \$2.00, each $25 \mathrm{c}$

No. S50. 50 chick size. $18 \times 11 \times 5 \%$ deep. two compartments, weight 16 lbs. per doz, bundles. Per doz. \$3.00. each 30c.

No. S100. 100 chlck size, $18 \times 22 \times 51 / 2$ deep. four compartments, weight 30 lbs. per doz. bundle. Per doz. \$3.so. each 35c.

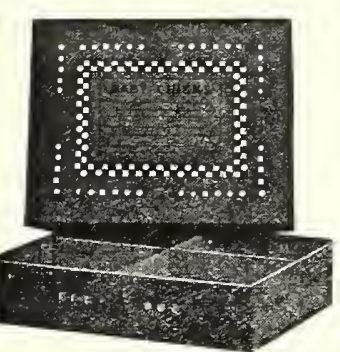

Fig. 110

Furnished complete with staplesfor assembling.

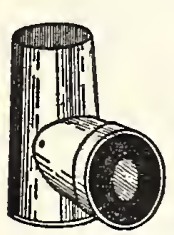

Fig. 111
Z-ray Egg Tester..............\$0.40 45c Postpaid

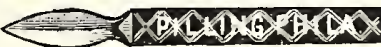

Fig. 112

Poultry Killing Knife Price each, \$0.50.

Reliable Brass Wafer Thermostats

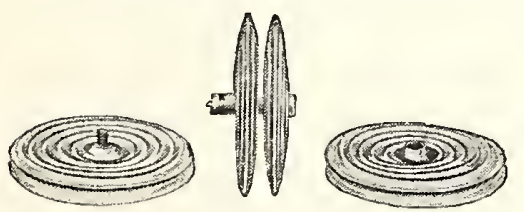

For any Incubator or Brooder. Made in both the single and double unit style. They are made of a special tem pered brass, vacuum filled and timed to meet their special requirements, so that each Fig. 113 and every wafer under a like condition will function the same. They are sensitive, accurate and durable.

The double wafer has a solid post between the two units, making each unit separate and independent of the other, so that should one of the units become damaged, the other would continue to function thus giving double protection. Price, postpaid, 3-1n., 500; 4-1n., 85c; 5-1n., \$1.10.

\section{BABY CHICKS}

Beginning March 15 we can furnish the following breeds at Market Price. White Wyandottcs, White Plymouth Rocks, Rhode Island Reds, Barred Plymouth Rocks.

Chicks delivered by Parcel Post from Worcester or direct from the hatchery. The breeds mentioned are what we recommend, but we can furnish almost any other breed from the hatchers.

Write for prices on breeds and quantities.

\section{Reliable Standard Coal Burning Colony Brooder}

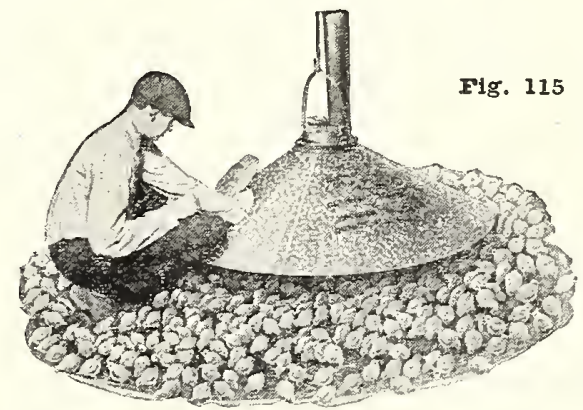

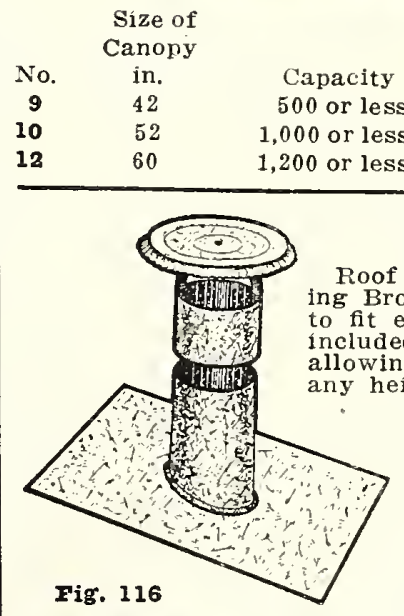

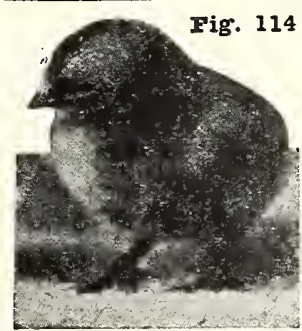

Ship. Wt.

Hgt., Complete,

in. $1 \mathrm{bs}$

$22-80$

$26-106$

$26 \quad 122$

\section{Roof Saddles}

oof saddles for installing Coal Burng Brooders. Made of galvanized stee to fit either side of roof. Rain cap is for not fastened to saddle o adjustment of outside pipe to wanted.

3-inch with Base Plate 11×12". Mailing weight, 5 lbs

4-inch with Base Plate $11 \times 12^{\prime \prime}$ Mailling weight, 5 lbs.

5-inch with Base Plate $11 \times 12^{\prime \prime}$ Mailing weight, 5 lbs.

Price, 3 and 4 in., $85 \mathrm{c}$ each; 5-in.; \$1.00. Add for postage.

\section{Husky Day Old Chicks}

Guaranteed safe arrival when shipped direct from our hatchery.

Every indication points to a large increase in the poultry industry for 1929 , and we see no reason why there should not. Our advice is to get your order in early for day-old chicks and not be disappointed the way many were last year, not being able to get their orders when wanted. 


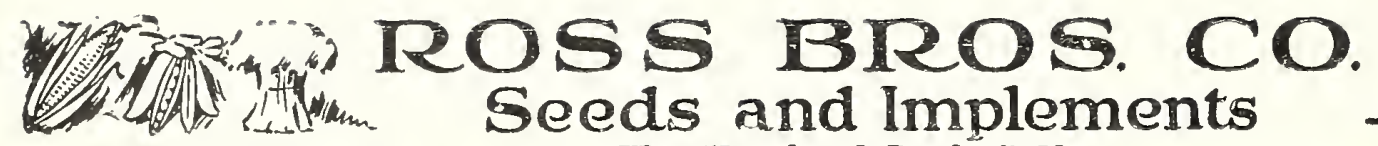

\section{Duplex Fount}

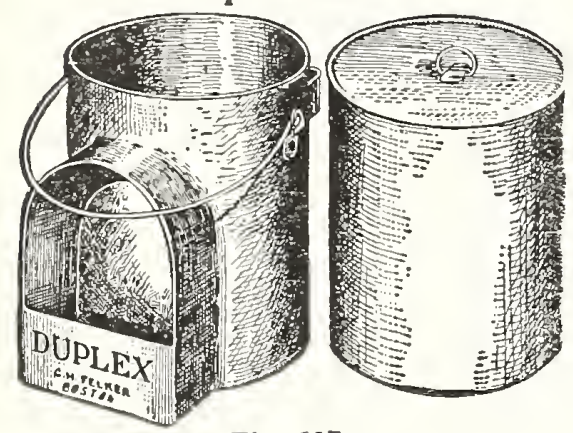

Fig. 117

Perfectly sanitary. Made of heavy galvanized iron. Take off the top, fill it, put on the lower part and you have a fount that will keep your flock healthy. does not freeze readily-winter.

does not freez $\theta$ readil. $\$ 3$ lbs.; 8 qt. $\$ 1.40$ each, wgt. 4 lbs.

DUPIEX TWIN FOUNTAIN (two out

let hoods), 8 qt. $\$ 1.65$. Wgt. 4 lbs.

\section{Round Baby Chick Feeders}

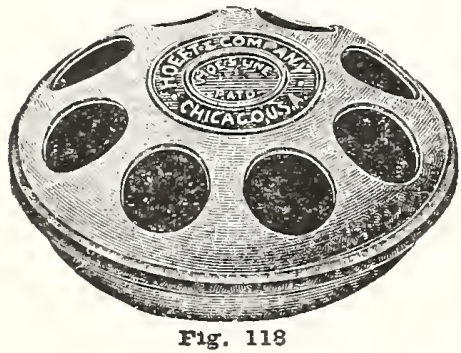

12 hole each. Wgt. each 2 lbs. 20 cts. 8 hole each. Wgt, each 2 lbs. 10 cts.

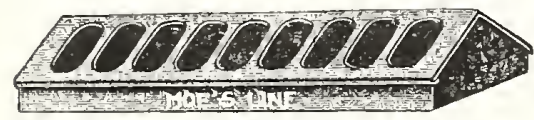

F19. 119

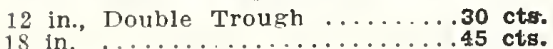

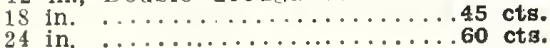
10 in. Tlough for feeding butter-

milk 20 in. Trough for feeding butterMailk $\cdots$ weight $\ddot{3}$ ibs.

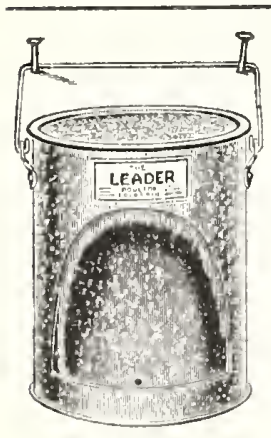

Fig. 120

\section{Leader Fountain}

A new Sanitary Fountain, practical to use, easy to keep clean.

A saving of from 30 to $40 \%$ over any fountain of its size.

$11 / 2$ gal. Mailing wgt. 5 lbs. Prioe, 85 cts.

3 gal. Mailing we 1 ght 8 l bs.
The "Insulated Duplex" NonFreezing Fountain

The extra large opening, or drinking trough, which this fountain car. ries makes it easy of access to a at the same time. An entirely new $\mathrm{nd}$ i $\mathrm{m} \mathrm{n}$ o ved method of insulation enables this fountain to keep water at an even temperature $t h$ e coldest day of win $t e r$ and the hot tes tay of summer.

\section{$3 \mathrm{gal} \ldots \ldots . \$ 4.50$ \\ TVgt. 20 lbs. \\ 4 gal.... 3 ibs. $\$ 5.00$}

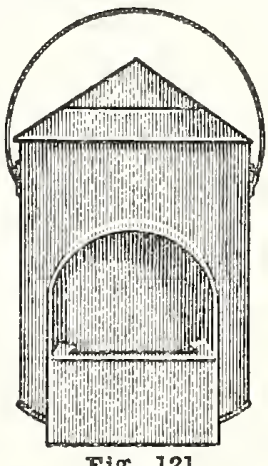

Fig. 121

\section{Wall Fount}

4 qt.......\$0.90

Wgt. 2 lbs.

$\$$ q $1 \ldots . . . \$ 1.10$

Wgt. 3 lbs.

Fig. 122

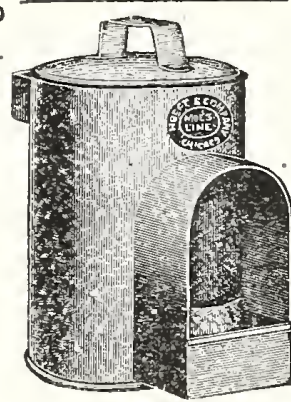

\section{Norwich Chick Feeder}

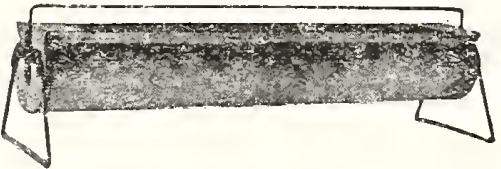

Fig. 123

20 1n., without rain top, wgt. 2 lbs. $\$ 0.75$ 20 in. with rain top, wgt, 3 lbs.... 1.00 Add postage for your zone.

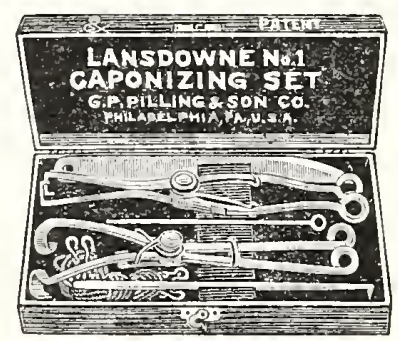

Fig. 124

Poultrymen can double their profits by Caponizing their chlcks. The operation is very simple-the instruction so full and explicit that anyone will be able to perform the operation. Capons ire worth $\$ 1.00$ to $\$ 1.50$ more than cocks not Caponized. They are very much quieter in disposition.

Complete with instructions, \$4.60. We send book, "Complete Guide for Caponizing," with every set. Farmer's plain set in pasteboard box,
\$2.75. Postpaid.

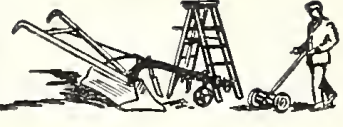

\section{Peerless Fount}

Take off bottom to fill.

1 qt. 45 cts., wgt. 1 Ib.; 5 qts. 90 cts., wgt. 3 1os.; 10 qts. $\$ 1.25$, wgt. 4 lbs. Fig. 125

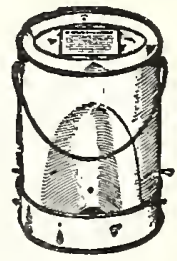

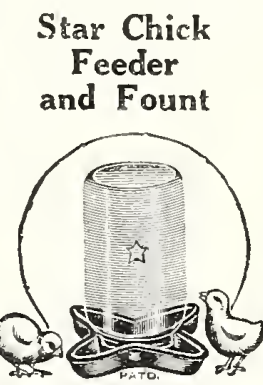

Fig. 126

Fit any" mason jar. Price, each, 10 cts. 15 cts. Postpaid. Sexton's Dry

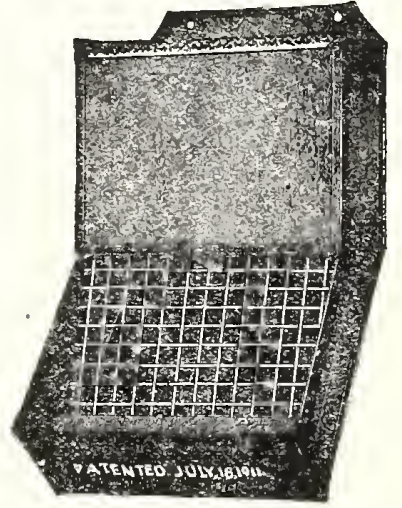

Fig. 128

Pronounced to be the best hopper of fered. Construction, easily operated and absolutely "Rat" and "Mouse" Proof.

The lower cover is so arranged that it is held up by locking the top cover of Hopper over same and by raising the top cover the lower cover will fall in place.

This Hopper is arranged to hang on the wall the desired distance from floor and never need be remored from the wall to be refilled. It is impossible to waste any feed, as the pan at the bottom takes any feed that may be picked out and the last crumb can be used therefore saving any waste.

Price, No. 2, 3 qt. $\$ 1.10,3$ lbs. Prioe, Nro. 1, 12 qt. $\$ 1.50,5$ 1bs. Price, No. 5, 24 qt. $\$ 2.40,7$ lbs.

\section{Earthen Pigeon Bowl}

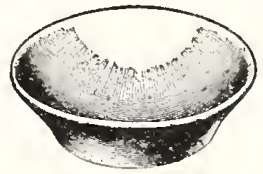

All pigeon fanciers recommend this style of bowl for their coops. Per doz.....\$2.00 Each .......25 Wgt. each, 4 lbs. Fig. 129 


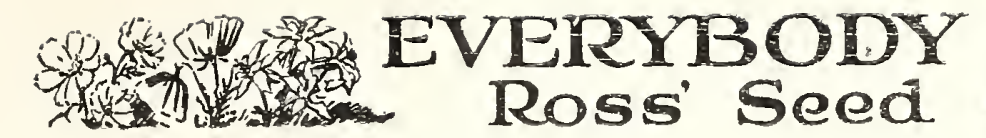

Lawn Park Coops

THE IAWN PAEK COOP SAVES THE CEICKS

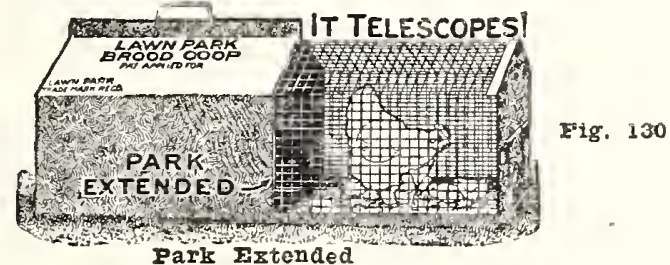

The wire park pulls out like a bureau drawer and is made from heavy galvanized hardware cloth. The main coop is made from strong 28 gauge galvanized iron. Size of coop, when park is fully extended as shown in cut, is 18 inches wide, $191 / 2$ inches high and 48 inches long. When park is closed it is 24 inches long.

A small door is provided to let small chicks only have full range as desired.

Protect the chicks from hawks, rats, weasels, vermin, cold, storms, etc. Give proper ventilation and sanitation. Price, each, \$3.75. Three for \$10.00.

\section{Worcester Oat Sprouter}

It pays to feed green stuff in winter. With this mechanical device green feed can be given to the poultry at all times. The tray contains five sprouting pans with a bottom drip pan fill of sprouted oats each day and replacing this same pan with a fresh supply of oats, the new shoots from one to four inches high can be supplied to the fowls dally, giving a never failing supply of green feed.

Endorsed by all the poultry raisers and egg producers. Price, \$6.00.

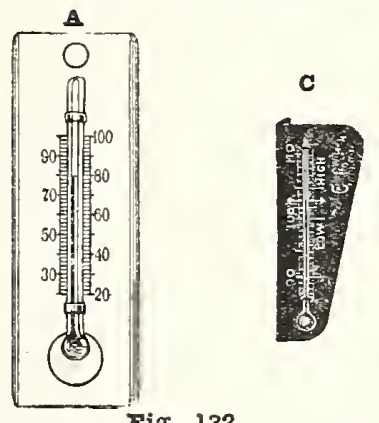

C Brooder Thermometer, 75 cts. cts. Add 5 cts. for postage.
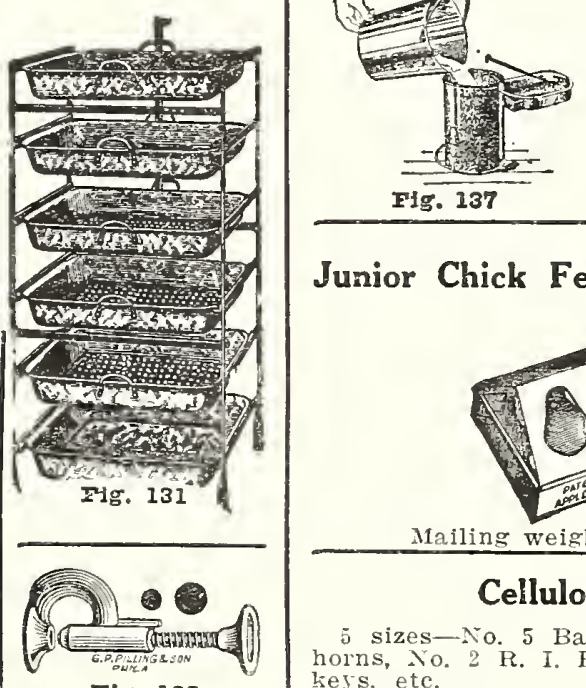

Fig. 133

Any number of combinations can be obtained with one of these punches. 35 cts. Postpaid 40 cts. keys, etc.

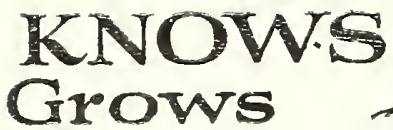

\section{Large Capacity Feeder}

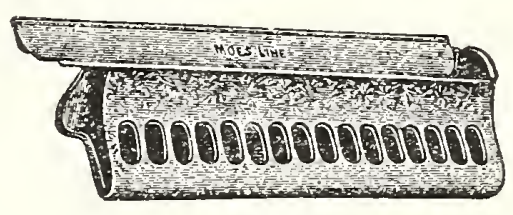

Fig. 136

No, 140 -Chick Feeder, each.................. $\$ 1.10$ No. $140 \mathrm{~W}$-Same as above but with wide rain cover..... 1.30 A fine feeder for growing stock, and a great time and labor saver. Has a total of 32 feeder holes. Sliding top, easy to fill and clean. Capacity, 10 quarts; length, 21 inches. No. 141-The same style, but larger. Length, 35 inches. Has 54 feeder holes, Capacity, 17 quarts, each .........\$1.75 No. 141 W-Same as above but with wide rain cover...2.15

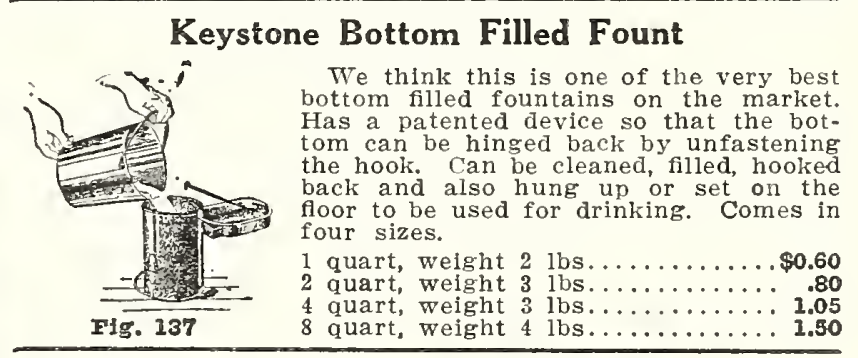

Junior Chick Feeder

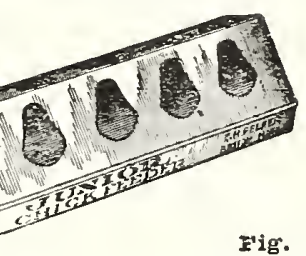

Price, 12 in., each 25 ots.

Mailing weight, each 2 lbs, 20-in., each 40 cts.

\section{Celluloid Bands}

5 sizes-No. 5 Baby Chicks, No, 3 Leghorns, No. 2 R. I. Red Rocks, No. 1 Tur-

Black-Thite-Pink-Red--Yellow.

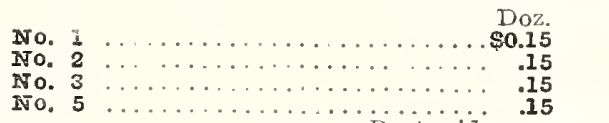

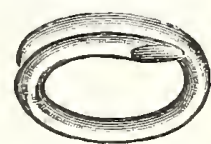

Fig. 139

100

$\$ 0.75$

.75

Postpaid

.60

1,000

$\$ 6.00$

6.00

5.00
4.50

\section{Felker's Handy Attachment}

To be used with any male of Fruit Jar A PERFECT FEEDER

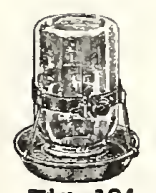

For Sour Milk, Water, Hard Grain or Grit

The Container is made of aluminum, the only metal in which sour milk can be fed with safety. It is rust-proof and non-corroding. The HANDY is adjustable, simple to operate and durable. Every one has some kind of a quart fruit jarthe HAND fits them all. Price 25 cts. Mailing IIg. 134 weight 2 lbs.

\section{Poultry Punch}

A poultry punch for marking baby chicks. Punches a clean hole In the web between the toes that will not bruise the foot. Guaranteed to work perfectly. 25 cts. each. Eostpaid $30 \mathrm{cts}$.

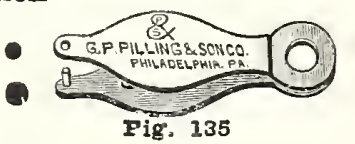

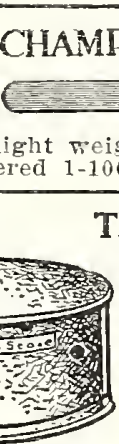

FIg. 141
Fig. 140

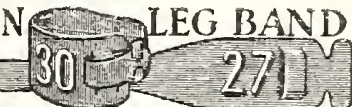

Very light Feight. Per 100, 75 cts.; doz., 15 cts. Numbered 1-100. Postpaid.

\section{The Putnam Stove}

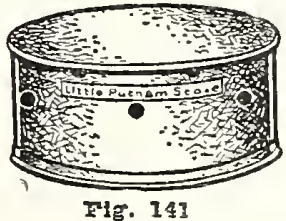

This little stove, $9 x 4$ inches, works wonders in cold weathel. Keeps water warm in the poultry house in the coldest weather. In order to have eggs in the winter time, hens must have plenty of water. They will not drinl: as much cold water as warm. Costs only from 20 to 35 cents to operate during the winter. Stove \$1.95.

Mailing weight 3 lbs.

See inside front cover of catalogwe for Darcel Post rates. 


\section{ROSS BROS. CO. Have a Conkey Corner in Your Poultry House}

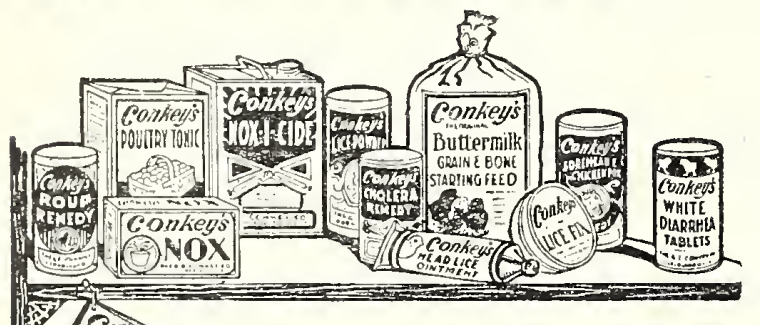

Raising poultry is pleasant and profitable when "good luck" is with you. Good luck, however, is not merely a matter of chance, but of BEING PREPARED. For more than twentyfive years Conkey has been THE POULTRY DOCTOR. Take his advice. Install a Conkey Corner of remedies in your poultry house as insurance against disease, trouble, loss and disappointment.

We sell Conkey's Poultry and Stock Remedies because we know they are reliable and we can guarantee them as follows:

Your money refunded cheerfully if any Conkey remedy does not satisfy.

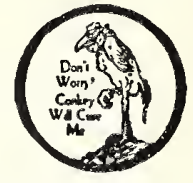

\section{Conkey's Roup Remedy}

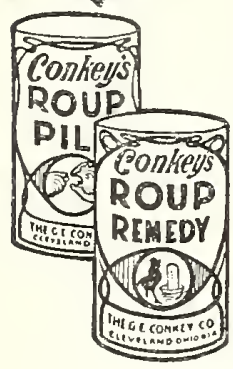

When Roup breaks out there's not time to experiment-start treatment at oncethe disease is very contagious. Cold, rainy weather and changeable conditions intensify Roup. When birds sneeze, froth in eyes, or run at nose, put Conkey's Roup Remedy in the drinking water. Sick birds doctor themselves and others are protected from catching the disease. Better still, always at the first sign of "roupy weather," place Conkey's Roup Remedy in fountains-it's a great preventive.

Prices-Fkg8. 25c, 50c, $\$ 1.00$; or $30 \mathrm{c}$, 55 c, $\$ 1.10$ postpaid; $11 / 2$ lb. can, $\$ 2.50$ postpaid; breeder size (5-1b. can), $\$ 5.76$ postpaid.

Conkey's Roup Pills

For treating individual cases and for use at shows when birds develop colds. These pills have saved many a valuable bira.

Prices-Fkgs. 25c, 50c, \$1.00; or 30c, 55c, \$1.10 postpaid; breeder size ( 1,000 pills), $\$ 3.00$; or $\$ 3.10$ postpaid.

\section{Conkey's White Diarrhea Remedy}

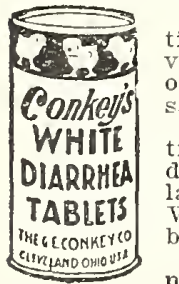

once you have used this old reliable preparation you will never be without it. As a preventive of bowel troubles, White Diarrhea and other digestive complaints, it has given great atisfaction for many years.

This remedy is also recommended as a preventive measure and in treatment of coccidiosis, a diarrhetic condition which attacks chicks similarly to White Diarrhea, but which differs from White Diarrhea in that a principal symptom is bloody droppings rather than white.

Frices-25c, 50c, $\$ 1.00$; Or $30 \mathrm{c}, 55 \mathrm{c}, \$ 1.10$ postpaid. Breeder size (1,200 Tablets), $\$ 4.00$; or $\$ 4.10$ postpaiá.

\section{Conkeys}

\section{Y-O}

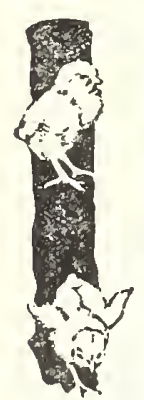

There is nothing finer than Conkey's Y-O to mix in with poultry mashes. Absolutely indispensable in raising chicks in backward season with little or no sunshine, as it is rich in vitamins $A$ and D (the "sunlight vitamins"). In addition, the $B$ vitamin in $\mathrm{Y}-O$ insures complete, rapid development giving birds ca pacit y and stamina for future production. Wonderful for growing stock. sary fol continued heavy egg production, as it replaces the vitamins used up in forming rich egg yolks. Hens won't break down as layers if given \% $0 \%$ of Y-O with mash feed. For breeding stock, it's wonderful, as it improves quality of the eggs, fertility and hatchability. Stop low hatches and high chick mortality by mixing $Y-O$ with the mash feed. Eastern Prices-Flrgs., 1 1b., $\$ 5 c ; 2$; 100 ibs., \$22.50.

\section{Conkey's Limberneck Remedy}

For limberneck (or ptomaine poisoning) this remedy should be on hand in your Conkey Corner at all times, as Limberneck

must be treated promptly.
Price $50 \mathrm{c}-55 \mathrm{c}$ postpaid.

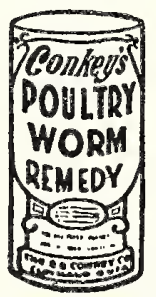

\section{Conkey's Poultry Worm Remedy}

Rids birds of many troublesome worms.

25c, 50c; or 30c, 55c postpaid; breeder size (5 lbs.), $\$ 2.75 ; \$ 2.85$ postpaid.

Conkey's Canker and Bronchitis Remedy

This splendid remedy checks cankerous growths and sores and soon restores the bird to normal. This remedy is Conkey's Specific for bronchitis. Also desirable in treating individual cases of Roup and for use at shows for colds. Pacirage, 50c; or 550 postpaid.

\section{Conkey's Lice Powder}

For dusting hens, nests, growing chicks-wherever body ice must be overcome.

Prices-Pkgs. 35c, wgt. I 1b.; 75c, wgt. 3 lbs.; pails 12 los. $\$ 2.60 ; 25$ 1bs., \$5.00. Parcel post, express or freight extra.

\section{CONKEY'S}

\section{Starting Feed With Buttermilk and Y-O}

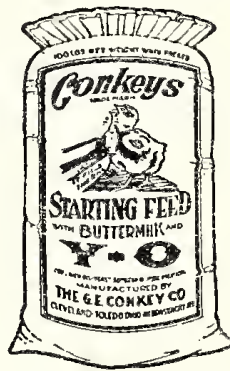

A great chick feed now better than ever! Guaranteed Analyzis: Crude Protein, 14\% Crude Fat, 5.5\%; Crude Fibre, 5\%; Nitro. Free Extract, 59\%; Carboliydrates, $64 \%$.

Ingredients: Buttermilk, Corn Meal Corn Feed Meal, Oatmeal, Wheat Middlings, Raw Bone Meal, Blood Flour, Meat Meal Crude Milk Albumen, Salt 1/2\%, X-O (cod liver oil, yeast, soybean oil meal, wheat middlings, $1 / 4 \%$ red oxide of iron).

Conkey's is the original buttermilk feed and has long been recognized as the safest feed for chicks because it is balanced just right and is scientifically prepared to give chicks all the body building elements to safely carry them through the first six weeks. The addition of Conkey's $\mathrm{X}-\mathrm{O}$ is in response to poultrymen all over the country who have been using $\mathrm{Y}-\mathrm{O}$ (a powder form of yeast and codiver oil) for vitamins. It is thus unnecessary to use cod liver oil or yeast in other form and $\mathrm{X}-\mathrm{O}$ fed chicks can be brooded successfully in any season, without regard to sunshine. Y-O furnishes all the $A, B$ and $D$ vitamins needed and not only causes wonderful development but absolutely INSURES AGAINST RICKETS OR "LEG WEAKNESS."

Unlimited testimonials on this feed. You need not have any hesitancy as it is the first choice of all feeds-in fact, it is easy to raise chicks on Conkey's feed.

STICK TO CONKEY'S AND RAISE HUSKY CHICKS. 


\section{EVERYBOI
Pratts Poultry Regu
Buttermilk Ba
For Health and Eggs
Pratts Poultry Regulator has no equal. It is the world's original poultry regulator and has been the stand- tonic supplying numerous health necessities required by heavy laying hens. Tones up systems, regulates bowels, aids digestion, sharpens appetite, wards off disease and in- creases vitality. Use it the year round for breeders, layers and growing stock.}

Weight 4 lbs., 50 cts., $\$ 1.40$ packages, weight 12 lbs.; 25-1b. pail, $\$ 3.00$; 100-1b. drum, $\$ 10.00$.

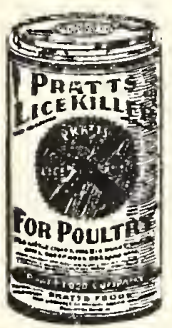

is powerful, economical, non-poisonous and non-irritating. For use on poultry, in dustbaths, nests, etc. Rids poultry of all ages, dogs, cats, horses, cattle, hogs and sheep of lice, ticks and other insect pests. Can also

In sifter top cans at $25 \mathrm{cts}$, and $50 \mathrm{cts}$.

30 cts. and 60 cts. postpaid. be used on vines, plants and flowers.
KNOW.S ris

Remedies

\section{ick Food}

When baby chicks come, keep them healthy and growing and bring even the weak ones a long by feeding.

Pratts Buttermilk Baby Chick Food

A largely predigested baby food for baby chicks. Guaranteed to raise every livable chick. Helps to prevent leg weakness, white diarrhea, "pasting up" and other chick diseases.

The cost per chick for three weelss is about one cent. If by using Pratts Baby Chick Food you can save five more chicks out of one hundred than you formerly did, considering these five chicks at three weeks of age as worth at least one dollar, your food has cost you nothing and you have five more husky chicks.

\section{Pratts Roup Tablets}

\section{(or Powder)}

Use it as a treatment or a preventive, A simple, powerful remedy with a long record of success in the treatment of colds, roup, diphtheria, catarrh, etc. Guaranteed to give satisfaction or your money back.

25 cts. and 50 cts. packages, $30 \mathrm{cts}$, and 55 cts. Postpaid.

\section{Pratts Disinfectant}

insures poultry health. It is a cheap, powerful, non-poisonous disinfectant. Spray it about poultry houses, roosts, dropping boards, nests and wherever a strong disinfectant is needed A deodorizer, germicide and liquid lice killer. Effective in the treatment of roup, cold and contagious diseases.

Quart, weight 3 lbs, 55 cts.; half gallon, weight 6 2bs., 90 cts.; gallon, weight 11 ibs., $\$ 1,50$.

Prices subject to change without notice.

\title{
DR. HESS Poultry and Stock Preparations
}

\author{
Prescriptions of Dr. Hess (M.D., D.V.S).
}

Dr. Hess Poultry Pan-a-ce-a

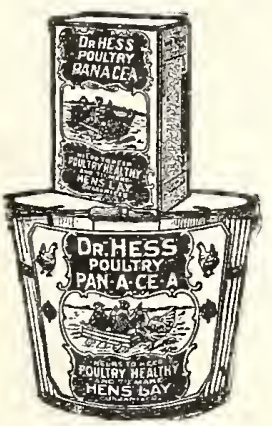

makes poultry healthy; makes hens lay; not a stimulant, but a tonic, that tones up the dormant egg organs, brings back the scratch and cackle, and compels each hen to put her share of eggs in the market basket.

It also contains internal antiseptics that counteract disease; insures a healthy, singing poultry flock. Cost but a trifle-a penny's worth enough for 30 hens per day. $1 \mathrm{I} / 2$ lbs. $25 \mathrm{c}, 5$ lbs. $75 \mathrm{c}, 12 \mathrm{lbs}$. $\$ 1.50$, 25-lb. pail $\$ 3.00$.

\section{Guaranteed}

Dr. Hess Stock Tonic Improved-with Minerals Added

A Conditioner and Worm Expeller

By promating health it makes hog raising, dairying and stock feeding more profitable. Provides the most efficient, most economical, and least bothersome method of treating hogs for worms.

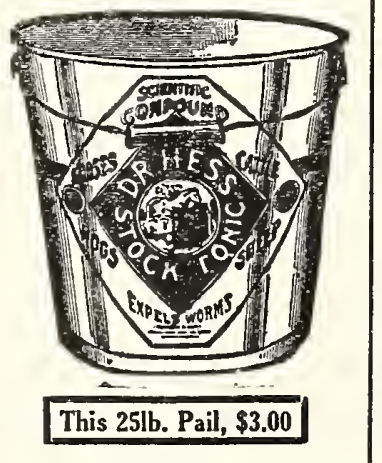

\section{Dr. Hess Roup Tablets}

For Roup, Diphtheria, Chicken Pox, Canker and all catarrhal diseases in poultry. Given in the drinking water. It is antiseptic, slightly astringent, non-irritating. It drys up the mucous discharges and heals affected parts.

50c and \$1.00. Postpaid, 55c and \$1.10.

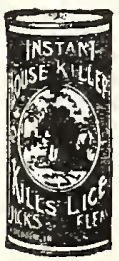

\section{Instant Louse Killer}

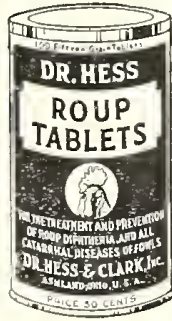

Kills lice on poultry, horses, cattle, sheep ticks; certain bugs on cucumber, squash and melon vines; slugs on rose bushes, and most lice and bugs on vegetation. Sold in sifting top cans. Look for the word "Instant" before buying. 1 lb. 25c, 2r/2 lbs. 50c. Guaranteed.

Dr. Hess Dip and Disinfectant Kills hog lice, sheep ticks and other animal parasites.
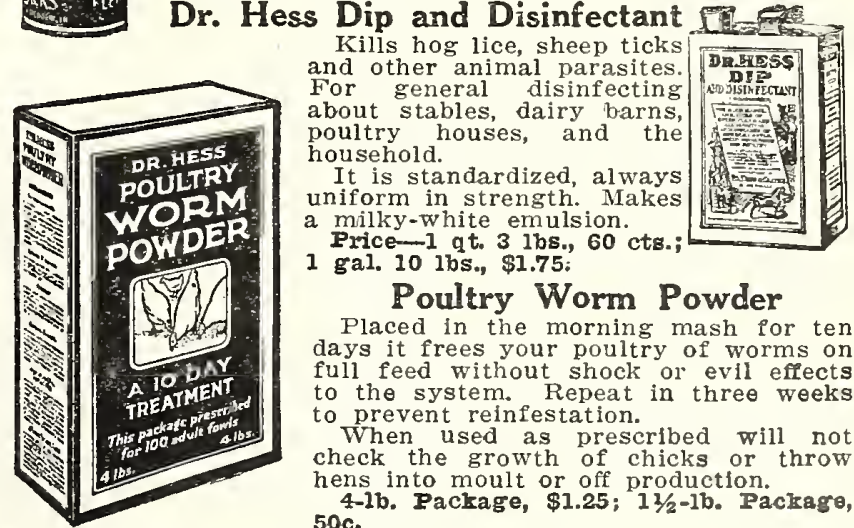
For general disinfecting about stables, dairy barns, poultry houses, and the household.

It is standardized, always uniform in strength. Makes a milky-white emulsion.

Price -1 qt. 3 lbs., 60 cts. 1 gal. 10 lbs., $\$ 1.75$ :

Poultry Worm Powder

Placed in the morning mash for ten days it frees your poultry of worms on full feed without shock or evil effects to the system. Repeat in three weeks to prevent reinfestation.

When used as prescribed will not check the growth of chicks or throw hens into moult or off production.

4-1b. Package, $\$ 1.25$; $11 / 2-1 \mathrm{~b}$. Package, $50 \mathrm{c}$. 


\section{Firis}

TFRox. Knocis Poultry Worms. Does not harm the Birds An effective Remedy for both Round and Tape Worms, consisting of a Special Preparation of Kamala combined with other drugs so prepared that they are not absorbed until they reach the Parts of the Digestive Tract Inhabited by the worms.

Price, Box 50 tablets.

$\$ 1.50$ Fostpaid

GOTD TFAT TOBACCO POWDFR FOR POUTTRY WORMS. How round worms affect poultry. Owners of poultry often do not realize the injury which may be done to their flocks by attacks of intestinal worms. The failure of young birds to develop properly, and an unhealthy condition of the older bilds, is often caused by the presence in their intestines of poultry round worms.

2 1bs. Mised with 100 lbs. of mash.

$\$ 0.35$

10 lbs. Mised with 500 lbs. of mash.

PUIVUTEs (Filled Capsules). Nicotine and Lloyd's Reagent. For the eradication of Round Worms in Poultry. Full directions with each package Price, per 100 capsules, \$1.00. Postpaid, \$1.05.

IAMBIRT'S DEATI TO IICE. As its name implies, it is sure death to lice on hens and chickens. It is harmless to human and animal life. Should be used on setting hens; it will not injure the eggs or harm the youngest chick. 15-0z. size 25 cts., 48-oz. size 50 cts., 100-0z. size $\$ 1.00$.

OID-FASFIONED BEFF SCRAPS. Very high in protein (per 100 lbs.) $\$ 4.50$.

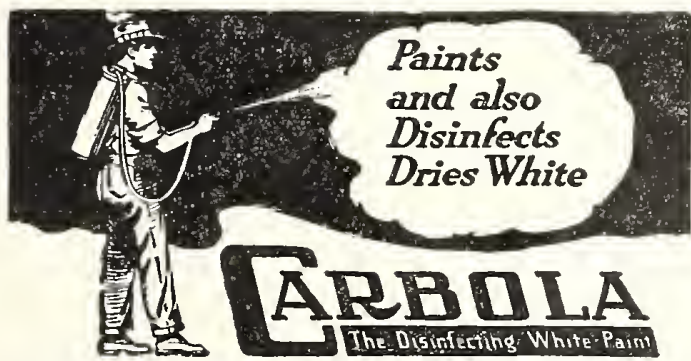

\section{THE POWDER OF MANY USES}

Carbola is a white paint and powerful disinfectant combined in powder form. It is ready to use as soon as it is mixed with water. It can be easily and quickly applied to building interiors with brush or spray pump. Disinfects and dries pure white. Does not flake or peel off. One pound covers 100 sq. ft.

5 pounds ( 5 gal.)

10 pounds (10 gal.)

50 pounds ( 50 gal.)

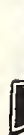

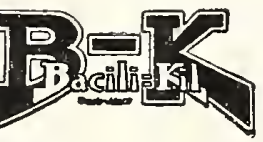

Farm Disinfectant

\section{Dairy Sterilizer}

The powerful, clean, non-poisonous germ killer.

The new and better way to sanitation.

Based on sound scientific principles proved by war experience.

\section{STERIUIZFRS}

Milking Machines, Cloths.

Ask for bulletins on these subjects. Pails, Cans, Strainers,

\section{PREVENTIOI AND TREATMLEFT OF}

Calf scours.

Retalned Afterbirth. Abortion.

1-gal. jugs 5-gal. jugs
$\$ 0.75$

1.25 5.00
CIINTON PIGEON FEED. It is a New England Feed made from clean thoroughly dried grains. There is no danger in feeding Clinton Pigeon Feed. Mixed with or without corn. Market Price.

CRUSHED OYSTER SHELI. For poultry or chicks. 100 Ibs, $\$ 1.50$.

POUITRY GRIT. Cracked in three sizes. No. 2 for poultry No. 3 for pigeons; No. 4 for small chicks. 100 1bs. \$1.25.

\section{Victor Egg Preservative}

Enjoy summer prices of eggs in winter. A harmless preparation in granulated form, easy to handle and economical to use. Will keep eggs 2 to 3 years in as good condition as when packed if directions are followed carefully. One quart will make four gallons of solution. Price, 35 cts. Shipping weight 3 lbs.

\section{Water Glass}

A transparent liquid for preserving eggs. Comes in pints, quarts and gallons. Pint can mixed with 11 pints of bolled water will preserve from 6 to 10 dozen eggs.

This preparation is used by many in preference to the dry powder. The preservative will preserve eggs perfectly.

Price, I pt., wt. 3 lbs., 20 cts.: 1 qt., wt. 4 lbs, 30 cts. 1 gal., wt. 14 lbs., 85 cts.

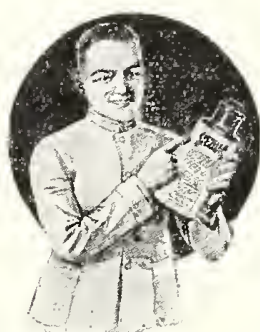

\section{Keep Down Bacteria with Sterilac}

S'TERILAC is a very powerful nonpoisonous, germ destroyer, in powder form, a wonderful agent placed in your hands to kill germs and control infection. It is 45 times stronger than carbolic acid as a germicide, yet it can be used without danger of poisoning. STERILAC is not a cleaning agent and is not to be used as such.

A one-pound bottle of STERILAC will make 480 gallons of sufficient strength for dairy purposes. Each gallon of solution will cost about one and onequarter cent. Such a solution for your milking machine will last a week, costing less than one cent per day. You can readily see it is the most economical germ killer on the norket. Price:

z-oz. bottle

8-oz. bottle

1-1b. bottle

5.00

5-1b. pkg.

Add postage for your zone.

\section{Roup-Canker-White Diarrhea}

Fed in drinking water-kills the germs.

No Poison-Clean.

The new and better way to prevent poultry diseases.

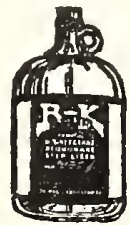

Based on sound principles of disease prevention of birds, animals and people. This was proved by war experience.

Leading poultry men and authorities recom mend it. Ask for bulletin 213.

Quarts ................... 1.25

1 gal. jugs.................. 8.00

5 gal. jugs.

12.50

Au prices in this catalogie are subject to change without notice. 


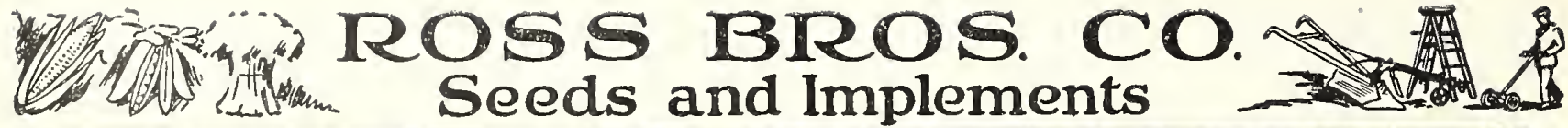

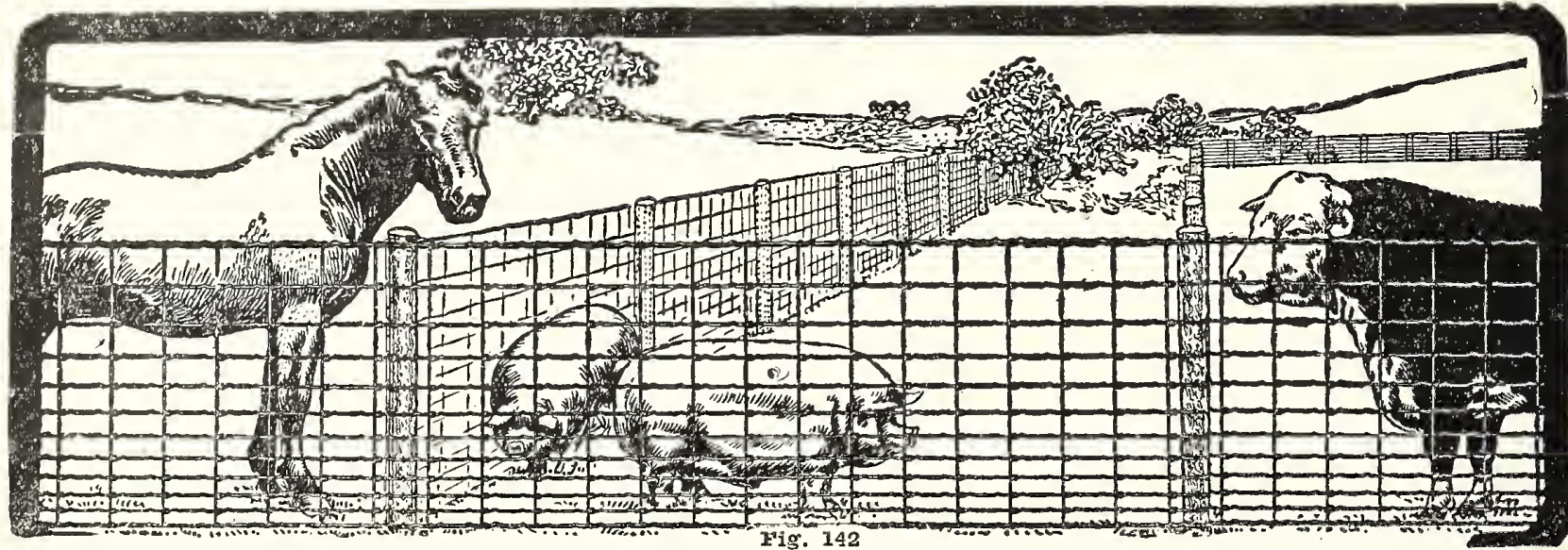

A SUBSTANTIAI FENCE plays an important part to the profitable side of farming, and the neatness in appearance of a well put up wire fence adds more than double the cost of the fence to the price of the farm. They are to the farm in general what paint is to the buildings. PUT UP FENCES and let the hogs and other animals go after the waste places and turn into profit what would otherwise go to waste.

Our general purpose farm fence is the $1047 \times 12$, and the dimensions contained in the above figures are explained as follows: Figure 10 represents the number of horizontal wires, 47 represents the height in inches, and 12 represents the distance apart of the upright bars. The top bars ale No. 9 wire, the bottom bar No. 10 , and the intermediate bars and stays No. 11 wire. This makes an ideal up-to-date farm fence, strong enough for any use. It is heavily galvanized and will last for years anc is much more sightly than the old ramshackle stone walls or wooden fences. When this fence is used in connection with steel posts, all of the weeds, etc., can be burned right up to the fence, which is another great advantage in kceping the field entirely free from refuse matter.

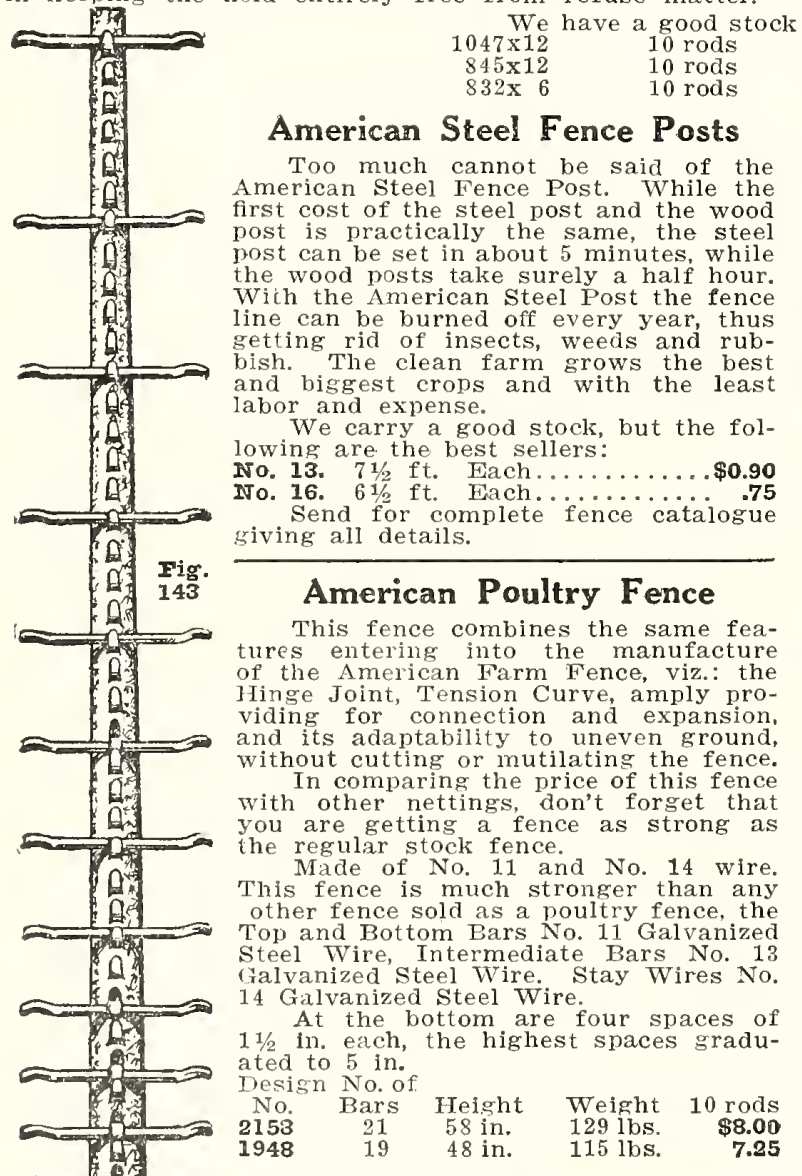

hand at all times of the following numbers:
$\$ 6.75$
5.75

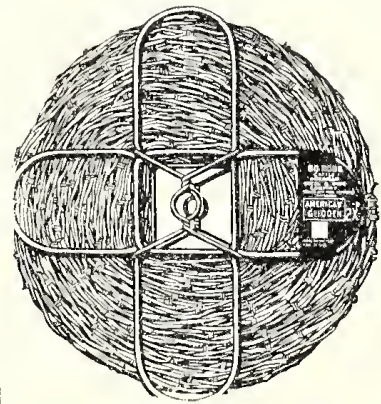

Two-Point Barb Wire

rig. 144

Two-Ply Twisted Wire

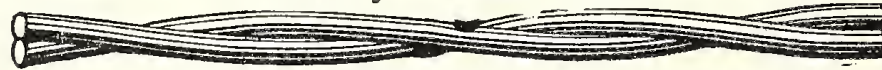

Fig. 1448

Four-Point Lyman Cattle, 80 rod spools, each........\$5.00 Two-Point Cattle, 80 rod spools, each..............4.65 Two-ply Twisted Wire, 80 rod spools, each............... 40

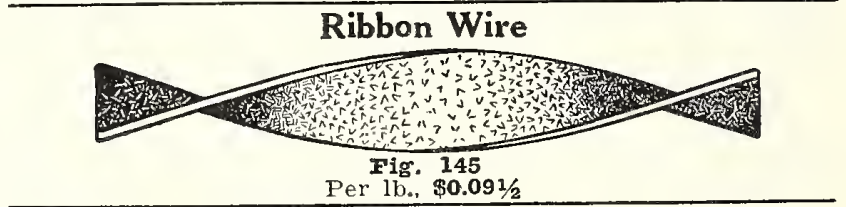

Bale Ties

choss Fig. 146

Wo carry the 9-ft. No. 15 cross head ties in stock. We find this to be the most popular size, as it makes the most convenient bale of hay.

It is made of large tough wire.

Per bundle of 250 wires, $\$ 3.50$.

Send for special fence catalogue. promptly to those in this vicinity.

Estimates on field, famn and lawn fences all put up furnished 


\section{EVERYBODY KNOWS Ross' Seed Grows}

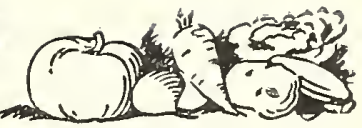

Galvanized Poultry Netting SUPERTOR

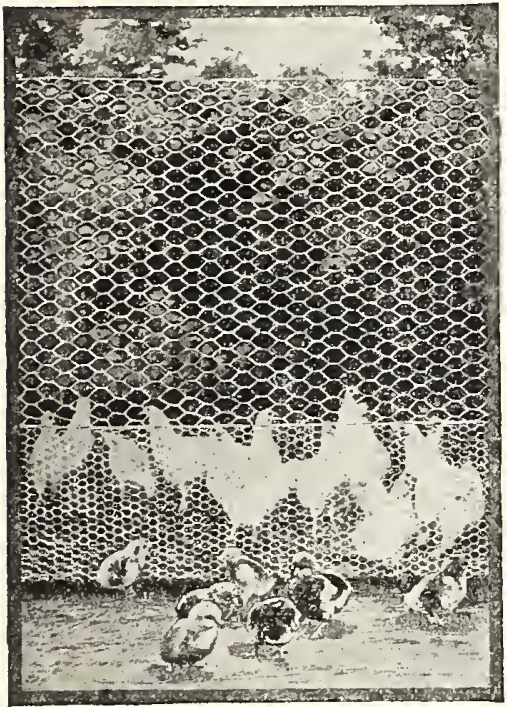

Combination 1 in. and 2 in. Mesh Netting. A popular method of erecting Poultry Netting for yalds where small chickens are to be kept on one side and fowls on the other sicle. Erect a strip 18 or $24 \mathrm{in}$. wide in 1in. Mesh Chicken Netting at the bottom and a strip 36 or $48 \mathrm{in}$. wide of 2 -in. Mesh Poultry Netting above the finer mesh, as illustrated in cut.

PRICE FOR ROIL OF 150 RUNNING FEET

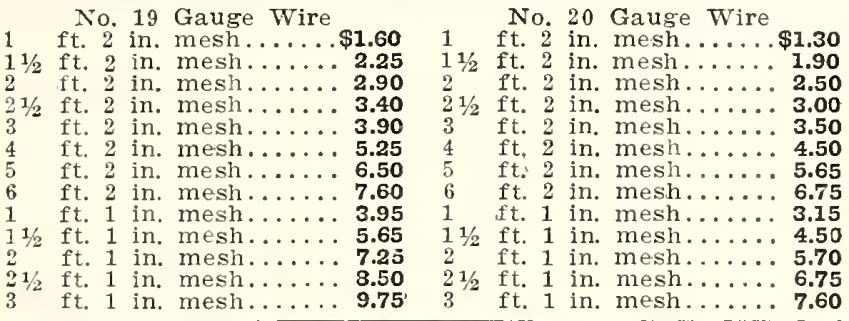

F'ig. 148

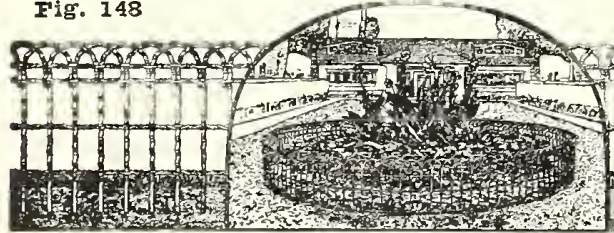

\section{Perfection Flower Bed Border}

Fits any shape or size flower bed. No posts required Bottom left straight to be inserted in the ground. Taken up in fall and used from year to year. 22-in. height, 13 cts. per ft.; 16-in. height, 12 cts, per ft.

\section{The American Fence Tool \\ The best and most $u s e f u l$ all around fence tool. It is a hammer, sta- ple and nail-puller, wire cut te $r$ and splicing tongs, com- bined. The tool is drop forged from tool-steel, high ly and skillfully tem- pered. We guaran- tee each tool. Wt.} Fig. 1493 lbs. Price, $\$ 1.50 \mathrm{ea}$.
"Economy" Brand, Red Strand Poultry Fence

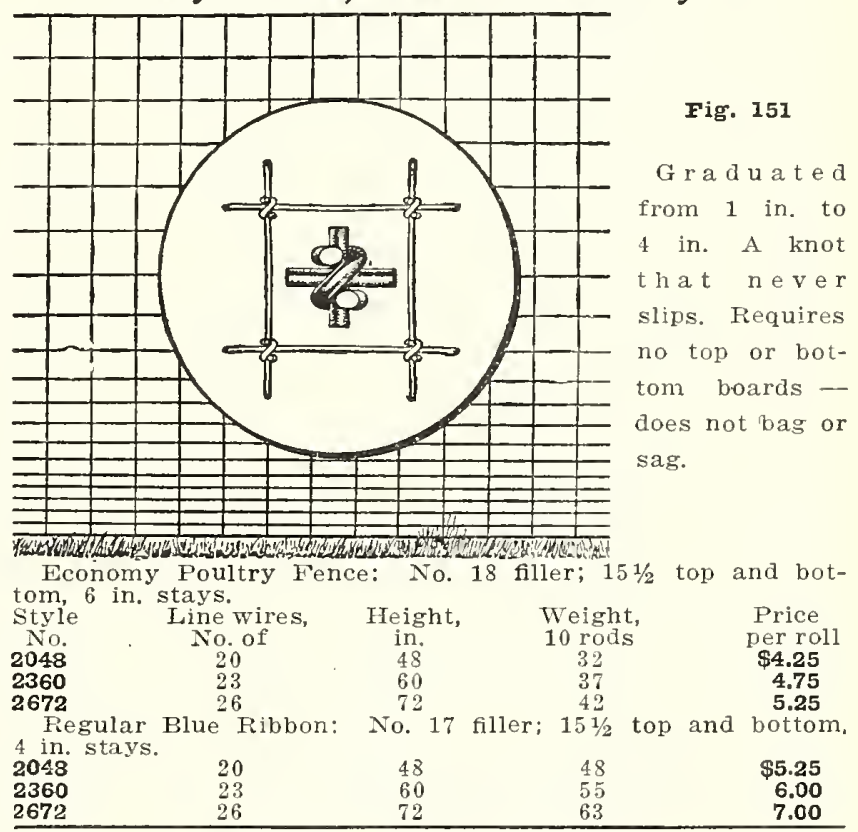

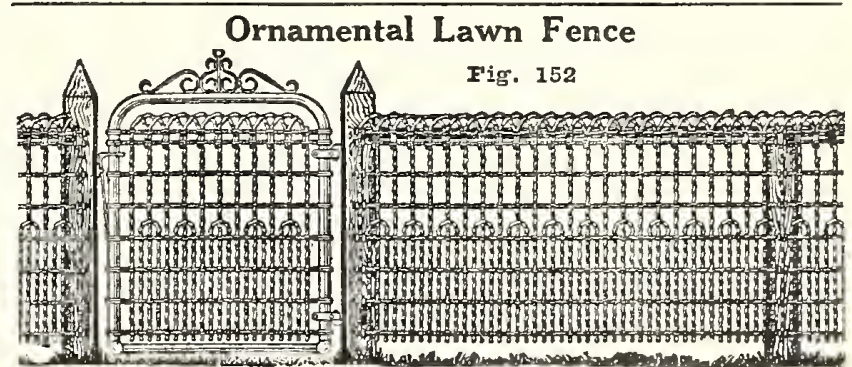

The above cut shows style 600 with the following specifications:

Upright or picket wires are No. 9, heavily galvanized, spaced $27 \%$ in apart at ton with an additional No 9 galvanized picket interwoven so as to give an extra close spacing $13 / 8$ in. at the bottom.

42 in., per ft., 18 cts.; 48 in., per ft., $22 \mathrm{cts}$.

We also carry style No. 100 with the following specificaions:

Upright or picket wires are No, 9 heavily galvanized. spaced $27 \%$ in apart. Cable line wires are No $121 /$ heavily galvanized, spaced 6 in. apart, except the two top cables

42 in., per $\mathrm{ft}$., 16 cts.; 48 in., per $\mathrm{ft}$., $18 \mathrm{cts}$.

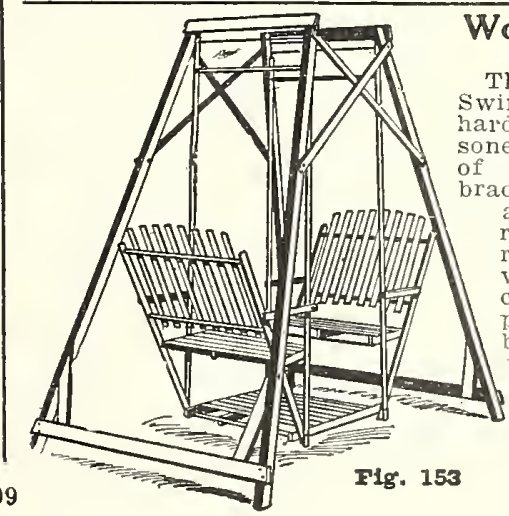

Worcester Lawn Swing The Wour Passenger Lawn swing is made of selected wood, thoroughly seaoned. The standard is made of 4 posts, $2 \times 3$ in., firmly and is painted vermillion vefore varnishing, the est of the swing being varnished in the natural color of the wood. The races The swing n steel rods by steel hangers and may easily be removed from the shipment or storage. Size Open-8 ft. high price, $\$ 13.00 \mathrm{each}$. 


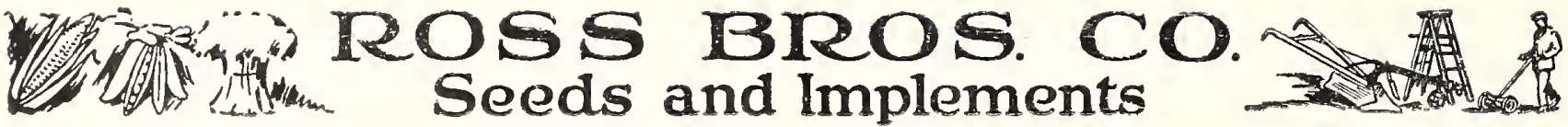

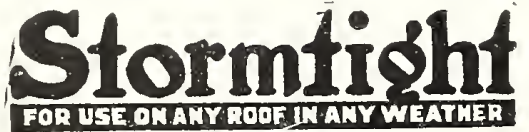

\section{WHAT STORMTIGTT IS}

Stormtight Is the National Roof Protector. Stormtight will make any roof seak-proof. It ls entirely different from the ordinary paints and compounds on the market. It Is thlck and elastic and therefore lasts for years.

Stormtight provides a one-piece coating over felt, composition, paper and metal roofs, which makes them waterproof and leak-proof. It is manufactured in black, maroon, light red and green. Anyone can apply stormtight. It is just poured and brushed fiat. Once applied, Stormtight needs no re-treatment.

\section{WHAT STORNTIGHT DOFS}

Stormtight will stop leaks and keep roofs water-proof for years. Roof paints form a thin film which dries out, cracks and permits leaks. Stormtight forms a heavy film which does not dry out, does not crack, does not leak.

\section{WIY STORMTIGHF PROTECTS}

Stormtight is not affected by heat, cold, rain or snow. It will not run, sag or dry out and crack. It remains elastic, expands and contracts and is impervious because of its special water and weather resisting ingredients. Stormtight can be applied in any weather.

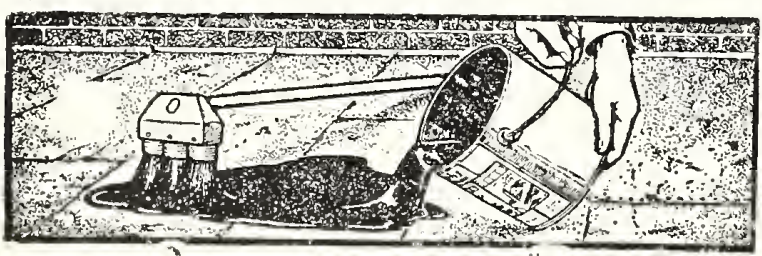

"Just Pour it on, and Brush It rlat"

\section{Stormtight-Liquid}

$\begin{array}{lrl}\text { Drums, } & 64 & \text { gals. } \\ \text { Drums, } & 38 & \text { gals. } \\ \text { Drums, } & 10 & \text { gals. } \\ \text { Cans, } & 5 & \text { gals. } \\ \text { Cans, } & 1 & \text { gal. }\end{array}$

\section{Black}

Per. gal.

$\ldots \ldots \ldots \ldots+\ldots \ldots+1.50$

2 per case $\ldots \ldots 1 . . .1 .90$

(6 per case).... $\mathbf{2 . 0 0}$
Maroon

Per gal.

$\$ 2.00$

2.10
2.30

2.40

2.50

\section{Stormtight-Plastic}

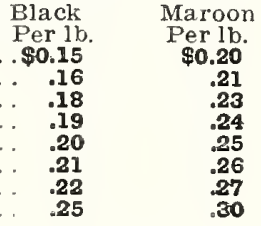

Red and Green

er gal.

$\$ 3.00$
3.10

3.30

3.40
3.60

Red and

Green

Per $1 \mathrm{~b}$.

$\$ 0.30$

.31

.34

.35

.36

40

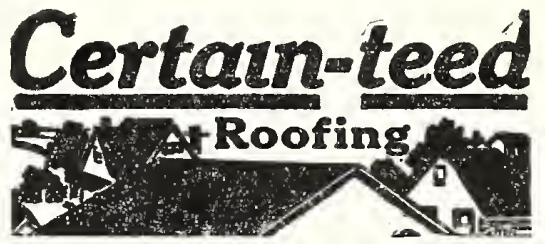

As Certain-teed goes up, roofing costs come down. Certain-teed costs less to buy and less to lay than any other type of good roofing. It reduces roof malntenance to practically nothing.

Certain-teed reduces labor costs, because it is easily and qulckly laid. It reduces roof renewals, because it is proof against most forms of attack which shorten the life of other types of roofing. It is spark-proof and fire-resisting.

Certain-teed Roofing is guaranteed 5, 10 or 15 years, according to thickness. You will save money when you buy Certaln-teed. See us before you buy.

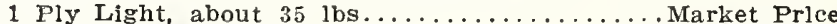

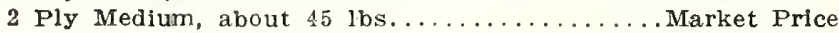

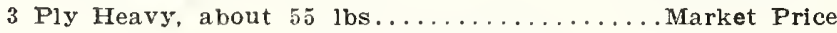

\section{Guard Roofing}

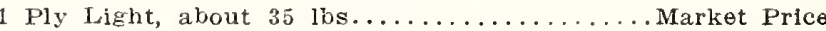

2 Ply Medium, about $45 \mathrm{lbs} . . . \ldots \ldots \ldots . . . .$. Market Prico

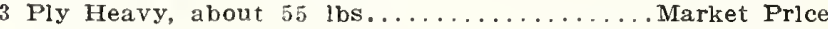

Each roll lays 100 square feet and contains nails, cement. etc.

\section{Corporal Roofing}

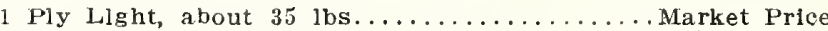

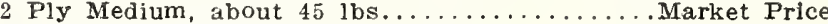

3 Ply Heavy, about $55 \mathrm{lbs} \ldots \ldots \ldots \ldots \ldots \ldots$ Market Prlce

\section{Certain-Teed, Slate Surface}

Green, Red or Blue Black, about 85 lbs........Market Prlce

\section{Major, Slate Surface Roofing}

Green, Red or Blue Black, 75-80 lbs...........Market Price

Tarred Felt

No. 2-Specify small or large roll.

Malket Price

Asphalt Sheathing

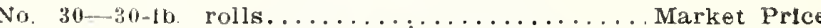

Certain-Teed Sheathing

No 25-25-1b. rolls.

Market Price

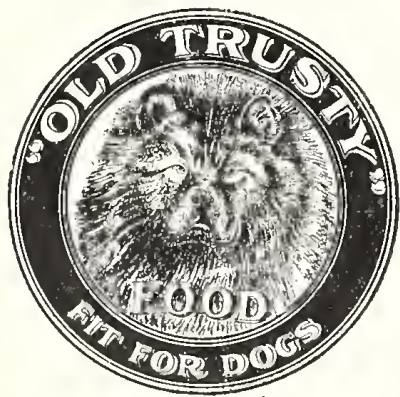

Purvejora to HIS MAJESTY, THE DOG

\section{AII TERRIER FOOD}

A graduated food of even balancc, carecully mixed not medicated or sweetened Relished by dogs of all breeds.

100 lbs., $\$ 9.25$; 50 lbE., $\$ 4.65 ; 25$ lbs., $\$ 2.50$; 10 lbs., $\$ 1.25$.

\section{"TOP NOTCF"}

A coarse granulated food for large breeds it has met with great success in many of the Hunt Clubs and sporting dog kennels.

100 lbs., $\$ 9.25$; 50 lbs.s $\$ 4.65$; 25 lb8., $\$ 2.50$; 10 lbs., \$1.25.

\section{"IIT BITS"}

A granulated food of the very hlghest or der, without a doubt the supreme in dos foods. Mixed with "VI-TI" tablets we cannot concelve of a more perfect food for bitches in whelp or dogs off thelr feed.

100 lbs., \$10.25; 50 lbs., \$5.25; 25 lbs., \$2.75; 10 Ibs., $\$ 1.50$.
PUPPY MEAI

A fine granulated food, well balanced, not a pasty meal. Mlxed with "old rrusty vI Tr" finer and stronger pupples will result Vigorous puppies mean less dlsease.

100 lbs., $\$ 9.25 ; 50$ lb8., $\$ 4.65 ; 25$ lbs., $\$ 2.50$; 10 lbs.; \$1.25.

DOG CAEFS (Whole or Broken)

100 lbs., \$8.75; 50 lbs., \$4.50; 25 lbs., \$2.35, 10 lbs., $\$ 1.25$.

\section{PUPEY BISCUITS}

100 lbs., \$9.25; 50 lbs., $\$ 4.65$; 25 lbs., $\$ 2.50$ 10 lbs., \$1.25.

VI-TI

Iargo tin, \$1.00; gmall tin, $\$ 0.50$.

Prices subject to change without notice. 


\section{EVERYBODY KNOWS

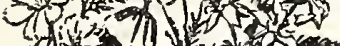 \\ Ross' Seed Grows}

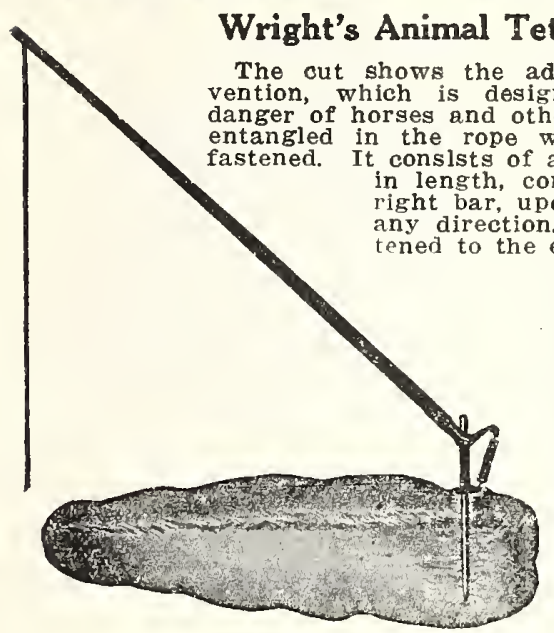

ether

The out shows the advantage of this invention which is designed to obviate the danger of horses and other animals becoming entangled in the rope wlth which they are of a pole about ten feet in length, connected with an upany direction. The animal is fastened to the end of this pole by a rope, which is kept taut above his head by means of a spring at the base of the pole; this keeps the pole high in the air, until in reaching for the feed the a nim a I pulls it down, thus at all times keeping the rope from under his feet.

Price $\ldots \ldots \ldots \$ 5.50$

Fig: 154

The Victor Lever Cutter

The best lever cutter made. Knife always up to its place.

Prices, No. $2, \$ 7.50$; No. $2 \frac{1}{2}, \$ 8.00$.

Fig. 155

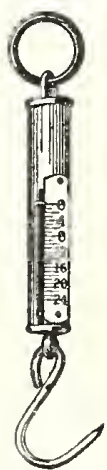

Eg. 158

F15. 156

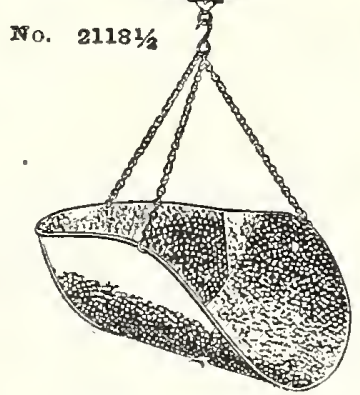

F1g. 157

0 , 7 ln dial, $\$ 8.50$.

No. 1030 Fish Scale (similar to the No. 2121), 15 in., blue and white enamel pan, weighs $30 \mathrm{lbs}$. by $1 \mathrm{oz}, 8$ in. dial, $\$ 13.00$

No. $2118 \frac{1 / 2}{}$ Circular Spring Balance, weighs 30 lbs. by oz., galvanized scoop, $\$ 9.50$.

No, 1001 Market Scale, 13 in. round white enamel pan, nickel bows, weighs 30 lbs. by 1 oz., $\$ 12.75$.

No. 16 Heavy Straight Spring Balance, weighs 25 lbs, by $1 / 2$ lb., 60 cts. each.

No. 26 Round Spring Balance, weighs $50^{\text {" }} \mathrm{lbs}$. by $1 / 2 \mathrm{lb}$ \$2.00. Mailing weight, 2 lbs.

\section{Close Mesh Wire Tree Guards}

will protect young trees from the ravages of mice and rabbits.

\begin{tabular}{|c|c|c|c|}
\hline Dian & Height & Doz & 100 \\
\hline $4^{\prime \prime}$ & $15^{\prime \prime}$ & $\$ 1.25$ & $\$ 8.70$ \\
\hline $4^{\prime \prime}$ & $18^{\prime \prime}$ & 1.50 & 10.40 \\
\hline $6 "$ & $15 "$ & 1.80 & 13.10 \\
\hline $6 "$ & $18^{\prime \prime}$ & 2.15 & 15.60 \\
\hline Diam. & Height & $\begin{array}{l}500 \\
\text { per } \\
100\end{array}$ & $\begin{array}{c}1,000 \\
\text { per } \\
100\end{array}$ \\
\hline $4^{\prime \prime}$ & $15 "$ & $\$ 7.90$ & $\$ 7.50$ \\
\hline $4 "$ & $18^{\prime \prime}$ & 9.45 & 9.00 \\
\hline 6" & $15 "$ & 11.90 & $11.2 b$ \\
\hline $6^{\prime \prime}$ & $18^{\prime \prime}$ & 14.20 & 13.50 \\
\hline
\end{tabular}

F1g. 159

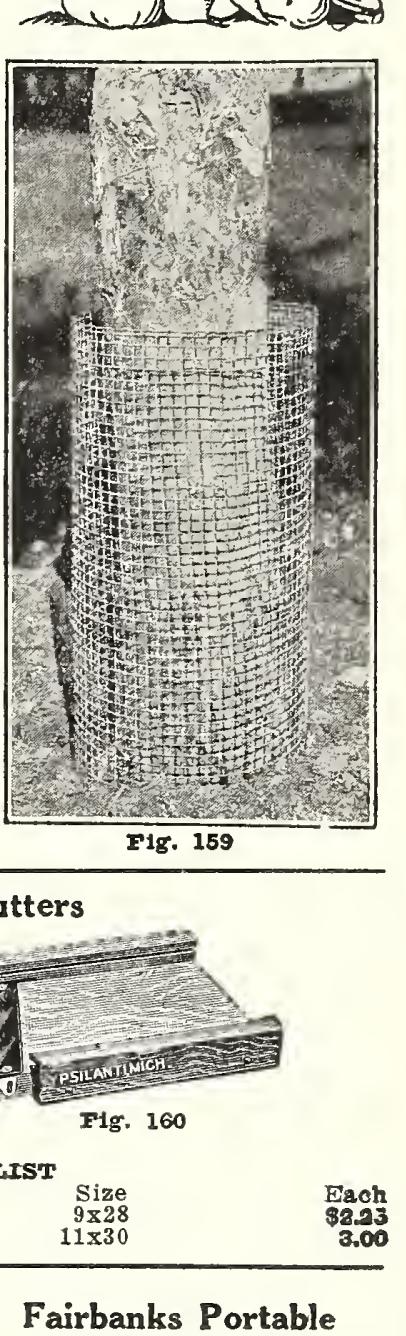

\section{Kraut Cutters}

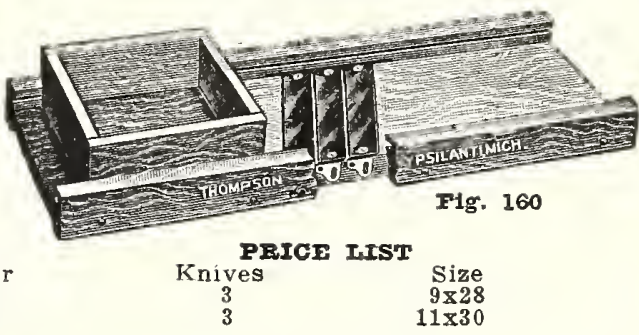

Each

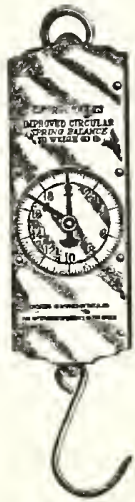

Fig. 161

\section{Dairy Scales}

Graduated in 1 oz. Weighs 30 lbs. Made especially for dairymen. Has adjustment for taking ou weight of pail.

Price, $\$ 7.00$

Weight $4 \mathrm{lbs}$
Fairbanks Portable Platform Scales

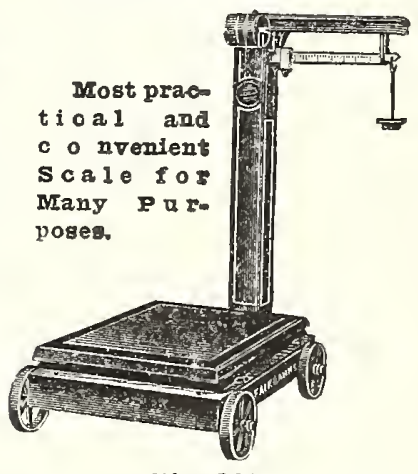

Fig. 162

This type of Portable Platform Scale is one of the most efficient for general use and may be furnished either with or without wheels. It is equipped with arrow-tip single beam having a sliding poise with set-screw, all of brass.

No. Capacity poise weam set-screw, allor of brass. $\begin{array}{lrrrr}\text { No. } & \text { Capacity } & \text { Beam } & \text { Platform } & \text { Price } \\ 1124 & 1,000 \mathrm{lbs} . & 100 \times 1 / 2 \mathrm{lbs} . & 18 \times 27 \mathrm{in.} & \$ 21.50 \\ 1128 & 500 \mathrm{lbs} . & 50 \times 1 / 4 \mathrm{lbs} . & 16 \times 25 \mathrm{in.} & 18.50\end{array}$ 


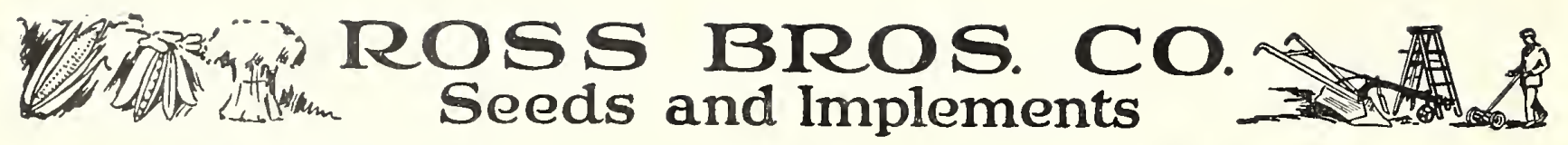

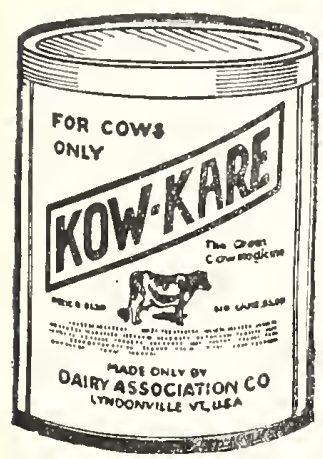

Fig. 163
KOW KA IE.

Prevents and cures abortion and barrenness. In creases $t h e$ llow of milk. It is for cows only. 65 cts. weight 2 lbs. $\$ 1.25$, weight 4 lbs.

B A G B A I M Cures caked bags and sore teats. Should be in e very cts., weight 1 Ib.

CAIF COFDIAI. Sure cure for scours and other similar complaints, 75 cts. weight 2 lbs.

WYANDOTIE DAIRYMAN'S CIEAJER. An absolute necessity in every dairy. A powder, easy to use, and recommended by everyone that ever tried it Price: 5-1b. bag, 45 cts E0-1b. keg \$4.95, 280-1b. barrel \$13.75.

Moore Bros. "Purpul" Medicated Wax Teat Dilators

For obstructions, spiders, sores on end of teat, hard milkers, etc.

1 doz. Dilators 25c, 5 doz. Dilators $\$ 1.00$ Postpaid.

Dr. Naylor's Medicated Teat Dilators

For the treatment of spider, obstruction, hard milliers, eut and bruised teats, etc.

These dilators are not rubber or wax, but are made of an absorbent texture. They heal the teat and keep it open The dilators are sterilized and packed in the medicated ointment.

$1 \mathrm{doz}$. Dilators in Jar Ointument....\$0.50 Postage 8c.

3 doz. Dilators in Jar ointment....\$1.00 Postage 10c.

\section{Dr. Naylor's Liquid Udder Balm}

This Udder Balm being a liquid is more penetrating, loosens up the tissues and removes the inflammation. Is much easier and cleaner to use than an ointment.

Price \$1.00; IHailing weight 2 lbs.

Dr. Naylor's Garget Powder

This powder is very effective in the treatment of Garget and Stringy milk.

Price 60c; Malling weight 2 lbs.

\section{Dr. Naylor's Stop-A-Leak}

A treatment for cows that leak milk. This condition occurs in some cows, at any or all times, and in others when the udder is over-distended during their best milk producing period. These cases are successfully treated with Stop-ALeak.

Price \$1.00; Postage 10c.

\section{Warriner's Patent Chain Cattle} Stanchions

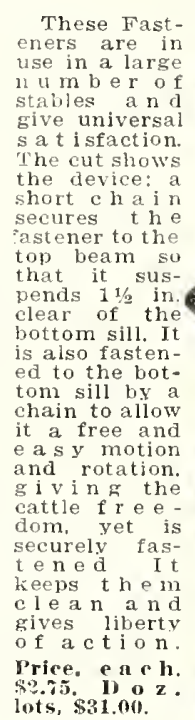

Fig. 164
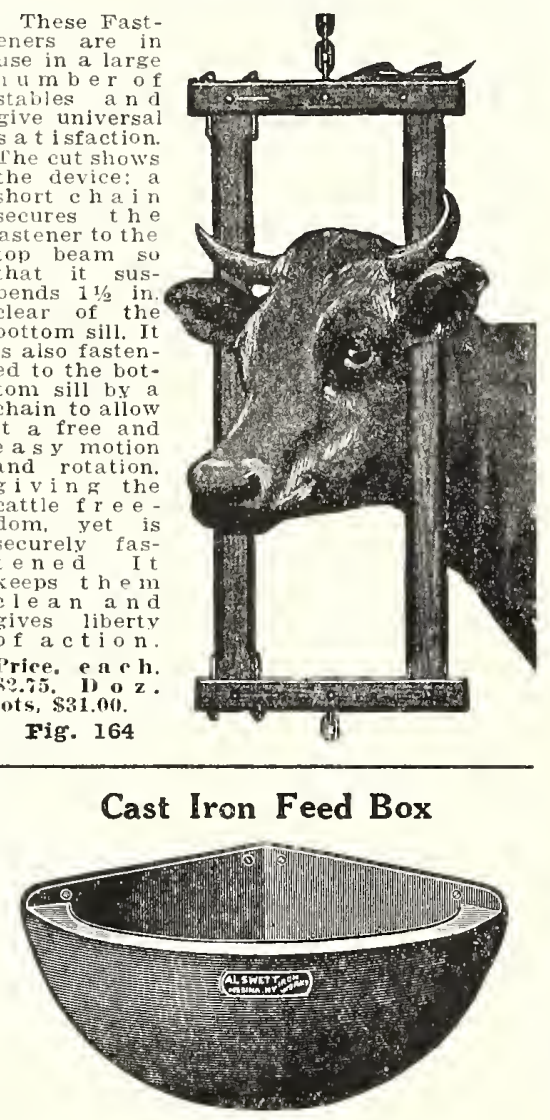

Fig. 165

Frice \$2.75; Weight 31 lbs.

Corner Rack

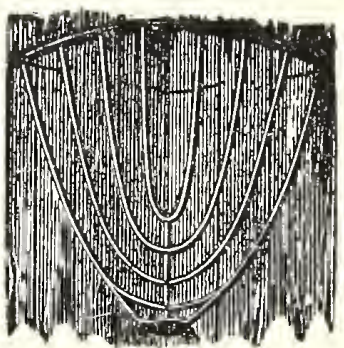

rig. 168

Price, cast iron...........

$\$ 3.75$

Frice, wrought iron.......... 3.25

The Banner Root and Vegetable Cutter

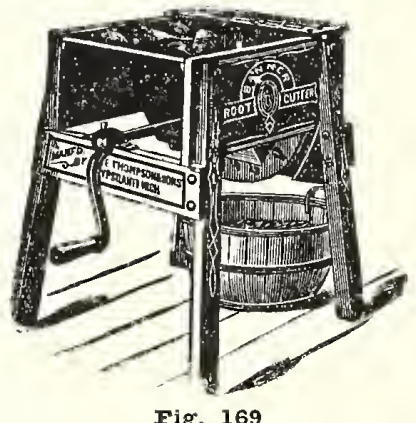

Fig. 169

The "Banner" root cutter contalns features found in no other machine. It has a self-feeder; separates the dirt from the cut feed, and leaves the cut food in such condition that the stock cannot cholic.

No. 20-For hand power......\$21.50

wo. 16-Hand and power...... 35.00

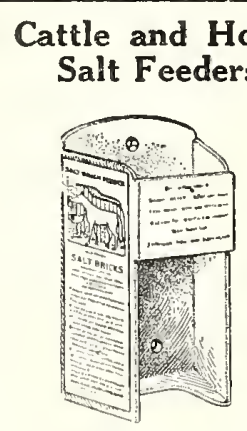

Fig. 166

This method of feeding pure salt to stock has been adopted in the largest stables and grows in favor daily. Salt brick, 25 cts. each; weight 5 lbs. each: $\$ 2.50$ per doz. Salt brick holders, 40 cts. Welght 3 lbs, 40

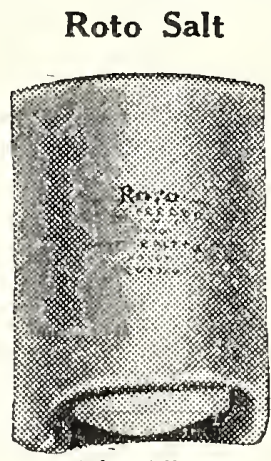

Fig. 167

Bricks and Holders

Consists of round container with round salt which automatically feeds down as used.

Salt 25c each. Weight 5 lbs. Holder 40c. Weight 6 lbs.

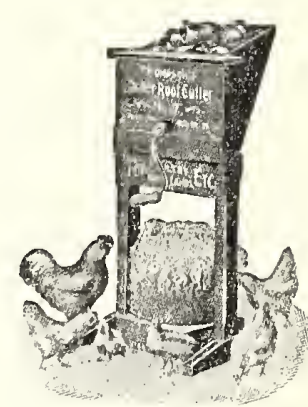

Fig. 170

No. 7

For Poultry

Hand power.....\$\$ \$8.75 see inside front cover of catalogue for Parcel Fost rates. 


\section{EVERTBODY KNOWS Ross' Seed Grows}

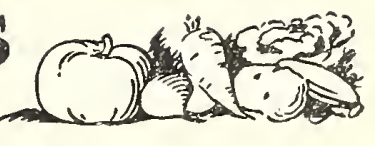

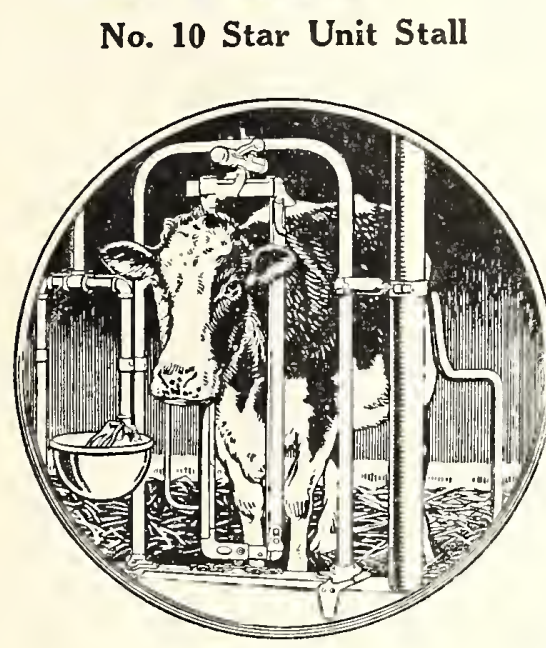

Fig. 171

Insures the profit of careful breeding and feeding. Protects cow from crowding and trampling. No cracks, dark corners, dirt catchers or dead air pockets. Eliminates accidents and diseases and gives cow maximum comfort that means more milk and more profit. Alignment device keeps cow in line at gutter.

Rust shield prevents partitions rusting off at floor line. Many other valuable features. Widths $3 \mathrm{ft}, 3 \mathrm{ft} .3 \mathrm{in}$., 3 ft. 4 in., 3 ft. 6 in.

Finished Grey Enamel. Each \$14.25.

\section{No. 443 Star Feed Truck}

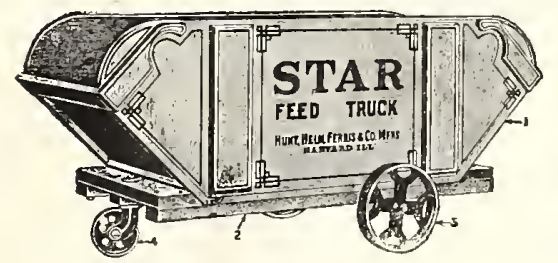

Fig. 175

Saves miles and miles of walking with a heavy feed basket. Selected wood sides. Heavy galvanized sheet steal bottom. Ends slanted for easy shoveling.

16 bushel size............\$40.00

25 bushel size............. 46.00

\section{Star Adjustable Stanchions}

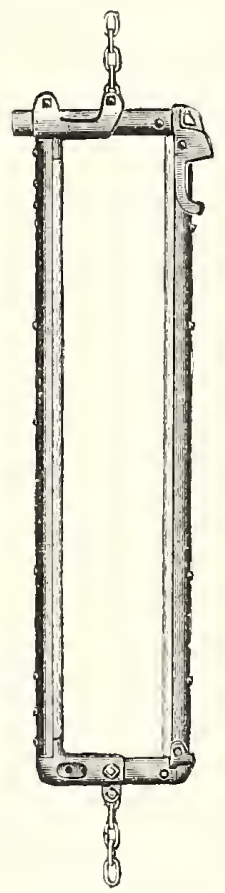

Fig. 172

No. 486 Giant wood lined with double lock and guide.

Each .......\$\$4.25

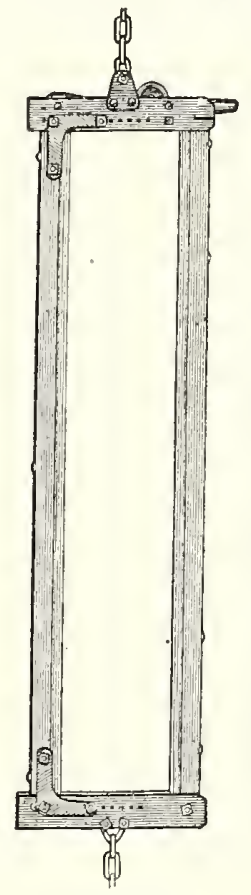

Fig. 173

No. $1185 \mathrm{~W}$ Wood lined with single lock and guide.

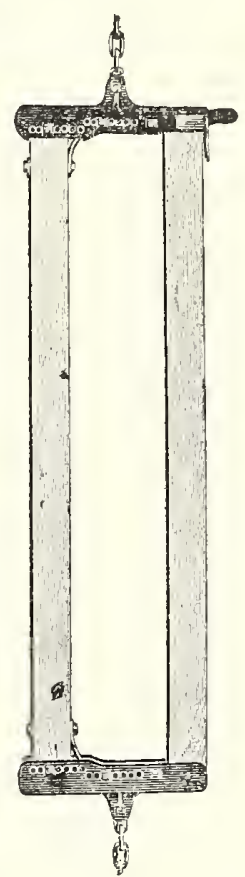

Fig. 174

No. 452 Have maple uprights, double lock and guide.
$\$ 2.90$
$\$ 3.50$
Each

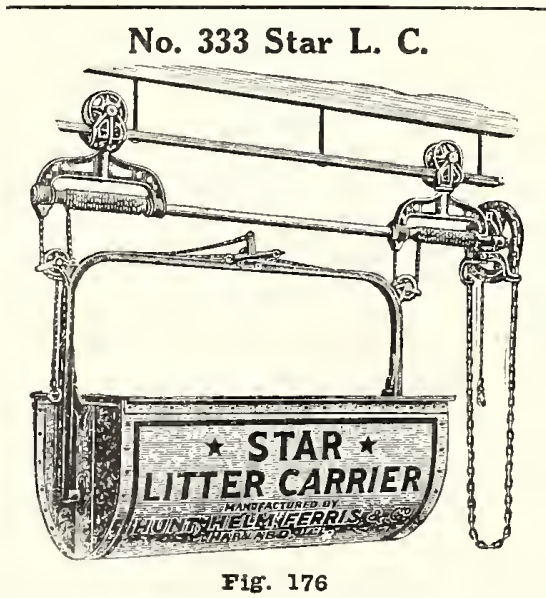

The No. 333 Litter Carrier. Quickest and easiest to raise and lower. Runs easy. Never in the way, always on the job.

Pays for itself in a year or two.

Hoisting shaft is a simple windlass without cogs or gears. Drive wheel bolted to shaft.

No. 6 Capacity 10 bushel.

Price $\ldots$............

No. 8 Capacity 12 bushel. .$\$ 47.00$

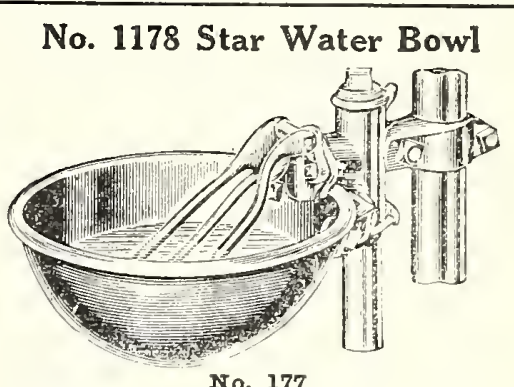

No. 177

Easiest to install. Easiest for cow

to work. the pocket. Cow drinks more water and gives $20 \%$ to $30 \%$ more milk. Water comes when the cow rests her chin on the valve lever. Valve snaps shut when she stops drinking. Simple valve; all brass; can't rust, corrode or clog. Incividual pressure control on each bowl. Round smooth bowl. Held by heavy bolts. Can't be broken, bent, dented, or worked loose. Working parts are all outside. Valve lever lifts clear out of the way so bowl can be cleaned without taking it off

No. 1178 With bracket for vood or any kind of steel stall.

As illustrated ............ \$ $\$ 3.90$

No. 1177 With saritary aluminum

lining ..................\$3.55 


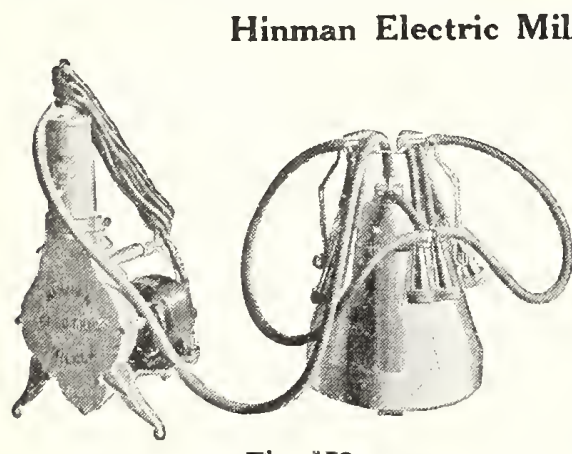

Flg. 178

Price, \$200.00.
A complete milkIng equipment, no installation. $O \mathrm{p}$ electric llght cir. cult, elther direct or alternating curor alternating cur-
rent. It is a light portable unit, containing all Hinman famous designed pump with rellef valve. All moving parts are enclosed and all that is necessary to do is to attach plug, turn on current and milk. Let us give a demonstration.

\section{Hinman Easiest to Clean}

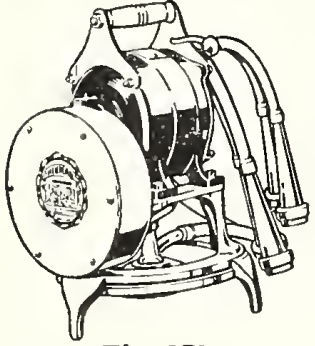

Fig. 179
Entirely different, a new milking machine that will sharply influence the future of the entire milking machine industry. New in conception, new in design, new in basically patented fundamentals. This new "easiest to clean Hinman" is adapted to a dairy of a hundred cows, as well as the dairy of two cows. The greatest advancement ever made in the milking machine industry.

Price

.........
Gas Engine Milker
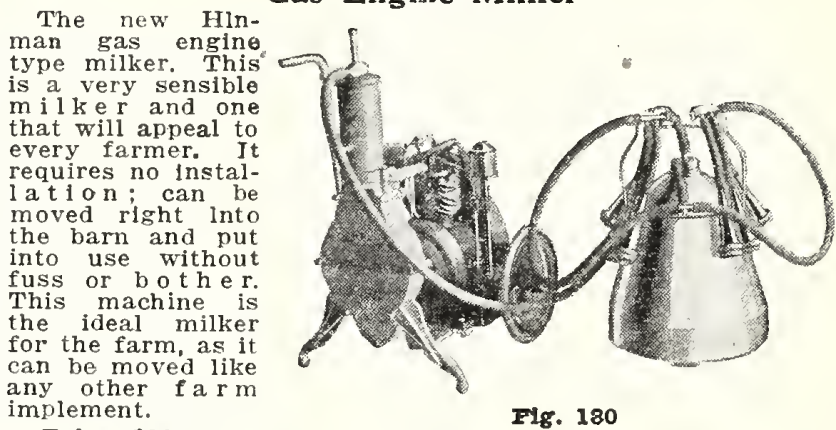

Fig. 180
Varnished Cylinder Churns

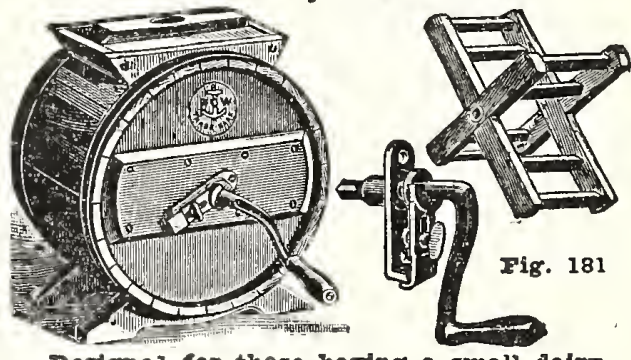

Designed for those having a small dalry

No. 0 , capacity 1 gallon. Wgt. 12 lbs............\$3.75

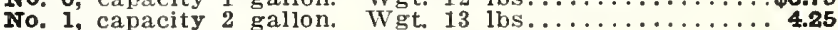

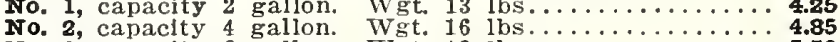

No. 3 , capacity 6 gallon. Wgt. 18 lbs.............5 No. 4, capacity 8 gallon.

Wgt. 20 lbs............. 6.50
Improved De Laval Cream Separators and Clarifiers

\section{FOR BOTH HAND AND POWER}

De Laval Cream Separators are guaranteed to be as represented and to fulfill all the claims made for them, belng sold subject to the guarantee of their unquallfied superiority in every material feature.

No. 7. Capacity per hr. $\$ 62.50$. No. 8. Capacity No. 10. Capacity per h1., $\$ 87.50$ No. 12. Capacity 500 lbs, per No. i6. Capacity 750 lbs. per hr., \$117.50.

No. 17. Capacity 1,000 lbs. per hr. $\$ 135.00$ No. 22. Capacity 1,350 lbs. per hr., $\$ 225.00$ Add for motor (alternating current), $\$ 55.00$.
6 prill churn 1 to 3 ral cream Weight, 27 lbs. Price. \$8.00. 10 gal. will churn it to 5 gal. cream. Welght. 33 jbs. Price, \$9.00. 15 gal. will churn 1 to ${ }^{7}$ gal. cream. Weight, 38 lbs. Price, sio.oo. 20 gai. will churn 2 to 10 gal. cream. Welght. 46 lbs. Price. \$12.00 Weight. 73 lbs. Price. $\$ 14.00$. 35 gal. will churn 3 to 17
Welght, 80 lbs. Price. $\$ 16.00$.
Whit e oak thoroughly seasoned and kiln le d. having rim in he a d. $m$ ak $\ln g$ it as - s 0 l i d having no as hers nor ohurning is done by revolving the churn. the cream and makes the butfrom

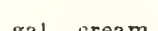
gal. cream. gal. cream. atrongas a

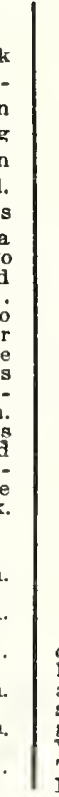

Flexible Shaft Hand Power Clipper

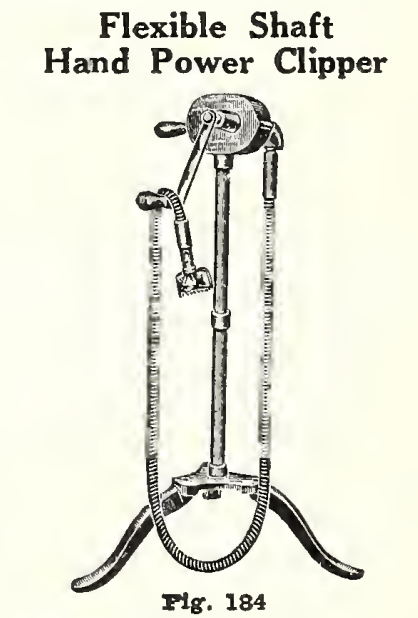

No stable is complete without one of these outfits for clipping cattle or horses. Inexpenslve, easily operated and Indispensable on the farm. Insures sanitary conditlons of making rade A mllk.

Weight. 15 lbs, Price, $\$ 14.00$ Top plate. welght, 1 lb. $\mathbf{1 . 5 0}$

All prices in this catalogue are subject to change without notice, 


\section{EVRYBODY KNOW:S}

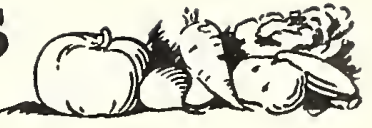

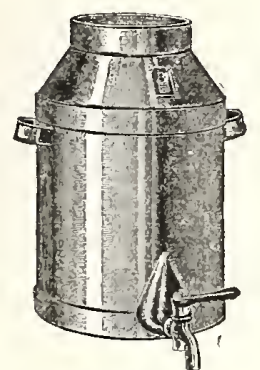

Fig. 185

Heavy Tin Mixing Can with removable strainer hoop and faucet; 6,8 and 10 can.

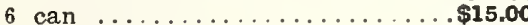

8 can $\ldots . . . . . . . . . . . . . . .16 .00$

$10 \mathrm{can}$

17.00

Horne Vertical Can Strainer

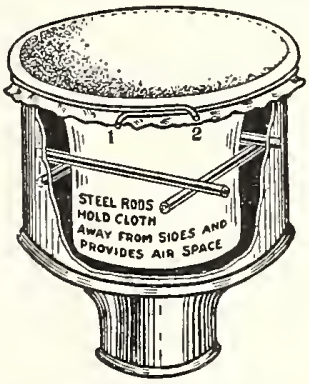

Fig. 186

Is warranted to filter milk through fltering flannel as fast as poured and remove the finest trace of sediment, leaving the milk absolutely clean.

Filtering flannel is superior to $\mathrm{ab}$ sorbent cotton when used with the vertical process. Note illustration showing air vents for the free circulation of air.

Were it not for the air circulation milk could not be successfully strained through filtering flannel as a quart of air must escape as fast as a quart of milk is poured.

Price of strainer with double fiannel, \$2.50. Extra Strainers, 25c each.

Weight, $41 \mathrm{bs}$.

\section{Buckley's Patent Watering Device}

For Watering Stock in Stables

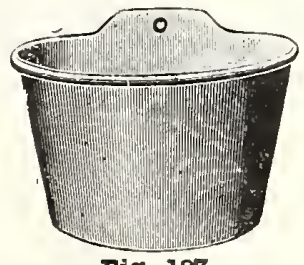

Fig. 187

Water where cattle can get it at any time during the day or night is a necessity in every first-class stable. With the Buckley Basins the water is always there and at the proper temperature.

Not so high priced as the Star. Will answer every requirement. Thousands sold. Threaded for $3 / 4$-in. pipe.

Price, each, \$2.00; per doz., \$21.60.

The Ideal Milk Cooler

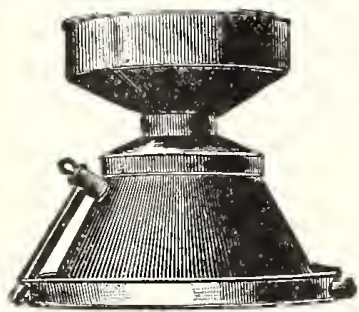

Ig. 188

The Ideal Milk Cooler and Aerator does what no other cooler does, namely, thoroughly cools the milk and at the same time aerates it perfectly, so that it is ready to ship or peddle at once. No time is lost in stirring morning's milk and getting it ready for customers, as it is cooled as fast as milked.

No. 2. Suitable for 10 to 15 cows. Price, $\$ 10.00$.

No. 3. Suitable for 25 to 40 cows. Price, \$12.00.

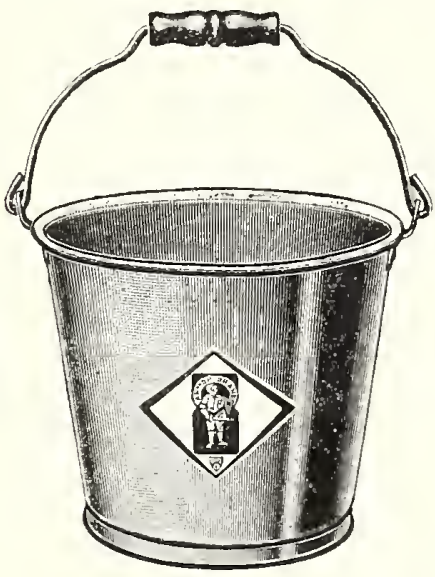

Fig. 189

Very heavy tin milk or cream pails with wood grip. Riveted ears.

12 quart .................\$1.05

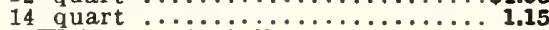

Weight each, $\overline{5}$ ibs

\section{Common Sense Milk Pail}

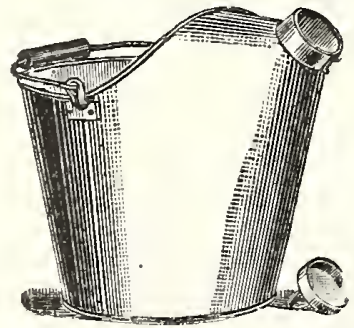

Fig. 190

It is made of extra heavy tin, strainer removable. easy to clean and keep in repair. Pitce, \$2 50. Welght, 6 lbs.

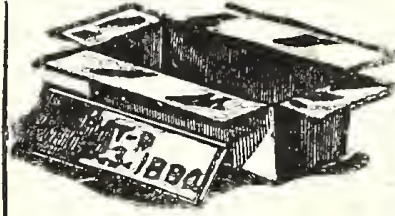

ELg. 191

$\mathrm{T} h \mathrm{e}$ D $\mathrm{u} m$ a $\mathrm{s}$ square box holds five I b s.; the only box that biltter can be turned o $u$ t o r and $l$ e $f t$ i $n \quad g o$ od shape.

Prlce per dozen, all papered, \$2.25.

\section{Milk Cans}

HI-grade $W$ o r-

cester Pat t e r n Cans with wo od bung.

No. 2- 8 qt.

Heavy ..\$1.75

so. $2-10$ qt.

Heavy … 1.95

To. $3-8 \mathrm{qt}$.

Light ..... 1.65 ro. $3-10$ qt.

Light .....1.85

Mailing *... each, 6 lbs.

Mailing

Wgt.

$6 \mathrm{qt} \quad 4$ lbs, $\$ 1.50$

$4 \mathrm{qt} \quad 4 \mathrm{lbs} . \quad \mathbf{1 . 1 0}$

$2 \mathrm{qt} . \quad 3 \mathrm{lbs}$. $\quad .75$

1 qt. $2 \mathrm{lbs}$.

1 qt. Funnels,

weight $1 \mathrm{lb}$. .15

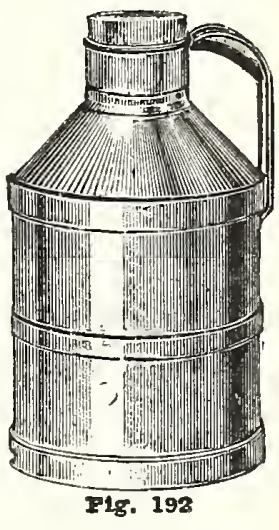

The New Dover Sanitary Milk Pail

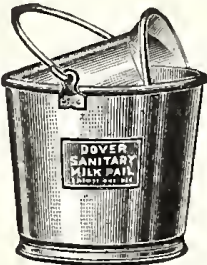

Fig. 193

The Breast on our Pail has a guard which absolutely prevents dirt from falling from the breast into the pail.

Capacity 14 qts.: diameter bottom $9 \%$ in.: diameter top, $121 / 4$ in.; extreme $h$ e $\mathrm{ight}$. $133 / 4$ in. Net weight. $41 / 4$ lbs. each. Shipping welght, 6 lbs, each. Price, \$2.50 each.

\section{Gem Combination Milk Bucket} With remorable Stralnex

It has no equal in its simplicity. Made of the best IX $\mathrm{t}$ i $\mathrm{n}, \mathrm{w}$ i t $\mathrm{h}$ Steel' Strainer Frame $\mathrm{T} h$ e $\mathrm{Ge} \mathrm{m}$ $c \circ \mathrm{m}$ b i nation Milk Bucket can be used for $\mathrm{m}$ i l $\mathrm{k}$ with strainer, or

the strainer

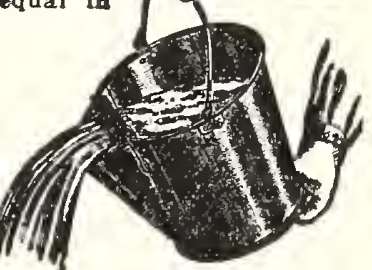

Fis. 194

can be latch and the bucket used for any other purpose. The Strainer is constructed of Steel with Fine Brass Wire Cloth and can be readily converted into a cloth or muslin strainer by simply covering the frame with the cloth and inserting the frame in place.

Prices, 10 quarts, each \$1.10; 18 quarts, each $\$ 1.25 ; 14$ quarts; each $\$ 1.40$. Weight, 3 lbs. 


\section{WOSS BROS. CO. Seeds and Implements}
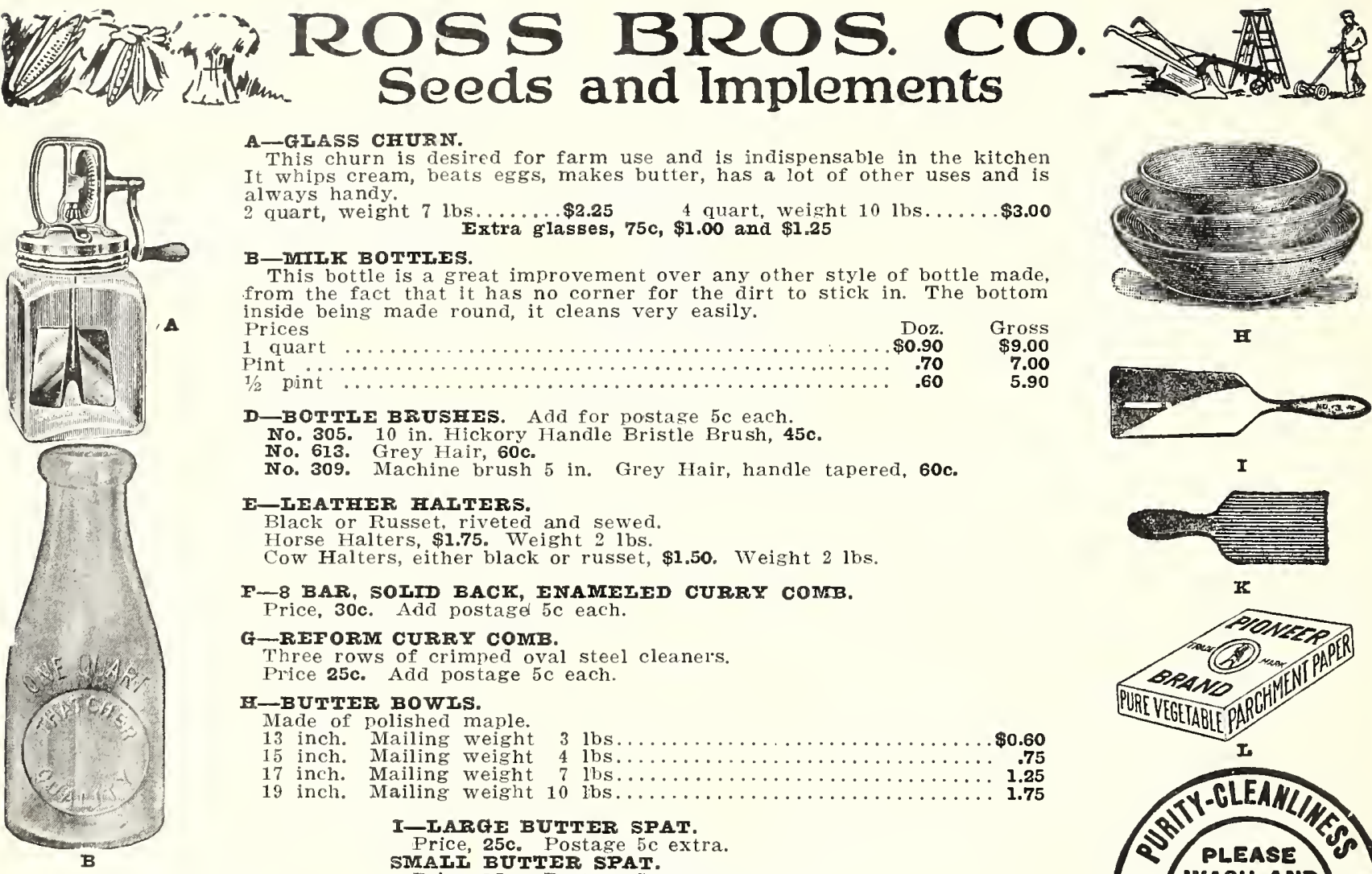

A-GIASS CHURN.

This churn is desired for farm use and is indispensable in the kitchen It whips cream, beats eggs, makes butter, has a lot of other uses and is always handy.

2 quart, weight 7 lbs.....\$2.25 4 quart, weight 10 lbs....\$3.00 Extra glasses, 75c, $\$ 1.00$ and $\$ 1.25$

B-MIK BOTTIES.

This bottle is a great improvement over any other style of bottle made, from the fact that it has no corner for the dirt to stick in. The bottom inside being made round, it cleans very easily.

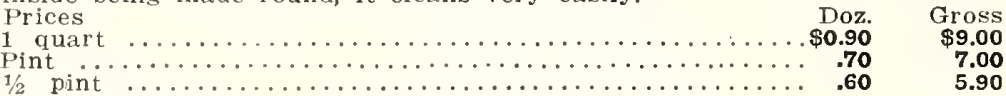

D-BOTTIE BRUSHES. Add for postage 5c each.

No. 305. 10 in. Hickory Handle Bristle Brush, 45c.

No. 613. Grey Hair, 60c.

No. 309. Machine brush 5 in. Grey Hair, handle tapered, 60c.

E-IEATHER HAITERS.

Black or Russet, riveted and sewed.

Horse Halters, \$1.75. Weight 2 lbs.

Cow Halters, either black or russet, $\$ 1.50$. Weight 2 lbs.

F-8 BAR, SOLID BACK, ENAMEIED CURRY COMB.

Price, 30c. Add postage $5 \mathrm{c}$ each.

G-REFORM CURRY COMB.

Three rows of crimped oval steel cleaner.s.

Price 25c. Add postage 5c each.

\section{H-BUTTER BOWLS.}

Made of polished maple.

13 inch. Mailing weight 3 lbs............\$0.60

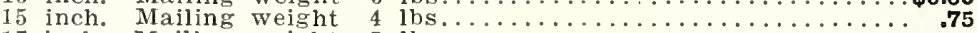

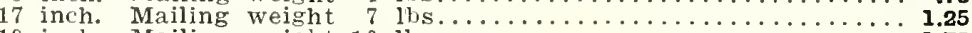

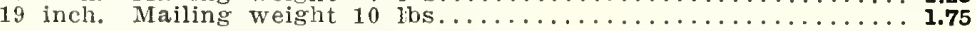

I-IARGE BUTTER SPAT.

Price, 25c. Postage 5c extra.

MMAII BUTTER SPAT.

Price, 15c. Postage 5c extra.

K-CORRUGATED BUTTER SPAT.

Price, 35c. Postage 5c extra.

I-BUTTER PAPER.

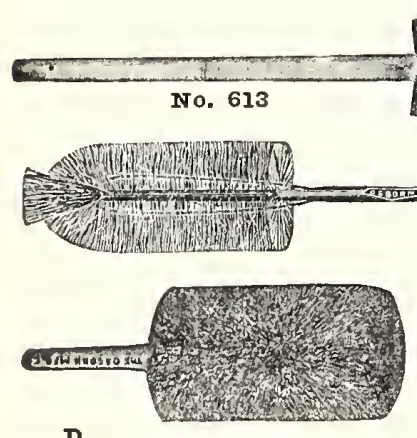

D

No. 309

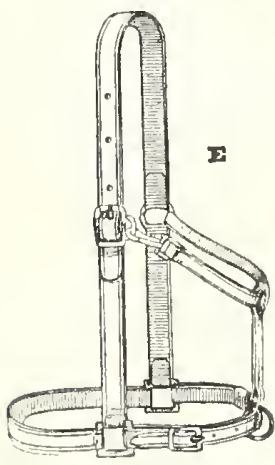

This parchment butter paper is used by most of the butter packers. Made of very strong fibre and will stand any amount of hard use.

Cut $8 \times 11$ in. for $1 / 2-1$ b. molds, $30 \mathrm{c}$ pex $1 \mathrm{~b}$. Cut $9 \times 12$ in., 30c per 1b.

M-BOTTLE CAPS.

Made of strong parafined cardboard guaranteed to be abso-

No. 305 lutely satisfactory.

Per box of $1,000.50 \mathrm{c}$. Weight $3 \mathrm{lbs}$.

Per box of $5,000, \$ 2.25$. Weight $15 \mathrm{lbs}$. Per barrel of 50,000. Ask for price.

IIPPED CAPS.

Add $2 \mathrm{c}$ per 1,000 to the above prices. Weight $3 \mathrm{lbs}$.

N-BIANCHARD'S BUTTER MOLDS.

Initial engraved, 25c extra per initial. Weight $1 \mathrm{lb}$

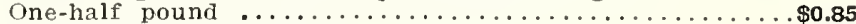

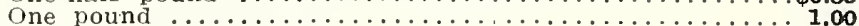

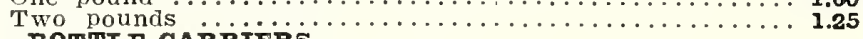

O-BOTTIE CARRIERS.

Flat Wire.

6 1-qt. Bottle Carrier, weight 5 lbs..............\$1.75

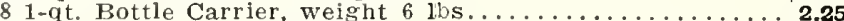

Round Wire.

6 1-qt. Bottle Carrier, weight 5 lbs................25 Add postage for your zone. See inside of front cover.

盛
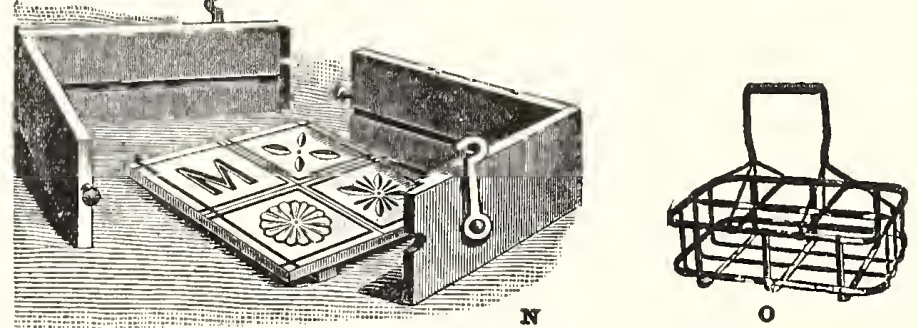

All prices in this catalogue are subject to change without notice,

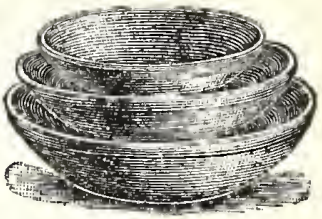

I
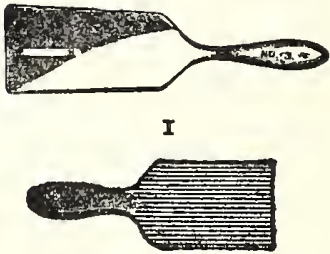

$\mathrm{x}$
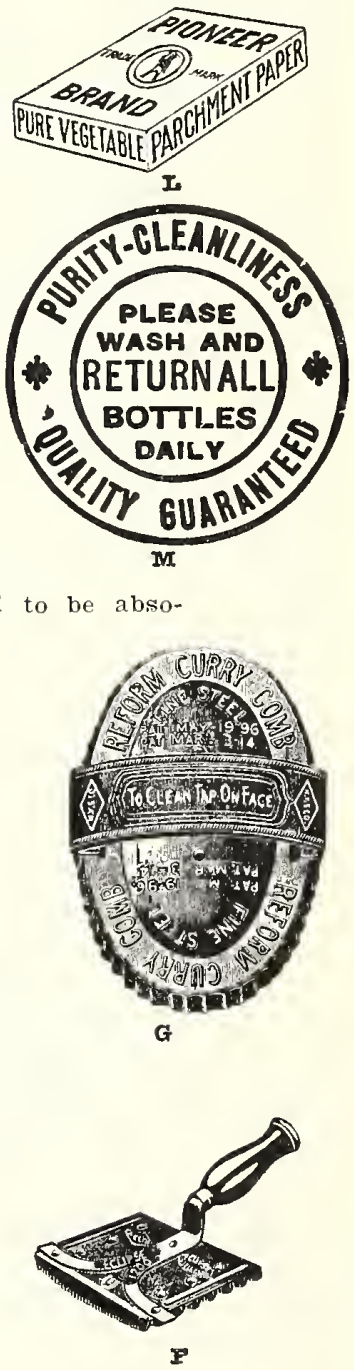


\section{S? Ross' Seed Grows}
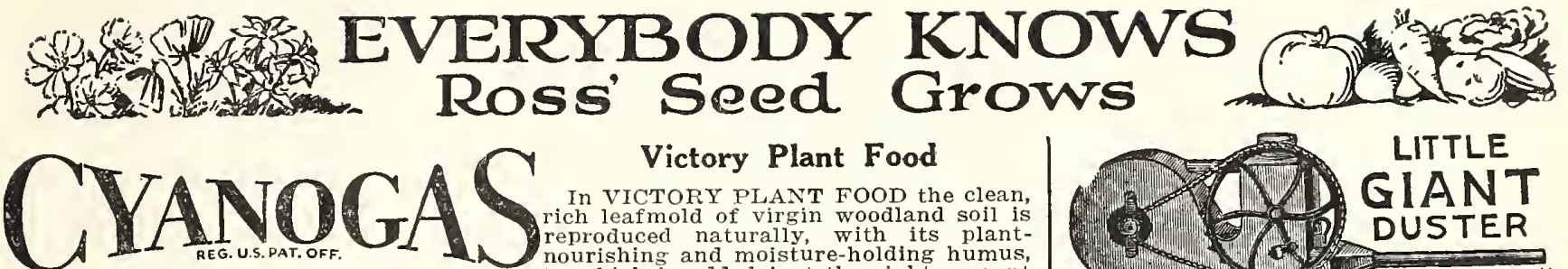

Victory Plant Food

In VICTORY PLANT FOOD the clean, rich leafmold of virgin woodland soil is reproduced naturally, with its plantnourishing and moisture-holding humus, to which is added just the right amount

The ideal fumigant for greenhouses is CYANOGAS G-Fumigant.

CYANOGAS A-DUST is certain death to woodehucks, rats, moles and ants.

For Woodchucks: Place a heaping tablespoonful well into the burrow and close carefully.

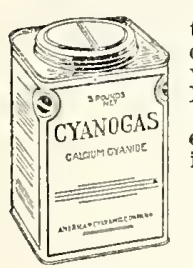

Rats: Plug all rat holes that can be located except one and blow in A-Dust with a Cyanogas Duster. Plug remaining hole.

Moles: Open $\mathrm{run}$ w a $\mathrm{y}$ every five feet and place in heaping tablespoonful. PRICES

Fig. 195 100-1b.

$\$ 0.75$
3.00
10.00
30.00

\section{"Nico-Fume" Powder}

Every florist knows that the battle with in-

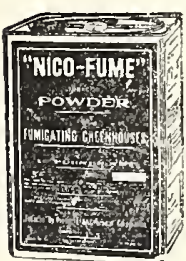

Fig. 196 sects is continuous Numerous insect $p$ est $\mathrm{s}$ destroy profits, but they can be controlled by "NICO-FUME"' Powder. It furnishes safe, dependable a n d effective protection to greenhouse crops. Many florists prefer a tobacco powder fumigant. "NICO-FUME" Powder consists of tobacco powder impregnated with high strength nicotine and is guaranteed to contain not less than $12 \frac{1}{1} \%$ of nicotine by weight. Use a $2 \frac{1}{2}$-inch flower pot for a measure. Pour the powder on the walk or bench in a loose pile and light at either end; or both ends for quick fumigation. Use one $21 / 2$-inch pot full (about four ounces)

Prices

1-lb. tin

$5-1 \mathrm{~b}$.
$10-1 \mathrm{~b}$.

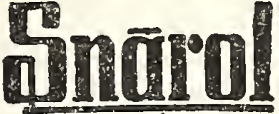

The National Pest Control

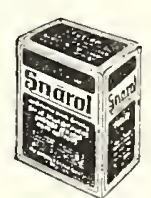

Fig. 197

This is a ready prepared meal that you simply broadcast on the ground about plants and shrubs. The pests eat this meal as a food and are quickly destroyed. Snarol is easy and inexpensive to use. It does the work quickly, safely and surely?

\section{THE PESTS IT KIILS}

Snalol destroys Cutworms, Slugs, Snails, Earwigs, Sowbugs and Grasshoppers.

\section{Price}

Snarol 1-1b. Packages.

Snaro1 3-1b. Packages.

Snarol being poisonous is not mailable. of vital food elements to take care of every need of the plant for
health and vigorous growth.

$\mathrm{U} s$ e it regularly and the results will

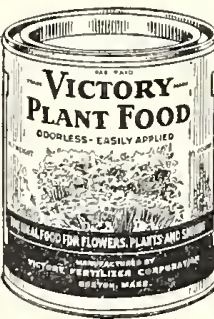

Fig. 199 and $\mathrm{Y}$ our ferns and other plants will soon have full, luxuriant foliageleaves that shine as though they had been w a $x$ e $d$ - abundant bright - colored blos soms. V I C T O R Y PLANT FOOD is the secret of your success with plants. Follow simple directions and you cannot fail! Clean and odorless. Leading florists and nurserymen use and recommend "VICTORY."

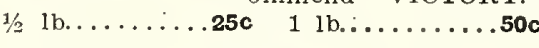

\section{STIM-(U)-PLANT}

\section{PLANT STIMULANT TABLET}

Use it and you will have the largest crops of fruit and vegetables. and an abundanc of the largest and sweetest-scented fowers of intense and vivid colors. It is rich in 12 per cent Phosphoric Acid and 15 per cent Potash odorless and clean. Compare this Potash, odorless and clean. Compare
analysis with that of other fertilizers.

Not to be thrown broadcast. but put at feeder roots of individual plants. trees. shrubs. etc. There is no waste. you feed the plants that need it. Increases production, brightens color. improves quality. Sim ply insert a tablet in the soil near each plant (1 foot apart if in rows) once or twice during season. Or, dissolving four tablets per gallon of water is less trouble and gives better results than the objectionable manure water. A proven success with rose growers. nurserymen, landscape gardeners, strawberry growers and gardeners. Complete directions with every package. Price, postpaid: 30 tablets, $250:$
bucket. $\$ 3.50$.

\section{Antrol}

Ants Killed in Their Nests! Whole culonies of these pests destrowed at their source. New method does
the work safely, effectively and permanentix.

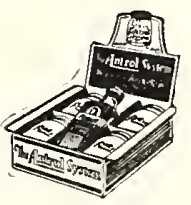

Fig. 198

\section{How It IVorks:}

The Antrol Syrup in the containers at tracts the ants. The worker ants then begin feeding on the syrup and carry it back to the nest. The syrup is mildiv poisonous and after a sufficient quantity of it is con-
sumed the entire ant colony is destroved.

Price: Antrol Sets, each conslsting of 4 containers and a 4-oz. bottle Antrol

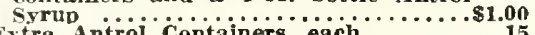
Extra Antrol Containers. each....... Antrol Syrup. pint bottles..............00 Antrol beins a poison is not maijable.

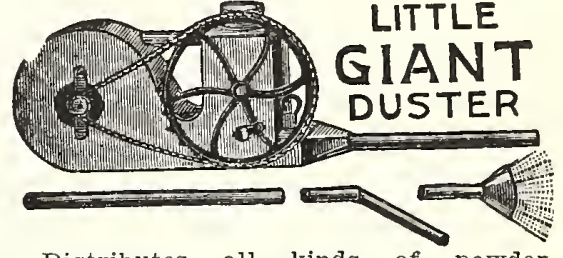

Distributes all kinds of powder. Weight, 12 lbs. Price, \$12.00.

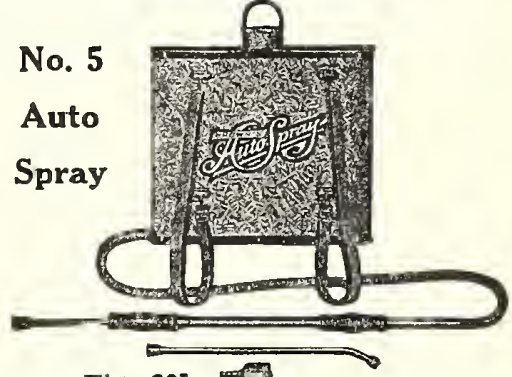

Fig. 201 ats

Pump made entirely of brass. Valves easily taken apart if they become ciogged. Nozzle designed for trees or in fine mist for bushes, potatoes. etc. This pump is double acting, thereby giving a continuous spray. Auto-Spray Pump. hose, nozz.

ixtension. extra. 50 ets.

\section{Iess tank. \$4.80. \\ Queen \\ Out-Door \\ Fly-Trap}

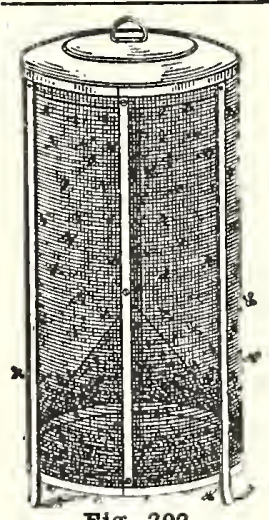

Fig. 202

Is 19 inches high and 11 inches in d i a meter. The framework is galvanized sheet metal covered with black painted wire cloth.

One of the best traps yet invented, ridding the stable of flies.

Price, \$1.75 each.

Weight 3 lbs.

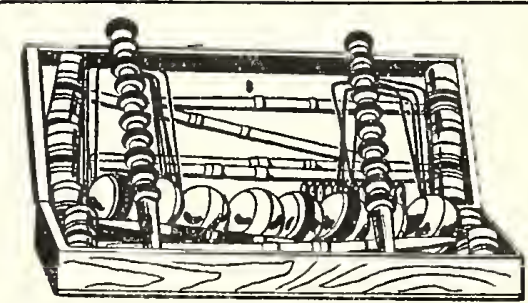

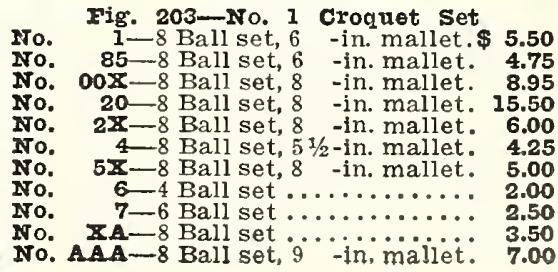




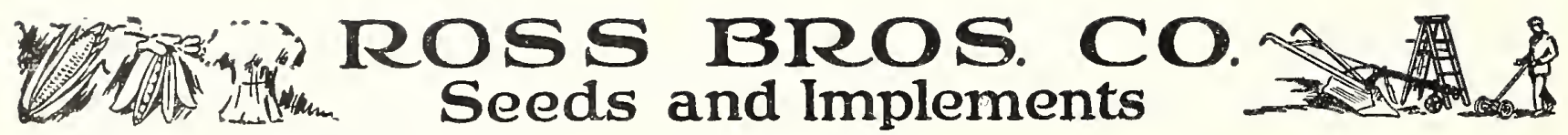

The Myers Junior Power Spray Outfit

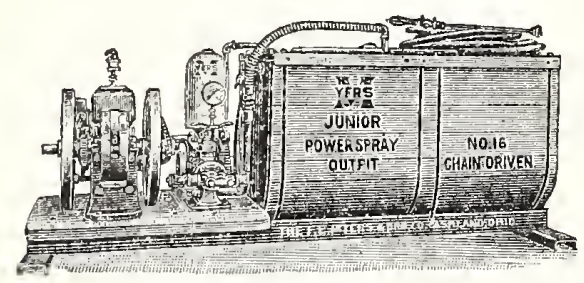

남. 204 Pump. lows:
Chain Driven 250 1bg. Pressure

Fitted with 2-in. Horizontal Double Acting $F$ o $r$ c e

Equipped as fol-

One Myers Spray Gun. Fifty feet of 1/2-in Myers High Pressure $\mathrm{Sp}$ r a Hose with fittings complete. Double c u t-o ff for discharge line, pressure gauge, agita-

tor, relief valve, strainer and suction hose

PRICP TIST

No, 16. Myers Junior Spray Outfit complete with 100-gal1on tank, No. 581 D. A. Spray Pump with Chain and Sprockot: for Pump and Engine equipped as above. Engine not included in this list. Price, $\$ 125.00$.

No. 8. Engine, 2 II. P. with Magneto. Price, $\$ 86.00$. 5\% Discount for Cash.
The Myers Junior Low Down Power Spray Rig No. 19

With all steel short turn

truck. Furnished with Thills

lnstead of Pole if specified on

order. Double acting pump.

chain driven. 46 -in. tread. 43

in. $\mathrm{hlgh}, 72$-in, long.

Specially de-

signed for the

farmer with a

small orchard

for his own use.

or for $S$ p $a$

Rings or Com

munity spray-

ing where sev-

e ral tarmer.

thelr o w

praying or hire one of their number to gpray for all.

Equipped as follows:

One Myers Spray Gun 0 feet of $1 / 2$-inch Myers High Pressur Spray Hose with fittings complete. Double cut-off for alscharge lines, pressure gauge, agitator, relief valve. strainer and suction hose. Price List:

No. 19. Myers Junior Low Down Power Spray Rig. 100 gallon tank. all steel truck and No. $\mathbf{5 8 1}$ Double Acting Purnp, chain driven, equipped as above. Engine not included in this list. Price, \$200.00. No. 22. Engine, 2 H.P. with magneto. Price. \$86.00.

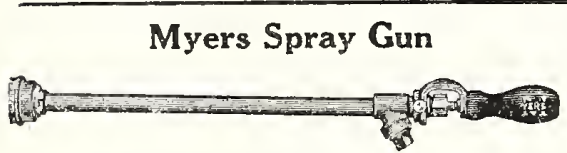

Fig. 206

Illustrates the Spray Gun. This gun diselarges a long distance spray, by means of which the top of the highest rruit tree can be reached, a slight turn of the handle widens the spray and another short turn throws off spray entirely when ready to move to next tree. Price, welght 5 lbs............\$6.00

\section{Myers Whitewash and Painting Ma- chine and Gen- eral Purpose Spray Pump}

The most durable spray pump for whitewashing and applying cold water paint there is made. All parts are of the best material.

Price, $\$ 13.00$

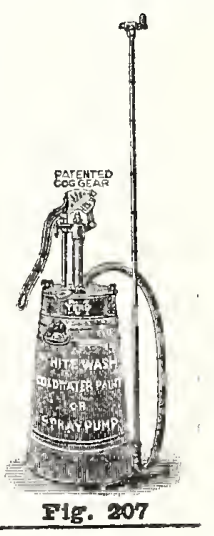

\section{Bordeaux Special}

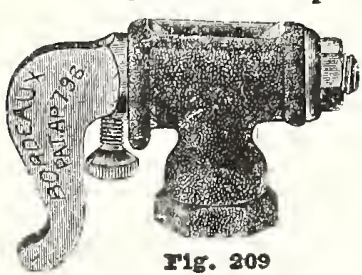

Thls noz-

z le w 111

throw a fine

fan - shaped

spray a nd

will readily

should it be-

conie clog-

Eed by turn-

ing cock

will throw a

solld stream

orice. $\$ 1.00$. Weicht ib.
The Auto Spray Pump

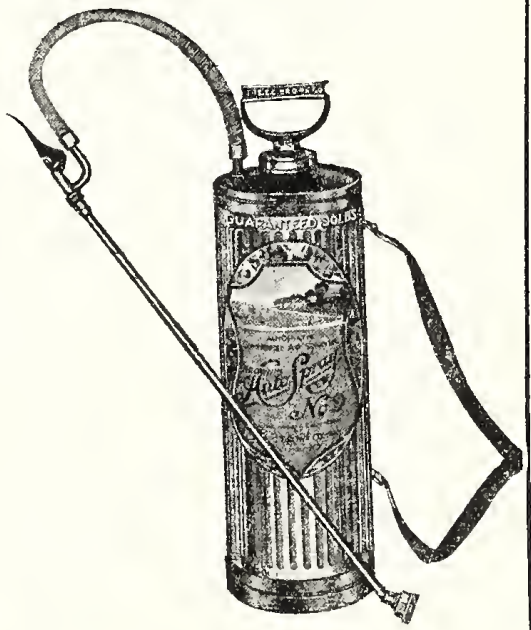

EHE. 208

The "Auto Spray" works automatically for six to fifteen minutes, according to the nozzle opening. It may be charged in fifteen seconds by a few strokes of the plunger, and two punpings will usually discharge the entire contents. Simply fll twothirds full of solution and pump up air pressure. Diameter, 7 inches height, 2 feet; capacity, 4 gals.: weight, 16 libs. with all attachments.

Price with autopop: Brags, $\$ 9.75$ Galvanized, \$6.75. $\$ 1.50$

AUTO HOSE POP No. I. Price, TWO ROW ATTACHMENT. Price, $\$ 1.50$.

TWO FOOT BRASS EXTENSION. Price, 50 cts.

BRAss ztBOW. Price, $50 \mathrm{cts}$

The Myers Compressed Air Sprayer The tank ls made of
heavy galvanized iron or brass. The side walls are double seamed, rlveted and soldered. The top and bottom are extra heavy material with flanged edge over which the side walls are the side w a lis are soldered. Has $1 \%$-lnch soldered. Has 1\%/-Inch nut ls operated by lugs on the lower part of the handle. which engage in opening at the top of the nut.

The 45 degree nozzle and 20-lnch brass extenslon furnlshed wlthout extra charge are so constructed that the nozzle can be attached to the end of the brass rod or direct to the connection at the end of the hose.

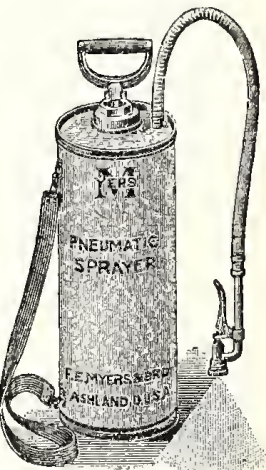

FIg. 210 iving the advantage of 45 degree discharge either way. Welnht 12 lbs.

No. 229: Price, $\$ 6.75$.

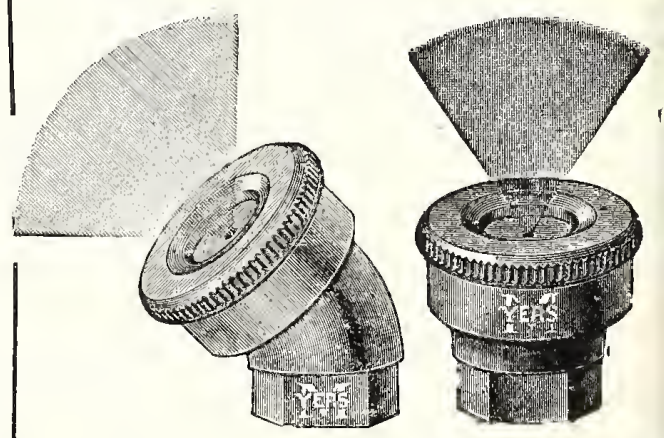

Fig. 211

Hig. 212

Fembro 45 degree Fembro nozzle. 60 cts nozzle. 70 cts. or 75 cts., or $65 \mathrm{cts}$. Post paid.
Postnaid. 


\section{Myers Cog Gear Spray Pump, Double Acting}

Complete Outfit, mounted on platform with 50-gallon Barrel and Mechanical Agitator, with Brass Valves and Ground Bevel Brass Seats, 2-1nch S e a m les Brass Removable Cylinder Hemp Packed Plunger and Double Lever Shut-Off Discharge. Cog Gear Movement increases the leverage, adapting it for spraying under heavy pressure. Mounted complete. Occupies smallest possible space. An ideal outfit for spraying potatoes. Will set in an ordinary farm wagon box

Price: No, R316B, Pump complete, 50-gallon barrel mounted as shown, with pressure gang $\theta$, one 15-foot lead of $3 / 8-i n c h$ 7-ply digcharge hose, one Fembro rig. 1290 nozzle, one 8-foot plpe extension with lever ghut-off and mechanical agltator, $\$ 54.00$.

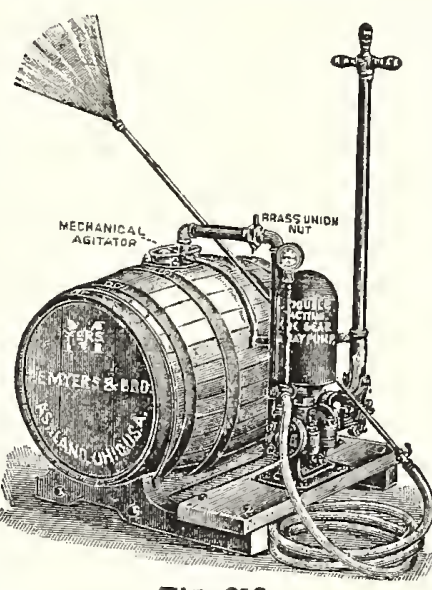

P1g. 213
Four row spraying attachment, to be used with the above pump or with any pump which can be used successfully to spray four rows at once. Equipped with four nozzles, one to each row; is adjustable to any height or width, giving a spray up or down. Indispensable for large acreage of potatoes and can be easily used with Myers' Double Acting Cog Gear Spray Pump.

Price, complete with hose, nozzles, etc., \$26.00.

\section{Savage Duster}

Sprays Everything in Powder Form

Easier to carry and operate than any hand duster made. Perfect balance. Ball bearings and gears packed in grease, require no lubrication. Discharge tube may be raised or lowered for low or high plants or trees so that the operator always stands in an upright, comfortable position.
Bullt of the finest materia! and workmanship and made to stand long, hard service.

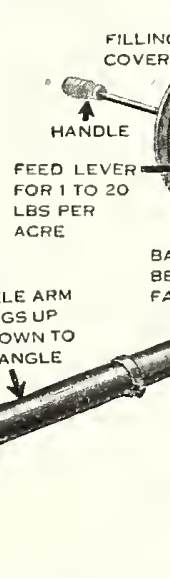

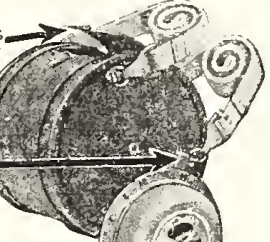

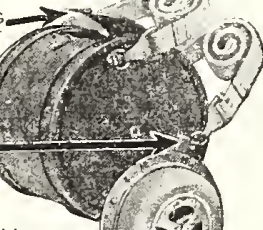

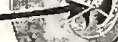
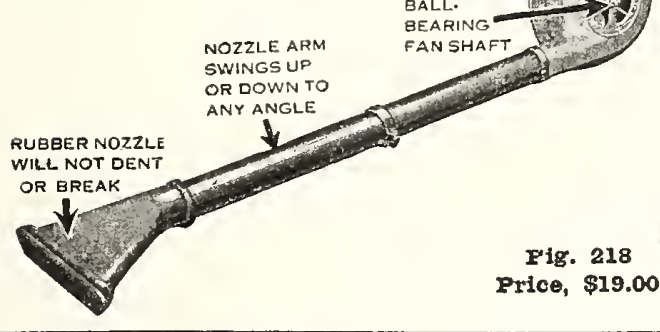

\section{Bamboo Spray Rods}

The Bamboo Extension $1 \mathrm{~s}$ made of selected bamboo, $8 \mathrm{ft}$, $10 \mathrm{ft}$ and $12 \mathrm{ft}$. in length, through which is placed a special brass tube of 5 inch inside diameter: the shut-off lever and male end are attached to the brass tube by heavy threads (no solder) and has wide shield at top to prevent solution running down the pole.

\section{PRICE IIST}

8-ft. bamboo extension, with lever shut-off cock. Each. $\$ 3.50$ 10 -ft. bamboo extension, with lever shut-off cock. Fach.. 3.90 12 -ft. bamboo extension, with lever shut-off cock. Each.. 4.30

\section{Myers Cog Gear Barrel Spray Pump}

Hat Bronze Ball Valves and Brass Seats. The plunger is self-expanding. Will handle any caustic mixture. The cylinder and discharge pipes are all brass. The air chamber is 32 inches in length, enabling the pump to throw a uniform, constant and elastic spray. It has good leverage, is very powerful and easily operated.

Price, ro. R318B, Myerg Cog Gear Barrel spray Pump complete, with one lond of 15 feet of $1 / 2-\operatorname{lnch} 5-\mathrm{ply}$ discharge hose, graduating vermorel nozzlo, and mochanical agitator, $\$ 16.00$.

Price, complete, all set in barrel, $\$ 8.50$.

The Myers Portable S 218.214

\section{The Myers Portable Sprayer}

Is fitted with cog gear handle and is securely attached to the tank by means of a clamp connected direct to the channel Iron that surrounds the top of the tank held in position by one thumb screw. The handle can be located at any point desired.

The Pump is fitted complete with dasher agitator, hose and an 8-10ot pipe extension in two 4-foot parts, which adapts it for spraying large trees and also for use in whitewashing on the inside of low bulldings.

The tank is made of heavy galvanized iron thorough ly rein-
forced at top and
bottom by ateel ough ly re in-
forced at top and
bottom by ateel ough ly re in-
forced at top and
bottom by ateel trunlons, 121/2 gallons capacity.
The wheel and handles are
made of wrought steel thoroughly braced. The wheel is 15 is inches in diameter, with 3 -inch tire.

30. I336B. Prioe, \$26.00.

Can be furnished with two wheels at same price.

The Myers Perfect Knapsack Spray Pumps

The tank, made of either galvanized iron or copper, holds 5 gallons of mixture. It is double seamed and soldered, and is fitted with t tight lid and stralner. The top and bottom are recessed into ends of Tank, seamed and soldered, making a very stiff and substantial Tank. It is shaped so that it can be carried on the back, shoulder strapg being provided for this purpose. Handle lever is arranged for shifting from right to left at will of operator.

The Spray Pump used in this Outfit is constructed entirely of brass. It is provided with a large air chamber and has heavy brass cylinders, brass ball valves, patent agitator to keep liquid thoroughly mixed.

$$
\text { Weight } 16 \text { lbs. }
$$

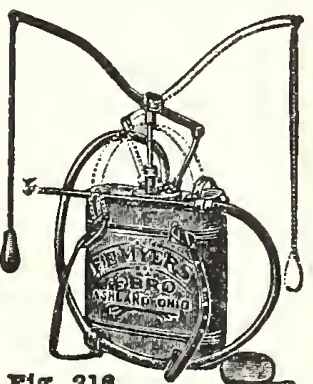

Fis, 210
Price

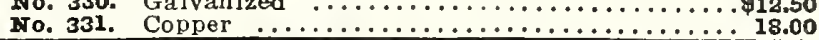

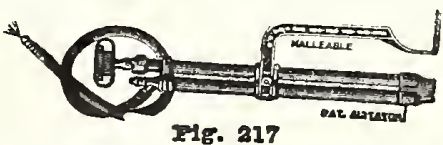

No. 3274. Little Giant Brass Spray Pump with agitator. complete with hose and Imperial combination fine coarse spray and solid stream nozzle, with malleable foot rest. Price, \$4.30. Welght, 6 lbs. 


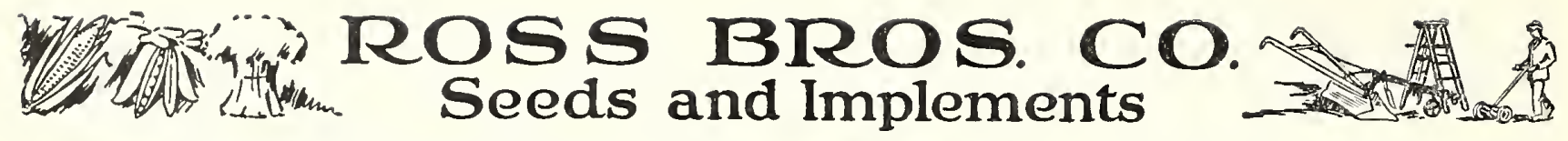

TANGLEFOOT ANT-DESTROYTR. Guaranteed to drive ants from any lawn. Put up in powder form and used by scattering on the 15 cts., 8 oz. 35 cts.

\section{Kayso} Kays Means Economy. Kayso makes the spray apply easily and cover quickly-causes
the spray to set and dry rapidly without exces$= \pm$ sive run-off waste, and gives increased coverage of as much as 10 to 25 per cent.

USE KAYSO WITH AII SPRAYS. Price, 2 lbs. 45 cts., 100 lbs. $\$ 18.00$. Use $11 \frac{1}{2}$ lbs. to 200 gallons of water.

DRY ARSENATE OF IEAD. The trade seems to demand this in the dry state as it has so many advantages over the paste. The dry will keep forever, is less bulky, does not freeze and spoil. Send for descriptive catalogue which gives valuable information for every tree grower. $1 / 2-1 b$. pkg. 25 cts. each, 1-1b. pk. 45 cts., 4-1b. bag $\$ 1.00$.

\section{Black Leaf 40}

\section{(Nikoteen Sulphate, Nikoteen 40 per cent)}

BIACK IFAF 40 is the best known remedy for Potato Lice and other similar insects. Is perfectly soluble in cold water. Can be used in combination with lime, sulphur, arsenate of lead, Bordeaux mixture. Is used as safe and effective for plant lice, thripe, leaf hoppers, etc. Highly recommended by State and Government Experts. Use about 1 to 1,000 , or $1 \mathrm{oz}$. will make six gallons of solution.

1 oz. 35 cts., $1 / 2$ lb. $\$ 1.25,2$ lbs. $\$ 3.25,10$ lbs. $\$ 11.85$.

\section{Sprays for Roses and Other Plants}

\section{FUNGTROGFN}

A highly concentrated fungicide that conquers Mildew and controls Black spot on roses, phlox and other plants, and is an effective plant stimulant, as well.

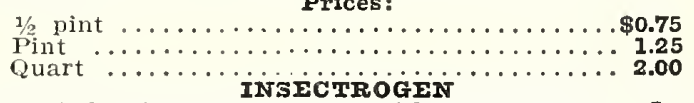

For leaf-chewing insects-caterpillars, slug worms, Japanese beetles, etc., and blight. Used alternately with Fungtrogen. Both carry their own spreader.

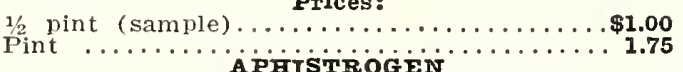

Destroys the destructive aphis in two or three applications. For all plants subject to aphids or plant lice. All these sprays carry the noted Rosenbluth leaf fertilizerHortogen. Prices:

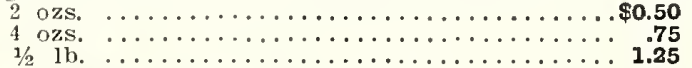

DRY BORDEAUr POWDER. For preventing blight on grapes, potatoes and other crops that are subject to rust, cts., $41 \mathrm{lb}$. bag $\$ 1.00$.

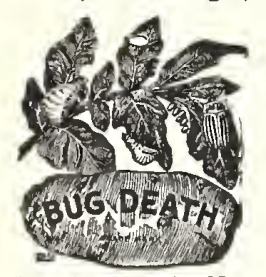
Pat. in Canada Nov.
2,1897 . Pat. Mar. 16 COA Nov. 1906. it. $1 / 2 \mathrm{pt}$. $15 \mathrm{cts}$ 2 lbs, and 4 lbs.

CREOSOTE FOR GYPSY MOTHS. For the destruction of the eggs of gypsy moth. Qt. 55 cts. Shipping weight 3 lbs. Gal. \$1.15, weight 9 lbs.

CUTWORM FOOD. Rid your garden and farm of the Cutworm pest. There was a time when Cutworms were not considered very seriously by farmers and market-gardeners, but in late years it seems they have come to stay. for the operator. Put up in 1-1b. package. Directions for using on every package. 1 lb. 40 cts. Shipping weight 2 lbs.

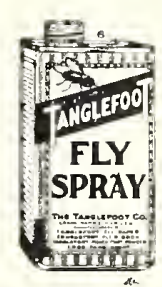

\section{Tanglefoot Fly Spray}

Tanglefoot Fly Spray has a pleasing odor and leaves no stain. It destroys Flies, Fleas, Mosquitoes, Bed Bugs, Wasps, Spiders, Moths, Roaches and Ants, as well as certain other insects that infest houses, stores, etc. $1 / 2$ pt., wt. 1 lb. 25 cts.; 1 pt. wt. 2 1bs. 45 cts.; 1 qt., wt. 3 lbs. 85 cts.; 4 qts., wt. 9 lbs. $\$ 2.50$.

1/2-pint hand sprayer, wt. 2 lbs., $40 \mathrm{cts}$.

\section{Tree Tanglefoot}

A perfect safeguard for trees against gypsy, brown-tail and tussoca moth, canker worm, ants and all creeping things. It will remain sticky about three months, fully exposed to the weather. 1-1b. can 60 cts., 5-1b. can $\$ 2.75,10-1 b$. can $\$ 5.25$,

FIIT. Destroys flies, mosquitoes, moths, ants, bed bugs and

roaches. $1 / 2$ pt., wt. 1 lb. 50 cts.; 1 pt., wt. 2 lbs., 75 cts.;

1 qt., wt. 3 lbs., $\$ 1.25 ; 1$ gal., wt. 9 lbs., $\$ 4.00$.

K-O FIY SPRAY for Cattle is safe, clean and clear-contains no tar, refuse or heavy dark oils. It has one hundred per cent efficiency and is highly economical. Will not taint milk, when used as directed. Price per gal. \$1.50, weight 9 lbs.

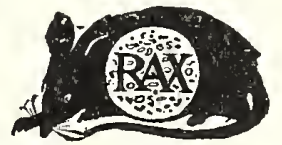

\section{Ray Is Not a Poison}

Within a few days after eating bait vrepared with Rax, rats and mice become feverish and seek the open air, where they die-outdoors.

Directions with each package. One bottle is enough for an ordinary house; allow one bottle to each 500 feet of floor space in large bains, mills, etc. Price, 75 cts. per bottle, postpaid.

GRAFTING WAX. Prices, $1 / 4$ lb. 20 cts., $1 / 2$ Ib. 30 cts., lb. 50 cts.

FrLIEBORE. Sure death to the currant worm. Ib. 60 cts., $1 / 2$ lb. 35 cts., $1 / 4$ lb. 20 cts.

\section{"Herbicide"-The Weed Exterminator}

“HERBICIDE”-THE WERD EXTEFMINATOR. IKills grasS and weeds of every kind on roadways, gutters, tennis courts, ctc., by one application. Its use will save much labor and expense in the long run. 1 qt. 70 cts., 1 gal. cans, $\$ 2.00,5$ gal. cans $\$ 7.50,10$ gal. cans $\$ 12.50 ; 30$ gal. cask $\$ 30.00,50 \mathrm{gal}$. barrel $\$ 45.00$. Full directions accompany each package.

IN-A-MIINUTE. Will destroy bugs, roaches and similar vermin. Used for cleaning clothing, ink stains, etc. Price 14 oz. bottle 50 cts.

MEROSENE EMUISION. Not injurious to foliage and a sure remedy for lice, scale insects and most soft-bodied by contact. Qt. 50 cts., gal. $\$ 1.50$.

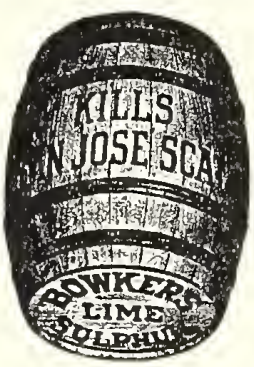

DRY IIME SUIPHUR. All the old disagreeable features of spraying with liquid lime sulphur is done away with by using the new sulphur compound. It is not caustic, does not freeze, is good till used and is fully 25 per cent cheaper to use than that in the liquid state. Put up as follows: 1-1b. cans 30 cts., $5-1 \mathrm{~b}$. cans $\$ 1.25,10-1 \mathrm{~b}$. cans $\$ 2.15,25-1 b$. cans $\$ 3.75,100-1 b$. cans $\$ 13.00$

CONCEITRATED IIME SUTPHUR. Kills San Jose Scale, Oyster Shell, Bark Lice, etc., and gives the tree a thorough "housecleaning." It should be applied any time after the leaves drop in the Autumn and before the buds start in the Spring. Needs only to be dilut it is ready to apply; gallon makes 10 gallons of spray. Weight 3 lbs.; 1 gal. 85 cts., weight 12 lbs.; 5 gals. $\$ 3.25,50$ gals. 24 cts. gal. No charge for barrel. 


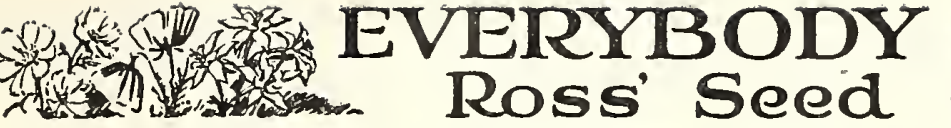

\section{Why Raise Roses to Feed Bugs?}

Mlelrosine-the only remedy-endorsed by leading authorities. The GENERAL CONBAGS and other insects. Used with any good spray-pump diluted with from 20 to 25 parts of water. Pleasant and harmless to use. Guaranteed eftective when used according to directions on can. Gal., weight 10 lbs., $\$ 6.00$; half-gal., weight 7 lbs., \$3.25; qt., weight 4 lbs., \$1.75; pint, weight 2 lbs., \$1.00. Trial size 50 cts. By mail or express at customer's expense. Or Trial Size, sufficient to make one dallon when diluted, and care for several plants for the season, postpaid for $60 \mathrm{cts}$

\section{MELROSINE-IT KIILS ROSEBUGS}

\section{"Readeana" Rose Bug Exterminator}

A most effective insect killer that is absolutely harmless to even the most delicate flowers or foliage. 1 gal. \$4.00, 5 gal. $\$ 17.50,10$ gal. $\$ 34.00$.

\section{"Nico-Fume" Liquid (Nicotine Solution)}

Fas the advantage of being suitable BOTH for spraying and for Fumigating Purposes.

"Nico-Fume" Liquid is packed in screw-top cans, and is sold in the following sizes:

Can containing 8 lbs., price $\$ 11.50$; can containing 1 lb., $\$ 2.00$ Can containing 4 lbs., price 6.25 ; can containing $1 / 4$ lb., $\mathbf{7 5}$ FORIMAIDEHYDE-plevents potato diseases and insures a

big, healthy erop. Directions mailed upon application. 7 lb. 45 cts.

PARIS GREEN. A poisonous, insoluble powder, for preventing the ravages of potato-bugs, codling inoth, caterpillars, slugs and bugs. Mix one pound to 100 pounds of plaster, or 200 gallons of water. Lb. 50 cts., $1 / 2$ Ib. 30 cts., 1/4 Ib. 20 cts.

PINE TAR. Used in the stable for cuts and bruises. $1 / 2$ pt. 20 cts., pt. 30 cts., qt. 40 cts.

\section{Stanley's Crow Repellant} What It Does

It rids your Corn Crop cf Crows and other corn pulling birds, and animal pests, such as Moles, Gophers, Woodchucks, Squirrels, etc.

Saves loss of seed and labor of replanting.

Positively will not clog any planter.

Aids and hastens germination of seed corn.

protects seed from rotting in the ground.

Insures larger yield per acre.

Is non-poisonous and will not injure the seed.

Will not kill birds or animals, but will keep them away and prevent destruction by them.

Has been used successfully by experienced corn growers for over ten years.

Large can, enough for two bushcls of seed corn.......\$1.50 Small can, enough for one bushel..................00 Mailing weight each 2 lbs.

\section{Bowker's Pyrox}

powerful fungicide; it controls fungous diseases, even some serious ones that other fungicides do not control.

A strong poison insecticide; it kills chewing insects, even those which are hard to kill, like the hard-shelled potato beetle.

Over twenty years of practical farm use have proved Pyrox the most effective remedy against both serious fungous diseases and chewing insects. It contains the essential copper in proper quantity for safe use and in most active form fol greatest fungicidal value. In Pyrox the poison insecticide is chemically blended with the copper fungicide which increases the effectiveness of both.

Simply mix witl cold water and spray

It gives more lasting protection; it sticks like paint and stays on for weeks. Even hard rains do not wash it off once it is thoroughly dry.

It helps to increase yields; the copper fungicide in Pyrox imulates the ieaves, makes them greener and more vigorous and helps to increase yields even when there is no disease.
1 lb. jar
$\$ 0.50$
5 lb. drum
50 1b. drum
$100 \mathrm{lb}$. keg
$300 \mathrm{lb}$. barrel
$\$ 10.75$
43.50
3.00
6.25

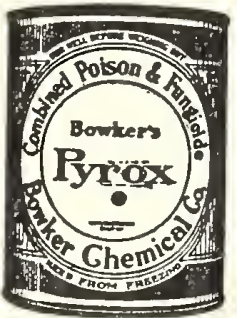

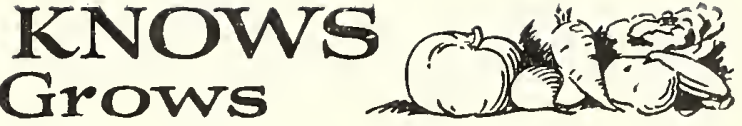

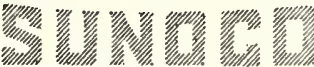 \\ SELF-EMULSIFYING

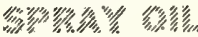

emulsion and will carry or foliage in which the insect pests choose to harbor.

50 gallon steel drums, per gallon.

30 gallon steel drums, per gallon.

For scale insects, aphis and red mite on apple trees. The ideal petroleum spray is an oil that will form a perfect and permanent mixture with water. The most distinctive characteristic of SUNOCO SPRAY OIL is that it forms a perfect, permanent

15 gallon steel drums, per gallon.

$\$ 0.50$

5 gallon car, per gallon

1 gallon car, per gallon.

SCALECIDE. The quality miscible oil. Oldest and best known dormant spray them more shrubs and vines-makes fruitful. Used by leading fruit growers. Pleasant to use-non-caustic, non-corrosive, non-poisonous. Kills scale, insects, eggs, larvae and disease cankers and fungous spores wintering on the plant. Mixes instantly -dilute 1 to 15 . Prices: 1 qt., weight 3 lbs, $\$ 0.75$; 1 . Pal gals., $\$ 10.60 ; 15$ gals., $\$ 13.50$; 30 gals., $\$ 26.00 ; 50$ galls., $\$ 38.00$. One gallon equals $31 / 2$ gallons line-sulphur.

CARBOLINEUM. Of the numelous preservative compounds on the market Carbolineum stands alone as time-tried and thoroughly tested. It is the only superficial preservative method that has been used the world over and demonstrated its value in the thirty past years. It is the only one that has received recognition and met with the approbation of engineers of Europe and America-the only preparation favorably reported along with the reliable but expensive and inconvenient Creosoting and Burnetizing process. Gallon can \$1.75. Weight 11 lbs.

SLUG SFIOT. A fine powder used for potato bugs and other insects. Recommended for cabbage worms. 5-1b. package $60 \mathrm{cts}$.

TOBACCO DUST, in one pound package for dusting plants for lice, etc. $1 \mathrm{lb} .25 \mathrm{cts}$.

FISH OIL SOAP. For destroying insects on plants, etc., in small boxes. Ib. $40 \mathrm{cts}$., $1 / 2 \mathrm{Ib} .25 \mathrm{cts}$.

SOAP, SUIPFO-TOBACCO. 3-oz. pkg. 10 cts., mailed postpaid 13 cts., per doz. $\$ 1.00 ; 1 / 2 \mathrm{lb}$. pkg. 20 cts., mailed postpaid 28 cts., per doz. $\$ 2.00$.

SEMESAN. The Modern Seed Disinfectant for all agricultural purposes. Full directions with each can. Circulars mailed upon application. 2-oz. can 50 cts., 8 oz. can $\$ 1.60$, $1-1 b$, can $\$ 2.75$.

SEMESAN JR. For sweet and field corn diseases. 1-1b. tins $\$ 1.75$.

SEMESAN BEI. For bulbs, roots and tubers. 1-1b. tins \$1.75. Semesan being poisonous disinfectant is not mailable.

\section{Dolge Weed Killer}

A minute a day keeps the weeds away.

Kills all growth on Tennis Courts, Walks and Drives. Destroys Ivy, etc., on walls, fences and court yards.

\section{PRICES}

1-qt. can (enough for

10 gals.)

1-gal. can (enough for

40 gals.)

$\$ 0.60$

5-gal, can (enough for 200 gals.)

1.75

10 -gal. can (enough for 400 gals.)

30 -gal. bbl. (enough for 1,200 gals.)

5.00

37.50

52.50 


\section{1)}

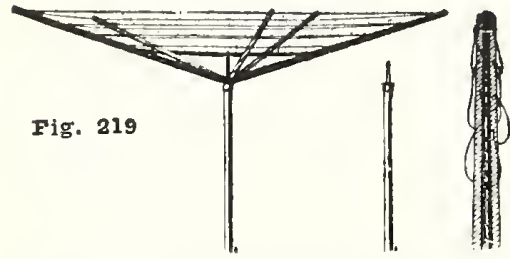

HIII'S CHAMTION DRYER. Made f selected wood, neatly painted. Ground box has galvanized cover. A very attractlve dryer, one that will last. Can be folded and put away easily. Price Wood post, $115 \mathrm{ft} . \ldots \ldots \ldots \ldots \ldots . \$ 10.50$ Wood post, $150 \mathrm{ft} \ldots \ldots \ldots \ldots \ldots \ldots 12.00$ Can be furnished with galvanized steel post. $\$ 1.50$ extra.
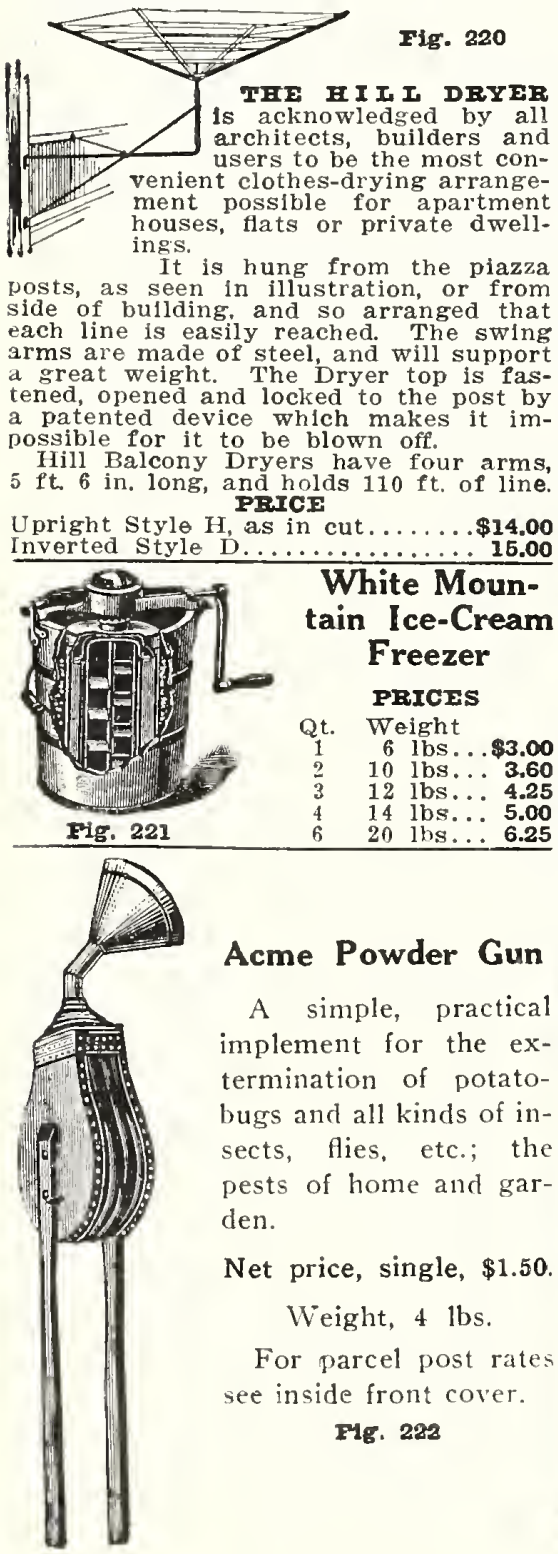

Acme Powder Gun

A simple, practical implement for the extermination of potatobugs and all kinds of insects, flies, etc.; the pests of home and garden.

Net price, single, $\$ 1.50$.

Weight, 4 lbs.

For parcel post rates see inside front cover. Flg. 282

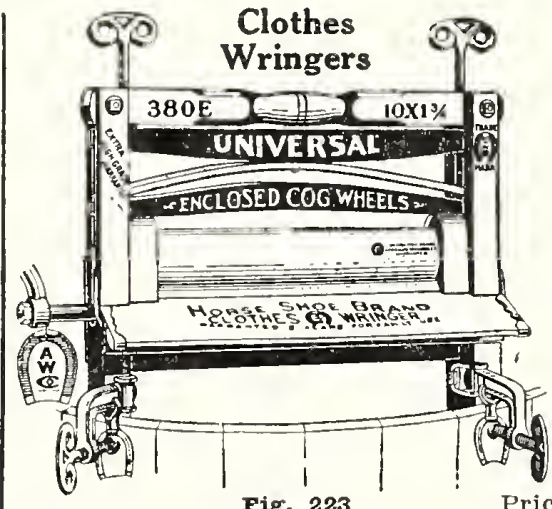

No. 380 ב. Univers Guaranteed 3 years; for round tubs only; enclosed gears; ball bearings; rolls $10 \times 13 / 4$ in.: 3 in a carton, 62 lbs. Hi Grade. Weight each $201 \mathrm{bs}$.

No. 360 . 2. Universal...........\$6.75 For set or round tubs; ball bearings enclosed; guaranteed 3 years; rolls $10 \times 13 / 4$ in.; 2 in carton, 54 lbs.; each 24 lbs.

No. 361 E. Universal. . . . . . . . . \$7.00 Same as No. 360 F. except has 11 in. rolls. Weight 25 lbs.

No. 100 Rival $\$ 4.75$ Self-olling wood bearings; for round tubs only; guaranteed for one year. Weight 18 lbs.

\section{Small's Calf Feeder}

The original cali feeder. Price, $\$ 5.00$ postpaid. Weight 4 lbs. Nipples, 50c each. Postage 5c.

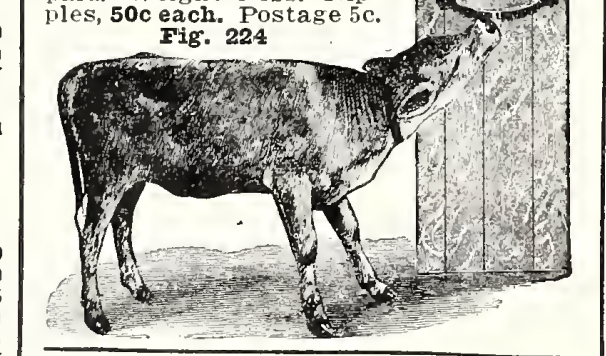

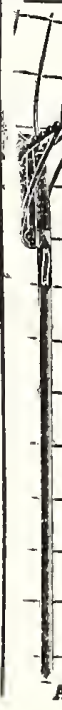

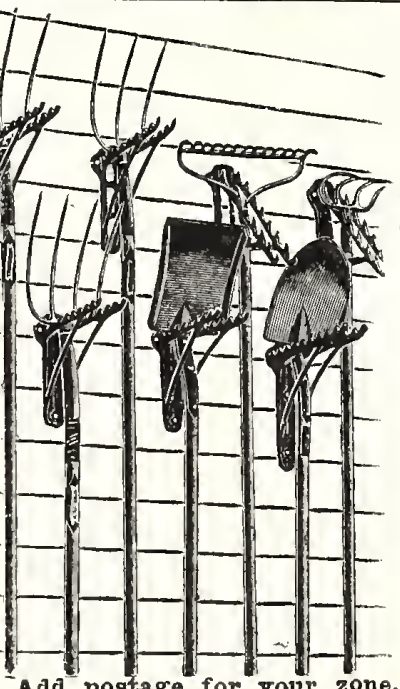

Add postage for your zone.
Hager Tool Rack

Designed for store or stable. $M$ a d e in t h r e e styles ror shoreis forks.

Combina tion racks for stores c a $n$ bo e d ror 211. Price. Wt. $3 \mathrm{lbg}$ Fig. 225

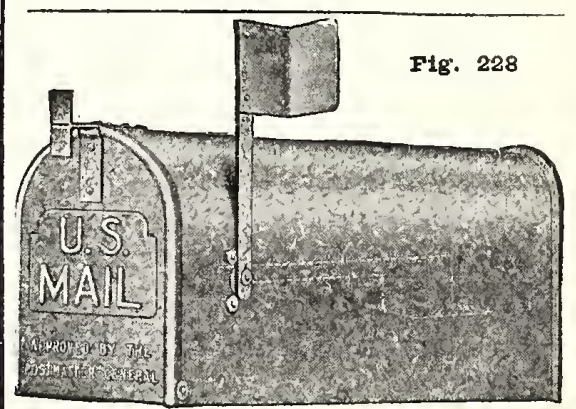

The Hessler Mail Box

Conforming in every way to the Post Office requirements for rural dellvery box. Dimensions: No. 1, $181 / 2$ in. long. $6 \frac{1 / 4}{4}$ in. wide and $7 \frac{1}{2}$ in. high. Inside measurements, No. 1
10 lbs. Price of No. 1 is \$1.50.

weighs

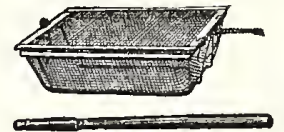

Corn Poppers

Made u p of heavy woven wire. with stained hand le. E.verybody

Fig。. 229 should have one.

4 qt...............

Maiing weight, each 2 lbs. 


\section{EVERYBODY KNOWS Ross' Seed Grows}
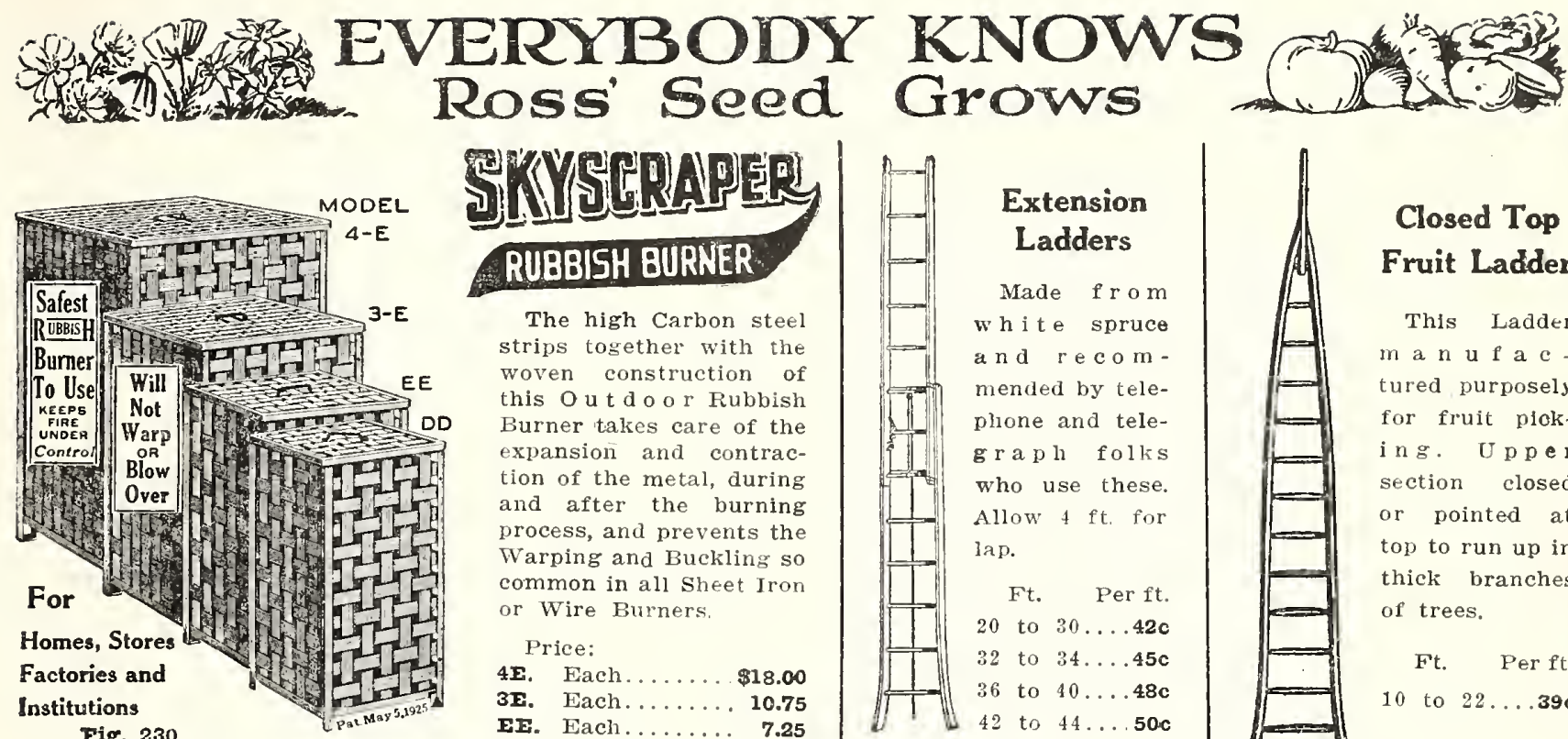

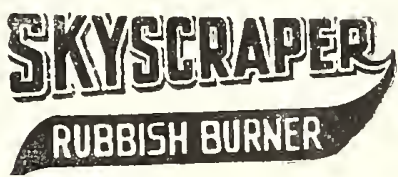

The high Carbon steel strips together with the woven construction of this out door Rubbish Burner takes care of the expansion and contraction of the metal, during and after the burning process, and prevents the Warping and Buckling so common in all sheet Iron or Wire Burners.

\section{Price:}

4E. Each....... \$18.00

3耳. Each........ 10.75

E․ Each........ 7.25

DD. Each....... 6.25

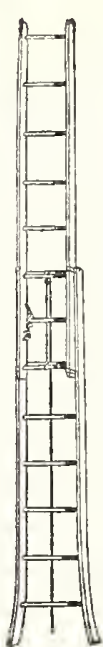

Extension Ladders

Made from white spruce a $\mathrm{nd}$ recom mended by teleplione and telegraph folks who use these. Allow $4 \mathrm{ft}$. for lap.

Ft. Per ft. 20 to $30 \ldots 42 \mathrm{c}$ 32 to $34 \ldots 45 \mathrm{c}$ 36 to $40 \ldots 48 \mathrm{c}$ 42 to $44 \ldots 50 \mathrm{c}$ Fig. 231

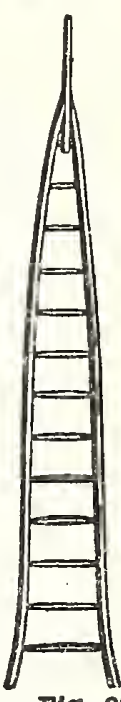

Fig. 232

\section{Closed Top Fruit Ladder}

This Ladder $\mathrm{m}$ a $\mathrm{n} \mathrm{u} \mathrm{i}$ a $\mathrm{c}$. tured purposely for fruit pioki n g. Up per section closed or pointed at top to run up in thick branches of trees.

Ft. Per ft. 10 to $22 \ldots 39 \mathrm{c}$

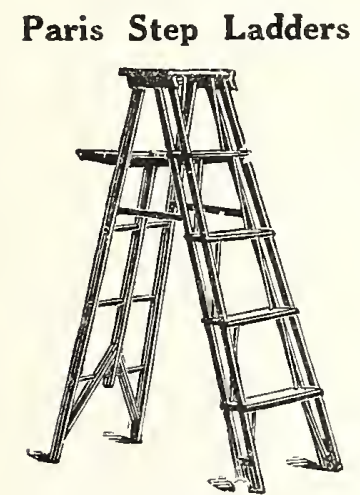

Fig. 233
These Iadders are made by the Paris Mfg. Co., which is sufficient guarantee for their d u r a b i l i t y and workmanship. Every ladder heavily trussed and $r$ e i f f o r c e d. we carry all lengths.

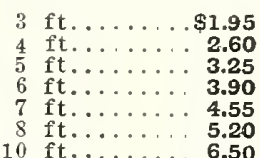

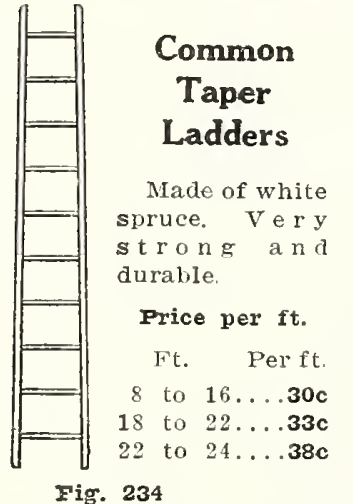

Fig. 234

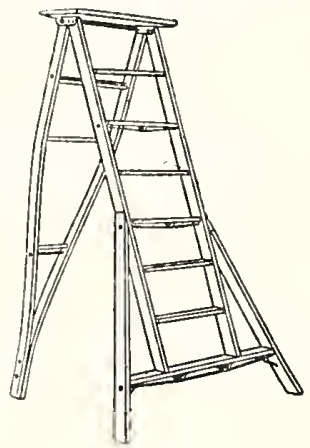

Fig. 235
Plain Galvanized Ash Can

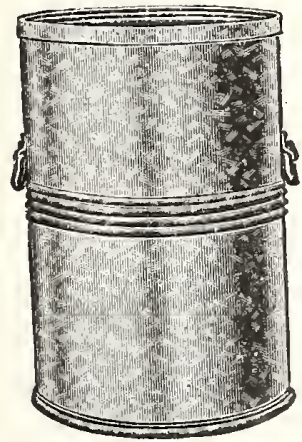

Fig. 236

No. 1. $17 \times 26$ in., a medium welght can suitable for all purposes. Used by the poultrymen for grain cans and the iike. Price, \$1.65.
Corrugated Galvanized Ash Can

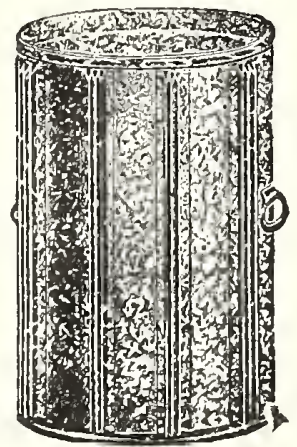

Pig. 237

Ajax. A medium weight can, corrugated, which makes it extra strong. Price, \$3.75.

covers, 90c.

\section{Columbia Fruit} Step Ladder

This Fruit Step is the latest, strongest, best and most practical fruit step on the market. Ma de from Clear Spruce; $s \mathrm{t}$ e $\mathrm{p}$ reinforced with $\mathrm{truss}$ rods. Made in $5,6,8,10$ and $12 \mathrm{ft}$. lengths. Price per ft. $70 c$.

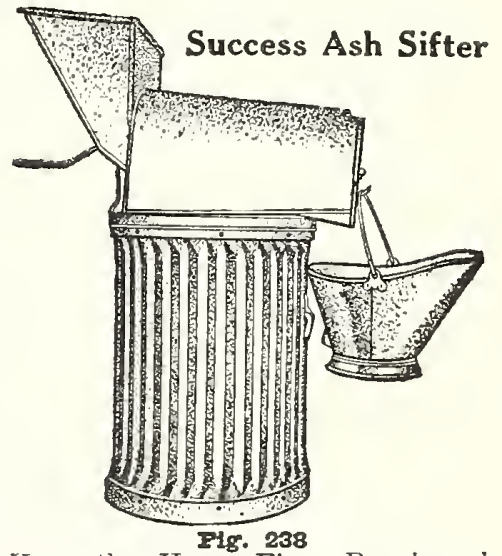

Keep the Home Fires Burning, bu sift your coal and save every piece.

Rightly named, for it does the work in nalf the time with no dust or nolse and with very little work.

No. 1. Family size............\$\$.00 No. 1. Complete with galvanized 4.50

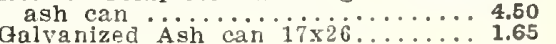




\section{ROSS BROS. CO.}

Pruning Saws

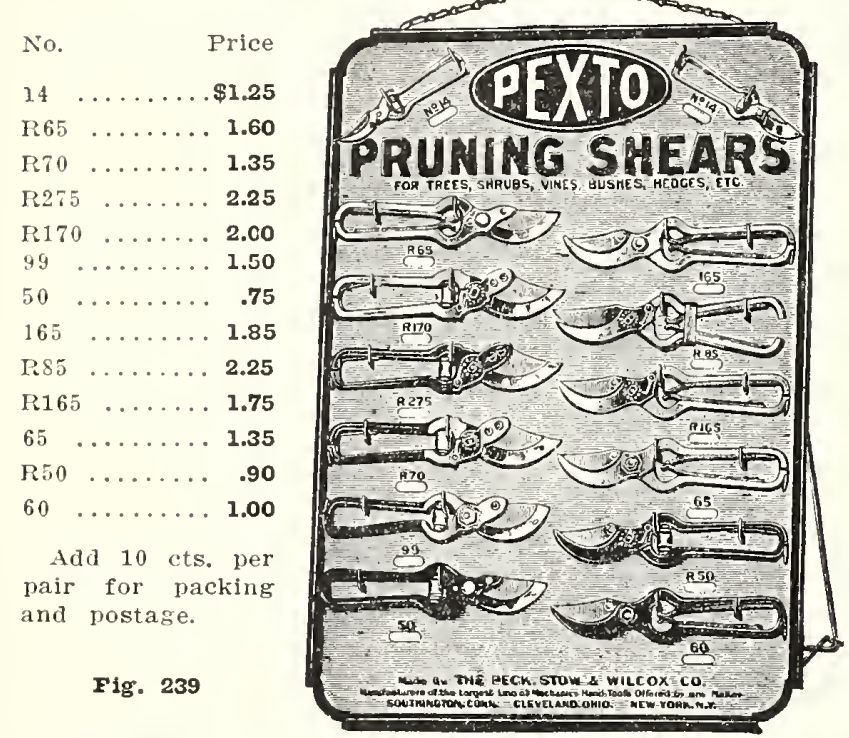

\section{Budding Knife}

$41 / 4$ inch es long. Price, \$1.25. Bone. 1 blade. Postpaid.

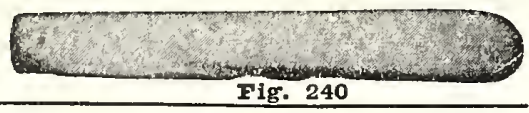

\section{McKinney Pruners}
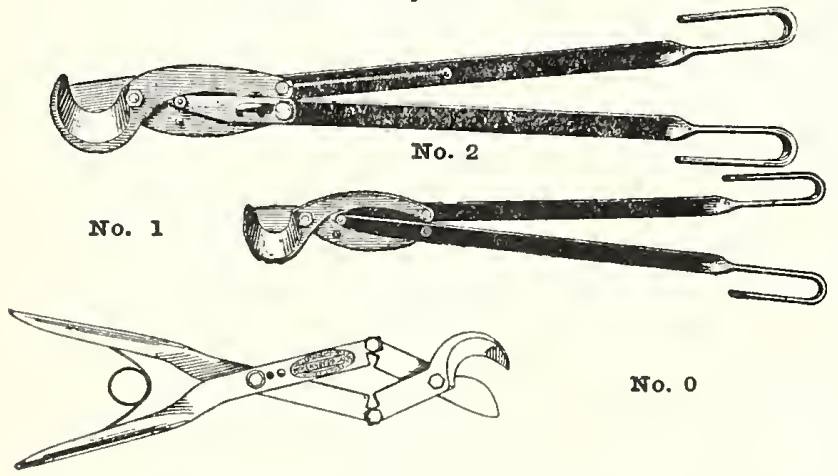

No, 0

Fig. 241

Latest, strongest and best hand pruner made. Very powerful and easy to operatc. The only perfect cutting pruner on the market. No. 0 is a hand pruner having two cutting blades, cuts limbs $5 / 8$ in. in diameter. No. 1 cuts $1 \mathrm{in.} \mathrm{in}$ diameter. No. 2 cuts $1 \frac{1 / 2}{2}$ in. in diameter.

\begin{tabular}{lllr} 
& Weight & Length & Price \\
No. & 1 & $15 \mathrm{in.}$ & $\mathbf{\$ 3 . 0 0}$ \\
No. 1 & $21 / 4$ Ibs. & $23 \mathrm{in.}$ & $\mathbf{4 . 0 0}$ \\
No. 2 & $5 \mathrm{l}$ lbs. & $30 \mathrm{in.}$ & $\mathbf{5 . 5 0}$ \\
\hline
\end{tabular}

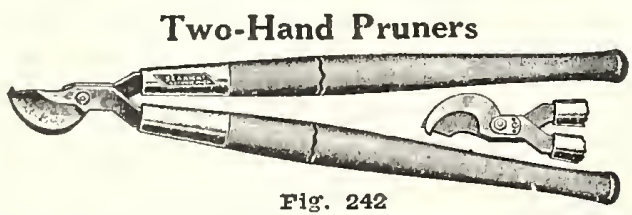

A heavily constructed pruner with an absolute broad cut, made for lieavy duty work. 24 in. handle. Price each \$2.50. Malling welght 6 Ibs.
Fig. 243

$\$ 3.25$

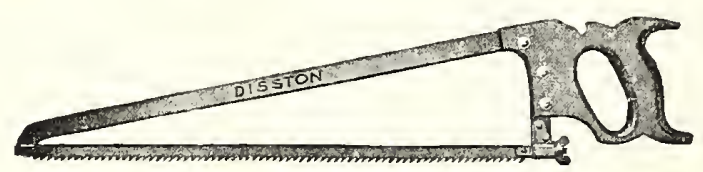

No. 19. 18 in. Mailing weight 2 lbs.............\$1.90

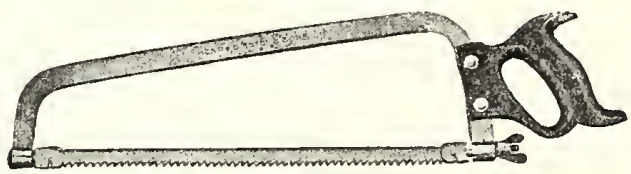

P1g. 245 No. 15. Blade 14 in. Mailing weight 31 bs. Price..... $\$$ 2.00

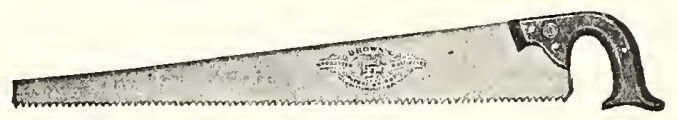

F1g. 246

No. 3. 16 in. Mailing weight 2 lbs............\$1.35 18 in. Mailing weight 2 lbs....................

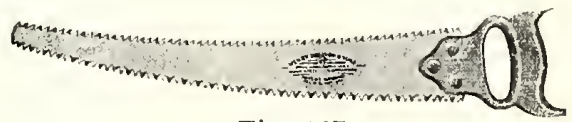

Fig. 247

No. 5. 16 in. Malling weight 2 lbs..............\$1.90

18 in. Mailing weight 2 Ibs..............2.00

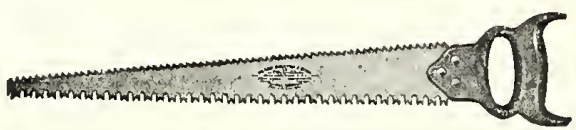

Fig. 248

No. 4. 16 in. Mailing weight 2 lbs............. \$1.65

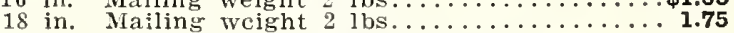

\section{Heinisch Hedge Shears}

One edge serrated and one knife edge. Forged Steel Handles, Tempered Steel Blades.

They are concording to Heinisch standards of quality and design. The blades

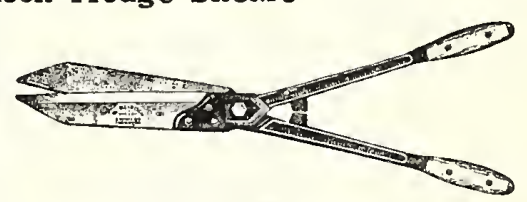

Fig. 249 are made of high car-

bon cutlery steel, hardened and tempered with great accuracy. The handles are made of drop forged steel, like the handles of tinners' snips, with wood grips for the sake of comfort. Mailing weight 4 lbs.

\section{Prices}

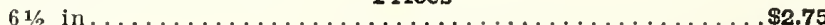

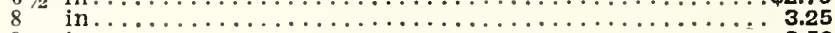

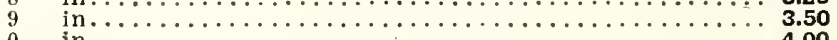
See inside of front cover. 


\section{EVERIBODY}

Victor Traps with Chains

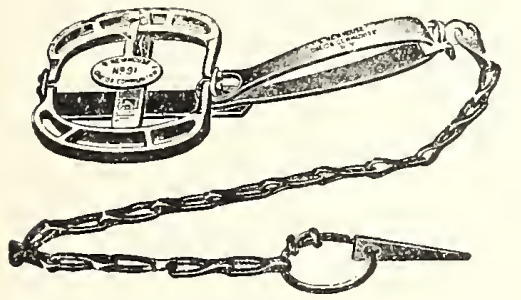

Fig. 250

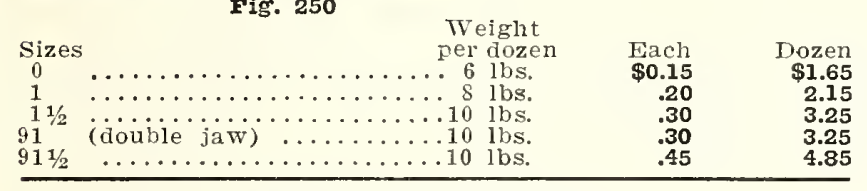

\section{Jump Trap with Chains}

Not Illustrated

Light in weight, open up flat and used extensively by lots of trappers. The Nos. 91 and $91 \frac{1}{2}$ have double jaws which catch the animal high on leg and prevent gnawing off leg.

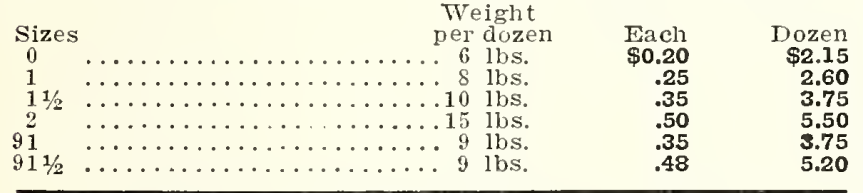

\section{Hold-Em Wire Rat and Mouse Traps}

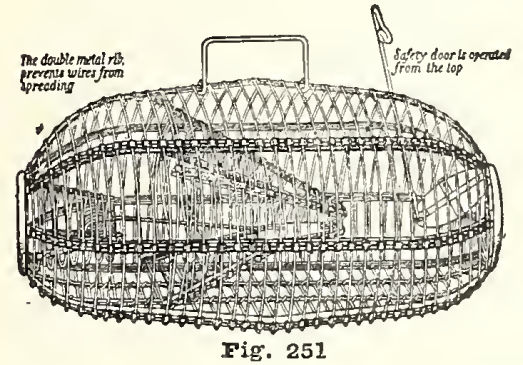

Made of $\mathrm{s}$ tee $\mathrm{l}$ wire. Has patent trigger attachment to catch the first rat, which is the hardest to get. The first one used as a decoy for others.

Rat Trans. Weight, 2 Ibs.................................... $\$ 1.00$ Mouse Traps. Weight, 1 lb............................

\section{KNOWS Grows}

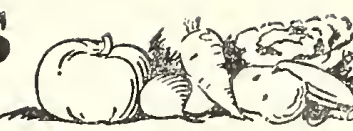

\section{Corn Hooks}

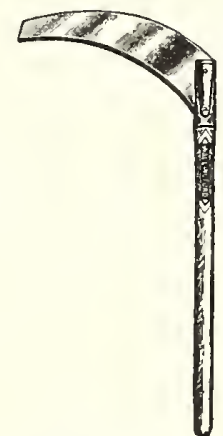

Fig. 253-A

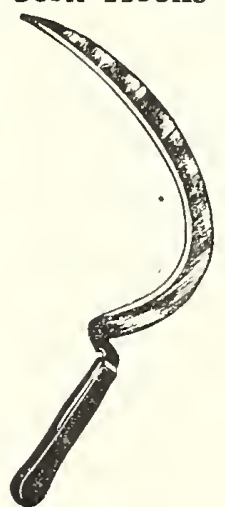

Fig. 254-C

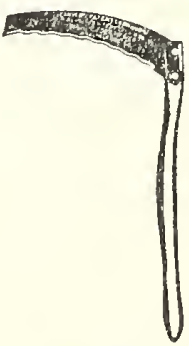

rig. 255-B
A. Vt. Corn Hooks, plain hantle, plain blade.... Price, $\$ 0.40$ B. Spring Steel Corn Hooks, curved handle...... Price,
C. Solid Steel with off-set blade............... Mailing weight cach 2 ibs.

\section{Simplicity Hedge Trimmer}

"Cutting More Sur-
face with More Cutface with More Cut-

The Simplicity Hedge Trimmer works so rapidly and easily that it makes frequent cuttings possible.

No experience is necessary to do a first class job with the simplicity. Anyone can operate it, everyone wants to operate it when they see it.

To get a thick, beautiful hedge, it is necessary to trim it often, at least every three weeks. When
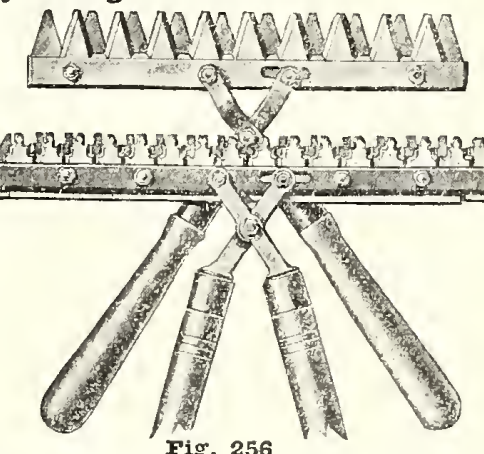

Fig. 25

chots sirou out immediately is freshly cut.

Thims every variety of hedge grown. Will trim a hedge to any shape and cut desired.

Make your hedge trimming a pleasure by oldering a Simplicity today.

1. Simplicity Hedge Trimmer, for fresh new growth only Simpos.

2. Simplicity Hedge Pruner and Trimmer, for pruning back old growth and trimming new. Price, \$6.00. Weight, 5 lbs.

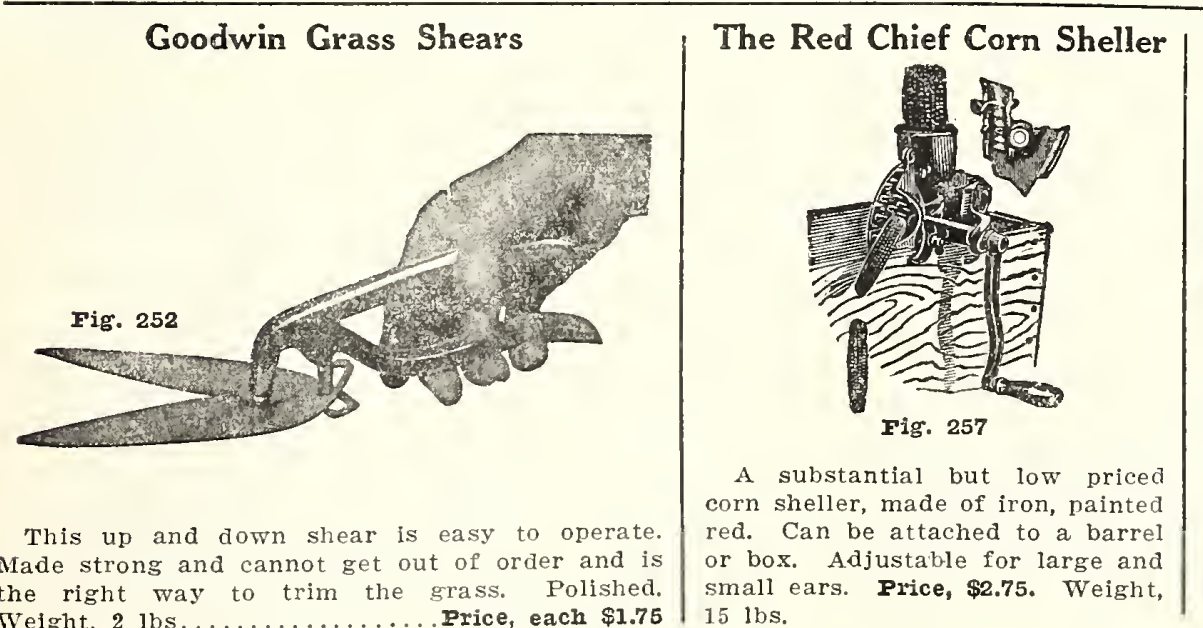

\section{Norcross Improved Hand} Garden Cultivator

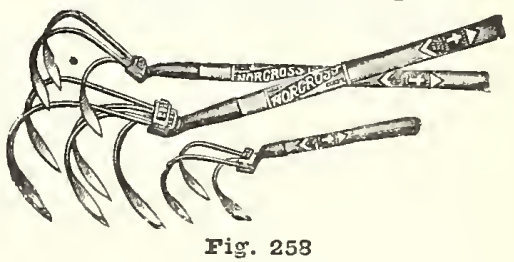

A very handy garden tool, 5 prongs, $\$ 1.00 ; 3$ prongs. 75 cts. Hand, 50 cts. Mailing weight, 3 lbs.

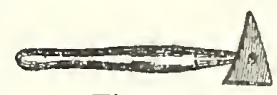

Fig. 259

STEET BLADE TREE SCRAPER 75 cts. each. 2 lbs. 


\section{Ross' Seed Grows}

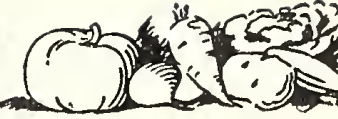

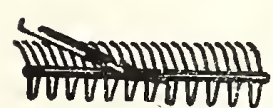

A

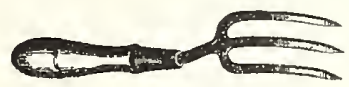

c

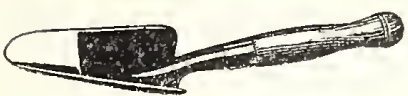

D
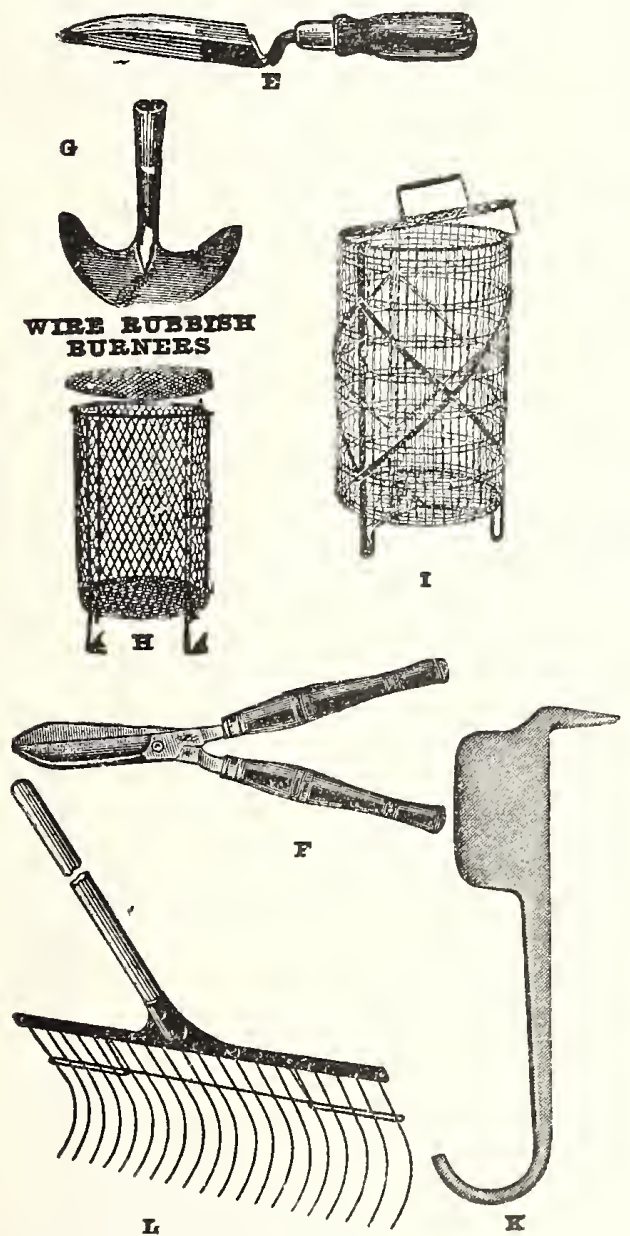

T.

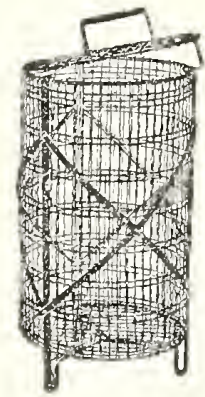

$\mathbf{I}$

I.
A. Qu $\mathbf{Q}$ on Reversible Wire Lawn Rake with hand 1 e. A strong substantial lawn rake for all purposes. Price...\$0.90 Malling weight 4 lbs.

B. Diamond Weeder.

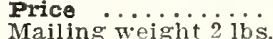

c. No. 3 Garden Fork $\mathrm{M}$ a iling weight 2 lbs.............. 45

D. Long Handled Steel Garden Trowel. Malling weight 2 lbs..

B. Short Handled Steel Garden Trowel. Malling welght 2 lbs. No. 211 .................. 75

F. Hedge Shears. Malling welght 4 lbs. ...................25 With notch for lieavy work...... $\mathbf{2 . 5 0}$

G. Turf Edger for lining walks, etc. Mailing weight 5 lbs......... 1.20

H. Wire Rubbish Burners.

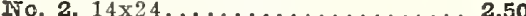

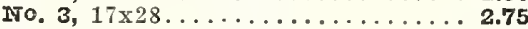

I. No. 4, 18x34, extra heavy....... 9.30

J. Peerless Fruit $P$ i cker. Mailing weight 2 lbs............... 50

F. Steel Grafting Chisel Mailing weight 1 lb............... 1.00

I. Hoover Lawn Rake. Made from flexible steel spring wire. Mailing weight 5 lbs............ 1.00

m. Solid Steel Garden Trowel with offset shank. Mailing weight 2 ibs. ...................... 90

N. Sunnyside Hoe. The best strawberry hoe. Mailing weight 4 lbs. 1.00

o. 6-in. Cheap Trowel. Mailing weight 2 lbs. No. $213 \ldots \ldots \ldots . .18$

P. No. S8 12-in. Grass Shear, bevel steel blades, mailing weight 2

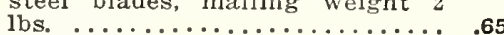

Q. Cast Dibble ................75 With wood nandle. Mailing weight

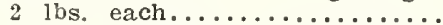

R. Weeding Hook, 3 tine. No. E. Mailing weight 2 lbs..........

S. Cotton Gloves for Garden Work. Per pair, postpaid............

T. Bouquet Holder, Iron. Mailing weight 3 lbs............ \$0.65; Tin, painted green. Miailing weight

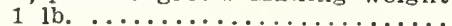
Glass, with holder. Mailing weight

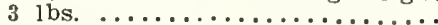

U. Asparagus Knife. Mailing weight $31 \mathrm{bs} . \ldots \ldots \ldots \ldots \ldots \ldots \ldots \ldots . . . \ldots$

v. Garden Peel.

$200 \mathrm{ft}$ capacity. Mailing weight

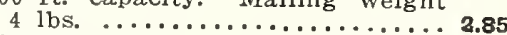
300 ft. capacity. Maijing weight 5 lbs. 3.85 Garden Line, 96 ft. Mailing weight

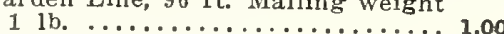

w. Arlington Slide Hoe

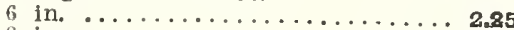

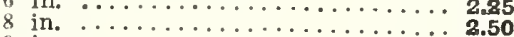

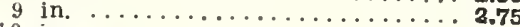

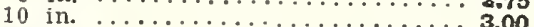
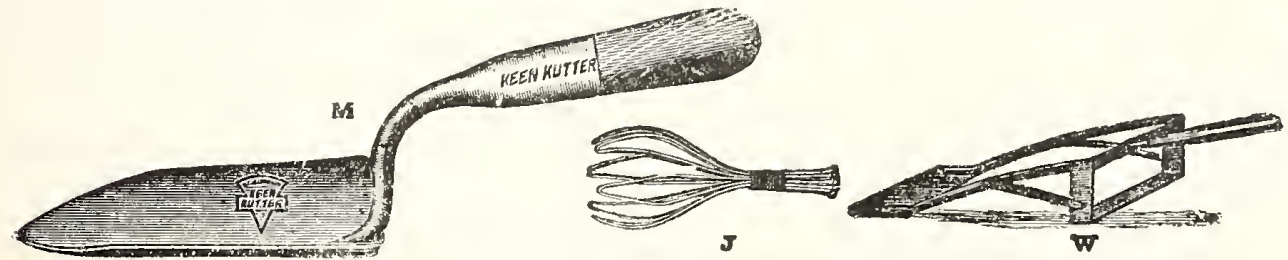

See Inside front cover of catalogue for Parcel Post rates.
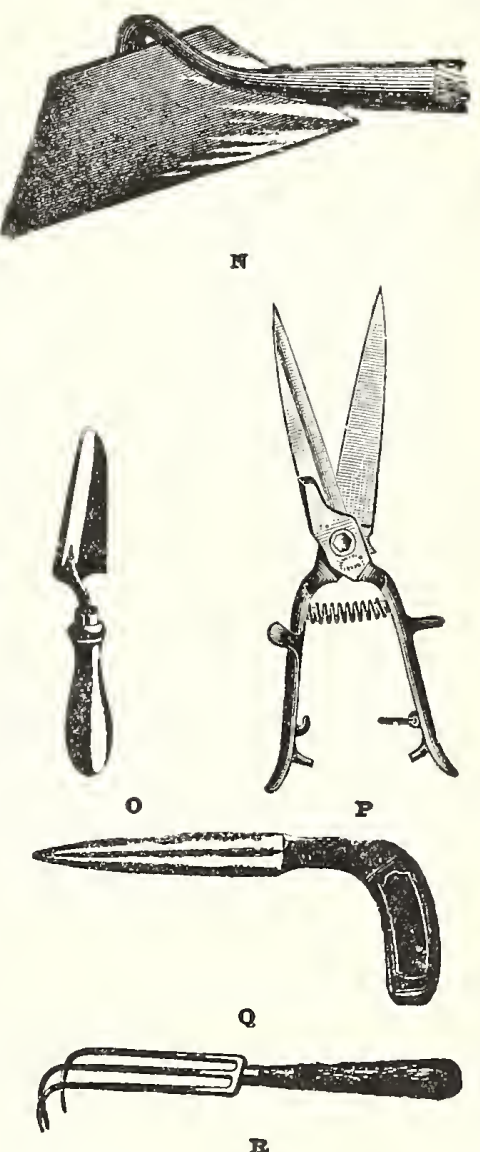

I
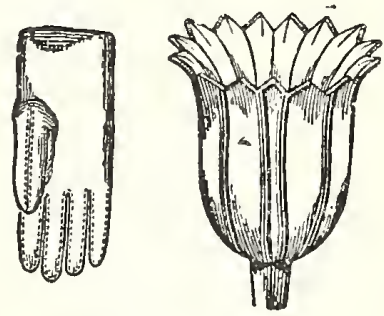

$\mathbf{s}$
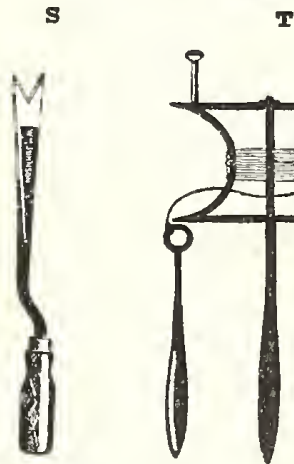

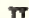

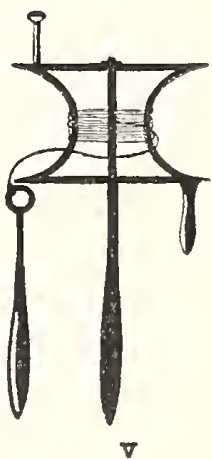



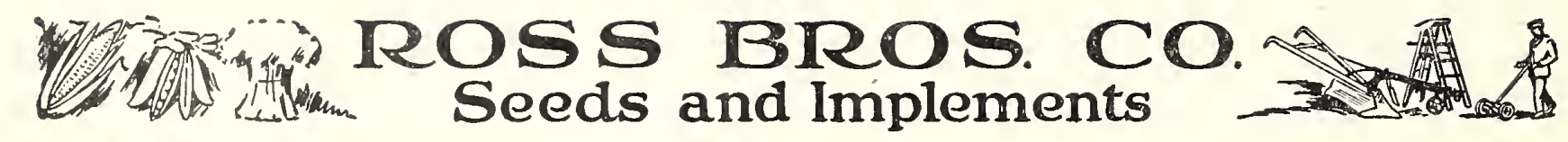

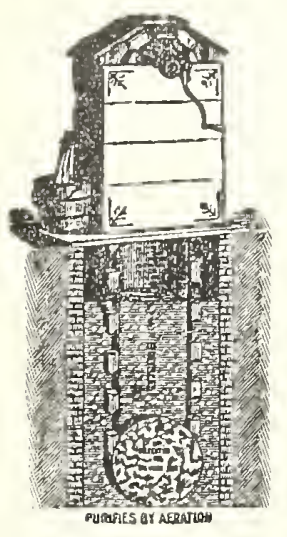

The Bucket Pump

We will guarantee it to purify any well in five days, or we will refund the money. Cannot freeze. Can be set up without going below platform. Frice for 10-ft. well $\$ 12.50$, for each additional foot of well add 50 cts.

Fig. 260

\section{Round End Stock Watering and Storage Tanks}

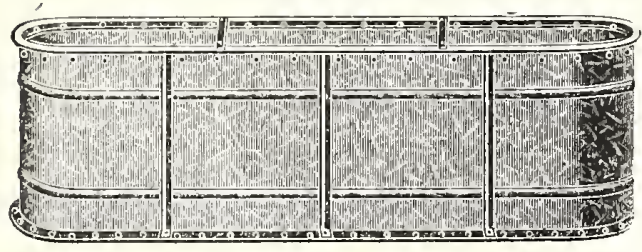

rig. 263

Well braced. These prices f. o. b. Worcester or delivered by freight to your nearest station from the factory.

\begin{tabular}{lcccccr} 
& Wd., & Hgt., & Lgt., & Cap., & Wt., & \\
101 & ft. & ft. & ft. & bbls. & lbs. & Price \\
102 & 2 & 2 & 4 & 3 & 65 & $\$ 9.00$ \\
103 & 2 & 2 & 5 & $33 / 4$ & 75 & $\mathbf{1 1 . 0 0}$ \\
104 & 2 & 2 & 6 & $41 / 2$ & 90 & $\mathbf{1 2 . 5 0}$ \\
105 & 2 & 2 & 7 & $51 / 2$ & 105 & $\mathbf{1 4 . 0 0}$ \\
$108 \mathrm{~b}$ & $21 / 2$ & 2 & 6 & $63 / 1$ & 120 & $\mathbf{1 5 . 0 0}$ \\
& & & & $53 / 4$ & 110 & $\mathbf{1 3 . 5 0}$ \\
\hline
\end{tabular}

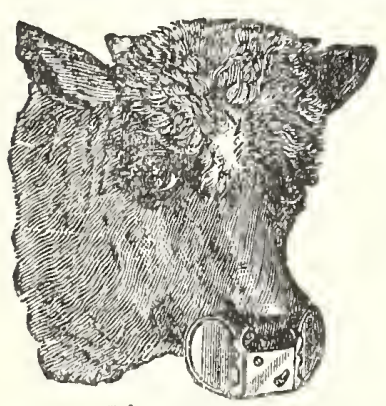

Frig. 269
The Rice Calf Weaner

Does not hinder the animal from eating or d r inking. Endorsed by all users. Works like a charm. Three sizes. S m a ll, price each. Med., price each, 75 cts.

Large, price each, Wt. each, 1 Ib.

Asparagus Buncher Price, $\$ 4.50$

Mailing weight, 5 lbs. Fig. 268
$50 \mathrm{cts}$.

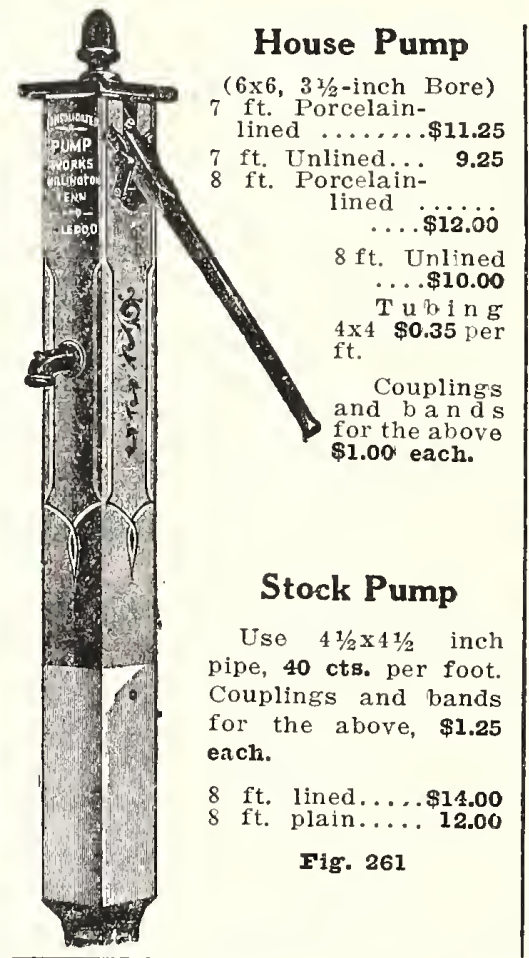

Rubber Bucket Chain Pump

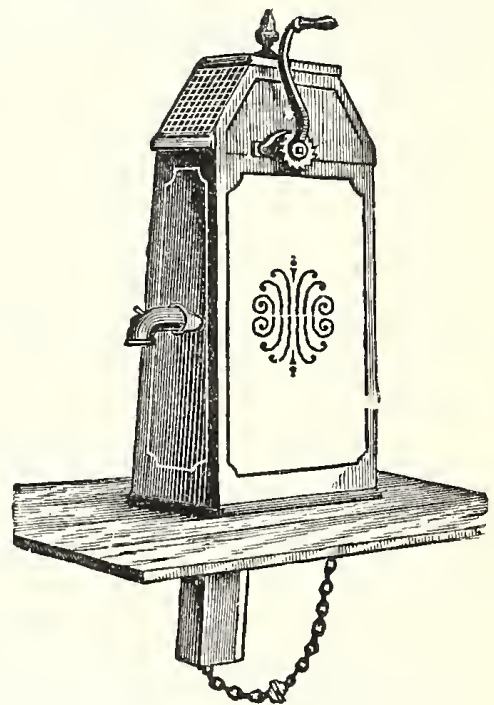

Fig. 262

They are the best cheap pumps. Price, Curbs, $\$ 6.00$ each. Chain (3 ft. to 1b.) 15 cts. per 1b.

Wood tubing, 20 cts. per foot. Rubber Buckets, 15 cts. each.

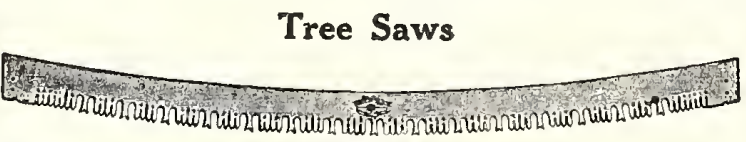

\section{Fig. 264}

Simonds Hollow Back Pattern, 5 ft., \$3.25; 51/2 ft., \$3.55; 6 ft., \$1.10.

Same as above, only two gauges thinner on back. 5 ft., $\$ 3.65 ; 51 / 2 \mathrm{ft}$ $\$ 4.00 ; 6 \mathrm{ft.9} \$ 4.40$.

Common V-Tooth, $5 \mathrm{ft}$., \$2.20; $51 / 2 \mathrm{ft}$., \$2.40; $6 \mathrm{ft} ., \$ 2.60$.

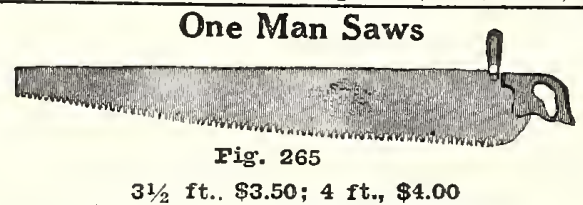

\section{Saw Bucks}

Extra grade saw buck. Made from heavy maple stock, folding. Can be closed and put away in a small space. Lach 75 cts.

\section{Saw Handles}

Triumph patterm. Clamps on end of saw with thumb nut. Per pair, 50 cts.

Loop pattern, loop nade of welded steel. Per pair, 65 cts.

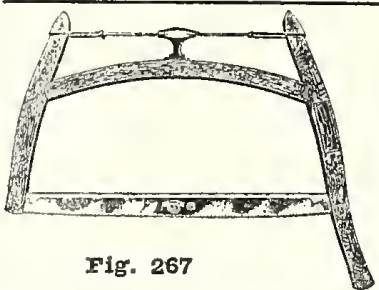

\section{Wood Saws}

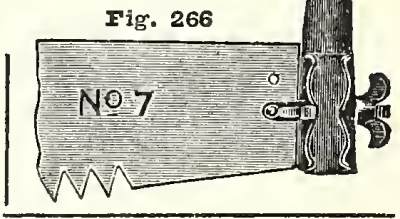

No. 104. Double braced frame. Natural wood $2 \frac{3}{8}$ in. blade. $\$ 1.60$.

2ro. 106. Red frame, 2 in. blade. \$1.25.

All prices in this catalogue are subject to change without notice. 
Garden Wheelbarrow

8 SPOKE WOOD WHEEI

These Wheelbarrows are made specially for us, are well constructed throughout, of hard wood and s t r o n g l y ironed. Finished with two coats of paint and one coat of varnish. This is the best garden barrow on the market.

Price, \$7.00.

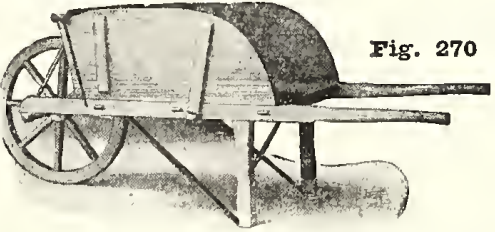

\section{Tubular Steel} Barrow

Tubular steel barrow, with pressed steel bowl, and steel frame; double braced and $m$ ade for heavy work. 3 cu. ft. Price, $\$ 8.50$ each.

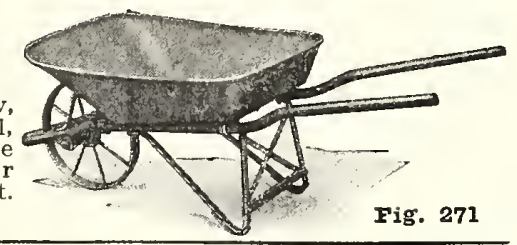

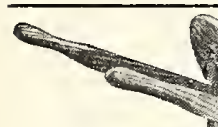

Fig. 272

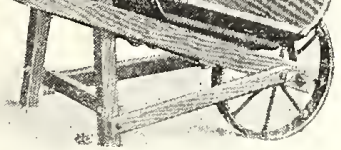

\section{Wood Dump Barrow} most durable, d u m p barrow on the marliet. Price, Steel Wheel, $\$ 4.95$ each.
Without doubt the

\section{Contractor's Angle Leg Barrow}

The very best allround contractor's barrow made. Tray pressed from one solid piece, $29 \times 36$ at top. Frame of hardwood and thoroughly braced and bolted. 16 in. steel wheel; t i r e, $13 / 4 x_{16}^{5}$ $5 \%$ in. axle. Heavy rod rolled in edge. $\mathrm{Wt} .825$ lbs. Per doz. Each $\$ 7.75$.
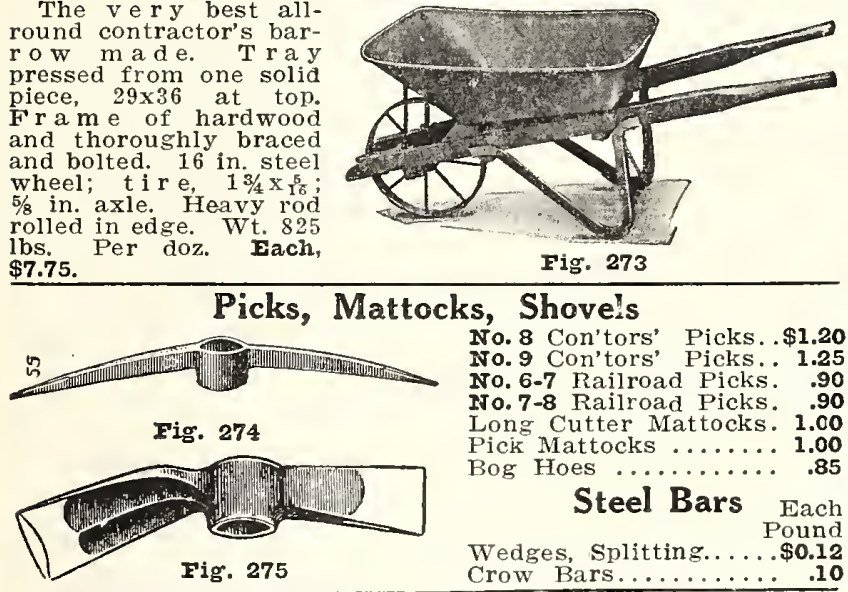

Our Best Shovels

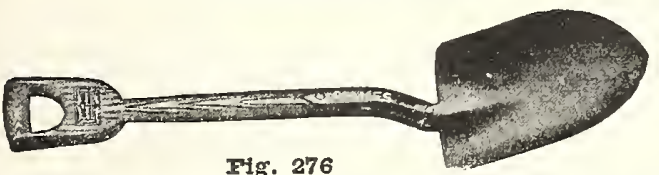

Fig. 276

No. 8 Con'tors' Picks. $\$ 1.20$ No. 9 Con'tors' Picks.. 1.25 No. 6-7 Railroad Picks. .90 No.7-8 Railroad Picks. .90 Long Cutter Mattocks 1.00 Bog Hoes .......... Steel Bars Each Wedges Splitting... Pound Crow Bars.......... .10

,

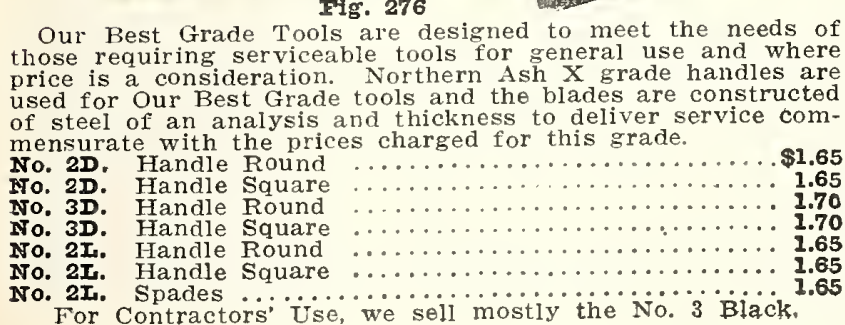

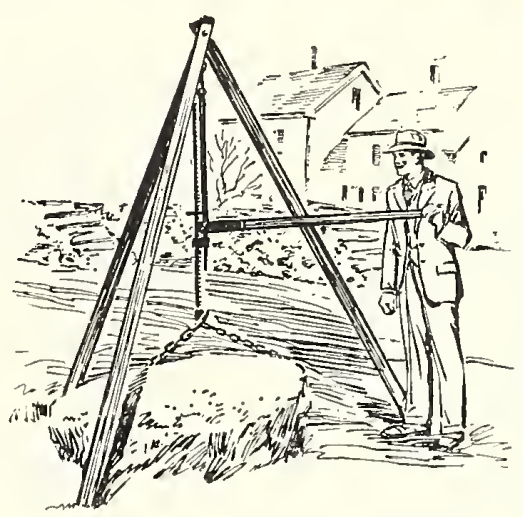

\section{Eureka Stump Puller and Rock Lifter}

This is by far the simplest and $\mathrm{most}$ efficient device on the market for pulling stumps, lifting stones bodies, and will be found $\mathrm{very}$ useful. No. 2, weight 26 lbs., capacity 6 tons, $\$ 22.00$. No. 3 , weight 32 1bs.,
capacity 8 tons, $\$ 24.00$. This price includes
the metal part only. Fig. 277
Th e lilustration below shows a simple device whereby a stone-boat can be made in a few minutes by using a straight plank with the addition of the Iron Head. Anyone in need of a stoneboat will readily see how easy it is done, will last for years, it is not only cheap. but durable.

Cast Iron-Frice, \$6.50; Bolts, 85 cts. per set. SteelPrice, 34 in., $\$ 5.50 ; 40$ in., $\$ 6.25$.
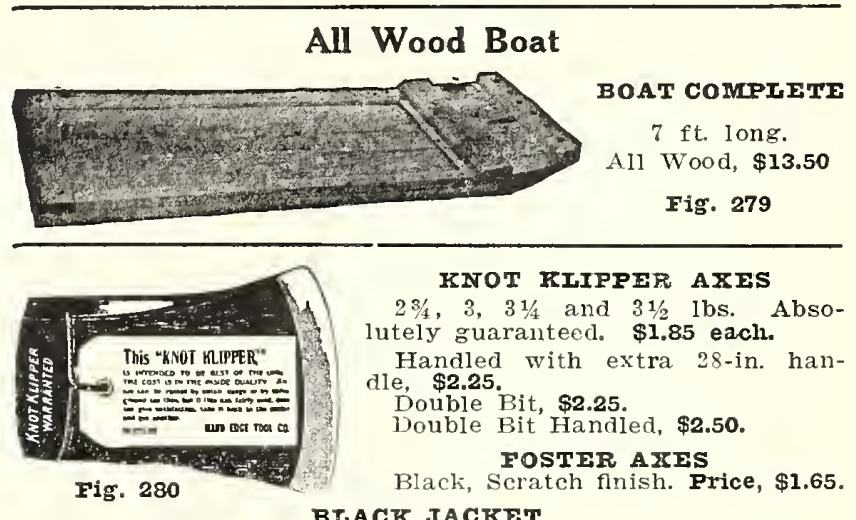

KNOT KIIPPER AXES

$2 \frac{3}{4}, 3,3 \frac{1}{4}$ and $3 \frac{1}{2}$ lbs. Absolutely guaranteed. $\$ 1.85$ each.

Handled with extra 28-in. handie, $\$ 2.25$

Double Bit, \$2.25.

Double Bit Handied, $\$ 2.50$.

FOSTER AKrS

Black, Scratch finish. Price, \$1.65.

BACK JACKET

ROYS FAIDEED AXES

26-in. Price, $\$ 1.50$.

HOUSE AXES

Price, $\$ 1.25$

\section{Steel Scraper} with Runners

No. 1 carries $7 \mathrm{ft}$. of earth....\$11.75

No. 2 carries $5 \mathrm{ft}$. of earth....\$11.50

No. 3 ....\$11.00

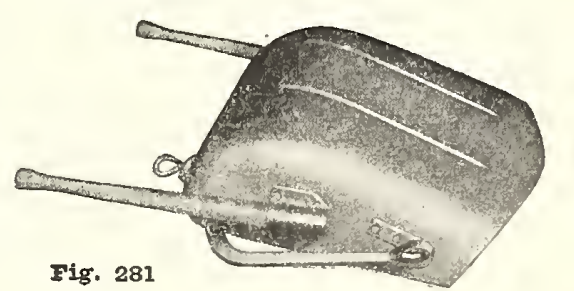




\section{ROSS BROS. CO.}

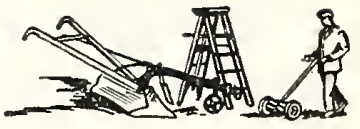

Burlap Hotbed Mats

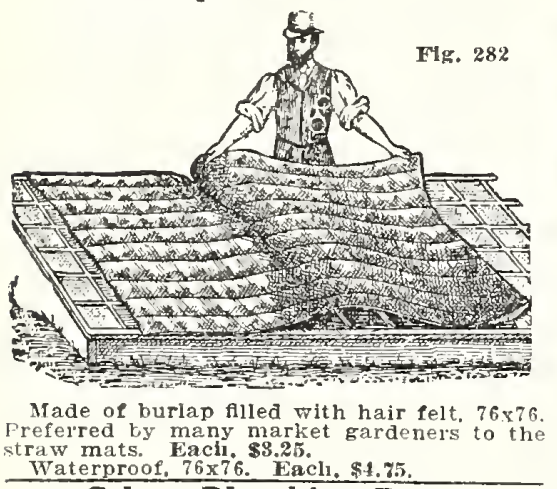

Waterproof, $76 \times 76$. Eacl. \$4.75.

\section{Celery Bleaching Paper}

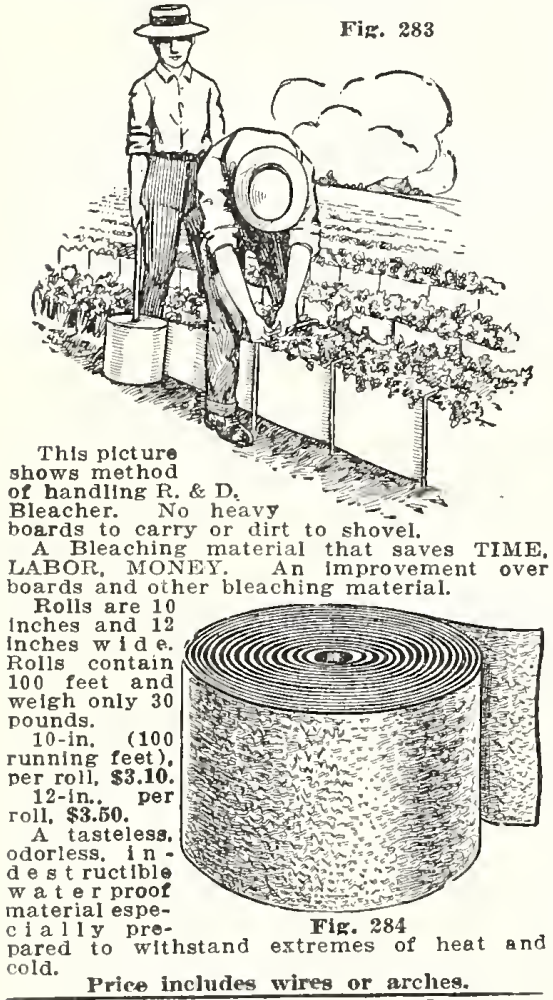

Richmond Plant Tubs

Palnted green, rd. wire hoops

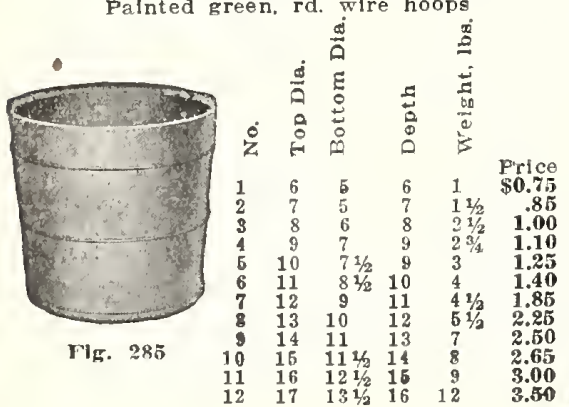

A. B. C. Plant Protector

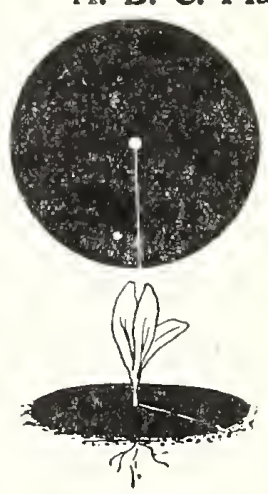

Fig. 286
This illustration

shows the A. B. C.

Tar red Felt Pad

used to protect Cab-

bage. Tomato a n d ot he $r$ plants from cut-worins, maggots, and insects that will destroy plants. Easy to apply. They lie un the top of the ground and can be used elther for outdoor or greenhouse use. Excellent 1 or protecting carnations from cut-worms. Es. pecially adapted for Cabbage and Tomato outside. They will save practically the entlre crop of Cabbage if used at the time plants are set. The cut-worms and like the used and oreat care is taken to accurately used and to deposit the ego, which does the damage. Pacted 1.000 in good strong fibre box. Price, 1,000 . mailing wt., $10 \mathrm{lbs} . . . . . . \$ 2.50$ 25,000 lots..............\$2.25 per 1.000 Plant Trellises Postage, extra. 10c

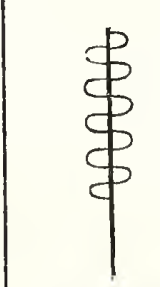

Tig. 287 20-in. stick. $31 / 2$ - in. wlde. Erach. Wo.

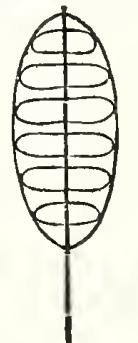

Fig. 288 24-in. stick. $7 / / 2$ - in. wide.

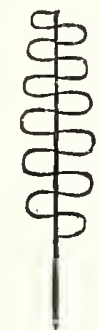
24 -in. stick.
5 -inch wlde.

\section{Plant Sticks}

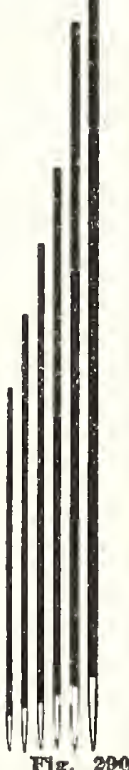

For not or garden $u$ e: square. wainted green.

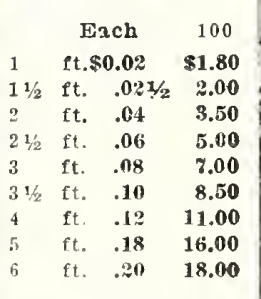

\section{VTRANDA}

High Widtl Each

$3 \mathrm{ft}$

$\begin{array}{ll}3 \mathrm{ft} . & \mathbf{1 . 2 5} \\ 4 \mathrm{ft} & \mathbf{1 . 7 5}\end{array}$

$5 \mathrm{ft} \quad 18 \mathrm{in}: \quad 2.25$

6 ft. 18 in. 2.75

$10 \mathrm{ft} .20 \mathrm{in.} \mathbf{4 . 7 5}$

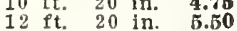

HAMBOO STAERS

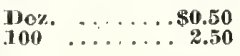

Fig. 280

\section{"Peerless" Glazing Points}

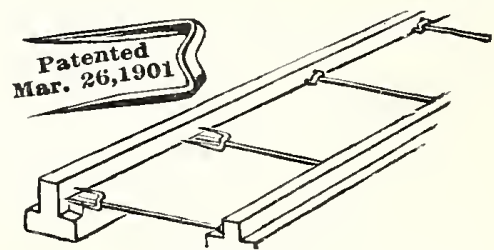

FIg. 292

PEERLESS GLAZING POINTS. Improved Van Reyper. Weicht per box o lbs Per box, 1,000 points..............\$0.90

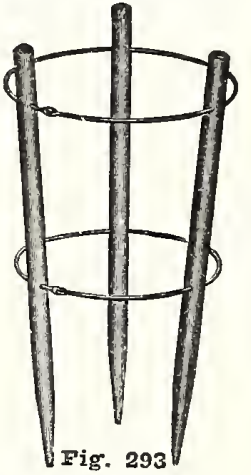

\section{Tomato}

Supports

34 in. high, 20 in. in diameter at the top.

Price, 350 each, $\$ 4.00$ per doz.
Fiz. 289
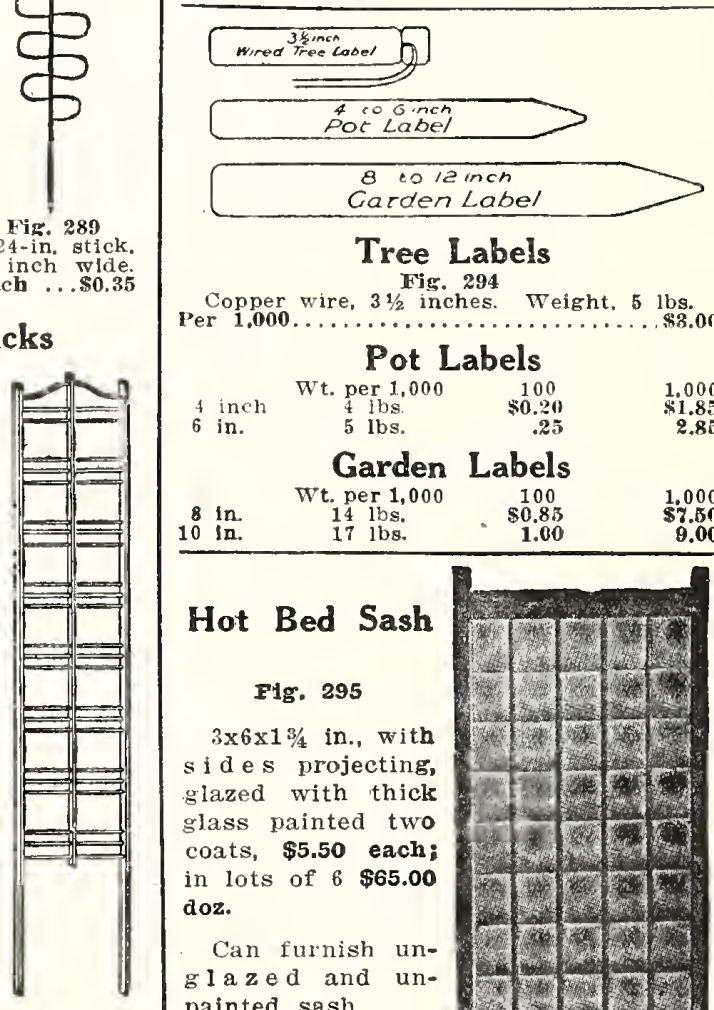

Tree Labels Fig. 294

Copper wire, $31 / 2$ inches. Weight, 5 lbs. Per $1.000 \ldots \ldots \ldots \ldots \ldots \ldots \ldots \ldots \ldots \ldots . . \$ 3.00$

\section{Pot Labels} $\begin{array}{cccc} & \text { Wt. per 1,000 } & 100 & \mathbf{1 0 0 0} \\ 4 \text { inch } & 4 \text { ibs. } & \$ 0.20 & \$ 1.85 \\ 6 \text { in. } & 5 \text { lbs. } & . \mathbf{2 5} & \mathbf{2 . 8 5}\end{array}$

Garden Labels

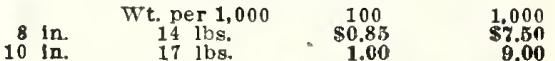

\begin{tabular}{llll}
$10 \mathrm{in.}$ & $17 \mathrm{lbs}$. & $\mathbf{1 . 0 0}$ & $\mathbf{9 . 0 0}$ \\
\hline
\end{tabular}

\section{Hot Bed Sash}

Fig. 295

$3 \times 6 \times 13 / 4$ in., with sides projecting. glazed with thick glass painted two coats, $\$ 5.50$ each in lots of $6 \$ 65.00$ doz.

Can furnish ungI $z$ ed and unpainted sash.

Straw hot bed mats (not shown) FIg. 291

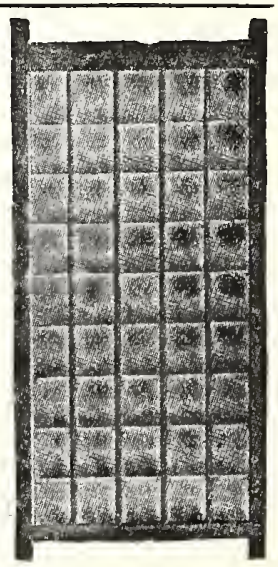



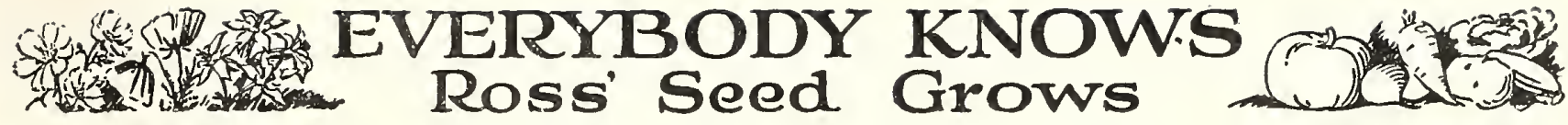

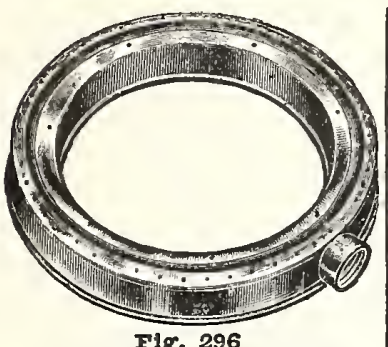

The Ring Lawn Sprinkler

Our "Ring" Lawn Sprlnkler is made entirely of sheet brass and stamped into the form shown. in Measures about 8 throws a fine mist: covers a large circle and can be convenlently moved about without shutting off tre water. not be erced apart. even under the heaviest pressu

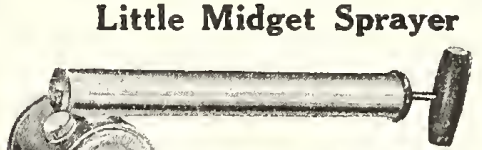

Fig. 298

This is a small sized powerful atomizer for use in the home or poultry louse Very convenient for applying dust layers or disinfectants. Weight, 3 lbs. 35 cts. each.

\section{The Acme Atomizer}

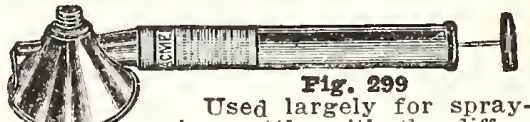
ent mixtures on the market, to keep off the flies; spraying Paris Green and other insecticides in potato vines, shrubs small trees, house plants, livestock and poultry. Price, tin, 60 cts. with brass cup, \$1.00. Weight, 3 lbs.

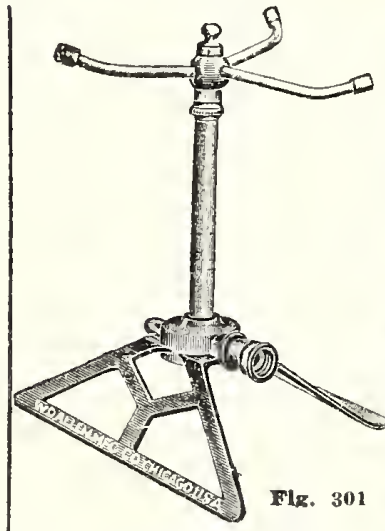

CYCLONE I IT SPRINKLER

Twelve inches high, made in fine workmanship m a n e r

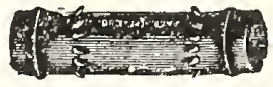

FIr. 302

COOPER H OS A MEN DER. (All brass.) 1/2-ln. and $a / t$ in. 10 cts. each: 90 cts. doz. Postpaid.

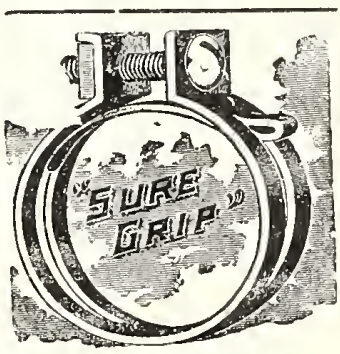

Fig. 303

SURE GRIP HOSE BAND, $1 / 2-1$. and $3 / 4-i n$.. cts.

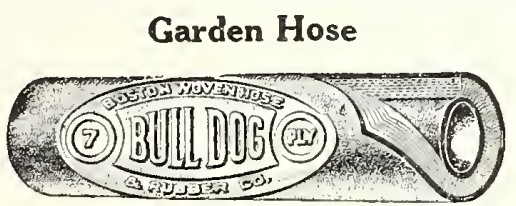

FYg. 297

BULL-DOG HOSE (pletured above). For the very best hose that it is possible to buy, we recommend the Bull I Woven Hose \& Rubber Co. A T-ply hose unconaltionally guaranteed by the manufacturers. Is made of the best quality of materials, which makes it ast.

TIGER HOSE-6-ply, and for general purposes a verv fine tiece of goods.

LEADER HOSE-5-ply.

MIIO CORIUGATED

VIGILANT MOLDED.

SPRAY HOSE-The Bull Dog Spray Hose is made equally as well as the Bull Dog Garden Hose, bullt up to stand pressure up to 300 lbs. to the square inch. The inner core is made of specially prepared rubber to take care of the aclds used in spraying. such as Scalecide. Lime of Sulphur, Arsenates, etc. Per ft. 28 c

TIGER SPRAY IIOSE Where hand power is used Price, per foot, $0 \mathrm{c}$.

Both of these spray hose come in $1 / 2-1 n$ ch slze. not coupled. In using with power it ls quite necessary to have longer tall couplings, whlch are supslied extra at $\$ 1.25$ per coupling.

\begin{tabular}{|c|c|c|c|c|c|c|c|c|}
\hline & & Wt. & $1 \mathrm{bs}$. & er 2 & ft.: & Pric & cts., & per $f$ \\
\hline $\begin{array}{c}\text { Bran } \\
\text { Bulla }\end{array}$ & & $1 / 2 "$ & $5 \% "$ & $8 / 4$ & $\begin{array}{r}\text { Ply } \\
7\end{array}$ & $1 / 2 "$ & $181 / 2$ & \\
\hline Tlge & & $\ddot{6}$ & 10 & $\dot{9}$ & 6 & $\mathbf{i} \dot{z}$ & & \\
\hline Good & & 6 & & 9 & & 10 & $131 / 2$ & \\
\hline $\begin{array}{l}\text { Leader } \\
\text { Mllo. }\end{array}$ & & & 10 & & 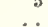 & & ii & \\
\hline Vlgllant & & & & 10 & & 12 & & \\
\hline
\end{tabular}

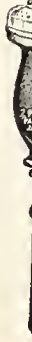

\section{2-Purpose Rain King Nozzle}

The 2-Purpose $\mathbf{R}$ a In approved by home owners, park superintendents and landscape gardeners and does the work of both the ordinary hose nozzle and stationary garden spray. Mailing wt. 2 lbs. Price, \$2.00.

F'ls. 308
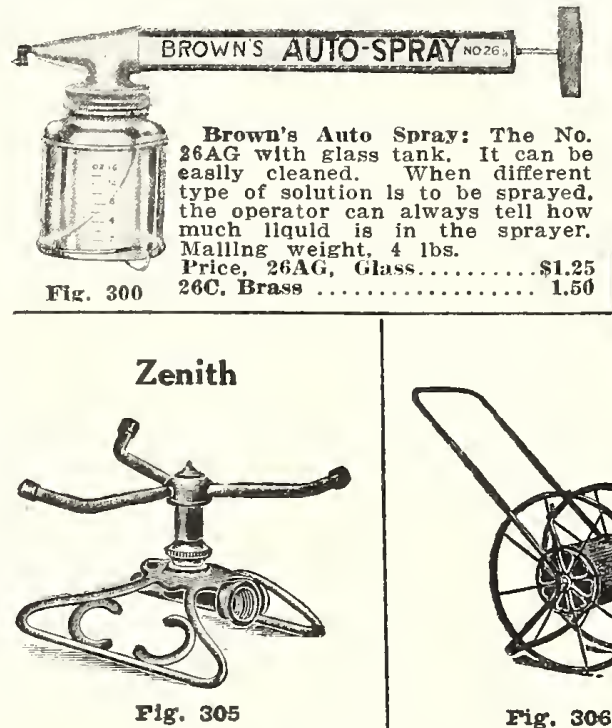

REVOIVING IAWN SPRINKIFR

$4 \frac{1}{2}$ in. high, low down, does not vibrate. Polished b $1^{\circ}$ as $\mathrm{s}$ a $\mathrm{rms}$ and head, japanned base. Weight, 3 lbs. Price, \$1.00.

\section{Rain King Hose Nozzle}

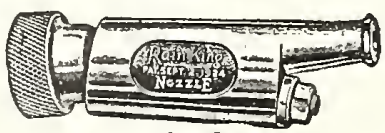

IIg. 309

This is the only hose nozzle without moving parts to wear, clog, or give trouble. The different sprays are obtained by a new and unique principle. Throws more water farther than any other hose nozzle made. Mailing welght 2 lbs Price each, $\$ 1.50$.

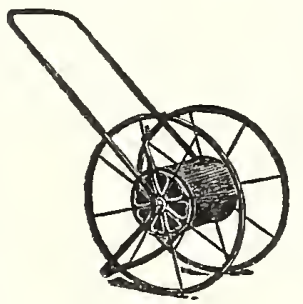

Fig. 306

TUBUIAR MITAT HOSE REFT

The most durable reel made. Holds 100 feet of hose

Frice, $\$ 3.00$

\section{Boston Spray Nozzle}

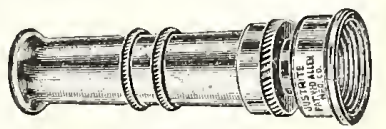

F'1g. 304

Will throw a spray, a large or a small solid stream. Prico. 75 cts. 80 cts. postpald.

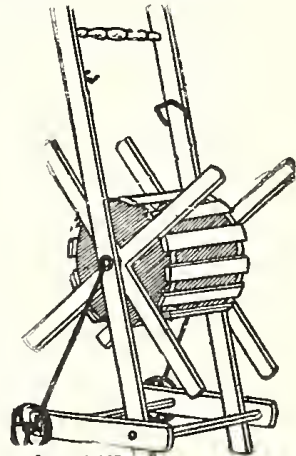

Fig. 307

handy and wellmade Hose Reel mounted on wheels. can be easily moved from one place to another. Hose should always be wound on a reel, as it prevents it from rotting. Price, $\$ 1.75$.

\section{Rain King Lawn Sprinkler}

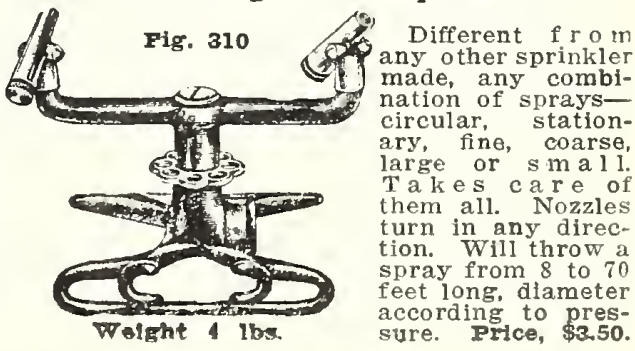




\section{ROSS BROS. CO.}

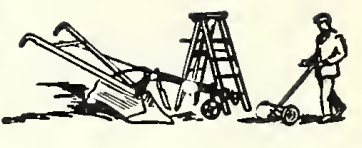

The Ideal Power Iawn Nower fills a long-felt want, for it works on an cntirely different principle from most power lawn mowers. The cutting cylinder operates entirely independent of the truck, as the mower is pushed the same as any hand mower and is as near fool-proof as any machinc can be. Other methods of operating have proven themselves a fallure. Experience has taught us that the obstructions which the mover will nick up on the lawn break under the old method where the cuting reel is driven direct. This cannot occur with the Ideal operated, as it is without any chain or gear connection with the mower.

Specifications-Width cut, 30 inches; diameter mower wheel, 11 inches; number of cutting blades, 5; weight, 610 pounds: diameter roller, 14 inches.

Price, \$385.00; extra cutting reel, \$63.00; riding attachment, $\$ 25.00$.
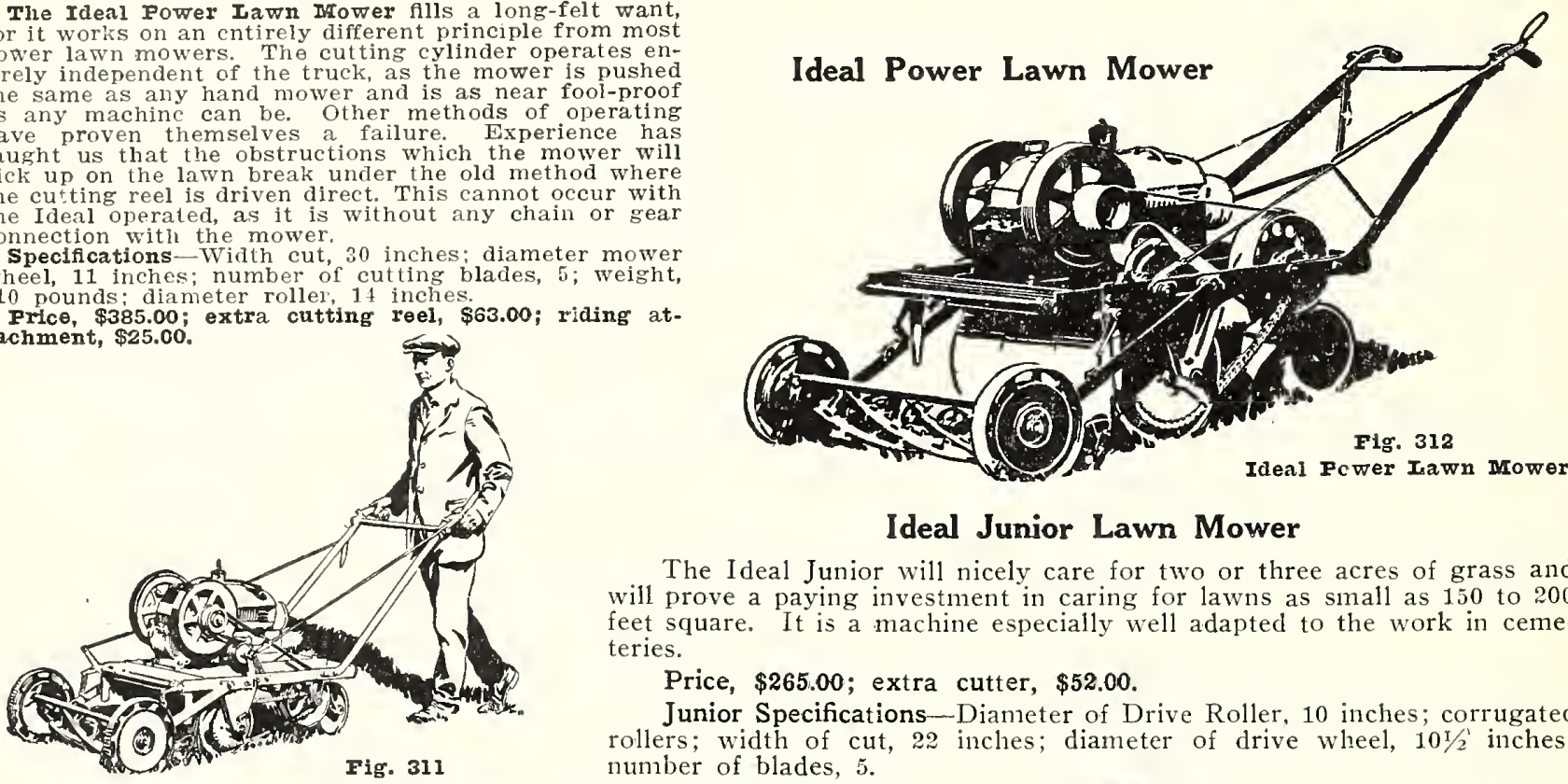

\section{Ideal Junior Lawn Mower}

The Ideal Junior will nicely care for two or three acres of grass and will prove a paying investment in caring for lawns as small as 150 to 200 feet square. It is a machine especially well adapted to the work in cemeteries.

Price, $\$ 265.00$; extra cutter, $\$ 52.00$.

Junior Specifications-Diameter of Drive Roller, 10 inches; corrugated rollers; width of cut, 22 inches; diameter of drive wheel, $10 \% \frac{1}{2}$ inches; number of blades, 5 .

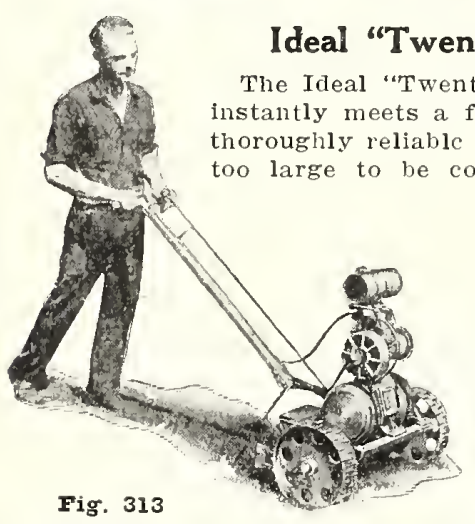

Ideal Horse-Drawn "Bull Dog" 3-Unit Mower

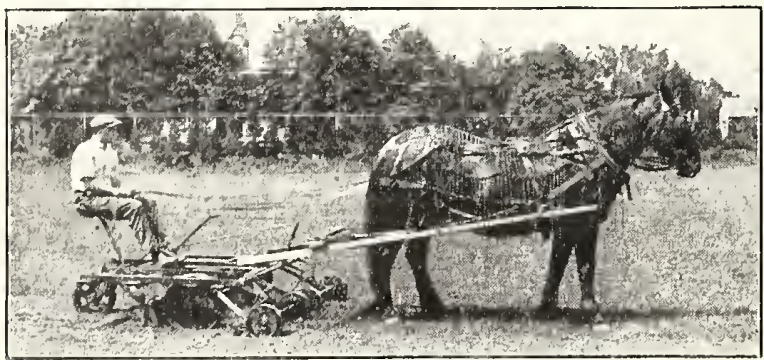

Fig. 315

This 3-Unit Mower cuts 84 inches and is the same highgrade mower as the Ideal Power Mower. We consider this the best horse-drawn lawn mower on the market today. Price complete with thilis, $\$ 420.00$.

Shipping weight, 1,365 pounds.

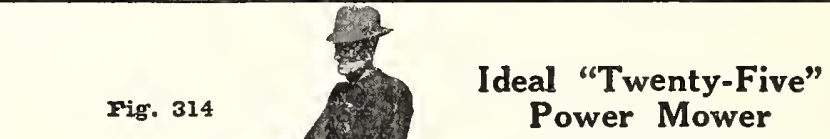

The I DEA L "TWENTY. FIVE" is a mower that will soon pay its cost on any large lawn, yet its greatest utility is in cemetery work and for use on lawns and parks where there are steep grades to climb. Being extremely simple in design, it is a mower that anyone can easily operate and care for. Very sturdy in construction, plenty of nower for the hardest work and built for years of service. Price ............\$290.00

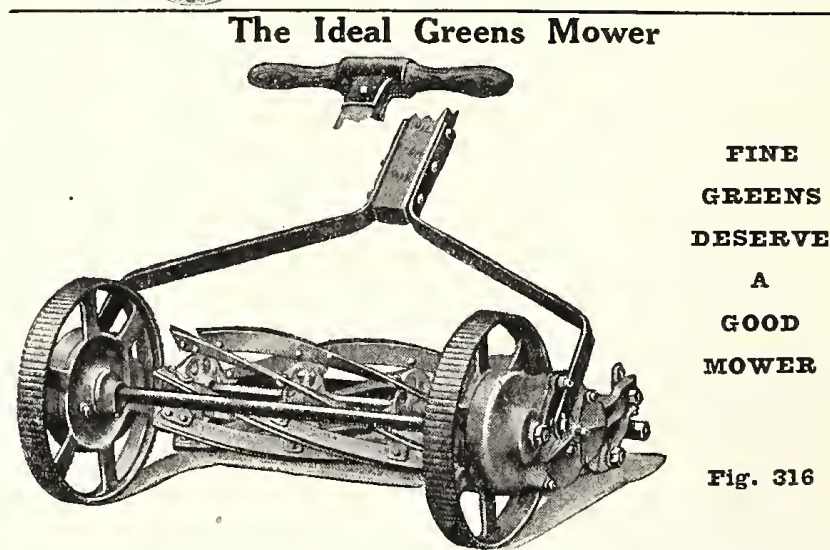

The Ideal Greens Mower was designed to meet the present day demand for a high-grade, close cutting, easy running mower for use on modern golf greens where accuracy and close work are the prime essentials.

Price, 18-inch Fand Putting Greens Mower, $\$ 38.00$.

Extra for metal Grass Catcher, $\$ 8.50$. 


\section{FVISTHODY KNOWS Ross' Seed Grows

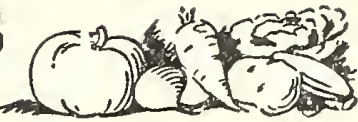 Hand Lawn Mowers}

The Knollwood Jr. Ball Bearing High-Wheel Spade-Handle Lawn Mower

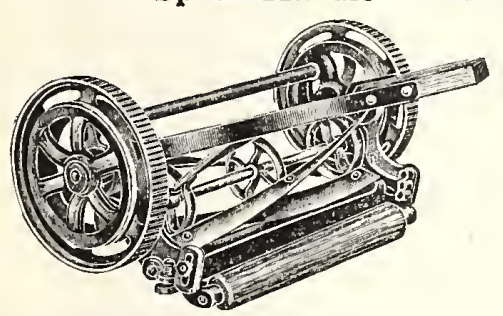

Fig. 317

We offer our customers this machine, not as an experiment but as a guaranteed article, one that we have tested ourselves during the past 10 years, and know what we are talking about. This machine runs on ball bearings (and all first-class machines ought to). The balls are of the very best quality and will last for years. They are enclosed in steel cups, which protect them from wear. The main axle is stee and lathe fitted and is adjusted as nice as any high-priced piece of machinery. The end of the axle where it comes in contact with the balls is cone-shaped, and any possible wear can be easily taken up. The machine has a nine-inch wheel, four knives of the best quality of steel and, last but not least, a handle that is made to fit your hands. See the spade handie (in cut). After giving you the best mower it is possible for us to get, we have put on it a handle we have been looking for. With this spade Handle the operator has perfect control over the machine and can handle it perfectly on a side hill or on narrow borders. We agree to take back any machine that is not satisfactory after a fair trial. This machine is the best one on the market for private homes: it is especially adapted for parks, cemeteries and large lawns. 14-inch, $\$ 12.50 ; 16-i n c h, \$ 13.15 ; 18-$ inch, $\$ 13.90 ; 20-i n c h, \$ 14.60$

\section{The Little Giant Lawn Mower}

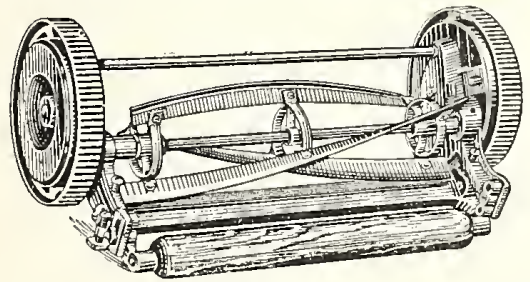

Fig. 318

For the benefit of those who want a low-priced mower or those who have but a small amount of grass to cut, we offer this machine, and we think we are safe when we state that it is as good as one-half of the mowers sold as high-grade machines and being a light-running mower, is preferred by many to the higher grade styles. We warrant every machine and have never had to replace one. 8 -inch wheels.

Net prices: 12 -inch, $\$ 6.75 ; 14$-inch, $\$ 7.15 ; 16-$ in $\mathrm{ch}, \$ 7.50$; 18-inch, \$8.c0.

\section{The Capitol Lawn Trimmer}

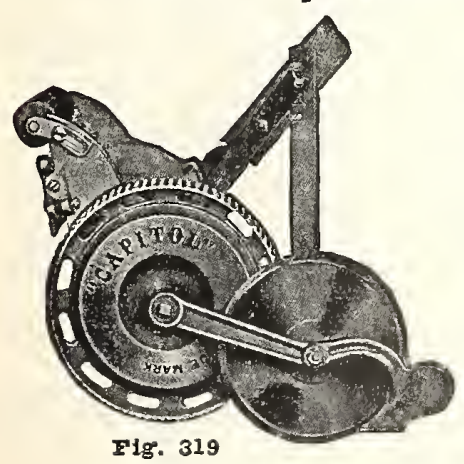

The Capitol Lawn Trimmer and Edger does what lawn mowers leave undone. It $t \mathrm{r}$ i m s and edges your lawn with remarkable s peed and perfection; th e shield over the blades protects the flowers. A trial will convince you, as it has thousands of others, that the day of shears, clippers, etc., is past. Four crucible steel blades, six inches in length, tempered in oil, swivel bushings, double adjustment.

Price: Plain, $\$ 10.00$ Complete with $\mathbf{E}$ ge $\mathrm{I}$, $\$ 11.00$.

\section{Knollwood Grand Lawn Mower}

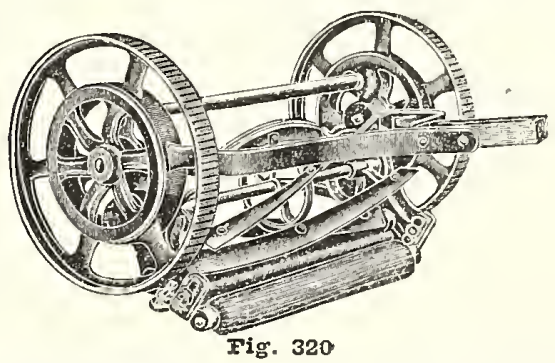

To our already complete line of lawn mowers we have added one additional, known as Knollwood Grand. This is an improved type of Knollwood Jr. which we have sold for the last 10 or 15 years. This mover has a 1 -inch higher wheel, or an 11-inch wheel, with extra blade. Where anybody wishes their lawn cut very close, we think this is a decided advantage. Every mower is guaranteed and should it prove otherwise we will refund your money or supply you with another machine. We will make the customer absolutely satisfled. This guarantee is given not only by ourselves but by the manufacturers

Price: 16-inch, $\$ 15.00 ; 18-i n c h, \$ 16.50 ; 20-i n c h, \$ 18.00$.

\section{Rossmoyne Lawn Mower, Nine-Inch Wheels}

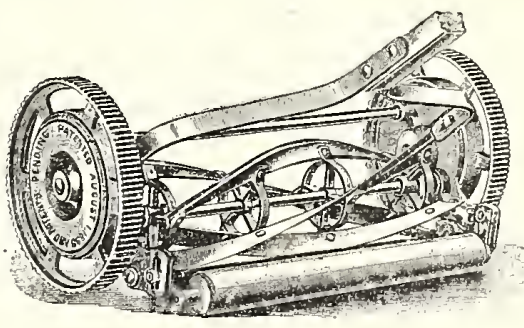

Fig. 321

This machine has four knives, high wheels. It runs on ball bearings of the same quality as those used on other machines. It is a first-class, medium-priced mower AIl parts are fitted on a lathe, and we warrant every machine we sell. For a medium-priced machine, you will make no mistake in buying this one $\$ 13.00$.

14-Inch, \$11.10; 16-inch, \$11.75; 18-inch, \$12.25; 20-inch,

\section{Easy Emptying Grass Catcher}

Galvanized s heet steel bottom, heavy weight duck sides. The sides are firmly fastened to the bottom by three folds of steel. This protects against any possibility of the canvas ripping along the bottom edge. The last fold in the metal stands upright, and holds the bottom rigid.

Finished with convenlent well-balanced, Easy Emptying Handle. Projections on the bottom prevent grass from slipping forward while mowing.

Price:

10G. For size mower

12-18 in. ........ \$1.75

12G. For size mower 2.00

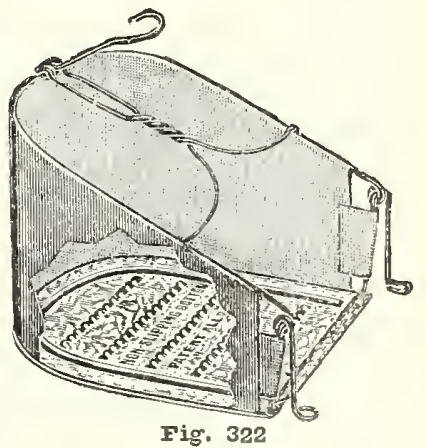




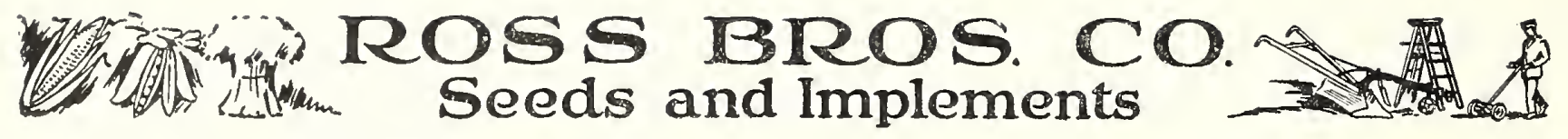

List of Standard Pots, Pans and Saucers

Inside measurement. width and depth equal

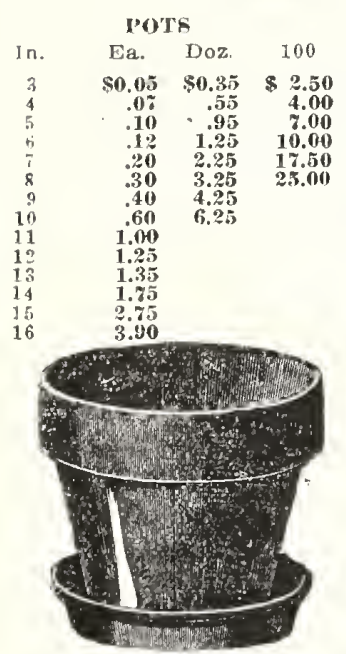

F18. 323
SACCERS BOTH

\begin{tabular}{rrrrr} 
Ea. & Doz. & \multicolumn{1}{c}{100} & \multicolumn{1}{c}{ Ea. } & \multicolumn{1}{c}{ Doz. } \\
$\$ 0.05$ & $\$ 0.30$ & $\$ 2.35$ & $\$ 0.08$ & $\$ 0.60$ \\
.05 & .35 & 2.95 & .10 & .80 \\
.05 & .50 & $\mathbf{3 . 9 0}$ & .13 & $\mathbf{1 . 2 5}$ \\
.07 & .70 & $\mathbf{5 . 8 5}$ & .17 & $\mathbf{1 . 7 5}$ \\
.10 & .95 & $\mathbf{7 . 8 0}$ & .25 & 2.75 \\
.12 & $\mathbf{1 . 7 5}$ & $\mathbf{1 0 . 7 2}$ & .37 & $\mathbf{4 . 0 0}$ \\
.18 & 1.80 & & .52 & $\mathbf{5 . 5 0}$ \\
.20 & $\mathbf{2 . 2 5}$ & & .75 & $\mathbf{7 . 5 0}$ \\
.25 & & & $\mathbf{1 . 1 5}$ & \\
.28 & & & $\mathbf{1 . 3 5}$ & \\
.35 & & & $\mathbf{1 . 5 5}$ & \\
.45 & & & $\mathbf{2 . 0 0}$ & \\
.55 & & & $\mathbf{2 . 8 5}$ & \\
.75 & & & $\mathbf{4 . 2 0}$ &
\end{tabular}

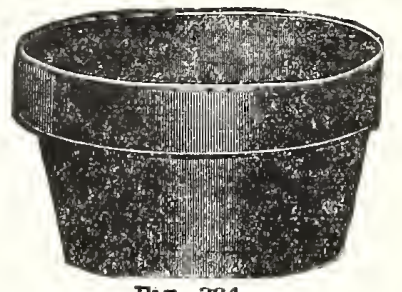

Fig. 324

BUIB PANS

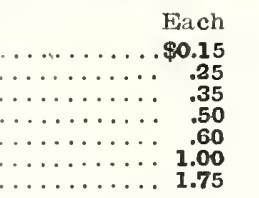

Doz.

$\$ 1.50$

2.25

3.50

5.00

6.00

10 inch

14 inch

FERN PAIS

\begin{tabular}{|c|c|c|c|}
\hline & Each & Doz. & 100 \\
\hline $\begin{array}{l}4 " \times 178 " \\
43 / 4 " \times 21 / 8 " \\
51 / 2 " \times 21 / 4 " \\
61 / 4 " \times 21 / 2 " \\
8^{\prime \prime} \times 2 \% 8 " \\
8 " \times 31 / 8 " \\
9 " \times 31 / 4 "\end{array}$ & 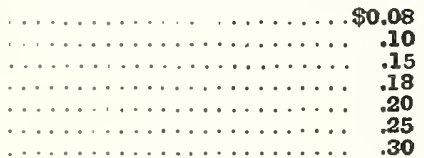 & $\begin{array}{r}\$ 0.80 \\
1.00 \\
1.50 \\
1.75 \\
2.25 \\
2.75 \\
3.25\end{array}$ & $\begin{array}{r}\$ 7.00 \\
9.00 \\
11.00 \\
13.00 \\
15.00 \\
21.00 \\
25.00\end{array}$ \\
\hline
\end{tabular}

\section{Neponset Waterproof Paper Flower Pots}

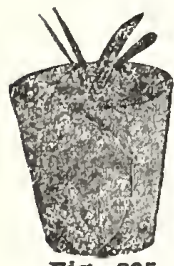

These pots are nested and packed in cases of 1,000 each, except 4,5 and 6 -inch sizes, which re put up in cases of 500 each.

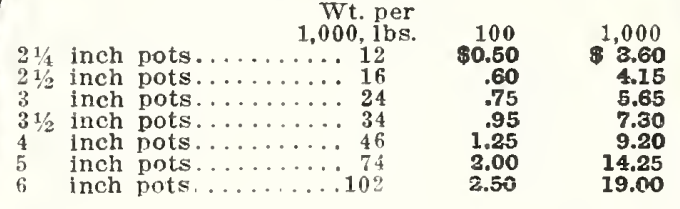

The Box That Makes the Plant Grow

GATVAITZED STIEL WINDOW BOX, painted green with water re ceptacle-an ornament to any house. Also used with best results in the cemetery or for Llving Bouquets. $30 \mathrm{in.}$ long, $8 \frac{1}{2} \mathrm{in}$. wide and $6 \frac{1 / 4}{\mathrm{in}}$. deep ...............\$1.75

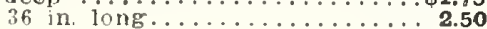

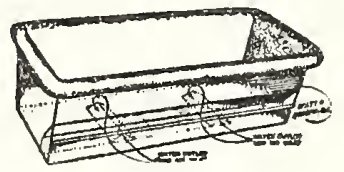

IIg. 326
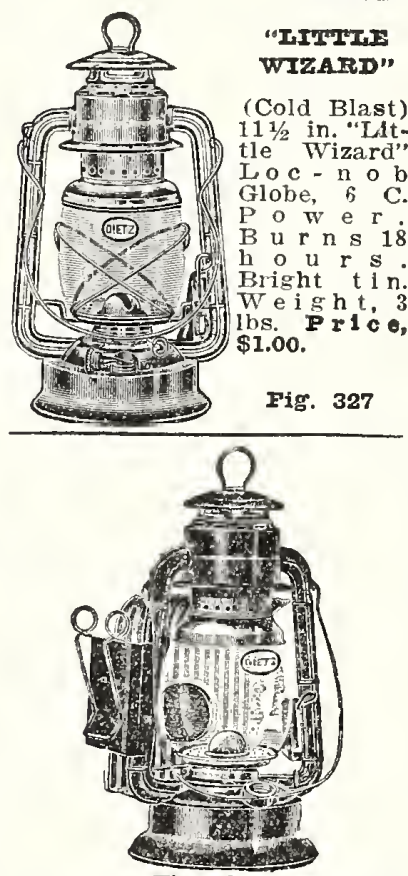

ROADSTER iv 328 G N . with Ruby Rear Signal (Cold Blast). Ruby Rear Signal (Cold Blast).
12 inches high. "Junches high. $\quad 5$-Inch Wlck. Burng 13 hours. Black enamel finish. Weight. \& Ibs.

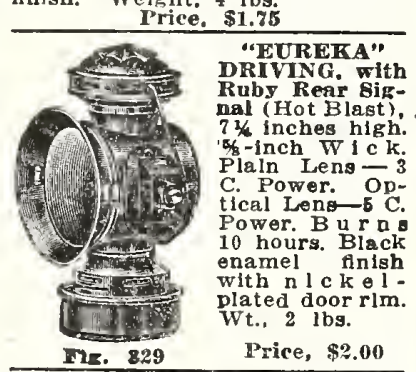

Butter Jars and Covers

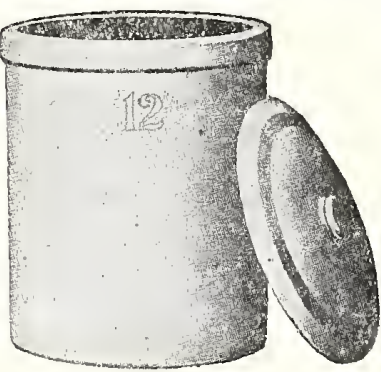

Frg. 330 The ideal package for keeping butter and putting down eggs in water 1 gal...\$0.40 $\begin{array}{ll}1 & \text { gal. } \ldots \$ 0.40 \\ 3 & \text { gal } \ldots . .60\end{array}$ 3 gal .... .90 5 gal...81.40 6 gal..... 1.60 8 gal. $\ldots .2 .42$

Lanterns

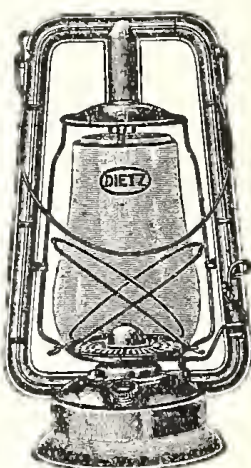

Fig. 331

"MONARCF." 131/2 in high, 5/8-in. wick, "Fitzall" (No. 0) Globe $4 \mathrm{C}$ Power Burns 19 hours. Bright tin. Wt., 3 lbs. Price, 95 cts.
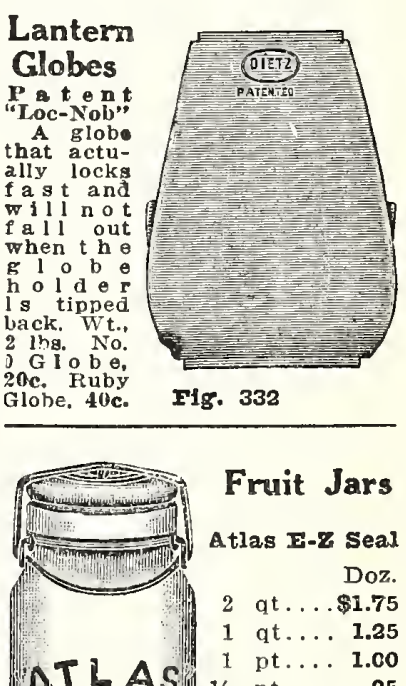

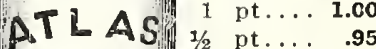

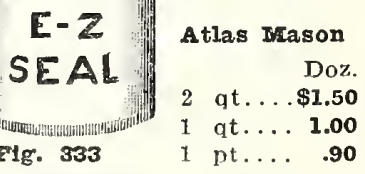

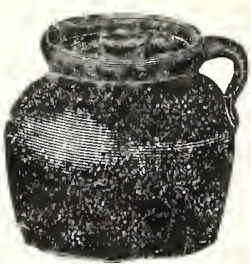

Brean

Pots with Cover

Fig. 334

1 qt., wt. 4 lbs., 25 cts.; 2 qt., wt. 5 lbs., 30 cts.; 3 qt., Wt. 8 lbs., 35 cts.; 4 qt., wt.
8 lbs., 40 cts. 


\section{EVERYBODY KNOWS}

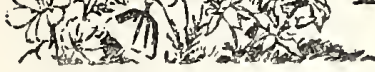
Ross' Seed

\section{Metal Rim One Quart Berry Baskets}

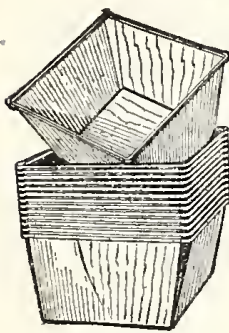

리. 335

Saving of $60 \%$ in

No sharp or rough points from stapling or tacks.

Pack in crates much easier; rims do not catch each other.

Show more surface on top and give fruit better appearance.

Every basket made accurate and $\mathrm{same}$

Welgh about onehalf as much as the old-style basket.

Each crate contains

2,000 baskets. Price, \$8.75 per M.; per 100 \$1.25; add for postage, 25 cts.

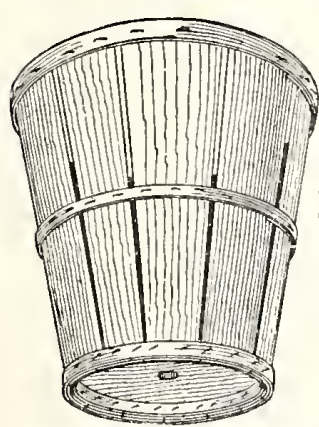

F12. 836

14-QT. MASS. STANDARD IMPROVEI BOTTOM PEACE BASTET

Each st a ye or the basket is secured to the hoons $\mathrm{sta}$ a les. makes the basket much more rigid. Per $100 \ldots . .8$ 8.00 Per $1.000 \ldots 70.00$

14-QT. MASS. FLAT BOT'TOII Per $100 \ldots \ldots \$ 7.50$ Per $1,000 \ldots 68.00$

\section{FOUR-QUART PONY BASEET}

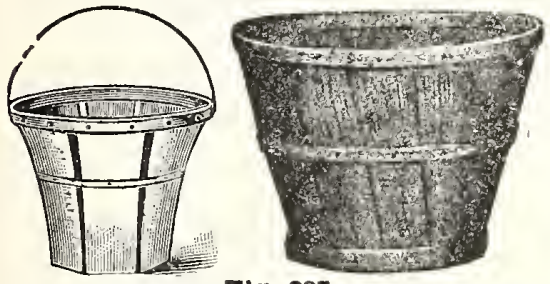

IIg. 337

4*qt. With wooden bottom. 100, \$7.50 $1,000, \$ 65.00$

(For Retail and Roadside Trade)

WIRE BAII ROADSIDE BASKETS

4 qt., per 100, $\$ 8.50$; per $1,000, \$ 78.00$.

BAMBOO GROCERS' DEIIVERT Frtra Heavy Fig. 338

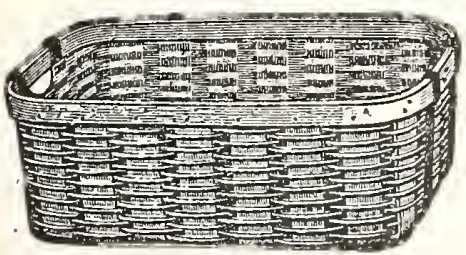

(With Block)

No

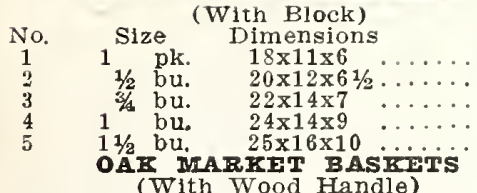

(With Wood Handle)

Same dimensions and prices as above.
BFRRY BASRETS

All white, $\$ 9.50$ per 1.000: Economy Brand $\$ 3.50$ per 1,$000 ; 10,000$ lots, 25 cts. less per 1,000. Close corner (for blueberries), $\$ 9.75$ per 1,000 . Groows

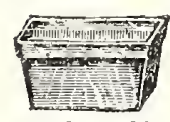

Fig. 389
Oval pints, $\$ 850$ per 1,000

Berry Baskets, per 100, $\$ 1.25$; add for postage 25 cts.

FOUR-QUART VIRGIHIA TIITS

For roadside containers. Per 100 , $\$ 2.60$; per $1,000, \$ 25.00$.

\section{VIRBENA ATP}

PANGY BASEFT

With Wire Handle.

Used largely for pansies, $100, \$ 2.50$ postage extra, 30

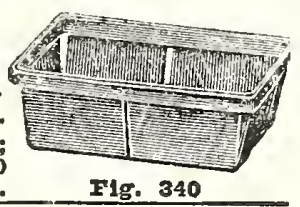

\section{OXFORD OAT BASTETT}

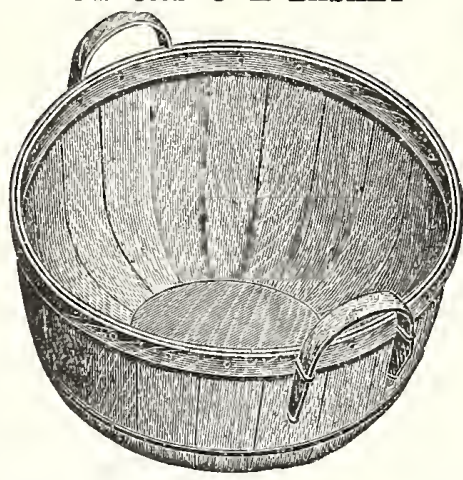

IIg. 341

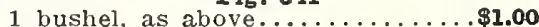
$1 / 2$ bushel, drop handie............. $1 / 4$ bushel, drop handle........... .75

A very serviceable basket, and the $1 / 2$ bushel is the best basket for picking peaches, as it does not brulse the fruit.

\section{WET WASH CIOTIES BASFIT}

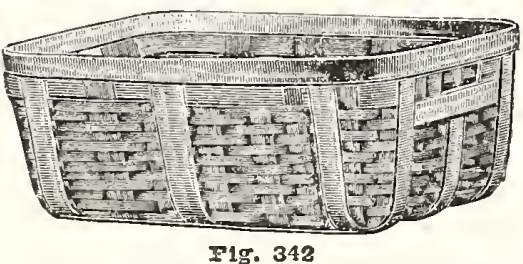

No. Dimenslons $25 \times 16 \times 10$

Prlce

$$
\begin{array}{ll}
3 & 27 \times 18 \times 10 . \\
4 & 30 \times 20 \times 11 . \\
5 & 32 \times 22 \times 12 . \\
\hline
\end{array}
$$

$\$ 1.55$

DLAMOND MAEKET BASTET

A cheap all 'round b a s k et: good for

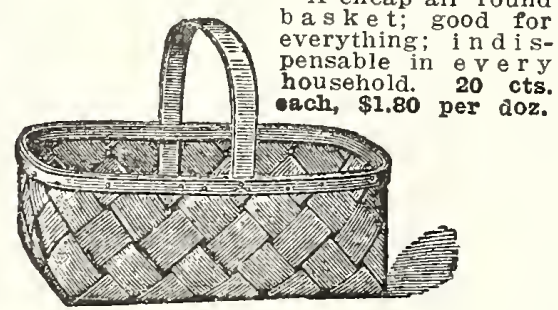

표. 343

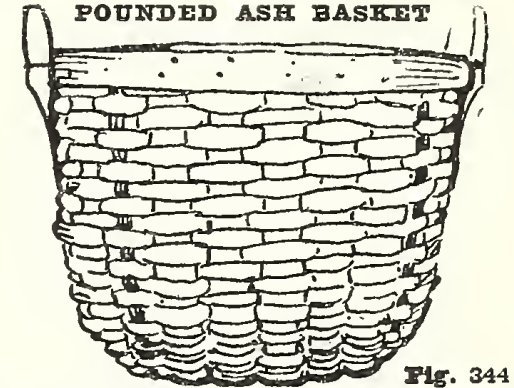

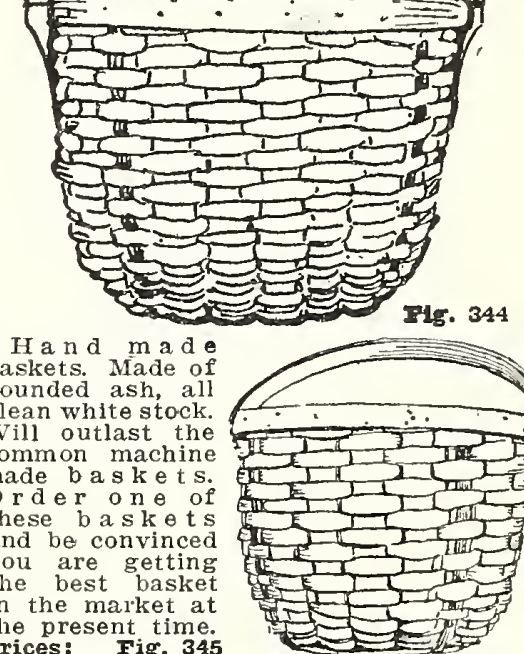

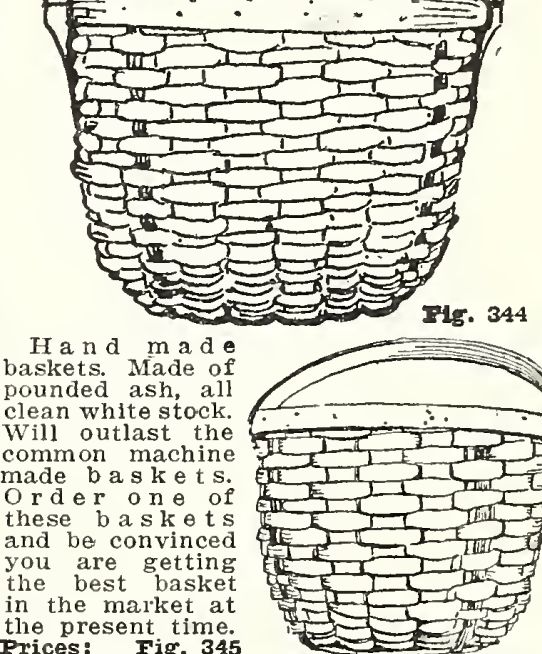
pounded ash, all clean white stock. Will outlast the common machine made basket $\mathrm{s}$. Order one of these baskets and be convinced you are getting the best basket in the market at the present time. Prices: Fig. 345 1 bushel ...............\$1.75 $1 / 2$ hushel (drop bail)............. 1.40

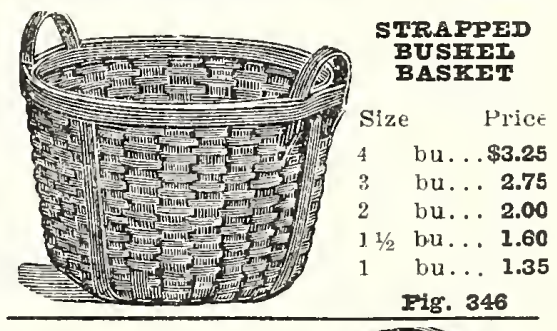

WOVEN PICKING BASKET

1/2-bushel drop bail.

Each $\$ 1.00$

Fig. 347
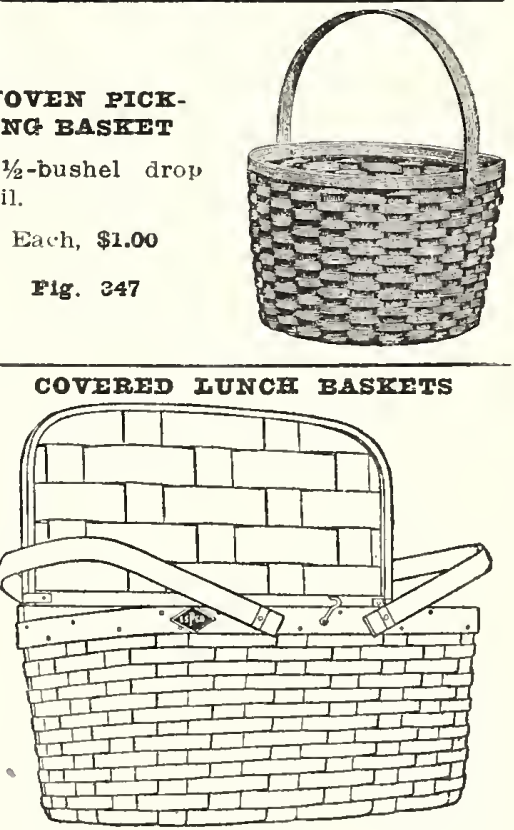
핑. 348

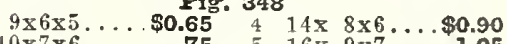
$10 \times 7 \times 6 \ldots .75 \quad 5 \quad 16 \times 9 \times 7 \ldots .1 .05$ 


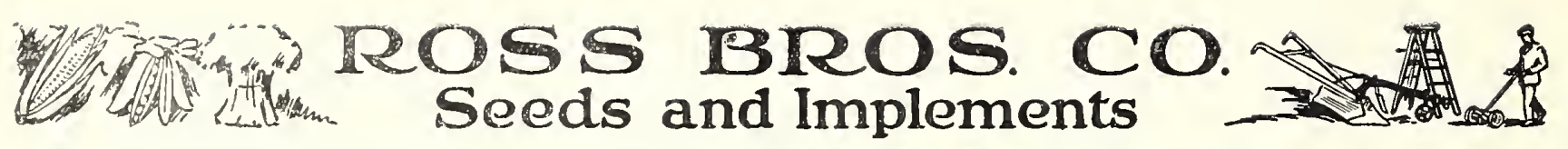

\section{Worcester Senior Cider Mill}

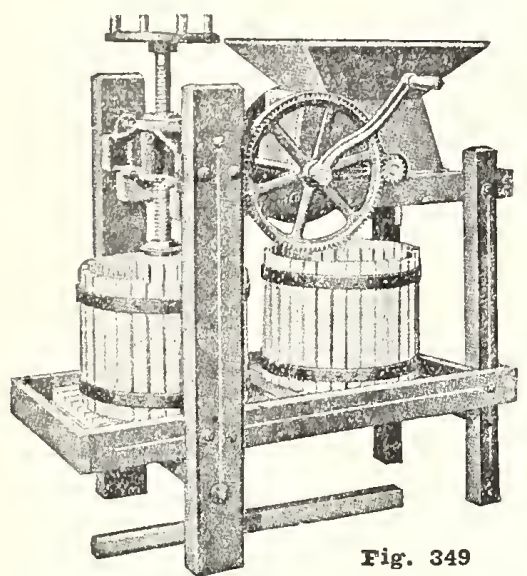
market.
The most up-to-date and best mill on the

Meets the demand where large capacity is wanted. Powerfully built with heavy hardwood frame strongly oolted together, best grade of iron and steel in working parts. Furnished with two tubs 14 in. high by 17 in. diameter, fitted with 2 cranks.

This mill, as are all of the Worcester Mills, even to the special small capacity mill, has "POSITIVE FORCE FEED." The grinding mechanism consists of a hardwood cylind e $r$ in which is securely im. b e d d e d a series of steel knives for cutting and grating the fruit. Capacity, 6 to 12 bbls, of cider per day. Weight, 330 lbs. Price, \$4.00

\section{$5 \%$ Discount for Casl}

MIEIUMI AND JUNIOE MIIIS

Absolutely forced feed, constructed in a heavy manner, frame strongly bolted together.

These mills, as in other Worcester Mills, have a grinding cylinder which consists of a hardwood cylinder with steel knives, Which makes the best possible cutter and grater. No iron comes in contact with the fruit, which does not discolor the cider.

Both the Junior and the Medium Mills are built on the same principle as the Senior Mill pictured above and are guaranteed absolutely satisfactoly in every way, both by the manufacturers and ourselves.

The Medium is furnished with two tubs $123 / 1 \times 14 \frac{1}{2}$; capacity, 4 to 6 bbls. per day. Weight, 215 lbs. Price, \$31.00. $5 \%$ Discount for Cash

The Juniol mill with two tubs $10 \frac{1}{2} \times 11$; capacity, 2 to 4 bbls, per day, Weirht, 155 lbs. Frice, \$25.50. $5 \%$ Discount for Cash

\section{Worcester Special Cider Mill}

A first-class single tub cider and wine press.

Frame is hardwood, wolking parts best grade of iron and steel with $11 / 8$-in. steel press screw.

Fitted with large balance wheel, making it run easy. Size of tub, $10 \frac{1}{2}$ in. high by 11 in. diameter.

The Spccial Mill has the "Positive Force Feed" grinder. as have the other Worcester line of mills, wood cylinder, which docs not discolor the fruit; capacity, 1 to $2 \mathrm{bbls}$. of cidel per day. Weight 130 lbs. Price, $\$ 23.00$. $5 \%$ Discount for casll.

All the Worcester Mills can be furnished with pulley for power at a slight additional expense.
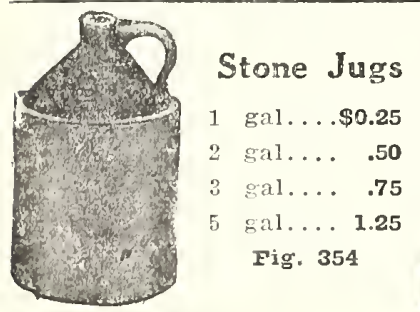

Fig. 355

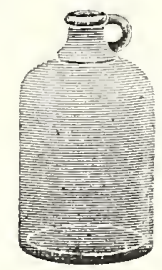

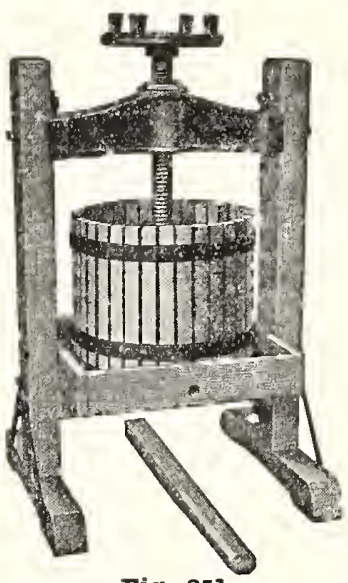

Fig. 351

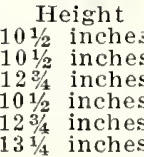

\section{Worcester Fruit Presses}

We carry a full line of fruit presses as shown in the accompanying illustration. The Nos. 4,5 and 6 presses are similar to the Nos. 2 and 3 illustrated, with the exception it has an iron cross head. The No. 1 is a smaller press, having $\mathrm{V}$-shaped standards, but with no top wheel, simply a heavy press screw with a square top with a strong lever for turning this screw.

This illustration shows Nos.? and 3 Presses.

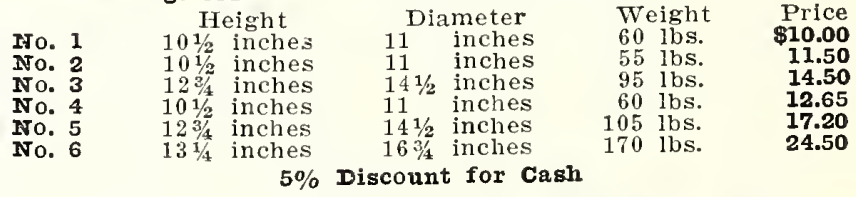

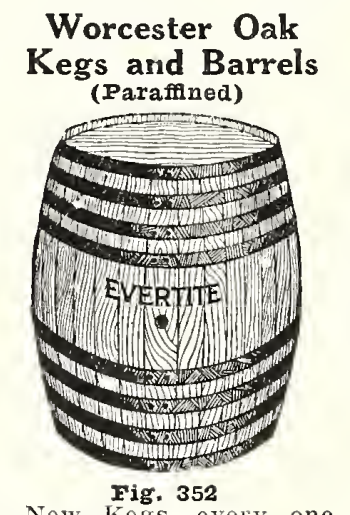
warranted $\mathrm{O} K$

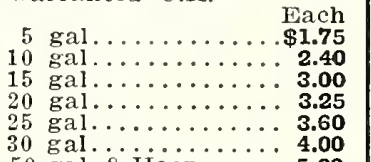

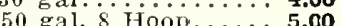

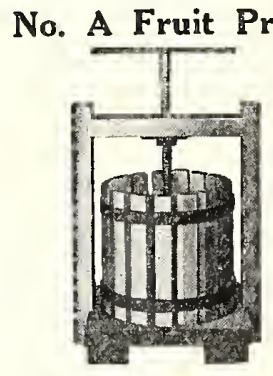

Fig. 353
No. A Fruit Press meets the demand of those who have a com paratively small amount of fruit to press and is designed for use on a bench or table, an excellent press for home use.

The Frame is made of high grade hardwood which assures a strong. durable, substantial press at a low cost.

Capacity of tub about eight quarts.

Price $\$ 4.50$

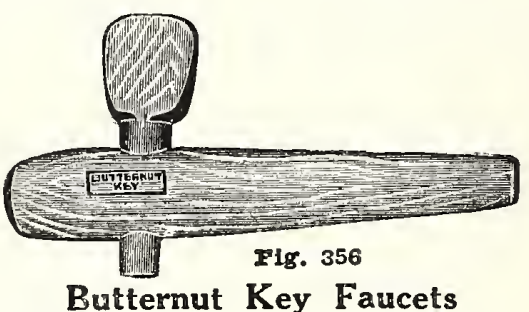

8 inch. Price each, $\$ 0.25 ;$ postpaid.............\$0.30

Metal Key Faucets

8 inch. Price each, \$0.40; postpaid................\$0.45

9 inch. Price each, .45 ; postpaid................50 Prices in this catalogue are subject to change without notice. 


\section{EVERTODY KNOWS \\ NOVELTY FRUIT PRESSES}

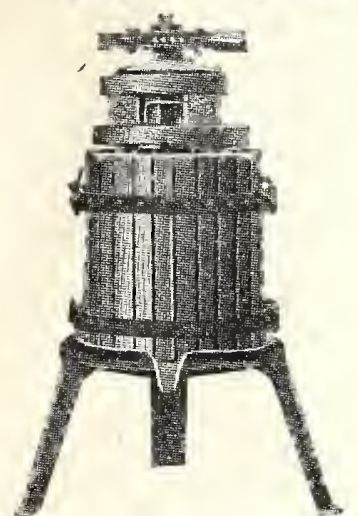

Fig. 357

We are illustrating a Fruit Press whlch has been the choice of the most discriminating buyers. Its point of superiority ls easily discernible on casual inspection, only the best materials being used in the manu. facture of these Frult Presses.

The ball bearing ratchet system makes it very easy to operate. A child has the same pressure results as an adult. The two points where the strength rests are on the two steel plates having between them No. 1 steel ball bearinss. The pressure working on ball bearings removes all friction and eliminates wasted energy. Otherwise the two surface points drag.

The wooden parts are made from seasoned oak, while the other parts are made from the best grade of metal. The base is made from substantial metal. A round disc of wood is placed upon the base to prevent the mash from coming in contact with metal.

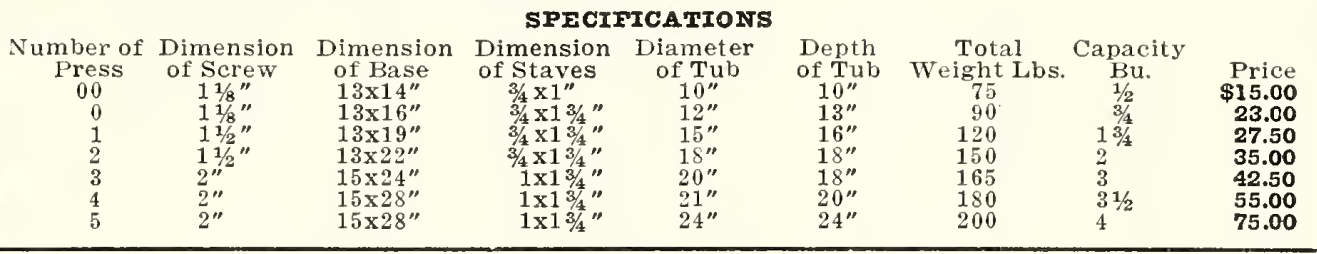

ICE TOOLS

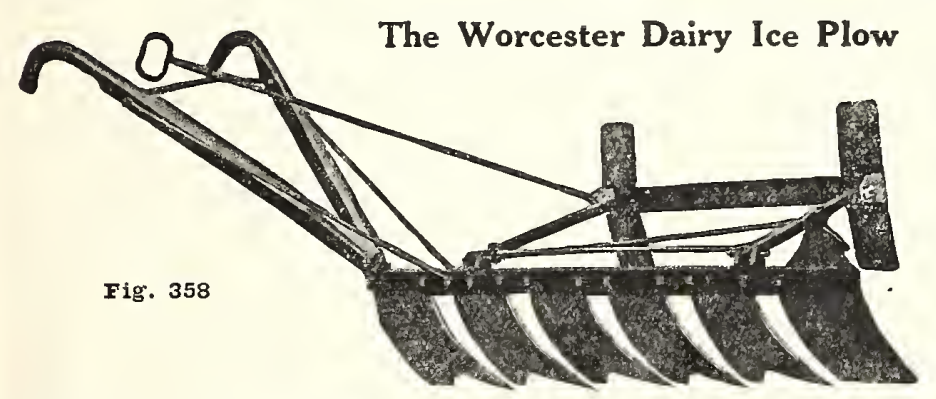

These plows are manufactured especially for dairymen, farmers, butchers, country estates who wish the best possible tools for their use. Has five cutting teeth, one Clearer tooth. Will cut 2 inches at a time to a depth of 8 inches. Are guaranteed to give satisfaction. 8-inch Plow with adjustable guide and case, $\$ 55.00$.

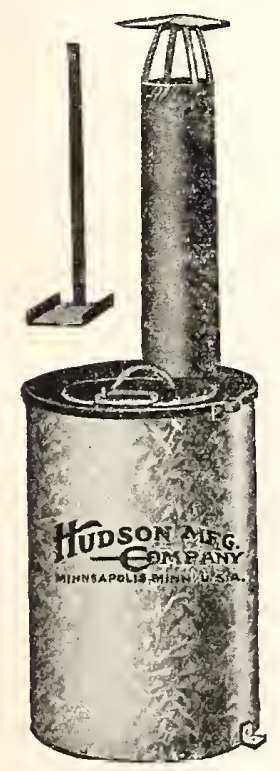

\section{Zero Tank Heater \\ Galvanized Steel}

This is a very popular type and very reasonable in price. Just the heater for small tanks and the stock raiser with only a few head of stock. It is made of No. 20 gauge galvanized sheet steel. Has cast top, galvanized steel bottom riveted and soldered. The grate is in two sections, the front resting on two legs. Grate and draft pipe can be taken out through the top. Furnished complete with shovel, one length of pipe, spark arrester and anchor bolts.

Diameter .....................

Height ........................

Weight .......................

Price ..................... \$8.50

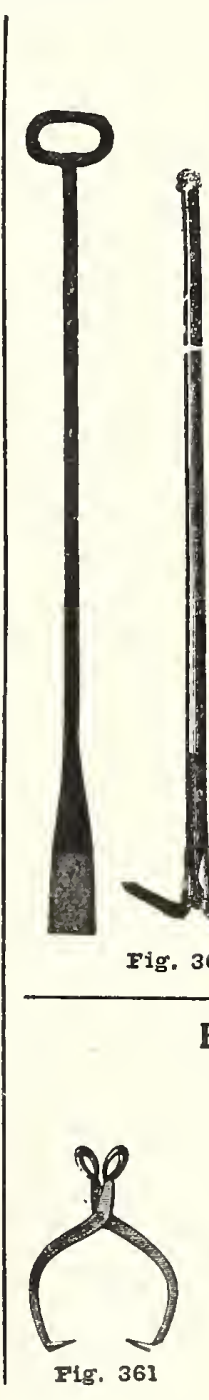

Ice Hooks
Boston Pattern

Fig. 359 
FARM, GARDEN AND FLOWER SEEDS, BULBS AND PLANTS

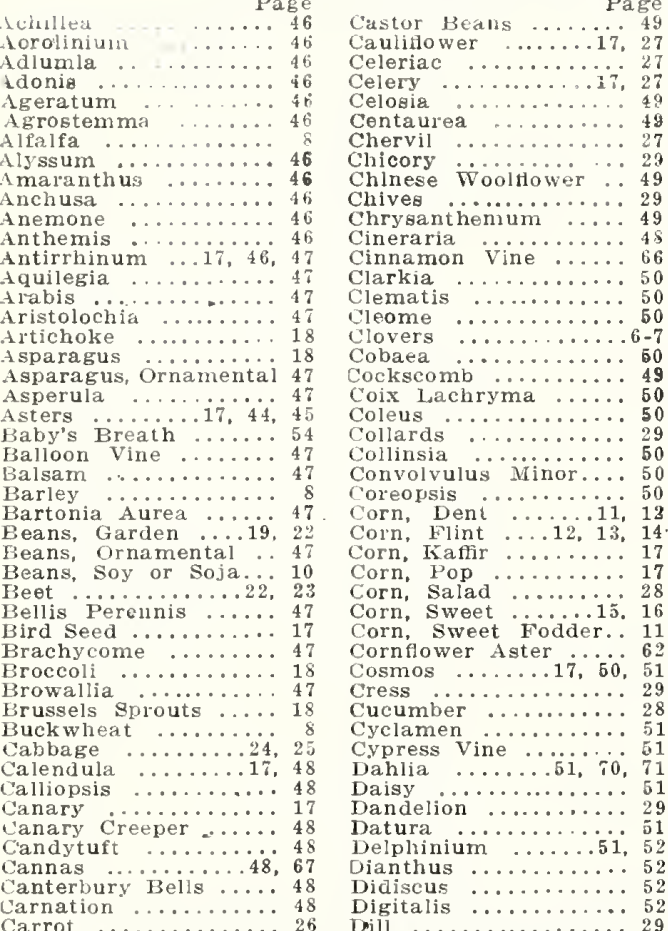

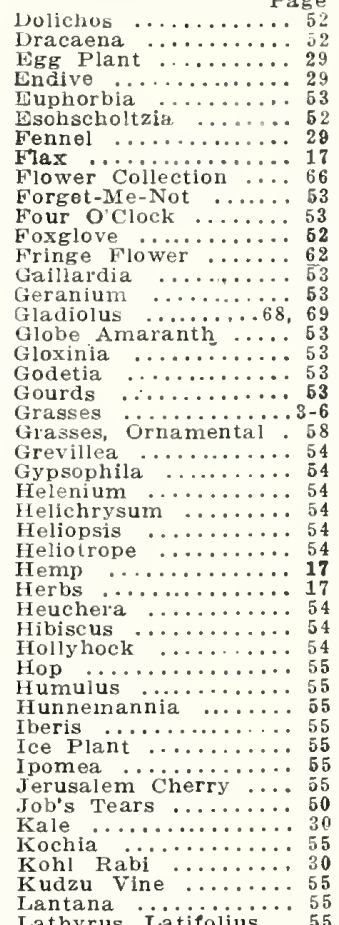

\begin{tabular}{|c|c|}
\hline atera Tremestris & \\
\hline$\ldots \ldots \ldots$ & \\
\hline eek ... & \\
\hline .......30 & \\
\hline ilies ......... & \\
\hline $\mathrm{um} \ldots \ldots$ & \\
\hline pelia & \\
\hline $\ln$ & \\
\hline nis & \\
\hline ra vine & \\
\hline angel-wurzels & \\
\hline Tarigold...$\ldots$. & \\
\hline hiola Bicornis. & \\
\hline icaria ........ & \\
\hline on $\ldots \ldots \ldots \ldots 32$, & \\
\hline onette $\ldots \ldots \ldots$ & \\
\hline$\ldots \ldots$ & \\
\hline lus $\ldots . .$. & \\
\hline ower & \\
\hline g Glory & \\
\hline oms $\ldots . . . .$. & \\
\hline$d \quad \ldots \ldots \ldots \ldots$ & \\
\hline tium ....57, & \\
\hline 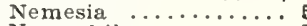 & \\
\hline ila $\ldots \ldots \ldots$ & \\
\hline na $\ldots \ldots$ & \\
\hline$\ldots \ldots \ldots$ & \\
\hline 赵 & \\
\hline$\cdots$ & \\
\hline$\ldots \ldots \ldots .33$ & \\
\hline Sets ... & \\
\hline ies $\ldots .$. & \\
\hline$\ldots \ldots \ldots$ & \\
\hline 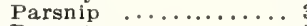 & \\
\hline its & \\
\hline Field & \\
\hline Garden & \\
\hline .17 & \\
\hline (2) & \\
\hline & \\
\hline codon & \\
\hline Polemonium & \\
\hline Poppy ..... & \\
\hline laca. & \\
\hline 37 & \\
\hline Pri & \\
\hline
\end{tabular}

Pyrethrum

........38, 39

Rainbow Corn ..... 50

Rhodanthe

Rhubarb

Rudbeckia

Rye Salpiglosis

Salsify

Salvia

Schizanthu

Seeds for Flavoring.

Senstive Plant

Silene

Smilax

Snapdragon

Spider Plant

Spinach

Squash

Statice

Stokesia Cyä........6. 62

Strawberry Plants ...6 67

Sudan Grass …i. $\ddot{17}, 62$

Sweet Peas .......62, 64

Sweet Willia $\ldots . \cdots 62,65$

Thunbergia

Tobacco

Tritoma

Tritoma

Tuberoses

Turnip ...........

Vegetable Collection.. 17

Veronica $\ldots \ldots \ldots \ldots \ldots \ldots 65$

Vetch

Viola Cornuta

Wallflow

$\because 10$

Wild cucumber vine. 65

Wild Flower Garden 66

\section{TOOLS, INSECTICIDES, FERTILIZER AND GENERAL FARM REQUISITES}

\begin{tabular}{|c|c|c|c|}
\hline & & & \\
\hline monia, Sulphate. 72 & Curry Combs & Hoes, & Pots, \\
\hline trol ............107 & Cutters, Ensilage .... 88 & Hoes, Wheel. & Pots, Flower \\
\hline shes $\ldots \ldots \ldots \ldots \ldots 72$ & Cutters, Kraut & Holder. & Pots, Neponset Paper.124 \\
\hline tomizers...... & Cutters, Vegetable. & Hooks, Cant ....... & Pots, Watering ....116 \\
\hline $\begin{array}{l}\text { Axes } \ldots \ldots \ldots \ldots 116-119 \\
\text { Bag Balm ........102 }\end{array}$ & Cutters. Victor Lever.101 & Hooks, Corn ... & Poultry Supplies .. \\
\hline $\begin{array}{l}\text { Bag Balm } \ldots \ldots \ldots \ldots \ldots 102 \\
\text { Bands, Leg } \ldots \ldots \ldots \ldots .93\end{array}$ & Cyanogas $\ldots \ldots \ldots \ldots 107$ & Hooks, Weeding $\ldots \ldots 117$ & ........90-91 \\
\hline $\begin{array}{l}\text { Bands, Leg ......... } \\
\text { Barn Equipment } \ldots . .89\end{array}$ & Dibbles $\ldots . . . \cdots \cdot$ & Hoppers & tive, Egg \\
\hline $\begin{array}{l}\text { Barn Equipment .... } \\
\text { Bars, Steel Crow.... }\end{array}$ & $\begin{array}{l}\text { Diggers, potato } \\
\text { Distributors Fertilizer }\end{array}$ & $\begin{array}{l}\text { Hose, } \mathrm{G} \\
\text { Ice Too }\end{array}$ & Presses, \\
\hline Basins, Buckley ....10 & $\ldots \ldots 81-82$ & Insecticides & Protectors, Plant \\
\hline Baskets $\ldots \ldots \ldots \ldots 125$ & Drills & Jars, Fruit & Pruners...$\cdots \cdots$ \\
\hline$\ldots \ldots \ldots \ldots 8$ & Dryers, Clothes & $\ldots \ldots 126$ & Pullers, Stump ......119 \\
\hline Binders, Corn ...... 88 & Dusters ‥73-74-107-109 & Kegs & Pulverizers $\quad \ldots \ldots \ldots \ldots$ \\
\hline B-K Solution & Dusting Materials ... 74 & $\ldots \ldots \ldots$ & Pulvules .. \\
\hline Blowers. Blizzard.... 88 & Edger, Grass ....... 85 & Asparagus & Punch, Poultry . \\
\hline Boat IIead ..... & Edger, Turf $\ldots \ldots \ldots .117$ & Knives, Hay ..... & Pumps \\
\hline Boats, Stone & Emulsion, Balnes & Knnives, Poultry & Pumps, Spray \\
\hline Bone, Fertilizer & Worm .. & Kow Kare & Racks, Corner \\
\hline Books, Poultry- & Engine & Labels, Plant & Racks, Tool . \\
\hline Border, Flower Bed.. & Faucets & Ladders. & Raflia $\ldots \ldots \ldots$ \\
\hline $\begin{array}{l}\text { Border, Flower Bed..999 } \\
\text { Bottles, Milk .......106 }\end{array}$ & Feed, Conkey's But- & Lanterns & Rakes $\ddot{n} \ddot{0}$. \\
\hline $\begin{array}{l}\text { Bottles, Milk } \ldots \ldots \ldots 106 \\
\text { Bowls, Butter } \ldots \ldots \ldots 106\end{array}$ & $\ldots \ldots 94$ & Lice Death, Lambert's 97 & Rakes, Drag \\
\hline $\begin{array}{l}\text { Bowls, Butter } \ldots . . .106 \\
\text { Bowls, Pigeon } \ldots . .9992\end{array}$ & $\begin{array}{l}\text { Feed, } \\
\text { Feed, Pigl-O-Per) } \ldots \ldots .96 \\
\end{array}$ & 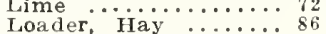 & $\begin{array}{l}\text { Rakes, lawn } \\
\text { Rakes, } 1 \text { or } 2 \text { Hors }\end{array}$ \\
\hline Bowls, Watering ....103 & Feed. Pratt's Butter- & Loma. & Rax, Rat Poison. \\
\hline Boxes, Butter ......105 & milk $\ldots$ & Manure, Premier Poul- & Reels, Hose ..... \\
\hline Boxes, Ghick ...... & Feeders, Calf & try & Reels, Garden \\
\hline Boxes, Egg. & Feeders, Poultry....92-93 & Manure & Remedles, Conkey \\
\hline Boxes, Feed & Fencing & Markers & Remedies, \\
\hline Boxes, Mail & Fence Tool & Mat, Hot B & Remedies, Pratt's \\
\hline Boxes, Parcel Post... 90 & Fertilizers & Mattocks & Rods, Spray \\
\hline Boxes, Window ......124 & Food, Old Trusty Dog & Menders, IIose & Rollers, Land \\
\hline Brooders ........90-91 & Food, Plant & Milkers & Rollers, Lawn \\
\hline ns & Forks & 5, Cide & Roofing \\
\hline Ishes, Bottle .. & Forks, Garden .... & ds. Butter & \\
\hline Bunchers, Asparagus.. 118 & Forks, Hay & Mowers, Lawn & Saddles, Foof \\
\hline Burners, Rubbish.113-117 & Fountains, Poultry..92-93 & Mowers, Power Lawn.122 & Salt, Brick \& Holde \\
\hline Cans, Ash $\ldots \ldots$. & Fumigator. Nico Fume & MeCornick.. 86 & Sash. Hot Bed. \\
\hline Cans, Milk. & $\ldots \ldots \ldots \ldots \ldots \ldots 107$ & Mulford Culture ... & Saws \\
\hline Cans, Mlxing & Fur & Nettlng, Poultry & $\mathrm{B}$ \\
\hline Caponizing Sets & Fre & Nitrate of Soda.. & Saws, Rig Mounted... \\
\hline Caps, Bottle .......106 & Garden Sets & Nozrles & S. Tilting Table \\
\hline la & Globes, Lantern .. & 1ls, Mille & Scales \\
\hline Cards, Cattle & es ... & Paper, Butter & Scales, Egg \\
\hline Carriers, Bottle & ders, Knife.. & Paper, Celery & Scraps, Beef \\
\hline Carrlers, Litter & Grindstones. & Picks & Scrapers, Steel \\
\hline Catchers, Grass & Crit. Poultry & ckes & Scrapers, \\
\hline Chicks, Baby & Guards. Tree & anet $\mathrm{Jr}$. & hes \\
\hline Chlsel, Grafting & Gun, Powder & anters, Corn & Mach \\
\hline urns & Gun, spray. & Planters, Potato & lers \\
\hline eaners, Wyandotte. & Haltors $\ldots$ & Plaster, Land & lers, Hand \\
\hline ers & Handles, Saw & Plows & Separators \\
\hline Coolers, Milk .. & $\ldots 75-78-79-80$ & Plows, Ice & Shears, Grass.115 \\
\hline Coops, Brooder. & Heaters, Tank .....127 & Plows, Tractor ... & Shears, Hedge ...1 \\
\hline Cordial, Calf & Hillers, Celery .... & Points, Glazing & Shears, Lawn \\
\hline Crock日 & 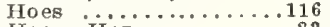 & Poppers, Corn & Shears, Pruning \\
\hline ets & Hoes, & Post & Shells, Oyster \\
\hline Cultí-Paoker & Hoes, Prout & Potash, Mu & Shellers, Corn .... \\
\hline Cultlvators & Hoes, Sllde & Potash. & Shovels \\
\hline
\end{tabular}

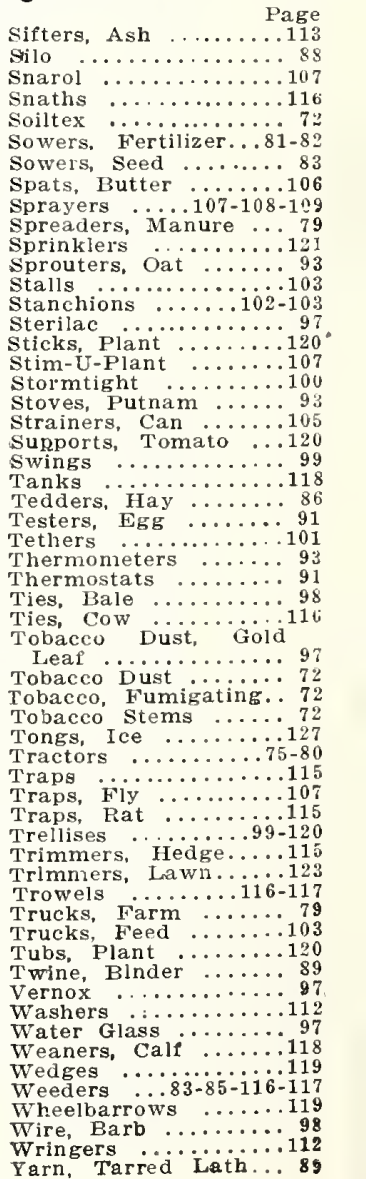

Sifters, Ash .........113

Snaths

Sowers, Fertilizer...81-82

Sowers, seed ........8 83

Spats, Butter $\ddot{107-108-109}$

Spreaders, Manure ...779

Sprouters, oat .........99

Stalls $\ldots \ldots \ldots \ldots \ldots \ldots 103$

Sterilac $\ldots \ldots \ldots \ldots \ldots .97$

Stim-U-Plant $\ldots \ldots . .107$

Stolmtight .........100

Strainers, Can .....105

Supports, Tomato ...120

Tanks ...............118

Tedders, Hay $\ldots \ldots \ldots 86$

Tethers ..............

Thermostats .........99

Ties, Cow ...............

Tobacco Dust, Gold 9

Tobacco Dust ........ 72

Tobacco Stems ..... 72

Tongs, Ice ..........127

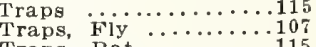

Traps, Rat .......99-120

Trimmers, Hedge....115

Trimners, Lawn........116-117

Trucks, Farm …....103

Tubs plant ......120

Twine, Blnder ...... 89

Washers ........... 112

Weaners, Calf .........118

Weeders ‥83-85-116-117

Wheelbarrows .........99

Yarn, Tarred Lath...89 


\section{Reference Table}

\section{GARDEN SEEDS}

Artichoke, $1 \mathrm{oz}$. to 500 plants............ 1/2 pound

Asparagus Seed, $10 \%$ to 800 plants.................. 4500 to 7000

Asparagus foots $\ldots \ldots \ldots \ldots \ldots \ldots . \ldots \ldots 2500$ to 7000

Beans, Pole, 1 pound to 100 hills............... 30

Beet, Garden, 1 oz. to $100 \mathrm{ft}$. of drill........... to

Beet, Sugar and Mangel, 1 oz. to $100 \mathrm{ft}$. of drill.

Broccoli, 1 oz. to 3000 plants..........

Brussels sprouts, 1 oz. to 3000

Carrot, 1 oz. to 150 feet of drili.

Cauliftower, 1 oz to 3000 plants......

Celery, 1 oz to 10,000 plants $\ldots \ldots \ldots \ldots$

Celeriac, 1 oz. to 10,000 plants.............

Cliervil, 1 oz. to sovio plants.

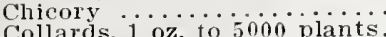

Collards, 1 oz. to son plants $\ldots \ldots \ldots \ldots \ldots \ldots$

Corll, Sweet, $1 / 4$ pound to 1 oulls..........

Cucumber, $1 \mathrm{oz}$. to 50 hills.

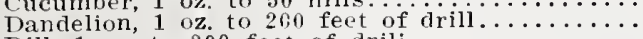

Dill, $1 \mathrm{oz}$. to 200 feet of drili.

Egg Plant, 1 oz to 2000 plants:

Kale, 1 oz. to 3000 plants.

12

$2 \frac{1}{2}$

4 ozs.

$4 \frac{1 / 2}{2}$ pounds
Per Acre

Kohl Rabi, 1 oz. to 200 feet of drill..

Leek, 1 oz. to 200 feet of drill.

Lettuce, $10 \%$ to 200 feel of drill.

Melon, Water, 1 oz. to 25 hills.

Mustard, 1 oz. to 50 feet of drill.

Okra, $1 \mathrm{oz}$ to 50 feet of drill.

Onion seed 1 oz to 200 teet of drill.

Onion Seed for sets. . 50 feet of diril

$\begin{array}{lll}4 & \text { ozs. } & \text { Onion Seed for sets. } \\ 4 & \text { “ } & \text { Onion Sets, } 2 \text { pounds to } 50 \text { feet of } \\ 4 & \text { Parsnip, } 1 \mathrm{oz} \text { to } 200 \text { feet of drill }\end{array}$

$2 \frac{1 / 2}{5}$ pounds $\quad \begin{aligned} & \text { Parsnip, } \\ & \text { Parsley, } 1 \text { oz. to } 200 \text { feet of drill. . . . . . } \\ & \text { Peas, Garden, } 1 \text { pound to } 100 \text { foot drill. }\end{aligned}$

4 pounds

Pepper, 1 oz. to 1500 plants.

Pumpkin, 1 oz. to

Padish, 1 oz. to 150 feet of drili.

Sage, $1 \mathrm{oz}$. to 100 feet of drill.

Salsify, $1 \mathrm{oz}$. to 60 foot row

Spinach, $1 \mathrm{oz}$. to 100 feet of drill.

Squash, Summer, 1 oz. to 25 hills.

Squash, Winter, $1 \mathrm{oz}$. to 10 hills.

Tomato, 1 oz. to 2500 plants.

Tobacco. $1 \mathrm{oz}$ to 5000 plants.

Turnip, 1 oz. to 200 feet of drili

Per Acro

$11 / 2$ pounds

$\frac{3}{4}$

8

4 to 5

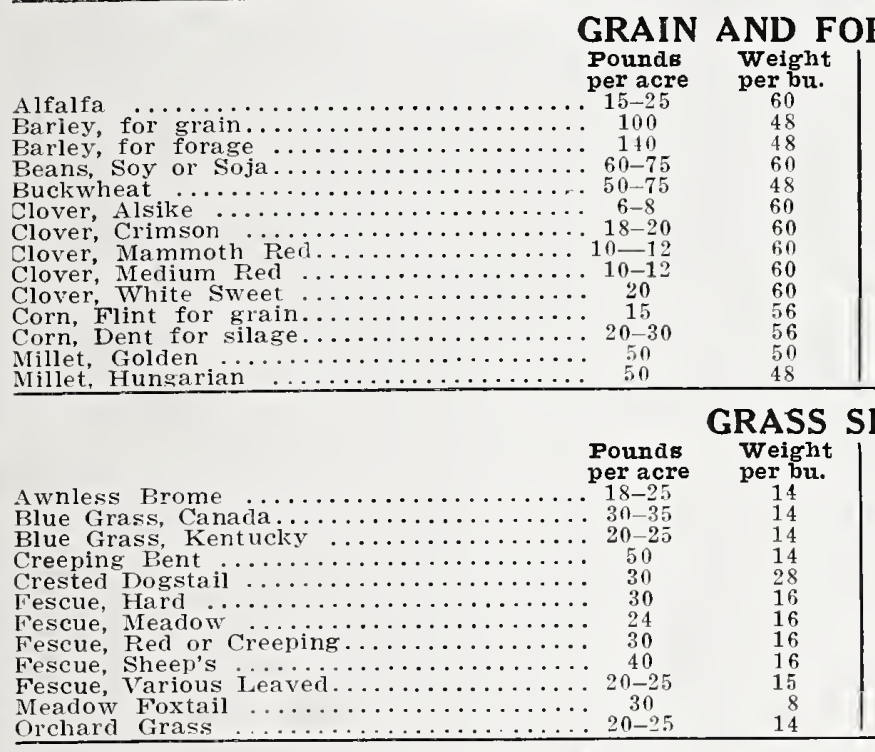

Millet. Japanese

Oats for grain.
Oats for forage

Peas, Field, Broadcast.

Peas with Oats

Rye for grain

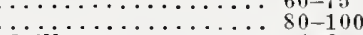

Rape, Dwarf Essex, in drills.............. $4-6$

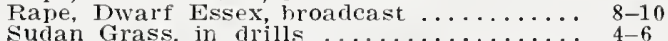

Sudan Grass, in drills

Vetch, Spring, with one bushel small grain $40-60$

Vetch, Winter or Hairy, with one bushel small grain

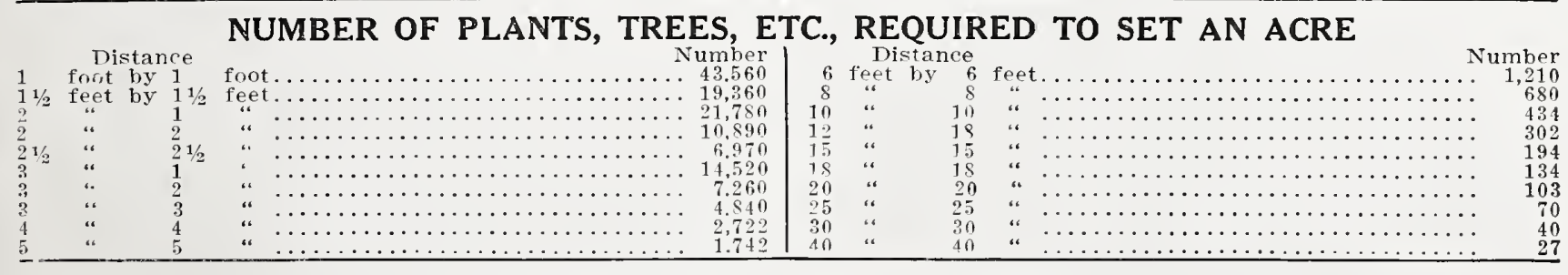

\section{A PRACTICAL POULTRY LIBRARY}

Success in the pouitry business is entirely within the grasp of anyone who will take the time to master its

lying principles. It is a science, not a game of chance.

We can furnish you a list of poultry books which give the different phases of poultry breeding and poultry keeping for profit. Whether you have a small coop or have thousands of fowls, it will certainly be of interest to rou and in all probability to read any one of these books will be a source of profit. We have the following list which we can furnish: Price.

Profitable Culling and Selective Flock Feeding. By Homer W. Jackson of 300 -riggers and Better by Iine Breeding. By M. E. Atkinson.

Art Cover

Cloth Bound

Use of Artificial $\mathrm{i} i \mathrm{ght}$ to increase winter $\mathrm{Egg}$ Produc-

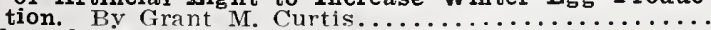

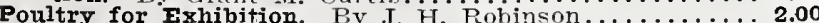

High Egg Production. Pv Grant M. Curtis..............

\begin{tabular}{|c|c|c|}
\hline EDS & Pounds & welght \\
\hline Rye Grass, English & $\begin{array}{l}\text { per acre } \\
. \quad 50\end{array}$ & $\begin{array}{l}\text { er bu. } \\
28\end{array}$ \\
\hline Rye Grass, Italian. & 60 & \\
\hline Rye Grass, Pacey's . & 50 & \\
\hline Red Top, Pecleaned seed, Worcester Brand & d $40-50$ & 36 \\
\hline Red Top, Unhulled seed $\ldots \ldots \ldots \ldots \ldots \ldots$ & . 70 & \\
\hline Rhode Island Bent..... & . $20-40$ & \\
\hline $\begin{array}{l}\text { Rough Stalk Meadow . . . . . . . . . . . } \\
\text { Sweet Vernal use only in mixture }\end{array}$ & $30-35$ & 2 \\
\hline $\begin{array}{l}\text { Sweet Vernal, use only in mixture. } \\
\text { Tall Meadow Oat................. }\end{array}$ & 45 & \\
\hline 'Timothy & $12-2$ & 45 \\
\hline Iawn Seed Mixture, Shady spot & $100-125$ & \\
\hline Lawn Seed Mixture, Worcester Brand & $.100-125$ & 20 \\
\hline Wood Meadow ..... & $25-30$ & 19 \\
\hline
\end{tabular}

Rye Grass, English

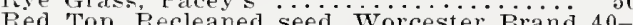

Red Top Unhulled seed . ............... 70

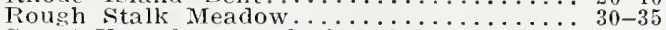

.

$\ldots \ldots 12-25$

Lawn Seed Mixture, Worcester Brand .....100-195

ight (1)

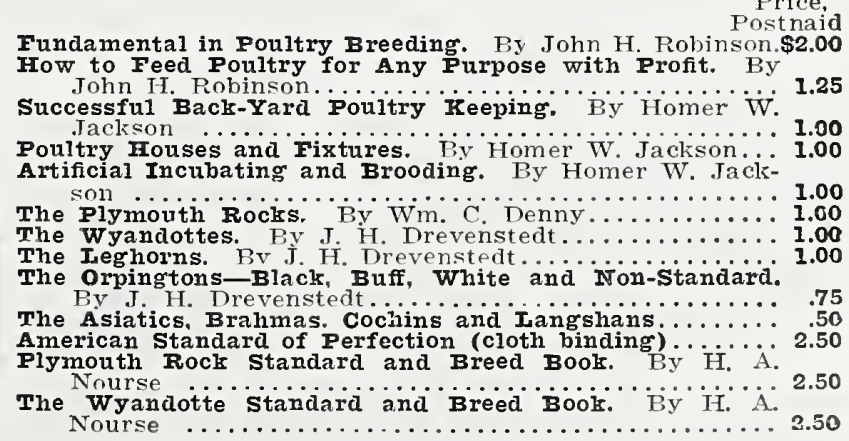


